UNIVERSIDADE DE SÃO PAULO

INSTITUTO DE GEOCIÊNCIAS

\title{
EVOLUÇÃO PETROGRÁFICA E MINERALÓGICA DAS ASSOCIAÇÕES ALCALINA E ALUMINOSA DOS GRANITOS TIPO-A DA GRACIOSA, PR
}

\author{
GUILHERME AUGUSTO ROSA GUALDA
}

Orientador: Dr. Silvio Roberto Farias Vlach

DISSERTAÇÃO DE MESTRADO

COMISSÃO JULGADORA

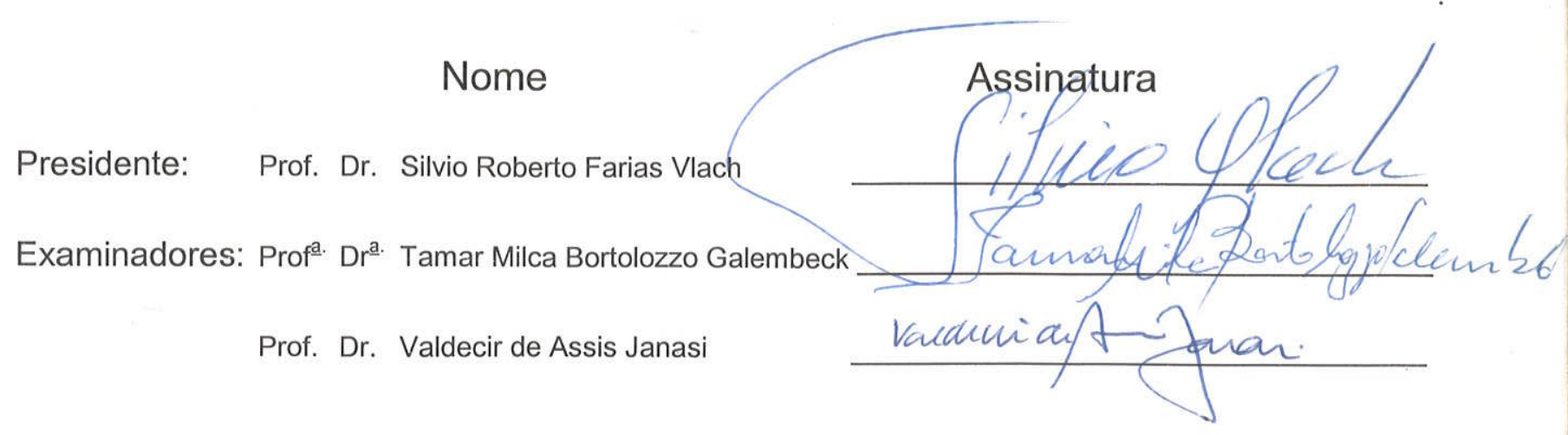

SÃO PAULO

2001 


\section{UNIVERSIDADE DE SÃO PAULO INSTITUTO DE GEOCIENCIAS}

\section{EVOLUÇĀO PETROGRÁFICA E MINERALÓGICA DAS ASSOCIAÇÕES ALCALINA E ALUMINOSA DOS GRANITOS TIPO-A DA GRACIOSA, PR}

Guilherme Augusto Rosa Gualda

Orientador: Prof. Dr. Silvio Roberto Farias Vlach

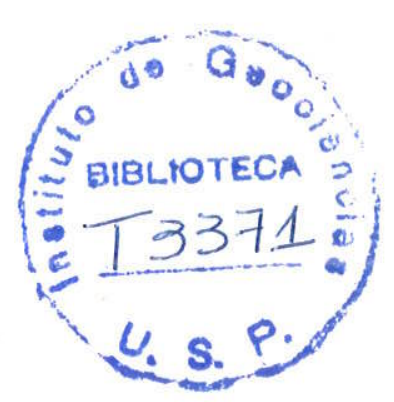

DISSERTAÇĀO DE MESTRADO

Programa de Pós-Graduação em Mineralogia e Petrologia

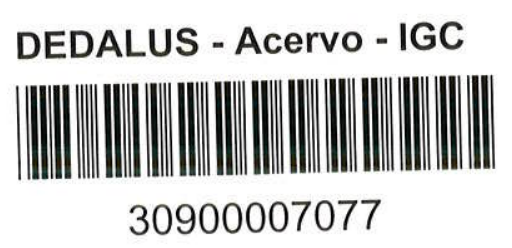

$$
\begin{gathered}
\text { SẢO PAULO } \\
2001
\end{gathered}
$$


Ao Silvio,

pela amizade e dedicação incansáveis 


\section{PARTE I: INTRODUÇÃO}

I. INTRODUÇ̃̃O AO TEMA

II. ABORDAGEM METODOLÓGICA E ESTRUTURA DA DISSERTAÇÃO ....................................... 1.2

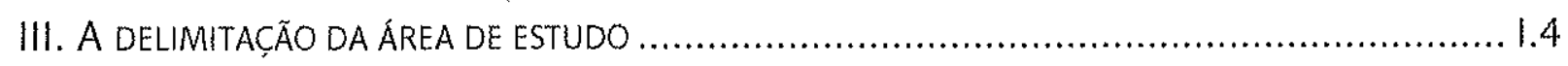

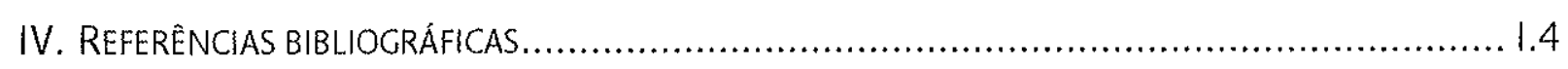

PARTE II: MAGMATISMO GRANITICO TIPO-A: UMA REVISÃo DAS IDÉIAS ATUAIS

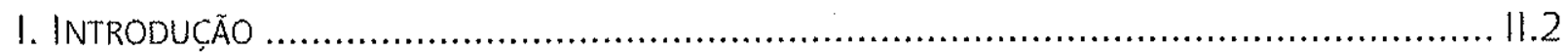

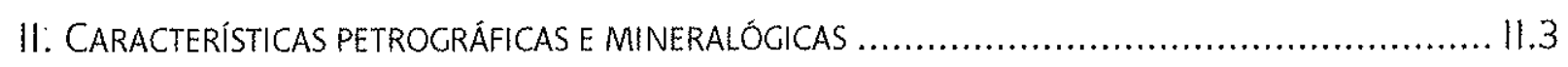

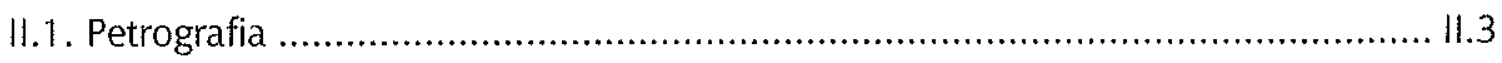

11.2. Condições de cristalização ........................................................................... 11.5

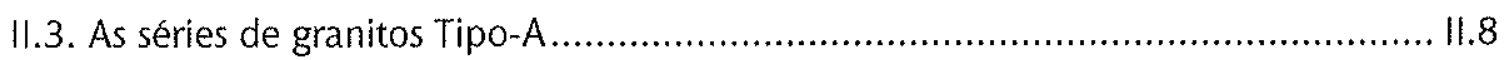

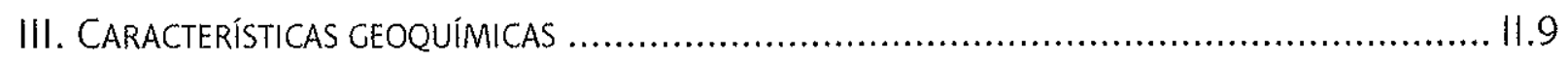

111.1. Geoquímica de elementos maiores e traços ................................................. 11.9

111.2. Geoquímica isotópica ........................................................................15

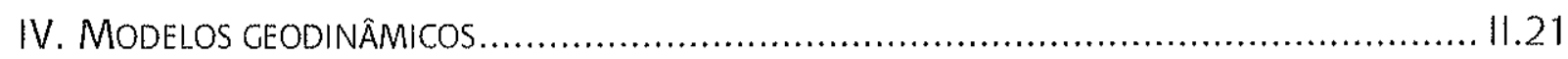

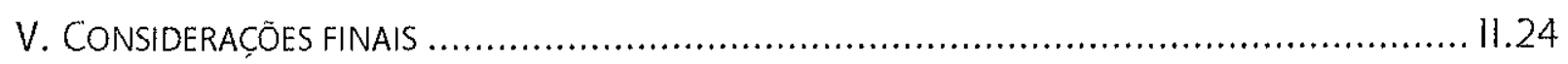

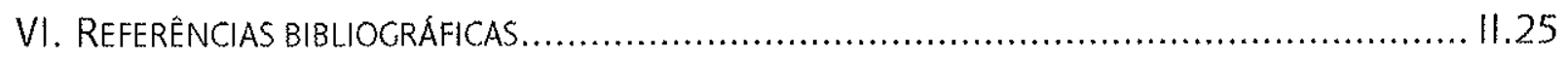

Parte III: Os Granitos Tipo-A da Graciosa: Contexto Regional e Caracterização GEOLÓGICA

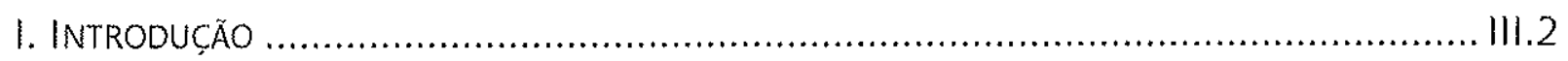

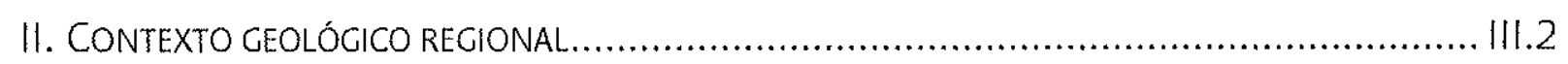

II.1. O embasamento da Plataforma Sul-Americana no Sul-Sudeste do Brasil.............. 111.2

II.2. A Província Serra do Mar........................................................................111.6

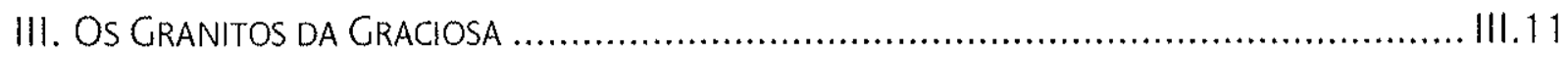

III.1. Aspectos naturais e localização ..................................................................II.11

1II.2. Histórico dos trabalhos anteriores .......................................................... 111.11

III.3. Materiais e métodos............................................................................111.13 
111.4. Características geológicas gerais

111.15

111.5. Geologia e petrografia dos maciços ......................................................17

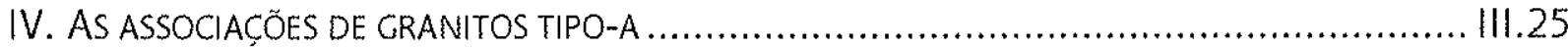

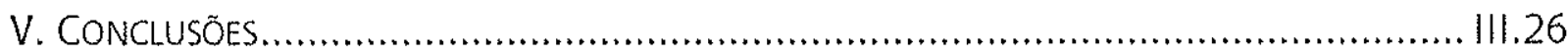

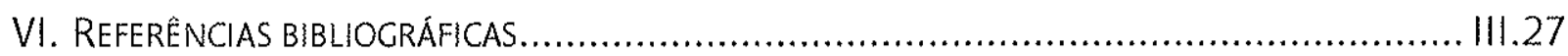

ANEXOS

\section{Parte IV: Os GRanitos Tipo-A da Graciosa: Petrografia e quimismo Mineral}

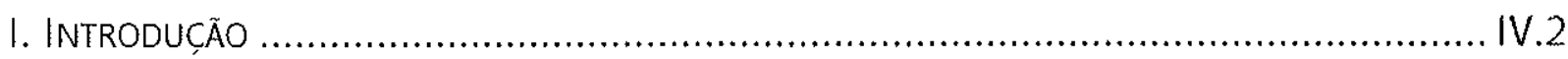

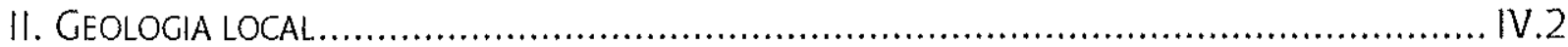

III. MATERIAIS E MÉTODOS .........................................................................

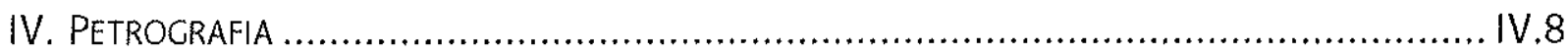

IV.1. A associação petrográfica alcalina I ........................................... IV. 10

IV.2. A associação petrográfica alcalina II ................................................ IV.16

IV.3. A associação petrográfica aluminosa ....................................................... IV.18

IV.4. Rochas monzodioríticas e associadas ....................................................... IV.23

IV.5. Seqüências de cristalização, paragêneses minerais e evolução modal ............... IV.26

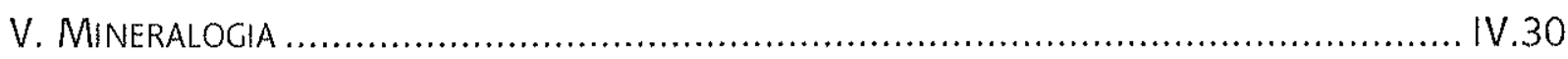

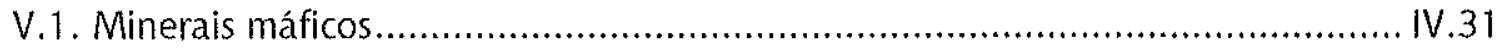

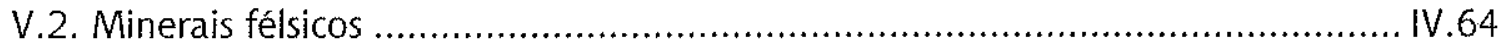

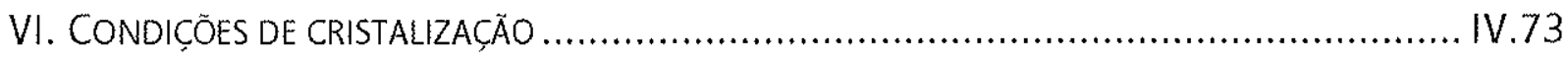

VI.1. Temperaturas liquidus .................................................................. 73

VI.2. Temperaturas solidus e pressão de colocação .......................................... IV.76

V1.3. Temperaturas sub-solidus ............................................................... IV.78

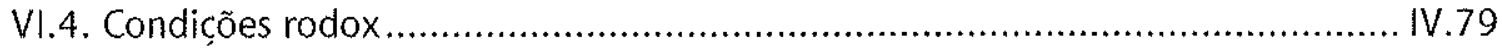

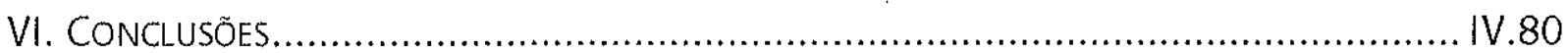

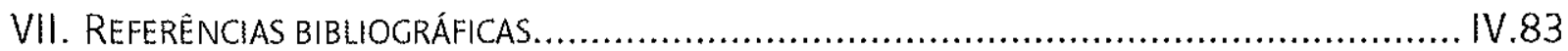

ANEXO I: PRANCHAS

ANEXO II: ANÁLISES QUIMICAS DE MINERAIS

PARTE V: CONSIDERAC̄ões Finais 
APÊNDICE I: ANÁlISE MODAL REVISTA: PRECISÃo E EXATIDÃO ASSOCIADAS À CONTAGEM DE PONTOS

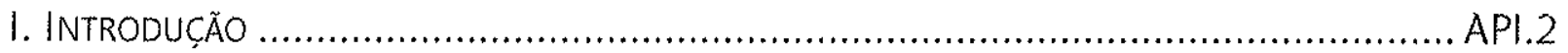

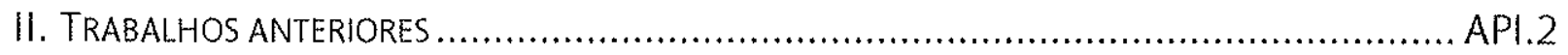

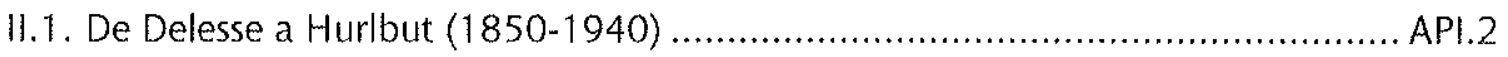

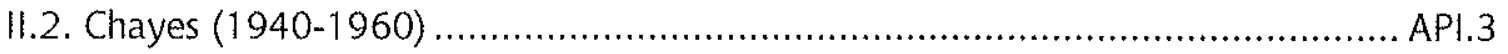

11.3. Desenvolvimentos recentes $(1960-1990)$......................................................API.4

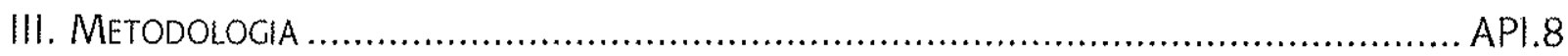

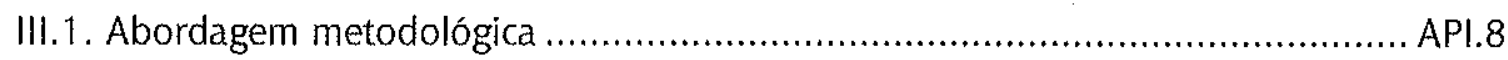

III.2. Aquisição de imagens.................................................................. API.9

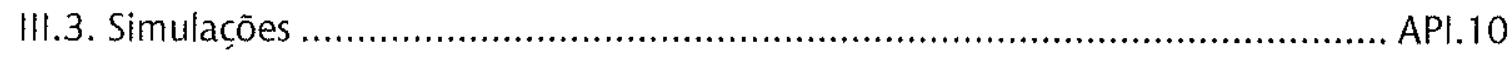

111.4. Método de Neilson e Brockman (1977) ....................................................11

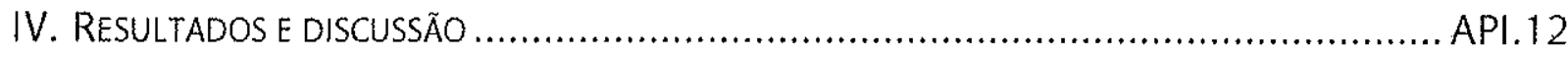

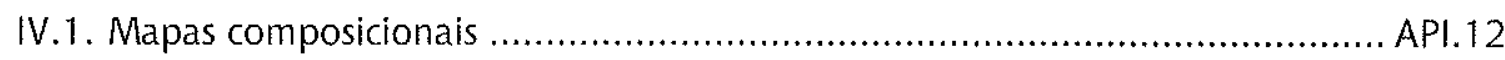

IV.2. Simulaçōes .............................................................................. API. 12

IV.3. Método de Neilson e Brockman (1977) ............................................API.18

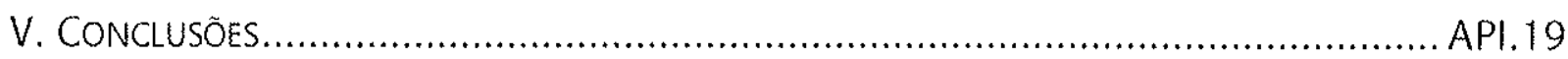

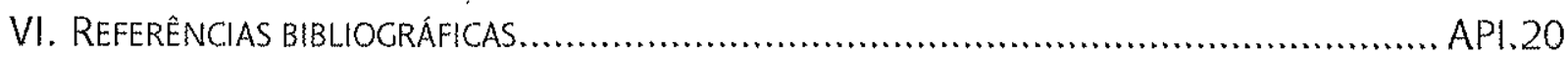

APÊNDICE II: UMA AVALIAC̄ĀO CRÍTICA DO MÉTODO DE SCHUMACHER DE AVALIAC̄ÃO DAS RAZÕES $\mathrm{FE}^{2+} / \mathrm{FE}^{3+}$ EM ANFIBÓLIOS

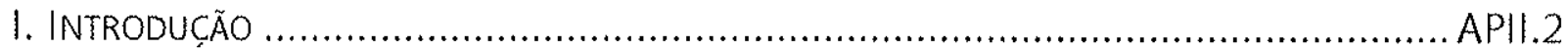

II. O MÉTODO DE SCHUMACHER .............................................................. APII.3

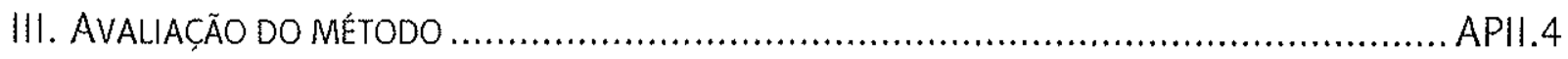

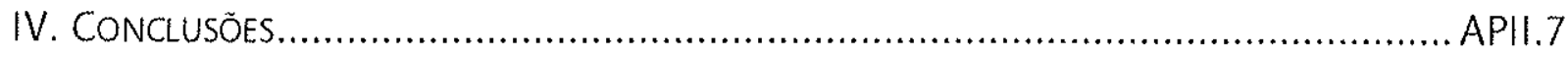

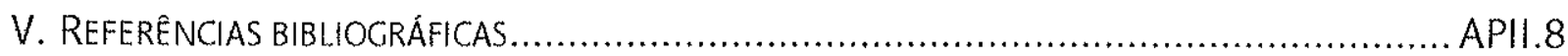




\section{ÍNDICE DE TABELAS}

Tabela 11.1: Estimativas de parâmetros intensivos a partir de equilíbrios minerais diversos para granitos Tipo-A alcalinos e aluminosos

Tabela 11.2: Razões ${ }^{87} \mathrm{Sr} /{ }^{86} \mathrm{Sr}$ e $\varepsilon_{\mathrm{Nd}}$ para granitos Tipo-A alcalinos e aluminosos .11 .17

Tabela III.1: Características principais dos maciços que compõem os Granitos da Graciosa (PR) 1111.18

Tabela IV.1: Condições analíticas utilizadas IV.5

Tabela IV.3: Legenda para as Figuras IV. 30

Tabela IV.2: Composições modais e erros estimados de amostras representativas das diversas fácies dos Granitos da Graciosa. Anexo

Tabela IV.4: Análises químicas completas (WDS) de olivinas dos Granitos da Graciosa Anexo

Tabela IV.5: Análises químicas completas (WDS) de clinopiroxênios dos Granitos da Graciosa........ Anexo

Tabela IV.6: Análises químicas completas (WDS) de anfibólios dos Granitos da Graciosa. Anexo

Tabela IV.7: Análises químicas completas (WDS) de biotitas dos Granitos da Graciosa Anexo

Tabela IV.8: Análises químicas completas (WDS) de plagioclásios dos Granitos da Graciosa. Anexo

Tabela IV.9: Estimativas da composição química primária de feldspatos alcalinos dos Granitos da Graciosa Anexo

Tabela API.1: Valores de $c_{\gamma}$ em função de $\gamma^{*}$ API.5

Tabela API.2: Características das imagens obtidas API. 10

Tabela API.3: Códigos e caracteristicas das simulações realizadas para cada amostra API.10

Tabela AP1.4: Composições modais "ideais" API.12 


\section{ÍNDICE DE FIGURAS}

Figura II.1: Composições modais de granitos Tipo-A da Província da Nigéria. Extraído de Pitcher (1993).Il.3

Figura 11.2: Composições modais de granitos da associação aluminosa do Cinturão Anorogênico Transcontinental Norte Americano. Extraído de Anderson e Bender (1989). .11 .4

Figura II.3: Diagramas $\mathrm{Zr}$, Nb, Ce e $\mathrm{Y}$ versus $1000^{*} \mathrm{Ga} / \mathrm{Al}$ para vários granitos Tipo-A, e também, para comparação, os campos para os granitos I. S e $\mathrm{M}$ e para dois grupos de granitos Tipo-l e Tipo-S fracionados (contornos pontilhados). Extraído de Whalen et al. (1987).

Figura II.4: Diagrama \% atômica de álcalis $(\mathrm{Na}+\mathrm{K})$ versus \% atômica de $\mathrm{Al}$ para rochas do Complexo Anelar Tessalit (Mali). Extraído de Liégeois et al. (1996).

Figura 11.5: Diagrama $Z r+C e+Y$ versus Rb/Ba para granitos Tipo-I e Tipo-S fracionados (Ackley e Sandy Cape) e para granitos TipomA da Suite Topsails. Símbolos como na Figura 3. Extraído de Whalen et al. (1987).

Figura 11.6: Diagrama discriminatório de Pearce et al. (1984). Símbolos como na Figura 3. Extraído de Whalen et al. (1987). Campos: ORG $=$ granitos orogênicos; $V A G=$ arco magmático; $C O L G=$ granitos colisionais; WPG $=$ granitos intra-placa. Símbolos como na Figura /1.3. Extraído de Whaten et a!. (1987).

Figura 11.7: Diagrama triangular $\mathrm{Y}-\mathrm{Ce}-\mathrm{Nb}$ mostrando a separação entre os subtipos $\mathrm{A} 1$ e $\mathrm{A2}$; a reta que separa os dois campos corresponde à relação $\mathrm{Y} / \mathrm{Nb}=1$,2. Extraído de Eby (1992).

Figura 11.8: (a) Diagrama $\mathrm{Sc} / \mathrm{Nb}$ versus $\mathrm{Y} / \mathrm{Nb}$, são indicadas as trajetórias devidas ao fracionamento de piroxênio (P) e anfibólio (A) para magmas com teores de sílica altos $(H)$ e moderados (L); (b) diagrama Ba versus Eu/Eu*, indicadas as trajetórias devidas ao fracionamento de plagioclásio (P) e feidspato alcalino (AF). Extraído de Eby (1990).

Figura II.9: Diagramas Índice Agpaítico versus 1000*Ga/Al para vários granitos Tipo-A, e também, para comparação, os campos para os granitos I, S e M e para dois grupos de granitos Tipo-I e Tipo-S fracionados (contornos pontilhados). Símbolos como na Figura 3. Extraído de Whalen et al. (1987).

Figura II.10: Diagrama $\mathrm{Sr}$ versus $\mathrm{SiO}_{2}$ para rochas do Complexo Anelar Tessalit - Mali. (à esquerda, extraído de Liégeois et al., 1996); Diagrama Ba versus $\mathrm{Sr}$ para rochas do enxame de diques Tin Zebane - Argélia (à direita, extraído de Hadj-Kaddour et al., 1998),

Figura II.11: Diagrama ${ }^{87} \mathrm{Sr} /{ }^{86} \mathrm{Sr}$ versus $\mathrm{Sr}$ para Granitos Mesozóicos do Norte de New England (Estados Unidos). Extraido de Foland e Allen (1991). 11.16 
Figura II.12: Composições isotópicas de granitos das associações alcalina ( $\mathrm{P}$ - peralcalinos; AH metaluminosos) e aluminosa (AS) da Província Anorogênica da Córsega. Extraído de Poitrasson et al. (1995).

Figura 11.13: Diagrama $\varepsilon_{\mathrm{Nd}}$ versus ${ }^{87} \mathrm{Sr} /{ }^{86} \mathrm{Sr}$ mostrando a composição dos granitos Tipo-A da Província Padthaway (quadrados), que se sobrepõe às composições dos granófiros (outros símbolos) e gabros (hachura) do Complexo Black Hill; são mostrados também os campos de granitos Tipo-l e Tipo-S do Cinturão Dobrado Lachlan. Extraído de Turner et al. (1992a).

.11 .18

Figura 11.14: Diagramas $\mathrm{Zr}$ em rocha total versus $\varepsilon_{\mathrm{Nd}}$ e $(\mathrm{Si}+\mathrm{Na}+\mathrm{K}) /(\mathrm{Ca}+\mathrm{All})$ em anfibólio versus $\varepsilon_{\mathrm{Nd}}$ para granitos Tipo-A alcalinos do Complexo Anorogênico da Córsega. Extraído de Poitrasson et al. (1995).

Figura 11.15: Diagrama $N d$ versus $\varepsilon_{N d}$ para granitos Tipo-A alcalinos do Complexo Anorogênico da Córsega. Extraído de Poitrasson et al. (1995).

Figura II.16: Esquema mostrando a evolução de um orógeno desde o estágio colisional (A) até os estágios pós-colisionais (B). Para detalhes, ver texto. Extraído de Turner et al. (1992b).

Figura II.17: Níveis estruturais relacionados ao magmatismo granítico Tipo-A. Para detalhes, ver texto. Extraído de Bonin (1996).

Figura III.1: Compartimentação tectónica do embasamento da Plataforma Sul-Americana nos Estados de São Paulo, Paraná e Santa Catarina. Adaptado de Hallinan et al. (1993).

Figura III.2: Modelo gravimétrico e perfil de idades de resfriamento (K-Ar). Adaptado de Mantovani et al. (1989) e Siga Jr. et al. (1989).

Figura Ill.3: Perfil geológico da regiäo compreendida entre os Cinturões Ribeira e Dom Feliciano. Adaptado de Basei et al, (1992).

Figura 111.4: Diagramas discriminatórios de granitos Tipo-A. Dados geoquímicos extraídos de Kaul (1997). Círculos preenchidos: granitos Tipo-A aluminosos; triângulos vazios: granitos Tipo-A alcalinos. Médias dos granitos Tipo-I, -S e -M segundo Whalen et al. (1987) (a), (b), (c): campos dos granitos Tipo-1, -S e - M segundo Whalen et al. (1987). (d): campos segundo Pearce et al. (1984). Em (b), $\mathrm{FeO}^{*}=$ todo ferro calculado como FeO.

Figura III.5: Vista das serras da região da Serra da Graciosa a partir do primeiro planalto paranaense. Foto tirada na da BR-116 nas proximidades da cidade de Curitiba (vista para NE).

Figura III.7: Esboço da situação dos maciços de granitos alcalinos da Serra do Mar no Estado do Paraná segundo Maack (1961). 
Figura III.6: Mapa de pontos de afloramento e toponímia da região da Serra da Graciosa Anexo

Figura III.8: Composições de imagens Landsat $5(T M)$ da região da Serra da Graciosa Anexo

Figura III.9: Modelo Digital de Terreno (MDT) e mapas aerogeofísicos da região da Serra da Graciosa Anexo

Figura III.10: Esboço geológico dos maciços graníticos da região da Serra da Graciosa Anexo

Figura IV.1: llustração do procedimento adotado para integração composicional em felsdpatos alcalinos pertíticos. Acima, fotomicrografia mostrando a localização dos pontos analíticos. Intermediário, imagem de elétrons retro-espalhados com áreas representativas de núcleo e borda delimitadas. Abaixo, histogramas obtidos no programa Corel PHOTO-PAINT mostrando a freqüência relativa de pixels por tonalidade de cinza.

Figura IV.2: Diagrama modal Quartzo (Q) - Feldspato alcalino (A) - Plagioclásio (P) mostrando as variações composicionais nas associações alcalina 1, alcalina II e aluminosa dos Granitos da Graciosa (PR). Campos segundo Streckeisen (1976). Campos: I - álcali-feldspato granito; II - sienogranito; III - monzogranito; IV - granodiorito; V - álcali-feldspato quartzo sienito; VI - álcali-feldspato sienito; VII - monzonito; VIII - quartzo monzodiorito

Figura IV.3: Diagramas binários mostrando a variação nos teores de minerais máficos em função do parâmetro $[Q /(Q+F A+P)]$ para as associações alcalina I, alcalina II e aluminosa dos Granitos da Graciosa (PR). $M=$ somatória de todos os máficos. IV.10

Figura IV.4: Quadro interpretativo da seqüência de cristalização das rochas das associações alcalinas dos Granitos da Graciosa (PR)

Figura IV.5: Quadro interpretativo da sequêencia de cristalização das rochas da associação aluminosa dos Granitos da Graciosa (PR)

Figura IV.6: Composições das olivinas da associação alcalina I dos Granitos da Graciosa no diagrama catiônico $M n \times$ Fe $\times M g$.

Figura IV.7: Correlação entre as proporções catiônicas de $\mathrm{Fe} \times[\mathrm{Mn}+\mathrm{Mg}]$ em olivinas da associação alcalina I dos Granitos da Graciosa.

Figura IV.8: Composiçōes dos clinopiroxênios das associações alcalinas e dos quartzo sienitos dos Granitos da Graciosa no diagrama catiônico $\mathrm{Ca} \times \mathrm{Mg} \times\left[\mathrm{Fe}^{2+}+\mathrm{Mn}\right]$. IV.35

Figura IV.9: Composiçôes dos clinopiroxênios da associação alcalina l e dos quartzo sienitos dos Granitos da Graciosa no diagrama catiônico $\mathrm{Mn} \times \mathrm{Fe}^{2+} \times \mathrm{Mg}$. IV.35 
Figura IV.10: Correlação entre as proporções catiônicas de $\left[\mathrm{Na}+\mathrm{Fe}^{3+}\right] \times\left[\mathrm{Ca}+\mathrm{Fe}^{2+}+\mathrm{Mg}+\mathrm{Mn}+\mathrm{Al}\right]$ em clinopiroxênios da associação alcalina 1 e dos quartzo sienitos dos Granitos da Graciosa em diagrama.

Figura IV.11: Composições dos clinopiroxênios da associação alcalina 1 e dos quartzo sienitos dos Granitos da Graciosa no diagrama catiônico $\mathrm{Na} \times \mathrm{Mg} \times\left[\mathrm{Fe}^{2+}+\mathrm{Mn}\right]$. IV. 36

Figura IV.12: Diagramas catiônicos $[\mathrm{Ca}+\mathrm{Na}]_{8} \times[\mathrm{Na}]_{8}$ de classificação dos anfibólios das associações (a) alcalina I: (b) alcalina II; (c) aluminosa; e (d) das rochas monzodioríticas e associadas dos Granitos da Graciosa (segundo a IMA - Leake et al., 1997) IV. 45

Figura IV.13: Diagramas catiônicos Si $\times\left[\mathrm{Mg} /\left(\mathrm{Mg}+\mathrm{Fe}^{2+}\right)\right]$ de classificação dos anfibólios das associações alcalinas e aluminosa dos Granitos da Graciosa (segundo a IMA -- Leake et al., 1997).

Figura IV.14: Diagramas catiônicos $[\mathrm{Na}]_{\mathrm{B}} \times[\mathrm{Na}+\mathrm{K}]_{\mathrm{A}}$ de classificação dos anfibólios das associaçóes (a) alcalina I; (b) alcalina II; (c) aluminosa; e (d) das rochas monzodioríticas e associadas dos Granitos da Graciosa (segundo Leake et al., 1997) IV. 49

Figura IV.15: Correlação entre as proporções catiônicas de $\left([\mathrm{Na}+\mathrm{K}]_{A}+\mathrm{R}^{2+}+\mathrm{Si}\right) \times\left([\mathrm{Na}]_{8}+\mathrm{Fe}^{3+}+{ }^{\mathrm{V}} \mathrm{Al}\right)$ em anfibólios das associações alcalina I, alcalina II, aluminosa e das rochas monzodioríticas e associadas dos Granitos da Graciosa.

Figura IV.16: Correlação entre as proporções catiônicas $[\mathrm{Si}+\mathrm{Na}+\mathrm{K}] \times\left[\mathrm{Ca}+{ }^{\mathrm{V}} \mathrm{Al}\right]$ em anfibólios das associaçōes (a) alcalina I; (b) alcalina II; (c) aluminosa; e (d) das rochas monzodioríticas e associadas dos Granitos da Graciosa. Em (a) e (b), inclui esboços mostrando as tendências evolutivas mais importantes ( $N$ - núcleo; $B$ - borda).....

Figura IV.17: Correlação entre as proporções catiônicas $[\mathrm{Si}+\mathrm{Na}+\mathrm{K}] \times[\mathrm{Na}+\mathrm{K}] / \mathrm{Al}$ ern anfibólios das associaçōes (a) alcalina I e (b) alcalina II dos Granitos da Graciosa. IV. 52

Figura IV.18: Correlação entre as proporções catiônicas Si $x[\mathrm{Na}+\mathrm{K}]_{\mathrm{A}}$ em anfibólios das associações (a) alcalina I (apenas Amostra 78A); e (b) alcalina II dos Granitos da Graciosa. Curvas mostram tendências evolutivas mais importantes $(\mathrm{N}$ - núcleo; $\mathrm{B}$ - borda). IV.53

Figura IV.19: Correlação entre as proporções catiônicas $[\mathrm{Si}+\mathrm{Na}+\mathrm{K}] \times\left[\mathrm{Na}_{\mathrm{B}}+\mathrm{Fe}^{3+}\right]$ em anfibólios das associações (a) alcalina I; e (b) alcalina II dos Granitos da Graciosa. Curvas mostram tendências evolutivas mais importantes. IV. 54

Figura IV.20: Correlação entre as proporções catiônicas $[\mathrm{Na}+\mathrm{K}]_{\mathrm{A}}+{ }^{\mathrm{IV}} \mathrm{Al}+\mathrm{Fe}^{3+}+1 / 2 \mathrm{Ti} \times{ }^{\mathrm{IV}} \mathrm{Al}$ em anfibólios (a) da associação aluminosa; e (b) das rochas monzodioríticas e associadas dos Granitos da Graciosa. IV. 55 
Figura IV.21: Correlação entre as proporções catiônicas $\mathrm{Fe} /[\mathrm{Fe}+\mathrm{Mg}] \times \mathrm{Al}^{\mathrm{ll}}$ em biotitas das associaçôes (a) alcalinas e (b) da associação aluminosa e das rochas monzodioríticas e associadas dos Granitos da Graciosa.

Figura IV.22: Correlação entre as proporções catiônicas [Soma_- $\left.Y+0,5^{*} \mathrm{Al}^{\mathrm{VI}}+\mathrm{Ti}\right] \times \mathrm{Al}^{\mathrm{lv}}$ em biotitas das associações (a) alcalinas e (b) da associação aluminosa e das rochas monzodioríticas dos Granitos da Graciosa.

Figura IV.23: Correlação entre as proporções catiônicas Si x Soma X em biotitas das associaç̄os (a) alcalinas e (b) da associação aluminosa e das rochas monzodioríticas dos Granitos da Graciosa. IV.62

Figura IV.24: Diagramas catiônicos $[\mathrm{Fe}+\mathrm{Mg}+\mathrm{Mn}]^{\gamma} \times \mathrm{Ti}$ mostrando a variabilidade química observada em biotitas das associações alcalinas dos Granitos da Graciosa. IV.63

Figura IV.25: Correlação entre as proporçôes catiônicas $[\mathrm{Fe}+\mathrm{Mg}+\mathrm{Mn}]^{\mathrm{Y}} \times \mathrm{Al}^{\mathrm{vl}}$ em biotitas da associação aluminosa e das rochas monzodioríticas dos Granitos da Graciosa. IV. 63

Figura IV.26: Diagrama ternário An-Ab-Or (proporções moleculares) com representação das composições de plagioclásio e feldspato alcalino (a) da associaçăo aluminosa; (b) das rochas monzodoriíticas e associadas; (c) da associação alcalina 1; e (d) da associação alcalina II dos Granitos da Graciosa. As composições dos feldspatos alcalinos representam valores integrados de zonas de núcleo e borda de grãos. Linhas representadas em (a) e (b) unem fases coexistentes. IV.70

Figura IV.27: Imagens e perfís analíticos quantitativos (WDS) para cristais selecionados de plagioclásio. (a) de sienogranito (Amostra 7B) da associação aluminosa e (b) de monzodiorítico (Amostra 59E). Acima: imagem otica digital; ao meio, imagem composicional (BEl), abaixo variações composicionais expressas em termos das moléculas de Anortita (An), albita (Ab) e ortoclásio (Or). Espaçamento entre análises sucessivas: (a) $10 \mu \mathrm{m}$; (b) $15 \mu \mathrm{m}$ IV.72

Figura IV.28: Diagrama comparativo para temperaturas de saturação de $\operatorname{Zr}(\mathrm{TZr})$ e P(TAp) obtidas para amostras dos Granitos da Graciosa. Símbolos como na Figura IV.2. Temperaturas fixas de $600^{\circ} \mathrm{C}$ correspondem a valores obtidos para amostras com caracteristicas químicas fora do limite aceitável para aplicação do método de cálculo correspondente.

Figura IV.29: Composiçōes dos feldspatos da associação aluminosa e das rochas monzodioríticas no diagrama An x Ab x Or. Em cinza, curvas do solidus para a temperatura indicada e "tie-lines" para $800^{\circ} \mathrm{C}$ (segundo modelo de Elkins e Grove, 1990). Símbolos como na Figura IV.2. IV.78 
Figura API.1: Composições PC1 (R) - PC2(G) - PC3(B). Amostras (a) 11A; (b) 3A; (c) 9 API.13

Figura API.2: Histograma mostrando a freqüência relativa de simulaçöes que levaram a médias iguais aos valores esperados com nivel de confiabilidade de $95 \%$

API.14

Figura API.3: Histogramas mostrando os módulos dos desvios relativos das médias em relação ao valor esperado ([observado - esperado]/valor esperado). Amostras (a) 11A, (b) 3A, (c) 9

API.15

Figura AP1.4: Histograma mostrando a freqüência relativa de simulações que levaram a desvios padrão observados iguais aos esperados com nível de confiabilidade de $95 \%$. API.16

Figura API.5: Histogramas mostrando os módulos dos desvios relativos dos desvios padrão em relação aos esperados ([valor - esperado]/ esperado). Amostras (a) 11 A, (b) 3A, (c) 9 API.17

Figura API.6: Histograma mostrando a freqüência relativa de simulações que levaram a desvios padrão observados iguais aos esperados por uma distribuição binomial, com nível de confiabilidade de 95\%. De FK a Plag, integração dos resultados de testes de Razão de Variancias; Neilson e Brockman corresponde a um método que considera todos os minerais de cada amostra. API. 19

Figura APIl.1: Diagrama NaB x [Ca+ Na]B de classificação dos anfibólios (Leake et al., 1997) mostrando a diversidade composicional do conjunto analisado. Cátions calculados com base no método de Schumacher (in Leake et al., 1997) APII.3

Figura APII.2: Histograma mostrando a freqüència relativa com que cada critério cristalográfico foi utilizado pelo método de Schumacher (in Leake et al., 1997) para o conjunto total de dados. APII.5

Figura APII.3: Histograma mostrando a freqüência relativa com que determinadas combinações de critérios cristalográficos foram utilizadas pelo método de Schumacher (in Leake et al., 1997) para cada um dos grupos principais de anfibólios (classificação segundo Leake et al., 1997). Combinações com freqüência relativa menor que 0.01 foram omitidas. APII.3 


\section{RESUMO}

O estudo geológico de campo, integrado com a caracterização petrográfica de fácies e o tratamento de imagens de satélite e de dados aerogamaespetrométricos levou à compartimentação do denominado "Maciço Graciosa" em três unidades independentes: Maciço Capivari, Maciço Órgãos e Maciço Farinha Seca que, juntamente com os Maciços Marumbi e Anhangava são aqui denominados Granitos da Graciosa. Em geral, estes maciços têm formas elípticas com orientação NESW e áreas entre $34 \mathrm{e} 100 \mathrm{~km}^{2}$.

Quatro associações petrográficas foram reconhecidas. A associação alcalina / é caracterizada por álcali-feldspato sienitos do Maciço Anhangava e ocorrências isoladas de álcali-feldspato granitos do Maciço Farinha Seca, que mostram paragêneses máficas variáveis com o aumento nos teores de quartzo. Nas variedades mais máficas ocorrem anfibólio cálcico + clinopiroxênio tolivina (+allanita + titanita + ilmenita +zircão +apatita), enquanto anfibólio cálcico-sódico (+chevkinita-perrierita) ou sódico é o máfico essencial dos termos intermediários em diante. Biotita e anfibólio sódico se formam nos estágios pós-magmáticos, substituindo anfibólio cálcico-sódico. Álcali-feldspato granitos com anfibólio - Maciços Farinha Seca e Órgãos - compõem a associação alcalina Il. que contrasta com a anterior por apresentar intervalos restritos de variação modal, porém espectro composicional dos anfibólios semelhante. Biotita granitos (s.s.) com anfibólio (+titanita +allanita + magnetita +ilmenita) dos Maciços Capivari, Órgãos. Anhangava e Marumbi caracterizam a associação aluminosa. De maneira geral, as variedades mais ricas em feldspato alcalino são as mais pobres em quartzo. As rochas monzodioríticas têm afinidade potássica e são caracterizadas pela paragênese biotita +anfibólio cálcico + clinopiroxênio augítico + magnetita +ilmenita. Aparecem como ocorrências discretas isoladas, com algumas evidências de relaçōes locais de hibridismo com magmas graníticos

De maneira geral, os minerais máficos presentes em todas as associações são ricos em Fe e pobres em $\mathrm{Mg}$ e Al. Os anfibólios são importantes indicadores da evolução química dos magmas, particularmente nas associações alcalinas, em que mostram extenso espectro composicional desde anfibólios cálcicos até sódicos. Na associação a/calina l, os anfibólios cristalizam em condiçōes progressivamente mais oxidantes e alcalinas; na associação alcalina Il, as condições iniciais são algo mais oxidantes e tendem a redutoras nos estágios finais; já na associaçāo a/uminosa, os anfibólios são cálcicos e se destacam pela homogeneidade; os anfibólios magnesianos das rochas monzodioríticas são muito distintos dos anteriores, assim como os clinopiroxênios. O plagioclásio da associação 
aluminosa varia de oligoclásio a albita cálcica, enquanto o dos monzodioritos varia de labradorita a oligoclásio. Os maiores teores de Or nos feldspatos alcalinos são observados nas rochas subsolvus $\left(\mathrm{Or}_{65-97}\right)$, sendo menores nas hipersolvus $\left(\mathrm{Or}_{35-65}\right)$.

As pressões de cristalização foram estimadas em $2 \pm 0,6 \mathrm{kbar}$ para as rochas monzodioriticas (Al-em-hornblenda). As temperaturas liquidus e solidus dos magmas graníticos foram de $800-900^{\circ} \mathrm{C}$ e $700-750^{\circ} \mathrm{C}$, respectivamente, tanto para as associações alcalinas $\left(\mathrm{T}_{\mathrm{zr}}\right.$ e temperatura mínima de estabilidade de feldspatos ternários a $\mathrm{P}_{\mathrm{H} 2 \mathrm{O}}=2 \mathrm{kbar}$ ) como para a aluminosa $\left(\mathrm{T}_{\mathrm{Ap}}\right.$ e hornblendaplagioclásio). Para as rochas monzodioríticas, os melhores valores são $1000^{\circ} \mathrm{C}\left(\mathrm{T}_{\mathrm{Ap}}\right)$ e $750^{\circ} \mathrm{C}$ (hornblenda-plagioclásio).

A comparação dos Granitos da Graciosa com províncias análogas sugere envolvimento de fontes mantélicas na geração da associação alcalina /; porém, a ligaçāo com magmas primários básico-intermediários portadores de plagioclásio é incerta. As características da associaçăo alıminosa parecem mais compatíveis com fontes da crosta inferior. As rochas monzodioríticas constituem provavelmente uma linhagem magmática discreta, não vinculada diretamente com os magmas graníticos e sieníticos. 


\section{ABSTRACT}

Geological fieldwork, integrated with petrographic characterization and the interpretation of satellite images and airborne gamma-ray spectrometric maps led to the division of the so called "Graciosa Massif" in five independent units: the Capivari Massif, the Órgãos Massif and the Farinha Seca Massif, which, together with the Marumbi and Anhangava Massifs are here designated Graciosa Granites. On general grounds, these massifs appear at surface as ellipses oriented along NE-SW direction with 34 to $100 \mathrm{~km}^{2}$ in area.

Four distinct petrographic associations were recognized. The alkaline / association is characterized by alkali-feldspar syenites of the Anhangava Massif and isolated occurrences of alkalifeldspar granites of the Farinha Seca Massif, which show mafic paragenesis variable according to the increase in quartz contents. In the more mafic varieties, calcic amphibole + clinopyroxene \pm olivine (+allanite +titanite +ilmenite +zircon + apatite) occur, while calcic-sodic or sodic amphibole is the essential mafic phase in the intermediate (bearing chevkinite-perrierite) and the more felsic varieties. Biotite and sodic amphibole form in the post-magmatic stages, substituting calcic-sodic amphibole. Amphibole-bearing alkali-feldspar granites - Farinha Seca and Órgãos Massifs - compose the alkaline // association, which contrasts with the preceding one by presenting a more restricted interval of modal variation, although the compositional range of the amphiboles is similar. Biotite granites (s.s.) bearing amphibole (+titanite + allanite + magnetite +ilmenite) of the Capivari, Órgãos, Anhangava and Marumbi Massifs characterize the aluminous association. In general, the varieties richer in alkalifeldspar also have the lowest quartz contents. The monzodioritic rocks have potassic affinity and are characterized by the paragenesis biotite + calcic amphibole + augitic clinopyroxene + magnetite +ilmenite. They appear as discrete isolated occurrences showing evidence of local mingling with granitic magmas.

The mafic minerals present in all associations are, on general, Fe-rich, with correspondingly low $\mathrm{Mg}$ and $\mathrm{Al}$ contents. The amphiboles are important indicators of the chemical evolution of the magmas, particularly in the case of the alkaline associations, in which they present a large range of compositions, from calcic to sodic. In the alkaline / association, the amphiboles crystallize in progressively more oxidant and alkaline conditions; in the a/kaline // association, the initial conditions are somewhat more oxidizing and shift to reducing in the final stages; in the aluminous association, on the other hand, the amphiboles are calcic and comparatively homogeneous, while the Mg-rich amphiboles of the monzodioritic rocks are contrasted, as well as their clinopyroxenes. Plagioclase 
from the aluminous association varies from oligoclase to calcic albite, while in the monzodiorites it varies from labradorite to oligoclase. Higher contents of Or in the alkali-feldspars are observed in the subsolvus rocks $\left(\mathrm{Or}_{65-97}\right)$, when compared to the hypersolvus ones $\left(\mathrm{Or}_{35-65}\right)$.

The crystallization pressures were estimated in $2 \pm 0.6$ kbar for the monzodioritic rocks (Al-inhornblende). The liquidus and solidus temperatures of the granitic magmas were $800-900^{\circ} \mathrm{C}$ and $700-750^{\circ} \mathrm{C}$, respectively, both for the alkaline $\left(\mathrm{T}_{\mathrm{zr}}\right.$ and minimum temperature of stability of ternary feldspars at $P_{H 12 O}=2 \mathrm{kbar}$ ) and aluminous associations $\left(T_{A p}\right.$ and hornblende-plagioclase). For the monzodioritic rocks, the best values are $1000^{\circ} \mathrm{C}\left(\mathrm{T}_{\mathrm{Ap}}\right)$ and $750^{\circ} \mathrm{C}$ (hornblende-plagioclase).

The comparison of the Graciosa Granites with analogous provinces suggests the involvement of mantle sources in the genesis of the alkaline / association; however, the connection with plagioclasebearing basic-intermediate primary magmas is uncertain. The characteristics of the aluminous association seem compatible with sources of the lower crust. The monzodioritic rocks are probably a distinct magmatic series, not directly related to the granitic and syenitic magmas. 


\section{AGRADECIMENTOS}

Depois de quase dez anos como aluno da Universidade de Sāo Paulo, na iminência de meu desligamento, aproveito a oportunidade para agradecer às pessoas que guiaram minha carreira como geólogo.

É neste sentido que dedico este trabalho à pessoa que mais tempo e esforço concentrou na minha formaçăo. Uma das raras pessoas que merecem o título de Orientador. Que soube me conduzir por um longo caminho, respeitando e despertando meus interesses. Tenho consciência do enorme papel que já exerceu na minha vida e por isso me orgulho ao dedicar este trabalho a Silvio Roberto Farias Vlach, um grande amigo, professor, e, definitivamente, um Mestre.

Muitas outras pessoas foram importantes ao longo deste período, mas duas tiveram papel especial na minha formação, pelo exemplo como amigos e professores. Não poderia deixar de agradecer a Valdecir de Assis Janasi e Cláudio Riccomini, por tudo que me ensinaram.

Dois amigos também merecem destaque especial: Lucelene Martins e Marcos de Souza Mansueto, meus fiéis companheiros no dia-a-dia.

A importância da minha família não precisa ser aqui destacada. Agradeço a meus pais, irmãos e também aos meus padrinhos de casamento, meus maiores amigos.

Minha querida esposa. Maria Luisa, merece muito mais do que posso oferecer nessa página, mas devo pelo menos agradecer pelos dias e noites que passou me ajudando na conclusăo desse volume.

No âmbito do presente trabalho recebi o apoio de diversas pessoas, a quem sou grato, em especial os Profs. Drs. Francisco J. F. Ferreira (UFPR) e Wladimir Shukowsky (IAG-USP), a Dra. Monica Perrotta (CPRM) e os colegas Alexandre Camier Nunes da Silva e George de Barros, pelo auxílio nas etapas de tratamento e interpretação de imagens. Agradeço também aos meus companheiros nos trabalhos de campo: Alessandro Rappini, André Stern, Daniel Fernandes Jelin e Maria Raquel de Carvalho. Estendo meus agradecimentos a José Paulo Sertek, Paulo Mori e Sandra de Andrade, pelo apoio nas etapas analíticas. Gostaria de lembrar também de Renato Paes de Almeida, pela revisão de parte do texto, e pelo entusiasmo nas discussões geológicas.

Finalmente, agradeço à FAPESP pelo apoio recebido através do processo 98/15656-7. 
Parte 1:

INTRODUCÃO 


\section{ÍNDICE}

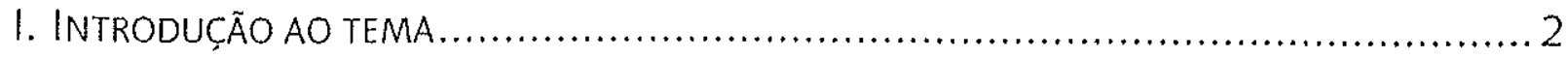

II. ABORDAGEM METODOLÓGICA E ESTRUTURA DA DISSERTAÇĀO ................................ 2

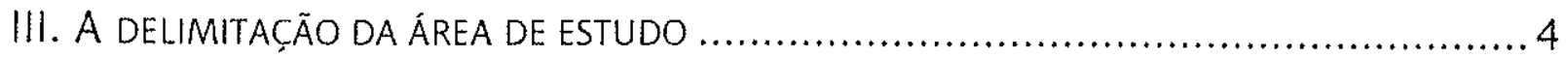

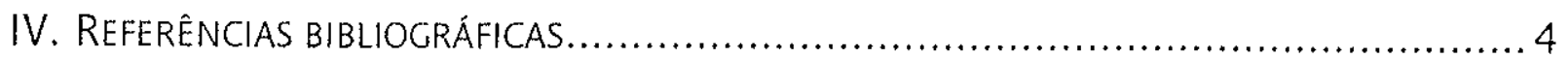




\section{INTRODUÇÃO AO TEMA}

Desde que os granitos Tipo-A foram propostos como um grupo independente de granitos por Loiselle e Wones há mais de 20 anos, muitos autores têm discutido a propriedade desta distinção (e.g. Whalen et al., 1987; Eby, 1990. 1992; Hogan et al., 1992; Pitcher, 1995; King et al., 1997; entre muitos outros).

A maior dificuldade parece ser a reunião, em um mesmo grupo, de rochas com afinidades geoquímicas contrastantes, peralcalinas por um lado e peraluminosas por outro, e formadas em ambientes geotectônicos variados (e.g. pós-colisionais, anorogênicos). Por outro lado, a singularidade geoquímica deste grupo é marcante, e certamente aponta para aspectos comuns na sua origem e evolução (Pitcher, 1995).

A coexistência de granitos Tipo-A metaluminosos a peralcalinos (associação alcalina; Lameyre e Bowden, 1982) e meta- a peraluminosos (associação aluminosa) em ambientes pós-colisionais permite estudar as diferentes fontes e processos que levam à formação da diversidade observada nos granitos Tipo-A. Sendo assim, o presente trabalho foi concebido como parte de um projeto mais amplo de estudo das associações alcalina e aluminosa de granitos Tipo-A.

Associaçōes de ambos os tipos estão presentes na região Sul do Brasil em mais de uma dezena de maciços graníticos e sieníticos que compõem a Província Serra do Mar (Kaul, 1984; Vlach et al., 1996). formada ao final do Ciclo Brasiliano por importante magmatismo pós-colisional. Destacam-se as ocorrências nas proximidades da Serra da Graciosa (Maciço Graciosa - Cordani e Girardi, 1967; Fuck et al., 1970; Maciço Anhangava - Fuck, 1966; e Maciço Marumbi - Cordani e Girardi, 1967). que são o objeto do presente trabalho (cf. Figura III.1).

\section{ABordagem METOdológICA E ESTRUTURA DA DISSERTAÇ̃̃o}

Granitos Tipo-A têm sido alvo de um grande número de estudos petrológicos nos últimos anos. A grande maioria destes trabalhos se fundamenta em dados geoquímicos, principalmente isotópicos. e o objetivo comum é identificar a importância relativa de fontes crustais e mantélicas na geração deste grupo de rochas. Com base nas informaçōes disponiveis, alguns modelos vêm sendo propostos como responsáveis pela geração destas rochas (Parte II). 
Entretanto, o fato de nestas suites predominarem amplamente tipos diferenciados dificulta a identificação de trajetórias de diferenciação. Essa virtual inexistência de termos poucos diferenciados. juntamente com o potencial fracionamento de diversas fases, normalmente torna o problema de difícil solução. A situação é ainda dificultada pela freqüente sobreposição de processos pósmagmáticos.

O resultado é que apesar do crescente esforço analítico, que tem possibilitado uma caracterizaçăo mais detalhada de diversas localidades, a compreensão dos processos de geração e evolução dos magmas formadores de granitos Tipo-A, depois de um grande salto no início dos anos 90 , tem progredido de maneira relativamente lenta nos últimos anos.

Por outro lado, a caracterizaçāo mineralógica detalhada - tanto textural como química - tem se firmado cada vez mais como importante chave para a descrição e compreensão de processos magmáticos e pós-magmáticos. Ainda assim, pelo menos nos estudos petrológicos mais convencionais, ela não tem sido utilizada amplamente até o momento.

Diante deste panorama, o presente trabalho tem como foco principal a descrição detalhada da evolução textural e química das principais fases minerais presentes, como chave para a identificaçāo dos processos envolvidos na gênese de granitos Tipo-A (Parte IV).

Como os maciços que compōem a Província Serra do Mar - as ocorrências aqui estudadas inclusive - foram alvo apenas de trabalhos de cunho geral (Kaul, 1984, 1997; Siga Jr., 1995), este detalhamento tem de ser precedido por uma caracterização geológica e petrográfica geral (Parte III).

Alguns desdobramentos, apenas indiretamente relacionados ao tema principal desta dissertação, acabaram sendo desenvolvidos ao longo da pesquisa. Os principais foram uma avaliação dos métodos de estimativa de composiçōes modais e dos erros envolvidos (Apêndice l), além de uma avaliação crítica do método de Schumacher de estimativa, a partir de ferro total, das proporçōes entre $\mathrm{Fe}^{2+}$ e $\mathrm{Fe}^{3+}$ em anfibólios (Apêndice 1 ).

A forma de organização escolhida segue a seqüência (crono)lógica em que o trabalho foi desenvolvido. Além disso, cada uma das partes tem como base uma abordagem específica, e conseqüentemente, uma metodologia associada, justificando a sua individualização. Por fim, cada uma foi construída independentemente das demais, com o objetivo de facilitar a posterior publicação. 


\section{A DELIMITAÇÃO DA ÁREA de ESTUdDo}

O projeto original previa o estudo "apenas" do Maciço Graciosa. De acordo com a literatura existente naquele momento (e.g. Maack. 1961; Kaul. 1997), este maciço apresentava uma combinação de características favoráveis a um estudo de granitos Tipo- $A$, principalmente a coexistência de rochas de associaçōes aluminosas a alcalinas bem como de variedades dioríticas.

Os trabalhos de campo mostraram que o denominado "Maciço Graciosa" é composto, de fato, por pelo menos três maciços independentes. Estes, juntamente com os Maciços Anhangava e Marumbi, constituem um conjunto geologicamente coerente nesta região da Província Serra do Mar. e, portanto, o seu estudo integrado se mostrou uma alternativa mais interessante.

Por outro lado, as características naturais da área (e.g. alta declividade, densa cobertura vegetal, etc.) impuseram severas limitações de acesso à área, impedindo o mapeamento faciológico bem como uma amostragem adequada de diversas regiões, de tal forma que o detalhamento geológico originalmente previsto foi prejudicado. Neste sentido, a expansão da área - sobretudo a inclusão do Maciço Anhangava - permitiu que uma maior variedade de tipos petrográficos fosse estudada, possibilitando uma melhor caracterização das associações petrográficas presentes na área.

\section{REFERÊNCIAS BIBLIOGRÁFICAS}

Cordani, U.G.; Girardi, V.A.V. (1967) Geologia da Folha de Morretes. Boletim da Universidade Federal do Paraná, Geologia, 26:Y-40.

Eby, G.N. (1990) The A-type granitoids: A review of their occurrence and chemical characteristics and speculations on their petrogenesis. Lithos, 26: 115-134.

Eby, G.N. (1992) Chemical subdivision of the A-type granitoids: Petrogenetic and tectonic implications. Geology. 20: 641-644.

Fuck, R.A.: Muratori, A.; Trein, E.; Bertoldo, A.; Hausen, J. (1970) Rio Capivari. folha geológica 1:70.000. Comissão da Carta Geológica do Paraná. Paraná.

Hogan, M.C.; Gilbert, M.C.; Weaver, B.L. (1992) A-type granites and rhyolites: Is A for ambiguous? EOS, 73: 508.

Kaul, P.F.T. (1984) Significado dos granitos anorogênicos da Suite Intrusiva Serra do Mar na evolução da crosta do sul-sudeste do Brasil. no âmbito das folhas SG-22. Curitiba e SG-23. Iguape. In: CONCRESSO BRASILEIRO DE GEOLOGIA, 33. Rio de Janeiro. SBG, Anais... 6:2815-2825.

Kaul, P.F.T. (1997) O magmatismo na Serra do Mar e adjacências (Sul do Brasil) no final do Neoproterozoico e seus condicionantes tectônicos. Tese de Doutoramento. IG-USP. Inédita. $293 \mathrm{p}$. 
King. P.L.; White, A.J.R.; Chappel, B.W.; Allen, C.M. (1997) Characterizations and origin of aluminous A-type granites from the Lachlan Fold Belt, Southeastern Australia. Journal of Petrology. 38(7): 371 - 391.

Lameyre, J. e Bowden, P. (1982) Plutonic rock type series: discrimination of various granitoid series and related rocks, Journal of Volcanology and Geothermal Research. 14: 169-189.

Pitcher. W. S. (1995) Origin and nature of granite. Blackie Academic \& Professional. New York. 321 p.

Siga Jr., O (1995) Domínios tectónicos do sudeste do Paraná e nordeste de Santa Catarina: geocronologia e evolução crustal. Tese de Doutoramento. IG.USP. Inédita. 164 p.

Whalen. J.B.: Currie, K.L.; Chappel, B.W. (1987) A-type granites: Geochemical characteristics, discrimination and petrogenesis. Contributions to Mineralogy and Petrology, 95: 407-419. 
Parte //:

MAGMATISMO GRANÍTICO TIPO-A:

Uma revisão das idéias atuais 


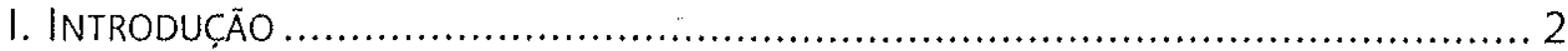

II. CARACTERÍSTICAS PETROGRÁFICAS E MINERALÓGICAS.................................... 3

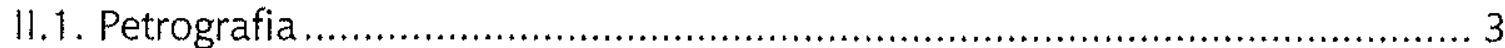

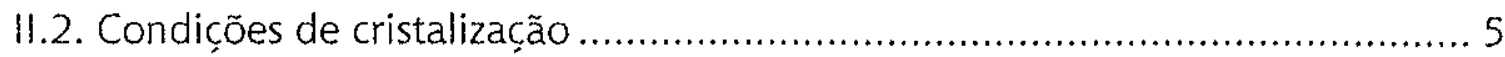

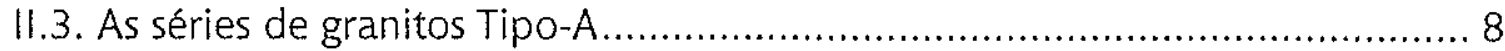

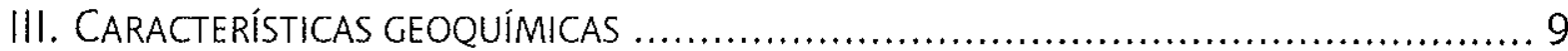

III.1. Geoquímica de elementos maiores e traços........................................... 9

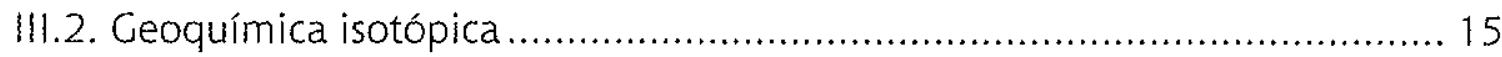

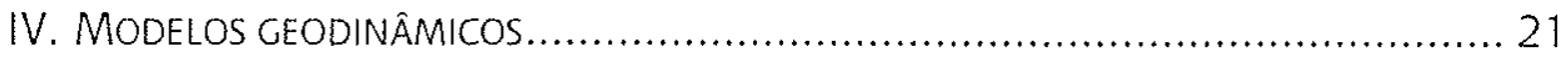

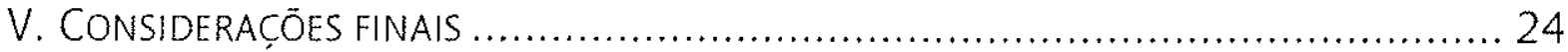

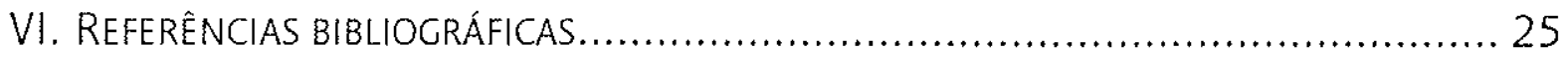




\section{INTRODUÇÃO}

Os granitos Tipo-A foram definidos originalmente por Loiselle e Wones em 1979 com o intuito de separar um grupo de rochas tipicamente formadas em ambiente anorogênico (intraplaca ou zonas de rift), anidras e normalmente de tendência alcalina (mas também incluindo tipos peraluminosos). das rochas graníticas mais comuns, pertencentes aos grupos I, S e M (cf. Eby, 1990; Hogan et al., 1992: Pitcher, 1993).

Desde então, diversos trabalhos têm discutido a viabilidade e a validade dessa subdivisão (Whalen et al., 1987; Eby, 1990, 1992; King et al., 1997, entre outros).

Se por um lado, parece haver consenso quanto à singularidade geoquímica deste grupo de rochas (altos valores de álcalis, Fe/Mg, F, Zr, Nb, Ga, Y e ETR - exceto Eu, e baixos valores de Ca, Ba e Sr), por outro, parece difícil aceitar um grupo coeso que inclua associaçōes petrográficas contrastadas (alcalinas e aluminosas) formadas em ambientes geodinâmicos variados (pós-colisionais e anorogênicos).

Igualmente diversos são os modelos petrogenéticos propostos, e ainda não se tem claro quais são as fontes de calor e material envolvidas, o que levou Hogan et al. (1992) a descrever este grupo de rochas como Tipo-Ambiguo.

Ainda que seja razoável acreditar que mais de um modelo. envolvendo fontes variadas, tenha de ser invocado para explicar a gênese destas rochas, as características em comum levam à necessidade de aspectos unificadores entre esses modelos.

Recentemente, um grande esforço vem sendo realizado com o objetivo de compreender mais satisfatoriamente a gênese dos granitos Tipo-A. que cada vez mais se confirmam como um grupo independente de rochas graniticas (Eby. 1992; King et al., 1997).

Apresenta-se a seguir uma revisão geral do conhecimento acumulado para os granitos Tipo-A, enfocando características petrográficas e mineralógicas, características geoquímicas: e isotópicas e, finalmente, os modelos geodinâmicos viáveis. 


\section{Características petrográficas e mineralógicas}

\section{II.1. Petrografia}

Os granitos Tipo-A são bastante variáveis do ponto de vista mineralógico e petrográfico. 0 aspecto mais marcante é a coexistência, em proporções variadas, de granitóides hiperso/vus peralcalinos e subsolvus peraluminosos, que dificilmente podem ser acomodados em um grupo com significado petrogenético ou descritivo único.

Torna-se evidente então a necessidade de dividir os granitos Tipo-A em pelo menos duas associaçōes petrográficas fundamentais: (1) uma associação alcalina, que inclui álcali-feldspato granitos hipersolvus, peralcalinos e metaluminosos; (2) uma associaçăo aluminosa, correspondente às variedades graníticas subso/vus metaluminosas ou peraluminosas. (cf. Lameyre e Bowden, 1982; King et al., 1997; Bonin et al., 1998; Liégeois et al., 1998).

\section{Associação alcalina}

Inclui rochas maciças, com amplo predomínio de álcali-feldspato granitos hipersolvus (Figura II.1)

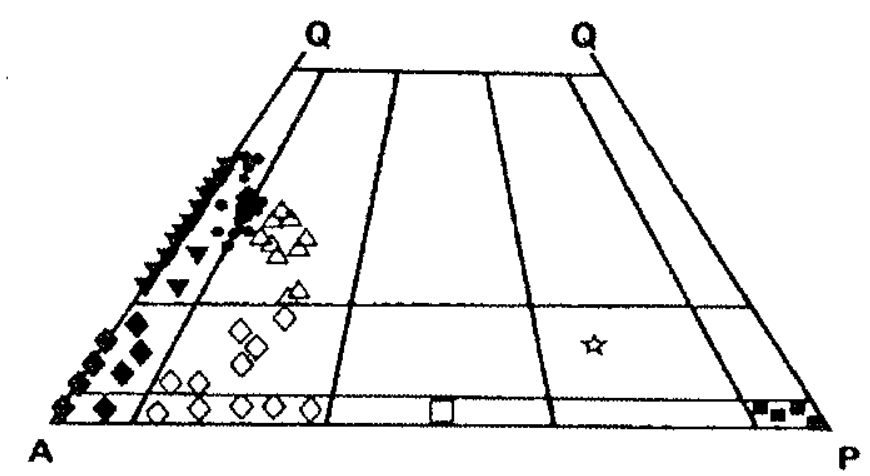

Figura II.1: Composiçôes modais de granitos Tipo-A da Provincia Anorogênica da Nigeria. Extraido de Pitcher (1993).

De maneira geral, feldspato alcalino e quartzo, subidio- a idiomórficos, são as fases dominantes ( $>50 \%$ e $>30 \%$ modal, respectivamente): o feldspato alcalino é sempre mesopertítico, a partir do qual eventualmente se formam cristais de albita independentes ou bordas em continuidade ótica com as lamelás de exsolução. Plagioclásio aparece em pequenas quantidades, como fase tardia, em rochas menos diferenciadas, que foram referidas como transso/vus (Martin e Bonin, 1976). 
Os máficos são pouco abundantes (normalmente $<5 \%$ ), com predomínio de anfibólios, tipicamente cálcico-sódicos (ferrobarroisita e ferrowinchita) e sódicos (riebeckita e arfvedsonita), mas também cálcicos (ferroedenita e ferrohastingsita) nas variedades metaluminosas. Assim como estes anfibólios, biotita, olivina e piroxênio cálcico, quando presentes, são dominados pelas moléculas ricas em Fe e pobres em Al (annita, faialita e hedenbergita respectivamente).

Os acessórios presentes são normalmente ricos em elementos de alto potencial iônico (H.FSE) e elementos terras raras (REE) como zircão, allanita, chevkinita-perrierita, e apatita, além de outros mais exóticos nas variedades peralcalinas como astrofilita, torita, etc.. Fluorita é comum nestas variedades. Dentre os óxidos predomina a ilmenita, sendo a magnetita rara ou ausente. (para detalhes, cf. Turner et al., 1992a; Poitrasson et al.. 1995; Liégeois et al., 1996; Han et al., 1997; Bonin et al., 1998; Hadj-Kaddour et al., 1998).

\section{Associação aluminosa}

Os granitos desta associação săo também maciços, aparecendo predominantemente sieno- e monzogranitos e mais raramente granodioritos e quartzo monzonitos, todos subsolvus (Figura 11.2). Em algumas províncias aparecem ainda álcali-feldspato granitos.

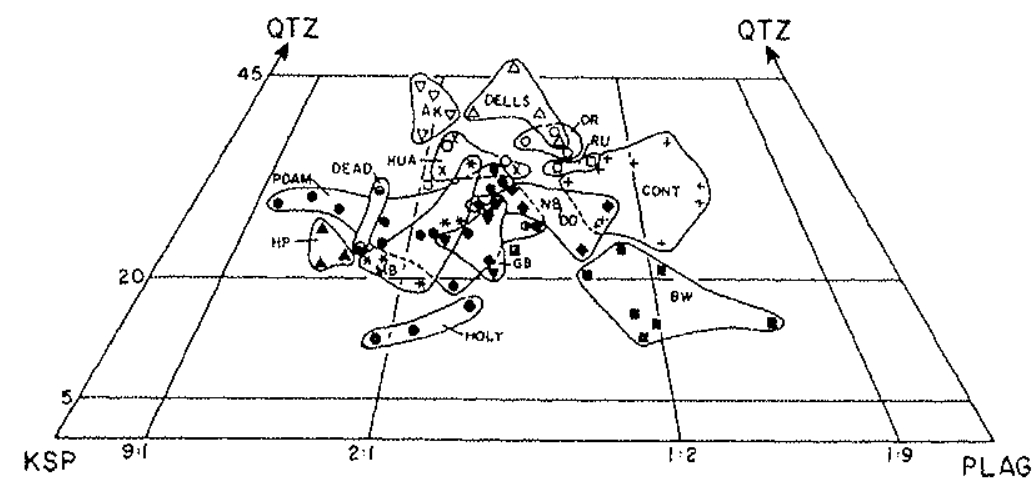

Figura 11.2: Composições modais de granitos da associação aluminosa do Cinturão Anorogênico Transcontinental Norte Americano. Extraido de Anderson e Bender (1989).

De maneira geral, plagioclásio zonado desde andesina nos núcleos até oligoclásio nas bordas é a primeira fase a se cristalizar. Quartzo é a fase seguinte, seguida de feldspato alcalino pertítico, que, tipicamente, apresenta teores de $\mathrm{K}$ menores nos tipos mais diferenciados.

Biotita annítica é o máfico mais importante e está sempre presente ao lado de anfibólio cálcico (ferroedenita e ferrohastingsita) em teores variados; ambos aparecem desde idiomórficos, precoces, 
até intersticiais, tardios. Muscovita e granada sāo observados em alguns tipos peraluminosos. Anfibólios sódicos aparecem em alguns álcali-feldspato granitos.

Os acessórios incluem zircão, apatita; allanita e titanita, além de xenotima e monazita em alguns casos.

llmenita é o óxido mais comum na maioria das províncias (e.g. Cinturão Dobrado Lachlan. Austrália - King et al., 1997; Fennoscandia. Finlândia - Rämö e Haapala, 1995); magnetita é rara ou ausente, diferentemente do que ocorre em outras províncias (e.g. Cinturão Anorogênico Transcontinental da América do Norte - Anderson e Bender, 1989; granitos Jamon e Musa, Leste do Cráton Amazônico - Dall'Agnol et al., 1999), onde magnetita primária é observada.

As características petrográficas e mineralógicas dos granitos rapakivi (e.g. Rämö e Haapala, 1995) permitem inclui-los na associação aluminosa. e por isso eles serão tratados de forma integrada com os demais granitos deste grupo.

\subsection{CONDICÕES DE CRISTALIZACÃO}

Os magmas formadores de granitos Tipo-A são freqüentemente tidos como de alta temperatura, anidros, ricos em $\mathrm{F}$ e reduzidos. As características mineralógicas das rochas dos dois grupos permitem verificar a consistência destas deduções.

\section{Associação alcalina}

Nestas rochas, os máficos anidros cristalizam precocemente como cristais idiomórficos, enquanto os hidratados cristalizam tardiamente, formando cristais isolados ou em agregados intersticiais; este fato evidencia o caráter anidro destes magmas, que só no final da sua cristalização atingem niveis de água altos o suficiente para estabilizar as fases hidratadas. Esta conclusão é corroborada pelo fato de serem raras as ocorrências de pegmatitos (Turner et al., 1992a).

A ausência de xenólitos ou de restitos tem sido interpretada como indicativa de altas temperaturas magmáticas (Whalen et al., 1987; Turner et al., 1992a; Pitcher, 1993, entre outros). Estimativas por métodos diversos (Tabela I.1) levam à conclusão de que as temperaturas magmáticas se situam entre $1000^{\circ} \mathrm{C}$ (liquidus) e $700^{\circ} \mathrm{C}$ (solidus).

A presença comum de cavidades miarolíticas e de rochas vulcânicas associadas em parte significativa dos maciços indica colocação em niveis crustais rasos. Além disso. o caráter hipersolvus 
destes granitos é compatível com baixos teores de água e pressões litostáticas, o que está de acordo com as estimativas barométricas existentes (Tabela 11.1).

Finalmente, as estimativas de fugacidade de oxigênio sugerem condições reduzidas, 2 ou 3 unidades abaixo do tampão QFM (quartzo-failita-magnetita).

Tabela 11.1:

Estimativas de parámetros intensivos a partir de equilibrios minerais

diversos para granitos Tipo-A das associaçōes alcalina e aluminosa

\begin{tabular}{|c|c|c|c|c|c|}
\hline & Local & Temperaturas & $\begin{array}{c}\text { Pressão de colocação } \\
\text { litostática }\end{array}$ & $\begin{array}{l}\text { Fugacidade } \\
\text { de oxigênio }\end{array}$ & Referência \\
\hline \multirow{2}{*}{ 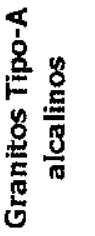 } & $\begin{array}{c}\text { Província Anorogênica } \\
\text { da Córsega (França) }\end{array}$ & $\begin{array}{l}900^{\circ} \mathrm{C} \text { (liquidus) } \\
700^{\circ} \mathrm{C} \text { (solidus) }\end{array}$ & $0,5 \mathrm{kbar}$ & $<\mathrm{QFM}$ & $\begin{array}{l}\text { Poitrasson et al. } \\
\text { (1995) }\end{array}$ \\
\hline & $\begin{array}{c}\text { Cordilheira Padthaway } \\
\text { (Austrália) }\end{array}$ & $\begin{array}{c}1000-800^{\circ} \mathrm{C} \\
(\mathrm{Ilm}+\mathrm{Magn} \pm \mathrm{QtZ} \pm \mathrm{Fa})\end{array}$ & $<1 \mathrm{kbar}$ & $\begin{array}{c}-2 a-3{ }_{\triangle} Q F M \\
(I m+M a g n \pm Q t z \pm F a)\end{array}$ & $\begin{array}{l}\text { Turner et a/. } \\
\text { (1992a) }\end{array}$ \\
\hline \multirow{4}{*}{ 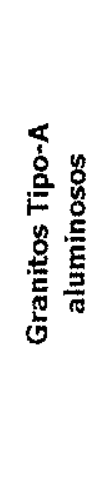 } & $\begin{array}{l}\text { Cinturão Dobrado } \\
\text { Lachlan (Austrália) }\end{array}$ & $\begin{array}{c}900-800^{\circ} \mathrm{C} \\
\text { (saturação em Zr) }\end{array}$ & $\begin{array}{c}1-2 \text { kbar } \\
\text { (mínimo granítico) }\end{array}$ & $<$ NNO & King et al. (1997) \\
\hline & $\begin{array}{c}\text { Cinturão Anorogênico } \\
\text { Transcontinental } \\
\text { (América do Norte) }\end{array}$ & $\begin{array}{r}800-600^{\circ} \mathrm{C} \\
\text { (feldspatos) }\end{array}$ & $\begin{array}{c}\text { 2,7-3,2 kbar (muscovitas) } \\
\text { 3-3,5 kbar (Al em Hbl) }\end{array}$ & $0 a+3{ }_{\Delta} Q F M$ & $\begin{array}{c}\text { Anderson e Bender } \\
\text { (1989) }\end{array}$ \\
\hline & $\begin{array}{l}\text { Complexo Granitóide } \\
\text { (Finiândia Central) }\end{array}$ & $\begin{array}{c}\left.870-7400^{\circ} \mathrm{C} \text { (Plag }+\mathrm{Hbl}\right) \\
950-700^{\circ} \mathrm{C} \text { (Biot) }\end{array}$ & $2,4 \times 4,3 \operatorname{kbar}(\mathrm{Al} \mathrm{em} \mathrm{Hbi)}$ & $\begin{array}{c}+0,6 a-1,6 \Delta Q F M \\
\text { (IIm+Biot) }\end{array}$ & Eliott et al. (1998) \\
\hline & $\begin{array}{l}\text { Complexos Rapakivi } \\
\text { Wiborg e Suomenniemi } \\
\text { (Sul da Finlândia) }\end{array}$ & $820-800^{\circ} \mathrm{C}(\mathrm{Plag}+\mathrm{Hbl})$ & 2,8-3,6 kbar (Al em Hbl) & - & Eliott et al. (1998) \\
\hline
\end{tabular}

Turner et a/. (1992a) descrevem ainda inclusões reliquiares de ferrosilita e pigeonita invertida com dois conjuntos de exsoluçōes, formadas a temperaturas da ordem de $1000^{\circ} \mathrm{C}$ e a pelo menos 5 kbar de pressão de acordo com a projeçāo dos piroxênios de Lindsley. Além disso, os valores de Mg\# observados nestas pigeonitas sugerem cristalização a partir de magmas com Mg\# próximo de 20. enquanto os valores observados nas rochas estudadas não uttrapassam 12, evidenciando uma origem a partir de magmas básico-intermediários. As estimativas de pressāo a parțir do teor de Al nos anfibólios cálcicos (ferrohastingsita) que hospedam estas inclusōes conferem valores da ordem de 2 2.5 kbar. Com isso, os autores sugerem uma cristalização em regime de pressão decrescente em paralelo à ascensão dos magmas, com uma clara tendência de enriquecimento em fe nos termos mais diferenciados. 


\section{Associação aluminosa}

Como nas variedades dá associaçāo alcalina, materiais restíticos ou xenólitos sāo raros ou ausentes, indicando também temperaturas relativamente elevadas (Rämö e Haapala, 1995). As estimativas termométricas (Tabela H.1) indicam um intervalo máximo entre 900 e $600^{\circ} \mathrm{C}$, algo inferior ao estimado para magmas geradores das rochas da associação alcalina, mas com temperaturas liquidus superiores às de granitos Tipo-/, da ordem de $750^{\circ} \mathrm{C}$ (King et al., 1997).

As estimativas barométricas indicam pressões entre 2,4 e $4.3 \mathrm{kbar}$, superiores às obtidas para as rochas da associação a/calina. Por outro lado. King et al. (1997) argumentam que as proporçōes entre quartzo e feldspatos são normalmente próximas das composições de mínimo para 1-2 kbar. Para os granitos pós-cinemáticos do Complexo Granitóide da Finlândia Central, com base no equilibrio olivina ferrosa - piroxênio - quartzo, Elliott et al. (1998) encontram ainda pressōes de até 8 kbar para rochas monzoníticas. Tais observações também sugerem uma evoluçāo sob pressão decrescente para os granitos da associação aluminosa.

A fugacidade de oxigênio é um parâmetro bastante variável de uma província para outra, como evidenciado na Tabela 11.1.

O teor de água nestes magmas também foi estimado como baixo com base na ocorrência de máficos hidratados como cristais intersticiais por alguns autores (e.g. Anderson e Bender, 1989). Entretanto, as variaçōes na forma de ocorrência de biotitas e anfibólios cálcicos encontradas no Cinturão Dobrado Lachlan levaram King et al. (1997) a questionar esta interpretação. Experimentos de cristalização conduziram Clemens et al. (1986) à conclusão de que os teores de água de granitos da associação aluminosa deste mesmo cinturão estāo entre 2.4 e $4.3 \%$. semelhantes aos valores observados em granitos Tipo-/adjacentes, levando King et al. a considerar que o caráter anidro não é compartilhado pelas variedades aluminosas.

Além disso, valores altos de F nos magmas foram apontados como característicos de granitos Tipo-A por diversos autores (e.g. Whalen et al., 1987: Pitcher, 1993). De fato, granitos da associação alcalina apresentam máficos hidratados com teores acima da média de F; entretanto, King et al. (1997) mostram que o mesmo não ocorre com os granitos da associação aluminosa, cujos máficos hidratados apresentam valores de $F$ relativamente baixos.

Sendo assim. pode-se afirmar que as rochas da associação a/uminosa apresentam características que os diferenci - dos demais tipos de granitos (e.g. maior temperatura dos magmas); entretanto, 
as características tidas como típicas dos granitos Tipo-A são na sua maioria mais pronunciadas ou até mesmo exclusivas da associação alcalina. justificando a divisão proposta com base em características petrográficas descritivas.

\subsection{AS SÉRIES DE GRANITOS TIPO-A}

Recentemente, Bonin et al. (1998) reafirmaram a existência de duas séries: (a) monzonito sienito - sienogranito - álcali-feldspato granito, alcálica no sentido de Peacock (1931) ou alcalina na concepção de Lameyre e Bowden (1982): e (b) monzonito - monzogranito - sienogranito - álcalifeldspato granito. tipicamente alcali-cálcica no sentido de Peacock (1931). cálcio-alcalina de alto potássio na concepçāo de Lameyre e Bowden (1982), ou ainda aluminosa. As associações alcalina e aluminosa aqui descritas seriam, neste contexto, os termos finais destas séries alcalina e aluminosa.

Tal visão invoca a gênese dos granitos Tipo-A por diferenciação de termos mais máficos. Na grande maioria das ocorrências, as rochas graníticas de ambas as séries aparecem associadas a rochas básico-intermediárias, que ocorrem como diques e derrames basálticos ou como corpos intrusivos gabróides e anortosíticos; além disso, enclaves máficos microgranulares sāo pouco abundantes mas estão sempre presentes (Turner et al., 1992a; Pitcher, 1993; Rämö e Haapala, 1995, entre outros).

Entretanto, tais observações năo bastam para se supor uma relação comagmática entre os termos máficos e félsicos e, de fato, variedades intermediárias săo relativamente raras. Neste contexto, as inclusões observadas por Turner et al. (1992a; cf. acima) evidenciam, pelo menos para os granitos da associação a/calina, a evolução através de cristalização fracionada a partir de termos básico-intermediários, tornando provável a existência de uma série alcalina como proposto por Bonin et a/. (1998). Resta saber se os granitos da associaçăo aluminosa de fato pertencem a uma série petrográfica como a idealizada por Bonin et al. (1998); as informações petrográficas até aqui levantadas não permitem confirmar ou negar esta hipótese.

De qualquer modo, a divisão proposta em uma associaçāo alcalina e outra aluminosa de granitos Tipo-A é fundamentalmente descritiva e independente da existência ou não destas séries, mas os contrastes observados devem refletir diferenças genéticas importantes entre os dois grupos. 


\section{CARACTERÍSTICAS GEOQUÍMICAS}

\section{III.1. GeOQUÍMICA DE ELEMENTOS MAIORES E TRACOS}

Do ponto de vista geoquímico, granitos Tipo- $A$ são tipicamente enriquecidos em sílica, álcalis, Fe, HFSE, REE e Ga, e empobrecidos em Ca, Al e Mg. Razōes Ga/Al e as somas de $\mathrm{Zr}+\mathrm{Nb}+\mathrm{Ce}+\mathrm{Y}$ são tipicamente altas nos granitos Tipo-A quando comparadas aos valores encontrados nos demais tipos de granitos (I, S, M); sendo assim, diagramas envolvendo estas quantidades (Figura II.3) podem ser utilizados para discriminá-los (Whalen et al., 1987; Eby, 1990).

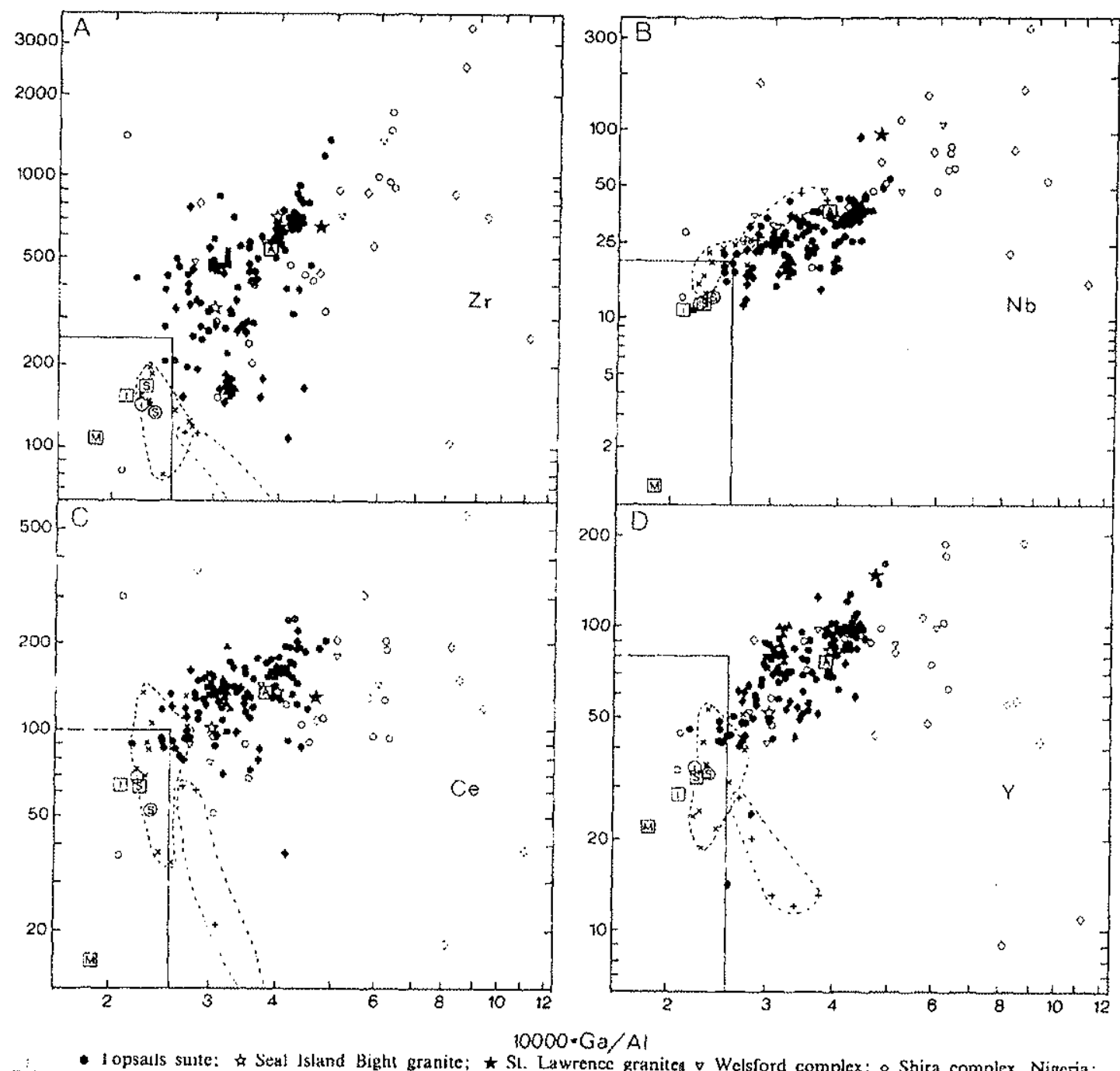

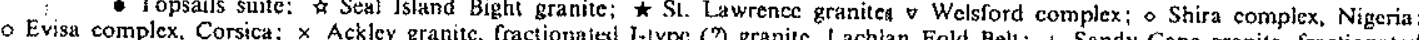
S-type granitex, Corsica; $\times$ Ackley granitc, fractionated $1+$ lype (?) granitc. Lachian Fold Belt; + Sandy Cape granite, fractionated (1) Feisic I-type from New Britain, P.N.G.

Figura 11.3: Diagramas Zr, Nb. Ce e Y versus 1000*Ga/Al para vários granitos Tipo-A, e também, para comparação. os campos para os granitos I, 5 e M e para dois grupos de granitos Tipo-l $e$ Tipo-S fracionados (contornos pontilhados). Extraido de Whalen et al. (1987). 
Os teores elevados em álcalis dos granitos Tipo-A (média de $8.72 \%$ em peso, em comparação com 5.23\% - Tipo-M. 6.53\% - Tipo-/ e 6.37\% - Tipo-S; Whalen, 1987) levaram muitos autores a denominá-los genericamente como granitos alcalinos (e.g. Sylvester, 1989). De fato, em algumas províncias, as rochas das associações alcalina e aluminosa não se diferenciam pelos teores de álcalis. mas sim pelos teores de Al, mais baixos na associação alcalina (Figura 11.4), o que thes confere o caráter peralcalino. Neste caso, estas rochas foram denominadas coletivamente de peralcalinas, inclusive as variedades que quimicamente se mostraram metaluminosas (Liégeois et al., 1996). Tal denominação, entretanto, se mostra pouco satisfatória, já que a saturação em alumina é um parâmetro químico importante e o termo "peralcalino" tem significado bastante específico e difundido: talvez fosse mais adequado denominar a série alcalina de granitos Tipo $A$ de série agpaítica, já que (1) a característica mais marcante das rochas agpaíticas insaturadas é o enriquecimento de álcalis em relaçāo à alumina: (2) essas associações mostram uma diferenciação agpaítica (Hadj-Kaddour et al., 1998), de forma que (3) algumas das variedades mais diferenciadas apresentam acessórios exóticos (i.é. agpaíticos) como a astrofilita, constituindo-se em verdadeiros agpaitos supersaturados na concepção de Ulbrich (1984), inclusive com cristalização tardia dos minerais máficos, a que se refere como seqüência agpaitica de cristalização (Ulbrich, 1984). Ainda assim, considera-se aqui mais relevante destacar a existência de uma associação alcalina do que a presença de rochas "agpaíticas".

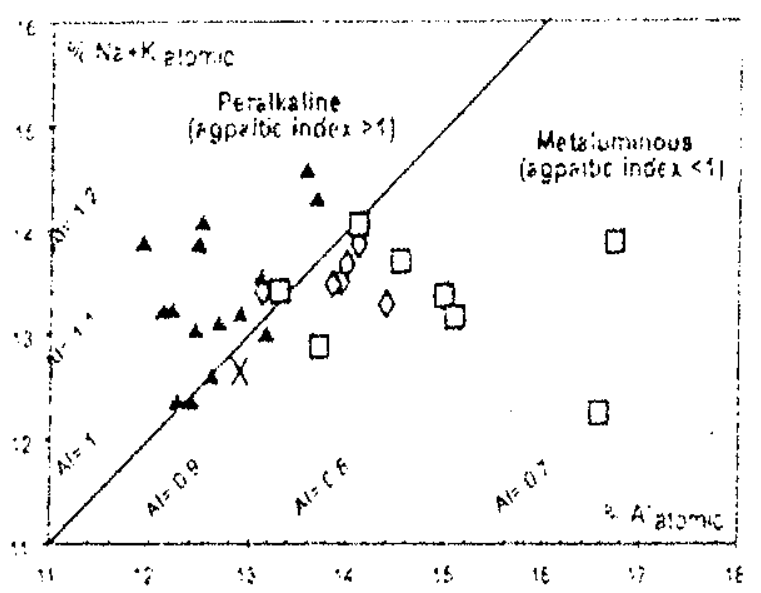

Figura 11.4: Diagrama \% atômica de álcalis $(\mathrm{Na}+K)$ versus \% atômica de Al para rochas do Complexo Anelar Tessalit (Mali). Extraído de Liégeois et al. (1996).

É importante notar que principaimente granitos Tipo-l, mas também Tipows. bastante fracionados, apresentam composiçoes similares às de granitos Tipo-A meta- e peraluminosos. sobretudo no que tange a elementos maiores - já que todas essas composições estão próximas do 
mínimo granítico - mas também em elementos traços, devido ao seu comportamento geoquímico semelhante nesses sistemas (cf. Figura 11.3).

Ainda assim. Whalen et al. (1987) mostram que razões entre elementos incompatíveis de grande raio iônico (LILE, e.g. Rb, Sr, Ba) evidenciam o caráter claramente fracionado destes granitos Tipo-/e Tipo-S, o que nāo é observado nos granitos Tipo-A (Figura II.5).

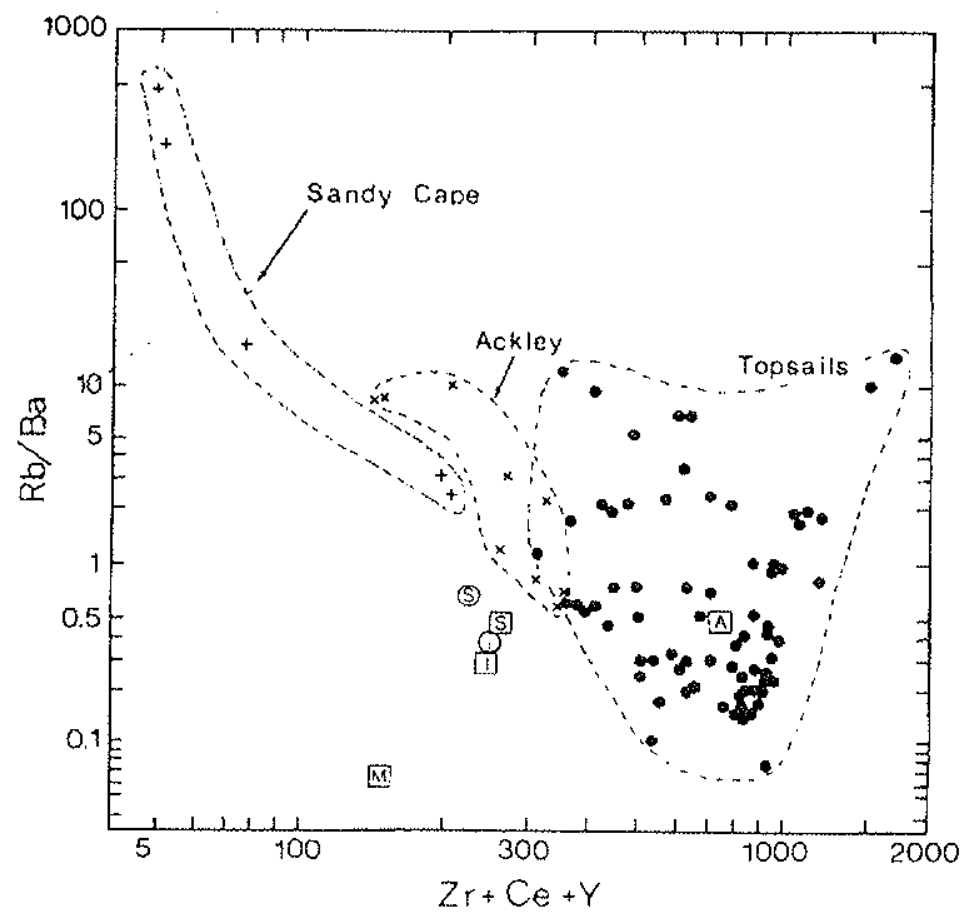

Figura 11.5: Diagrama Zr+Ce+Y versus Rb/Ba para granitos Tipo-/ e Tipo-S fracionados (Ackleye Sandy (ape) e para granitos Tipo-A da Suite Topsails. Simbolos como na Figura II.3. Extraido de Whalen et al. (1987). Simbologia como na Figura II.3.

Whalen et al. (1987) e Eby (1990) mostram que nos diagramas discriminatórios de Pearce et al. (1984), os granitos Tipo-A se localizam no campo dos granitos intraplaca, sendo possível separálos dos granitos Tipo-/e Tipo-S com esse tipo de diagrama (Figura II.6). 


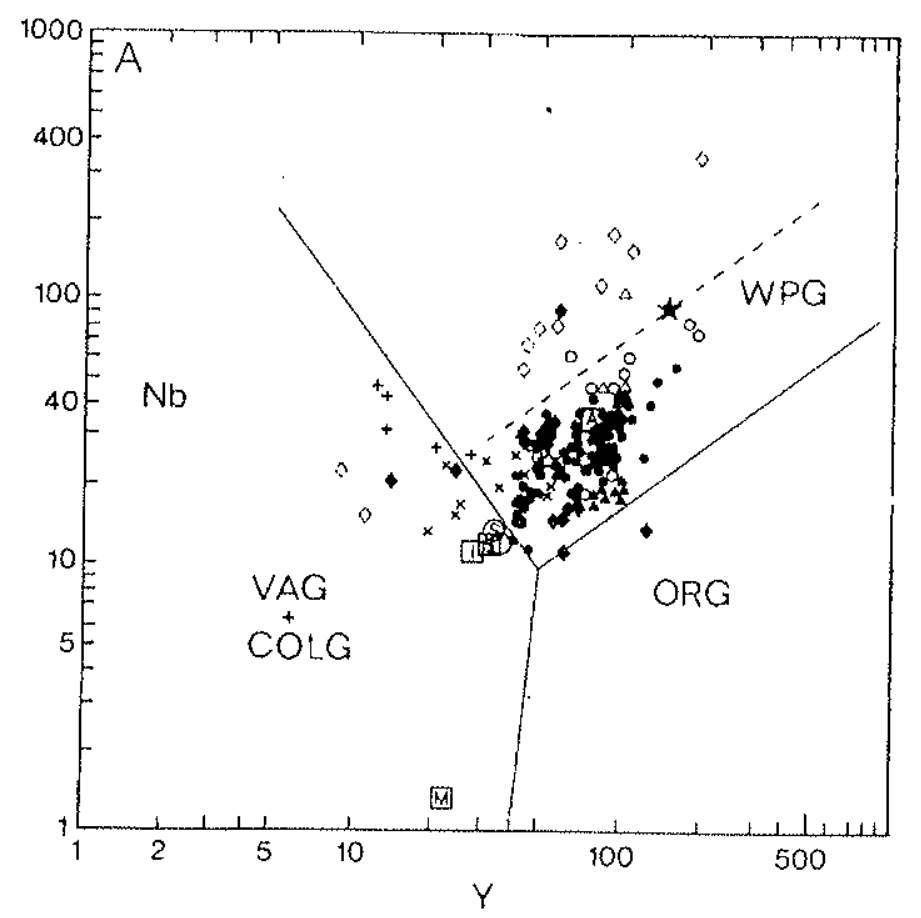

Figura 11.6: Diagrama discriminatorio de Pearce et al. (1984). Campos: ORG = granitos orogênicos; $V A C=$ arco magmático: $C O L G=$ granitos colisionais; $W P G=$ granitos intra-placa. Simbolos como na Figura 11.3. Extraido de Whalen et al. (1987).

Eby (1992) foi capaz ainda de distinguir dois grupos de granitos Tipo-A com base em diagramas envolvendo elementos traços: um com assinatura típica de diferenciados mantélicos. semelhante à de basaltos de ilhas oceânicas $\left(A_{1}\right)$, incluindo os granitos anorogênicos (de zonas de rift ou intraplaca); e outro com padrões semelhantes aos de magmas de arcos de ilhas e margens continentais $\left(A_{2}\right)$, correspondendo aos granitos pós-colisionais e rapakivi (Figura 11.7).

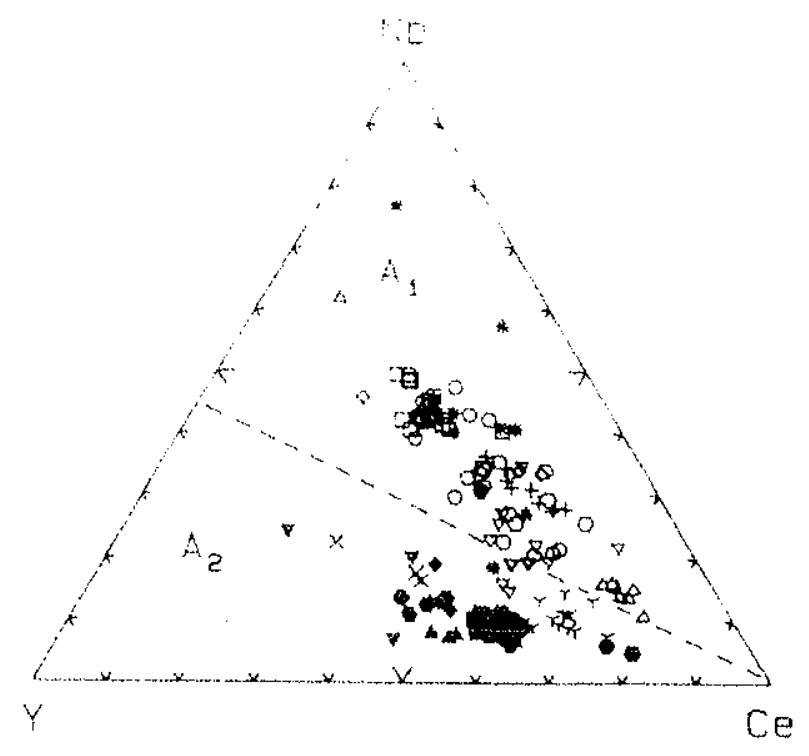

Figura 11.7: Diagrama triangular Y-Ce-Nb mostrando a separação entre os subtipos $A_{1}$ e $A_{2}$; a reta que separa os dois campos corresponde à relação $Y / N b=1$.2. Extraido de Eby (1992). 


\section{Modelamentos geoquímicos}

Os dados geoquímicos disponíveis podem ainda ser utilizados para avaliar a importância relativa entre as fases fracionadas ao longo da diferenciação, assumindo-se que esta se dá por cristalização fracionada.

Segundo Eby (1990), as razões $\mathrm{Y} / \mathrm{Nb}$ e Sc/Nb são profundamente modificadas pelo fracionamento de clinopiroxênio ou anfibólio, já que apenas $Y$ e Sc são incorporados nestes minerais. No conjunto de dados analisado pelo autor, é pequena a variação observada nestas razōes, de forma que. na maioria dos casos, fracionamento de apenas $5 \%$ destes minerais pode explicar as variacōes observadas (Figura 11.8a).
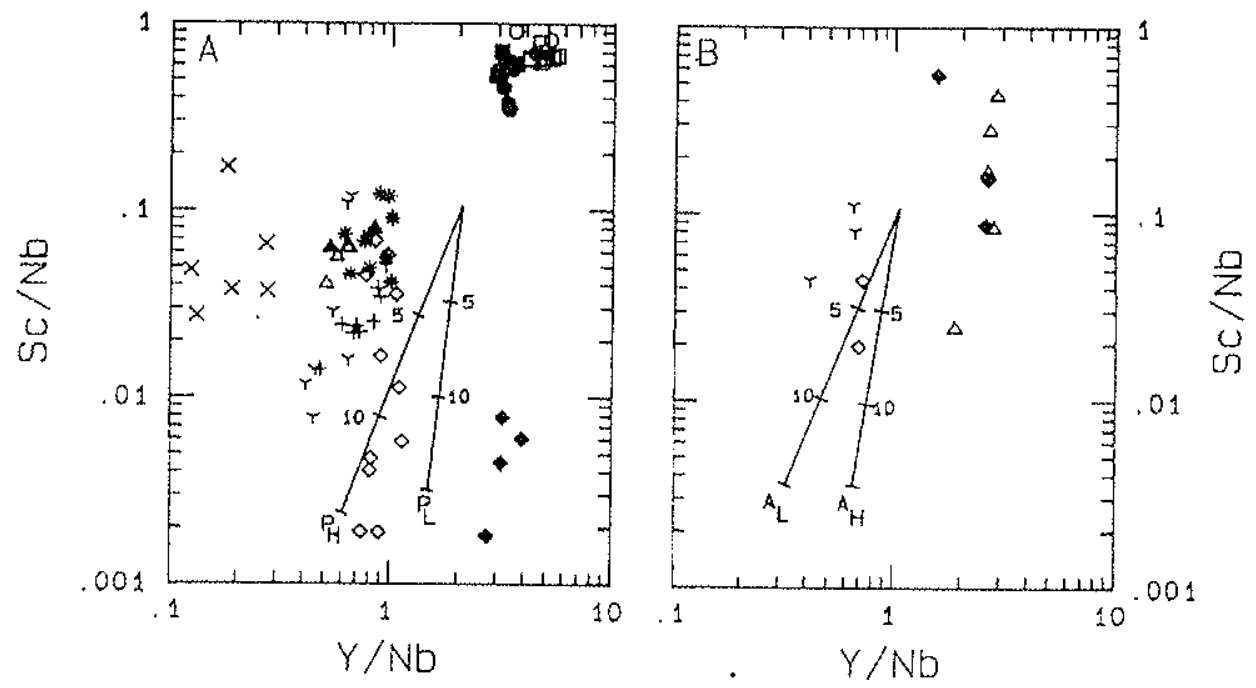

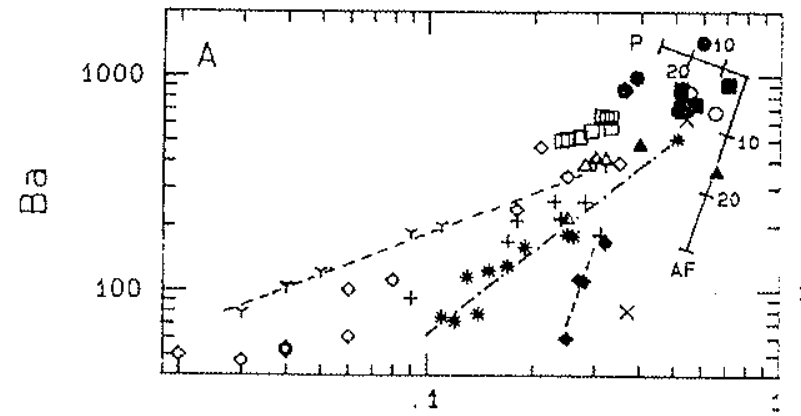

EU/EU*

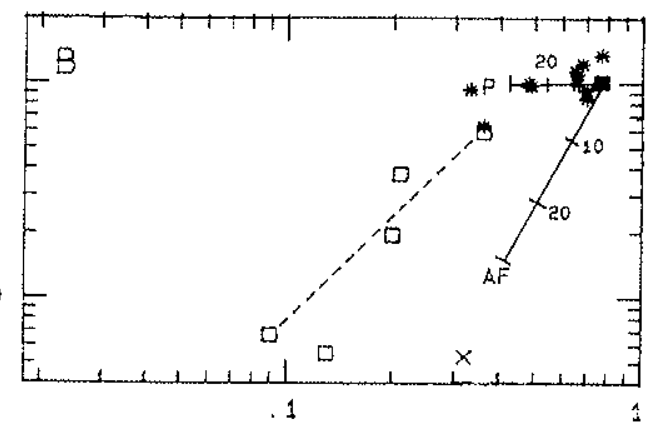

EU/EU*

Figura II.8: (a) Diagrama SC/Nb versus Y/Nb, são indicadas as trajetórias devidas ao fracionamento de piroxênio (P) e anfibolio (A) para magmas com teores de sílica altos (H) e moderados (L); (b) diagrama Ba versus Eu/Eu*, são indicadas as trajetorias devidas ao fracionamento de plagioclásio (P) e feldspato alcalino (AF). Extraido de Eby (1990).

Além disso, diagramas Ba versus Eu/Eu* permitem inferir o papel exercido pelos feldspatos: analisando diagramas como este, o referido autor atribui as variações presentes ao fracionamento de 
feldspato alcalino e quantidades menores de plagioclásio (Figura 11.8b). De fato, vários autores descrevem o fracionamento de fases félsicas como o principal mecanismo de diferenciação das rochas graníticas, com atuaçāo restrita de fases máficas e acessórias (e.g. Liégeois et al., 1996; Hadj-Kaddour et al., 1998; Dall'Agnol et al., 1999).

\section{Associações alcalina versus aluminosa}

A análise da Figura 11.9 permite verificar que as razões Ga/Al apresentam forte correlação positiva com o Índice Agpaítico $\left(\mathrm{IA}=\left[\left(\mathrm{Na}_{2} \mathrm{O}+\mathrm{K}_{2} \mathrm{O}\right) / \mathrm{Al}_{2} \mathrm{O}_{3}\right]_{\mathrm{mol}}\right)$, o que torna claro o fato de que os valores em questão são crescentes com a diferenciação dos granitos da associaçāo a/calina, enquanto são constantes nos granitos da associação aluminosa e apenas pouco maiores que os valores apresentados por granitos Tipo-/ e Tipo-S mais comuns. Fica evidente que, como destacado acima com relação às propriedades dos granitos Tipo-A e às respectivas condições de cristalização, as características geoquímicas tidas como típicas de granitos Tipo $A$ são mais acentuadas ou até exclusivas de rochas da associação alcalina. Ainda assim, é relevante notar que os granitos da associação aluminosa se destacam dos granitos de outros tipos, justificando a sua distinção também do ponto de vista geoquímico.

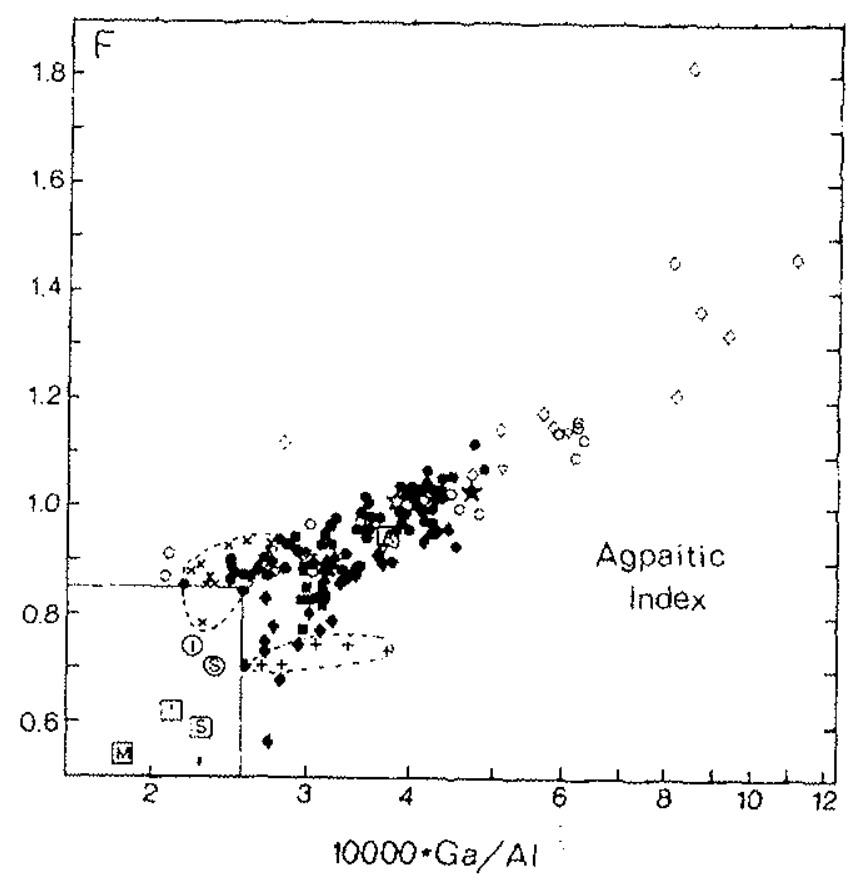

Figura 11.9: Diagrama Índice Agpaitico versus $1000^{*} \mathrm{Ca} / \mathrm{Al}$ para vários granitos Tipo-A, e também. para comparação, os campos para os granitos I, S e M e para dois grupos de granitos Tipo-1 $e$ Tipo-S fracionados (contornos pontilhados). Simbolos como na Figura II.3. Extraido de Whalen et al. (1987). 
Finalmente, o estudo de variações inter-elementais como as mostradas na figura 11.10 permitiu que Liégeois et al. (1996) e Hadj-Kaddour et al. (1998) demonstrassem que as séries aluminosa e alcalina seguiram trajetórias de diferenciação distintas pelo menos desde os termos menos diferenciados encontrados (i.é. monzonitos), dando apoio adicional à divisão proposta.
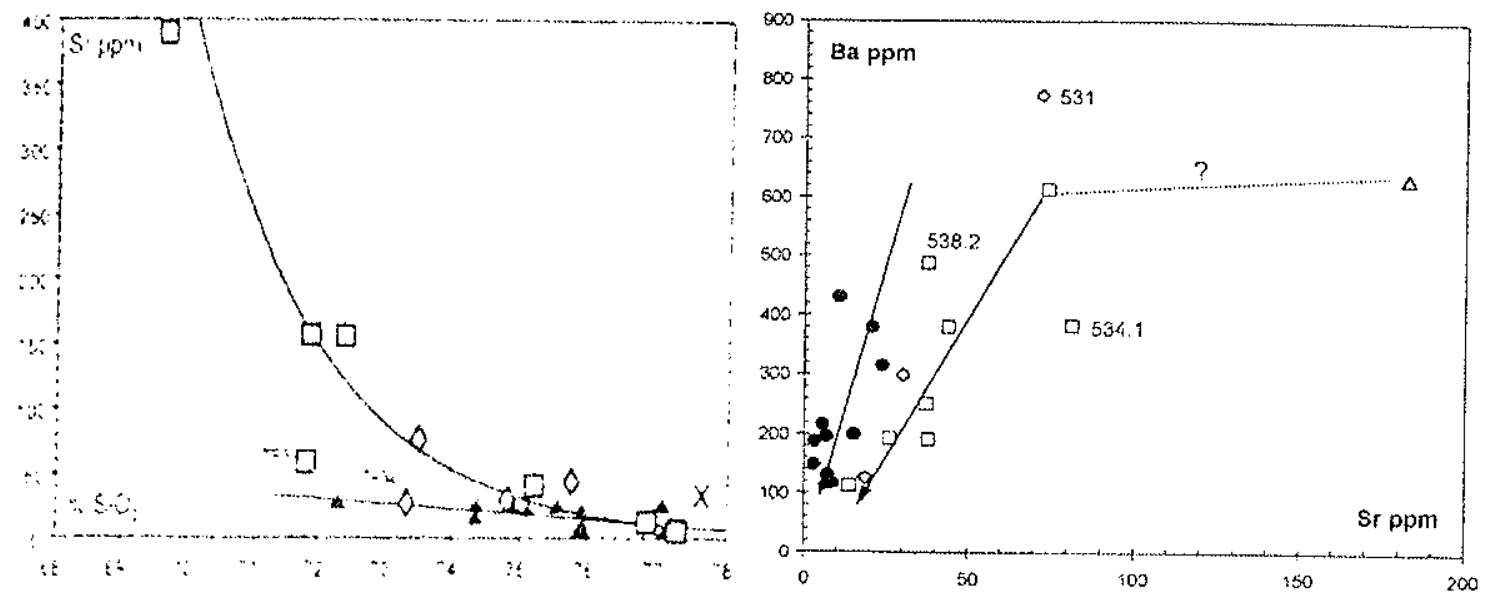

Figura 11.10: Diagrama Sr versus $\mathrm{SiO}_{2}$ para rochas do Complexo Anelar Tessalit - Mali. (à esquerda, extraido de Liégeois et al., 1996): Diagrama Ba versus Si para rochas do enxame de diques Tin Zebane - Argélia (à direita, extraido de Hadj-Kaddour et al., 1998);

\section{III.2. GEOQUÍMICA ISOTÓPICA}

Desde a definição dos granitos Tipo- $A$, as mais variadas fontes foram imaginadas como geradoras de magmas deste tipo. com ou sem atuação de cristalização fracionada: (1) crosta inferior residual, a partir da qual magmas Tipo-/ teriam sido anteriormente extraídos; (2) crosta inferior granodiorítica ou tonalítica com teores de água reduzidos; (3) basaltos toleíticos alojados na interface crosta-manto: (4) manto litosférico subcontinental: (5) manto astenosférico empobrecido.

Entretanto, apenas recentemente, estudos isotópicos detalhados têm permitido avaliar de forma mais realista o papel de cada uma dessas possiveis fontes (cf. Tumer et al., 1992a; Kerr e Fryer, 1993; Poitrasson et al., 1995; Rämö e Haapala, 1995: Whalen et al., 1996: Frost e Frost. 1997; entre outros).

Cabe ressaltar que por se tratarem de rochas com teores de $S r$ bastante baixos, as razōes iniciais ${ }^{87} \mathrm{Sr} /{ }^{86} \mathrm{Sr}$ podem ser significativamente modificadas por adições de pequenas quantidades de $\mathrm{Sr}$ em função da ação de fluídos pós-magmáticos ou hidrotermais, comuns no ambiente geológico em que estas rochas se formam. Neste sentido, Foland e Allen (1991) interpretam a forte correlação negativa entre as razões iniciais de $\mathrm{Sr}$ e os teores deste elemento (Figura II.11) como resultado da ação de 


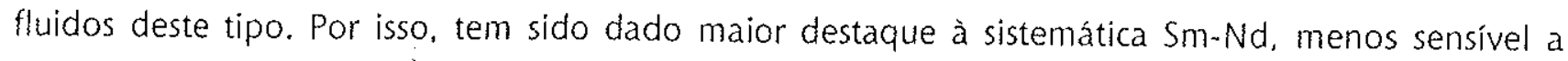
esse tipo de fenômeno e. portanto, de maior poder interpretativo.

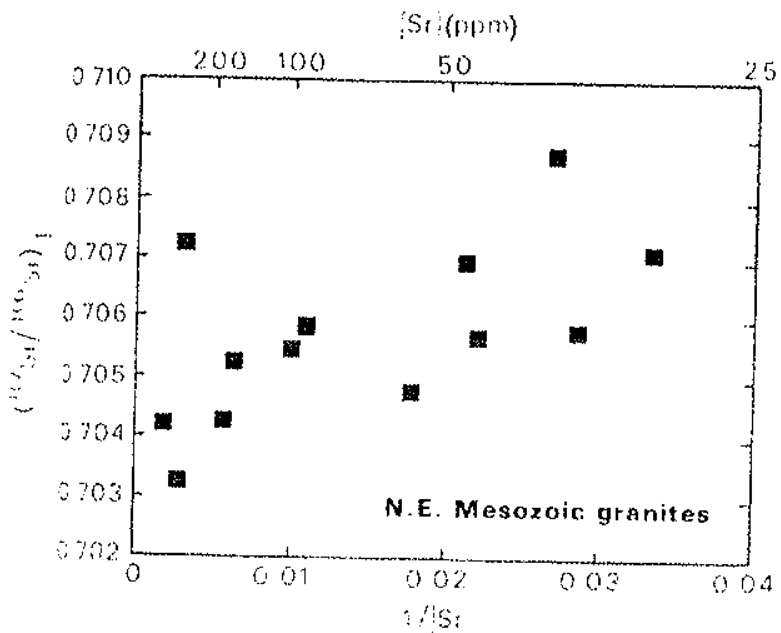

Figura 11.11: Diagrama ${ }^{87}{ }^{\beta}{ }^{\beta 6} S r$ versus Sr para Granitos Mesozóicos do Norte de New England (Estados Unidos). Extraido de Foland e Allen (1991).

\section{Associação alcalina}

Os dados disponíveis para as rochas da associação alcalina e rochas máficas associadas (cf. Tabela 11.2$)$ revelam razões iniciais ${ }^{87} \mathrm{Sr}^{86} \mathrm{Sr}$ relativamente baixas e $\varepsilon_{\mathrm{Nd}}$ positivos ou pouco negativos para a maior parte das ocorrências.

Estes valores são indicativos de uma fonte homogênea isotopicamente (Figura II.12; Poitrasson et al. 1995), tipicamente mantélica. As composições isotópicas de Sr e Nd medidas por Turner et al. (1992a) são indistinguíveis das composiçōes das rochas básicas e granófiros associados, estes últimos claramente formados por diferenciaçāo in situ dos magmas básicos mantélicos (Figura II.13). Tal observação sustenta a dedução de que magmas peralcalinos são formados por cristalizaçāo fracionada a partir de magmas básicos, evidentemente provenientes do manto (cf. acima).

Os valores de $\varepsilon_{\mathrm{Nd}}$ positivos sugerem a predominância de fontes localizadas no manto litosférico empobrecido. Valores como os observados na Suite Topsails, pouco menos positivos que os obtidos para rochas básicas associadas, permitem inferir uma derivação por fusão parcial de crosta inferior juvenil, como sugerido por Frost e Frost (1997). Entretanto, alguns dos valores de $\varepsilon_{\mathrm{Nd}}$ mais altos (e.g. +6.2 - Enxame de Diques. Tin Zebane) sāo de fato superiores aos máximos encontrados em rochas máficas associadas (i.é. +5.1 ), o que inviabiliza um modelo como este e indica a participaçāo de um manto empobrecido com composição isotópica semelhante à de basaltos de ilhas oceânicas como 
fonte (Hadj-Kaddour et al., 1998), o que já havia sido sugerido por Eby (1992) com base no comportamento de elementos traços.

Tabela 11.2:

Razões ${ }^{87} \mathrm{Si}^{\beta 6} \mathrm{Sr}$ e $\varepsilon_{\mathrm{No}^{\prime}}$ para granitos das associações aicalina e aluminosa

\begin{tabular}{|c|c|c|c|c|}
\hline & Local & $\left({ }^{87} \mathrm{Sr} /{ }^{86} \mathrm{Sr}\right)$ & $\varepsilon_{\mathrm{Nd}}$ & Referência \\
\hline \multirow{2}{*}{ 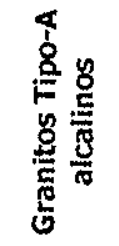 } & $\begin{array}{c}\text { Cordilheira Padthaway } \\
\text { (Austrália) }\end{array}$ & $0,7043-0,7063$ & $+2,4$ a $-2,7$ & $\begin{array}{l}\text { Turner et al. } \\
\text { (1992a) }\end{array}$ \\
\hline & $\begin{array}{c}\text { Suíte Ígnea Topsails } \\
\text { (Austrália) }\end{array}$ & $0,7018-0,7065$ & $\begin{array}{l}+1,0 a+4,0 \text { (félsicas) } \\
+3,5 \text { a }+5,5 \text { (básicas) }\end{array}$ & $\begin{array}{l}\text { Whalen et al. } \\
\qquad(1996)\end{array}$ \\
\hline \multirow{3}{*}{ 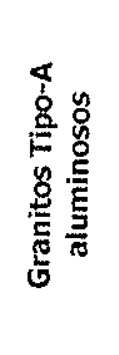 } & Granitos Rapakivi & $\begin{array}{c}0,7000-0,7488 \\
\mu=0,7087 \pm 0,0095[1 \sigma]\end{array}$ & $0,0 a-10,0$ & $\begin{array}{l}\text { Rämo e Haapala } \\
\text { (1995) }\end{array}$ \\
\hline & $\begin{array}{c}\text { Cinturão Proterozóico } \\
\text { Damara (Namíbia) }\end{array}$ & $0,70338-0,70928$ & $0,0 a-6,3$ & $\begin{array}{l}\text { Jung et al. } \\
\text { (1997) }\end{array}$ \\
\hline & $\begin{array}{l}\text { Granitos Oceânicos do } \\
\text { Ofiolito Masirah (Oman) }\end{array}$ & & $+5,5 a+8,7$ & $\begin{array}{l}\text { Nägler e Frei } \\
\quad(1997)\end{array}$ \\
\hline \multirow{3}{*}{ 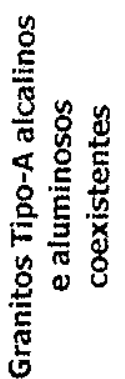 } & $\begin{array}{l}\text { Província Anorogênica } \\
\text { da Córsega (França) }\end{array}$ & & $\begin{array}{l}+0,5 \text { a }-2,0 \text { (alcal.) } \\
-3,5 \text { a }-5,0 \text { (alum.) }\end{array}$ & $\begin{array}{l}\text { Poitrasson et al. } \\
\qquad(1995)\end{array}$ \\
\hline & $\begin{array}{l}\text { Granitos do Rio } \\
\text { Ulungur (China) }\end{array}$ & $\begin{array}{c}0,7043 \text { (alcal.) } \\
0,7017-0,7096 \text { (alum.) }\end{array}$ & $\begin{array}{l}+5,1 \text { a }+6,7 \text { (alcal.) } \\
+5,7 \text { (alum.) }\end{array}$ & $\begin{array}{l}\text { Han et al. } \\
\text { (1997) }\end{array}$ \\
\hline & $\begin{array}{l}\text { Enxame de Diques } \\
\text { Tin Zebane (Argélla) }\end{array}$ & 0,7028 (ambos) & $+6,2$ (ambos) & $\begin{array}{l}\text { Hadj-Kaddour et al. } \\
\text { (1997) }\end{array}$ \\
\hline
\end{tabular}

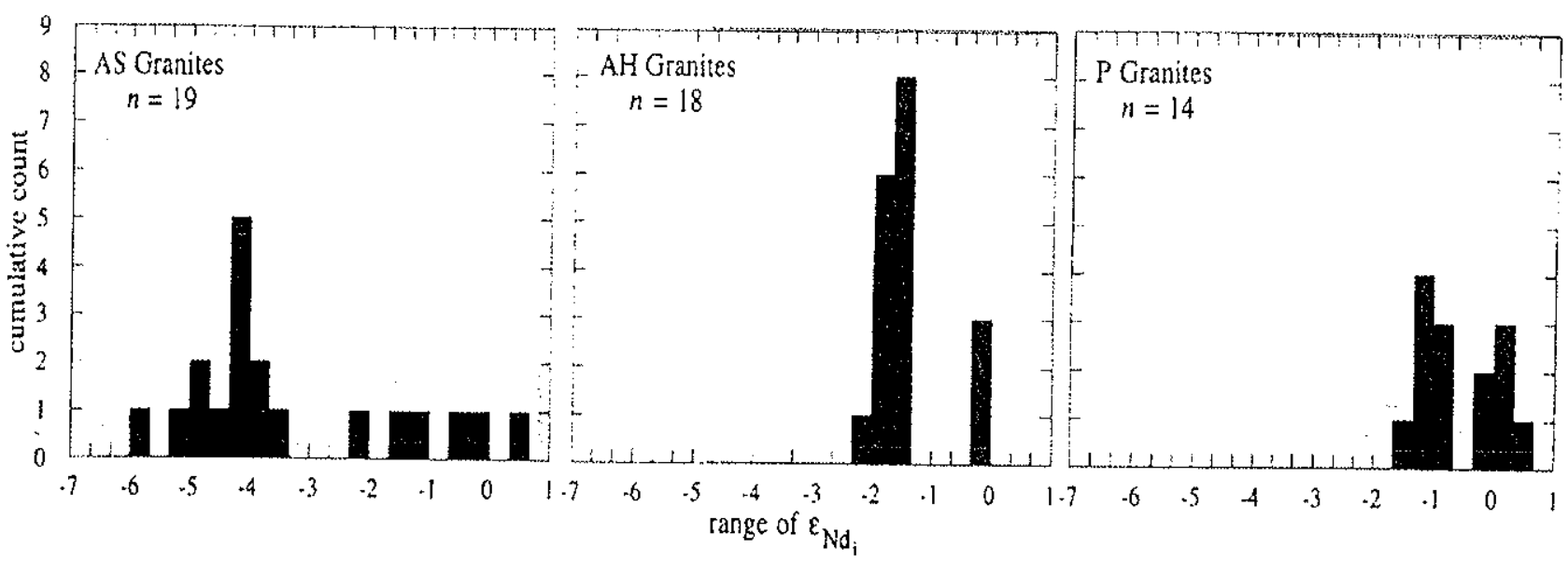

Figura II.12: Composições isotópicas de granitos das associaçóes alcalina ( $P$ - peralcalinos; $A H-$ metaluminosos) e aluminosa (AS) da Província Anorogênica da Corsega. Extraído de Poitrasson et al. (1995). 


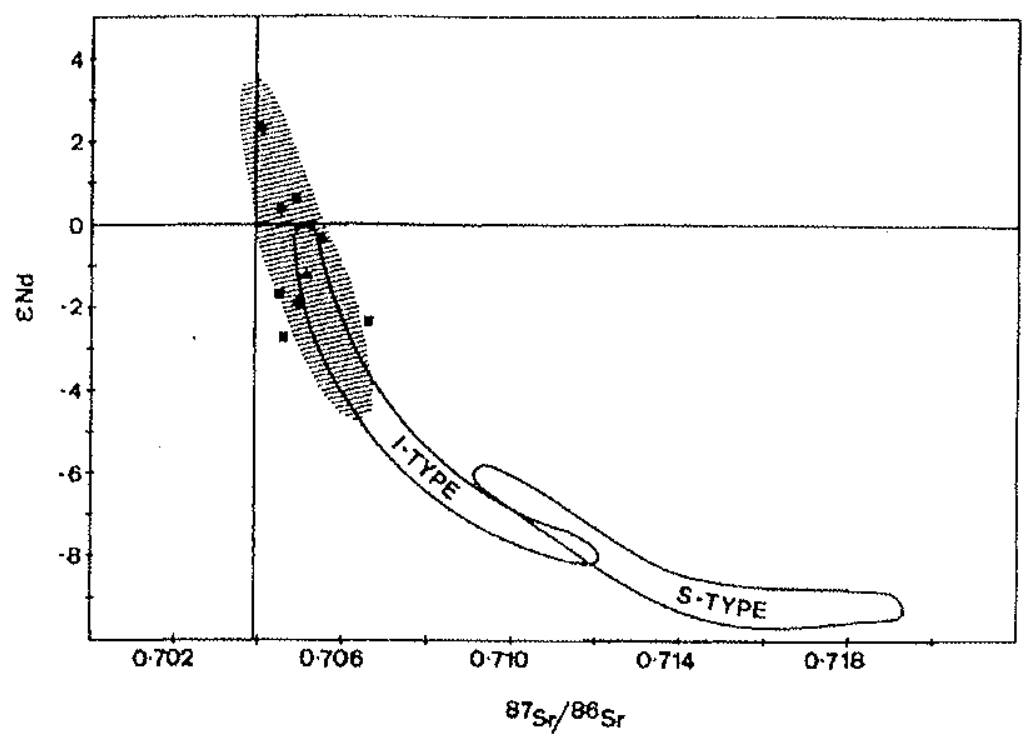

Figura 11.13: Diagrama $\varepsilon_{N d}$ versus ${ }^{\beta 7} S^{\beta 6}{ }^{\beta} S$ ) , mostrando a composição dos granitos Tipo-A da Provincia Padthaway (quadrados), que se sobrepõe às composiçoes dos granofiros (outros simbolos) e gabros (hachura) do Complexo Black Hill: são mostrados também os campos de granitos Tipo-I e Tipo-S do Cinturão Dobrado Lachlan. Extraido de Turner et al. (1992a).

O grande espectro de variação observado seria gerado por contribuições variáveis de materiais menos radiogênicos, tipicamente crustais, que levariam a uma diminuição dos valores de $\varepsilon_{\mathrm{Nd}}$.

A clara correlação positiva entre os valores de $\varepsilon_{\mathrm{Nd}}$ e a alcalinidade das rochas presentes na Província Anorogênica da Córsega (Figura 11.14) conduzem à idéia de que magmas metaluminosos podem se formar a partir de magmas peralcalinos pela adição de material crustal (Poitrasson et al., 1995). A ausência de correlação entre os valores de $\varepsilon_{N d}$ e $N d$ mostra que modelos de assimilação e cristalização fracionada, como imaginados por Foland e Allen (1991), não respondem por este processo, sugerindo que a contaminação deve ter ocorrido precocemente, ainda na crosta inferior (Figura II.15).

Mesmo que seja possivel obter composições isotópicas semelhantes a estas a partir da fusão de crosta inferior juvenil, uma fonte de calor mantélica parece imprescindivel. muito provavelmente na forma de magmas, modificando pouco ou em nada o panorama acima (Whalen et al., 1996).

\section{Associação aluminosa}

Poucas são as razões iniciais de Sr determinadas para rochas desta associação, e os resultados obtidos mostram um grande espectro de variação (Tabela 11.2). Os valores relativamente altos e a grande variação sugerem uma fonte heterogênea enriquecida em Rb, tipicamente crustal. 

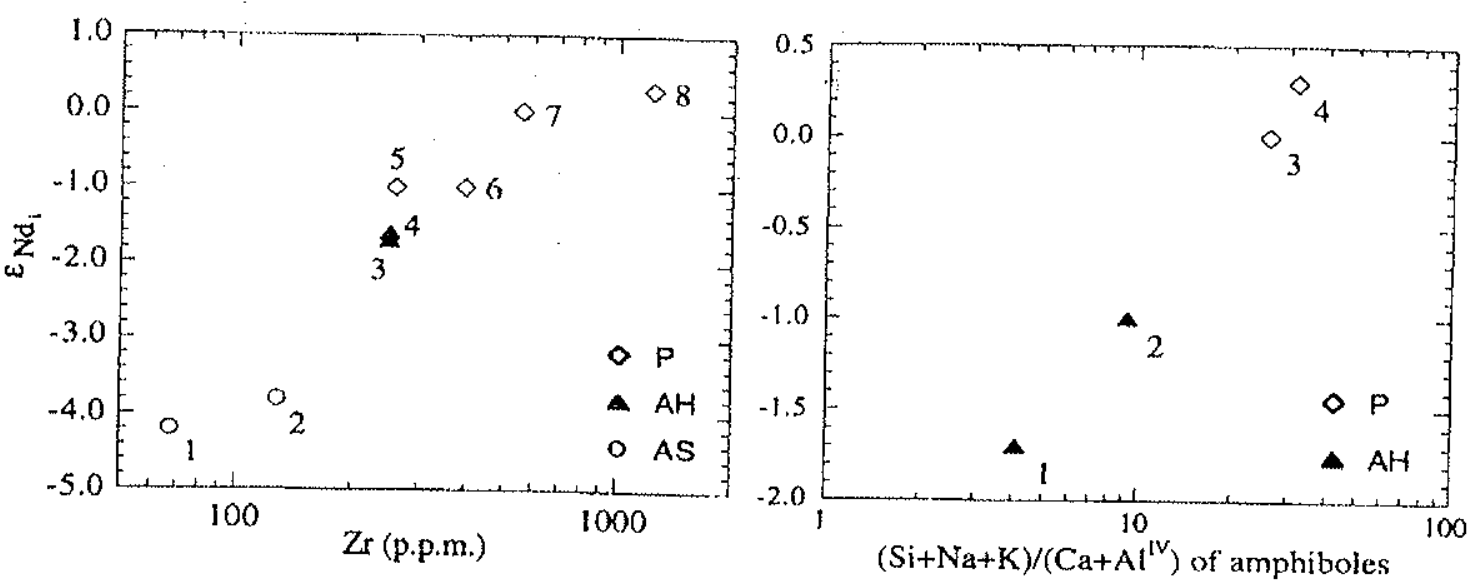

Figura 11.14: Diagramas Zr em rocha total versus $\varepsilon_{N d}$ e $(S i+N a+K) /\left(C a+A l^{\prime}\right)$ em anfibolio versus $\varepsilon_{N d}$ para granitos da associação alcalina do Complexo Anorogênico da Corsega. Extraído de Poitrasson et al. (1995). Simbologia como ná Figura 11.12.

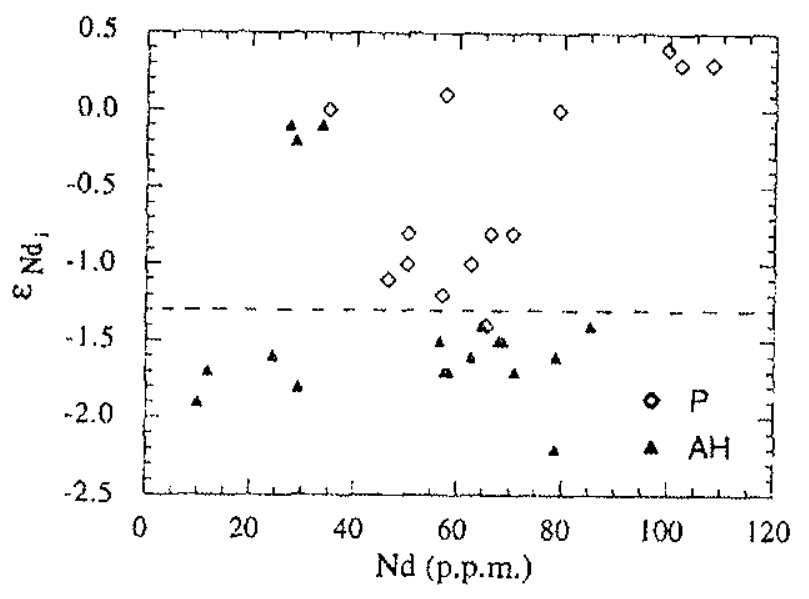

Figura 11.15: Diagrama Nd versus $\varepsilon_{N d}$ para granitos da associação alcalina do Complexo Anorogênico da Córsega. Extraído de Poitrasson et al. (1995). Simbologia como na Figura II.12.

Os valores de $\varepsilon_{\text {Nơ }}$ negativos (Tabela II.2) e heterogêneos (Figura II.12) são característicos de materiais crustais. Segundo Poitrasson et al. (1995), a heterogeneidade não pode ser explicada por mistura com magmas mantélicos, já que os magmas são homogêneos em relação aos elementos maiores e a homogeneidade isotópica deveria ser atingida mais rapidamente; sendo assim, as variações são reflexo de fontes crustais heterogêneas.

Os dados de Rämö e Haapala (1995) mostram que os valores mais baixos de $\varepsilon_{\text {Nad }}$ são obtidos em rochas com encaixantes Arqueanas, enquanto as demais têm como encaixantes rochas Proterozóicas, evidenciando a correlação entre a composição isotópica dos granitos e a crosta encaixante. Analogamente, Anderson e Bender (1989) mostram que granitos metaluminosos e peraluminosos ocupam posições geográficas distintas no Cinturão Anorogênico Transcontinental Norte Americano. com limites entre os dois tipos grosseiramente coincidentes com as isógradas 
separando terrenos encaixantes de alto e médio graus metamórficos. Conclui-se deste fato que as rochas tipicamente metaluminosas são formadas pela fusão de rochas granulíticas anidras de composição tonalítica a granodiorítica, enquanto as variedades peraluminosas são produto da fusăo da crosta mais hidratada com maior quantidade de componentes metassedimentares ricos em Al.

Segundo King et al. (1997), os teores elevados de Zr, Eu, Rb, Sr e Ba nos magmas geradores da associação aluminosa do Cinturão Dobrado Lachlan mostram que estas rochas não podem ser produto de cristalização fracionada expressiva. Sendo assim, a composição dos magmas seria determinada em grande parte pela composição da fonte crustal. Os primeiros modelos desenvolvidos para explicar a gênese dos granitos da associação aluminosa envolviam a fusão de uma crosta empobrecida pela extração de magmas Tipo-/ (e.g. Collins et al., 1982; Whalen et al., 1987). Neste caso, essa fonte empobrecida seria caracterizada por teores mais elevados de $F$ e mais baixos de água. já que as moléculas de biotita e anfibólio contendo F são mais refratárias; as temperaturas relativamente elevadas necessárias para fundir esta fonte, além dos aitos teores de F permitiriam uma maior solubilidade de HFSE como Zr. Nb, Y e REE. Entretanto, Creaser et al. (1992), com base em evidências experimentais, argumentam que uma fonte residual como esta seria enriquecida em plagioclásio cálcico e máficos ferro-magnesianos, e dificilmente apresentaria feldspato alcalino e biotita, tornando-se inviável a geração de magmas Tipo-A. A fonte preferida por estes autores têm composição tonalítica a granodiorítica, e segundo Poitrasson et al. (1995) e King et al., (1997), a fusão por desidratação de uma crosta pobre em água como esta pode gerar magmas com as composiçōes observadas.

Por outro lado, estudos recentes em granitos da associação aluminosa coexistentes com variedades da associação alcalina (e.g. Rio Ulungur - China; Tin Zebane - Argélia) têm mostrado valores de $\varepsilon_{\text {Nd }}$ bastante elevados (i.é. $\sim 6$ ) e semelhantes aos dos granitos da associaçāo alcalina coexistentes (Tabela 11.2). Nestes casos (cf. item anterior), resta pouca dúvida de que se tratam de magmas mantélicos geradores de granitos da associação aluminosa, sem importante contaminação crustal. Prova ainda mais contundente é oferecida pelos Granitos Oceânicos do Ofiolito de Masirah Oman: típicos granitos da associaçăo aluminosa, posteriores à formaçăo da crosta oceânica, anteriores à obducçcão e, portanto formados sem a presença de crosta continental, apresentam $\varepsilon_{N d}$ elevado (Tabela 11.2), corroborando à conclusão acima delineada.

Se por um lado uma parte considerável dos pesquisadores envolvidos com o estudo de granitos da associação aluminosa (e.g. Anderson e Bender. 1989; Poitrasson et al., 1995; Rämö e Haapala, 1995: King et al.. 1997: Dall'Agnol, 1999) têm poucas dúvidas de que a fonte predominante para a 
geração deste magmas é crustal, é crescente a evidência de que estes magmas podem ser geràdos diretamente de manto com composição isotópica semelhante à de basaltos de ilhas oceânicas, como acontece com os granitos da associação alcalina (Han et al. 1997; Nägler e Frei. 1997; HadjKaddour, 1998).

\section{MODELOS GEODINÂMICOS}

Os granitos da associação alcalina são parte importante de uma associação petrográfica de ocorrência abrangente, que aparece na maioria dos ambientes geotectônicos, sobretudo naqueles marcados por regimes distensivos, tipicamente zonas intraplaca continentais e oceânicas, zonas de rift, e no estágio pós-colisional de margens continentais ativas. A grande homogeneidade nos produtos observados e o enorme contraste entre as propriedades das fracōes crustais presentes, independentemente do ambiente de geração, torna evidente a importância de fontes mantélicas: mostra também que esses ambientes devem ser caracterizados por processos dinâmicos análogos (Turner et al., 1992b; Liégeois et al., 1998).

As zonas de rift continentais são caracterizadas por forte distensão crustal, o que permite a ascensão de manto astenosférico e a geraçāo de magmas básicos por descompressão, capazes de gerar, por sua vez, magmas básicos a partir do manto litosférico.

Condiçōes análogas podem ser atingidas em regiōes intraplaca, seja oceânicas ou continentais, pela atuação de plumas mantélicas, que levam ao aquecimento e à instalação de um regime tectônico distensivo semelhante ao de ambientes de rift.

Atingir condições análogas em ambientes pós-colisionais parece bem menos trivial. Ainda assim. Turner et al. (1992b) defendem a idéia de que o forte espessamento litosférico proporcionado pela convergência continuada entre dois blocos continentais leva a uma situação de instabilidade convectiva, com conseqüente remoçăo de parte significativa do manto litosférico: é possibilitada entāo a ascensão do manto astenosférico, o que cria uma força divergente, forte o suficiente para proporcionar distensāo da litosfera (Figura II.16); a deformação convergente é acumulada em grandes zonas de transcorrência em regime rúptil. Por efeito, um ambiente análogo ao de zonas de rift pode ser gerado, que ao final da convergência, pode ou não evoluir para um sistema de rift propriamente dito (cf. também. Bonin et al., 1998). Neste contexto, parece permissivel um intervalo de tempo relativamente grande $(e . g .>10 \mathrm{Ma}$ ) entre o final do magmatismo tipicamente orogênico e o início do magmatismo pós-colisional. 


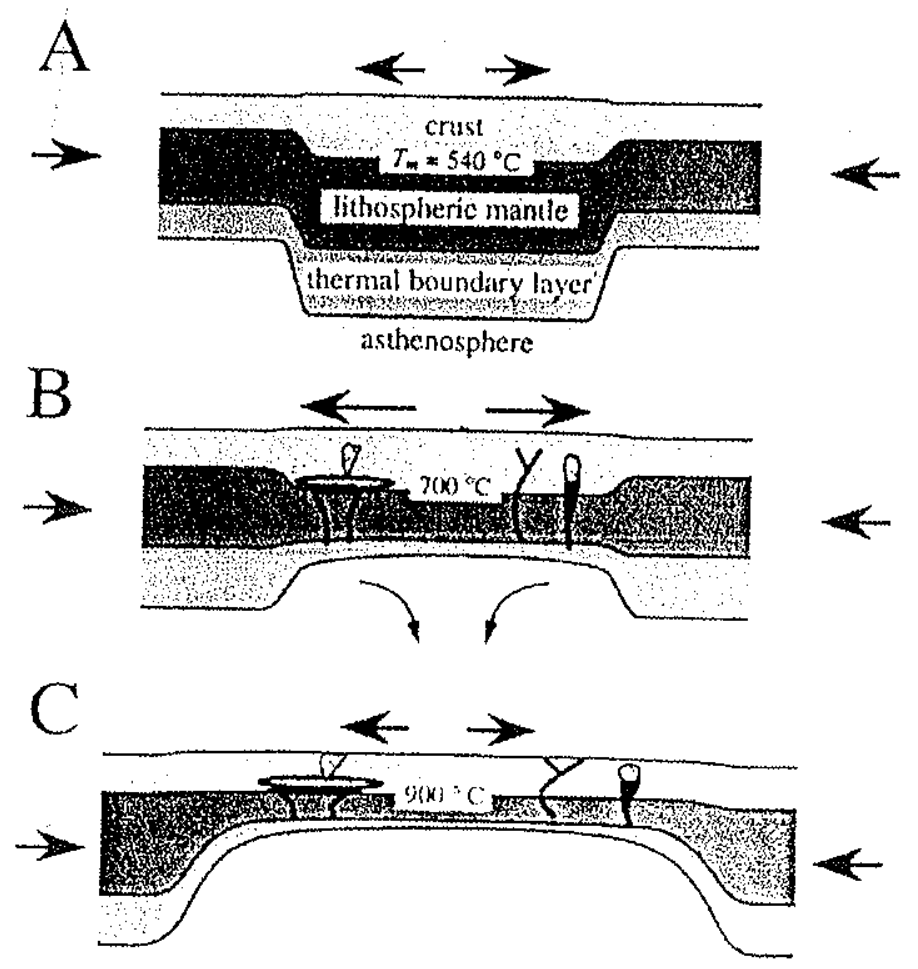

Figura II.16: Esquema mostrando a evolução de um orogeno desde o estágio colisional (A) até os estagios pós-colisionais (B). Para detalhes, ver texto. Extraido de Turner et al. (1992b).

Em todos os casos acima mencionados, os magmas mais importantes têm sua origem no manto litosférico, com composiçōes determinadas pelo grau de fusão e de mistura com componentes astenosféricos e crustais. $O$ acesso destes magmas às regiões mais rasas da crosta só é possivel através de estruturas rúpteis de escala crustal ou ainda litosférica, mesmo nos ambientes tipicamente anorogênicos (Tack et al.. 1996), e o tempo de residência em profundidade é o principal determinante do grau de interação entre os materiais das diversas fontes.

De acordo com Bonin (1996), a crosta serve como um filtro de densidade para os magmas mantélicos. Ao atingir uma situação de equilíbrio gravitacional com as encaixantes, os magmas estagnam e se diferenciam através de cristalização fracionada, até que magmas derivados possam se movimentar novamente em busca de equilíbrio gravitacional, repetindo-se o processo em múltiplos passos; um cenário como este seria adequado para explicar a evolução polibárica de muitas rochas (cf. acima). Por efeito, grandes proporçoes de cumulatos devem ser gerados, porém seu reconhecimento através de métodos geofísicos, sobretudo gravimétricos, é dificultado pela provável semelhança de suas características com as das encaixantes.

A interação com os materiais encaixantes se dá sobretudo através de fluidos - que servem como catalisadores das reações químicas - contaminados por materiais crustais. Neste contexto, 
torna-se compreensível a abundância de termos básicos, insaturados em água, e que portanto, dificilmente atingem a diferenciação completa; por outro lado, os magmas intermediários, mais ricos em água, podem se diferenciar mais rápida- e completamente, o que leva ao desaparecimento dos mesmos em favor de magmas félsicos e rochas cumuláticas. Os produtos félsicos naturais desta evolução são principalmente granitos da associação alcalina, porém o reabastecimento das câmaras com magmas menos diferenciados pode levar à geração de granitos da associação aluminosa de origem mantélica (cf. também Han et al., 1997). A interação com fluidos crustais leva à abertura dos sistemas isotópicos, que passam a indicar contribuiçōes crustais mais evidentes. (Bonin, 1996)

Neste cenário, os corpos de granitos rapakivi representam fases intermediárias mais profundas, onde os magmas derivados se formam e depois seguem até a porção rasa da crosta para dar origem aos complexos anelares, de dimensões mais restritas. Analogamente, os anortositos e corpos máficos bandados associados a granitos rapakivi correspondem às frações cumuláticas restantes da geração destes magmas graníticos. A concentração de ocorrências de granitos rapakivi no Proterozóico e de complexos anelares no Fanerozóico reflete apenas diferentes níveis de erosão (Figura II.17; Bonin. 1996).

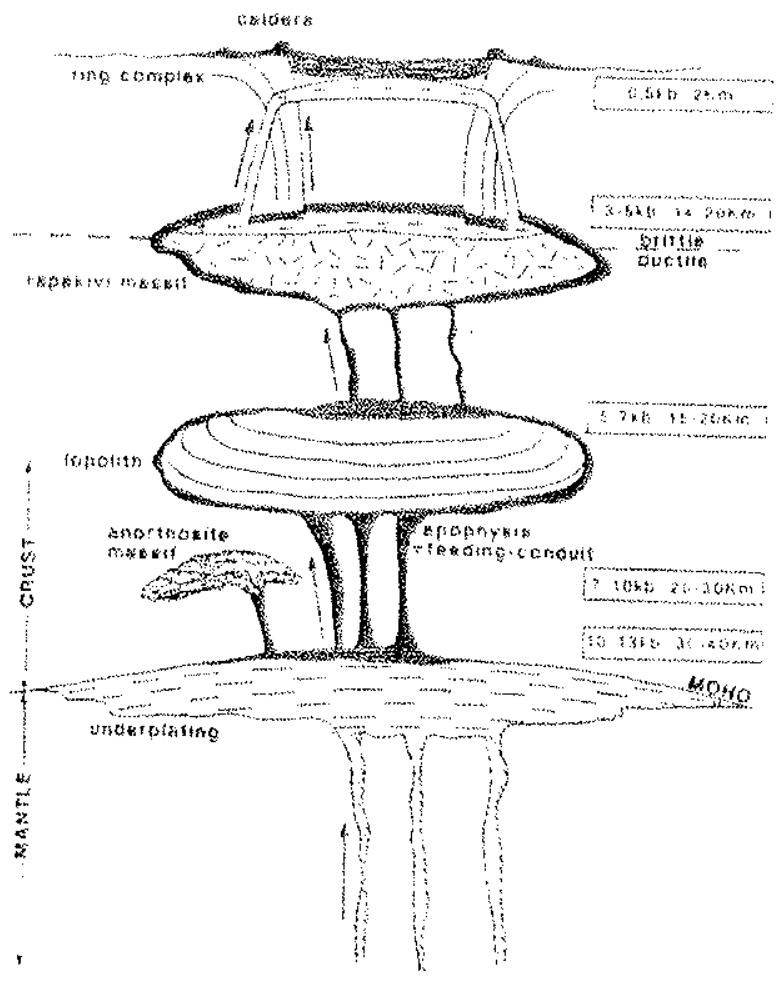

Figura II.17: Niveis estruturais relacionados ao magmatismo granitico Tipo-A. Para detalhes, ver texto. Extraido de Bonin (1996). 
Entretanto, acredita-se hoje que a geraçāo de grandes volumes de granitos rapakivi no Proterozóico esteja relacionada à formação das primeiras grandes massas de crosta continental (Condie, 1993) e ao grande espessamento ocasionado pelas orogêneses Proterozóicas (Puura e Flodén. 1999). Segundo Anderson e Bender (1989), esta crosta deve ter sido essencialmente nãodiferenciada, e portanto, sua porçăo inferior, particularmente fértil; desta forma, a acumulação de calor na base da crosta devido à existência de um supercontinente Proterozóico, ampliada pela atuação de eventuais plumas mantélicas ou pela aproximação do manto astenosférico. permitiram que esta crosta inferior fosse fundida, dando origem ao extensivo magmatismo anorogênico Proterozóico, sem equivalentes Fanerozóicos, responsável pela diferenciação da crosta continenta!.

Windley (1993), por sua vez, favorece uma interpretação como a de Turner et al. (1992b), em que os corpos de granitos da associação aluminosa se formam em ambientes pós-colisionais. A geração dos magmas a/uminosos é condicionada pelo fornecimento de calor ocasionado pela invasão de magmas básicos na crosta inferior e pela composição dessa porção da crosta; as temperaturas relativamente mais altas atingidas neste estágio permitem que protólitos semelhantes aos geradores de granitos Tipo-/, porém não-fundidos devido ao seu caráter mais anidro, sejam mobilizados, dando origem aos granitos da associação aluminosa essencialmente crustais. Contudo, como observado por Bonin (1996), não se conhecem até hoje rochas anatéticas que apresentem leucossomas tipicamente de Tipo-A, o que pōe em xeque a natureza crustal dos magmas aluminosos.

\section{CONSIDERAÇÕES FINAIS}

A revisão apresentada ressalta as caracteristicas descritivas e genéticas singulares dos granitos Tipo-A quando comparadas com as dos demais grupos de granitos (1. S. M). Adicionalmente, deixa clara a necessidade de se separar duas associaçōes petrográficas fundamentais, com características próprias, denominadas genericamente de associações alcalina e aluminosa.

Se os granitos Tipo-A devem ser considerados um subgrupo dos granitos Tipo-/ como sugerido por Creaser et al. (1992) ou não, parece um problema de menor relevância, desde que se tenha em mente que os granitos Tipo-A năo são distintos por apresentarem uma fonte singular.

Parece existir. consenșo quanto à natureza das fontes de magmas geradores de granitos da associação alcalina, tipicamente mantélicas, e em relação à sua geração por cristalização fracionada de termos básicos; neste sentido, a proposiçăo de Bonin et al. (1998) parece ter fundamento. O 
mesmo não ocorre com os granitos da associação aluminosa; historicamente, a geraçăo destas rochas é atribuída a processos de fusäo parcial de crosta continental inferior; entretanto, recentemente foi proposto um modelo que considera fontes mantélicas para estes magmas, atribuindo as assinaturas isotópicas à interação com fluidos hidrotermais crustais. Este é um ponto de debate na literatura internacional, e o estudo da geração e evoluçāo dos granitos desta associação deve ser priorizado.

\section{REFERÊNCIAS BIBLIOGRÁFICAS}

Anderson, J.L.; Bender, E.E. (1989) Nature and origin of Proterozoic A-type granitic magmatism in the southeastern United States of America. Lithos, 23: 19-52.

Bonin. B. (1996) A-type granite ring complexes: mantle origin through crustal filters and the anorthosite - rapakivi magmatism connection. In: Demaiffe, D. (Ed.) Petrology and Geochemistry of magmatic suites of rocks in continental and oceanic crusts. Universite Libre de Bruxelles - Royal Museum for Central Africa (Tervuren). Bélgica. p. 201-217.

X Bonin, B.; Azzouni-Sekkal. A.; Bussy, F.; Ferrag, S. (1998) Alkali-calcic and alkaline post-orogenic (PO) granite magmatism: petrologic constraints and geodynamic settings. Lithos, 45: 45-70.

\% Clemens, J.D.: Holloway, J.R.; White, A.J.R. (1986) Origin of an A-type granite: Experimental constraints. American Mineralogist, 71: 317-324.

Condie, K. (1993) Plate tectonics and crustal evolution. Pergamon Press. Inglaterra. $492 \mathrm{p}$.

Creaser, R.A.; Price, R.C.; Wormald, R.J. (1991) A-type granites revisited: Assessment of a residualsource model. Geology, 19: 163-166.

Dall'Agnol, R.; Rämö, O.T.; Magalhães, M.S.; Macambira, M.J.B. (1999) Petrology of the anorogenic, oxidised Jamon and Musa granites. Amazonian Craton: implications for the genesis of Proterozoic A-type granites. Lithos, 46: 431-462.

Eby. G.N. (1990) The A-type granitoids: A review of their occurrence and chemical characteristics and speculations on their petrogenesis. Lithos, 26: 115-134.

Eby. G.N. (1992) Chemical subdivision of the A-type granitoids: Petrogenetic and tectonic implications. Geology, 20:641-644.

Elliott, B.A.: Rämö, O.T.; Nironen, M. (1998) Mineral chemistry constraints on the evolution of the 1.88-1.87 Ga post-kinematic granite plutons in the Central Finland Granitoid Complex. Lithos, 45: 109-129.

Foland, K.A.: Allen, J.C. (1991) Magma sources for Mesozoic anorogenic granites of the White Mountains magma series, New England, USA. Contributions to Mineralogy and Petrology. 109: $195-211$.

Frost, C.D.; Frost, B.R.(1997) Reduced rapakivi-type granites: the tholeite connection. Geology, 25: 647-650.

Hadj-Kaddour, Z.; Liégeois, J.-P.; Demaiffe, D.; Caby, R. (1998) The alkaline - peralkaline postcollisional Tin Zebane dyke swarm (Pan-African Tuareg shield. Algeria): prevalent mantle signature and late agpaitic differentiation. Lithos, 45: 223-243. 
Hogan, M.C.: Gilbert, M.C.; Weaver, B.L. (1992) A-type granites and rhyolites: Is A for ambiguous? EOS, 73: 508 .

Y. King, P.L.: White, A.J.R.: Chappel, B.W.; Allen, C.M. (1997) Characterizations and origin of aluminous A-type granites from the Lachlan fold Belt, Southeastern Australia. Journal of Petrology, 38: $371-391$.

x Kerr, A.; Fryer, B.J. (1993) Nd isotope evidence for crust-mantle interaction in the generation of Atype granitoid suites in Labrador. Canada. Chemical Geology. 104: 39-60.

K Lameyre, J. e Bowden, P. (1982) Plutonic rock type series: discrimination of various granitoid series and related rocks. Journal of Volcanology and Geothermal Research, 14: 169-189.

Liégeois, J.-P.; Diombana, D.: Black, R. (1996) The Tessalit ring complex (Adrar des Iforas, Malian Tuareg shield): a Pan-African, post-collisional, syn-shear, alkaline intrusion. In: Demaiffe, D. (Ed.) Petrology and Geochemistry of magmatic suites of rocks in continental and oceanic crusts. Université Libre de Bruxelles - Royal Museum for Central Africa (Tervuren). Bélgica. p. 227-244.

Liégeois, J.-P.; Navez, J.; Hertogen. J.: Black, R. (1998) Contrasting origin of post-collisional high-K calc-alkaline and shoshonitic versus alkaline and peralkaline granitoids. The use of sliding normalization. Lithos, 45: 1-28.

* Martin. R.F.: Bonin. B. (1976) Water and magma genesis: the association hypersolvus granitesubsolvus granite. Canadian Mineralogist, 14: 228-237.

Nägler, T.F.; Frei, R. (1997) True K-feldspar granites in oceanic crust (Masirah ophiolite, Sultanate of Oman): A U-Pb and Sm-Nd isotope study. Chemical Ceology, 138: 119-126.

Pearce, J.A.; Harris. N.B.W.; Tindle, A.G. (1984) Trace element discrimination diagrams for the tectonic interpretation of granitic rocks. Journal of Petrology, 25: 956-983.

Pitcher. W.S. (1993) The nature and origin of granite. Blackie Academic \& Professional. England. p. 218.237 .

X Poitrasson, F.: Duthou, J.L.; Pin, C. (1995) The relationship between petrology and Nd isotopes as evidence for contrasting anorogenic granite genesis: Example of the Corsican Province. Journal of Petrology, 36: 1251-1274.

Puura, V. e Flodén. T. (1999) Rapakivi-granite - anorthosite magmatism - a way of thinning and stabilisation of the Svecofennian crust, Baltic Sea Basin. Tectonophysics, 305: 75-92.

Rämö. O.T.; Haapala, I. (1995) One hundred years of Rapakivi Granite. Mineralogy and Petrology, 52: 129-185.

X Sylvester. P.J. (1989) Post-collisional alkaline granites. Journal of Geology, 97: 261-281.

Tack, L.; Deblond, A.; Paepe, P.; Duchesne. J.C.; Liégeois. J.-P. (1996) Proterozoic alignments of alkaline plutons revealing lithospheric discontinuities: evidence from eastern Africa. In: Demaiffe, D. (Ed.) Petrology and Geochemistry of magmatic suites of rocks in continental and oceanic crusts. Université Libre de Bruxelles - Royal Museum for Central Africa (Tervuren). Bélgica. p. 219-226

Turner, S.P.; Foden, J.D.; Morrison, R.S. (1992a) Derivation of some A-type magmas by fractionation of basaltic magma: An example from Padthaway Ridge. South Australia. Lithos. 28: 151-179. 
Lurner, S.P.: Sandiford, M.: Foden, J.D. (1992b) Some geodynamic and compositional constraints on "postorogenic" magmatism. Geology, 20: 931-934.

Whalen. J.B.; Currie, K.L.; Chappel, B.W. (1987) A-type granites: Geochemical characteristics, discrimination and petrogenesis. Contributions to Mineralogy and Petrology, 95: 407-4.19.

Whalen, J.B.; Jenner, G.A.; Longstaffe, F.J.; Robert, F.; Gariepy, C. (1996) Geochemical and isotopic $(\mathrm{O}, \mathrm{Nd}, \mathrm{Pb}$ and $\mathrm{Sr}$ ) constraints on A-type granite petrogenesis based on the Topsails Igneous Suite. Newfoundland Appalachians. Journal of Petrology. 37: 1463-1489.

Windley. B.F. (1993) Proterozoic anorogenic magmatism. Journal of the Geological Society of London, 150: 39-50. 
Parte /l/:

\section{OS GRANITOS TIPO-A DA GRACIOSA:}

Contexto Regional e Caracterização Geológica 


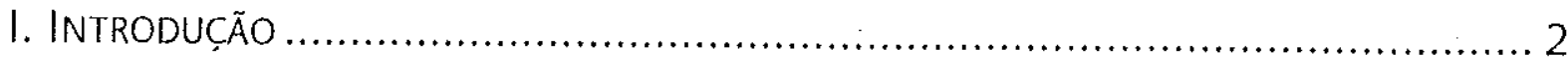

II. CONTEXTO GEOLÓGICO REGIONAL.......................................................... 2

11.1. O embasamento da Plataforma Sul-Americana no Sul-Sudeste do Brasil.... 2

II.2. A Província Serra do Mar ............................................................................ 6

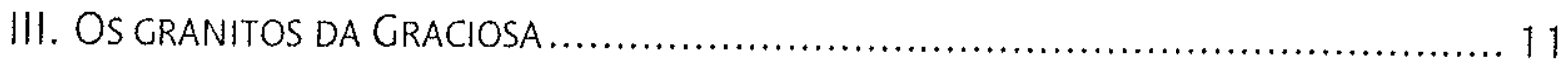

111.1. Aspectos naturais e localização .......................................................... 11

111.2. Histórico dos trabalhos anteriores .......................................................... 11

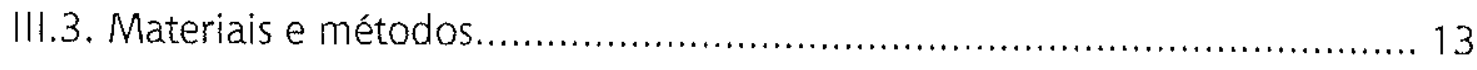

III.4. Características geológicas gerais........................................................ 15

111.5. Geologia e petrografia dos maciços ................................................ 17

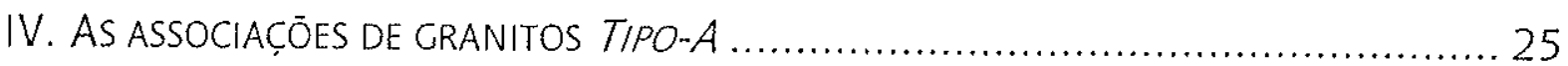

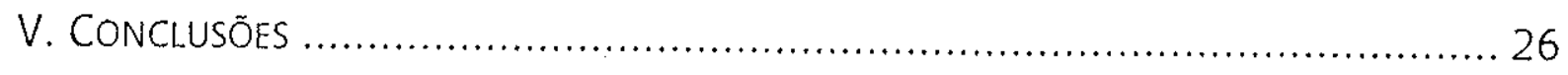

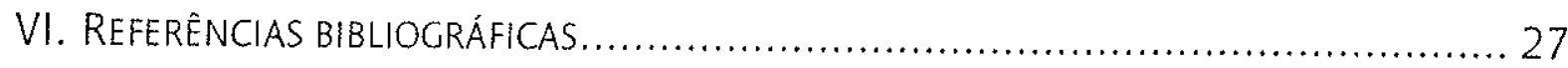

ANEXOS 


\section{INTRODUÇÃO}

A regiāo da Serra da Graciosa, no E do Paraná, concentra algumas das ocorrências mais expressivas de granitos dentre as que compõem a Província Serra do Mar.

Formada no final do Ciclo Brasiliano (ca. $580 \mathrm{Ma}$ ) por importante magmatismo pós-colisional, esta provincia congrega mais de uma dezena de macicos graníticos e sieníticos, caracterizados pelas associações alcalina e aluminosa de granitos Tipo- $A$, que se distribuem paralelamente ao litoral, ao longo da Serra do Mar, desde a região NE de Santa Catarina até o SE de São Paulo, sendo intrusivos principalmente em rochas Arqueanas do Cráton Luiz Alves e Neoproterozóicas da Microplaca Curitiba.

Esse conjunto de macicos foi alvo apenas de trabalhos de reconhecimento geral, faltando o detalhamento das variedades petrográficas presentes bem como das relaçōes genéticas entre elas. A coexistência das associaçōes alcalina e aluminosa de granitos Tipo-A em ambientes pós-colisionais. como acontece na região da Serra da Graciosa, é ponto de debate na literatura internacional, e portanto, a regiāo é adequada para o estudo das relaçōes genéticas entre essas duas séries petrográficas.

Entretanto, um estudo petrológico como este só é possível com base em um corpo consistente de conhecimentos geológicos e petrográficos sobre as ocorrências da área. Desta forma, o objetivo deste trabalho é fazer a caracterização geológica dos maciços da região da Serra da Graciosa, com o intuito de fundamentar um trabalho petrológico futuro, bem como resultar em uma contribuição à geologia regional.

\section{CONTEXTO GEOLÓGico REGIONAL}

\subsection{O EMBASAMENTO DA PLATAFORMA SUL-AMERICANA NO SUL-SUDESTE DO BRASIL}

Os macicos que compōem a Província Serra do Mar - isolados ou associados a bacias vulcanosedimentares - são intrusivos nas rochas do "Maciço de Joinville" de Hasui et al. (1975), balizado a N pelo Cinturão Ribeira e a S pelo Cinturāo Dom Feliciano (Figuras III.1 e III.2).

O Cinturăo Ribeira (Hasui et al., 1975) se estende por uma faixa adjacente ao litoral SE do Brasil (desde o Espírito Santo até o S de São Paulo). Desenvolveu-se durante o Ciclo Brasiliano - PanAfricano, uma colagem que inclui duas orogêneses importantes: "Brasiliana I". com idades mais comuns próximas de 650-600 Ma; e Rio Doce, mais recente, com idades no intervalo 600-535 Ma 
(Campos Neto e Figueiredo, 1995). São separadas por uma fase extensional caracterizada pela colocação dos granitóides pós-colisionaị da Província Itu (Vlach et al. 1990). No extremo $S$ do. Cinturăo Ribeira afloram os metassedimentos da Faixa de Dobramentos Apiaí - Grupos Setuva e Açungui - gerados durante a orogênese "Brasiliana I". (Hasui et al., 1975: Campanha et al., 1987: Campos Neto e Figueiredo. 1995; entre outros).

O Cinturão Dom Feliciano, também gerado durante a colagem Brasiliana, pode ser dividido, na sua porção N (no Estado de Santa Catarina), em três porções com limites tectônicos entre si, de norte para sul: Domínio Externo, incluindo a Bacia de Itajaí e o Maciço Granítico Subida; Domínio Intermediário, caracterizado pelas seqüencias metavulcanossedimentares do Grupo Brusque e pelas Suítes Granitóides Valsungana e Guabiruba; Domínio Interno, composto por ortognaisses e migmatitos, cortados por granitóides das Suítes São Pedro de Alcântara e Pedras Grandes, alén de rochas sedimentares da Formação Queçaba (Basei. 1985; Basei et al., 1987).

A denominação "Maciço de Joinville" (Hasui et al., 1975) para os terrenos localizados entre os Cinturōes Ribeira e Dom Feliciano foi abandonada por Basei et al. (1992), que defiriram três unidades tectônicas independentes: Microplaca Curitiba (a N); Microplaca Luiz Alves (a S); Cinturâo Granitóide Costeiro (a E). (Figura III.3)

- A porção NW da Microplaca Curitiba é denominada Domínio dos Gnaisses Retrabalhados, com predomínio de biotita-anfibólio gnaisses bandados a NW e de gnaisses graníticos bandados a SE, ambos apresentando intercalações de anfibolitos e biotita-granada anfibolitos: estas rochas foram geradas durante o Ciclo Transamazônico (2.150-1.800 Ma) e migmatizadas no Ciclo Brasiliano (620$550 \mathrm{Ma}$ ). Separado desta porção por uma zona de cisalhamento, aparece, na porção SE da Microplaca Curitiba, o Domínio do Arco Magmático, caracterizado por biotita-anfibólio monzogranitos deformados de idade Brasiliana (720 Ma - U-Pb em zircões; $580 \mathrm{Ma}$ - Rb-Sr em rocha total). (Basei et al., 1992; Siga Jr. et al., 1993)

A Microplaca Luiz Alves é dominada por gnaisses granulíticos, bandados a maciços, de composição tonalítica a granodiorítica, com intercalações de granulitos máficos. Os dados geocronológicos se concentram ëm dois períodos de formação, um referente ao Ciclo Transamazônico (2.250-1:850 Ma), e outro mais antigo (2.700-2.600 Ma). (Basei et al., 1992; Siga Jr. et al., 1993) 


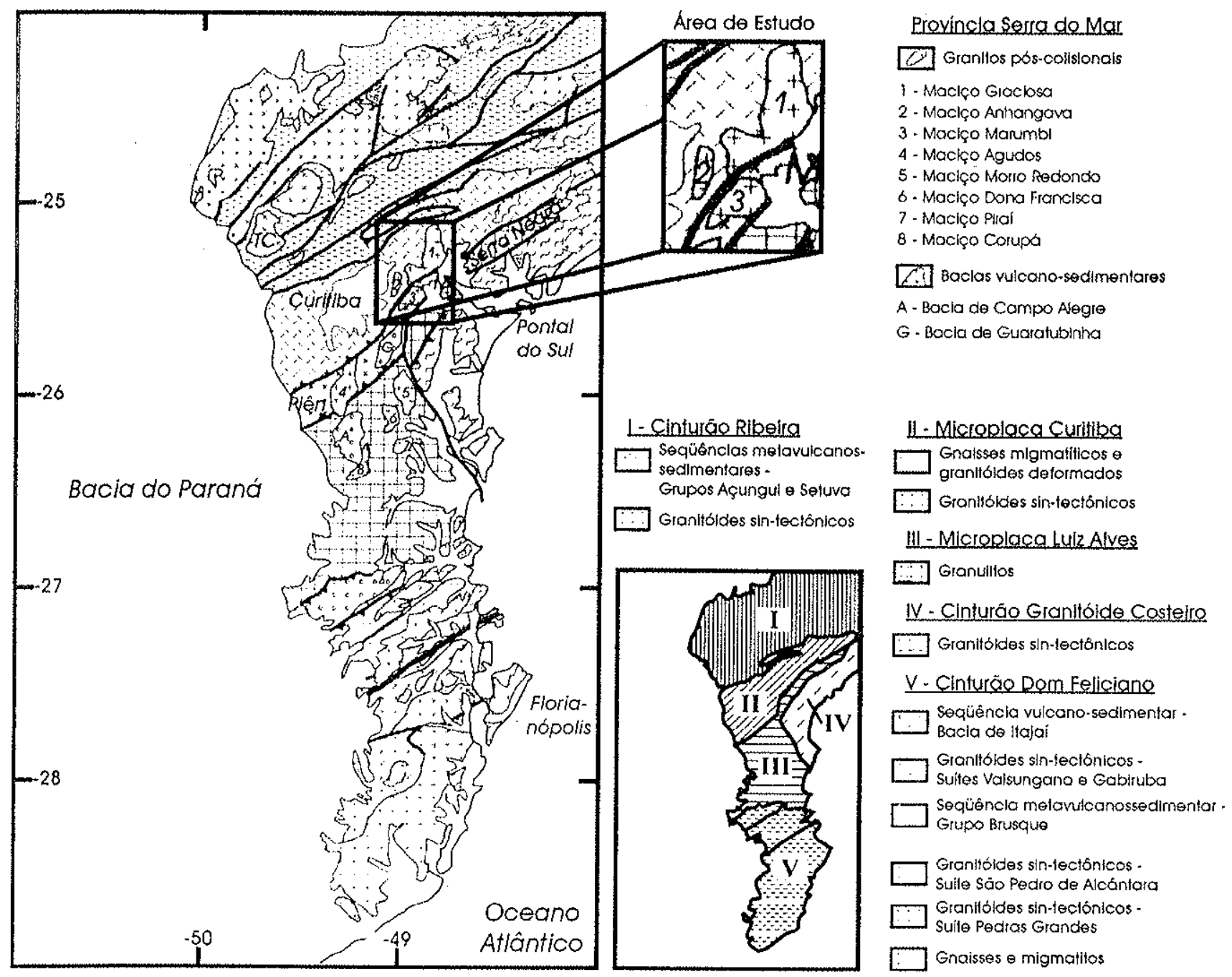

Figura III.1: Compartimentação tectônica do embasamento da Plataforma Sul-Americana nos

Estados de São Paulo, Paraná e Santa Catarina. Adaptado de Hallinan et al. (1993).
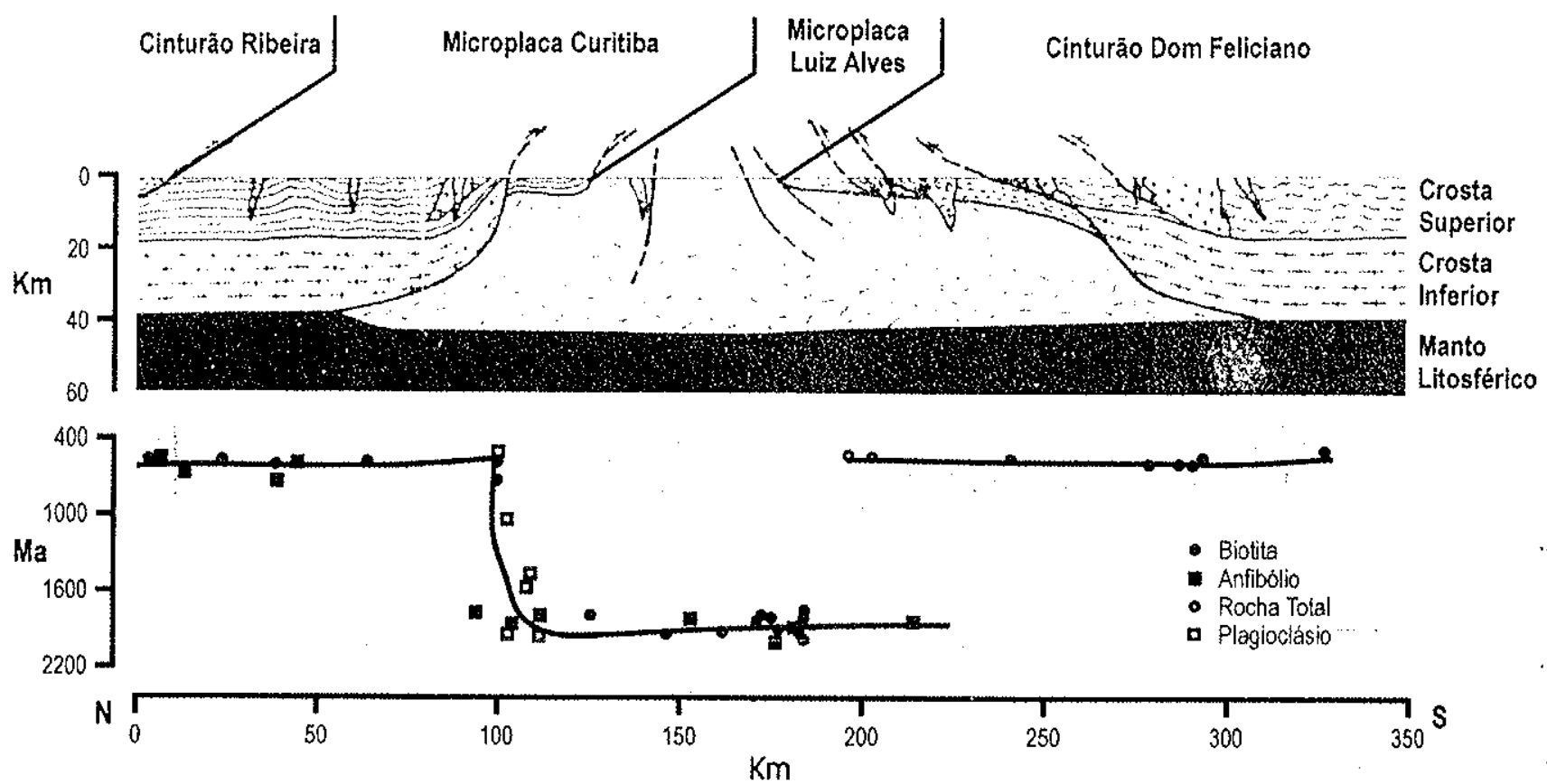

Figura Ill.2: Modelo gravimetrico e perfil de idades de resfriamento (K-Ar). Adaptado de Mantovaniet al. (1989) e Siga Jr. et al. (1989). 

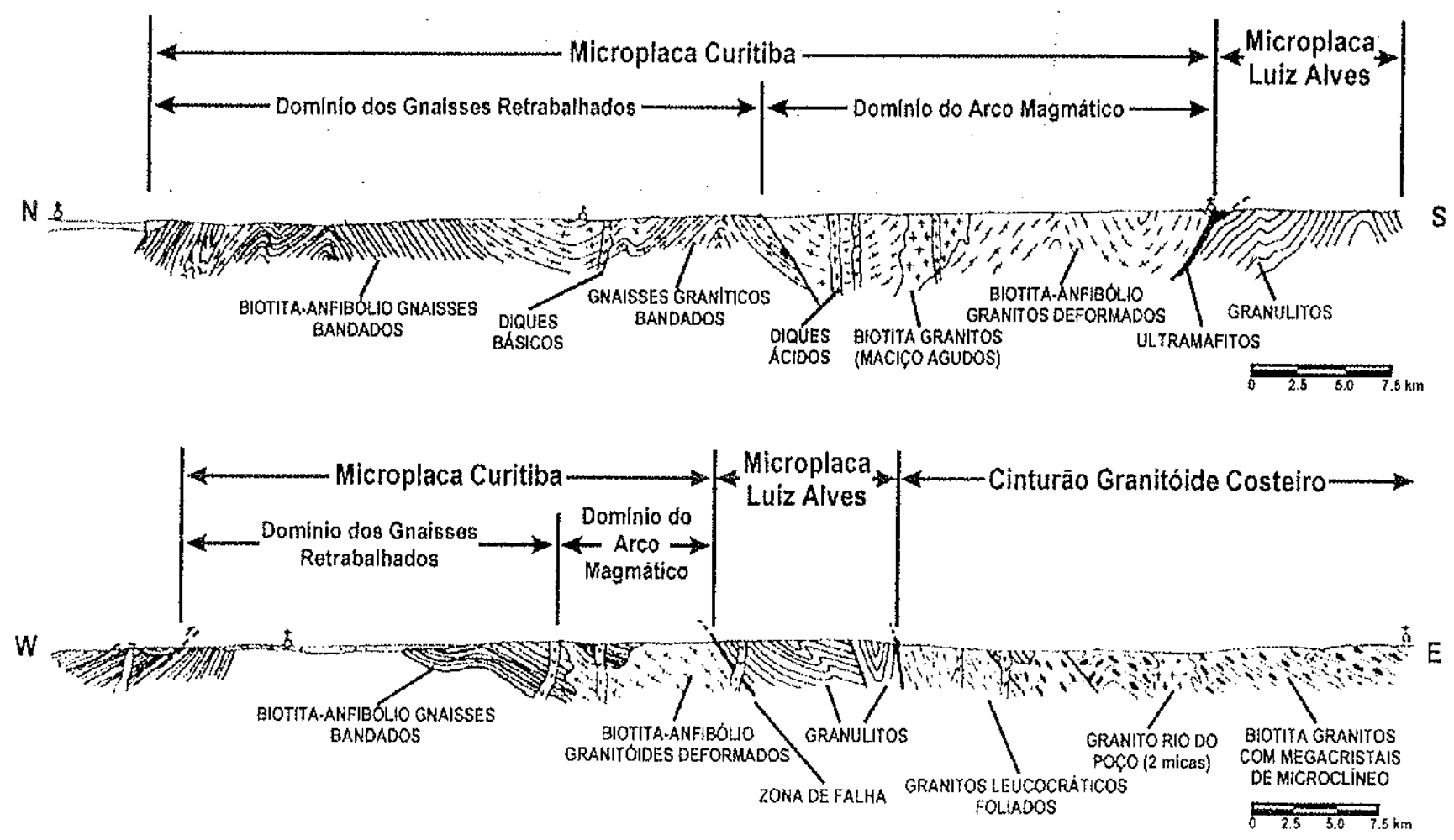

Figura III.3: Perfil geologico da região compreendida entre os Cinturöes Ribeira e Dom Feliciano. Adaptado de Baseiet al. (1992).

- No Cinturão Granitóide Costeiro predominam biotita monzogranitos porfiriticos, formados durante o Brasiliano (615-570 Ma). Leucogranitos isótropos a duas micas aparecem como ocorrências tardias, enquanto restos de rochas encaixantes como xistos, gnaisses, quartzitos e anfibolitos aparecem freqüentemente migmatizados. (Basei et al., 1992; Siga Jr. et al., 1993)

As rochas da Microplaca Luiz Alves revelam idades K-Ar Transamazônicas (2.100-1.700 Ma), mostrando que o bloco se comportou como um cráton durante o Ciclo Brasiliano. Em direção ao contato com a Microplaca Curitiba, observa-se uma variaçāo gradual das idades K-Ar desde os valores Transamazônicos típicos da regiăo interna até idades Brasilianas equivalentes às encontradas em toda a Microplaca Curitiba (Figura II.2), o que evidencia se tratar de um contato "quente" (Siga Jr. et al., 1990: Siga Jr. et al., 1993): neste contato, bastante verticalizado (Mantovani et al., 1989), as rochas da Microplaca Curitiba cavalgam sobre os granulitos da Microplaca Luiz Alves. Ainda nesta região, nas proximidades da Cidade de Piên, são observadas rochas ultramáficas serpentinizadas (Girardi, 1974), interpretadas como restos oceânicos obductados (Basei et al., 1992); neste contexto. as Microplacas Curitiba e Luiz Alves se configuram como "terrenos suispeitos", justapostos pelo fechamento de um oceano (Basei et al., 1992; Mantovani et al., 1989). Entretanto. Siga Jr. et al. (1993) (i) não encontram restos de sedimentos associados a este oceano. (ii) identificam núcleos Transamazônicos na Microplaca Curitiba, e (iii) observam que, do ponto de vista isotópico, as rochas 
deste domínio poderiam ser geradas a partir dos granulitos da Microplaca Luiz Alves, o que os levou à conclusão de que a Microplaca Curitiba corresponde a um Maciço Marginal do Cráton Luiz Alves.

Na porção S. os Domínios Externo e Intermediário do Cinturāo Dom Feliciano formam uma unidade tectônica relativamente rasa (Mantovani et al., 1989), que se coloca, através de empurrões, sobre a Microplaca Luiz Alves, enquanto o Domínio Interno corresponde a uma unidade crustal independente justaposta à Microplaca Luiz Alves. Os dados K-Ar mostram que estes contatos, menos verticais que o contato entre as Microplacas Curitiba e Luiz Alves, são tipicamente frios (Figura III.2; Siga Jr. et al., 1990).

\subsection{A PROVÍNCIA SERRA do MAR}

A Província Serra do Mar reúne mais de uma dezena de maciços graníticos e sieníticos distribuidos paralelamente à costa atântica desde o extremo SE do Estado de São Paulo até o NE de Santa Catarina (Kaul, 1984). (Figura III.1)

\section{Características geológicas}

Os granitóides são intrusivos principalmente em rochas granulíticas arqueanas do Cráton Luiz Alves e em gnaisses e migmatitos da Microplaca Curitiba (Kaul, 1984: Siga Jr. et al., 1993). dispondo-se paraielamente ao contato entre o Cráton Luiz Alves e o Cinturão Granitóide Costeiro.

Os corpos têm geometria variada, com predomínio de formas subcirculares (e.g. Maciço Morro Redondo), mostrando a ausência de controle estrutural importante. Outros maciços apresentam formas irregulares, evidenciando o controle da injeção por estruturas rúpteis (e.g. Maciço Corupá); formas irregulares são desenvolvidas também pela atuação de tectônica rúptil após a colocacão dos corpos (e.g. Maciço Agudos) (Kaut, 1997). As estruturas isótropas das rochas formadas corroboram a idéia de que a instalação dos corpos se deu em ambiente caracterizado pela ausência de esforcos compressivos. De acordo com Kaul (1997), o controle das intrusões é dado por deformação rúptil. principalmente na forma de falhas extensionais de gravidade que compõem dois sistemas, um mais recente e de distribuiçāo mais ampla, de direção aproximada N450-50E (Maciços Corupá. Dona Francisca e Piraí e Bacia de Guaratubinha), e outro mais antigo de direção N20 $20^{\circ}$ - W (Maciços Agudos, Graciosa e Morro Redondo).

A presença de bacias vulcano-sedimentares contemporâneas e associadas a diversos maciços (e.g. Corupá, Agudos, Morro Redondo), bem como características estruturais e texturais dos granitos 
e sienitos (e.g. presença de cavidades miarolíticas, quartzo bipiramidal, etc.), evidenciam a colocação em níveis crustais rasos. Hallinan et al. (1993) chegam à mesma conclusão a partir da análise de dados gravimétricos.

As idades ( $\mathrm{U}-\mathrm{Pb}$ em zircões e $\mathrm{Rb}-\mathrm{Sr}$ em rocha total) dos diversos maciços se concentram no intervalo 595-550 Ma, pouco mais jovens e em parte contemporâneas às dos granitóides do Cinturão Costeiro (615-570 Ma). As idades de resfriamento (K-Ar), por outro lado, apresentam relação contrária, mostrando que os maciços da Província Serra do Mar se resfriaram mais rapidamente, o que também é compatível com uma colocação em níveis crustais relativamente rasos (Siga Jr. et al., 1994).

Todas essas características mostram que a geração destes magmas está associada ao rearranjo crustal decorrente da colisão entre o Cinturão Granitóide Costeiro e o conjunto formado pelas Microplacas Curitiba e Luiz Alves (Siga Jr. et al., 1994), em ambiente tipicamente pós-colisional como definido por Liégeois (1998) -, em que ainda existe convergência entre os dois blocos, porém a deformação tem caráter notadamente mais rúptil e se acumula em grandes falhas de rejeito transcorrente, com pouca ou nenhuma deformação nos terrenos localizados entre essas falhas.

\section{Características petrográficas}

Do ponto de vista petrográfico, os diversos maciços têm sido tradicionalmente descritos como compostos por rochas graníticas e mais raramente sieníticas de tendência alcalina e em alguns casos claramente peralcalinas (e.g. "Granitos Alcalinos da Serra do Mar" - Fuck et al., 1967; "corpos alasquíticos ou de tendência alcalina" - Wernick e Penalva, 1978; "Fácies Graciosa [...], caracterizada pela presença de granitos de acentuada alcalinidade" - Hasui et al., 1978; "granitos alcalinos e peralcalinos" - Kaul, 1984; Siga Jr. et al., 1994).

Entretanto, tal visão representa uma simplificação frente à variedade de tipos petrográficos observados na maioria dos maciços. Invariavelmente são descritas rochas claramente peralcalinas contendo ạnfibólio ou piroxênio sódicos -, rochas tipicamente metaluminosas, contendo anfibólio cálcico como máfico predominante, e ainda rochas levemente peraluminosas, em que a biotita é o. máfico principal.

De maneira geral, este conjunto de rochas pode ser subdividido em duas associações petrográficas contrastadas, uma alcalina (incluindo termos peralcalinos e metaluminosos associados, na concepçäo de Lameyre e Bowden. 1982) e outra aluminosa (incluindo termos peraluminosos e 
metaluminosos associados). Essas duas associações compõem o que se denomina de granitos Tipo-A (Pitcher, 1995).

\section{A associação petrográfica alcalina}

A associação de sienitos e álcali-feldspato granitos hiperso/vus (na concepção de Tuttle e Bowen, 1958), metaluminosos a peralcalinos, que caracterizam a associação alcalina, é típica e está distribuída por toda a Província Serra do Mar.

São rochas hololeucocráticas e leucocráticas com estruturas maciças e texturas equigranulares a seriadas de granulação fina e média. Ocupam a totalidade do Maciço Corupá e frações significativas dos Maciços Morro Redondo e Anhangava. Nos Maciços Graciosa e Mandira são conhecidos os termos mais diferenciados, tipicamente álcali-feldspato granitos (Kaul, 1997).

Os sienitos (e.g. Maciço Corupá) mais máficos são tipicamente metaluminosos, contendo clinopiroxênio e anfibólio cálcico, além de olivina, como máficos principais. Já os álcali-feldspato sienitos e granitos (e.g. Maciços Corupá. Graciosa, Mandira) mais diferenciados, gradam desde metaluminosos a peralcalinos, com correspondente variação na composição dos anfibólios, desde cálcicos até sódicos.

A presença típica de (i) cristais de anfibólio zonado, gradando desde variedades cálcicas a cálcico-sódicas e sódicas (Oliveira, 1997: Chiessi et al., 1998); (ii) núcleos corroídos e transformados de plagioclásio manteados por feldspato alcalino em alguns sienitos mais máficos (Kaul, 1997); e (iii) enclaves microgranulares com composição quartzo monzonítica (Oliveira, 1997), levam à hipótese de que tais rochas representam uma série originada por cristalização fracionada, possivelmente a partir de magmas básico-intermediários ou, alternativamente, que pelo menos interagiram com estes últimos durante sua evolução.

\section{A associação petrográfica aluminosa}

Esta associação inclui principalmente sienogranitos e álcali-feldspato granitos subsolvus, metaluminosos a moderadamente peraluminosos, com biotita e anfibólio cálcico como máficos característicos. Quartzo-monzonitos metaluminosos, portando clinopiroxêniö, ocorrem no Maciço Graciosa (Kaul, 1997). Tipicamente são rochas leucocráticas a hololeucocráticas com estruturas predominantemente maciças, de granulaçăo variável desde fina até grossa; as texturas são variadas, desde equigranular a seriada e porfiritica (com megacristais de feldspato alcalino pertítico). 
Esta associação é importante nos Maciços Morro Redondo e Anhangava, e dominante nos Maciços Graciosa e Mandira (Kaul، 1997 e Oliveira, 1989). No Macico Morro Redondo, Kaul (1997) descreve passagens gradacionais de hornblenda-clinopiroxênio sienitos a álcali-feldspato sienitos com faialita e finalmente a biotita álcali-feldspato granitos.

\section{Rochas gabro-dioriticas}

Gabros e dioritos, comuns em outras áreas de ocorrência de granitos Tipo-A (e.g. Upton e Emeleus, 1987), são muito raros na provincia. Uma única ocorrência importante de biotita hornblenda quartzo dioritos e monzodioritos, já descrita como "sieno-dioritos" por Maack (1961), aflora no Maciço Graciosa, próximo ao Pico Paraná. Recentemente, rochas similares foram encontradas por nós no Maciço Corupá (Garin, em preparação).

\section{As associaçōes de rochas vulcânicas contemporâneas}

As ocorrências de rochas vulcânicas contemporâneas às rochas plutônicas se concentram em quatro regiões: nas bacias vulicano-sedimentares de Campo Alegre, Guaratubinha e Corupá (Figura 111.1) e associadas às rochas plutônicas do Maciço Morro Redondo. (Figura III.1)

As seqüencias vulcano-sedimentares apresentam na base arenitos e conglomerados, seguidos de rochas vulcânicas básicas e mais raramente ácidas: seguem-se sedimentos variados desde finos. incluindo siltitos e arcóseos finos, até grossos, como conglomerados: finalmente aparecem rochas efusivas e piroclásticas ácidas associadas a siltitos e tufos. A variação na maturidade mineralógica e textural dos sedimentos mostra uma progressiva estabilização das bacias. Metamorfismo incipiente é sempre observado, e os estratos apresentam inclinação da ordem de $20^{\circ}$ a $40^{\circ}$, à exceção das zonas de falha, onde podem se tornar subverticais. (Kaul. 1997).

A caracteristica mais importante a ser aqui destacada é a natureza bimodal do vulcanismo, com rochas efusivas básicas e ácidas coexistentes, e típica lacuna composicional, com ausência de termos intermediários (Góis, 1995).

\section{Características geoquímicas}

Do ponto de vista geoquímico, as características mais marcantes dos granitos Tipo-A, capazes de discriminá-los dos demais tipos de granitos (I, S, M) são os valores elevados de álcalis, elementos de alto potencial iônico (e.g. Zr, Nb, Y), elementos terras raras (e.g. Ce), e das razöes Fe/Mg e Ga/Al. Nos diagramas de Pearce et al. (1984), os granitos Tipo-A se concentram no campo dos granitos 
intraplaca (Whalen et al.. 1987). Fica evidente a partir da análise da Figura III.4 que os granitos da Província Serra do Mar compartilham essas características (cf. Kaul. 1997: Kaul e Cordani. 2000).
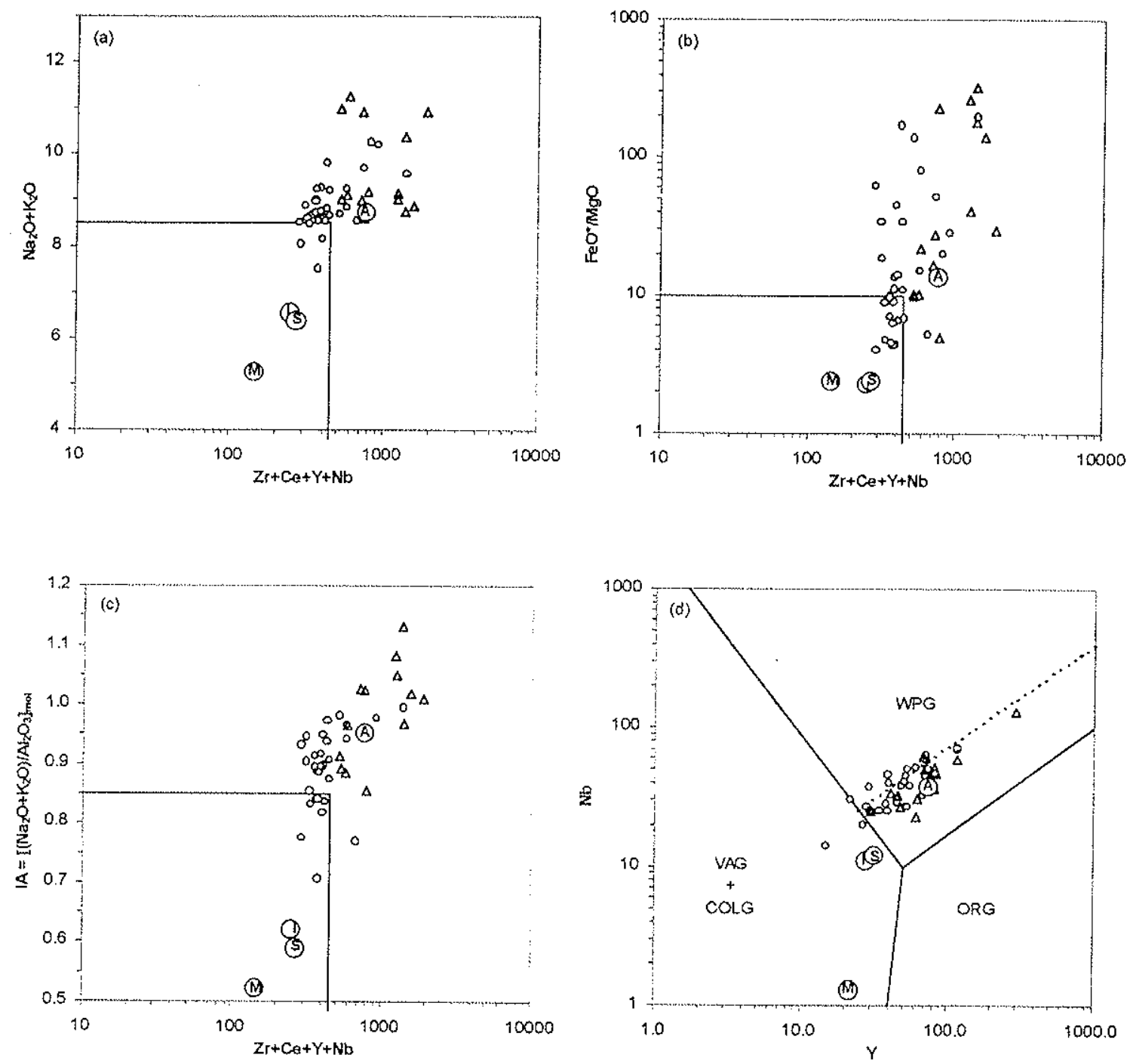

Figura Ill.4: Diagramas discriminatórios de granitos Tipo-A. Dados geoquímicos extraídos de Kaul (1997). Circulos preenchidos: granitos Tipo-A aluminosos; triângulos vazios: granitos Tipo-A alcalinos. Médias dos granitos Tipo-I, -S e-M segundo Whalen et al. (1987) (a). (b). (c): campos dos granitos Tipo-1, -S e -M segundo Whalen et al. (1987). (d): campos segundo Pearce et al. (1984). $\mathrm{Em}\left(\right.$ b), $\mathrm{FeO}^{*}=$ todo ferro calculado como FeO. 


\section{OS GRANITOS DA GRACIOSA}

Os granitos da região da Serra da Graciosa, no seu conjunto, afloram por uma área de aproximadamente $500 \mathrm{~km}^{2}$. constituindo-se em um dos maiores volumes de rochas graníticas existentes na Província Serra do Mar.

\section{III.1. ASPECTOS NATURAIS E LOCALIZACÃO}

A Serra do Mar faz a transição entre o Primeiro Planalto Paranaense a W, com elevação em torno de $900 \mathrm{~m}$. e a Planície Litorânea a E. Nas áreas onde aparecem os corpos graníticos, ao contrário do que ocorre nos demais locais, observam-se serras destacadas em relação ao planalto, com altitudes máximas entre 1400 e 2000 m (Figura 1II.5). Esta região de relevo bastante acidentado preserva uma porção praticamente intacta da Mata Atlântica de Encosta, caracterizada por uma vegetação do tipo Floresta Montana Ombrófila Densa.

A região enfocada neste trabalho, aqui denominada genericamente de Serra da Graciosa, inclui um conjunto de serras (Capivari, Órgãos, Graciosa - Farinha Seca e Marumbi) que compõem a serra do Mar, além da serra da Baitaca - - Boa Vista, à W da Serra da Graciosa, inteiramente localizada no Primeiro Planalto. A região situa-se cerca de $40 \mathrm{~km}$ a $\mathrm{E}$ da cidade de Curitiba, tendo forma alongada na direção NNE-SSW, com dimensões aproximadas de $50 \times 17 \mathrm{~km}$. (Figura 111.6, em anexo)

\subsection{HISTÓRICO DOS TRABALHOS ANTERIORES}

A identificação de volumes expressivos de rochas graníticas de "afinidade alcalina" na região foi efetuada pioneiramente por Maack (1961). que descreveu amostras provenientes da Serra dos Órgãos, nas proximidades do Pico do Paraná; do "pedestal" da Serra da Graciosa, junto à estrada da Graciosa; e da Serra do Marumbi (Figura III.7).

Os tipos descritos são predominantemente granitos, que com base em características petrográficas e em parâmetros geoquímicos, foram classificados como granitos alcalinos (Pico do Paraná e pedestal da Serra da Graciosa) ou de tendência alcalina (Pico Marumbi). Na Serra dos Órgãos foram identificadas ainda rochas dioríticas (cf. abaixo), além de vulcânicas não-descritas.

Maack (1961) reúne os granitos das Serras da Graciosa e dos Órgāos sob a denominação de "complexos de granitos alcalinos", mas observa que estāo separados por rochas gnáissicas do embasamento e por "diques do vulcanismo gondwânico". Os granitos da Serra do Marumbi são 
mapeados como uma unidade independente, e é inferida a presença de granitos "alcalinos" na Serra do Capivari (Figura III.7).

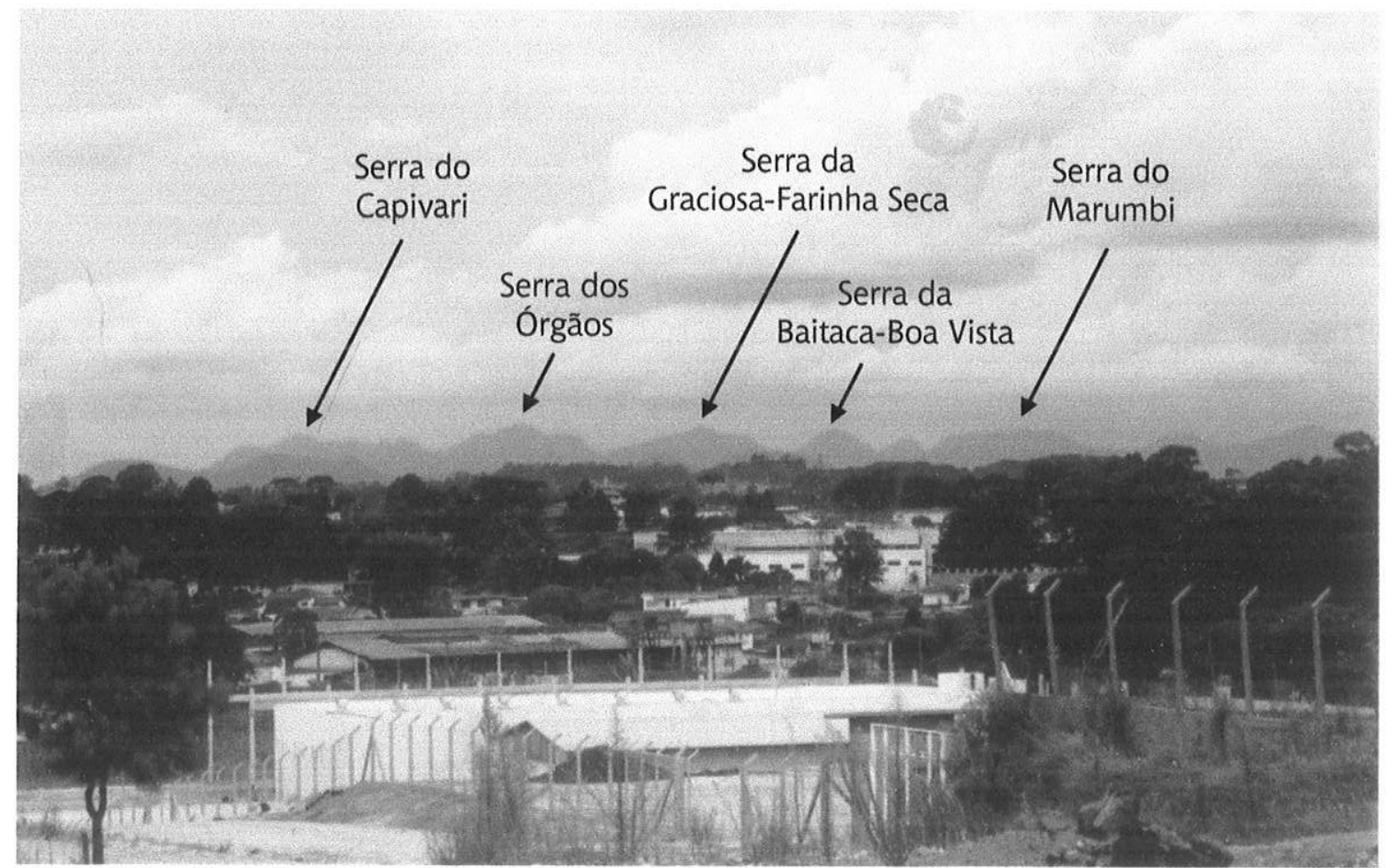

Figura III.5: Vista das serras da região da Serra da Graciosa a partir do primeiro planalto paranaense. Foto tirada na da BR-116 nas proximidades da cidade de Curitiba (vista para NE).

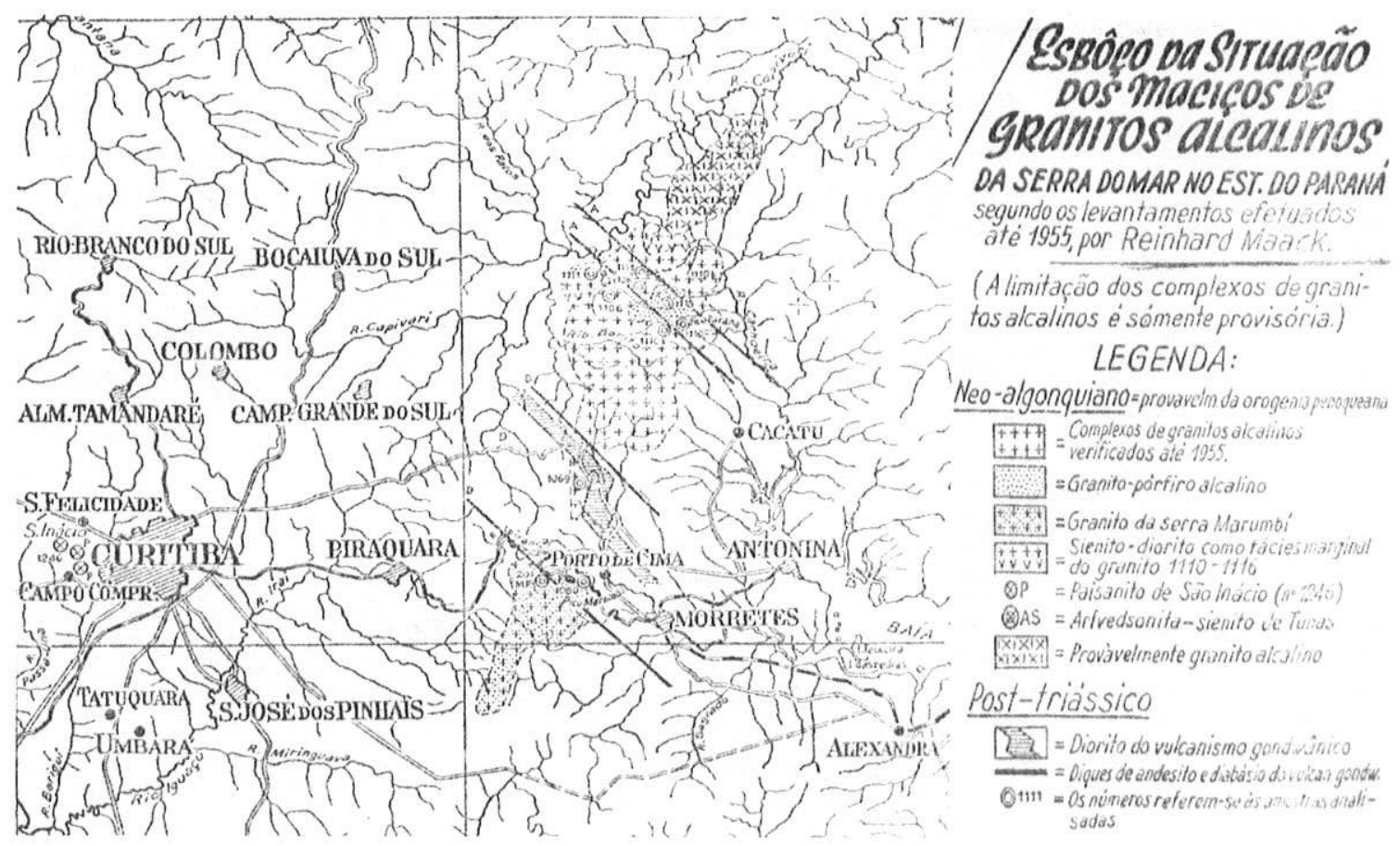

Figura III.7: Esboço da situação dos maciços de granitos alcalinos da Serra do Mar no Estado do Paraná segundo Maack (1961). 
Os primeiros mapeamentos geológicos sistemáticos são devidos a Cordani e Girardi (1967) e Fuck et al. (1970), que definem o Maciço Graciosa, nele incluindo as ocorrências das Serras do Capivari. Órgāos e Graciosa - Farinha Seca, e o Maciço Marumbi, com área de ocorrência semelhante à descrita por Maack (1961). Mais à W. na serra da Baitaca - Boa Vista, Fuck (1966) define o Maciço Anhangava. Mais recentemente, Siga Jr. (1995). Kaul (1984, 1997) e Kaul e Cordani (2000) adicionaram novos dados geológicos e petrográficos sobre os três maciços, acompanhados por dados geoquímicos e isotópicos.

Entretanto, a compreensão da distribuição geral das rochas presentes e das relações geológicas e petrográficas entre elas é ainda muito restrita, faltando ainda uma caracterizaçāo mais detalhada dessas ocorrências, objetivo principal deste trabalho.

\subsection{MATERIAIS E MÉTODOS}

A caracterização geológica dos granitos da região teve como base a realização trabalhos de campo. a interpretação de imagens de satélite e de mapas aerogamaespectrométricos, e descriçoes petrográfica das amostras coletadas.

\section{Trabalhos de campo}

Os trabahos de campo foram efetuados essencialmente ao longo de perfis por estradas e caminhos com auxílio de cartas topográficas em escala 1:50000 e um Sistema de Posicionamento Georeferenciado (GPS). Os objetivos foram concentrado na descriçăo das características estruturais e petrográficas das variedades graníticas presentes, sua distribuição espacial e, quando possível. relaçöes geológicas mútuas e/ou com as rochas encaixantes regionais. Foram cartografados cerca de 100 afloramentos e coletadas mais de 150 amostras de rochas graníticas e dioríticas.

A densa vegetação e o relevo muito acidentado representam fortes limitantes ao acesso e também à qualidade dos afloramentos. Assim, diversas áreas não puderam ser visitadas e, à exceção de algumas áreas dos Maciços Capivari e Anhangava, em que ocorrem diversas pedreiras de médio e pequeno porte : a maioria dos afloramentos visitados é constituída por grupos de matacōes isolados ou, mais raramente, lajedos. Cumpre também ressaltar que, apesar de tentativas exaustivas, não foram observadas relações claras entre rochas das associações alcalina e aluminosa. Os contatos apresentados em mapa (cf. Figura 111.10. em anexo) são. portanto. baseados na interpretação de imagens, com controle apenas parcial de dados de campo. Adicionalmente, a movimentação de 
blocos em direção a cotas mais baixas deve ter sido expressiva em algumas áreas, de forma que alguns afloramentos seguramente nazo se encontram in situ, como se depreende de sua localizaçăo externa em relação a alguns dos contatos sugeridos (cf. Gualda et al., 2001).

As rochas graníticas e associadas foram caracterizadas com base nos conceitos associados ao mapeamento faciológico (Vlach, 1985), reconhecendo-se uma fácies petrográfica como uma unidade descritiva, caracterizável a partir de critérios macroscópicos observáveis no campo e em amostras de mão (e.g. estruturas, texturas, composição mineralógica, índice de cor - IC). Especial atenção foi dada ao conteúdo em minerais máficos e acessórios, indicativos da saturação em alumina da rocha (e.g. biotita, anfibólio). uma vez que este é importante critério para contrastar as associações alcalina e aluminosa de granitos Tipo-A. Paralelamente aos trabalhos de campo, as amostras foram examinadas ao microscópio petrográfico com o objetivo de identificar as suas características texturais e composicionais mais relevantes.

\section{Tratamento de imagens}

As dificuldades para mapeamento faciológico sistemático implicaram a necessidade de ferramentas alternativas. Imagens de satélite (sensor Landsat 5 - TM) foram tratadas com auxilio do programa ER-Mapper ${ }^{\text {B }}$ no Laboratório de Informática Geológica (LIG) do Instituto de Geociências USP. Foram utilizadas as bandas 3, 4, 5 e 7. corrigidas para o efeito da absorção atmosférica. Entre as composições RGB (falsa cor) testadas, aquelas que se mostraram mais apropriadas para interpretaçōes geológicas foram as composições $4(R) 5(G) 7(B)$ e $3(R) 4(G) 7(B)$ (Figuras III.8a e III.8b, em anexo), que destacam a informação textural (i.é. relevo). Foram geradas ainda imagens em tons de cinza empregando razões entre bandas e principais componentes, dentre as quais a que mostrou melhores resultados foi a diferença normalizada entre as bandas 4 e 3 (Índice de Diferença de Vegetação Normalizado - NDV!; Figura III.8c), que destaca a informação espectral relativa à vegetaçāo.

Os mapas aerogamaespectrométricos foram obtidos por interpolaçăo dos dados provenientes do Projeto Levantamento Aerogeofísico Serra do Mar Sul - CPRM. Silva e Mantovani (1994) apresentam uma discussão detalhada da metodologia utilizada e da qualidade dos resultados obtidos. As contagens dos canais $K$. Th e $U$ foram convertidas para equivalentes em ppm por Misener et al. (1997). Estes dados, além das contagens totais foram integrados em mapas através do programa Geosofim. Adicionalmente foram gerados mapas para as razões $U / K$, U/Th e Th/K, para $O$ 
parâmetro $F\left(F=K^{*} U / T h\right)$ e para composições ternárias $K(R)-U(G)-T h(B)$ e $U / K(R)-U / T h(G)-T h / K(B)$ (Figura III.9, em anexo).

Finalmente, foi gerado um modelo digital de terreno (MDT), com base em uma malha regular de pontos com espaçamento de $500 \mathrm{~m}$ - cujas altitudes foram extraidas de folhas topográficas em escala 1:50 000 -, gentilmente cedidas pelo Dr. W. Shukowsky do Instituto de Astronomia, Geofísica e Ciências Atmosféricas da USP (Figura III.9a, em anexo).

\section{III.4. CaRACTERÍSTICAS GEOLÓGICAS GERAIS}

A ocorrência dos granitos como feiçōes evidentemente destacadas do relevo, bem como os teores elevados de elementos radioativos incompativeis (Th, U, K) em relaçāo às rochas gnáissicas e anfibolíticas encaixantes, tornam relativamente fácil, com o apoio dos trabalhos de campo, identificar as áreas de predomínio de rochas graníticas nas imagens obtidas (cf. Figuras 111.5, III.8 e III.9).

Podem ser individualizadas nestas imagens regiões compostas por uma ou mais unidades petrográficas, circunscritas por rochas do embasamento, que devem corresponder a unidades reologicamente independentes, justificando-se a sua individualização. Estas unidades serão aqui denominadas de maciços, em concordância com a denominação normalmente utilizada para as ocorrências da Província Serra do Mar, sendo estratigraficamente equivalentes aos plútons de outras áreas (e.g. Vlach. 1993).

Desta forma, na área em estudo, foi possivel identificar cinco macicos (cf. Figuras III.6, III.8 e 111.9). Destes, os maciços Marumbi e Anhangava já haviam sido individualizados anteriormente (Maack, 1961: Fuck, 1966: Cordani e Girardi, 1967). Os outros três compōem o que até hoje se denominou de Maciço Graciosa (Cordani e Girardi. 1967; Fuck et al., 1970).

A subdivisăo do Maciço Graciosa em pelo menos duas unidades independentes é coerente com as observaçōes pioneiras de Maack (1961), que identifica rochas do embasamento regional separando os granitos da Serra da Graciosa dos granitos da Serra dos Órgãos (cf. acima). A ocorrência de rochas gnáissicas nessa área foi confirmada durante os trabalhos de campo. Por outro lado, apesar da ausência de informaçōes geológicas, a individualidade estrutural dos granitos da Serra do Capivari é evidente nas imagens de satélite (Figura III.8). Uma unidade adicional, de dimensōes restritas, mas com resposta semelhante à dos maciços graníticos nas imagens de satélite e aerogamaespectrométricas, é observada entre os Maciços Órgãos e Capivari (Figuras III.8 e III.10); 
como nāo foi possível visitar a área, tal unidade é referida apenas como provável ocorrência granítica.

A análise dos mapas aerogamaespectrométricos mostra que estas unidades se destacam, em geral, como centros com teores mais elevados de $K$, Th e $U$, separados por porçoes com valores mais baixos, o que corrobora a subdivisão proposta (Figura III.9).

Merece ainda ser destacado que esta subdivisão, embora tentativa, é mais compatível com o padrão geral observado na própria Província Serra do Mar e em outras províncias similares, em que os maciços intrusivos raramente ultrapassam ca. 80-100 km² (cf. Kaul, 1997 e Kinnaird e Bowden. 1982, entre muitos outros). Assim, propõe-se a utilizaçāo de denominações específicas para cada uma destas unidades, de norte para sul: Maciço Capivari, Maciço Órgãos e Maciço Farinha Seca. Propõe-se ainda a utilização da denominação Granitos da Graciosa para se referir ao conjunto formado por estes três maciços e pelos já consagrados Maciço Marumbi e Maciço Anhangava.

Os contornos sugeridos para cada um destes maciços são ilustrados no esboço da figura III.10. Os contatos são essencialmente geomorfológicos, com apoio de algumas observaçoes de campo e dos mapas geofísicos. Cabe salientar, com relação a estes últimos, que as anomalias aerogamaespectrométricas normalmente se estendem para além dos limites propostos, principalmente para $E$ da vertente da Serra do Mar, devido à intensa movimentação de blocos (de dimensōes métricas a decamétricas) e à migração intempérica de radionucídeos (cf. Gualda et al., 2001). Ainda assim, pelo menos em alguns casos, pequenas variaçoes na resposta espectral observadas na composição K-U-Th (Figura 111.9i) dão suporte a estes limites.

De maneira geral, pode-se dizer que os cinco maciços aparecem em superficie com formas elípticas de eixo maior orientado segundo a direção NE-SW; o Maciço Órgãos tem forma mais arredondada e estrutura interna mais complexa, enquanto o Maciço Marumbi é algo mais irregular; finalmente, o Maciço Anhangava apresenta orientaçăo segundo a direção N-S. As imagens geofísicas mostram estruturas internas relativamente simples para os Maciços Farinha Seca, Órgãos e Capivari, e mais complexa para os Maciços Marumbi e sobretudo Anhangava.

Kaul (1997) sugere, com base na análise da forma do "Maciço Graciosa", que o controle da intrusão tenha sido um sistema de falhas mais antigo de direção N20-30 W. ao contrário do que ocorre em outros maciços, que teriam se aproveitado de sistemas mais recentes com direção aproximada $N 45^{\circ}-50^{\circ} \mathrm{E}$. Entretanto, as formas elípticas dos macicos ora individualizados, orientadas 
segundo a direção $N 45^{\circ} \mathrm{E}$ mostram que, de fato, o controle das intrusões deve ter sido este segundo sistema, o que é geodinamicamente mais simples e compatível.

Em toda a área, e sobretudo no Maciço Órgãos, é possivel observar (e.g. Figura Ill.8) importantes lineamentos de direção aproximada NW-SE que cortam indistintamente rochas graníticas e encaixantes. Correspondem a feições estruturais associadas à reativação Mesozóica que permitiu a instalação de um enxame de diques basálticos na região, associado ao vulcanismo básicointermediário na Bacia do Paraná (Almeida, 1967; Almeida, 1972; Almeida et al., 2000). Nos diversos maciços foram observadas estruturas rúpteis, freqüentemente com rejeitos normais, atribuídas a esse evento. Longos diques basálticos, com espessura variável desde centi- até decamétrica são comuns em muitos dos locais visitados. As amostras coletadas correspondem a típicos basaltos com texturas intergranulares a sub-ofíticas, portando essencialmente alguma olivina, clinopiroxênios (augita e pigeonita), labradorita e minerais opacos.

\subsection{GEOLOGIA E PETROGRAFIA DOS MACICOS}

Os maciços graníticos individualizados são brevemente caracterizados quanto aos aspectos geológicos e petrográficos nos itens que seguem. As suas principais características estão sintetizadas na Tabela 11.1.

\section{Maciço Capivari}

O Maciço Capivari é a ocorrência mais setentrional dentre os maciços estudados. Sustenta a Serra do Capivari, cujo ponto culminante atinge $1665 \mathrm{~m}$. De toda a área estudada, corresponde àquela que apresenta acesso mais fácil, devido à proximidade com a BR-116 e à exploração de blocos graníticos para utilização como cantaria.

Apresenta forma elíptica com eixos maior e menor com dimensōes aproximadas de 10.5 e 4.5 $\mathrm{km}$ respectivamente. ocupando uma área aproximada de $34 \mathrm{~km}^{2}$; é a menor unidade granítica individualizada. A análise das imagens e os dados de campo não sugerem qualquer estruturação internà no maciço, levando à inferência de que deva corresponder a um maciço simples. possivelmente formado por um evento discreto de colocacão de magmas (Figuras III.8 e III.9). Lineamentos estruturais mesozóicos são concentrados em suas porçōes central e $S$. 
Tabela III.1:

Caracteristicas principais dos maciços que compöem os Granitos da Graciosa (PR)

\begin{tabular}{|c|c|c|c|c|c|c|c|}
\hline Maciço & $\begin{array}{c}\text { Área }(\mathrm{km} 2) \\
\text { Dimensōes }(\mathrm{km})\end{array}$ & $\begin{array}{c}\text { Forma } \\
\text { Orientação }\end{array}$ & $\begin{array}{l}\text { Associação } \\
\text { Petrográfica }\end{array}$ & $\begin{array}{l}\text { Tipos } \\
\text { Petrográficos (IUGS) }\end{array}$ & Texturas & $\begin{array}{l}\text { Minerais Máficos } \\
\text { Principais }\end{array}$ & Enclaves \\
\hline Capivari & $\begin{array}{c}34 \\
10.5 \times 4.5\end{array}$ & $\begin{array}{l}\text { elíptica } \\
\text { NE }\end{array}$ & aluminosa & - sienogranitos & $\begin{array}{l}\text { - porfiriticas } \\
\text { - inequigranulares } \\
\text { - equigranulares médias }\end{array}$ & - biotita e anfibólio cálcico & $\begin{array}{l}\text { - microgranitos } \\
\text { com biotita e } \\
\text { anfibólio cálcico }\end{array}$ \\
\hline órgäos & $\begin{array}{c}100 \\
12 \times 12\end{array}$ & \multirow[t]{2}{*}{ subcircular } & aluminosa & - sienogranitos & $\begin{array}{l}\text { - equigranulares médias } \\
\text { - equigranulares finas } \\
\text { - porfiriticas }\end{array}$ & - biotita e anfibólio cálcico & $\begin{array}{l}\text { - microgranitos } \\
\text { com biotita e } \\
\text { anfibólio cálcico }\end{array}$ \\
\hline. & $\therefore$ & & alcalina // & $\begin{array}{l}\text { - alcali-feldspato granitos } \\
\text { - monzodioritos }\end{array}$ & - equigranulares médias & $\begin{array}{l}\text { - anfibólio cálcico } \\
\text { - anfibolio cálcico e biotita }\end{array}$ & 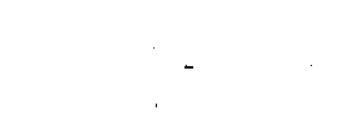 \\
\hline \multirow[t]{2}{*}{ Farinha Seca } & \multirow[t]{2}{*}{$\begin{array}{c}46 \\
12 \times 6\end{array}$} & \multirow[t]{2}{*}{$\begin{array}{l}\text { eliptica } \\
\text { NE }\end{array}$} & alcalina /I & $\begin{array}{l}\text { - alcali-feldspato granitos } \\
\text { - quartzo sienitos }\end{array}$ & - equigranulares medias & $\begin{array}{l}\text { - anfibólio cálcico a sódico } \\
\text { - anfibólio cálcico }\end{array}$ & $\begin{array}{l}\text { - monzodioritos } \\
\text { equigranulares } \\
\text { com anfibolio cálcico } \\
\text { e biotita. }\end{array}$ \\
\hline & & & alcalina / & - álcali-feldspato granitos & - equigranulares finas & - anfibólio sódico & - \\
\hline Marumbi & $\begin{array}{c}34 \\
13 \times 4 \\
\end{array}$ & $\begin{array}{l}\text { alongada } \\
\text { NE }\end{array}$ & aluminosa & - alcali-feldspato granitos & - equigranulares médias & - biotita & - \\
\hline \multirow[t]{2}{*}{ Anhangava } & \multirow[t]{2}{*}{$\begin{array}{c}51 \\
14 \times 4\end{array}$} & \multirow[t]{2}{*}{$\begin{array}{l}\text { alongada } \\
\qquad \mathrm{N}\end{array}$} & alcalinal & - álcali-feldspato sienitos & $\begin{array}{l}\text { - equigranulares a } \\
\text { porfiríticas finas } \\
\text { - equigranulares médias } \\
\text { - equigranulares médias }\end{array}$ & $\begin{array}{l}\text { - anfibólio cálcico e } \\
\text { piroxênio } \\
\text { - piroxênio e olivina } \\
\text { - anfibólio cálcico }\end{array}$ & - \\
\hline & & & aluminosa & $\begin{array}{l}\text { - sienogranitos } \\
\text { - ácali-feldspato granitos }\end{array}$ & - equigranulares médias & $\begin{array}{l}\text { - biotita e anfibólio cálcico } \\
\text { - biotita }\end{array}$ & $\begin{array}{l}\text { - microgranitos } \\
\text { com biotita e } \\
\text { anfibólio cálcico }\end{array}$ \\
\hline
\end{tabular}


As facies graníticas identificadas são também pouco diversificadas. Todas correspondem a rochas graníticas (strictu senso) contendo biotita e anfibólio - este em geral subordinado - como minerais máficos principais. Titanita pode ser também observada com lupa em algumas amostras de mão. As principais diferenças são dadas pelos aspectos texturais e, em parte, pelas proporções relativas entre feldspato alcalino e plagioclásio.

As fácies predominantes correspondem a sieno/monzogranitos hololeucocráticos (IC: 2-3) de coloraçōes cinzentas, esbranquiçadas ou rosadas - em dependência da cor dos feldspatos -, e estruturas maciças. As principais variedades catalogadas incluem fácies porfiriticas dominantes, apresentando megacristais de feldspato alcalino $(0.5-1.5 \mathrm{~cm})$ em matriz de granulaçāo fina, fácies inequigranulares de granulação média e fácies equigranulares de granulação fina. Em alguns cortes de pedreiras ou mesmo alguns matacões, estas três variedades aparecem juntas, com contatos interpenetrados, difusos, sugerindo colocaçăo simultânea de magmas.

Duas outras fácies petrográficas, mais tipicamente sienograníticas, foram mapeadas. Uma variedade de coloração cinzenta a esbranquiçada. com textura desde levemente porfirítica a inequigranular seriada de granulação média, com cristais maiores de feldspato alcalino de dimensōes variáveis, é ainda algo mais rica em máficos (IC: 3-5). É dominante nas regiões $S$ e $N$ do maciço. A última é uma variedade rósea equigranular de granulação média com $I C$ entre 2 e 3 , que se caracteriza pela distribuição de quartzo e feldspatos em pequenos agregados.

Pequenos diques sin-plutônicos e enclaves de dimensões deci- a centimétricas e formas arredondas aparecem ocasionalmente em todas as rochas. Apresentam sempre coloraçóes cinzentas escuras, estruturas maciças e textura equigranular alotriomórfica muito fina. De composição granítica. são sempre hololeucocráticos (IC:3-5). Ocasionalmente contêm megacristais de feldspato alcalino $(0,5-1.0 \mathrm{~cm})$ subidiomórficos ou subarredondados, aparentemente capturados dos granitos hospedeiros.

\section{Maciço Órgãos}

É o maior dos maciços estudados $\left(\sim 100 \mathrm{~km}^{2}\right)$, com forma subcircular de aproximadamente 12 km de diâmetro. Sustenta a Serra dos Órgāos, que inclui algumas das mais importantes elevaçoes do estado do Paraná, inclusive o Pico Paraná (1922 m), ponto culminante do estado. É a porção de mais difícil acesso na Serra da Graciosa, e por isso a amostragem do mesmo é das mais restritas. 
As formas reentrantes do corpo revelam certa complexidade estrutural. Uma importante descontinuidade, de orientaçāo aproximada NE-SW. é observada no centro do maciço (cf. Figura III.8). Separa duas porçōes, cada uma com forma elíptica e orientação NE-SW. com dimensões de 34 $\mathrm{km}^{2}$ (porção a SE) e $60 \mathrm{~km}^{2}$ (porção a NW). As características de cada uma dessas porções são muito semelhantes às dos demais maciços. A descontínuidade se mostra levemente curvada, representando um limite convexo para a porção a NW e côncavo para a porção a SE. Além disso, a porção a SE é mais alongada que a porçäo a NW (eixos maiores - 12 e $9 \mathrm{~km}$, respectivamente; cf. Figura 111.10). Esta geometria sugere a presença de duas unidades independentes em contato e, neste caso, o corpo a SE seria posterior àquele a NW. Alternativamente, essa geometria poderia ser explicada pela atuação de falhas posteriores e, neste caso, rejeitos verticais importantes seriam necessários; entretanto, a ausência da descontinuidade nas áreas de embasamento adjacente enfraquece essa interpretação (cf. Figura III.8).

No extremo NW do maciço observarse ainda uma segunda descontinuidade, menos pronunciada, que separa uma região de relevo bastante acidentado, característica das duas porçōes acima descritas, de outra a NW de relevo mais suave e com menores elevações, com cerca de $7 \mathrm{~km}^{2}$ de área (cf. Figura 1II.8). Acredita-se que corresponda a um outro contato interno, sendo que a porção no extremo NW é um pequeno remanescente (i.é. $7 \mathrm{~km}^{2}$ ) de um corpo mais antigo que os demais. Afloram nesta área álcali-feldspato granitos e rochas monzodioríticas bastante contrastados com os sienogranitos observados no restante do maciço.

Os dados espectrométricos para $K, U$ e Th mostram fortes anomalias positivas no centro do macico (Figuras (II.9b-d, (1I.9i). No corpo a SE, o padrāo se mostra mais complexo: uma forte anomalia negativa acompanha uma importante drenagem (cf. Figura III.9), sugerindo a atuação de processos intempéricos de remoção de radionuclídeos (cf. Gualda et al., 2001).

As principais variedades petrográficas que afloram säo macroscopicamente semelhantes aos sienogranitos encontrados no Maciço Capivari. Em contraste, a unidade no extremo NW é caracterizada por álcali-feldspato granitos com anfibólio e rochas dioríticas contendo biotita e anfibólio.

Sienogranitos equigranulares distinguem-se dos equivalentes do Maciço Capivari pelo predomínio do anfibólio em relação á biotita, pela granulação pouco mais grossa e ainda pela quantidade pouco maior de quartzo. Localmente aflora uma segunda variedade caracterizada por granulação mais fina e teor de máficos pouco mais elevado (IC: 5). 
Duas outras variedades de sienogranitos foram distintas. Uma constituida por rochas porfiríticas relativamente mais ricas em feldspato alcalino e pobres em quartzo, e outra formada por rochas equigranulares de granulação fina a média $(I C: 2-4)$, com estruturas de fluxo muito incipientes. Estas últimas foram encontradas apenas no extremo $E$ do maciço. junto aos contatos com as encaixantes.

No extremo NW do maciço dominam rochas muito contrastadas, tipicamente álcali-feldspato granitos isentos de plagioclásio. Apresentam estrutura maciça, textura equigranular de granulaçăo média e coloração rosada a azulada - em função da coloração do feldspato alcalino, que tem aspecto vítreo - característica. O teor em máficos é bastante variável (IC: 1-7) e anfibólio é a fase máfica mais importante. Como referido acima, nesta regiăo afloram ainda biotita-hornblenda monzodioritos. Estas rochas foram descritas por Maack (1961). que fez referência a uma transiçăo gradual de granito a granodiorito e diorito, que nāo foi verificada. Nos matacões estudados predominam rochas monzodioríticas, que contêm bolsões irregulares ou são cortadas por velos hololeucocráticos de composição granodiorítica. Maack (1961) classificou-os como "sieno-dioritos" ressaltando diferenças químicas com dioritos mais típicos (e.g., teor em $\mathrm{K}_{2} \mathrm{O}$ ). São rochas leucocráticas (IC: 30 ) de coloração cinza escura, com estrutura maciça e textura equigranular de granulação fina a média, sendo notória a presença de biotita, particularmente nas amostras mais alteradas.

Enclaves micrograníticos similares aos descritos no Maciço Capivari são também observados na maioria das fácies sienograníticas. Rochas semelhantes são por vezes observadas como blocos pequenos isolados, possiveis remanescentes de diques sin-plutônicos algo mais possantes.

\section{Macico Farinha Seca}

O Maciço Farinha Seca aflora a S do Maciço Órgāos, sendo balizado a NE pela histórica Estrada da Graciosa e a SW pela ferrovia Curitiba-Paranaguá. Apresenta forma alongada na direção NE-SW e ocupa uma área de aproximadamente $46 \mathrm{~km}^{2}$, com eixos maior e menor medindo respectivamente 12 e $6 \mathrm{~km}$. O acesso ao seu interior, nas Serras da Graciosa e da Farinha Seca, cujos pontos culminantes não ultrapassam os $1500 \mathrm{~m}$, só é possível através de trilhas e antigos caminhos de jesuítas.

Nos mapas geofísicos, o maciço aparece homogêneo, com anomalias positivas de K, U e Th. Diversas imagens mostram anomalias positivas também a $E$ da vertente da Serra do Mar. porém. como descrito acima, as tonalidades observadas na composição $\mathrm{K}$-U-Th mostram assinaturas 
diferenciadas para cada uma das porçōes (cf. Figura 111.9; Gualda et al., 2001), não ficando aparente algum tipo de estruturação interna.

Petrograficamente, este maciço é bastante diferenciado em relaçăo aos anteriores, com ampla predominância de álcali-feldspato granitos com anfibólio como máfico principal, em parte semelhantes àqueles observados no Maciço Órgãos. Variedades mais pobres em quartzo e contendo plagioclásio, tipicamente sieníticas, com piroxênio e anfibólio como máficos principais são observadas na porção $\mathrm{N}$ do maciço, no início da Estrada da Graciosa.

As fácies predominantes correspondem a álcali-feldspato granitos. São rochas tipicamente maciças, hololeucocráticas (IC: 4), com textura equigranular de granulação média e coloração variável, cinza escura ou esverdeada, até vermelha ou ainda esbranquiçada, dada pelo feldspato alcalino. A textura é caracterizada por uma trama de feldspato alcalino, com quartzo aparecendo em agregados intersticiais, associados aos quais aparecem os máficos. O máfico principal é um anfibólio. Ao microscópio (cf. Parte IV), verifica-se que varia desde cálcico a cálcico-sódico, estando freqüentemente substituído por anfibólio sódico e biotita vermelha; apenas em algumas variedades mais raras, anfibólio sódico primário é observado.

Em uma ocorrência isolada na porção NW do maciço, afloram álcali-feldspato granitos com anfibólio distintos em relação aos anteriores. São hololeucocráticos (IC: 4), maciços, com textura equigranular de granulação média-fina e coloração cinza clara. Predominam os cristais de feldspato alcalino, com quartzo aparecendo como cristais isolados subarredondados; anfibólio é tipicamente intersticial e grada de cálcico-sódico a sódico (Parte IV). Uma segunda variedade, contendo anfibólio tipicamente sódico, corresponde a um microgranito maciço, hololeucocrático de textura porfiritica. com matriz equigranular de granulação muito fina.

Uma única amostra de quartzo-sienito foi coletada no extremo NE do maciço, junto à Estrada da Graciosa. É uma rocha maciça, leucocrática (IC: 10). de coloração cinza escura e textura equigranular de granulaçāo média-fina. Contrasta com as rochas das fácies anteriores pela presença de plagioclásio. O máfico predominante é um anfibólio cálcico. com biotita muito rara. Nestas rochas são observados pequenos enclaves arredondados de composição monzodiorítica. 0 aspecto macroscópico desta é muito semelhante ao das rochas monzodioríticas do Maciço órgāos. 


\section{Maciço Marumbi}

Aflora a SW da ferrovia Curitiba-Paranaguá, com forma algo mais irregular, alongada e curvada, com dimensōes próximas de $13 \times 4 \mathrm{~km}$, totalizando uma área de cerca de $37 \mathrm{~km}^{2}$ (Figura (11.10). A regiăo NW da Serra do Marumbi corresponde a um Parque Estadual e o acesso é permitido apenas na sua vertente N: além desta área, apenas o extremo SW foi visitado e amostrado.

Os mapas aerogamaespectrométricos evidenciam dois centros mais ricos em radionuclídeos, um em cada extremo do maciço (Figura 111.9). Apesar da amostragem restrita, os tipos observados nas duas regiões são bem semelhantes entre si.

Na porção NE do maciço, granitos in situ sustentam vertentes da Serra do Mar subverticais: com isso, a movimentação de blocos é intensa na região, e blocos decamétricos ocorrem bem distantes dos contatos com as encaixantes. Em conseqüência, as anomalias aerogamaespectrométricas se estendem para além dos contatos geológicos, sem mudança perceptivel da assinatura espectral ( $c f$. Figura Ill.9i; Guaida et al., 2001).

As áreas percorridas são muito homogêneas, sempre aflorando uma mesma fácies petrográfica. Corresponde a um álcali-feldspato granito contendo biotita como máfico principal. É uma rocha hololeucocrática (IC:1-2), com estrutura maciça e textura equigranular de granulação média, de coloração branca ou cinzenta - dada pelo feldspato alcalino - com pontuações rosadas típicas.

\section{Maciço Anhangava}

Com orientação N-S, e dimensōes de $14 \times 4 \mathrm{~km}$, o Maciço Anhangava é o de mais fácil acesso e já foi estudado com algum detalhe (e.g. Kaul, 1997: Lopes et a/., 1998). Ocupa lima área de aproximadamente $51 \mathrm{~km}^{2}$ no dominio das Serras da Baitaca e da Boa Vista. Apresenta morfologia pouco usual, sendo identificadas irregularidades morfológicas internas menores (Figura 111.8). Nas imagens aerogamaespetrométricas (Figura 111.9) aparece mal delimitado e com uma resposta espectral heterogênea. Na porção E, a composição K.U-Th mostra uma assinatura espectral semelhante àquela dos outros maciços; na porção $W$, entretanto, a mesma composição mostra um padrão diferenciado. sem análogos nos outros maciços (cf. Figura III.9j; Gualda et al., 2001).

O Maciço Anhangava é caracterizado por uma maior variedade de tipos petrográficos, mas não foi possivel correlacioná-los adequadamente com as heterogeneidades identificadas nas imagens. Foram identificadas diversas fácies petrográficas, incluindo álcali-feldspato sienitos com anfibólio. 
piroxênio e olivina em quantidades variáveis; álcali-feldspato granitos com biotita; e sienogranitos com biotita e anfibólio.

Álcali-feldspato sienitos com anfibólio e piroxênio afloram na porção $N$ do maciço e sāo macroscopicamente bem semelhantes às variedades de granulação média-fina de álcali-feldspato granitos do Maciço Farinha Seca. São rochas com estruturas predominantemente maciças; um único bloco isolado revela variedades com bandamento composicional bem marcado, em que se alternam bandas milimétricas a centimétricas mais ricas em minerais félsicos (IC: 2) e máficos (IC: 6). As variedades maciças são hololeucocráticas a leucocráticas (IC: 3-7) e apresentam texturas equigranulares, inequigranulares seriadas ou ainda porfiriticas, com granulação fina a média. A coloração é variável desde branca a cinza ou azul escuros, ou ainda esverdeada. Anfibólio cálcico a cálcico-sódico é o máfico principal, com piroxênio cálcico em proporções variáveis. Olivina aparece raramente nas variedades inequigranulares. Biotita vermelha e anfibólio sódico aparecem como produtos de substituição pós-magmática do anfibólio original, como observado no Maciço Farinha Seca (cf. Parte IV).

No extremos do maciço aflora um álcali-feldspato sienito equigranular com piroxênio e olivina (IC: 5) de coloração verde, com estrutura maciça e textura equigranular de granulação média. O máfico principal é um piroxênio cálcico, acompanhado de olivina. Esta rocha aparece associada a um álcali-feldspato granito equigranular, leucocrático (iC:6) de granulação média e cor tipicamente rósea; caracterizado por apresentar anfibólio cálcico como máfico principal, acompanhado por piroxênio.

Já na porção E do maciço, afloram álcali-feldspato granitos equigranulares com biotita, muito semelhantes aos que aparecem no Macico Marumbi.

Finalmente, na regiāo central ocorrem sieno- e monzogranitos equigranulares com biotita e anfibólio cálcico, semelhantes aos observados nos Maciços Capivari e Órgãos. Aparentemente, são as rochas mais abundantes no Maciço Anhangava. Enclaves e pequenos diques micrograníticos, equivalentes aos observados nos sieno- e monzogranitos dos Maciços Capivari e Órgãos são bastante abundantes em alguns afloramentos.

Kaul (1997) sugere uma estrutura anelar para o maciço, dividindo-o em três unidades maiores, denominadas Serra da Baitaca (biotita sienogranitos e biotita álcali-feldspato granitos), Serra da Boa Vista (riebeckita-biotita e biotita álcali-feldspato granitos) e Roça Nova (hornblenda e hornblenda- 
clinopiroxênio álcali-feldspato sienitos e biotita álcali-feldspato granitos). Considerando as paragêneses minerais máficas, parece mais natural reunir estas fácies em 3 associaçðes: uma de álcali-feldspato sienitos finos com anfibólio e piroxênio: outra de sieno/monzogranitos e álcalifeldspato granitos com biotita; e uma terceira de álcali-feldspato sienitos com anfibólio ou piroxênio e olivina. O mapeamento adequado destas unidades depende ainda de trabalhos mais aprofundados de campo e a estruturação proposta pelo referido autor parece ainda prematura.

\section{AS ASSOCIAÇÕES DE GRANITOS TIPO-A}

Uma das características marcantes dos granitos Tipo-A é a coexistência de rochas contrastadas petrograficamente: por um lado, uma associação aluminosa composta por rochas meta- e peraluminosas e por outro uma associação alcalina, caracterizada por variedades metaluminosas e peralcalinas (Lameyre e Bowden. 1982; Vlach et al., 1990; Pitcher, 1995; King et al., 1997). Como tal divisão é essencialmente petrográfica (na concepção de Lameyre e Bowden. 1982), torna-se possivel atribuir a essas associações as fácies petrográficas aqui descritas.

Neste sentido, os sieno/monzogranitos com biotita e anfibólio cálcico, subsolvus, portanto rochas metaluminosas a moderadamente peraluminosas, predominantes nos Maciços Capivari e Órgãos e na porção central do Maciço Anhangava, além dos álcali-feldspato granitos com biotita deste último e do Maciço Marumbi, podem ser agrupados em uma associação petrográfica aluminosa.

Por outro lado, as variedades de álcali-feldspato granitos e sienitos com anfibólio, piroxênio e olivina, tipicamente hipersolvus, desde metaluminosos a peralcalinos, amplamente predominantes no Maciço Farinha Seca e observados no extremo NW do Maciço Órgãos e nos extremos $N$ e $S$ do Maciço Anhangava, podem ser reunidos em uma associação alcalina. Esta pode ser ainda desmembrada em dois grupos (cf. Parte IV).

O primeiro - a associaçāo alcalina / - é composto pelas rochas predominantemente sieníticas do Maciço Anhangava e pelos álcali-feldspato granitos com anfibólio sódico mais finos do Maciço Farinha Seca (cf. Tabela III.1). Há uma gradação completa desde álcali-feldspato sienitos com quartzo - portando clinopiroxênio e olivina - até álcali-feldspato granitos com anfibólio cálcico-sódico ou sódico como máficos principais. Os termos intermediários, mais abundantes, são tipicamente álcalifeldspato sienitos com anfibólio e clinopiroxênio. Essas características contrastam com as da associação alcalina //, que compreende o restante das variedades encontradas nos Maciços Farinha 
Seca e Órgãos. É composta basicamente por álcali-feldspato granitos portando anfibólio de composição variável, desde cálcico até sódico.

As relaçōes genéticas entre as rochas monzodioríticas e as rochas graníticas não são claras. É marcante, contudo, que as áreas de ocorrência de rochas monzodioríticas coincidem com aquelas dos granitos da associação alcalina //. Neste sentido, a fácies sienítica com plagioclásio do Maciço Farinha Seca pode corresponder a uma variedade híbrida entre monzodioritos e álcali-feldspato granitos, o que corrobora outras evidências de contemporaneidade (cf. Parte IV).

A ocorrência dissociada das associações nos maciços (Capivari, Marumbi e Farinha Seca), ou em diferentes unidades de um mesmo maciço (Órgāos e Anhangava), abre a possibilidade de que eventuais contrastes na composiçāo dos magmas parentais ou nos processos que deram origem às duas associações sejam condicionados espacialmente, por exemplo, pela composição da crosta encaixante em cada um dos casos.

Finalmente, a observação de tipos petrográficos específicos em vários macicos pode ser explicada por modelos genéricos como o de Bonin (1996), que sugerem a presença de câmaras magmáticas mais profundas comuns. Alternativamente, pode indicar uma convergência na história evolutiva destas rochas. O detalhamento da evolução petrográfica e mineralógica (Parte IV) destas rochas deve trazer fundamentos para esta discussão.

\section{CONCLUSÕES}

As informaçōes geológicas, embora limitadas, associadas às advindas do estudo de imagens de satélite e de dados gamaespectrométricos e petrográficos elementares, permitem sugerir a compartimentação do denominado Maciço Graciosa em três unidades independentes, denominadas Maciço Capivari, Maciço Órgãos e Maciço Farinha Seca. Estas unidades, juntamente com os Maciços Marumbi e Anhangava, são aqui reunidos sob a denominação informal de Granitos da Graciosa. Este conjunto é uma das mais importantes manifestaçōes dentre as que formam a Província Serra do Mar. gerada como resultado da colisāo do Cinturão Granitóide Costeiro com o conjunto formado pelas Microplacas Luiz Alves e Curitiba ocorrida durante o Ciclo Brasiliano (ca. 580 600 Ma).

Critérios petrográficos, por um lado composicionàis - presença ou ausência de plagioclásio (caráter hipersolvus vs. subsolvus) e de biotita (caráter mais ou menos saturado em alumina). variações na abundância relativa de quartzo e nas paragêneses máficas - e por outro texturais, permitem reunir as fácies petrográficas mapeadas em associações contrastas. A primeira delas - 
a/uminosa -inclui sienogranitos com biotita e anfibólio dos Maciços Capivari. Órgãos e Anhangava, e álcali-feldspato granitos com biotita dos Maciços Marumbi e Anhangava. As demais - a/calinas - são constituídas por álcali-feldspato sienitos com anfibólio, piroxênio (e olivina) do Maciço Anhangava e álcali-feldspato granitos com anfibólio sódico do Maciço Farinha Seca (associação alcalina ), além dos álcali-feldspato granitos com anfibólio do Maciços Farinha Seca (associação alcalina I).

\section{REFERÊNCIAS BIBLIOGRÁFICAS}

Almeida, F.F.M. (1967) Origem e evolução da plataforma brasileira. Boletim. DNPM/DGM, 241: 36 p.

Almeida. F.F.M. (1972) Tectono-magmatic activation of the South American Platform and associated mineralization. In: INTERNATIONAL GEOLOGICAL CONGRESS, 24. Montreal. IUGS. Proceedings..., 3: 339-346.

Almeida, F.F.M.; Brito Neves. B.B.: Carneiro, C.D.R. (2000) The origin and evolution of the South American Platform. Earth-Science Reviews, 50: 77-111.

Basei. M.A.S. (1985) O Cinturão Dom Feliciano em Santa Catarina. Tese de Doutoramento. IG.USP. Inédita. $190 \mathrm{p}$.

Basei, M.A.S.; Cordani, U.G.; Vasconcelos, J.P.B.C. (1987) Tectônica e granitogênese do PréCambriano de Santa Catarina. In: SIMPÓSIO SUL-BRASILEIRO DE GEOLOGIA, 3. Curitiba. SBG. Atas... 2: 789-790.

Basei, M.A.S.: Siga Jr., O.: Machiavelli, A.; Mancini, F. (1992) Evolução tectônica dos terrenos entre os Cinturōes Ribeira e Dom Feliciano (PR-SC). Revista Brasileira Geociências, 22(2): $216-221$.

Bonin. B. (1996) A-type granite ring complexes: mantle origin through crustal filters and the anorthosite - rapakivi magmatism connection. In: Demaiffe. D. (Ed.) Petrology and Geochemistry of magmatic suites of rocks in continental and oceanic crusts. Université Libre de Bruxelles - Royal Museum for Central Africa (Tervuren). Bélgica. p. 201-217.

Campanha, G.A.C; Bistrichi, C.A.; Almeida, M.A. (1987) Considerações sobre a organizaçäo litoestratigráfica e evolução tectônica da Faixa de Dobramentos Apiaí. In: SIMPÓSIO SUL. BRASILEIRO DE GEOLOGIA. 3. Curitiba. SBG. Atas..., 2: 725-742.

Campos Neto. M.C.: Figueiredo, M.C.H. (1995) The Rio Doce Orogeny, Southeastern Brazil. Journal of South American Earth Sciences, 8(2): 143-162.

Chiessi, C.M.; Oliveira, D.G.G.; Gualda, G.A.R.; Vlach. S.R.F. (1998) Texturas e quimismo de minerais máficos do Maciço Sienítico Corupá (SC). In: SIMPÓSIO DE INICIAÇÃO CIENTÍfICA DA USP, 6. São Carlos. USP-CNPq. Resumos... 2: 498.

Cordani, U.G.; Girardi, V.A.V. (1967) Geologia da Folha de Morretes. Boletim da Universidade Federal do Paraná. Geologia, 26:1-40.

Fuck, R.A. (1966) Geologia da Folha Piraquara. Boletim da Universidade Federal do Paraná. Geologia. Inédito.

Fuck R.A.; Marini. O.J.; Trein. E. (1967) Contribuiçăo ao estudo das rochas graníticas do Estado do Paraná. Boletim Paranaense de Geociências, 23-25: 183-219. 
Fuck, R.A.; Muratori, A.; Trein, E.; Bertoldo, A.; Hausen, J. (1970) Rio Capivari: folha geologica 1:70.000. Comissão da Carta Geológica do Paraná. Paraná.

Góis, J.R. de (1995) Contribuição à petrografia e geoquímica da parte setentrional do complexo vulcano-plutônico Morro Redondo, divisa do Paraná com Santa Catarina. Dissertação de Mestrado. 1G-USP. Inédita, $86 \mathrm{p}$.

Girardi. V.A.V. (1974) Petrologia do complexo básico-ultrabásico de Piên. PR. Tese de LivreDocência. IG-USP. Inédita. $146 \mathrm{p}$.

Gualda, G.A.R.; Ferreira, F.J.F.; Portela Filho, C.V.: Vlach. S.R.F. (2001) Integração de dados aerogamaespectrométricos e geologicos para a individualização de maciços graníticos na Região da Serra da Graciosa (PR). In: CONGRESSO INTERNACIONAL DA SOCIEDADE BRASILEIRA DE GEOFÍSICA, 7. Salvador. (no prelo)

Hallinan. S.E.; Mantovani, M.S.M.; Shukowsky, W.: Braggion Jr., 1. (1993) Estrutura do escudo SulBrasileiro: uma revisão através de dados gravimétricos e magnetométricos. Revista Brasileira de Geociências, 23(3): 201-214.

Hasui, Y.; Cameiro, C.D.R.; Coimbra. A.M. (1975) The Ribeira Folded Belt. Revista Brasileira de Geociências, 5: 257-266.

Hasui, Y.; Carneiro. C.D.R.; Bistrichi, C.A. (1978) Os granitos e granitóides da Região de Dobramentos Sudeste nos Estados de São Paulo e Paraná. In: CONGRESSO BRASILEIRO DE GEOLOGIA, 30. Recife. SBG. Anais..., 6: 2594-2608.

Kaul, P.F.T. (1984) Significado dos granitos anorogênicos da Suite Intrusiva Serra do Mar na evolução da crosta do sul-sudeste do Brasil. no âmbito das folhas SG-22. Curitiba e SG-23, Iguape. In: CONGRESSO BRASILEIRO DE GEOLOGIA, 33. Rio de Janeiro. SBG. Anais..., 6:2815. 2825.

Kaul. P.F.T. (1997) O magmatismo na Serra on Mar e adjacências (Sul do Brasil) no final do Neoproterozóico e seus condicionantes tectónicos. Tese de Doutoramento. IG-USP. Inédita. 293 p.

Lameyre. J. e Bowden. P. (1982) Plutonic rock type series: discrimination of various granitoid series and related rocks. Journal of Volcanology and Geothermal Research, 14: 169-189.

Liégeois, J.P. (1998) Preface - Some words on the post-collisional magmatism. Lithos, 45: xv-xvii.

w Lopes, A.P.: Soares, A.P.; Lipski. M.; Vesely. F.F.; Vasconcellos, E.M.G. (1998) Análise faciologica do Granito Anhangava (PR) a partir de dados petrográficos e geoquímicos. In: CONGRESSO BRASILEIRO DE GEOL.OGIA, 40. Belo Horizonte. SBG. Anais..., 497.

Maack. R. (1961) Sobre a ocorrência de granitos alcalinos no Estado do Paraná e sua posição dentro das fases orogenéticas algonquianas. Boletim da Universidade Federal do Paraná, Geologia. 4:1-52.

Martovani, M.S.M.; Shukowsky, W.: Basei, M.A.S.; Vasconcellos, A.C.B.C. (1989) Modelo gravimétrico das principais descontinuidades crustais nos terrenos pré-cambrianos dos Estados do Paraná e Santa Catảrina. Revista Brasileira de Geociências, 19(3): 367-374.

Misener, D. J: Sinclair. R.: Mourão, L.M.F. (1997)A new Brazil radiometric database generation and application. In: CONGRESSO INTERNACIONAL DA SOCIEDADE BRASILEIRA DE GEOFÍSICA, 5. São Paulo. SBGf. Expanded Abstracts..., 1:564. 
Oliveira. M.C.B. de (1989) Petrologia do Maciço Granítico Mandira -- SP. Dissertação de Mestrado. IG-USP. Inédita. $178 \mathrm{p}$.

Oliveira. D.G. (1997) Petrografia e quimismo de fases minerais máficas em amostras selecionadas do Granito Corupá (SC). Relatório de Iniciação Científica. PIBIC-CNPq-USP. Inédito. 34 p.

Pearce, J.A.; Harris, N.B.W.; Tindle, A.G. (1984) Trace element discrimination diagrams for the tectonic interpretation of granitic rocks. Journal of Petrology, 25: 956-983.

Pitcher, W. S. (1995) Origin and nature of granite. Blackie Academic \& Professional. New York. $321 p$.

Siga Jr., O (1995) Domínios tectónicos do sudeste do Paraná e nordeste de Santa Catarina: geocronologia e evolução crustal. Tese de Doutoramento. IG-USP. Inédita. 164 p.

Siga Jr., O.; Basei, M.A.S.; Kawashita, K. (1990) Perfil térmico K-Ar através do Maciço Joinville (PR e SC) e do Cinturão Dom Feliciano (SC) - implicações tectônicas. In: CONGRESSO BRASILEIRO DE GEOLOGIA, 36. Natal, SBG. Anais..., 6: 2773-2785.

Siga Jr., O.; Basei, M.A.S.: Machiavelli. A. (1993) Evolução geotectônica da porçăo NE de Santa Catarina e SE do Paraná, com base em interpretações geocronológicas. Revista Brasileira de Geociências, $23(3): 215-223$.

Siga Jr. et al. (1994) Maciços Graniticos da porção Sudeste do Paraná e Nordeste de Santa Catarina: geocronologia e implicações tectônicas. In: CONGRESSO BRASILEIRO DE GEOLOGIA, 38. Camboriú. SBG. Anais..., 400-401.

Tutte, O. F.: Bowen, N. L. (1958) Origin of granite in the light of experimental studies in the system $\mathrm{NaAlSi}_{3} \mathrm{O}_{3}-\mathrm{SiO}_{2}-\mathrm{H}_{2} \mathrm{O}$. Geological Society of America Memoir, 74, $154 \mathrm{p}$.

Upton. B.G.J.; Emeleus, C.H. (1987) Mid.Proterozoic alkaline magmatism in southern Greenland: the Gardar province. In: Fitton, J.C.: Upton. B.G.J. (eds.). Alkaline igneous rocks. Geological Society Special Publications, 30:449-471.

Vlach, S.R.F. (1985) Ceologia, petrografia e geocronologia das regiões meridional e oriental do Complexo Granítico de Morungaba, SP. Dissertação de Mestrado, IG-USP. Inédita. 253 p.

Vlach. S.R.F. (1993) Geologia e petrologia dos granitóides de Morungaba. SP. Tese de Doutoramento, IG-USP. Inédita. $414 \mathrm{p}$.

Vlach, S.R.F.; Janasi. V.A.; Vasconcelios, A.C.B.C. (1990) The Itu Belt: associated calc-alkaline and aluminous A-type late Brasiliano granitoids in the States of São Paulo and Paraná. Southern Brazil. In: CONGRESSO BRASILEIRO DE GEOLOGIA, 36. Natal. SBG. Anais..., 4: 1700-1711.

- Wernick, E.; Penalva, F. (1978) Contribuiçăo ao conhecimento das rochas granitóides do Sul do Brasil. Revista Brasileira de Geociências, 8: 113-133.

Whalen. J.B.; Currie, K.L.; Chappel, B.W. (1987) A-type granites: Geochemical characteristics, discrimination and petrogenesis. Contributions to Mineralogy and Petrology, 95: 407-419. 
ANEXOS 

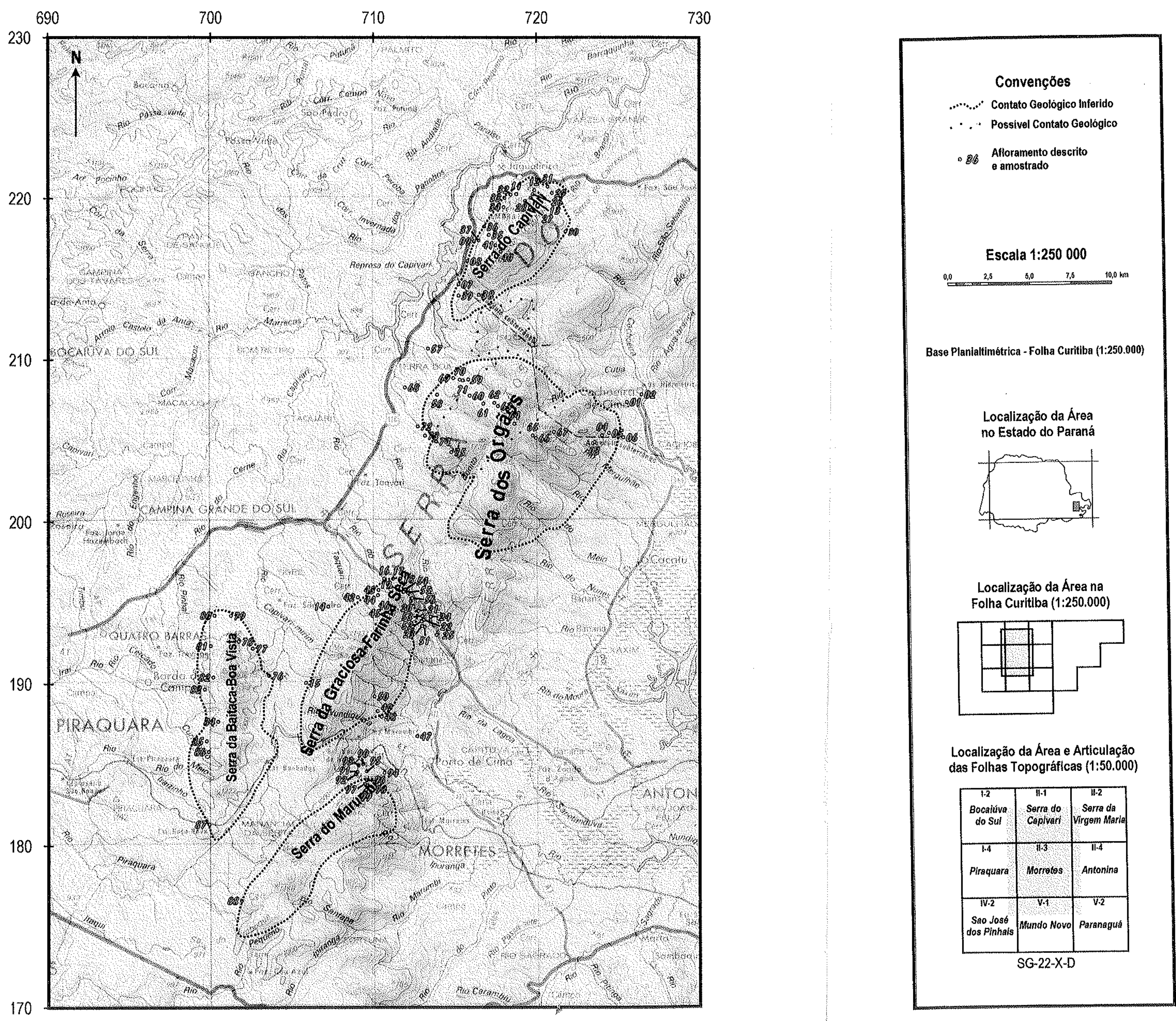

Figura Ill.6: Mapa de afloramentos visitados e toponímia da região da Serra da Graciosa (PR) 


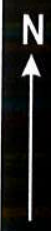

7220

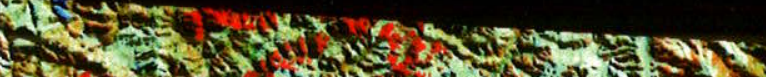

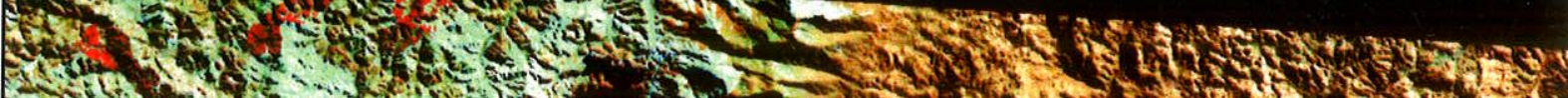

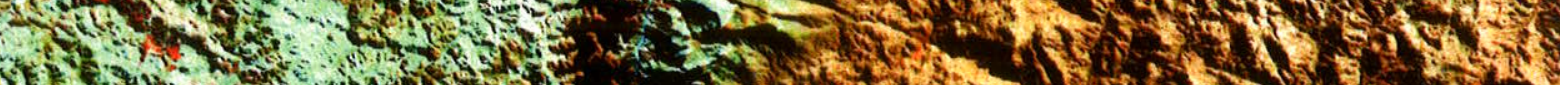

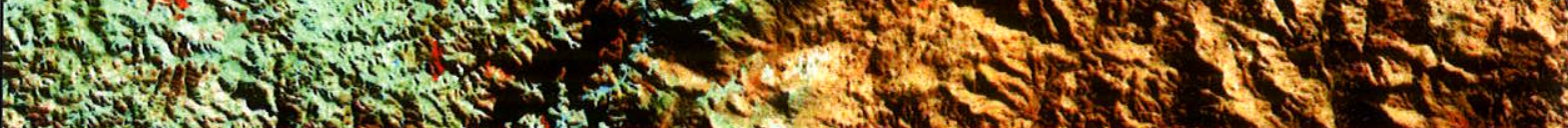

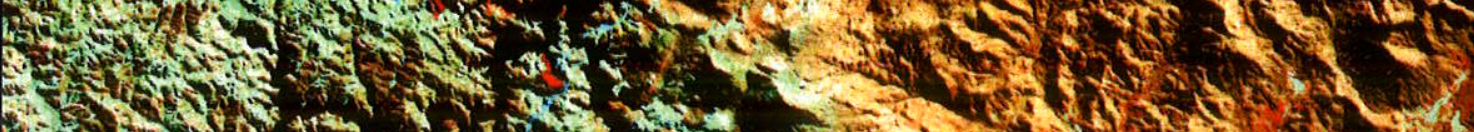

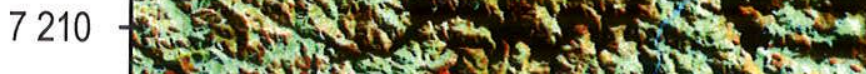

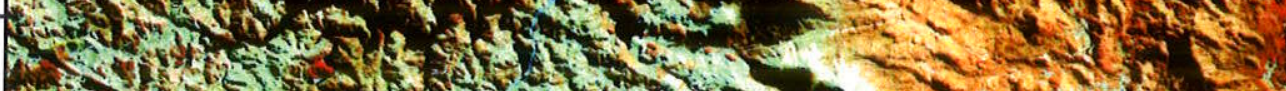

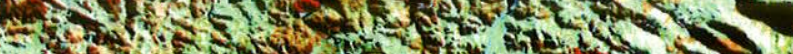

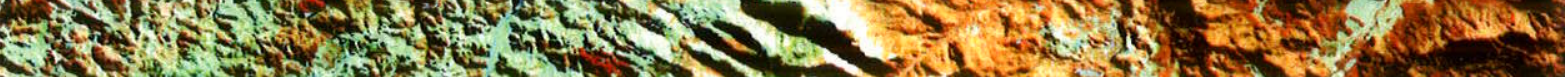

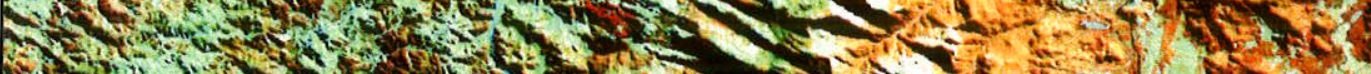

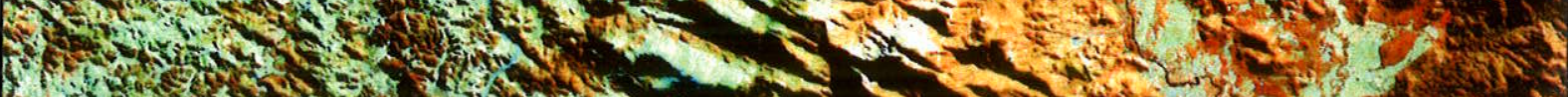

S.

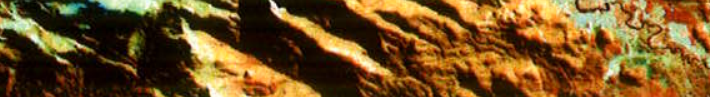

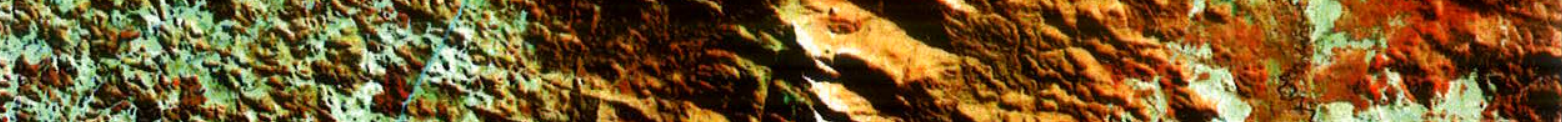

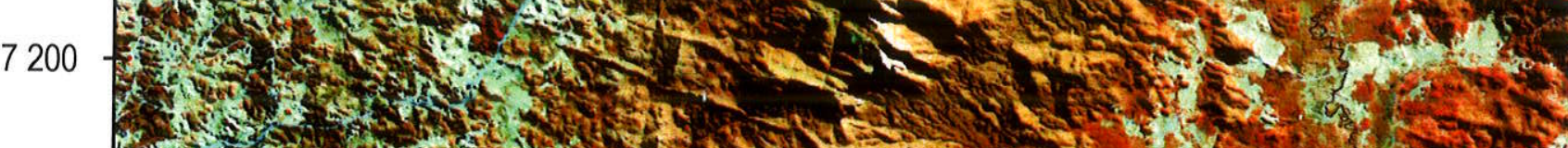

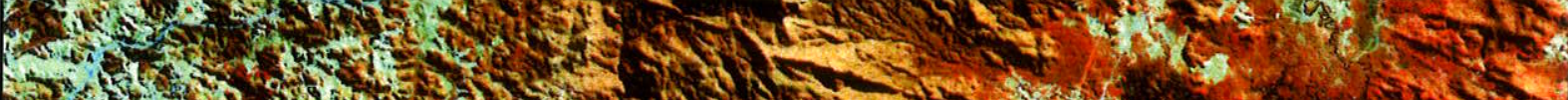

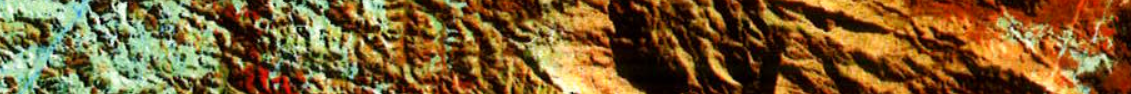

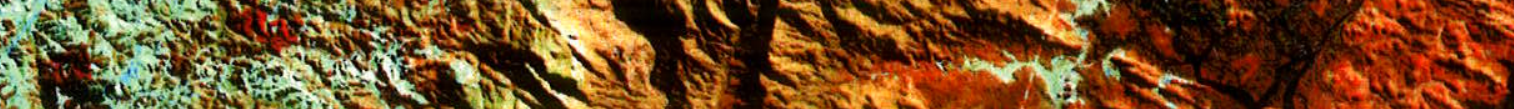

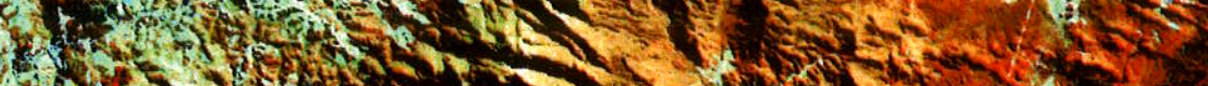

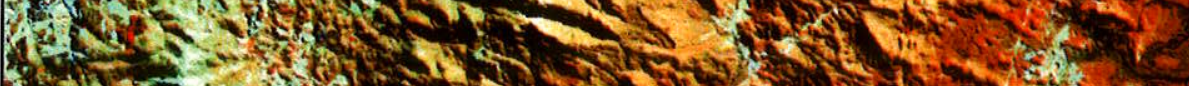

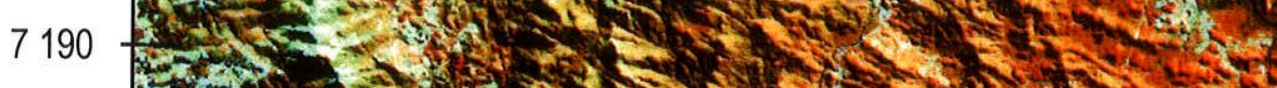

F.

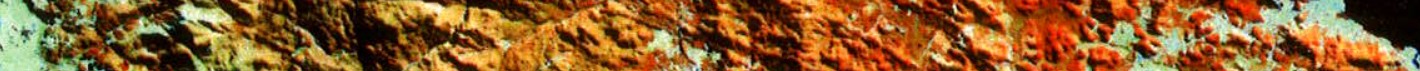

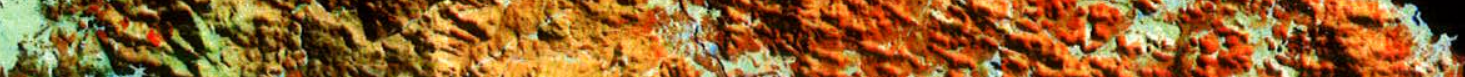

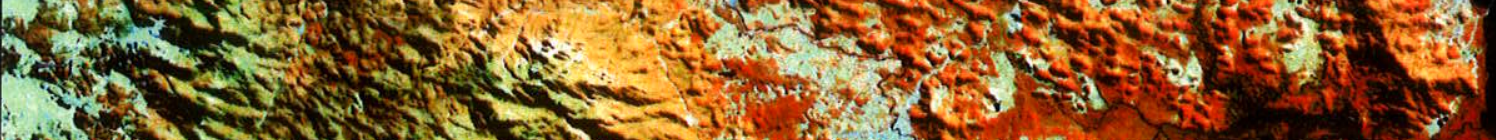

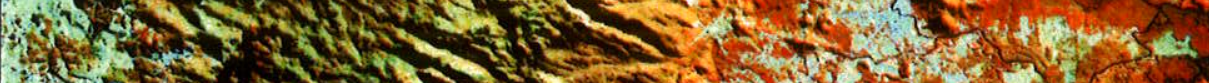

7180

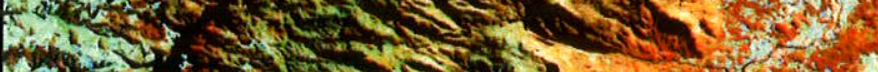

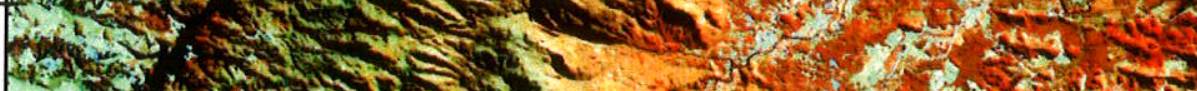

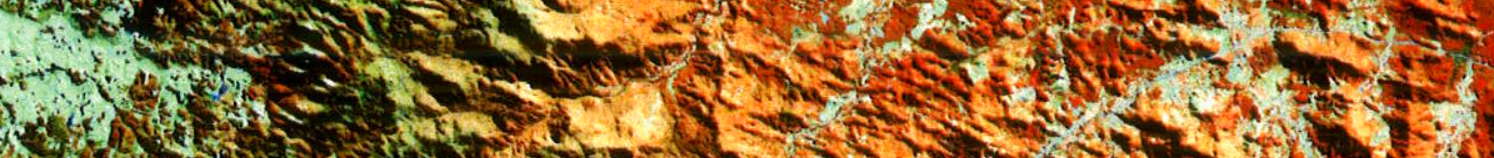

5. 12 .

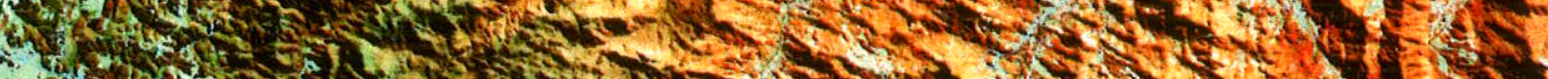

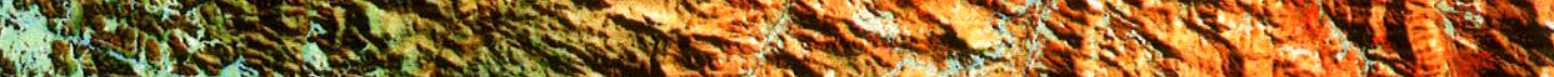

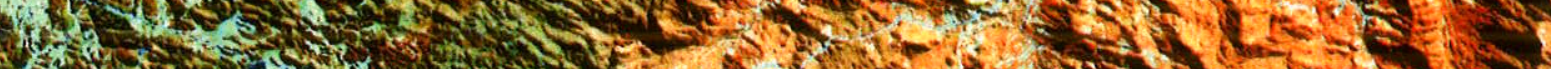

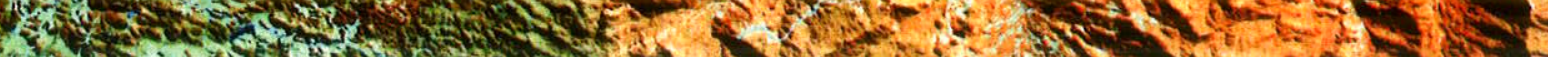

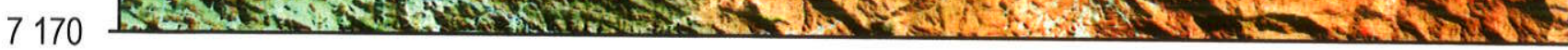

Figura III.8a: Composição 4(R)-5(G)-7(B) de imagens Landsat 5 (TM) da região da Serra da Graciosa Convenções como na Figura III. 6. 


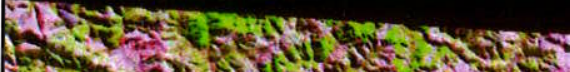

15.

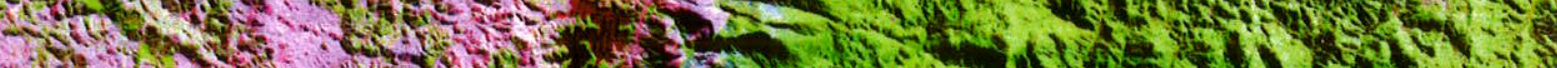

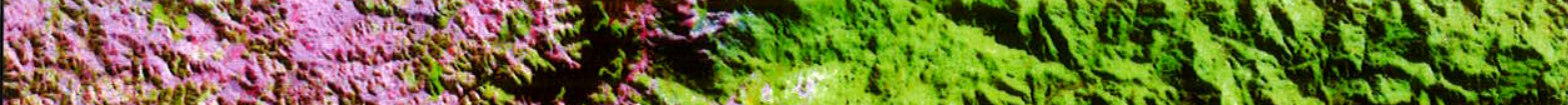

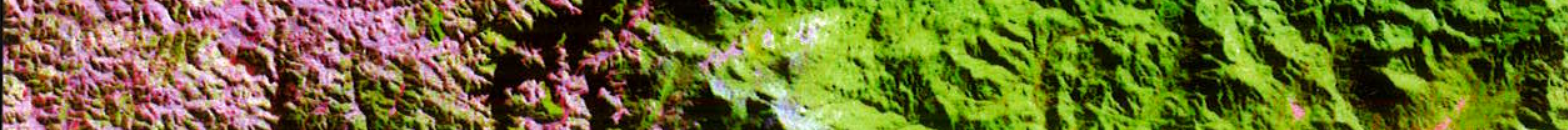

7210

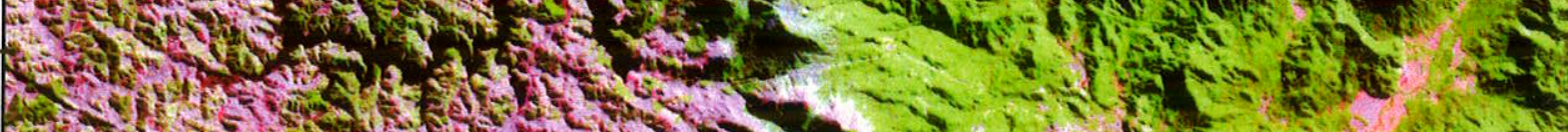

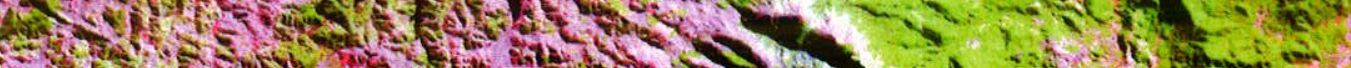

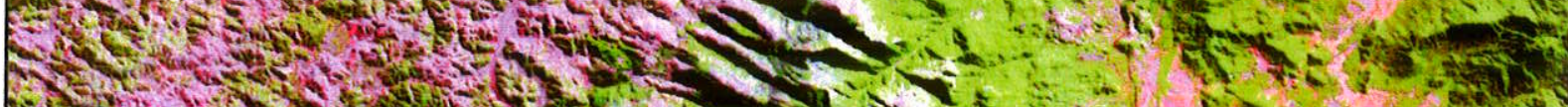

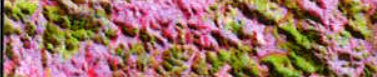

Shing

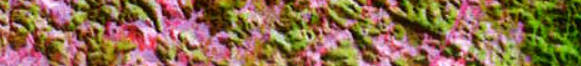

7200

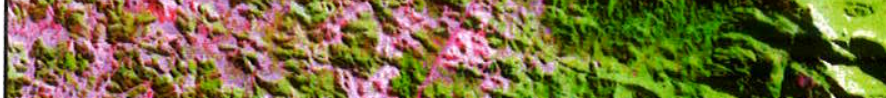
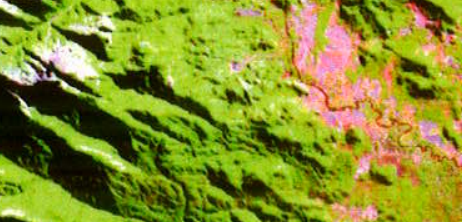

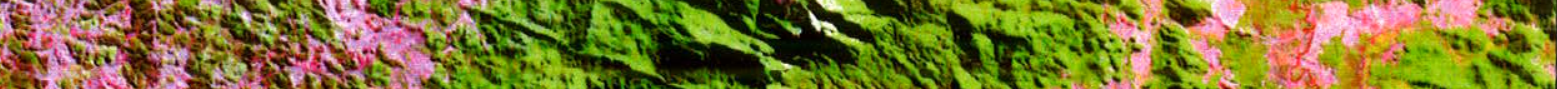

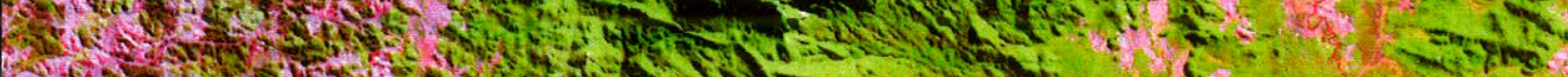

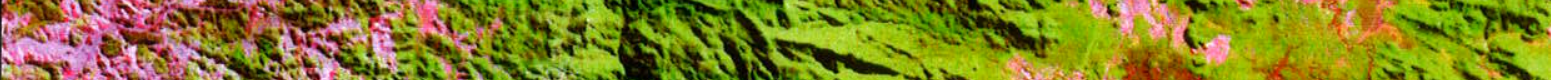

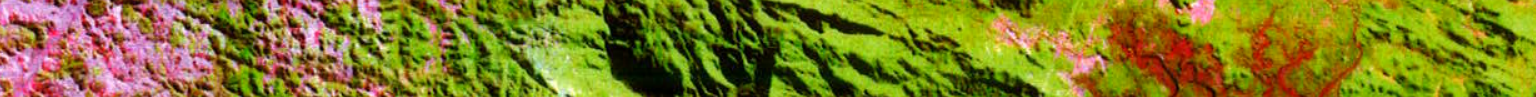

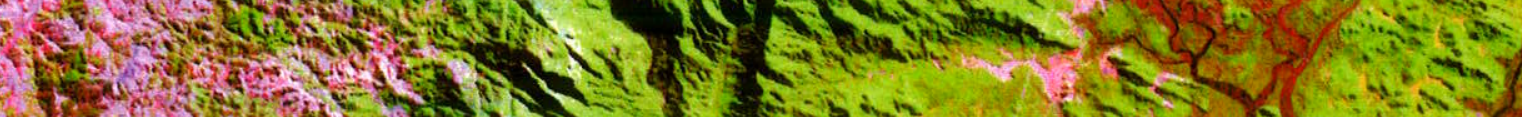

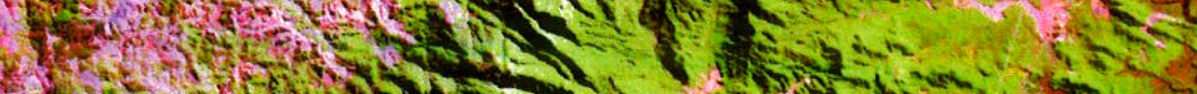

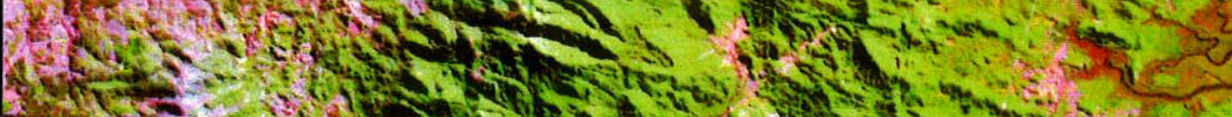

7190

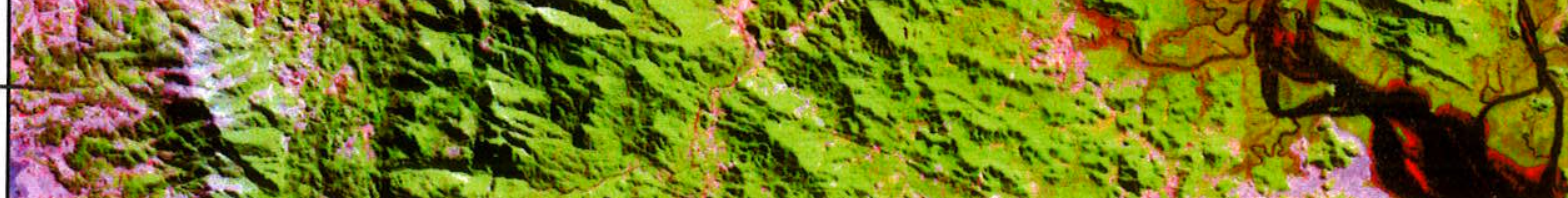

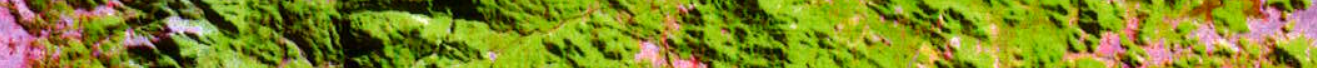

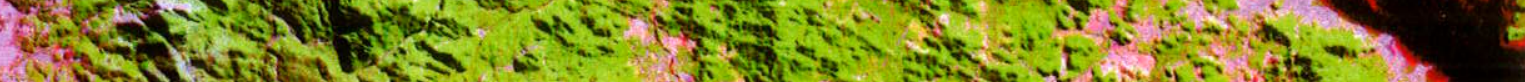

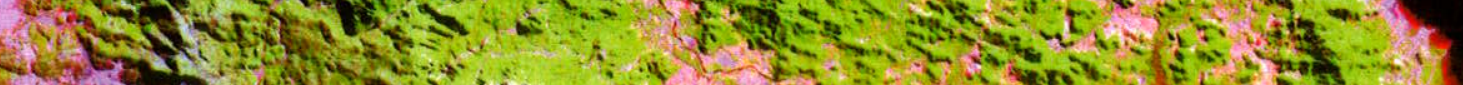

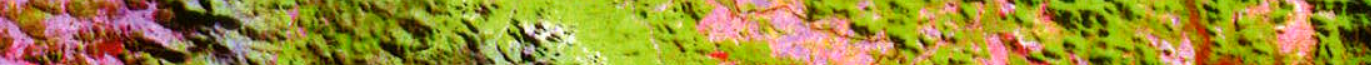

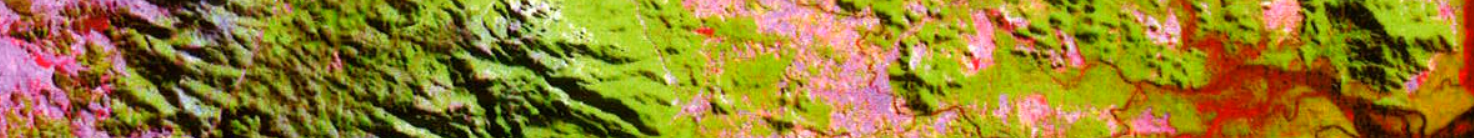

7180

7170

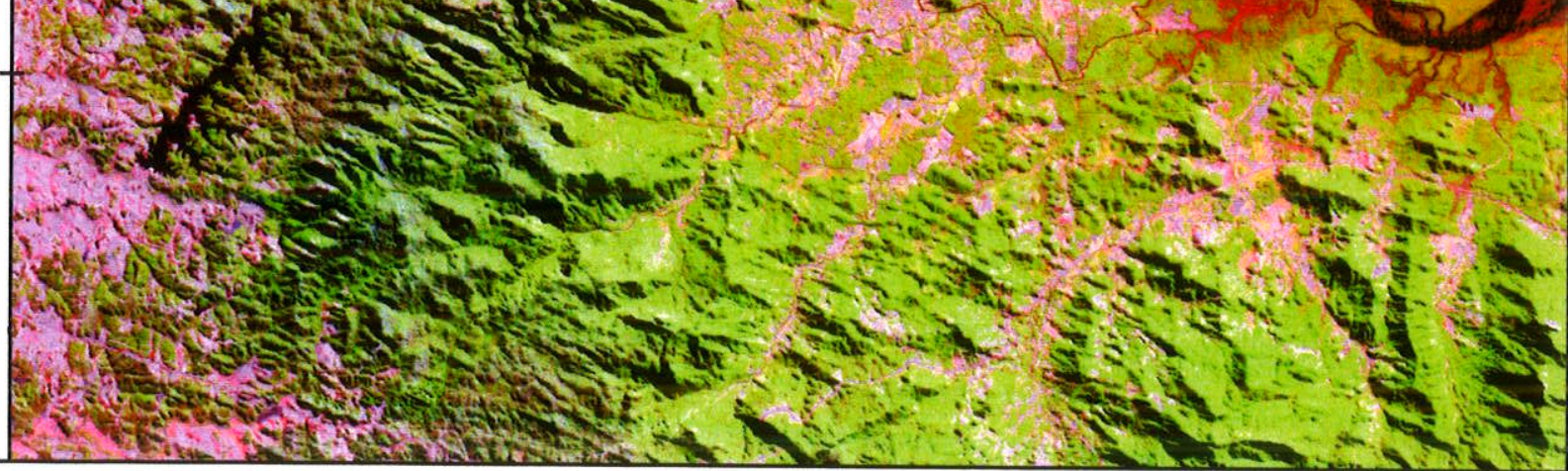

Figura III.8b: Composição 3(R)-4(G)-7(B) de imagens Landsat 5 (TM) da região da Serra da Graciosa Convenções como na Figura III. 6. 
7220

A

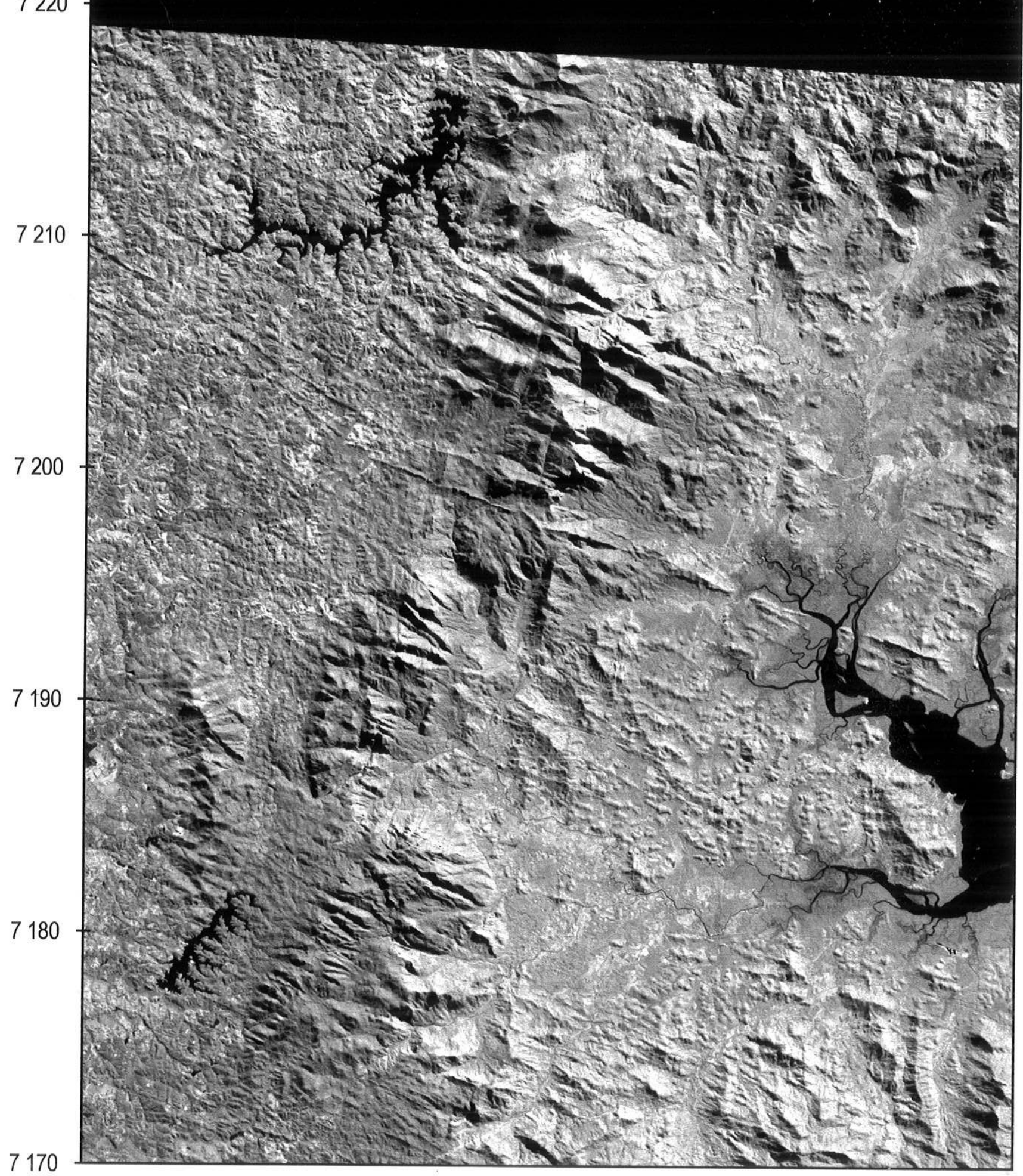

Figura III.8c: Imagem em tons de cinza do Indice de Diferença de Vegetação Normalizado (NVDI =[banda 4 - banda 3] / [banda $4+$ banda 3]) da região da Serra da Graciosa 


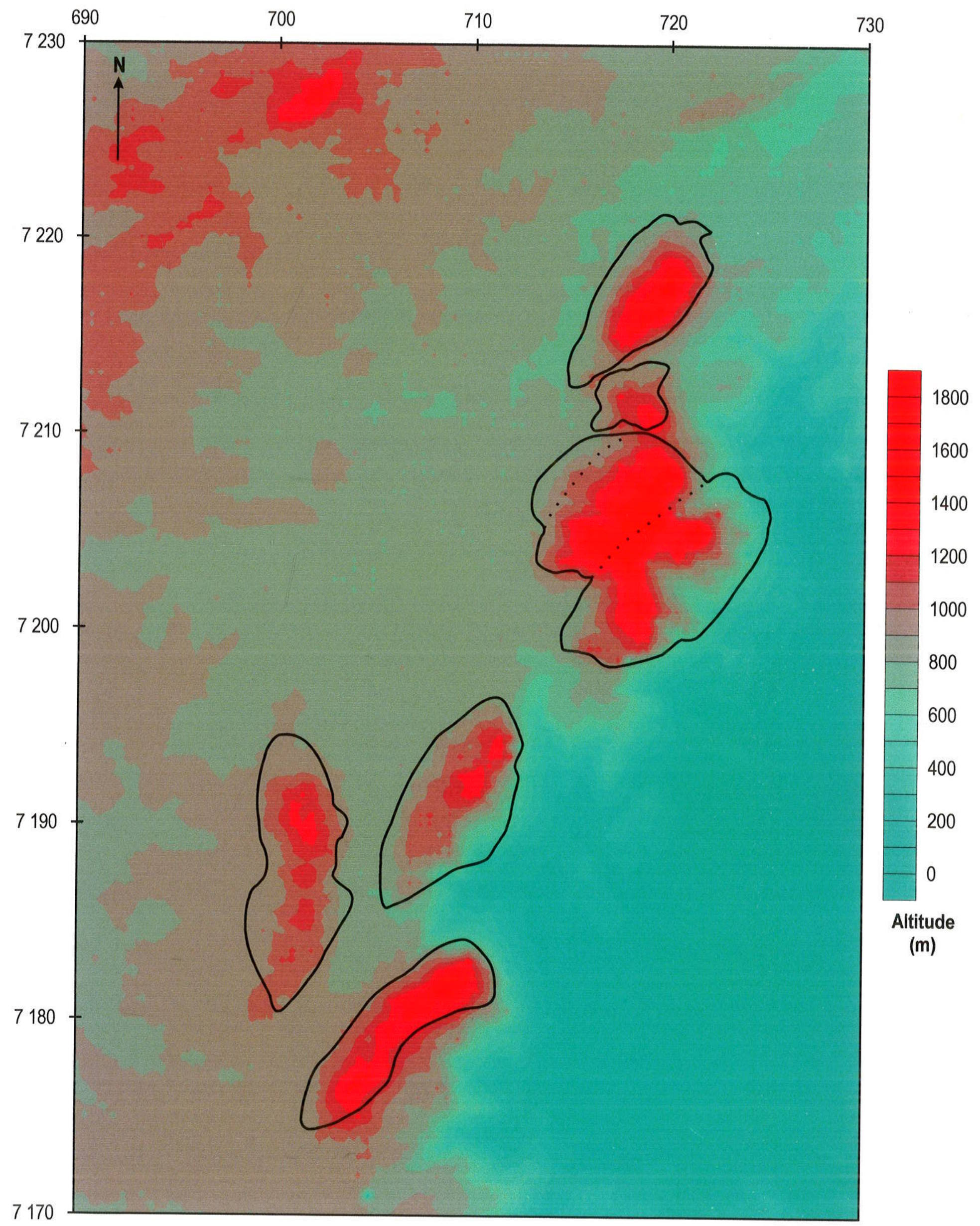

Figura III.9a: Modelo Digital de Terreno (MDT) da região da Serra da Graciosa Convenções como na Figura III. 6 


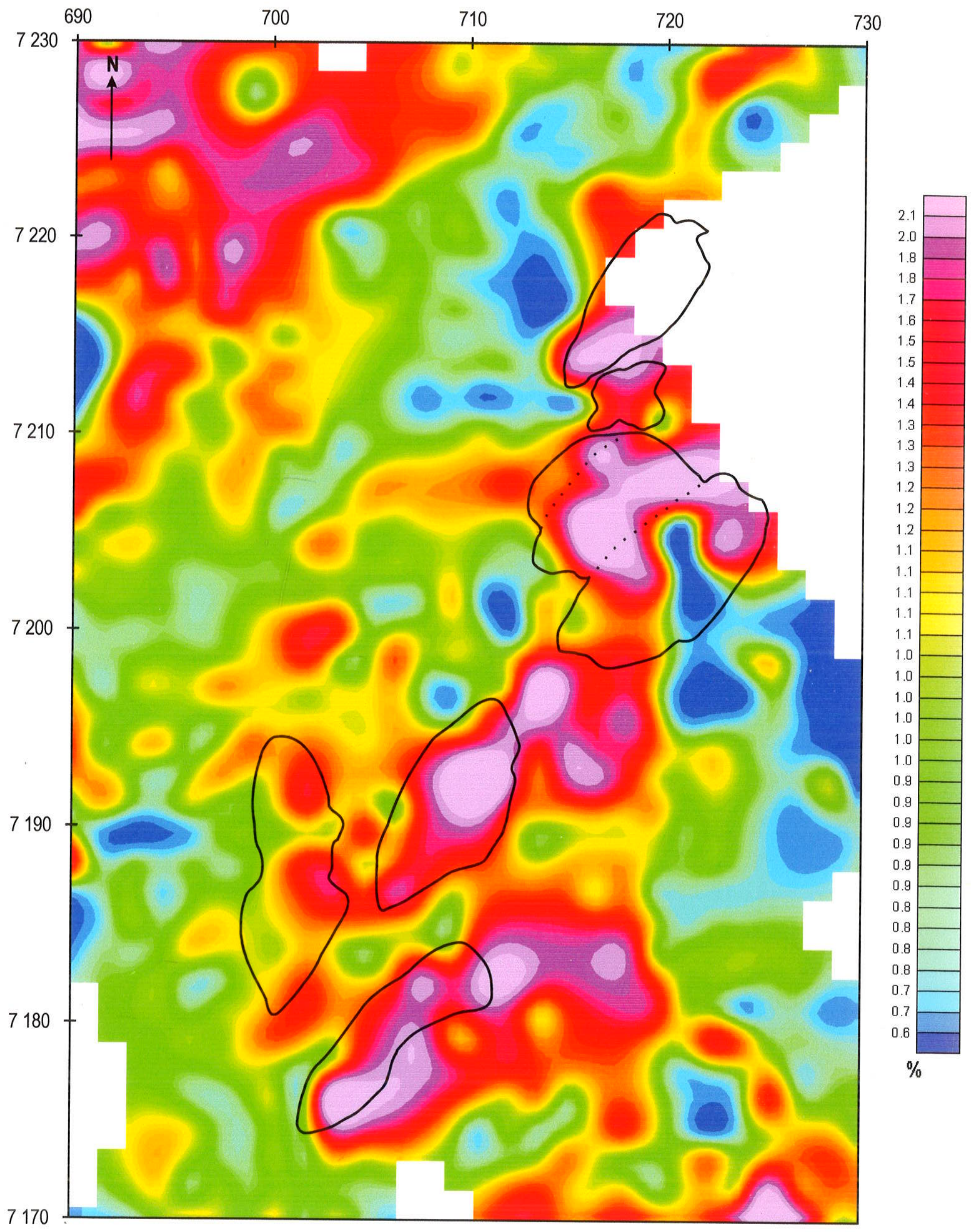

Figura III.9b: Mapa aerogamaespectrométrico de distribuição da concentração de K (\% em peso) na região da Serra da Graciosa. Convenções como na Figura III.6 


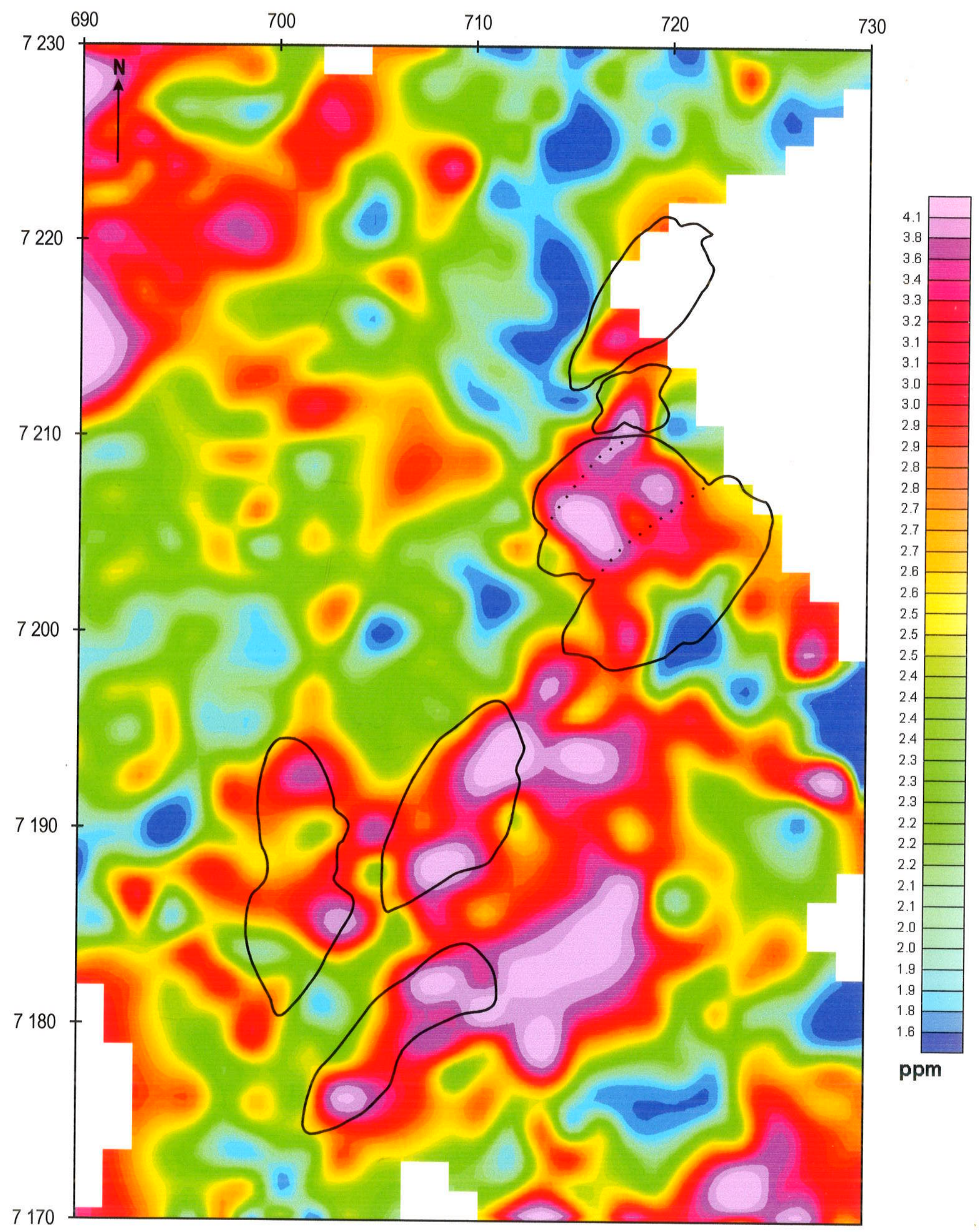

Figura III.9c: Mapa aerogamaespectrométrico de distribuição da concentração de U (em ppm) na região da Serra da Graciosa. Convenções como na Figura III. 6 


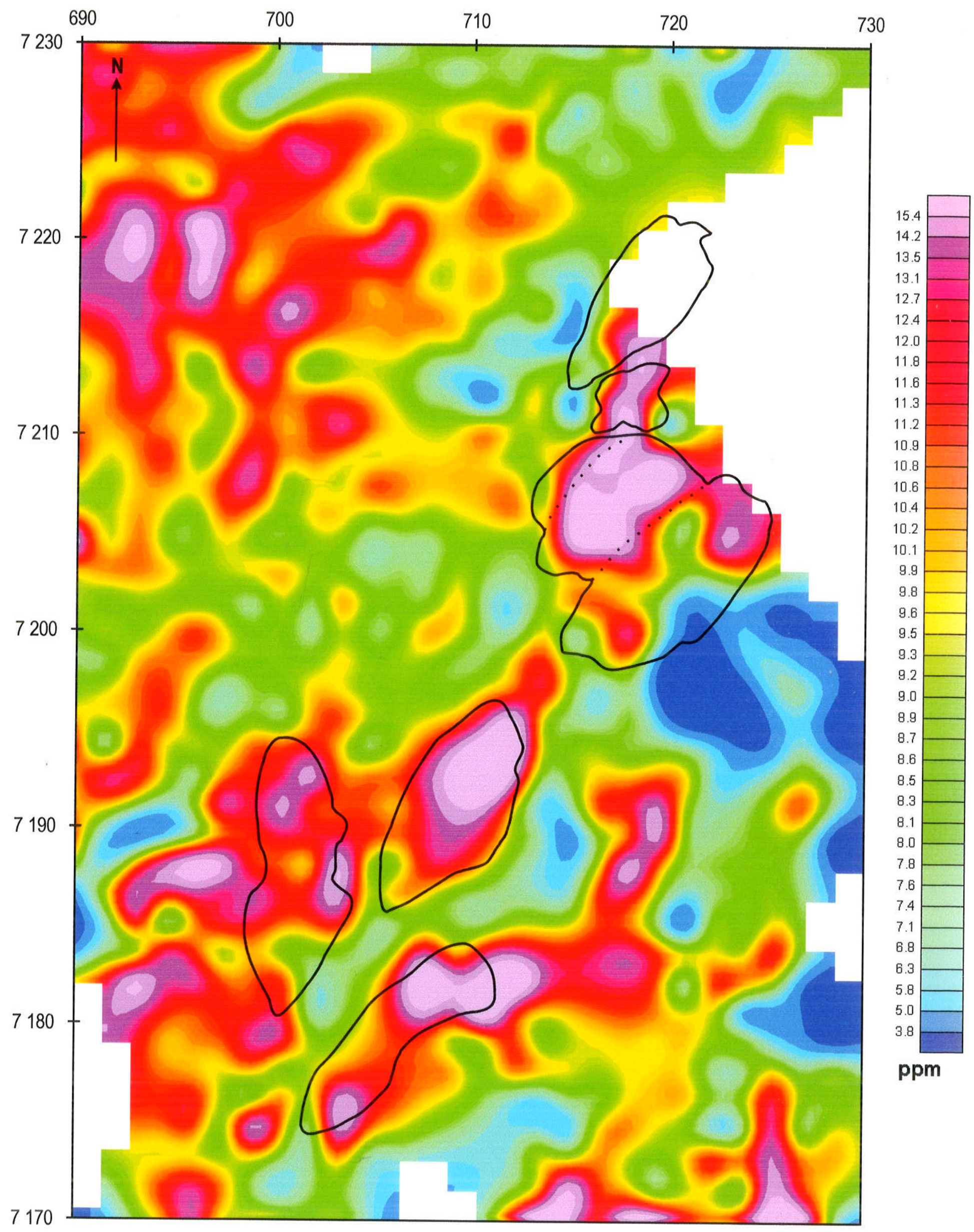

Figura III.9d: Mapa aerogamaespectrométrico de distribuição da concentração de Th (em ppm) na região da Serra da Graciosa. Convenções como na Figura III.6 


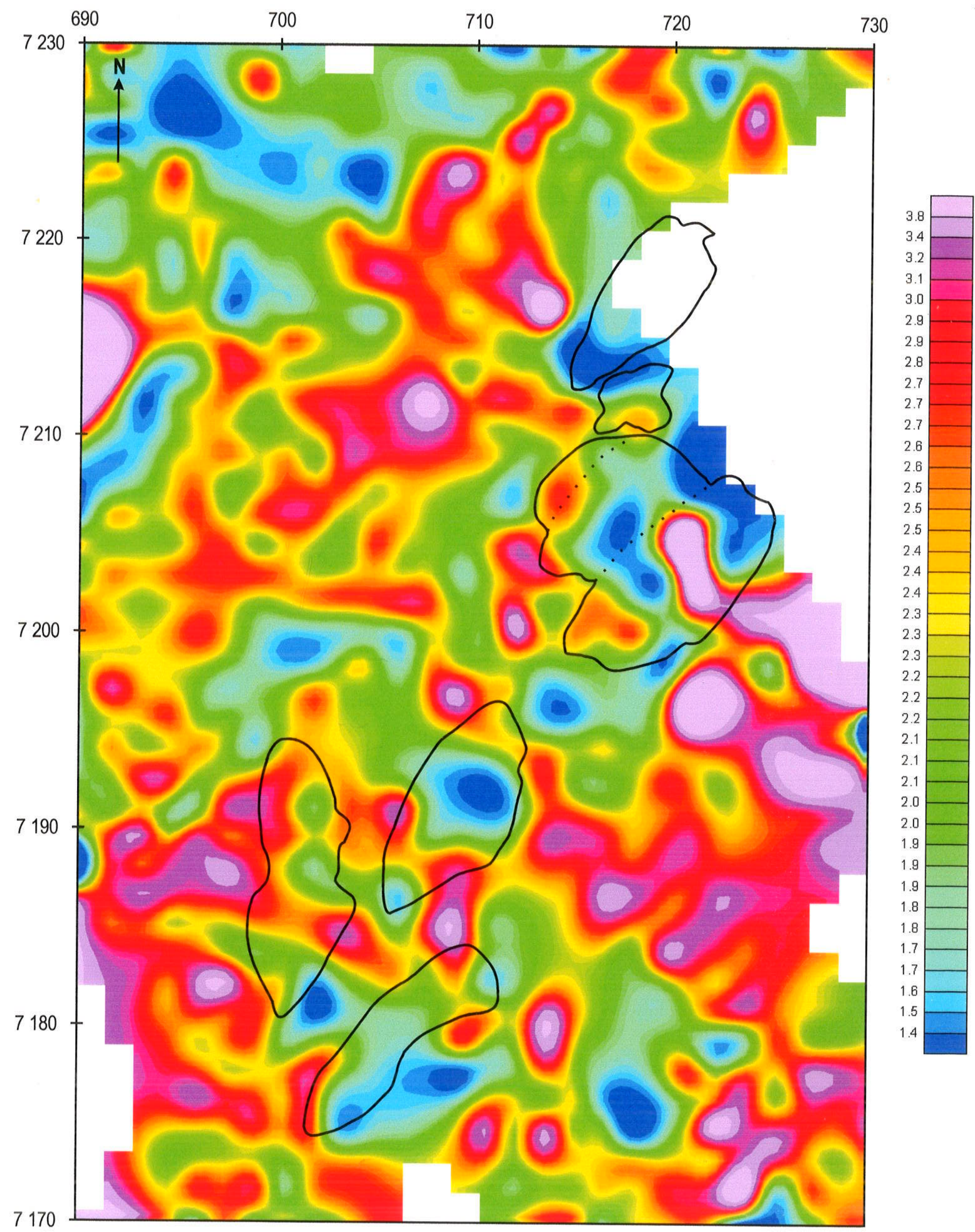

Figura III.9e: Mapa aerogamaespectrométrico de distribuição da razão U/K na região da Serra da Graciosa. Convenções como na Figura III. 6 


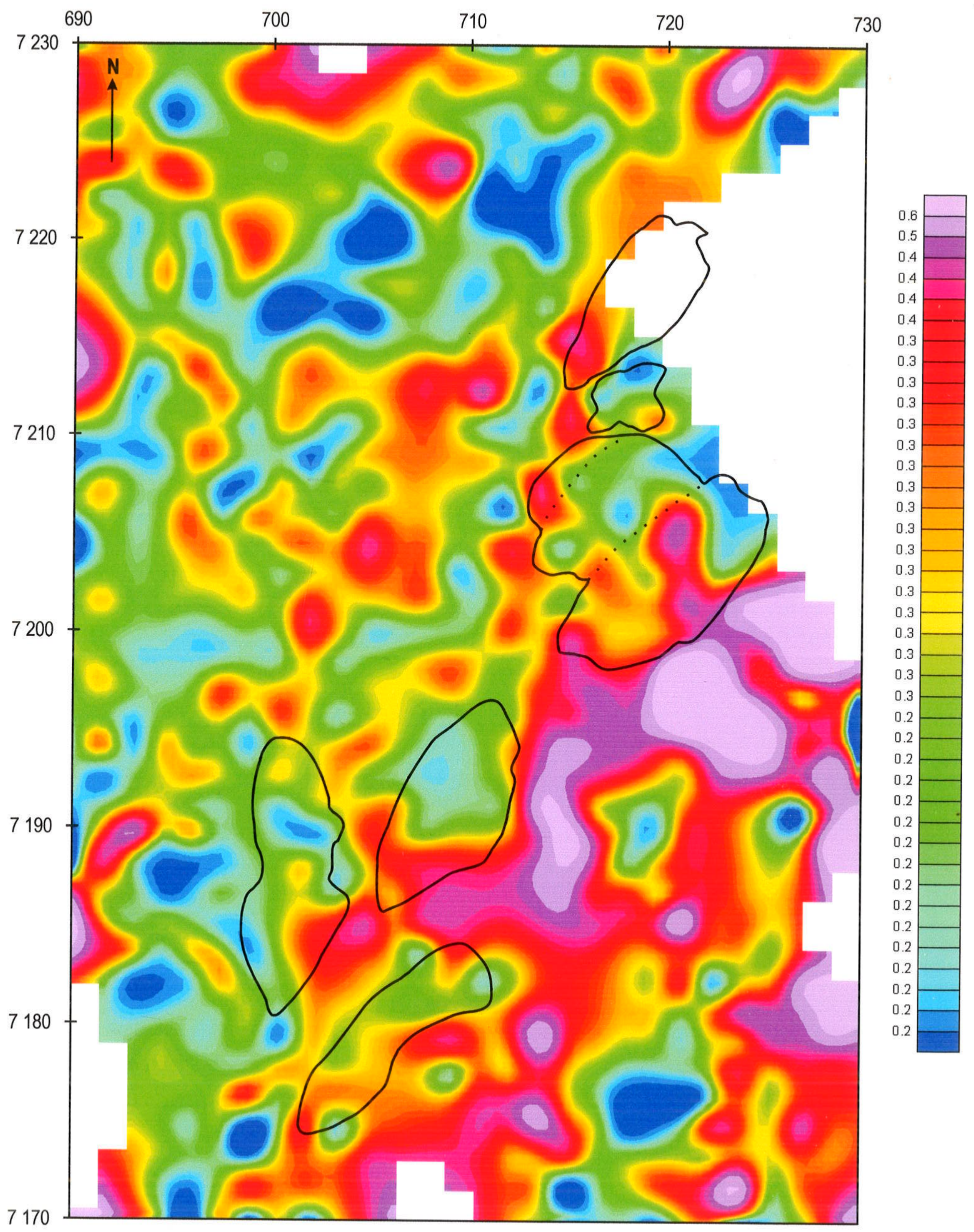

Figura III.9f: Mapa aerogamaespectrométrico de distribuição da razão U/Th na região da Serra da Graciosa. Convenções como na Figura III. 6 


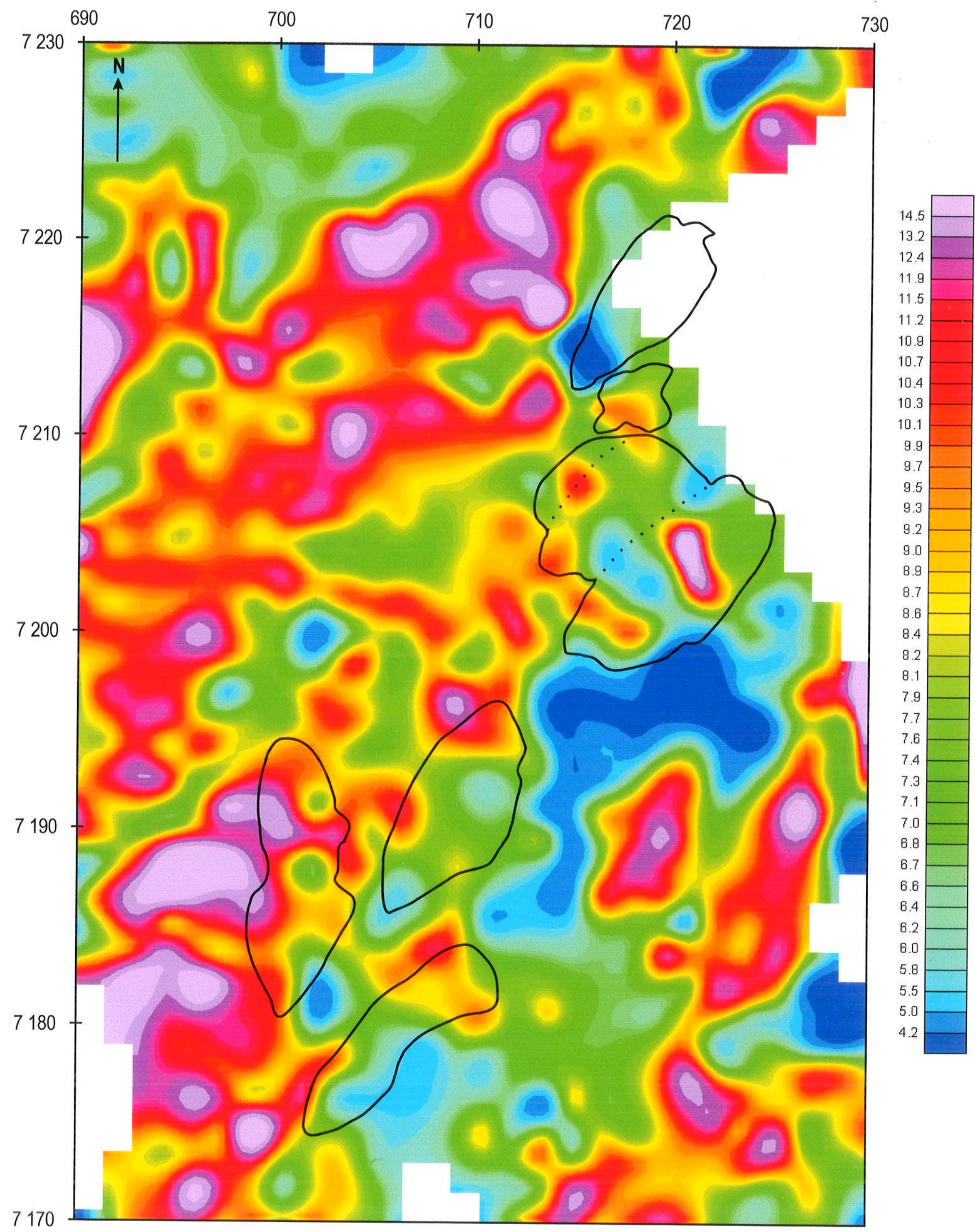

Figura III.9g: Mapa aerogamaespectrométrico da distribuição da razão Th/K na região da Serra da Graciosa. Convenções como na Figura III.6 


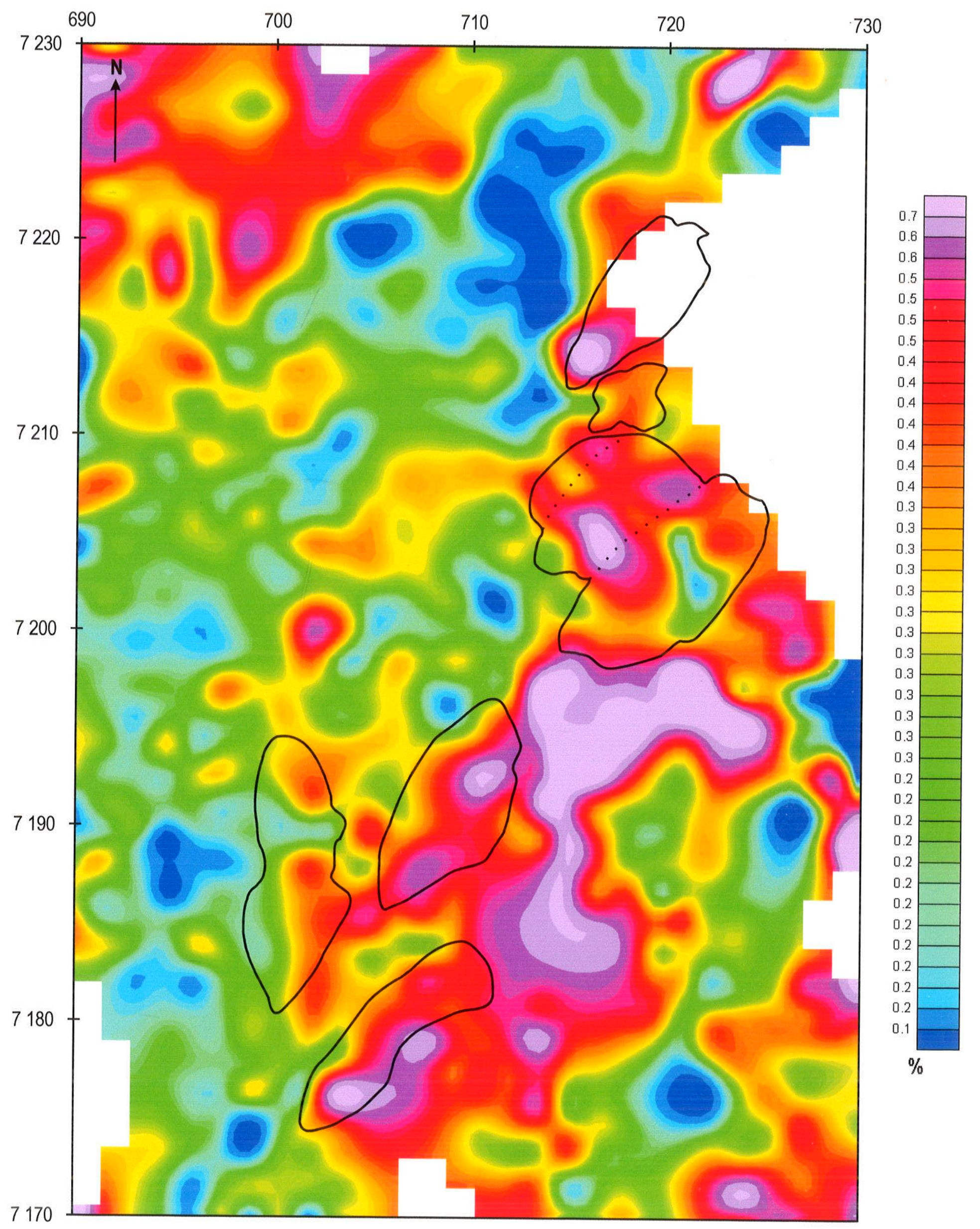

Figura III.9h: Mapa aerogamaespectrométrico do parâmetro $F\left(K^{*} U / T h\right)$ da região da Serra da Graciosa Convenções como na Figura III. 6 


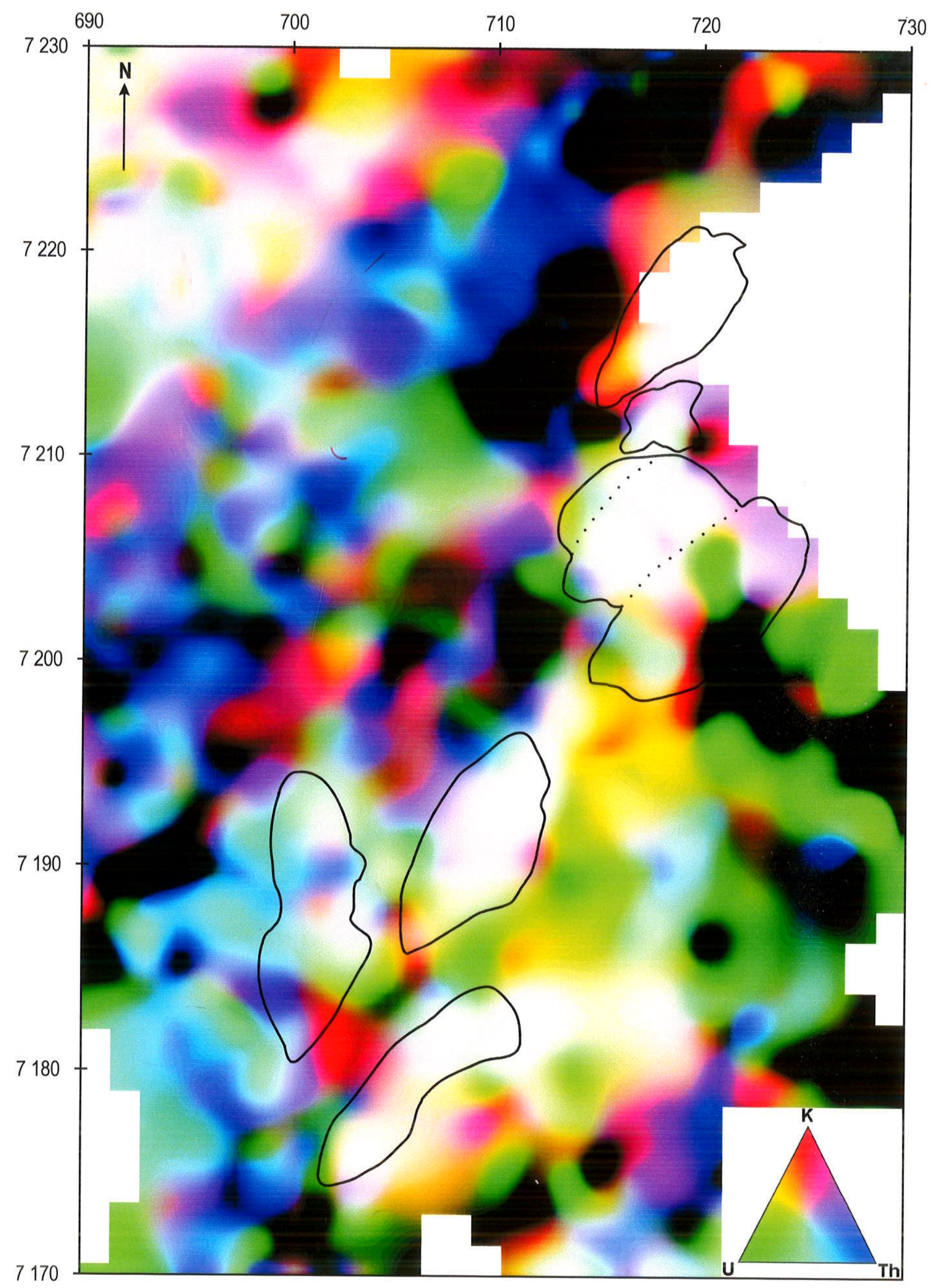

Figura III.9i: Composição ternária $K(R)-U(G)-T h(B)$ da região da Serra da Graciosa Convenções como na Figura III. 6 


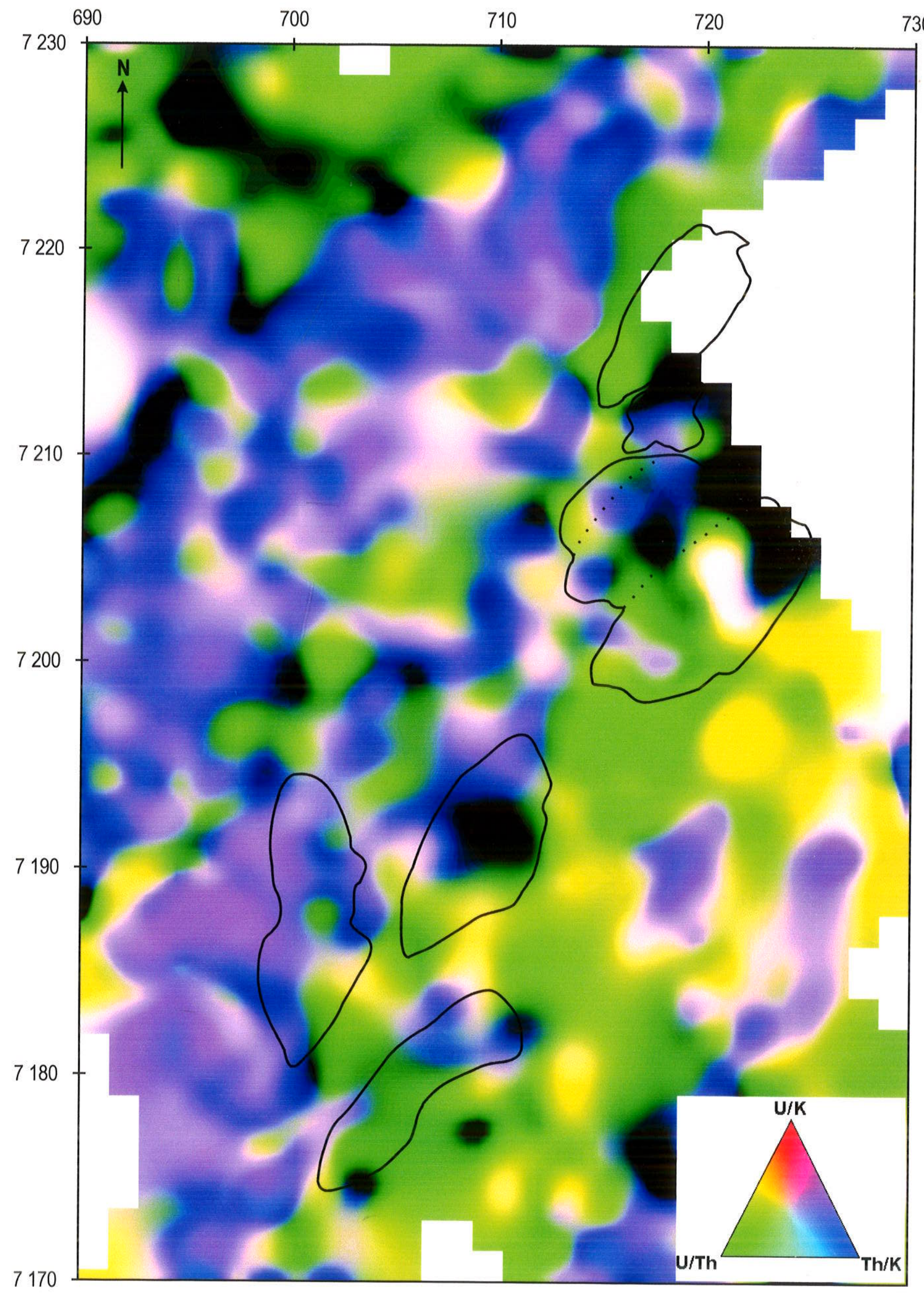

Figura III.9j: Composição ternária U/K(R)-U/Th(G)-Th/K(B) da região da Serra da Graciosa Convenções como na Figura III. 6 
Unidades Geológicas

Maciço Capivari

Maciço Orgäos

$\square$ Maciço Farinha Seca

Maciģo Anhangava

$\square$ Maciço Marumbi

Provavel "Stock" Granitico Embasamento Indifierenciado (Microplacas Curtiba e Lula)
Alves e Cinturấo Costeiro) Convençöes Contato Geológico Inferido

-. Possivel Contato Geológico

$\sim$ Rodovia Pavimentada

Rodovia Não Pavimentada

Estrada de Ferro

$\longrightarrow$ Localidade

Escala 1:250 000

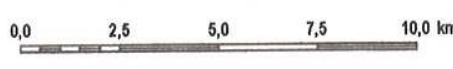

Localização da Área

no Estado do Paraná

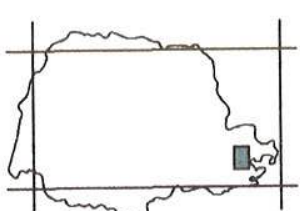
das Folhas Topográficas (1:50.000)

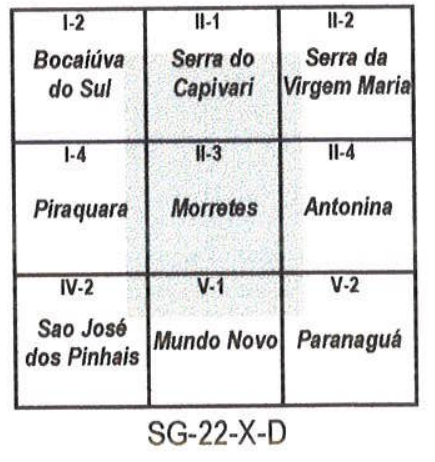

690

700

710

720

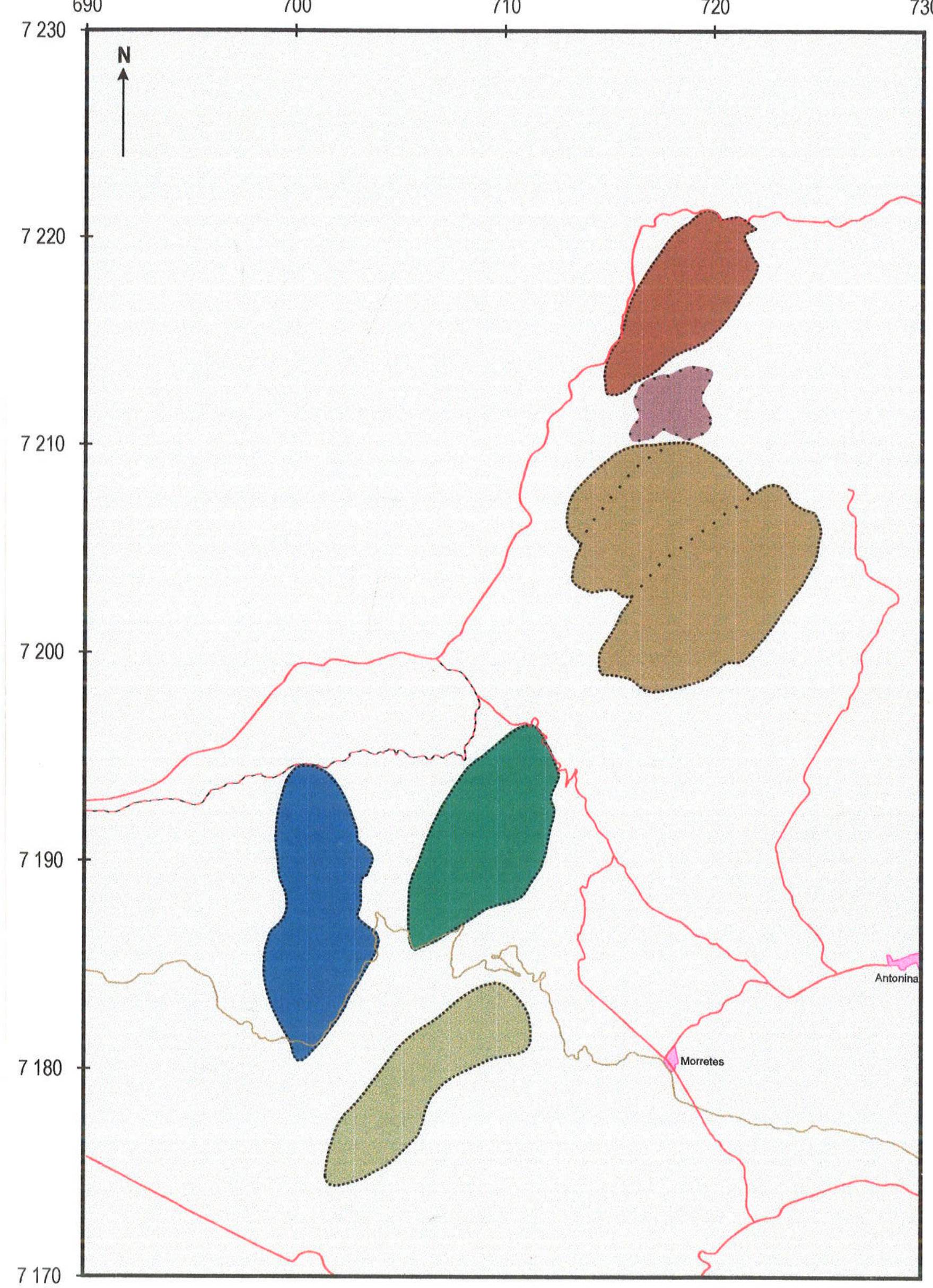

Figura III.10: Esboço geológico dos maciços graníticos da região da Serra da Graciosa (PR) 
Parte IV:

\section{OS GRANITOS TIPO-A DA GRACIOSA:}

Petrografia e mineralogia 


\section{ÍNDICE}

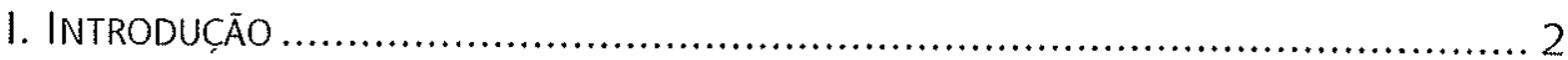

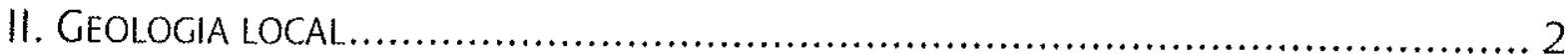

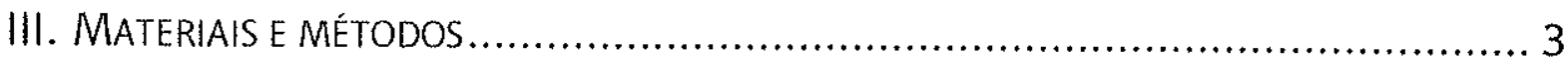

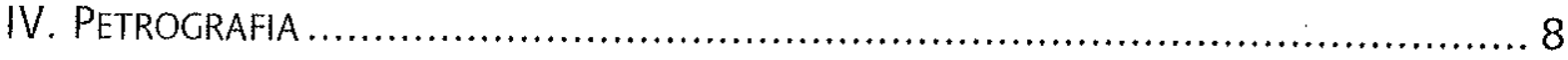

IV.1. A associação petrográfica alcalina /...................................................... 10

IV.2. A associação petrográfica a/calina //........................................................ 16

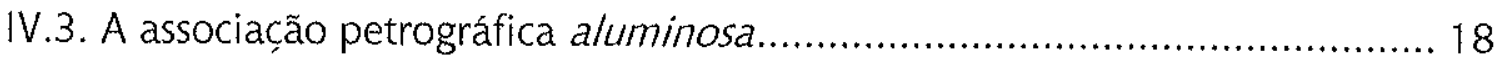

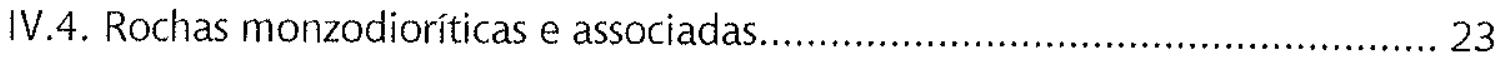

IV.5. Seqüências de cristalização, paragêneses minerais e evolução modal......... 26

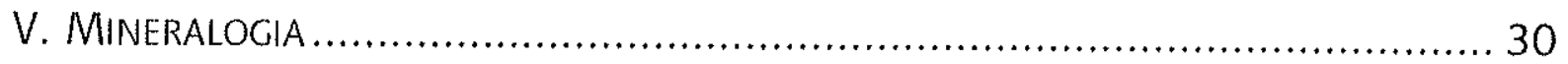

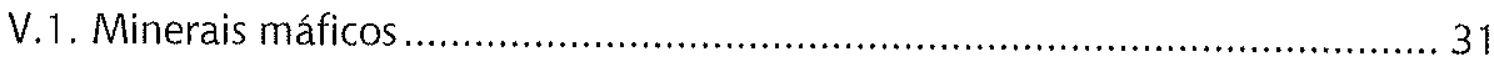

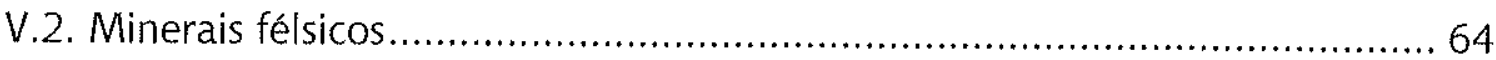

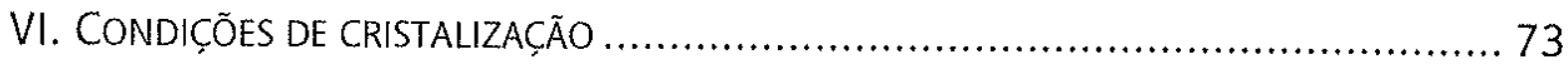

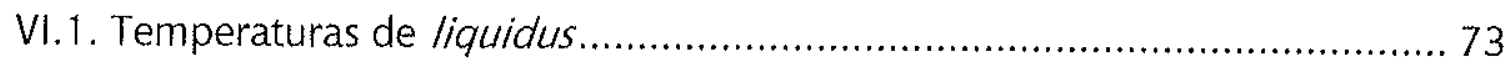

VI.2. Temperaturas solidus e pressão de colocação .............................................. 76

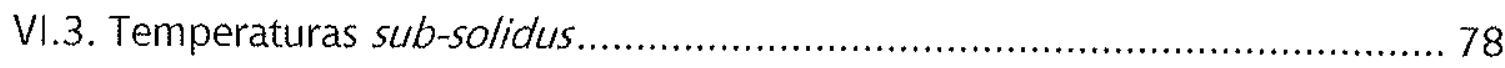

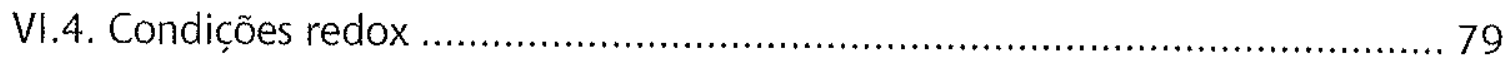

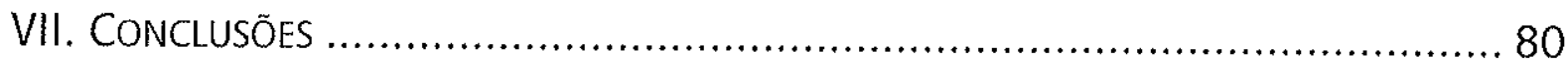

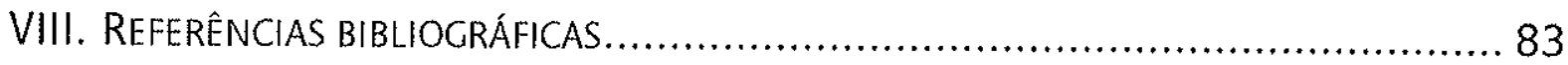

ANEXO I: PRANCHAS

ANEXO II: ANÁLISES QUIMICAS DE MINERAIS 


\section{INTRODUÇÃO}

Na regiāo da Serra da Graciosa (PR) afloram cinco maciços graníticos que constituem uma das mais importantes manifestações do magmatismo granítico de Tipo-A na Provincia Serra do Mar. gerada nos estágios pós-colisionais do Ciclo Brasiliano na porção E dos estados do Paraná e Santa Catarina e na porção SE do estado de São Paulo.

A caracteristica mais importante do conjunto formado pelos Granios da Graciosa é a coexistência de duas associaçoes de granitos Tipo-A: uma alcalina, composta por álcali-feldspato granitos e sienitos com anfibólio como máfico principal; e uma aluminosa, formada por granitos (s.s.) e subordinadamente álcali-feldspato granitos contendo biotita como máfico mais importante. Alem disso, destaca-se a ocorrência de rochas dioríticas, de maneira geral muito raras na província.

A presente contribuiçāo tem como objetivo caracterizar as associações existentes na regiāo através da descrição petrográfica das diversas fácies petrográficas presentes. detalhando as caracteristicas texturais e químicas das fases minerais máficas e félsicas - como indicativos da evolução magmática e pós-magmática dos granitos Tipo- $A$-. bem como avaliar alguns parâmetros intensivos e extensivos de cristalização.

\section{GEOLOGIA LOCAL}

Os Granitos da Graciosa (Parte III) fazem parte da Província Serra do Mar (Kaul. 1984; Vlach et al., 1996), que congrega diversos maciços graníticos e sieníticos localizados nas porçōes SE do Estado de São Paulo e E dos Estados do Paraná e Santa Catarina.

Correspondem ao conjunto formado pelos maciços graníticos Capivari, Órgãos, Farinha Seca (Parte III), Antiangava (Fuck, 1966) e Marumbi (Maack, 1961; Cordani e Girardi, 1967), que conjuntamente afloram por cerca de $275 \mathrm{~km}^{2}$. correspondendo a uma das mais expressivas ocorrências da referida província. (cf. Figura 111.10 )

Os macicos têm forma aproximadamente eliptica com dimensões que variam desde $35 \mathrm{~km}^{2}$ (Maciço Marumbi) até $100 \mathrm{~km}^{2}$ (Maciço Órgãos). Os Maciços Capivari, Órgãos, Farinha Seca e

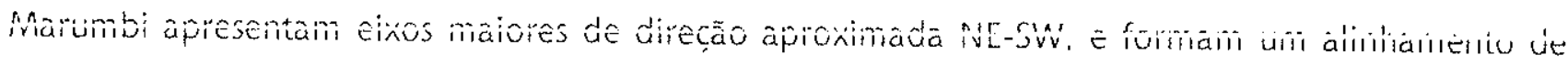
direção NNE-SSW que acompanha a Serra do Mar paranaense: o Maciço Anhangava. por sua vez, é alongado na direção N-S e se localiza pouco a W deste alinhamento. (cf. Figuras 11!.6 e III.10) 
São todos intrusivos em gnaisses e migmatitos da Microplaca Curitiba - gerados no Transamazônico (2.150-1.800 Ma) e migmatizados no Brasiliano (620-580 Ma) -, próximo ao contato tectōnico com granitos deformados de idade Brasiliana (720 Ma - U-Pb em zircōes; $580 \mathrm{Ma}$ - Rb-Sr em rocha total) desta mesma microplaca, localizados a SE. O magmatismo granitico de TipoA gerador da Província Serra do Mar mostra idades que se concentram no intervalo entre 600 e 580 Ma, tendo se formado nos estágios pós-colisionais da colisāo entre o Cinturão Cranitóide Costeiro. localizado a E. e o conjunto formado pelas Microplacas Curitiba e Luiz Alves. (Basei et al., 1992; Siga jr. et al., 1993)

\section{MATERIAIS E MÉTOdOS}

\section{Análise petrográfica}

Os estudos petrográficos foram realizados nas dependências do Laboratório de Ótica do Instituto de Geociências - USP. Foram estudadas seções petrográficas convencionais e secōes delgadas polidas sob luzes transmitida e refletida no microscópio Zeiss AXIOPLAN.

A análise petrográfica teve como objetivos o reconhecimento das fases minerais presentes bem como das suas relações texturais. que fundamentaram a definição das seqüencias de cristalização das rochas. Especial atenção foi dada à caracterização das feiçōes magmáticas e pós-magmáticas. A nomenclatura petrográfica aqui utilizada segue as definiçōes de Mackenzie et al. (1995).

Foram obtidas fotomicrografias em formato digital utilizando-se o microscópio Olympus BX-50, que dispõe de câmera digital 3CCD PRO-SERIES acoplada e sistema de aquisição de imagens IMAGEPRO PLUS, ambos da Media Cybernetics. A resolução das imagens é de $760 \times 570$ pixels.

\section{Avaliacoenes modais}

Apesar da importância das composiçōes modais em trabalhos petrográficos de rotina, a literatura sobre o tema é relativamente restrita. Mesmo em relação ao método de contagem de pontos - o mais amplamente utilizado - existem pontos de debate quanto às condiçoes em que as avaliações devem ser feitas, e sobretudo, quanto às formas de obtenção de estimativas de erros. Estas questōes conduziram à idéia de se fazer um estudo específico para avaliar a precisão e a exatidão associadas ao método de contagem de pontos em função das condições utilizadas, que aparece detalhado no Apêndice I. Os resultados guiaram a realização das avaliações modais no presente estudo. 
Estimativas das composiçōes modais de 40 amostras representativas das diversas fácies descritas foram obtidas através do método de contagem de pontos (Chayes, 1956; (f. Apêndice 1).

Na maioria dos casos foram contados cerca de 1200 pontos, com espaçamento da malha de contagem de $0.8 \mathrm{~mm}$. o que leva a uma área analisada próxima de uma seção petrográfica convencional. Apenas para algumas amostras de granulaçāo mais grossa foram contados cerca de 1500 pontos com espaçamento de $1,0-1.2 \mathrm{~mm}$, totalizando uma área de 2 seçōes petrográficas convencionais.

Para cada amostra, a coleta de dados se deu em 20-25 conjuntos de 50 pontos cada, o que permite o cálculo de erros associados às estimativas modais segundo o método de Neilson e Brockman (1977). Este método foi utilizado para o cálculo dos erros dos minerais maiores (i.é. quartzo. feldspato aicalino e plagioclásio), enquanto para os demais foi utilizado um erro de binomial de contagens (cf. Apêndice 1).

\section{Análises em microssonda}

Análises químicas pontuais (WDS) e imagens eletrônicas de varredura foram obtidas no Laboratório de Microssonda Eletrônica do Instituto de Geociências com equipamento Jeol JXA-8600S. munido de detector ED e 5 espectrômetros WD. com sistema de automação VOYACER 3.6 .1 da Noran Instruments.

As seçōes delgadas polidas foram cobertas com uma fina película $(\sim 25 \mathrm{~nm})$ de $\mathrm{C}$ com 0 evaporador AUTO 206 da Edwards disponivel no laboratório.

Imagens de elétrons retro-espalhados em modo composicional (BEI-COMPO) foram obtidas para verificar a presença de zoneamentos químicos. As condiçōes do feixe eletrônico foram de $15 \mathrm{kV}$, $20 \mathrm{nA}$ e $1 \mu \mathrm{m}$ para a voltagem de aceleração. corrente e diâmetro do feixe eletrônico focado. respectivamente.

Análises químicas completas pontuais - por WDS - foram obtidas ao longo de perfis núcleoborda para cada uma das fases presentes, utilizando-se como referencia os zoneamentos eventualmente observados em microscopia ótica ou eletrónica. As condiçōes analíticas aparecem resumidas na Tabela IV.1. 
Tabela IV.1:

Condiçōes analiticas utilizadas*

\begin{tabular}{|c|c|c|c|c|c|c|}
\hline \multirow{2}{*}{ Linha } & \multirow{2}{*}{ Cristal } & \multicolumn{4}{|c|}{ Padrōes } & \multirow[b]{2}{*}{$T_{\max }(s)$} \\
\hline & & CPx/Olivina & Anfibólio & Biotita & Feldspatos & \\
\hline Si Ká & TAP & wollastonita & wollastonita & wollastonita & microclínio & 10.20 \\
\hline Tika & LiF & rutilo & rutilo & rutilo & rutilo & $20-40$ \\
\hline Zrla & PET & zircào & zircão & zircão & $\ldots+n+\ldots$ & 30 \\
\hline A) lia & TAP & hornblenda & hornblenda & anortita & anortita & $10-40$ \\
\hline Fe Ka & Lif & olivina & olivina & olivina & olivina & $20-30$ \\
\hline Mn Ka & Lif & olivina & olivina & olivina & -..-. & $20-40$ \\
\hline $\mathrm{MgKa}$ & TAP & diopsidio & diopsidio & diepsidio' & diopsicis & 20.40 \\
\hline $\mathrm{ZnKa}$ & LiF & $\mathrm{ZnO}$ & $\mathrm{ZnO}$ & $\mathrm{ZnO}$ & $\ldots+\cdots$ & $20-40$ \\
\hline $\mathrm{CaKa}$ & PET & wollastonita & wollastonita & wollastonita & anortita & $10-30$ \\
\hline Ba La & Lif & $----\cdot$ & -........ & barita & $-\cdots-\cdot$ & 30 \\
\hline Ba La & PET & $\ldots . . . n+n$ & $\ldots$ & $\cdots$ & barita & 40 \\
\hline Sr La & PET & ----- & --.-- & $\cdots$ & Sr-anortita & 30 \\
\hline $\mathrm{Naka}$ & TAP & albita & albita & albita & albita & 10.20 \\
\hline KKরa & PET & microclínio & microclínio & microclínio & microdinio & 20.40 \\
\hline $\mathrm{Nb} \mathrm{Ka}$ & ……- & $\ldots$ & $-\cdots$ & $\cdots$ & ----- & 30 \\
\hline Cl Ka & PET & ----- & apatita & apatita & n...nnen. & 10 \\
\hline $\mathrm{FKa}$ & TAP & ....... & fluorita & fluorita & $\ldots$ & 10 \\
\hline
\end{tabular}

Tempo total de integração de contagens,

igualmente dividido entre pico e radiação de fundo

Foram obtidas análises de anfibólio, biotita, clinopiroxênio, olivina, plagioclásio e feldspato alcalino. Dada a presença de anfibólio na grande maioria das rochas estudadas e suas variaçoes quimicas serem bastante acentuadas, foi dada ênfase ao estudo desse grupo de minerais, o que se reflete em um número maior de análises químicas.

No caso do plagioclásio, foram efetuados ainda perfis analíticos núcleo-borda mais detalhados, com espacamento entre análises entre 5 e $30 \mu \mathrm{m}$.

Análises qualitativas e semi-quantitativas através de EDS foram empregadas para identificação de algumas fases acessórias de difícil identificação ao microscópio petrográfico, como chevkinita (perrierita) e cassiterita. Os óxidos de Fe e Ti, além de algumas dessas fases acessórias (e.g. chevkinita, allanita, titanita) foram caracterizadas em maior detalhe por WDS, porém a apresentacão dos resultados está além do escopo deste trabalho.

\section{Integraçôes composicionais de fases exsolvidas}

A grande maioria dos cristais de feldspato alcalino estudados apresenta lamelas de exsoluçāo bem desenvolvidas. Nestes casos, é importante caracterizar não só o quimismo das fases exsolvidas. mas principalmente a composição primária dos cristais, pois estas são as de maior relevância 
petrológica. No presente estudo. tais composições foram obtidas a partir da integração de dados químicos pontuais com base em imagens de elétrons retro-espalhados.

Foram selecionados preferencialmente cortes com padrão lamelar de exsolução. com lamelas regulares e homogêneas. Parte significativa dos cristais apresentam zoneamentos evidenciados por variações na morfologia. nas dimensōes ou na proporção relativa de lamelas albíticas (e.g. Figura IV.1). Nesses casos. as diferentes zonas foram analisadas independentemente.

Depois de identificadas as diferentes zonas nas imagens óticas e eletrônicas, foram realizadas 23 análises químicas pontuais das fases exsolvida e hospedeira para cada zona. Eliminadas análises eventualmente pouco satisfatórias, foram obtidas médias das composições de cada uma das fases.

Para se obter a composiçăo global da zona, essas composiçoes médias foram ponderadas com base na proporção em área ocupada por cada uma delas. Esta informação foi obtida a partir das imagens de elétrons retro-espalhados, com o auxilio do programa Corel PHOTO-PAINT. Neste aplicativo. pode-se obter histogramas da frequência de pixels por tonalidade de cinza, sendo possivel ainda conhecer o percentual ocupado por um intervalo de tons de cinza do histograma. Assim, uma vez identificados os picos correspondentes a cada uma das fases. as suas proporçōes em área podem ser facilmente obtidas (Figura IV.1).

O procedimento aparece ilustrado na Figura IV.1. em que são apresentados os histogramas para as porçōes de núcleo e borda de um dos cristais estudados, bem como a localização dos pontos analíticos.

Em alguns casos, as bordas dos cristais apresentam lamelas muito finas para serem analisadas independentemente. Nestes casos, foram obtidas 4-5 análises, sendo utilizadas as médias simples.

\section{Cálculos cristalográficos}

As análises foram tratadas utilizando-se o programa MINCAL (Gualda e Vlach, em preparaçāo). um conjunto de planilhas do programa Microsoft EXCEL dedicadas a cálculos mineralógicos.

No caso de olivina, biotita e feldspatos. as fórmulas estruturais foram calculadas com base em 4. 22 a o Orospcctivamente. 

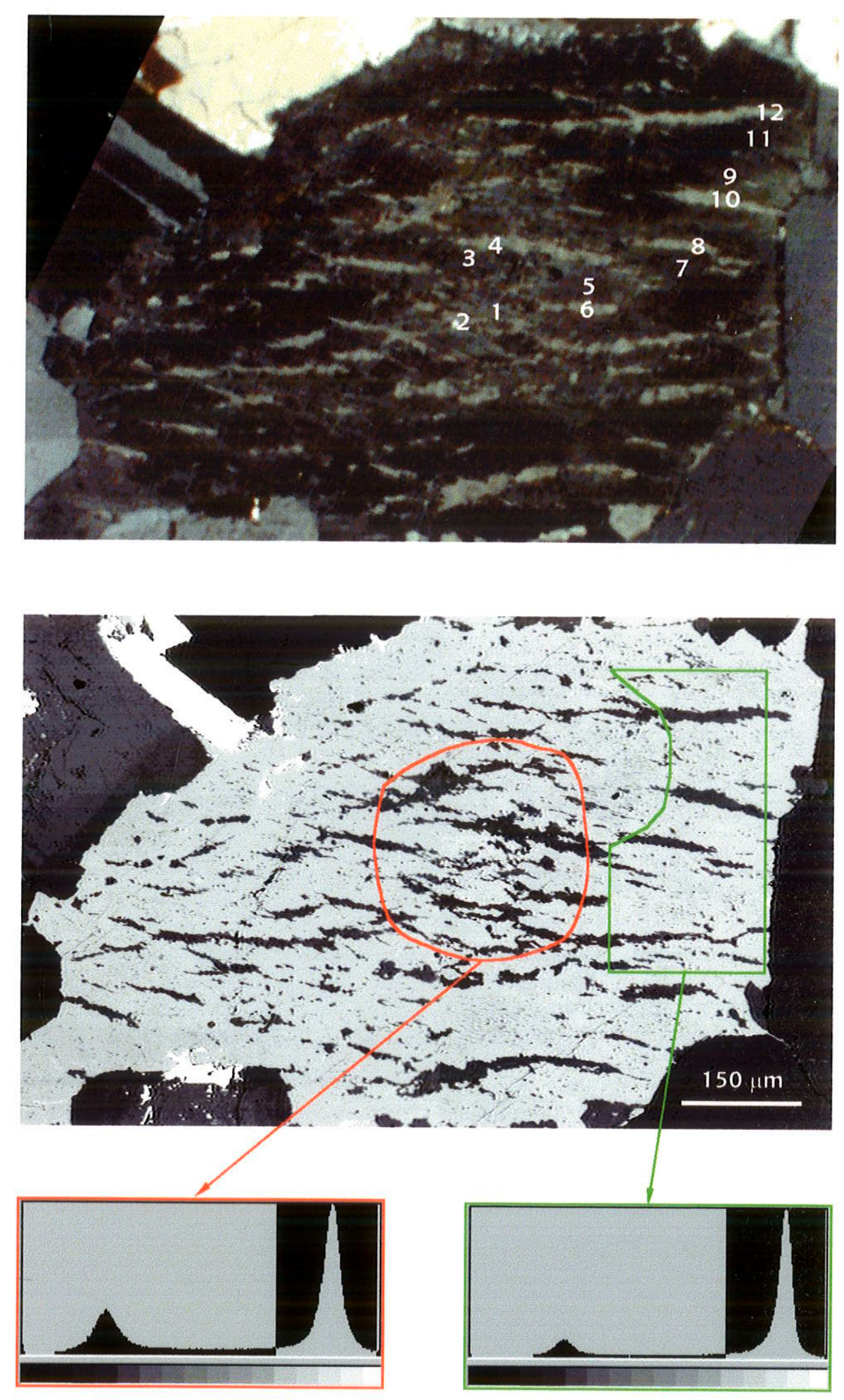

Figura IV.1: I/ustração do procedimento adotado para integração composicional em felsdpatos alcalinos pertíticos. Acima, fotomicrografia mostrando a localização dos pontos analíticos. Intermediário, imagem de elétrons retro-espalhados com áreas representativas de núcleo e borda delimitadas. Abaixo, histogramas obtidos no programa Corel PHOTO-PAINT mostrando a freqüência relativa de pixels por tonalidade de cinza. 
No caso de clinopiroxênio, ilmenita e magnetita, as proporcoooes relativas de $\mathrm{Fe}^{2+}$ e $\mathrm{Fe}^{3+}$ foram calculadas segundo o método de Droop (1987), considerando-se 6, 3 e 4 O e 4, 2 e 3 cátions totais respectivamente, ou ainda todo ferro como $\mathrm{Fe}^{3+}$ nos casos de deficiência de ferro total.

As amostras de $\mathrm{Fe}^{2+}$ e $\mathrm{Fe}^{3+}$ são mais completas nos anfibólios, devido à presença de grupos (OH,F.Cl); assim, foi dada atenção especial para a escolha do método mais apropriado. Atualmente, a International Mineralogical Association (IMA) recomenda a utilização do método de de Schumacher (in Leake et al., 1997). Porém, trabaihos recentes (e.g. Enders et al., 2000; Martins, 2001) têm destacado problemas com a sua aplicação. Uma análise crítica dos resultados obtidos (Apêndice II) mostrou que as estimativas máximas do método de Schumacher são mais adequadas que os valores médios sugeridos pela IMA, portanto, estas foram selecionadas neste trabalho.

\section{Petrografia}

As características petrográficas das rochas estudadas permitem dividi-las em associaçōes que se distinguem principalmente pela composição mineralógica. As afinidades de cada associaçāo são indicadas pela saturaçăo em alumina das rochas que a compōem. refletidas nas fases máficas e acessórias e. em parte, pela presença ou ausência de plagioclásio como mineral primário. Assim, a associação alcalina mais típica tem caráter hipersolvus e contém máficos pobres em alumínio (e.g. anfibólios cálcico-sódico e sódico, clinopiroxênio, olivina, etc.), enquanto as rochas da associação aluminosa são tipicamente subsolvus e contém biotita como máfico típico.

Três associaçōes distintas - duas alcalinas e uma aluminosa - foram identificadas dentre o conjunto de rochas estudado. A primeira delas - a associação alcalina / - é composta predominantemente por álcali-feldspato sienitos com conteúdo variável de máficos, e subordinadamente por álcali-feldspato granitos com anfibólio sódico. A segunda delas - a associação alcalina //-, por sua vez, é composta basicamente por álcali-feldspato granitos portando anfibólio de composição variável, desde cálcico até sódico, com ocorrência subordinada de quartzo sienitos. Na associação petrográfica aluminosa, predominam amplamente sienogranitos, com quantidades menores de monzogranitos e álcali-feldspato granitos, todos portando biotita e a maioria também anfibólio cálcico.

Dados modais - acompanhados dos respectivos desvios estatísticos - representativos para as rochas estudadas são apresentados na Tabela IV.2 (em anexo) e representádos no diagrama QAP de classificaçăo das rochas graníticas (Figura IV.2; Streckeisen, 1976). Diagramas adicionais ilustrando as 
relaçöes entre minerais máficos e destes com o indice modal Q/QAP [quartzo/(quartzo + feldspato alcalino + plagioclásio)], são apresentados na Figura IV.3.

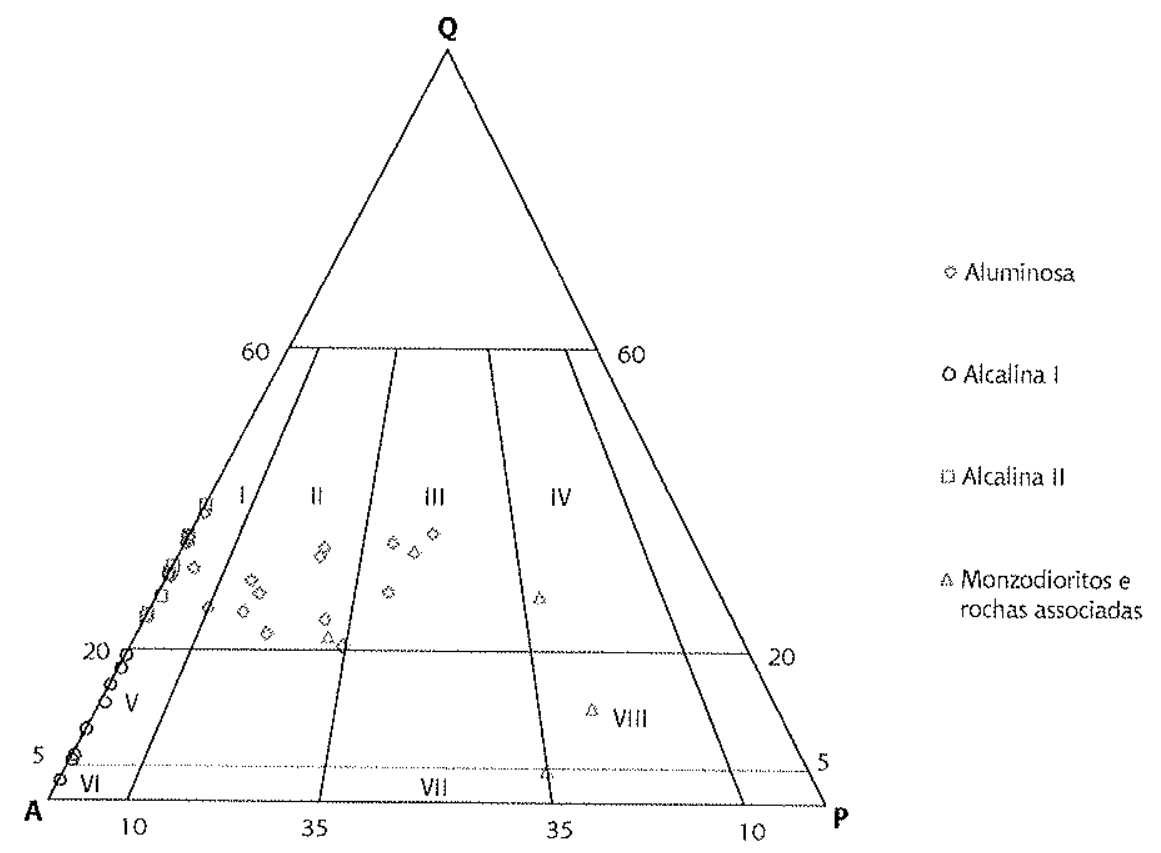

Figura IV.2: Diagrama modal Quartzo (Q) - Feldspato alcalino (A) - Plagioclásio (P) mostrando as variaçôes composicionais nas associaçôes alcalina 1, alcalina 11 e aluminosa dos Granitos da Graciosa (PR). Campos segundo Streckeisen (1976). Campos: 1 - alcali-feldspato granito; II - sienogranito; III - monzogranito; IV - granodiorito; V - álcali-feldspato quartzo sienito; $\mathrm{VI}$ - álcali-feldspato sienito; VII - monzonito; VIII - quartzo monzodiorito.

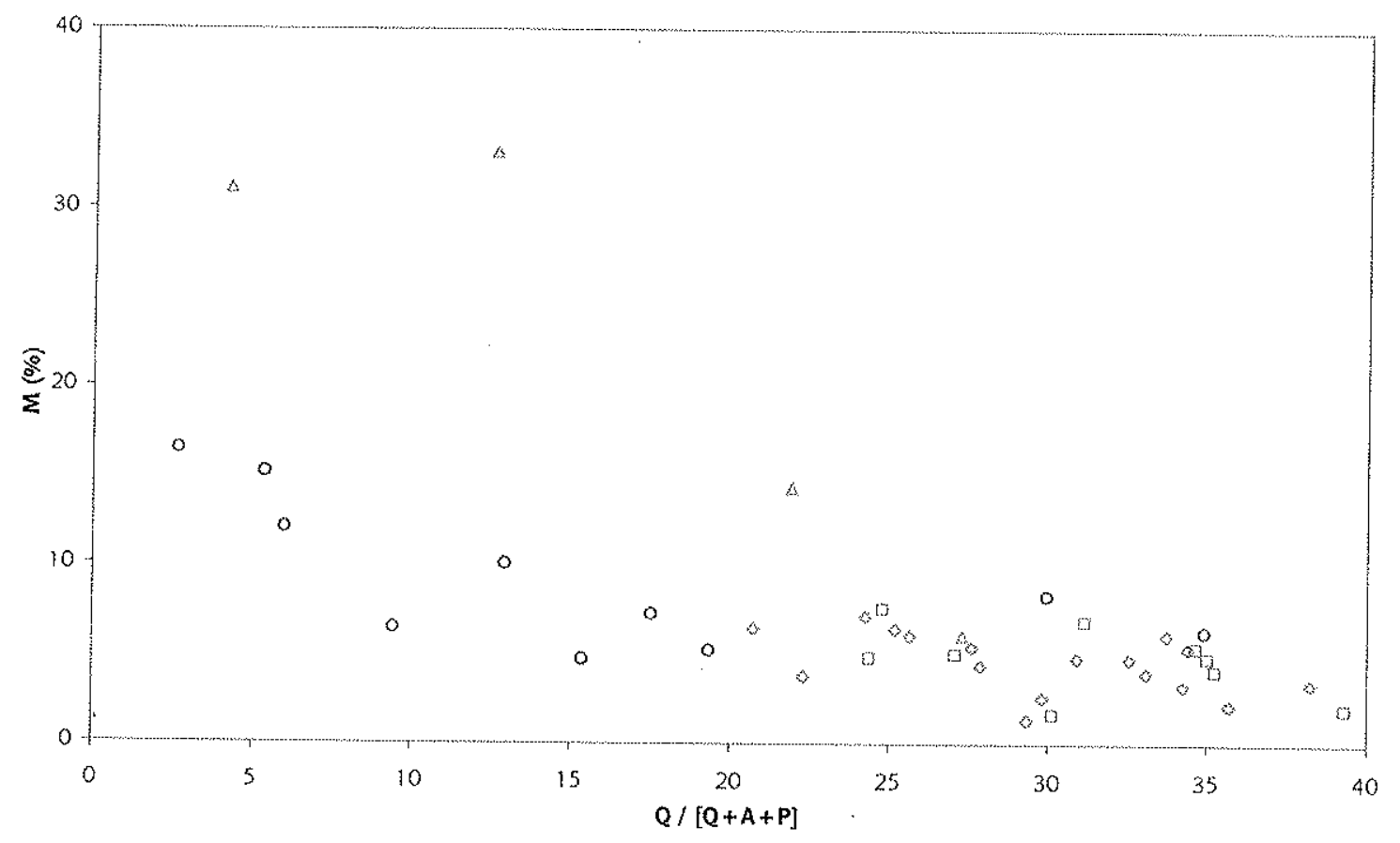

Figura IV.3: (Continua na proxima página) 

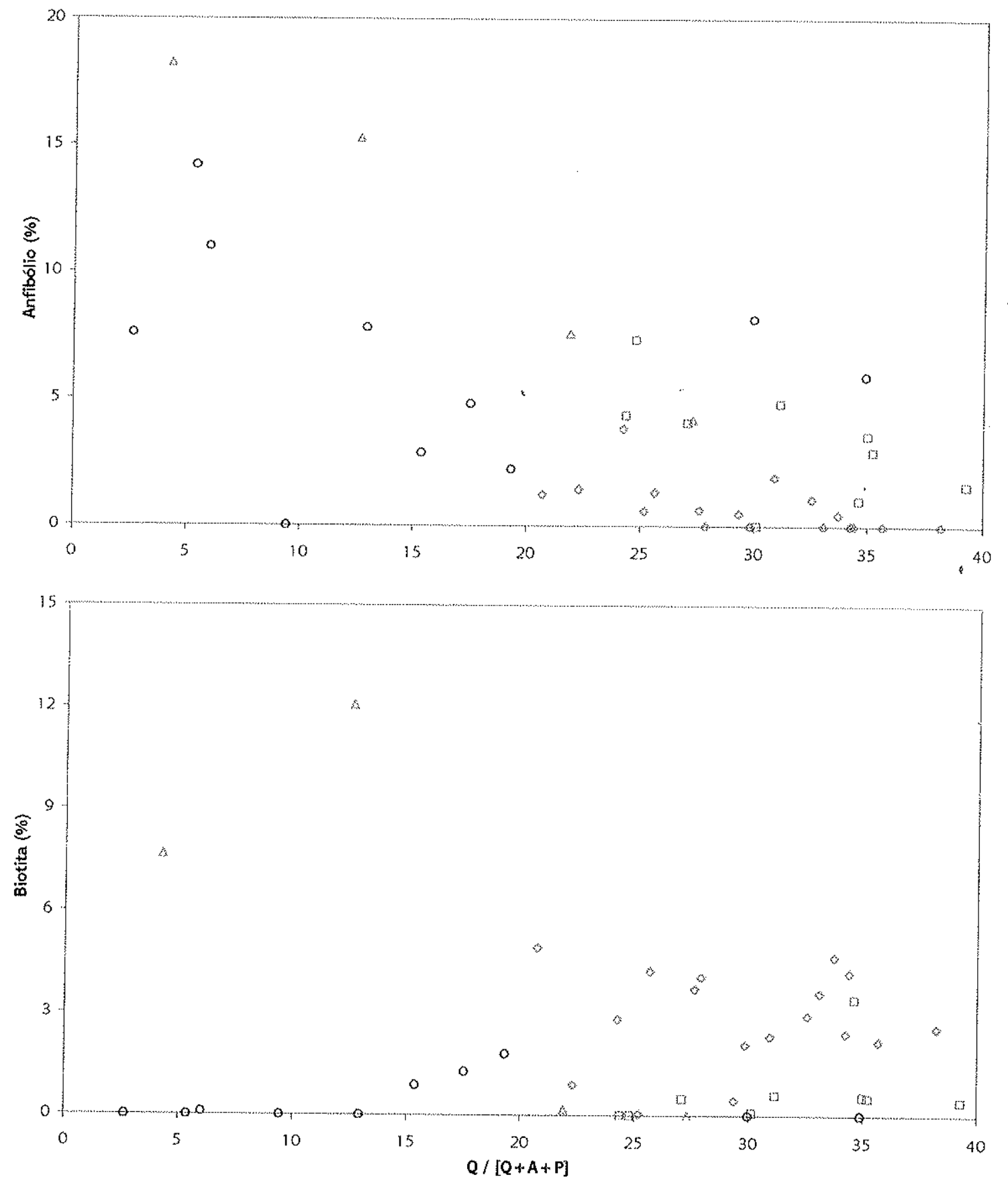

Figura IV.3: Diagramas binários mostrando a variação nos teores de minerais máficos em função do parâmetro $[Q /(Q+F A+P)]$ para as associações alcalina I, alcalina ll e aluminosa dos Granitos da Graciosa (PR). $M=$ somatória de todos os máficos.

\section{IV.1. A ASSOCIACÃO PETROGRÁFICA ALCALINA I}

As variedades que compõem esta associação alcalina aparecem em dois maciços: nos extremos $\mathrm{N}$ e $\mathrm{S}$ do Maciço Anhangava e como duas ocorrências isoladas próximo ao limite NW do Maciço Farinha Seca. 
Os tipos encontrados no Maciço Anhangava correspondem predominantemente a álcalifeidspato sienitos com proporçōes variadas de quartzo. Nas rochas mais primitivas, pobres em quartzo, clinopiroxênio é a fase máfica principal, acompanhado de olivina subordinada. Anfibólio de composição variável - cálcico ou cálcico-sódico - e clinopiroxênio subordinado são as fases máficas mais importantes na maioria das rochas da associação. As variedades mais evoluidas em termos do indice Q/QAP correspondem a álcali-feldspato granitos encontrados no Maciço Farinha Seca; estas são também as únicas em que anfibólio sódico é tipicamente primário. (cf. Figuras IV.2 e IV.3 e Tabela IV.2).

Os tipos petrográficos atribuidos a essa associação podem ser reunidos em quatro agrupamentos principais, descritos a seguir.

\section{Álcali-feldspato sienitos equigranulares com piroxênio e olivina - Maciço Anhangava}

As rochas desta fácies têm ocorrência muito restrita e aparecem em uma única localidade no extremo S do Maciço Anhangava (Afloramento 87). São rochas maciças, leucocráticas (IC: 5), de textura equigranular de granulação média e coloração verde.

A textura é dominada por cristais de feldspato alcalino euédricos com máficos em pequenos agregados homogeneamente distribuídos. Ao microscopio, a textura é equigranular, automórfica a hipidiomórfica. Feldspato alcalino é euédrico - tabular ou mais equidimensional --. enquanto máficos e quartzo - este último em quantidades muito subordinadas - aparecem como cristais intersticiais (Prancha 1a).

Feldspato alcalino, freqüentemente com contatos mútuos tríplices, é sempre pertítico, apresentando lamelas albiticas finas e pouco abundantes. Apresenta geminaçāo Carlsbad; a geminação em grade do microclínio é mais incipiente. Quartzo, anédrico, aparece sempre límpido. com extinçāo homogênea, em contatos tríplices entre cristais de feldspato alcalino.

O máfico principal é um clinopiroxênio hedenbergítico de coloração verde clara e pleocroísmo pouco acentuado. Aparece como cristais subédricos ou arredondados, também intersticiais aos agregados de feldspato alralino. Nirlens de clinopiroxênio mais incolor são sbrenados em a!guns cristais. Olivina é também um máfico importante, e aparece de modo semelhante ao clinopiroxênio. Em geral os cristais aparecem bem fraturados. 
Os minerais acessórios incluem zircāo e apatita (subordinada) evédricos, chevkinita-perrierita subédrica a arredondada, com coloraçōes castanhas variáveis a bem escuras e opacos (principalmente ilmenita).

Transformaçōes pós-magniáticas são relativamente restritas nestas rochas, o que é evidenciado pelos contatos primários bem preservados entre os cristais de feldspato alcalino, que se mostram sempre retilineos. Entre os minerais de alteração destacam-se agregados iddingsíticos substituindo parcialmente a olivina.

\section{Álcali-feldspato sienitos equigranulares com anfibólio cálcico - Maciço Anhangava}

Estas rochas aparecem associadas às rochas da fácies anterior (Afloramento 87). São rochas maciças, leucocráticas (IC: 6), de textura equigranular média e coloraçāo rosada. A textura é definida pelo feldspato alcalino. com quartzo e anfibólio homogeneamente distribuídos. Ao microscópio, a textura é equigranular alotriomórfica ou hipidiomórfica, com feldspato alcalino subédrico ou anédrico, além de quartzo e anfibólio intersticiais (Prancha 1b).

O feldspato alcalino, predominantemente geminado segundo Carlsbad, é mesoperitico: as lamelas de albita sāo em geral regulares e apresentam geminação polissintética bem desenvolvida. Zoneamento concêntrico gradual é evidenciado em alguns grãos por variações no ângulo de extinção e pela distribuição de lamelas de exsolução. O quartzo é límpido, intersticial ou sub-arredondado, e por vezes forma agregados de 3 ou 4 grãos.

O máfico predominante é um anfibólio cálcico, com pleocróismo em tonalidades de verde intenso a verde claro e castanho claro. Apresenta leve zoneamento concêntrico normal. Nos núcleos dos cristais com freqüência são encontrados restos mais ou menos corroídos de clinopiroxênio incolor.

Os principais acessórios são zircāo, apatita e opacos (principalmente ilmenita) euédricos, incluídos em cristais de anfibólio, além de allanita arredondada e fluorita intersticial rara.

As transformações pós-magmáticas mais evidentes são observadas ao longo dos contatos entre cristais de feldspato alcalino, que se apresentam serrilhados ou interpenetrados, com formação localizada de albita tardia, límpida, bem geminada, como cristais independentes ou em pequenos agregados. 


\section{Álcali-feldspato sienitos equigranulares a porfiríticos finos com anfibólio e piroxênio - Macico Anhangava}

As rochas desta fácies ocorrem na porção $N$ do Maciço Anhangava (Afloramentos 77-81). e se dividem em dois grupos: um incluindo rochas inequigranulares a porfiriticas com anfibólio cálcico e clinopiroxênio como fases máficas mais importantes (Afloramento 81); e outro incluindo rochas equigranulares com anfibólio cálcico-sódico como máfico principal. o clinopiroxênio sendo subordinado (Afloramentos 77-80).

\section{Variedades inequigranulares a porfiriticas}

Sāo rochas maciças, leucocráticas (IC: 7), de textura inequigranular de granulação fina-média ou porfiritica com matriz equigranular de granulação fina. A coloração é variável. desde cinza ou azul escuros até esverdeado.

Macroscopicamente observa-se o predominio de feldspato alcalino de dimensões variáveis, com uma matriz relativamente rica em máficos. Ao microscopio. a textura varia desde inequigranular até glomeruloporfiritica, hipidiomórficas. Feldspato alcalino subédrico (cristais menores) a euédrico (maiores) predomina amplamente. Anfibólio aparece isolado, substituindo clinopiroxênio, ou ainda variando desde intersticial até poiquilitico - com inclusões de feldspato alcalino euédrico: neste caso, associa-se a raros cristais de quarzo (Pranchas $1 c$ e 1 ).

O feldspato alcalino, com geminação de Carlsbad predominante, é sempre mesopertitico; em alguns cortes aparece antipertítico, as lamelas potássicas e albíticas raramente apresentando geminaçoes em grade e polissintética, respectivamente. Nas variedades porfiríticas, cristais relativamente precoces de feldspato alcalino formam glomérulos que, por vezes, são manteados por feldspato alcalino posteriọ; este manteamento é geralmente evidenciado pelo alinhamento de inclusões diminutas de anfibólio que marcam contornos euédricos. Alguns dos megacristais aparecem deformados, com extinção ondulante, mais evidenciada nas lamelas de albita.

O máfico principal é um anfibólio cálcico, pleocróico desde castanho claro, a escuro e verde grama. cujas variaçōes revelam freqüente zoneamento concêntrico. Clinopiroxênio aparece como cristais 'isolados em quantidades variáveis, com zoneamento concêntrico bem marcado pela mudança do padrão pleocróico, de incolor a levemente rosado nas zonas centrais, a levemente esverdeado a incolor nas bordas. 
Dentre os acessórios destaca-se o zircão euédrico e apatita diminuta. Olivina, sempre muito fraturada, está presente em algumas amostras. Biotita castanha aparece em alguns agregados com ilmenita. Finalmente, allanita completa a mineralogia acessória.

As transformaçōes pós-magmáticas são evidenciadas pelo desenvolvimento de albita em swapped rims nos contatos entre os cristais de feldspato alcalino. Em alguns cristais de feldspato alcalino observam-se núcleos contendo apenas albita límpida em continuidade ótica com as lamelas de exsolução. o que leva à suspeita de que parte do componente albítico no feld́spato possa ter sido adicionado nestes estágios.

\section{Variedades equigranulares}

São rochas predominantemente maciças, ocorrendo localmente variedades bandadas (Afloramento 79). Sāo leucocráticas (IC: 3-6). de textura equigranular de granulação fina-média e coloração cinzenta, esverdeada, ou ainda esbranquiçada.

Macroscopicamente observa-se a predominância de feldspato alcalino, com quartzo e máficos normalmente como fases intersticiais. Apenas em algumas amostras (Afloramentos 77-78) quantidades significativas de quartzo arredondado sāo observados. Ao microscópio, observa-se textura automórfica a hipidiomórfica dominada por feldspato akcalino tabular euédrico, com quartzo, anfibólio e biotita intersticiais (Prancha 1e).

Os padrões de exsolução do feldspato alcalino são semelhantes aos observados na variedade anterior. Quartzo aparece como cristais intersticiais pouco abundantes, que raramente apresentam inclusōes de feldspato alcalino. Em algumas amostras (77-78), quartzo é mais abundante e pode aparecer como cristais subédricos ou arredondados. Extinção ondulante é rara ou ausente.

O máfico principal é um anfibólio cálcico-sódico com pleocroísmo em tons desde castanho claro até verde e verde azulado. Nas amostras mais ricas em quartzo (77-78), o anfibólio aparece mais tipicamente com tons azulados, além de também formar cristais subédricos isolados. Biotita pleocróica em tons de castanho claro, castanho escuro e vermelho intenso (biotita vermelha) aparece como cristais isolados intersticiais de até $1 \mathrm{~mm}$. Clinopiroxênio, como o das variedades anteriores, é

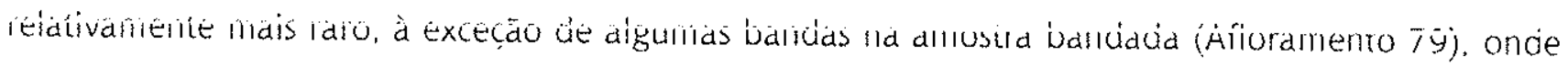
pode ser fase máfica importante. 
Fluorita pode ser abundante, principalmente nas amostras mais ricas em quartzo, formando cristais isolados intersticiais relativamente grandes (i.é. $1 \mathrm{~mm}$ ). Zircão euédrico aparece isolado e também como inclusōes em anfibólio, neste caso acompanhado também de chevkinita-perrierita.

Além de transformaçōes pós-magmáticas associadas ao feldspato alcalino. semelhantes às descritas para a variedade anterior, destaca-se nesta amostra a substituição do anfibolio primário por biotita vermelha e anfibólio sódico. tipicamente com pleocroismo em tons de azul escuro e indigo (cr. abaixo).

\section{Álcali-feldspato granitos equigranulares finos com anfibólio sódico - Maciço Farinha Seca}

As rochas desta fácies estão restritas a uma ocorrência isolada, próxima ao limite NW do Maciço Farinha Seca (Afloramento 14), em uma frente de lavra, e ainda uma segında variedade na forma de blocos junto ao limite SE deste mesmo macico (Afloramento 18).

\section{Variedade equigranular}

A primeira variedade é composta por rochas hololeucocráticas (IC: 4), maciças, de textura equigranular de granulação fina-média e coloração cinza claro.

Macroscopicamente, predominam os cristais de feldspato, com quartzo aparecendo como cristais isolados; anfibólio aparece tipicamente intersticial. Ao microscópio, a textura se revela hipidiomórfica seriada; aparecem cristais relativamente grandes de feldspato alcalino subédrico a euédrico e, em menor proporção, de quartzo, rodeados por uma matriz quartzo-feldspática com cristais subédricos a anédricos, contendo anfibólio intersticial a poiquilitico. (Prancha 1f)

Feldspato alcalino é normalmente intersticial em relação ao quartzo, contendo freqüentemente inclusōes goticulares de quartzo, mais abundantes junto às bordas, sendo que o conjunto lembra intercrescimentos granofíricos. É sempre mesopertítico, com lamelas albíticas bem desenvolvidas. Quartzo, quando em agregados, apresenta contatos tríplices comuns.

Anfibólio, pleocróico em tons de castanho claro a verde azulado e azul intenso muito escuro ou indigo. é o máfico essencial nestas rochas. Grada de anfibólio cálcico-sódico nos núclens a anfitúlin tipicamente sódico nas bordas. Em alguns núcleos cristalinos podem ser observados ainda restos corroídos de anfibólio com pleocroísmo em tons verde-acastanhados, mais característico de variedades mais cálcicas. 
Os acessórios presentes são essencialmente zircão, apatita e chevkinita. Fluorita, diminuta, intersticial, é relativamente rara. Ilmenita é o. único opaco presente.

Dentre as alteraçoes pós-magmáticas destaca-se o desenvolvimento de albita em "swapped rims", como mantos em torno de feldspato alcalino e. mais raramente, como cristais limpidos mais idiomórficos, intersticiais. Anfibólio tipicamente sódico (com coloração indigo), forma-se junto a fraturas nos cristais de anfibólio primário, ou como diminutos cristais aciculares.

\section{Variedade microgranítica porfiritica}

A segunda variedade (Afloramento 18) corresponde a um microgranito porfirítico. É maciço, hololeucocrático. de textura porfiritica, com matriz alotriomórfica equigranular de granulaçāo muito fina.

É muito semelhante, do ponto de vista mineralógico, à variedade anterior. Os megacristais de feldspato alcalino são semelhantes aos maiores cristais presentes da variedade anterior; já os de quartzo são um pouco menores; formas bipiramidais em alguns cristais são muito típicas. $O$ anfibólio é caracteristicamente sódico e aparece como pequenos prismas euédricos disseminados pela rocha e também formando agregados, que por vezes são radiados. Fluorita é relativamente mais abundante, enquanto chevkinita é escassa. Cassiterita, idiomórfica, zonada, com tonalidade castanha a incolor aparece raramente.

\section{IV.2. A ASSOCIACÃO PETROGRÁFICA ALCALINA II}

Esta segunda associação a/calina predomina amplamente no Maciço Farinha Seca, além de ocorrer no extremo NW do Maciço Órgãos. Observa-se ainda uma ocorrência isolada no extremo do Maciço Órgāos.

Em comparaçāo com a associação a/calina /, as rochas desta associação são tipicamente mais ricas em quartzo. classificadas como álcali-feldspato granitos (Figura IV.2 e Tabela IV.2). As texturas são também diferenciadas, caracteristicamente equigranulares e pouco mais grossas em comparação com as variedades sieníticas da associação anterior.

Anríbúlio é u máfico primcipal, estancio ausentes ciinopiroxênio e oiivina (Figura iv.z e Tabela IV.2). Como nāo há variação importante na composição modal máfica ou félsica, a variação composicional mais importante é dada pelo anfibólio, que grada desde tipicamente cálcico até 
sódico. A caracterição desta associação como alcalina é feita com base na presença de rochas com anfibólio sódico e chevkinita-perrierita.

Todos os tipos pertencentes a essa associação podem ser descritos como um único agrupamento.

\section{Álcali-feldspato granitos equigranulares com anfibólio - Macicos Farinha seca e órgãos}

As rochas desta fácies são predominantes no Maciço Farinha Seca (Afloramentos 15, 25, 42-44, 46. 49, 51 e 56) e tem ocorrência localizada no Maciço Órgãos (Afloramentos 3, 58, 70, 73 e 74). São rochas maciças, hololeuco-a leucocráticas (IC: 4-6). de textura equigranular de granulação média e coloração variável, desde cinza escuro ou esverdeado, até vermelho ou ainda esbranquiçado. No Maciço Órgāos observa-se uma variedade hololeucocrática com $I C \approx 1$ (Afloramento 58).

A textura da rocha é dada por uma trama de feldspato alcalino, com quartzo aparecendo em agregados, freqüentemente com máficos associados. Ao microscópio. a textura hipidiomórfica é dominada pelos cristais de feldspato alcalino subédrico, sendo que quartzo normalmente aparece formando agregados de 3-5 grãos arredondados; anfibólio intersticial aparece heterogeneamente distribuido (Prancha 1g).

Feldspato alcalino normalmente forma cristais com contornos externos intersticiais em relação ao quartzo: pequenas inclusões de quartzo são raramente observadas junto à borda. É mesopertítico e. em algumas amostras mais deformadas, as lamelas albíticas e potássicas apresentam geminaçōes polissintética e em grade, respectivamente.

O máfico principal é sempre um anfibólio. Ocorre concentrado nos interstícios entre os cristais de feldspato alcalino - juntamente com os de quartzo - ou ainda isolado, subédrico, em contato direto com feldspato alcalino. Há uma variação gradual desde termos mais primitivos contendo anfibólio cálcico - com pleocroísmo desde verde amarelado pálido até verde grama e verde azulado (Afloramentos 15, 42-44; 70,74). passando por termos cálcico-sódicos - com tons azulados mais importantes - (Afloramentos 25 e 51:59), e chegando a variedades sódicas - com padrāo pleocróico

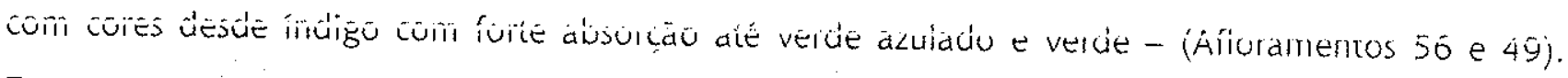
Zoneamento concêntrico, com bordas menos pleocróicas, assim como núcleos incolores são comuns. Geminação simples é freqüente. Biotita, pleocróica desde amarelo ouro até castanho acinzentado. 
raramente aparece isolada: mais freqüentemente aparece substituindo o anfibólio, em associação com fluorita (Afioramentos $15,42-44 ; 3,59,70,74$ ).

Chevkinita anédrica, zircão euédrico, fluorita intersticial e opacos (predominantemente ilmenita: magnetita subordinada nos termos com anfibólio cálcico) são acessórios comuns e aparecem normalmente associados ao anfibólio. Apatita aparece principalmente como inclusões euédricas no zircão: cassiterita é rara e aparece somente na variedade com anfibólio sódico primário (Amostra 49).

Transformaçōes pós-magmáticas estão sempre presentes e envolvem ambas as fases félsicas e máficas. Feldspato alcalino sempre apresenta "swapped rims"; nas amostras com sinais de em deformação mais marcados, cristais isolados de albita límpida sāo comuns. Nas amostras em que o anfibólio tende a variedades cálcico-sódicas ou sódicas (Afloramentos 25, 49, 51, 56), como ocorre em algumas variedades da associação anterior, biotita vermelha e anfibólio sódico substituem o anfibólio primário.

\section{IV.3. A ASSOCIACÃO PETROGRÁFICA ALUMINOSA}

As rochas da associação aluminosa aparecem em quatro dos cinco maciços estudados: compreendem a totalidade dos maciços Capivari e Marumbi, além da maior parte dos maciços Órgāos (porçōes central e leste) e Anhangava (porçāo central).

As fácies petrográficas observadas nos maciços Capivari e Órgãos são muito semelhantes entre si. correspondendo a sienogranitos e monzogranitos (subordinados) com biotita e anfibólio como máficos típicos. No Maciço Anhangava ocorrem, adicionalmente, álcali-feldspato granitos com biotita; já no Maciço Marumbi, apenas álcali-feldspato granitos com biotita estão presentes.

As variedades petrográficas podem ser reunidas em cinco grupos principais, descritos a seguir.

\section{Sieno/monzogranitos porfiríticos com biotita e anfibólio cálcico - Maciços Capivari e Órgãos}

As rochas desta fácies são dominantes no Maciço Capivari, sendo encontradas nas suas porcões centro-oeste e iv (Afioramentos 7-9, 34-36, 40-41: 11), em frentes de lavra e em blocos isolados. No Maciço Órgãos, foram observadas apenas como blocos isolados nas porções central e E (Afloramentos 2 e 63). São biotita sienogranitos maciços, hololeucocráticos (IC: 2-3), de coloração desde cinza ou esbranquiçada até rosada. 
A textura é variável, desde tipicamente porfiritica com matriz fina até mais inequigranular de granulação média; raramente, aparecem tipos equigranulares de granulação fina. Em alguns casos, as variaçōes texturais são observadas em um mesmo matacão, formando rochas híbridas, com relações estruturais de corte indicativas de coexistência de magmas. Ao microscópio apresentam textura caracterizada pela presenca de uma proporção variável de megacristais, em alguns casos de dimensões variadas, em uma matriz equigranular alotriomórfica de granulação fina ou muito fina. (Pranchas 2a e 2b).

Os megacristais de feldspato alcalino, plagioclásio e ocasionalmente quartzo são tipicamente subédricos. Feldspato alcalino é sempre pertítico. com lamelas em cordão: nos hospedeiros observase a formação de geminação em grade típica do microclínio. Os megacristais de placioclásio aparecem com alguma freqüencia em agregados de 2 ou 3 grãos que mostram contornos internos euédricos marcados por zonas mais "sujas" devido à alteraçāo. Zoneamento concêntrico gradual $\left(A n_{25} \rightarrow A n_{12}\right)$ é comum em algumas amostras: padrōes oscilatórios sāo mais raros. Muitas vezes aparecem manteados por feldspato alcalino. Assim como nos megacristais de feldspato alcalino, inclusões de quartzo são freqüentes junto à borda, mas ausentes nas zonas centrais; o contato com os grāos da matriz é irregular. Os megacristais de quartzo compõem agregados de 2-3 grāos. Também apresentam contatos irregulares com os grãos da matriz. A extinção é normalmente ondulante.

A matriz é composta por quartzo, feldspato alcalino e plagioclásio, nesta ordem de abundância. Quartzo e feldspato alcalino são anédricos enquanto plagioclásio varia desde subédrico até anédrico.

Os minerais máficos estão restritos à matriz, aparecendo homogeneamente distribuídos. Predomina a biotita pleocróica, desde amarelo a castanho escuro, que aparece na forma de cristais ou agregados de cristais subédricos a anédricos intersticiais. Anfibólio cálcico, pleocróico em tons de verde aparece em quantidades reduzidas. Com alguma freqüência, aparece com aspecto corroido bem marcado, sendo substituido principalmente por quartzo e biotita, por vezes associados a minerais opacos e titanita.

Os acessórios incluem titanita subédrica com tonalidades caramelo pálidas a incolores, allanita, aiaranjada a castanha avermeihada, evedrica, zonada, zircão incolor e apatita euédricos diminutos. além de fluorita intersticial, magnetita e ilmenita. 
As transformaçōes pós-magmáticas são freqüentes e incluem a formaçāo de albita junto às inclusōes e aos contatos entre cristais de feldspato alcalino em continuidade ótica com as lamelas internas e bordas albiticas desenvolvidas sobre cristais de plagioclásio quando em contato com feldspato alcalino. Mirmequitas de morfologias variadas também são comuns nos contatos entre plagioclásio e feldspato alcalino. Plagioclásio apresenta-se com alteraçāo saussurítica constituída por sericita, carbonato, epídoto e raramente fluorita. Clorita com tons de verde até amarelado substitue parcial ou totalmente a biotita primária.

\section{Sienogranitos inequigranulares com biotita e anfibólio cálcico - Maciço Capivari}

Ocorrem nos extremos N (Afloramentos 28, 29, 33) e 5 (Afloramento 38) do Maciço Capivari, principalmente como grandes blocos. São rochas maciças, hololeucocráticas (IC: 3-5), de coloração cinzenta ou esbranquiçada e textura inequigranular seriada de granulação média.

Dominam grandes cristais de feldspato alcalino de dimensōes variadas, muitas vezes manteados por material branco de aspecto leitoso, entre os quais se formam agregados de quartzo e máficos. com feldspatos mais raros. Ao microscópio, a textura se revela hipidiomórfica. Feldspato alcalino forma megacristais euédricos isolados ou agregados de 3.5 cristais subédricos, envoltos por uma matriz rica em quartzo. Comparativamente à fácies anterior, os megacristais são menores e a matriz mais grossa, o que confere à rocha uma textura tipicamente inequigranular. (Prancha 2c)

As características dos minerais presentes sāo semelhantes às observadas nas variedades da fácies de sienogranitos porfiríticos; destacam-se o caráter mais tipicamente euédrico do feldspato alcalino e maior abundância de quartzo na matriz.

\section{Sienogranitos equigranulares com biotita e anfibólio cálcico - Maciços Capivari, Orgãos e Anhangava}

São as rochas dominantes no extremo $N$ do Maciço Capivari (Afloramentos 13, 26, 27, 29, 32). Blocos métricos isolados são observados à $E$ da área de ocorrência do Maciço Órgãos (Afloramento 2) e na sua porção central (Afloramento 60). Domina também na porção central do Maciço Anhangava (Afloramentos 82, 83, 85, 86). São rochas maciças, hololeucocráticas (IC: 2-3), de coloração rosada. Comumente, as variedades observadas nos Macicos Órgãos e Anhangava mostram granulação pouco mais grossa que no Maciço Capivari. 
Texturalmente são bastante distintas das anteriores, com textura tipicamente equigranular de granulaçāo média, caracterizada pela presença de quartzo e feldspatos como pequenos agregados. Ao microscópio, observa-se textura hipidiomófica, formada por agregados de $3-5$ cristais de feldspato subédricos a anédricos justapostos a agregados semelhantes de quartzo. Biotita intersticial, - máfico principal, aparece tipicamente nos agregados de quartzo, mas também como cristais intersticiais isolados (Prancha 2d).

O feldspato aicalino tende a se amoldar às formas dos gräos de quartzo. É sempre mesopertítico. com lamelas em cordão. O plagioclásio tem composiçāo de oligoclásio ( $-A n_{30}$ ). pouco mais cálcico que nas fácies anteriores; zoneamento concêntrico gradual é ocasionalmente obsenado. Normalmente aparece nos agregados de feldspato alcalino. Ao contrário das outras fácies, as inclusões são muito raras ou ausentes nos cristais de feldspato alcalino e plagioclásio.

Biotita é o máfico principal. Como nas fácies anteriores, a biotita é pleocróica em tons de amarelo e castanho. Anfibólio aparece como cristais euédricos, em contraste com as fácies anteriores. Seus cristais têm dimensões reduzidas $(<1 \mathrm{~mm})$ e pleocroísmo desde amarelo a verde intenso. com leve zoneamento concêntrico. Nas variedades do Maciço Órgãos, anfibólio é mais abundante e aparece também como cristais intersticiais.

Allanita, zircão, apatita, titanita, magnetita, ilmenita e fluorita aparecem com características semelhantes às descritas para as outras fácies.

Transformaçōes pós-magmáticas são mais restritas. Incluem a formação de borda albítica ao redor de alguns cristais de feldspato alcalino, geralmente em continuidade ótica com as lamelas de albita, e o desenvolvimento de "swapped rims". Além disso, observam-se inclusōes euédricas de carbonato em biotita e anfibólio.

Uma segunda variedade, bastante semelhante, porém mais rica em máficos (IC: 5 ) foi coletada no Macico Capivari (Afloramento 26). Destacam-se os teores significativamente maiores de anfibólio. que aparece como cristais euédricos ou subédricos associados a titanita e opacos. Ocasionalmente aparecem corroídos e substituídos por biotita e quartzo. Os teores de biotita são também relativamente mais altos. Quanto aos acessórios, diferenciam-se pelos cristais maiores e mais abundantes de titanita e fluorita.

No Maciço Órgãos foi observada uma variedade adicional (Afloramentos 3 e 71). As rochas têm granulação mais fina e o teor de máficos é pouco maior (IC: 5). Ao microscópio, a maior 
diferenca está na presença de agregados de quartzo. opacos, titanita e allanita, com contatos tríplices freqüentes, que ocupam os intersticios entre os agregados de quartzo e feldspato alcalino. O maior teor em máficos é dado pela maior abundância de titanita e opacos (principalmente magnetita).

\section{Sienogranitos equigranulares finos com biotita e anfibólio cálcico - Maciço
Orgãos}

Amostras desta fácies são observadas no extremo $E$ do maciço (Afloramentos 1, 3 e 4). Hololeucocráticas (IC: 2-4), apresentam estrutura levemente orientada, coloração branca a rosada e textura equigranular de granulação fina-média.

Ao microscópio. a textura se revela equigranular alotriomórfica: feldspato alcalino forma cristais subédricos a anédricos isolados relativamente grandes, enquanto quartzo e plagioclásio formam agregados, todos com contornos irregulares (Prancha 2e).

Pequenas inclusões de plagioclásio e quartzo são comuns no feldspato alcalino, que é sempre pertítico. com lamelas em cordāo muito finas e geminaçāo em grade nos hospedeiros. Plagioclásio e quartzo aparecem com as mesmas caracteristicas observadas na fácies anterior.

Biotita é o máfico dominante nas amostras dos Afloramentos 1 e 4, mas está ausente nas amostras do Afloramento 3, em que anfibólio intersticial, pleocróico em tons de verde grama, é o máfico dominante.

\section{Álcali-feldspato granitos equigranulares com biotita - Maciços Marumbi e Anhangava}

As rochas destas fácies dominam todo o Maciço Marumbi (Afloramentos 88-96) e aparecem como ocorrências mais ou menos restritas na porção central do Maciço Anhangava (Afloramentos 76. 84). São rochas maciças, hololeucocráticas (IC: $1-2)$, com textura equigranular de granulação média e coloração cinza; pontuações rosadas são típicas destas rochas. Uma das variedades do Maciço Anhangava (Afloramento 84) apresenta coloração verde típica e não mostra as pontuações rosadas características das demais amostras; venulações de espessura centimétrica, bastante ricas em anfibólio cálcico são observadas nesta variedade.

A textura é dominada por uma trama de feldspato alcalino com quartzo e máficos intersticiais. Ao microscópio. a textura se mostra equigranular hipidiomórfica, marcada pela presença de agregados de grãos de quartzo arredondados, intersticiais aos cristais euédricos de feldspato alcalino 
(Prancha 2f). O feldspato alcalino é pertítico nas amostras do Maciço Marumbi e mesopertítico nas amostras do Maciço Anhangava.

Biotita pleocróica em tons de amarelo pálido e verde é o máfico mais importante, formando cristais intersticiais que ocasionalmente incluem cristais de quartzo. Zircão e opacos (ilmenita e magnetita) são as fases acessórias mais comuns.

As transformaçoes pós-magmáticas são similares àquelas observadas nas variedades anteriures.

\section{Enclaves micrograníticos- Maciços Capivari, Órgãos e Anhangava}

Enclaves deci- a centimétricos foram observados em todas as fácies de sienogranitos estudadas. sobretudo nas variedades equigranulares. Por vezes, rochas semelhantes sāo observadas como blocos isolados. Todos os enclaves estudados correspondem a microgranitos macicos, hololeucocráticos (IC: 3-5), de coloração cinza escuro. com textura equigranular fina a muito fina.

Ao microscópio. cristais anédricos de quartzo, feldspato alcalino, plagioclásio, biotita e anfibólio. sempre com dimensões inferiores a $0,25 \mathrm{~mm}$, formam uma matriz tipicamente alotriomórfica.

Cristais de biotita, pleocróica desde amarelo até castanho, de plagioclásio, feldspato alcalino e ocasionalmente quartzo e anfibólio se destacam da matriz. Muitos cristais aparecem corroídos, sugerindo serem xenocristais capturados da rocha hospedeira que reagiram com o magma formador dos enclaves.

O máfico principal é um anfibólio, ora diminuto, ora maior, apresentando núcleos incolores. Raros cristais de piroxênio, de coloração variável desde incolor até bege, estão presentes, muitas vezes corroídos e substituídos por anfibólio. Biotita está presente em teores variados e é raramente substituída por clorita.

Entre os acessórios, destaca-se a titanita, enquanto zircão, apatita e opacos são relativamente raros.

\section{IV.4. ROCHAS MONZODIORITICAS E ASSOCIADAS}

Apenas em dois locais foram observadas rochas dioriticas. No extremo NW do Maciço Órgãos observam-se as únicas ocorrências de rochas básico-intermediárias como blocos independentes da região, na mesma área de ocorrência dos álcali-feldspato granitos da associação alcalina //. 
No extremo NE do Maciço Farinha Seca, aparecem quartzo sienitos texturalmente semelhantes às rochas da associação acalina //. A presença de plagioclásio distingue claramente estas rochas daquelas das associaçoes a/calina / e a/calina //. Um aspecto típico, somente observado nestas rochas. é a presença de enclaves monzodioríticos e estruturas sugestivas de hibridismo em escala de afloramento.

\section{Rochas e enclaves monzodioriticos}

Os monzodioritos são rochas maciças leuco- a mesocráticas (IC: 30-35). de textura equigranular de granulação fina a média, nas quais se destacam quantidades importantes de biotita, mais facilmente observadas nas amostras mais intemperizadas. (Prancha li)

Ao microscópio, a textura se mostra equigranular hipidiomórfica, caracterizada por uma trama principal composta por plagioclásio, anfibólio cálcico e biotita subédricos. com quartzo e feldspato alcalino intersticiais, anédricos.

O plagioclásio aparece como cristais tabulares maiores. isolados, ou formando agregados de grāos menores. Sāo geminados segundo as Leis de Albita e Carlsbad (raramente Periclínio). Mostram zoneamento concêntrico gradual ou oscilatório no intervalo entre andesina e oligoclásio $\left(\mathrm{An}_{40} \rightarrow\right.$ $\left.A n_{25}\right)$. O feldspato alcalino é levemente pertítico e o quartzo é limpido. por vezes com extinção ondulante.

Anfibólio cálcico subédrico, levemente pleocróico em tons de verde grama é o máfico principal; núcleos incolores são relativamente comuns. Em geral, apresentam geminação simples. Encontra-se heterogeneamente distribuído, por vezes em agregados formados por vários cristais. Biotita, com hábito relativamente alongado e dimensões em média superiores às do anfibólio, apresenta pleocroísmo em tons de amarelo e castanho.

Apatita é o principal acessório, aparecendo como prismas euédricos muito alongados (e.g. 1 $\mathrm{mm}$ ). Titanita subédrica, zircão e allanita euédricos, além de opacos (magnetita e ilmenita). completam a mineralogia destas rochas.

As venulacōes e bolsōes de coloração branca que contam estas rochas são macicos hololeucocráticos, com textura equigranular de granulação média. Ao microscópio, a textura se mostra equigranular automórfica. Plagioclásio e feldspato alcalino formam cristais idiomórficos intercrescidos com quartzo intersticial. As demais características mineralógicas são semelhantes. 
Enclaves monzodioriticos foram observados apenas nos quartzo sienitos com anfibólio do Maciço Farinha Seca (Afloramento 16. ver a seguit). Têm composiçāo monzodioritica e são bastante semelhantes a rochas encontradas na mesma área de ocorrência dos álcali-feldspato granitos de granulação média do Maciço Órgãos (Afloramento 59).

\section{Quartzo sienitos equigranulares com anfibólio cálcico- Maciço Farinha Seca}

As rochas desta fácies ocorrem somente no extremo NE do Macico Farinha Seca (Afloramento 16). São rochas maciças, leucocráticas (IC: 10), de coloração cinza escuro e textura equigranular de granulação média-fina.

Predominam os cristais de feldspato alcalino, rodeados por agregados de quartzo e máficos. Ao microscópio. a rocha mostra textura equigranular alotriomórfica. composta por uma trama de feldspato alcalino com quarzzo subordinado, ambos anédricos, além de anfibólio e plagioclásio intersticiais (Prancha $1 \mathrm{~g}$ ).

Feldspato alcalino tabular. geminado segundo Carlsbad, é sempre pertítico. Intercrescimentos gráficos com quartzo são ocasionalmente observados nas zonas marginais dos cristais. Plagioclásio $\left(A n_{30}\right)$ apresenta leve zoneamento concêntrico normal ou oscilatório. Intercrescimentos gráficos com quartzo também sào observados. Quartzo aparece principalmente nos intercrescimentos gráficos, mas também subordinadamente como cristais arredondados associados ao anfibólio.

Anfibólio cálicico pleocróico em tons de verde grama é o máfico típico destas rochas. Cristais euédricos de magnetita e ilmenita são relativamente abundantes: biotita intersticial - pleocróica em tons de amarelo e castanho - é rara.

Como acessórios, aparecem zircão euédrico, allanita euédrica zonada e clinopiroxênio cálcico pleocróico em tons de verde pálido, além de apatita. Em algumas amostras, aparece chevkinita parcialmente substituida por allanita, sugerindo processos de mistura de magma. 


\section{IV.5. SEQÜÊNCIAS DE CRISTALIZACÃO, PARAGÊNESES MINERAIS E EVOLUCÃO MODAL}

\section{Associação alcalina !}

De maneira geral, a seqüencia de cristalizaçāo inferida para as rochas desta associação pode ser resumida como na Figura IV.4. Quando presentes, olivina e clinopiroxênio sāo provavelmente as fases máficas mais precoces (fato adicionalmente apoiado pela ocorrência de melassienitos com olivina. clinopiroxênio e opacos, com feldspato alcalino intersticial no Niaciço Corupá - Garin. dissertação em preparação). Seguem ilmenita, feldspato alcalino, anfibólio cálcico - que em parte substitui olivina e clinopiroxênio - e. posteriormente, quartzo. Apatita e zircão são também relativamente precoces. Chevkinita-perrierita acompanta de perto o anfibólio cálcico. No estágio magmático tardio aparecem fluorita e. em raras amostras, allanita e titanita. No decorrer da cristalizaçāo magmática, os anfibólios evoluem em direção a termos mais sódicos. Nos estágios pósmagmáticos, os anfibólios cálcico-sódicos se desestabilizam e são substituidos por anfibólio sódico e biotita vermelha.

As rochas desta associação são caracterizadas pela presença de feldspato alcalino como única fase feldspática primária e mostram um aumento contínuo dos teores de quartzo com a evolução (Figura IV.2). Essa evolução é acompanhada por uma diminuição na quantidade de minerais máficos (Figura IV.3), e também por uma mudança nas paragêneses máficas presentes. Neste sentido, as variedades relativamente mais máficas são marcadas pela presença de anfibólio cálcico + clinopiroxênio \pm olivina, enquanto nas variedades intermediárias o anfibólio é cálcico-sódico, clinopiroxênio é raro e olivina está ausente: nas variedades mais félsicas, anfibólio sódico é a única fase máfica importante. Allanita e titanita aparecem apenas nas variedades mais máficas, e são sempre bem tardias, enquanto chevkinita-perrierita é típica dos termos intermediários. Biotita composicionalmente muito peculiar (cf. abaixo) -, quando presente, está claramente associada às transformaçōes pós-magmáticas, juntamente com anfibólio sódico tardio.

A evolução modal das rochas desta associação em parte repete as tendencias das séries alcalinas de Lameyre e Bowden (1982). Entretanto. faltam completamente os termos portadores de plagioclásio (sienitos, monzonitos, monzodioritos), e chama a atenção a presença de paragêneses máficas relativamente primitivas, contendo apenas olvina e clinopirovênio. Acrim näo pareco tũo claro na região que a origem dos magmas desta associação esteja vinculada a priori a magmas parentais basálticos, como admitido por aqueles autores. A evolução das paragêneses máficas, por 
sua vez, evidencia a passsagem, aparentemente progressiva, de características metaluminosas para peralcalinas (ou mesmo "agpaíticas") em direçāo aos termos mais félsicos.

Nas variedades mais máficas, a presenca de olivina e quartzo, combinada com a ausência de magnetita, indica condições relativamente redutoras, inferiores ao tampāo QFM (quarzto-faialitamagnetita). A cristalizaçāo de allanita e titanita nos estágios magmáticos tardios sugere uma tendéncia de aumento do grau de oxidação dos magmas com a cristalização.

\section{Associação alcalina $\|$}

As rochas desta associação mostram seqüências de cristalização semelhantes às observadas na associação alcalina / (Figura IV.4).

Por outro lado, em contraste com aquela associação. as composiçoes modais sāo pouco variáveis. Os teores de quartzo sāo muito semehantes entre si em todas as variedades - sobretudo comparando.se as ocorrências dos Maciços Farinha Seca e Órgãos independentemente (Figura IV.2; Tabela IV.2) - - e semelhantes àqueles observados nos termos mais diferenciados da associação alcalina 1. As paragêneses máficas são igualmente menos variáveis; anfibólio é o máfico principal em todas as rochas, sendo que clinopiroxênio aparece como restos corroídos em anfibólio cálcico em apenas uma amostra e olivina não foi observada. O aspecto de variação dos anfibólios, entretanto, é semelhante ao observado na associação alcalina /, e revela uma trajetória desde termos contendo anfibólio cálcico até variedades mais evoluidas com anfibólio sódico. Também similar é a presença de allanita e titanita nas variedades menos evoluidas e de chevkinita-perrierita nos termos intermediários.

Se por um lado a semelhança nos anfibólios revela a afinidade alcalina desta associaçāo, a ausência de variação modal contrasta com a evidente evolução da associaçāo alcalina // e sugere uma evolução segundo trajetórias significativamente distintas.

A presença de magnetita, titanita e allanita primária em algumas das variedades com anfibólio cálcico parece indicar condiçōes relativamente mais oxidantes de cristalização, próximas do tampão TMQAl (titanita magnetita-quartzo-anfibólio-ilmenita; Wones, 1989). pelo menos nos estágios mais tardios. 


\section{Associação aluminosa}

No caso da associação aluminosa, a primeira fase féisica a cristalizar deve ter sido o feldspato alcalino, seguido por plagiclásio e quartzo. Entre os acessórios, apatita, seguida por zircão são as primeiras fases a aparecer. Anfibólio e ilmenita, provavelmente acompanhados por allanita, seguidos por biotita, magnetita e titanita completariam o quadro no estágio magmático principal. Fluorita aparece apenas nos estágios magmáticos mais tardios. (Figura IV.5)

As paragêneses minerais da associação aluminosa mostram tipicamente plagioclásio como fase mineral primária ao lado do feldspato alcalino e são marcadas pela presença de biotita. isolada ou associada a anfibólio cálcico, como máfico mais importante. A ocorrência de biotita \pm anfibólio cálcico \pm titanita \pm allanita \pm magnetita \pm ilmenita $(+$ zircāo, + apatita) é característica desta associação. indicando por um lado quimismo moderadamente peraluminoso dos magmas formadores e. por outro. cristalização em ambientes relativamente oxidantes - semelhantes aos da associação alcalina //-, próximos ao tampão TMQAl (Wones, 1989).

As tendências modais das variedades da associação aluminosa mostram variações restritas nos teores de quartzo e máficos. De forma geral as variedades mais ricas em feldspato alcalino (e pobres em plagiodásio). também sāo as mais pobres em quartzo. Novamente, uma vinculação com termos mais máficos, de uma série cálcio-alcalina potássica, como pretendido por Lameyre e Bowden (1982) não é clara.

\section{Rochas monzodioriticas e associadas}

As paragêneses máficas das rochas monzodioríticas, com biotita +anfibólio cálcico + clinopiroxênio augítico + magnetita + ilmenita (+apatita, allanita, zircão) evidenciam seu caráter potássico. em concordância com os dados químicos de Maack (1961). Tais rochas guardam similaridades com os dioritos da Província Itu. que contém apenas granitos de Tipo-A da associação aluminosa (Vlach et al., 1996) e também refletem condições relativamente oxidantes de cristalização.

As modas destas rochas se afastam das trajetórias das demais associaçoes. Observa-se nos diagramas um alinhamento entre os dados modais dos álcali-feldspato granitos da associação a/calina

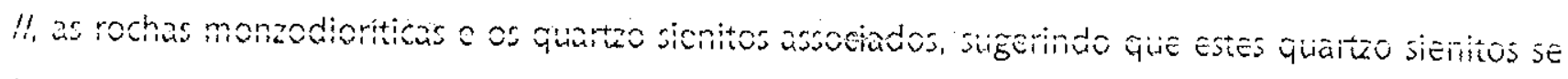
formaram por mistura local entre magmas monzodioríticos e graníticos. A ocorrencia conjunta destas rochas e a presença comum de enclaves monzodioríticos nos primeiros dão apoio a esta interpretação. As relaçōes de substituição de chevkinita por allanita reforçam essa idéia. 


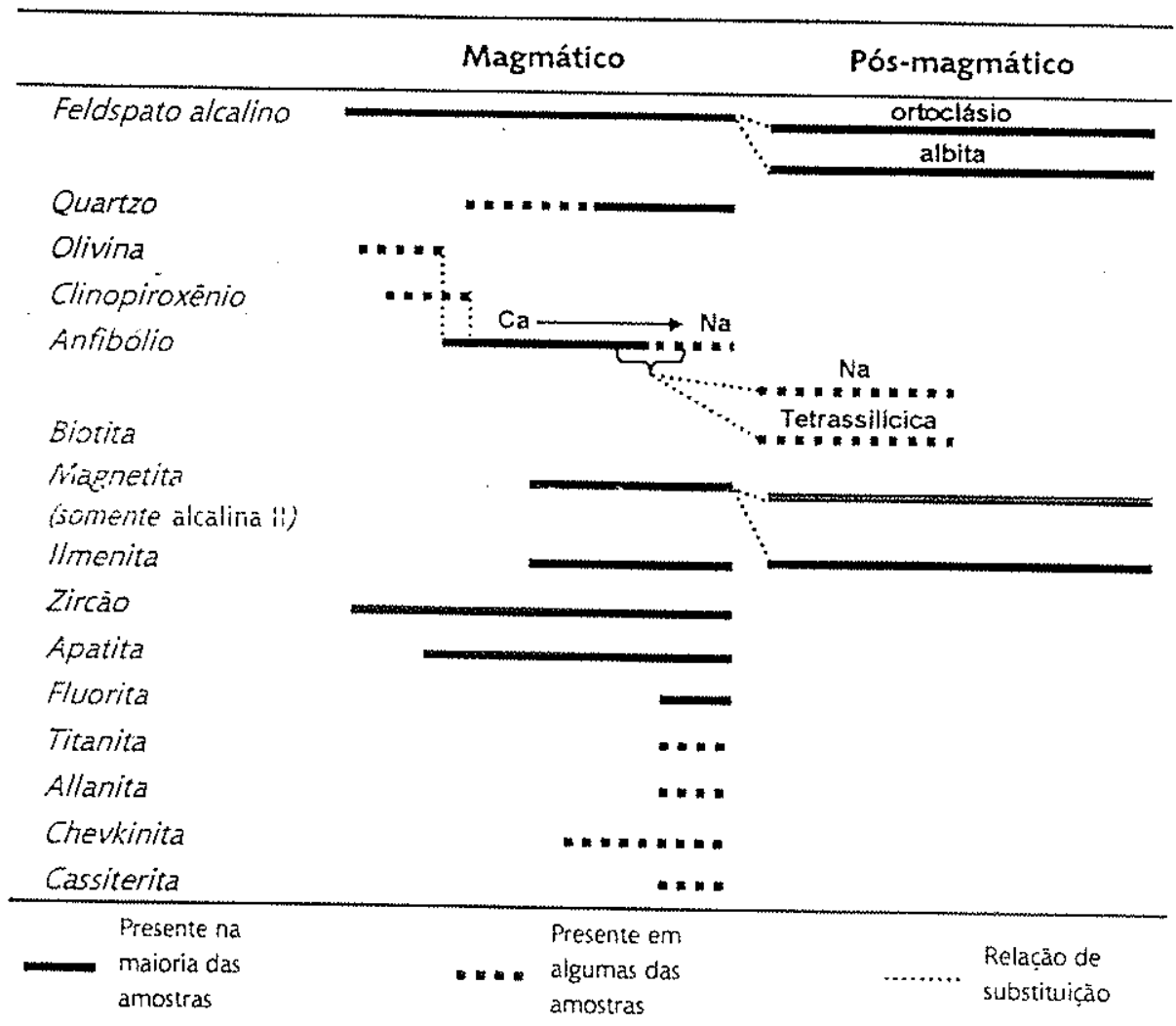

Figura IV.4: Quadro interpretativo da sëqüência de cristalização das rochas das associaçoes alcalinas dos Granitos da Graciosa (PR).

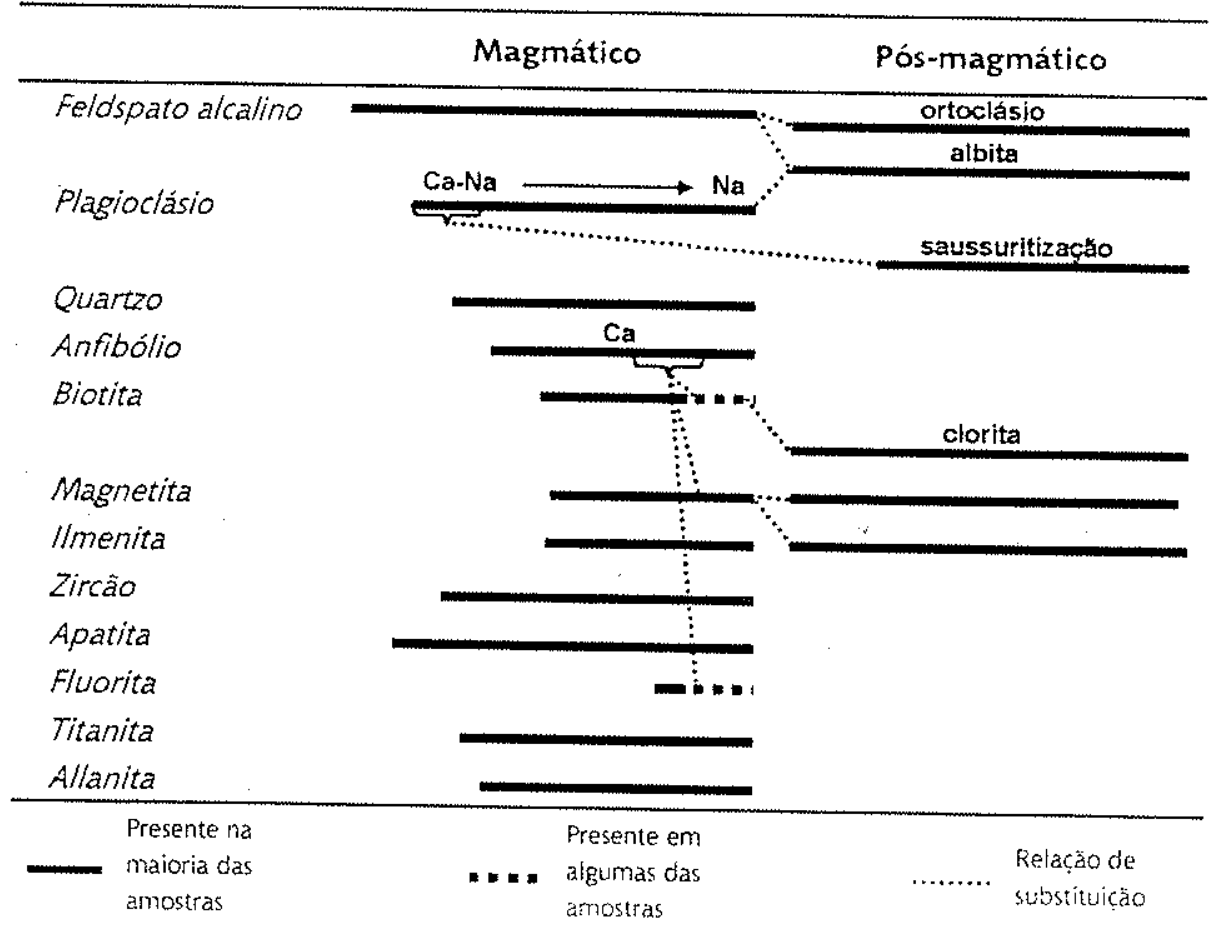

Figura IV.5: Quadro interpretativo da seqüência de cristalização das rochas da associação aluminosa dos Granitos da Graciosa (PR). 
A mineralogia das rochas das três associaçōes foi estudada em detalhe, tendo sido caracterizadas textural- e quimicamente as fases félsicas e máficas. A simbologia utilizada em todos os diagramas deste item é apresentada na Tabela IV.3.

\section{Tabela IV.3:}

Legenda para as Figuras

\begin{tabular}{|c|c|c|c|}
\hline \multicolumn{4}{|c|}{ Associacõos } \\
\hline Alcalina / & Alcalina /I & Aluminosa & $\begin{array}{c}\text { Rochas } \\
\text { monzodioriticas } \\
\text { e associadas }\end{array}$ \\
\hline$\Delta$ Gra-14B & Gra-15 & Gra-2A & - Gra-16B3 \\
\hline$\Delta G r a-18 A$ & $\diamond$ Gra-25B & - Gra-2B & $\Delta$ Gra-16B4 \\
\hline Gra-77 & $\Delta$ Gra-49 & $\Delta G r a-2 E$ & - Gra-59E \\
\hline D Gra 78A & - Gra-51 & Gra-3B & \\
\hline - Gra-79 & Gramb & Gra-7A & \\
\hline$\Delta \mathrm{Gra}-80$ & - Gra-3D & - Gra-7B & \\
\hline - Gra-81A & Gra-59A & $\Delta \mathrm{Gra}-11 \mathrm{~A}$ & \\
\hline Gra-81B & Gra-70 & Gra-13 & \\
\hline - Gra-81D & $\Delta$ Gra- 74 & Gra-28B. & \\
\hline$\triangle G r a-87 A$ & & - Gra-32 & \\
\hline \multirow[t]{9}{*}{ Gra-87B } & & $\triangle G r a-36 B$ & \\
\hline & & - Gra-40 & \\
\hline & & Gra-76 & \\
\hline & & Gra-83 & \\
\hline & & $\Delta G r a-84 A$ & \\
\hline & & o Gra-84B & \\
\hline & & Gra-85B & \\
\hline & & - Gra-88A & \\
\hline & & $\Delta$ Gra-95 & \\
\hline
\end{tabular}




\section{V.1. MINERAIS MÁFICOS}

\section{Olivina}

Olivina tem ocorrência bastante restrita, aparecendo apenas nas rochas mais máficas da associação alcalina /(Amostras 81D e 87-A), em quantidades subordinadas ( $\sim 1 \%$ modal).

\section{Texturas}

Nos álcali-feldspato sienitos equigranulares a porfiriticos finos com anfibólio e piroxênio (Amostra 81D), a olivina aparece corroída e invariavelmente incluída em anfibólio cálcico; em diversos casos, o contato entre os dois minerais é marcado pela presença de anfibólio incolor a amarelado (Prancha 3b), de composiçăo antofilitica (cf. abaixo). Esta mesma variedade de anfibólio é por vezes observada em núcleos de anfibólio cálcico dos quartzo sienitos equigranulares com anfibólio cálcico do Maciço Farinha Seca, sugerindo que olivina pode ter sido uma fase magmática precoce também nestas rochas.

Já nos álcali-feldspato sienitos equigranulares com piroxênio e olivina (Amostra 87A), em que anfibólio inexiste, olivina ora aparece constituindo agregados máficos com clinopiroxênio, ora como cristais isolados euédricos ou subédricos (Prancha 3a). Não sāo observadas relaçōes de reaçāo entre olivina e clinopiroxênio.

As olivinas encontram-se, em geral. parcialmente alteradas junto a fraturas e bordas para agregados id́dingsiticos.

\section{Quimismo}

As composiçōes das olivinas são pouco variáveis, com teores da molécula faialita acima de $92 \%$ $\left(\mathrm{Fa}_{92-96}\right)$; os teores de $\mathrm{Mg}$ sāo muito baixos $\left(\mathrm{FO}_{0-1}\right)$ e a maior variabilidade observada está associada à entrada de $\mathrm{Mn}\left(\mathrm{Te}_{8 \cdot 4}\right.$ ) no lugar do Fe, sobretudo nos sienitos finos (Amostra 81D), que apresentam um enriquecimento em Mn em direção à borda. (Figura IV.6; Tabela IV.4. em anexo). Um mecanismo simples de substituição:

$$
\mathrm{Fe} \Leftrightarrow[\mathrm{Mn}, \mathrm{Mg}]
$$

Eq. IV.1.

responde pela variação observada (Figura IV.7). Na Amostra 87A, a olivina é mais pobre em Mn e $\mathrm{Mg}$, e suas composições não se dispõem segundo a trajetória de variação composicional caracteristica dos sienitos finos. 


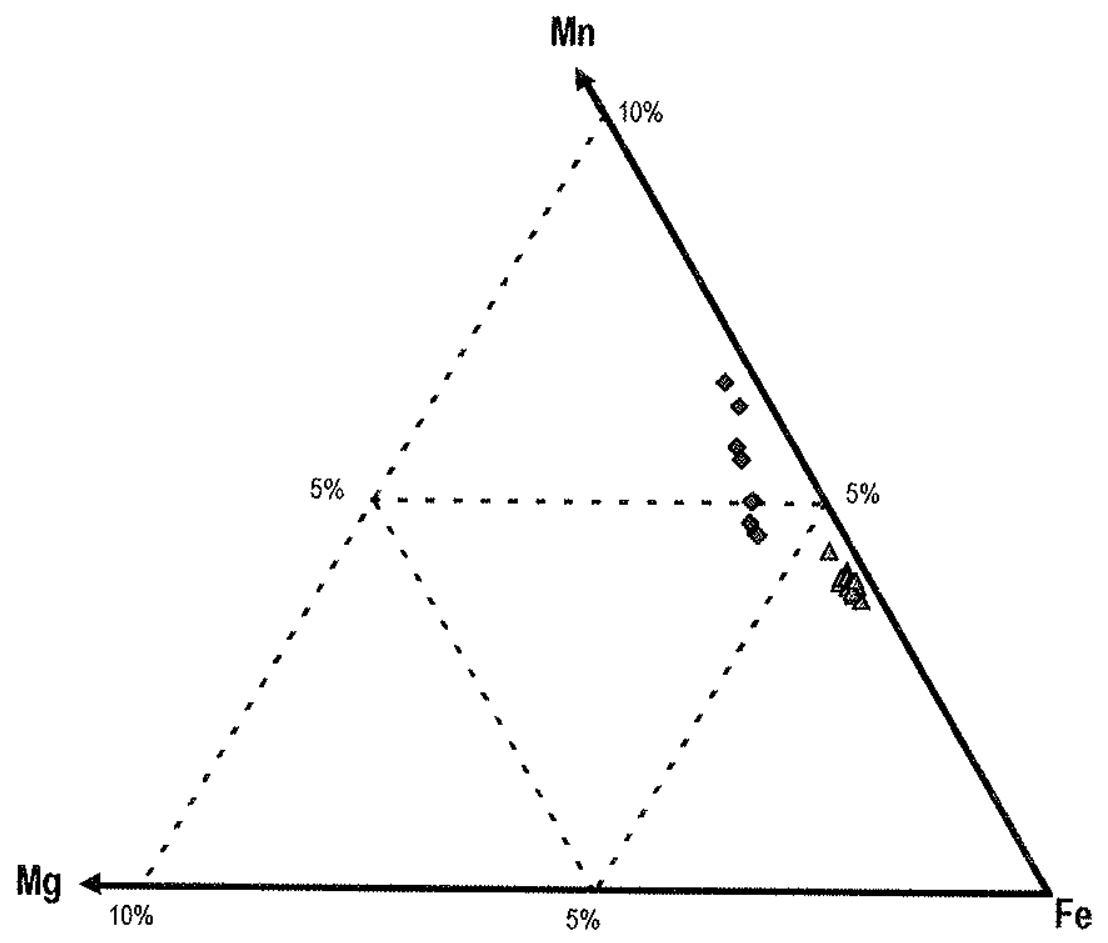

Figura IV.6: Composições das olivinas da associação alcalina / dos Granitos da Graciosa no diagrama catiônico $\mathrm{Mn} \times \mathrm{Fe} \times \mathrm{Mg}$.

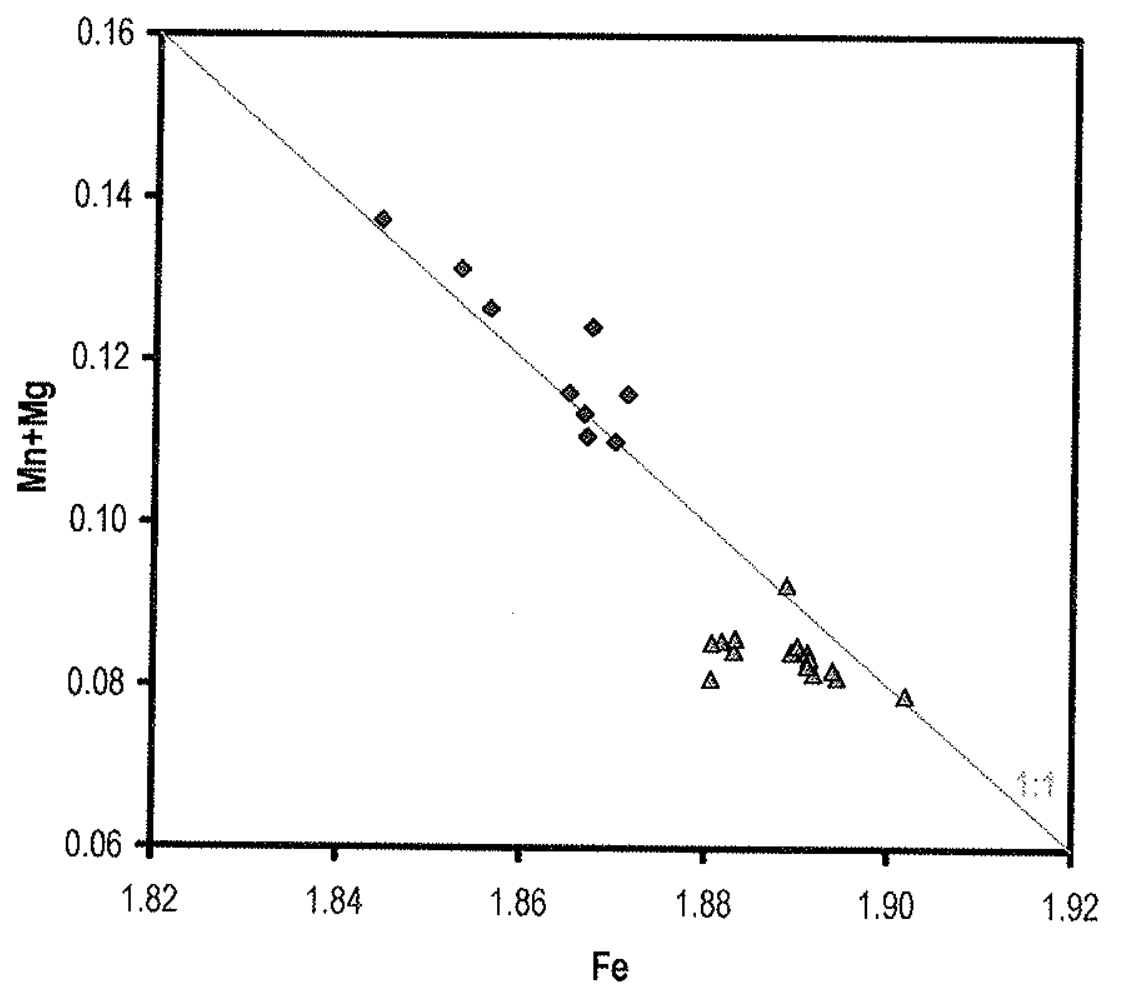

Figura IV.7: Correlação entre as proporçōes catiônicas de $\mathrm{Fe} \times[\mathrm{Mn}+\mathrm{Mg}]$ em olivinas da associação alcalina I dos Granitos da Graciosa. 


\section{Clinopiroxênio}

Clinopiroxênio está presente nas duas associaçōes alcalinas, porém é fase comum apenas na associação alcalina l. Aparece ainda nas rochas monzoioriticas e associadas.

\section{Texturas}

Na maioria das amostras da associação a/calina /, particularmente nas amostras mais máficas (Amostras 79-81 - Maciço Anhangava). clinopiroxênio aparece ora como cristais parcialmente corroídos inclusos em anfibólio (Prancha 3c), ora como cristais euédricos isolados ou manteados por anfibólio; estes são zonados, com centro pleocróico desde rosa pálido a incolor e borda pleocróica desde verde pálido a incolor (Prancha 3d).

Nos álcali-feldspato sienitos equigranulares do Maciço Anhangava (Amostra 87 A), isentos de anfibólio, os cristais de clinopiroxênio têm coloraçāo verde homogênea e nāo são visíveis zoneamentos óticos (Prancha 3a).

Já nos álcali-feldspato granitos da associação alcalina /l, clinopiroxênio é observado apenas em uma das amostras com anfibólio mais cálcico do Macico Farinha Seca (Amostra 25B), como restos corroídos inclusos em anfibólio.

Clinopiroxênio está presenta ainda, em pequenas proporções $(<3 \%)$, nas rochas monzodioríticas (Amostras 59E e 16B4) e nos quartzo sienitos associados (Amostra 16B3). Apresentam coloração bege claro, sendo homogéneos oticamente. Nos quartzo sienitos, estāo parcialmente corroídos por anfibólio cálcico.

\section{Quimismo}

Quimicamente, "os cristais da associação alcalina / se distribuem ao longo do eixo Di-Hd (Figura IV.8: Tabela IV.5, em anexo), mas correspondem sempre a hedenbergitas $\left(\mathrm{Di}_{20.1}\right)$. A variação composicional mais evidente é dada pela substituição simples:

$$
\left[\mathrm{Fe}^{2+}\right]^{M 1 . M 2} \Leftrightarrow[\mathrm{Mg}]^{M 1, M 2}
$$

sendo que Mn permanece constante. Nos cristais zonados, os núcleos rosados são mais magnesianos que as bordas esverdeadas; o zoneamento e marcadamente brusco. com uma lacuna composicional no intervalo $\mathrm{Di}_{20 \cdot 10}$ (Figura IV.9; cf. Prancha 3d).

Os cristais da Amostra 87A se mostram bastante homogêneos - como já sugerido pelas características óticas - com composição muito próxima de Ho pura. Em contraste, nos álcali-feldspato 
sienitos com anfibólio associados (Amostra 87B), o clinopiroxênio é também homogêneo, porém. comparativamente mais magnesiano que os anteriores, sendo o mais rico na molécula En de todo o conjunto (Figuras IV.8 e IV.9).

Uma variação de maior interesse, entretanto, é dada por uma substituiçāo acoplada envolvendo o eixo Di.Hd e a molécula Ac (Figura IV.10):

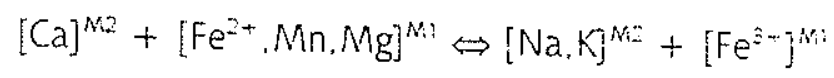

Os maiores teores de Ac são observados nas variedades mais ricas em Hd (Figuras IV.11), sugerindo uma trajetória, apesar de pouco pronunciada, semelhante às de clinopiroxênios de rochas graníticas de tendência alcalina de outras localidades (cf. Deer et al., 1978).

Dados os baixos teores de Al, diagramas envolvendo "Al e ${ }^{\mathrm{V}} \mathrm{Al}$ não produzem bons resultados. Ainda assim. o fato da correlação obtida na Figura IV.10 ser significativamente melhor com a inclusão de Al sugere que o Al é incorporado na estrutura dos piroxênios substituindo as moléculas Di e Hd e nāo associado ao Na na forma da molécula Ja. O mecanismo de substituição envolvendo o Al mais provável é, portanto:

$$
[\mathrm{Al}]^{\mathrm{Ml}}+[\mathrm{Al}]^{\top} \Leftrightarrow\left[\mathrm{Fe}^{2+} \cdot \mathrm{Mn}, \mathrm{Mg}\right]^{\mathrm{Ml}}+[\mathrm{Si}]^{\top}
$$

Eq. IV.4

Os clinopiroxênios da associaçāo alcalina // mostram quimismo contrastado em relação aos da associação alcalina /. correspondendo a clinopiroxênios subcálcicos, ricos em Al. São em parte semelhantes às pigeonitas invertidas descritas por Turner et al. (1992), que aparecem com padrões complexos de exsolução, como restos em hedenbergitas. Texturas como estas não foram por nós observadas, possivelmente devido ao alto grau de transformaçāo dos cristais.

Os cristais de clinopiroxênio analisados nas rochas monzodioriticas e associadas correspondem a augitas mais magnesianas que os demais clinopiroxênios estudados (Figura.IV.8). Para cada uma das amostras, os teores de $\mathrm{Mg}$ sāo relativamente constantes (59E: $\mathrm{Di}_{34-38} ; 16 \mathrm{B4}: \mathrm{Di}_{23-26} ; 16 \mathrm{B3}: \mathrm{Di}_{18-20}$ ), e as variaçōes mais importantes estão nos teores de Al, que diminuem do núcleo em direção à borda. São, neste sentido, claramente diferenciadas em relação às hedenbergitas típicas da associaçāo alcalina /. o que corrobora a idéia de que essa associação e os monzodioritos não fazem parte de uma mesma série comagmática (ct. acima). 


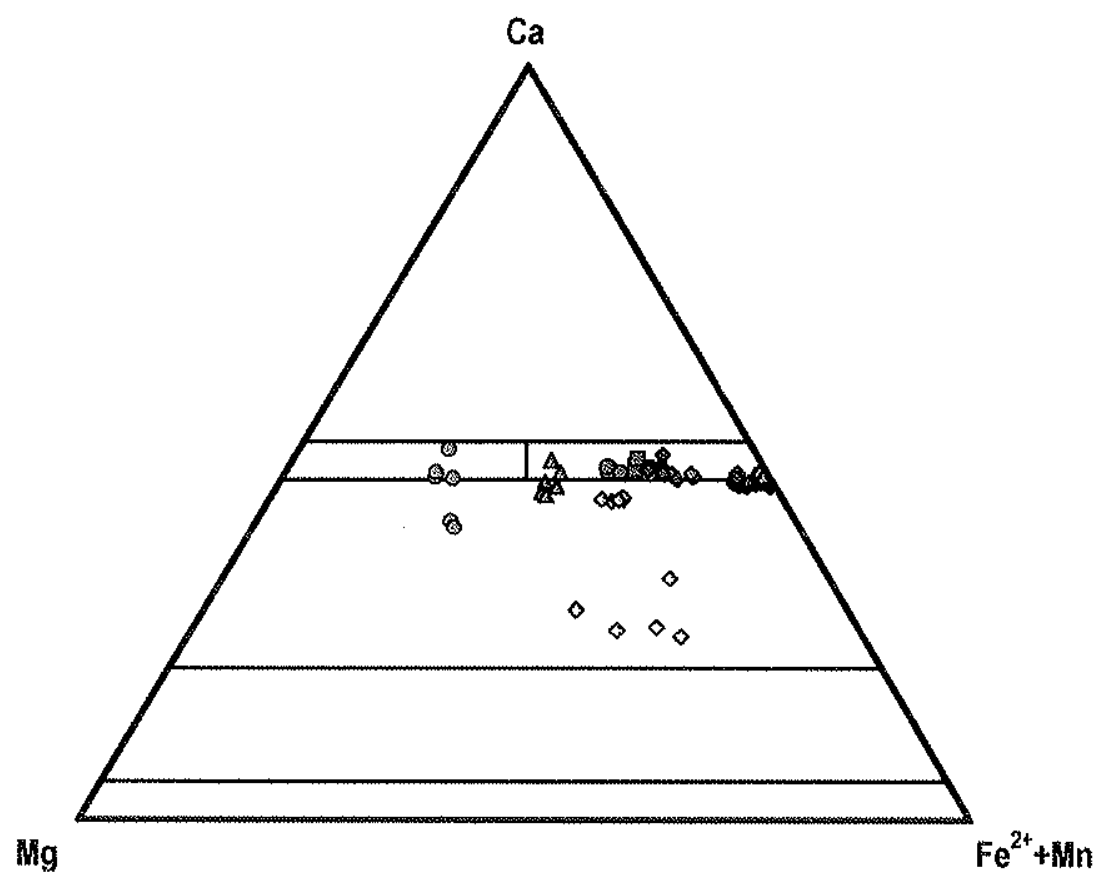

Figura IV.8: Composições dos clinopiroxênios das associações alcalinas e dos quartzo sienitos dos Granitos da Graciosa no diagrama cationnico Ca $\times \mathrm{Mg} \times\left[\mathrm{Fe}^{2+}+\mathrm{Mn}\right]$.

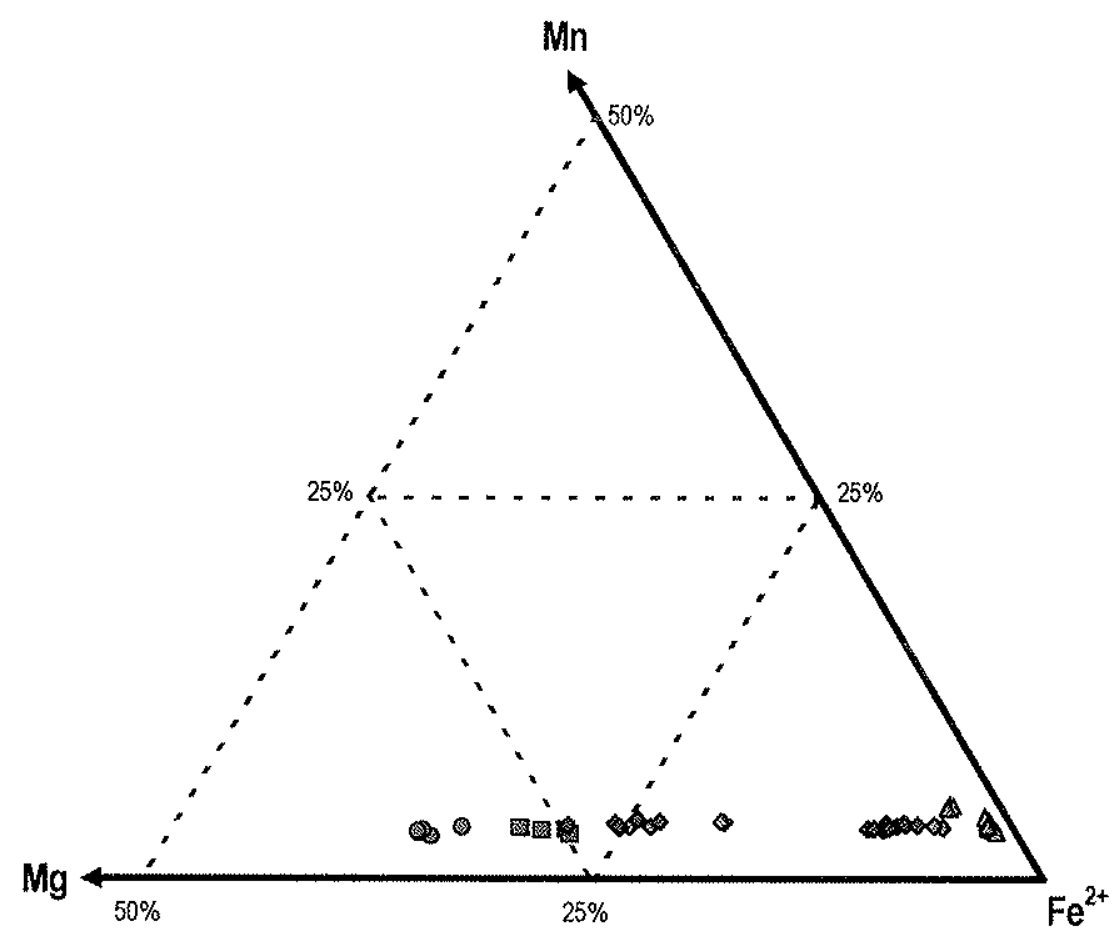

Figura IV.9: Composições dos clinopiroxênios da associação alcalina I e dos quartzo sienitos dos Granitos da Graciosa no diagrama cationnico $\mathrm{Mn} \times \mathrm{Fe}^{2+} \times \mathrm{Mg}$. 


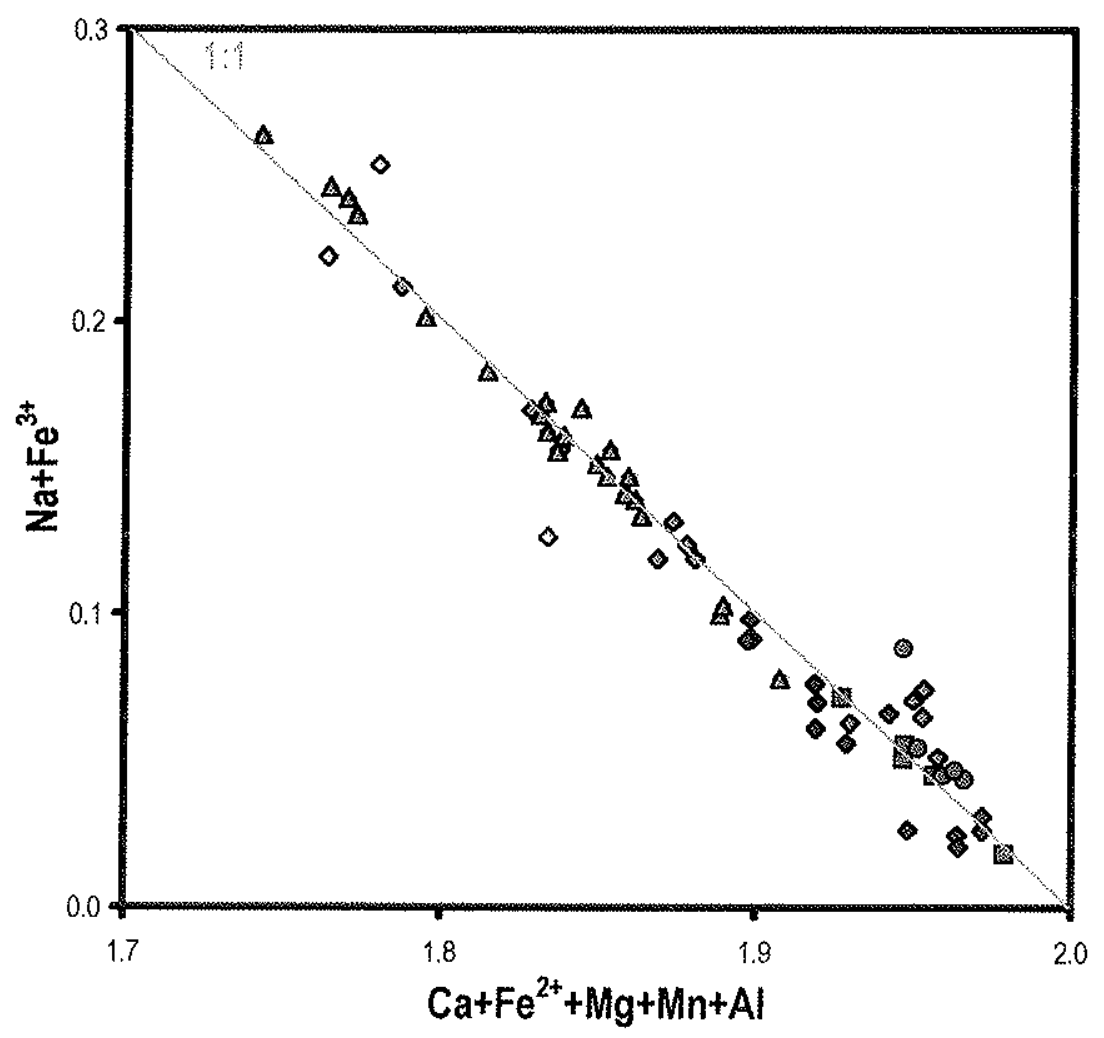

Figura IV.10: Correlação entre as proporções cationnicas de $\left[\mathrm{Na}^{2} \mathrm{Fe}^{3+}\right] x$ $\left[\mathrm{Ca}+\mathrm{Fe}^{2+}+\mathrm{Mg}+\mathrm{Mn}+\mathrm{Al}\right]$ em clinopiroxênios da associação alcalina I e dos quartzo sienitos dos Granitos da Graciosa em diagrama.

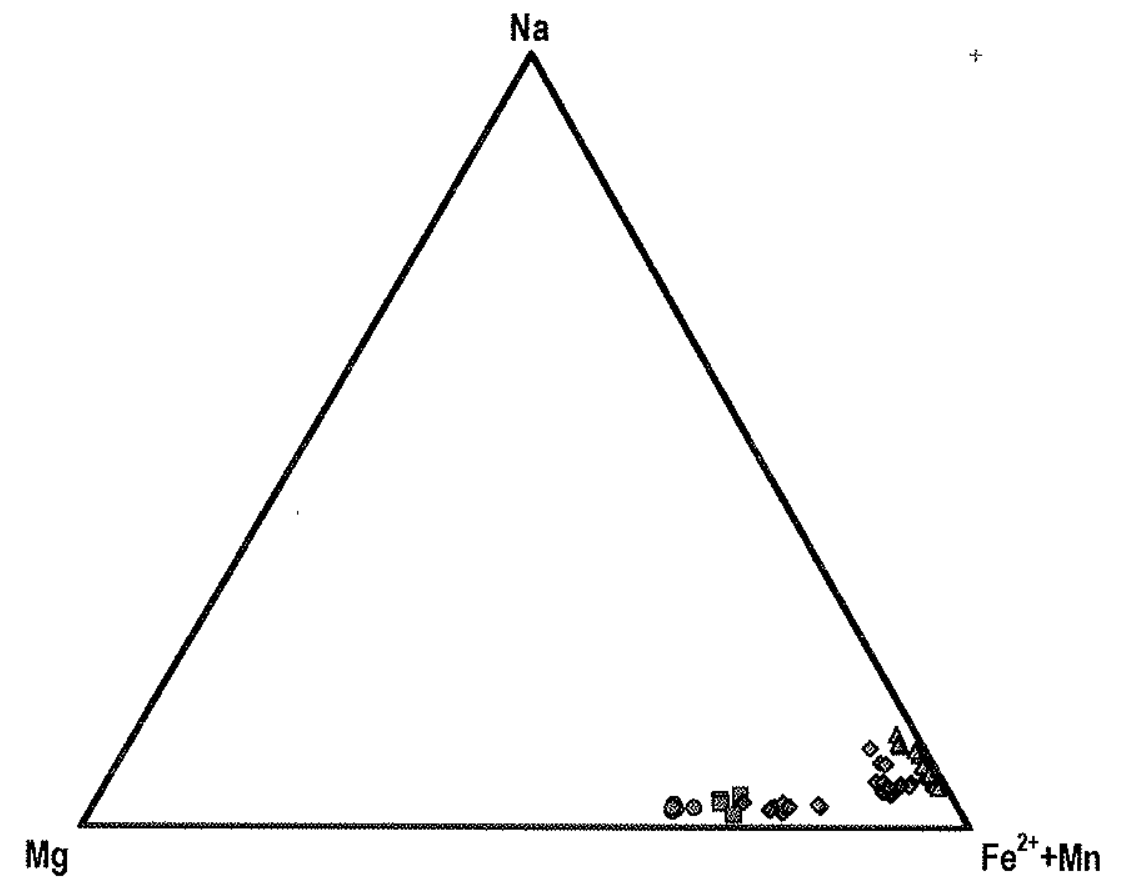

Figura IV.11: Composiçóes dos climopiroxênios da associação alcalina l e dos quartzo sienitos dos Granitos da Graciosa no diagrama catiônico $\mathrm{Na} \times \mathrm{Mg} \times\left[\mathrm{Fe}^{2+}+\mathrm{Mn}\right]$. 


\section{Anfibólio}

Anfibólios são os principais máficos na grande maioria das rochas das associaçôes a/calinas, sendo fases comuns também na associação aluminosa. Estão ausentes apenas nos álcali-feldspato granitos com biotita e em alguns sienogranitos desta associaçāo.

\section{Texturas}

Nas associaçōes a/calinas, formam criștais intersticiais, subédricos a anédricos, que aparecem isolados ou em agregados de 3-5 grãos (Prancha 3e). Em algumas amostras da associação alcalina // (e.g. Amostras 15 e 258 - Prancha 3f), em meio a esses agregados aparecem cristais euédricos. (Prancha 3f). O padrão pleocróico é bastante variável; as variedades mais cálcicas são caracterizadas por tons de verde intenso e castanho, havendo um espectro completo de variação até se atingirem os tons de azul e indigo típicos das variedades sódicas. De maneira geral, os cristais de anfibólio sódico tendem a ser mais ciaramente intersticiais, por vezes até poiquilíticos (Amostra 34B). Zoneamentos químicos são comuns, sempre concêntricos e graduais.

Anfibólio tipicamente sódico aparece também como produto de alteraçāo pós-magmática dos anfibólios primários. Pode aparecer ao longo de fraturas, formando franjas de cristais aciculares junto a anfibólio primário. ou ainda em agregados radiados. Normalmente estão associados a biotita (cf. abaixo), por vezes alterando completamente o anfibólio original (Pranchas $3 g$.i). A alteração tende a ser mais pronunciada nas variedades com anfibólio cálcico-sódico, sendo apenas incipiente ou até mesmo ausente nas variedades cálcicas. Nas variedades com anfibólio sódico primário (Amostras 14B, 18A, 49), a alteraçāo também não é observada.

$\mathrm{Na}$ associação aluminosa, as variedades subédricas a euédricas são mais comuns, tanto em agregados (Prancha 3k) como isoladamente (Prancha 31). Cristais intersticiais, apesar de raros. também estão presentes em algumas amostras. Apenas em algumas das variedades de álcalifeldspato granitos equigranulares com biotita (Amostras 84B e 95). cristais de anfibólio estão presentes; apresentam-se corroídos e substituídos por biotita (Prancha $3 \mathrm{~m}$ ). Os padrōes pleocróicos. sempre em tons de verde intenso e castanho, são indicativos da sua composição cálcica.

Finalmente, nas rochas monzodioríticas e nos quartzo sienitos associados, anfibólio aparece sempre ocupando os interstícios, ora como agregados de 2-3 grãos subédricos (Amostra 59E) ora como cristais isolados (Amostras 1684 e 16B3). Assim como na associação aluminosa, os padrões pleocróicos indicam composiçōes cálcicas. 


\section{Quimismo}

Os anfibólios estudados se distribuem ao longo de um grande espectro de variaçāo desde cálcicos até sódicos, incluindo tambẹm uma proporção reduzida de anfibólios ferro-magnesianos (Figuras IV.12; Tabela IV.6).

Os anfibólios das associações a/calinas mostram a maior variabilidade composicional, desde cálcicos. a cálcico-sódicos e sódicos (Figuras IV.12a e IV.12b), enquanto os anfibólios da associaçāo aluminosa sāo mais homogêneos e de composição cálicica (Figura IV.12c). De maneira geral, a composiçāo dos anfibólios é um importante indicador do grau de diferenciação das rochas, principalmente das associaçōes alcalinas, como já sugerido pelas variaçōes no padrão pleocróico.

As variedades cálcicas são tipicamente ferrohornblendas e ferro-edenitas, com quantidades subordinadas de ferro-actinolitas. Na associação aluminosa, dados os teores baixos de Si, ocorrem também ferropargasitas, enquanto nas rochas monzodioríticas, os anfibólios com maior Mg\# são magnesiohornblendas. (Figura IV.13)

Dentre as variedades cálcico-sódicas predominam amplamente ferrobarroisitas e ferrowinchitas, com quantidades subordinadas de ferrorichteritas e katophoritas. Os anfibólios sódicos são na maioria riebeckitas, e raramente arfvedsonitas. (Figuras IV.13; IV.14)

Finalmente, núcleos de coloração amarelo ou bege pálidos são observados em algumas amostras. Correspondem a anfibólios ferro-magnesianos. tipicamente antofilitas (Figura IV.13). As caracteristicas texturais ( $c f$. acima) bem como as composiçōes sugerem que se formaram por transformação de olivina magmática inclusa nos cristais de anfibólio.

As principais variações composicionais observadas podem ser explicadas por uma combinação de mecanismos de substituição acoplada do tipo:

$$
\begin{array}{ll}
{\left[\mathrm{Fe}^{2+}\right]^{C}+[\mathrm{Si}]^{\top} \Leftrightarrow\left[\mathrm{Fe}^{3+}\right]^{C}+[\mathrm{All}]^{\top}} & \text { Eq. IV.5 } \\
{[\mathrm{Ca}]^{B}+\left[\mathrm{Mg}, \mathrm{Fe}^{2+}, \mathrm{Mn}\right]^{C} \Leftrightarrow[\mathrm{Na}]^{B}+\left[\mathrm{Fe}^{3+}\right]^{C}} & \text { Eq. IV.6 } \\
{[\mathrm{Na}]^{A}+\left[\mathrm{Fe}^{2+}\right]^{C} \Leftrightarrow[\mathrm{CH}]^{A}+\left[\mathrm{Fe}^{3+}\right]^{C}} & \text { Eq. IV.7 }
\end{array}
$$

onde - corresponde a uma vacância. A resultante dessa combinação pode ser descrita por uma equação geral:

$$
\begin{aligned}
& {[\mathrm{Na}]^{A}+[\mathrm{Ca}]^{B}+\left[\mathrm{Fe}{ }^{2+}, \mathrm{Mg}, \mathrm{Mn}\right]^{\mathrm{C}}+[\mathrm{Sil}]^{\top} \Leftrightarrow[-]^{A}+[\mathrm{Na}]^{\circledR}+\left[\mathrm{Fe}^{3+}\right]^{C}+[\mathrm{All}]^{\top} \quad \text { Eq. IV. } 8} \\
& \text { i }
\end{aligned}
$$


A atuação destes mecanismos parece demonstrada pela excelente correlação obtida, com coeficiente angular muito próximo de -1 (Figura IV.15).

A evolução dos anfibólios de cada uma das associaçōes, sobretudo nas alcalinas, é diferenciada, e cada uma será discutida separadamente.

\section{Associacão alcalina I}

Ná associação aicalina /, observa-se uma gradação desde termos tipicamente cálcicos até sódicos. Essa variação composicional acompanha a evoluçāo modal das rochas da associação (Amostras 87B $\rightarrow$ 81D, 81B, 81A $\rightarrow 79 \rightarrow 78 \mathrm{~A} \rightarrow 77 \rightarrow 14 \mathrm{~B} \rightarrow 18 \mathrm{~A}$; Figura IV.16a; cf. Figura IV.2) É marcante, entretanto, a lacuna observada entre os anfibólios cálcico-sódicos e sódicos, evidente também em diagramas envolvendo a razāo [Na + K]/Al (Figura IV.17a).

Torna-se claro que os anfibólios da associaçāo a/calina / se dividem em dois grupos principais, separados por uma lacuna composicional. O primeiro deles inclui anfibólios que gradam continuamente desde cálcicos até cálcico-sódicos, enquanto o segundo inclui anfibólios cálcicosódicos e sódicos. Esses dois grupos foram pioneiramente identificados por Giret et al. (1980), que correlacionaram a sua existência às variaçōes no índice agpaítico $\left(\mathrm{A}=\left\{\left[\mathrm{Na} \mathrm{O}_{2} \mathrm{O}+\mathrm{K}_{2} \mathrm{O}\right] / \mathrm{Al}_{2} \mathrm{O}_{3}\right\}_{\mathrm{mol}}\right)$ das rochas; este, por sua vez, se correlaciona diretamente com as razōes $[\mathrm{Na}+\mathrm{K}] / \mathrm{Al}$ dos anfibólios.

Sendo assim, as rochas com anfibólios do primeiro grupo apresentam IA relativamente baixo, porem crescente com a diferenciação (cf. Figura IV.16a). Tais anfibólios são sempre zonados. Nas rochas menos diferenciadas (e.g. Amostra 87B), as trajetórias evolutivas se dão, na Figura IV.16a. segundo uma reta 1:1 intermediária aos valores máximos e mínimos possiveis. Tais variaçōes podem ser explicadas pela substituição edenítica (cf. Giret et al., 1980):

$[\mathrm{Na}, \mathrm{K}]^{\mathrm{A}}+[\mathrm{All}]^{\top} \Leftrightarrow[\mathrm{O}]^{\mathrm{A}}+[\mathrm{Si}]^{\top}$

Strong e Taylor (1984) concluem que trajetórias desse tipo são características da evolução magmática a subsolidus de anfibólios. Trajetórias semelhantes são seguidas pelos núcleos dos cristais das amostras mais diferenciadas (e.g. Amostras 78A, 79), progressivamente mais evoluídos. Revela-se assim, a continuidade evolutiva dos anfibólios desse grupo. compativel com a hipótese de que essa associação corresponde a uma linhagem comagmática.

Para uma dada amostra, entretanto, com o progresso da cristalização, as composições em direção às bordas divergem desta trajetória principal, em conseqüência da diminuição mais rápida 
dos valores de $[\mathrm{Na}+\mathrm{K}]_{\mathrm{A}}$, não correlacionada a variaçōes nos teores de Si, e, portanto, não explicada pelo mecanismo de substituiçāo da Equaçăo IV.9. Fica evidente a existência de uma evolução independente de cada amostra (cf. Figura IV.16a). Trajetórias como estas são atribuídas a processos magmáticos de oxidação (Strong e Taylor, 1984). mais especificamente, por uma reação do tipo:

$$
[\mathrm{Na}, \mathrm{K}]^{A}+\left[\mathrm{Fe}^{2+}\right]^{C} \Leftrightarrow[-]^{h}+\left[\mathrm{Fe}^{3+}\right]^{C}
$$

Diagramas envolvendo $\mathrm{Fe}^{\hat{3}}$ e $[\mathrm{Na}+\mathrm{K}]^{\mathrm{A}}$ são normalmente pouco satisfatórios devido à forte dependēncia desses valores a incertezas inerentes do cálculo das proporçōes entre $\mathrm{Fe}^{2+}$ e $\mathrm{Fe}^{3+}$. o que torna difícil testar a presença de um mecanismo de subtituição como este. Ainda assim, a Figura IV.18 mostra (como exemplo. para a amostra 78A) que efetivamente há uma diminuição de $[\mathrm{Na}+\mathrm{K}]_{\mathrm{A}}$ não correlacionada a variaçōes nos teores de Si, sugerindo a atuação do mecanismo descrito pela Equação IV.10. Existe, portanto, um segundo estágio na evolução dos anfibólios deste primeiro grupo. caracterizado pela cristalizaçāo em condiçōes progressivamente mais oxidantes

Os anfibólios que compōem o segundo grupo de Giret et al. (1980) correspondem, na maioria dos casos. a produtos de alteração dos anfibólios primários (e.g. Amostras 78A, 79). De fato. Giret et al. (1980) sugerem que a lacuna composicional observada se deva à desestabilização dos anfibólios cálcico-sódicos. A ocorrência destes cristais de anfibólio sódico em fraturas no anfibólio hospedeiro, bem como a formação de agregados radiados e de franjas de cristais aciculares, indicam que, nestas amostras, a alteração se deu nos estágios pós-magmáticos de cristalização (cf. acima).

Contudo, em algumas amostras (i.ê.. 77, 14B e 18A), os cristais de anfibólio sódico são intersticiais a poiquiliticos, por vezes texturalmente indistinguiveis daqueles do grupo anterior, donde se deduz que são fases magmáticas primárias. Esses anfibólios variam desde cálcico-sódicos até sódicos, porém são sempre mais sódicos (i.é. maior $\mathrm{Na}_{\mathrm{B}}$ ) que os do grupo anterior. $\dot{E}$ interessante notar que na Amostra 77 observam-se ainda cristais de anfibólio pós-magmático como os encontrados nos anfibólios do primeiro grupo.

As razões [ $\mathrm{Na}+\mathrm{K}] / \mathrm{Al}$ dos anfibólios deste segundo grupo são características de rochas agpaíticas (Giret et al., 1980). Deve ser destacado, entretanto, que devem ser consideradas agpaíticas apenas as rochas que apresentam anfibólio sódico primário. A existência de anfibólio sódico pós-magmático indica, por sua vez, a existência de fluidos pós-magmáticos de alta alcalinidade.

É interessante notar que a substituição mais importante para este grupo de anfibólios envolve o par $\left[\mathrm{Na}+\mathrm{Fe}^{3+}\right]$. ou seja, a molécula riebeckita (Figura IV.19). Esse acoplamento entre $\mathrm{Na}$ e $\mathrm{Fe}^{3+}$, 
identificado também por Czamanske e Dillet (1988). é típico de piroxênios de rochas agpaíticas insaturadas, o que reforça a idéia de que estes anfibólios se desenvolveram em ambientes de alta alcalinidade.

Finalmente, algumas variedades de anfibólio pós-magmático se mostram alteradas por perda de Na. Normalmente, aparecem incolores, sem o pleocroísmo típico desta variedade. Na Figura IV.12a. formam um alinhamento em direção a anfibólios ferro-magnesianos (Amostras 78A, 79 e $80)$, devendo corresponder a gruneritas.

\section{Associacão alcalina /l}

De maneira geral, os anfibólios desta associaçāo são semelhantes aos da associação a/calina / (Figuras IV.13 e IV.14b). diferenciando-se por valores de Mg\# pouco mais elevados.

Nas amostras do Maciço Farinha Seca, como na associação acalina /, as variaçōes composicionais seguem a seqüência de diferenciação petrográfica (Amostras $15 \rightarrow 25 \mathrm{~B} \rightarrow 51 \rightarrow 56$ $\rightarrow$ 49: Figuras IV.12b e IV13b). Já nas amostras do Maciço Órgãos (3D, 59A, 70 e 74), os anfibólios são mais homogêneos, com composições tipicamente cálcicas. (Figuras IV.12b e IV.13).

As trajetórias evolutivas dos anfibólios desta associação são, entretanto, diferenciadas. Apesar das variedades mais cálcicas serem semelhantes, a evolucăo de cada uma das amostras, bem como do conjunto todo, tende a uma gradual diminuição da ocupação do sítio A com o aumento de Si (Equação IV.9; Figuras IV.16b e IV.18b). É interessante notar que, em contraste com a associação alcalina /, as tendências de oxidação não são importantes para essas variedades (Figura IV.16b).

O reconhecimento dos dois grupos acima descritos é menos óbvio. A lacuna é muito menos marcada nesse conjunto, sendo inexistente nas razōes [Na + K]/Al (Figura IV.17b). A separação dos dois grupos de anfibólio é dada pela presença das variedades mais cálcicas de anfibólio pósmagmático, formadas a partir dos anfibólios cálcicos do primeiro grupo (e.g. Amostra 15), bem como pela presença de núcleos cálcico-sódicos, que caracterizam os cristais do segundo grupo. (Figuras IV.14b, IV.16b e IV.17b)

É interessante notar o acoplamento entre Na e Fe ${ }^{3+}$ nester anfibólios cátriro-sódicos gue indica a alcalinidade relativamente alta dos magmas a partir dos quais se formaram (Figura IV.19b).

Assim como na associação alcalina /, os anfibólios sódicos sāo predominantemente produtos de alteração dos demais anfibólios. Entretanto, também nessa associação sāo observados cristais 
primários (Amostra 49; cf. acima), texturalmente indistinguíveis dos cáicico-sódicos. Uma lacuna bem marcada separa os anfibólios cálcico-sódicos dos sódicos deste. segundo grupo (Figuras IV.14b e IV.16b). Mais uma vez, tal descontinuidade não é observada nas razões [Na+K]/Al (Figura IV.17b).

Apesar dos núcleos destes cristais se àpresentarem concordantes com as tendências evolutivas dos anfibólios cálcico-sódicos, a evoluçāo dos zoneamentos quimicos é bastante divergente em diversos diagramas (Figura IV.14b, IV.16b, IV.17b, IV.18b e IV.19b). Em todos os casos, essa evoluçāo tende a um enriquecimento na molécula arfvedsonita através de processos de redução. explicados por um mecanismo inverso ao da Equação IV.10 (Figura IV.19b).

Cabe destacar que tal enriquecimento se dá em ambiente com alcalinidade decrescente, ao contrário do que ocorre na associaçāo alcalina // (Figura IV.17b). A existência de um pico de alcalinidade. seguido de estágios relativamente mais aluminosos é típica de sistemas agpaíticos insaturados (cf. Khomyakov, 1993; Gualda, 1998), o que confirma a afinidade agpaítica das associações alcalinas.

\section{Associacão aluminosa}

Como indicado pelas suas características óticas, os anfibólios da associação aluminosa são muito mais homogêneos composicionalmente, restringindo-se a variedades cálcicas (Figuras IV.12ce IV.14C).

De maneira geral, são muito semelhantes às variedades mais cálcicas das associacões a/calinas (Figuras IV.14c e IV.16c). As composiçōes mostram grande sobreposição - à excessāo da Amostra 2B. que possui anfibólios pouco mais evoluídos (i.é. $[\mathrm{Na}]_{\max }^{\mathrm{B}}=0.45$ ) - não tendo sido observada correlação entre as variaçōes nas composições dos anfibólios e nas composições modais.

As principais variaçōes composicionais observadas podem ser explicadas pela combinação das substituiçōes edenítica (Equaçāo 9) e o conjunto das substituições tschermakíticas (Figura IV.20a):

$$
\left[\mathrm{Fe}^{2+}, \mathrm{Mg}, \mathrm{Mn}\right]^{\mathrm{C}}+[\mathrm{Sii}]^{\top} \Leftrightarrow\left[\mathrm{Al}, \mathrm{Fe}^{3+}, 1 / 2 \mathrm{Tij}\right]^{\mathrm{C}}+[\mathrm{All}]^{\top}
$$

típicas de anfibólios cálcicos. 


\section{Rochas monzodioríticas e associadas}

Os anfibólios presentes nestas rochas sāo também tipicamente cálcicos. Entretanto, em comparação com as variedades cálcicas das demais associaçōes, são mais pobres em $[\mathrm{Na}]^{B}$ e em $[\mathrm{Na}+\mathrm{K}]^{A}$. (ct. Figuras IV.12d, IV.13, IV.14d,'IV.16d)

Assim como no caso da associação aluminosa, as variacōes composicionais podem ser bem explicadas pela combinaçāo das substituiçōes edenítica e uschermakiticas (Equaçoes IV.9 e NV.11: Figura (V.20b).

Em função dos teores mais baixos de $N a$ e $K$, as análises deste grupo de anfibólios se distribuem ao longo de uma trajetória mais próxima do eixo hornblenda-barroisita no diagrama da Figura IV.16d. quando comparados aos anfibólios das demais associacōoes. Considerando que há grande sobreposição nos valores de $[\mathrm{Si}+\mathrm{Na}+\mathrm{K}]$, as trajetórias distintas parecem indicar a ausência de relação genética direta, ou seja, de derivação dos magmas graníticos - tanto aluminosos como alcalinos - a partir dos magmas monzodioríticos. 
(a)

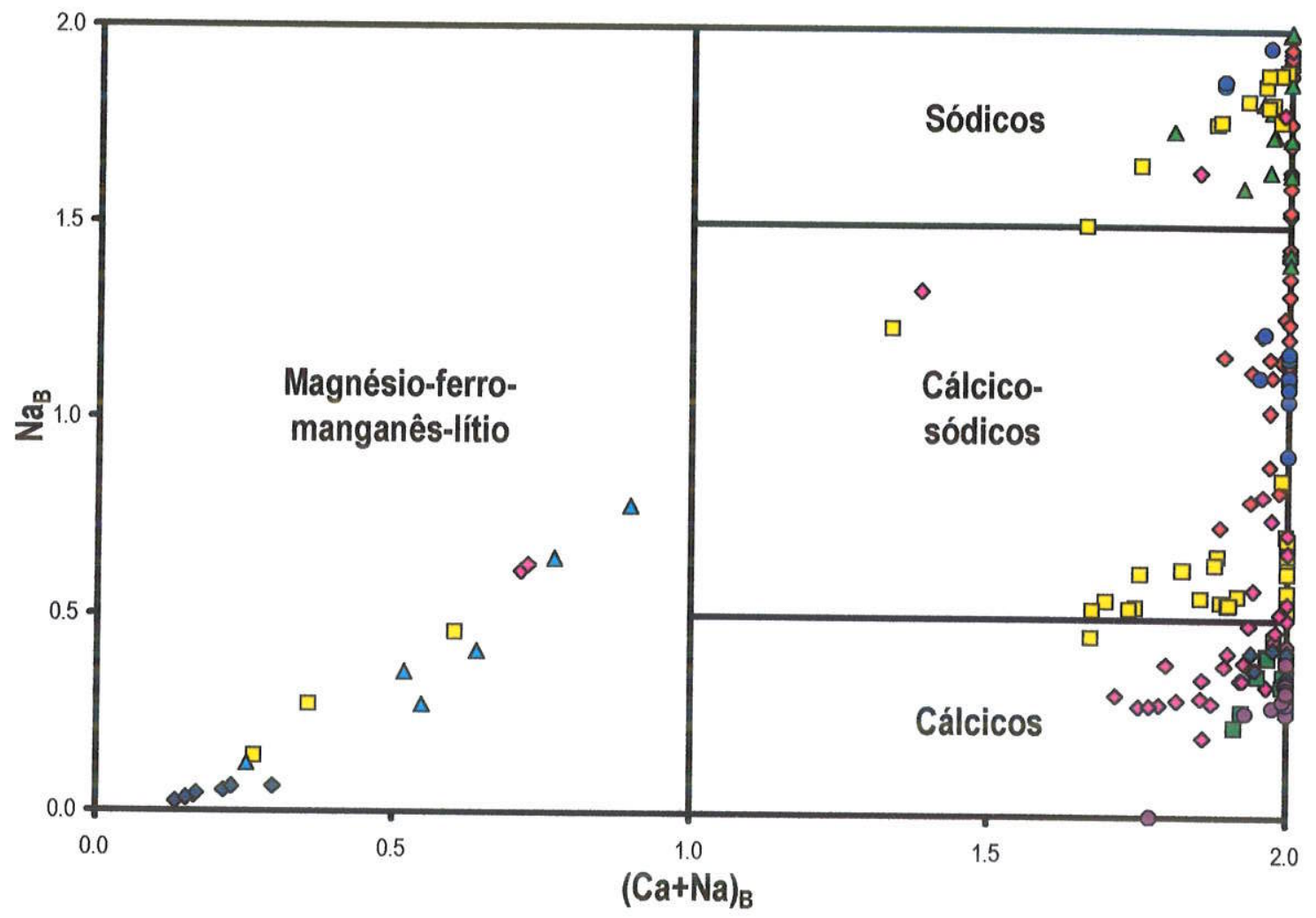

(b)

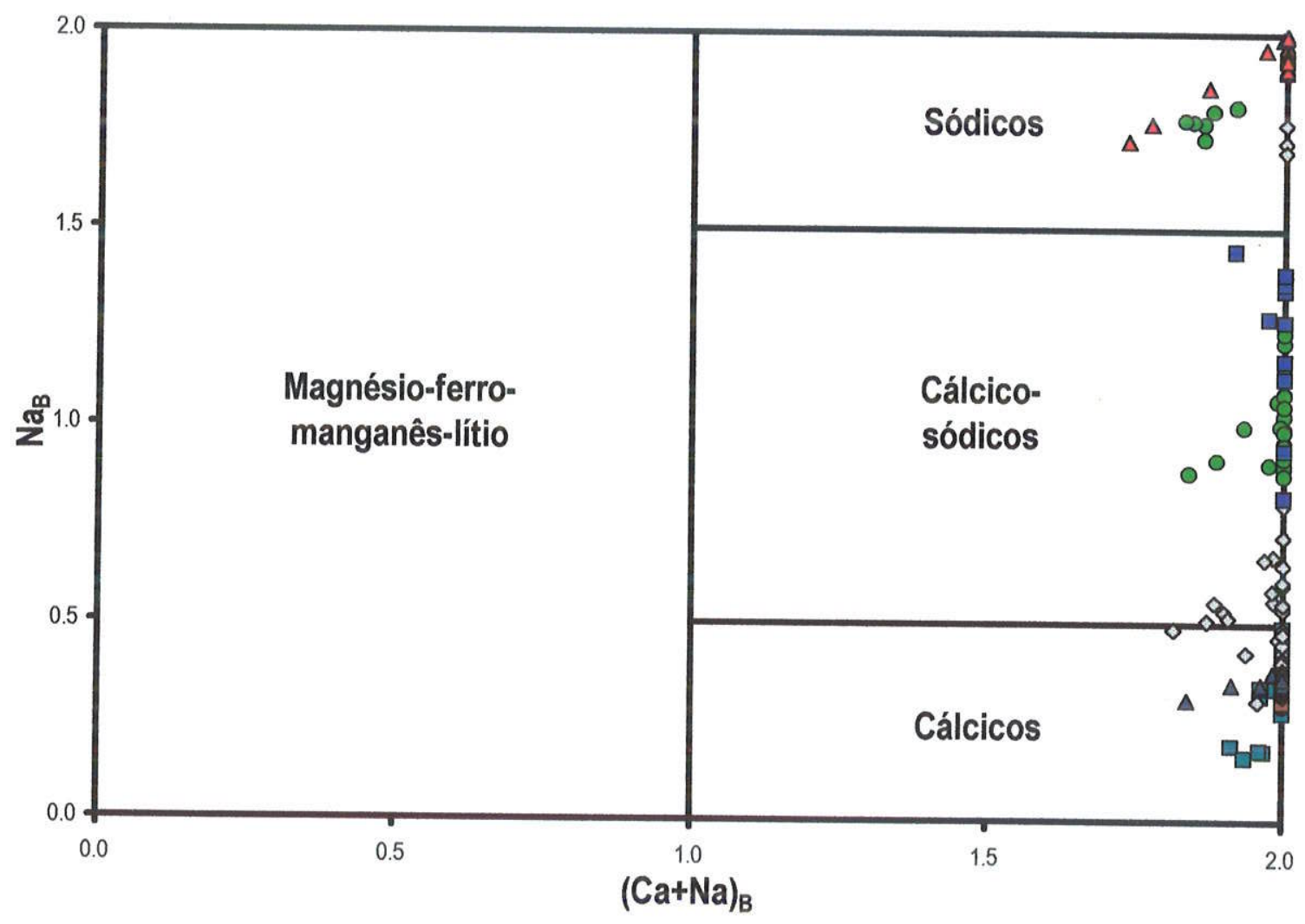

Figura IV.12: (Continua na próxima página) 
(c)

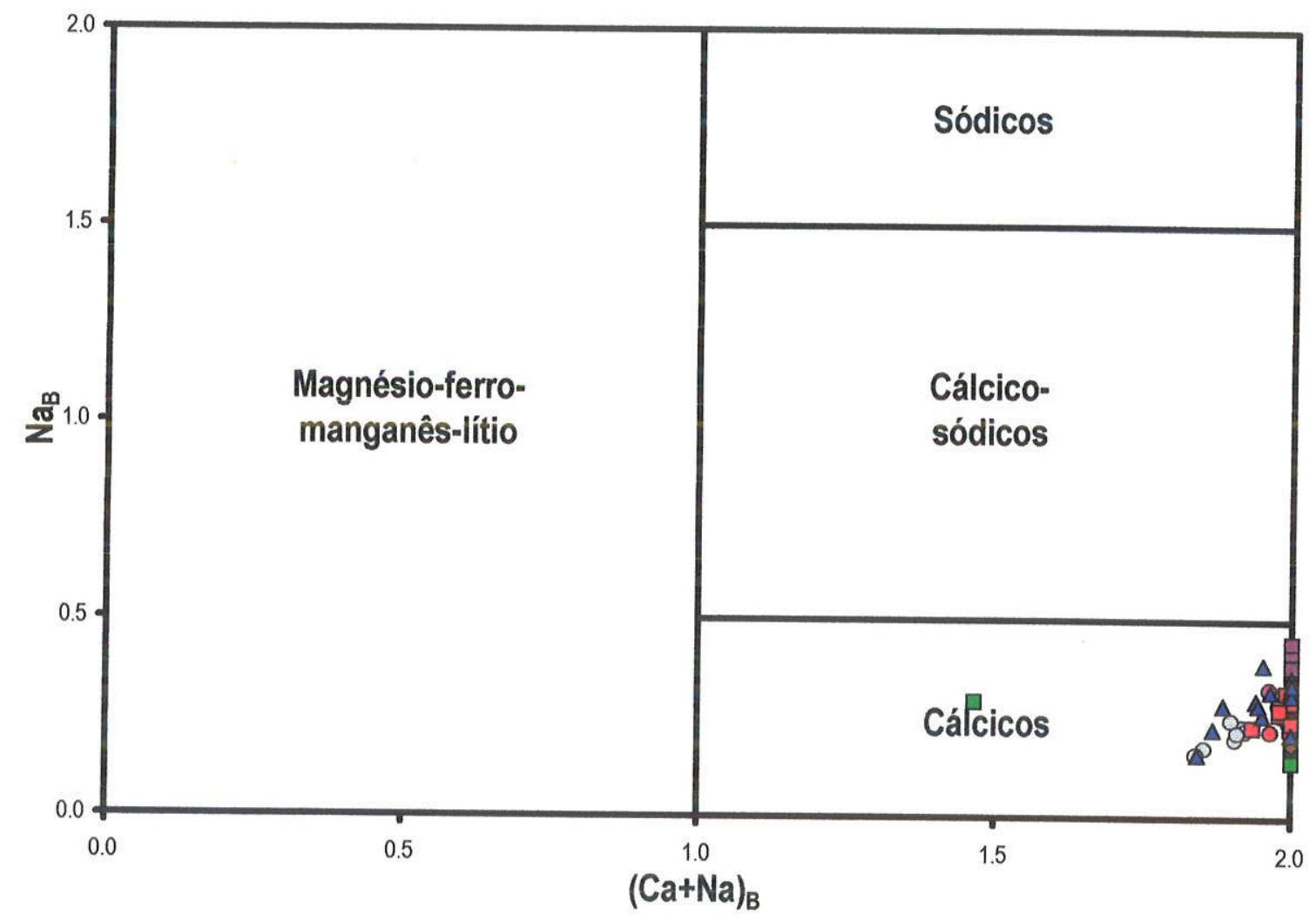

(d)

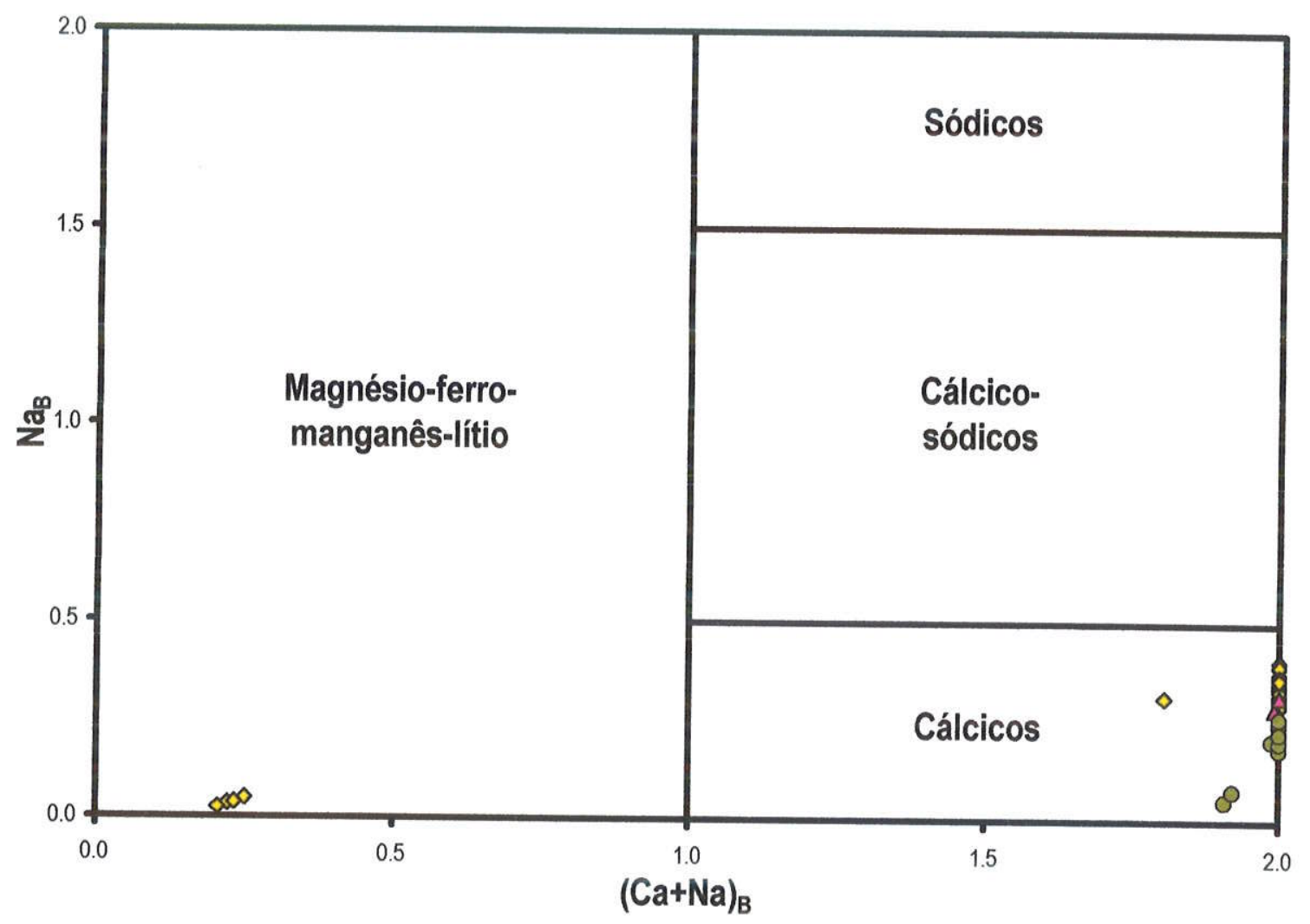

Figura IV.12: Diagramas catiônicos $[\mathrm{Ca}+\mathrm{Na}]_{B} \times[\mathrm{Na}]_{B}$ de classificação dos anfibólios das associações (a) alcalina I; (b) alcalina II; (c) aluminosa; $e$ (d) das rochas monzodioríticas $e$ associadas dos Granitos da Graciosa (segundo a IMA - Leake et al., 1997). 
(a)

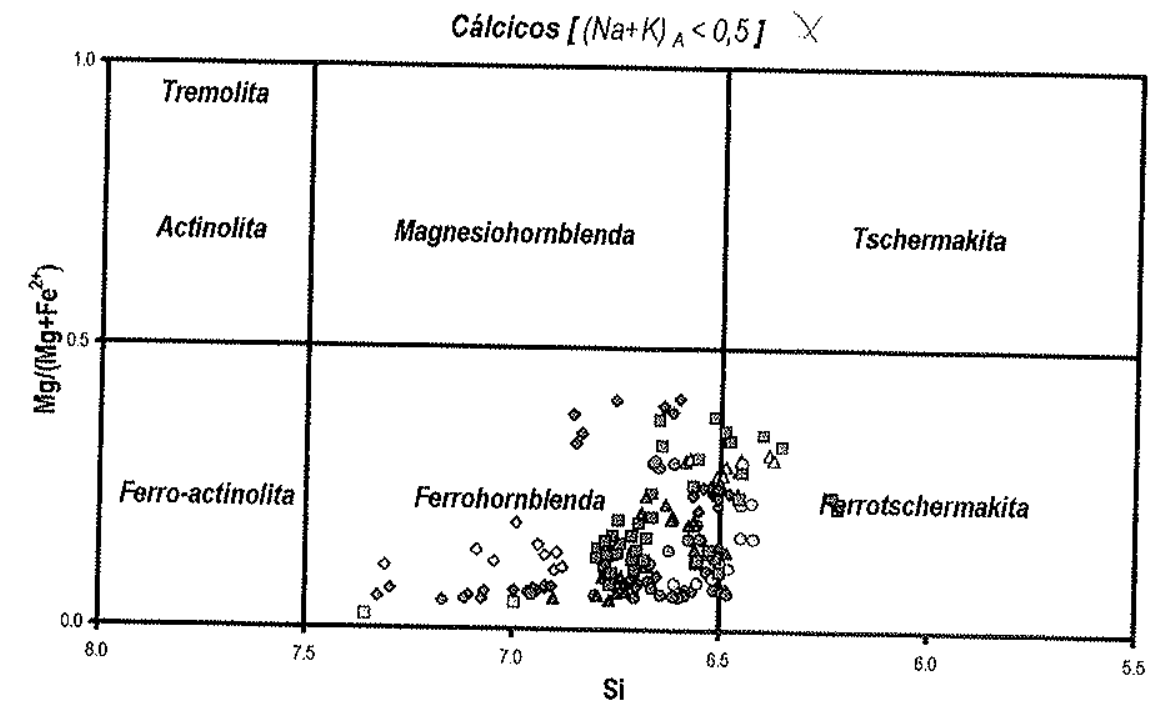

(b)

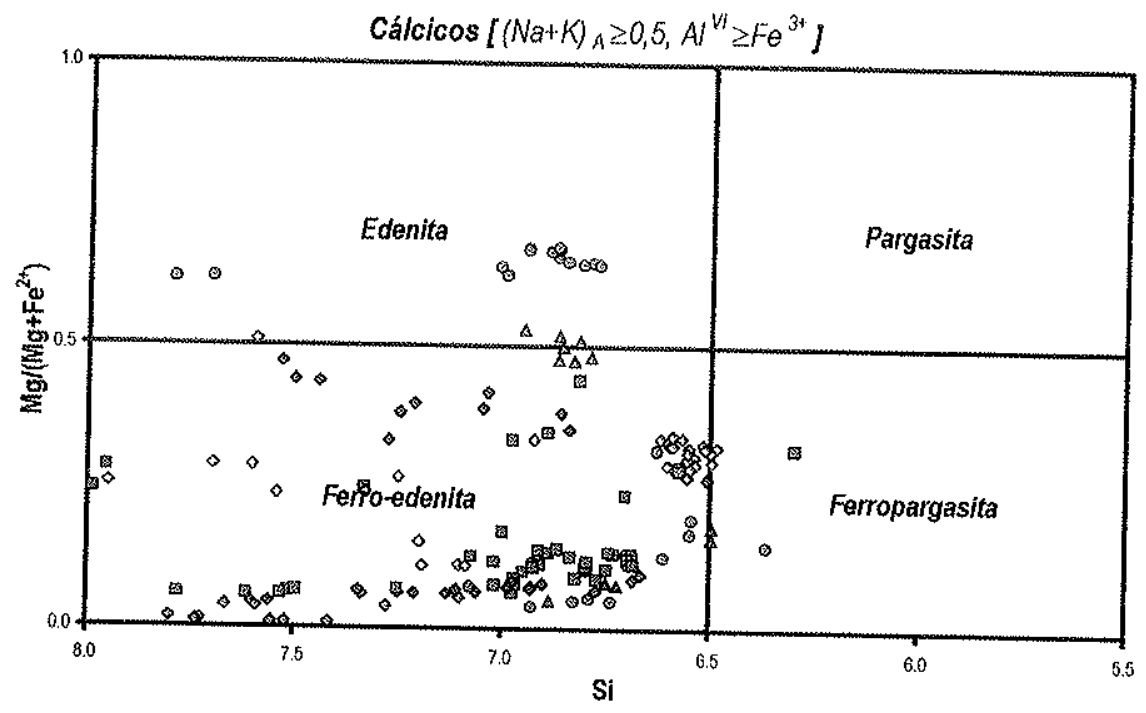

(c)

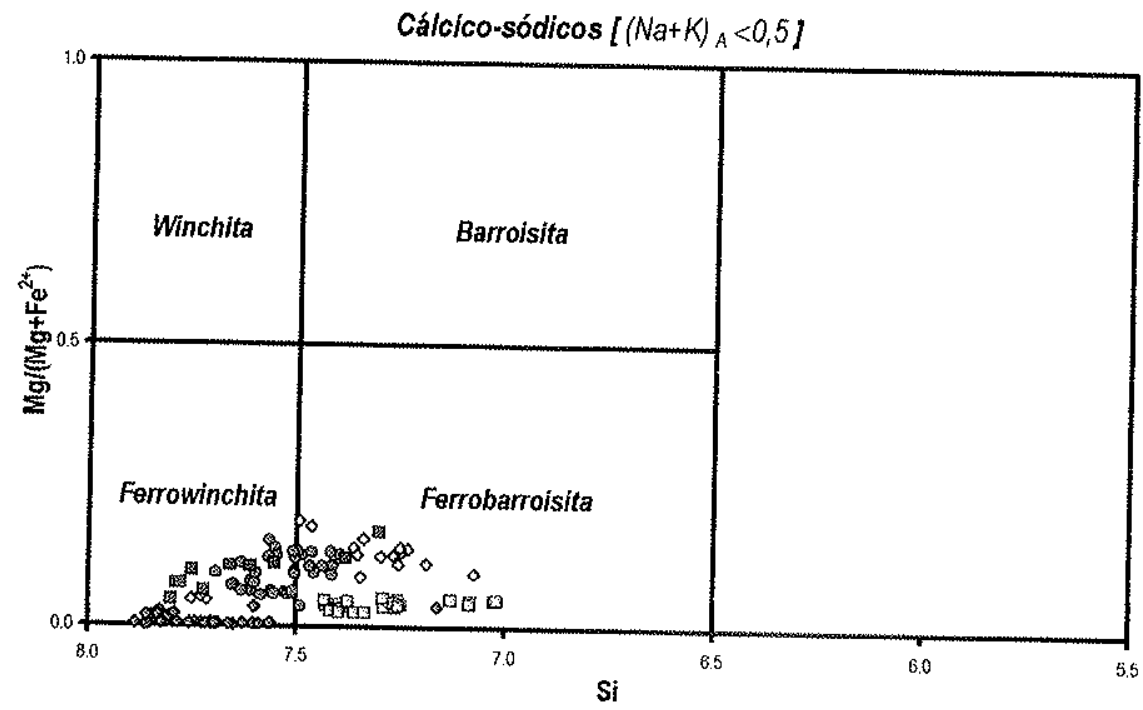

Figura IV.13: (Continua na próxima página) 
(d)

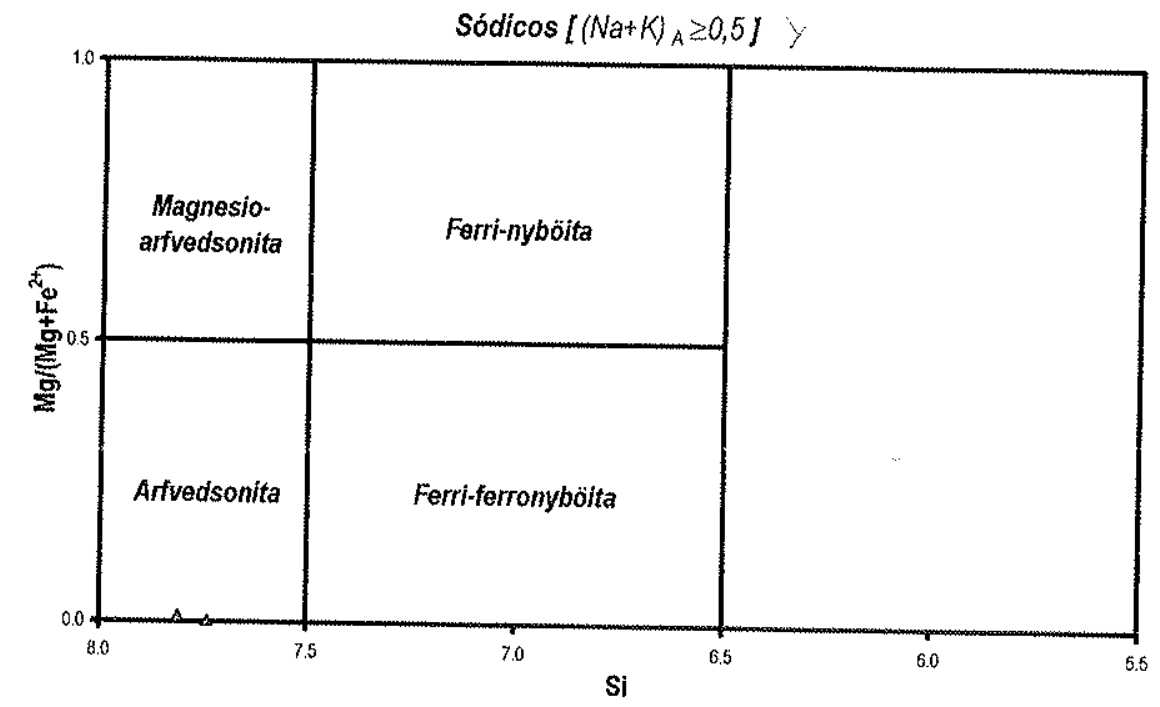

(e)

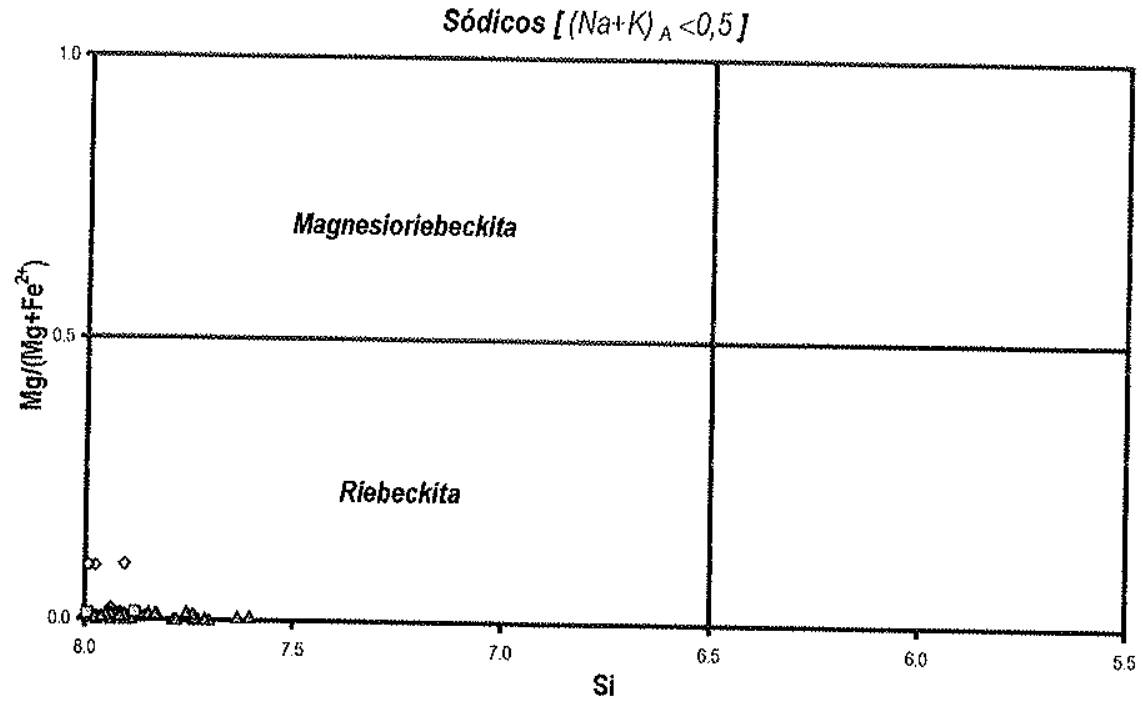

(f)

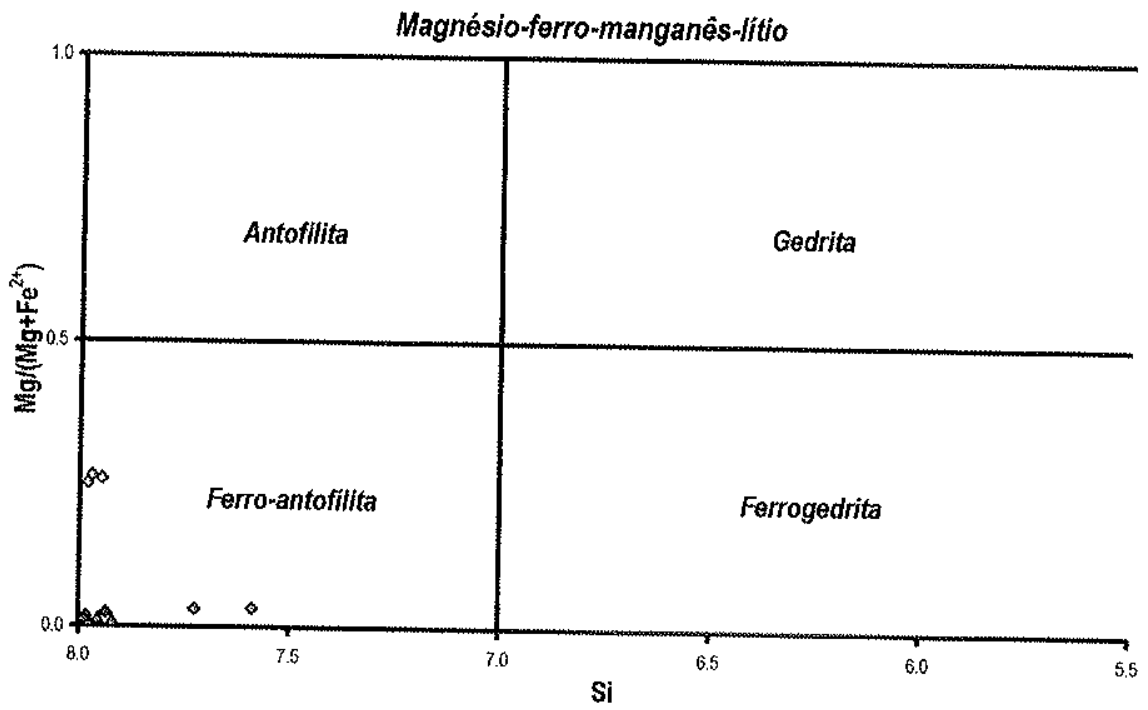

Figura IV.13: Diagramas catiônicos Si $\times\left[\mathrm{Mg} /\left(\mathrm{Mg}+\mathrm{Fe} \mathrm{e}^{2+}\right)\right]$ de classificação dos anfibólios dăs associaçoes alcalinas e aluminosa dos Granitos da Graciosa (segundo a IMA - Leake et al., 1997). 
(a)

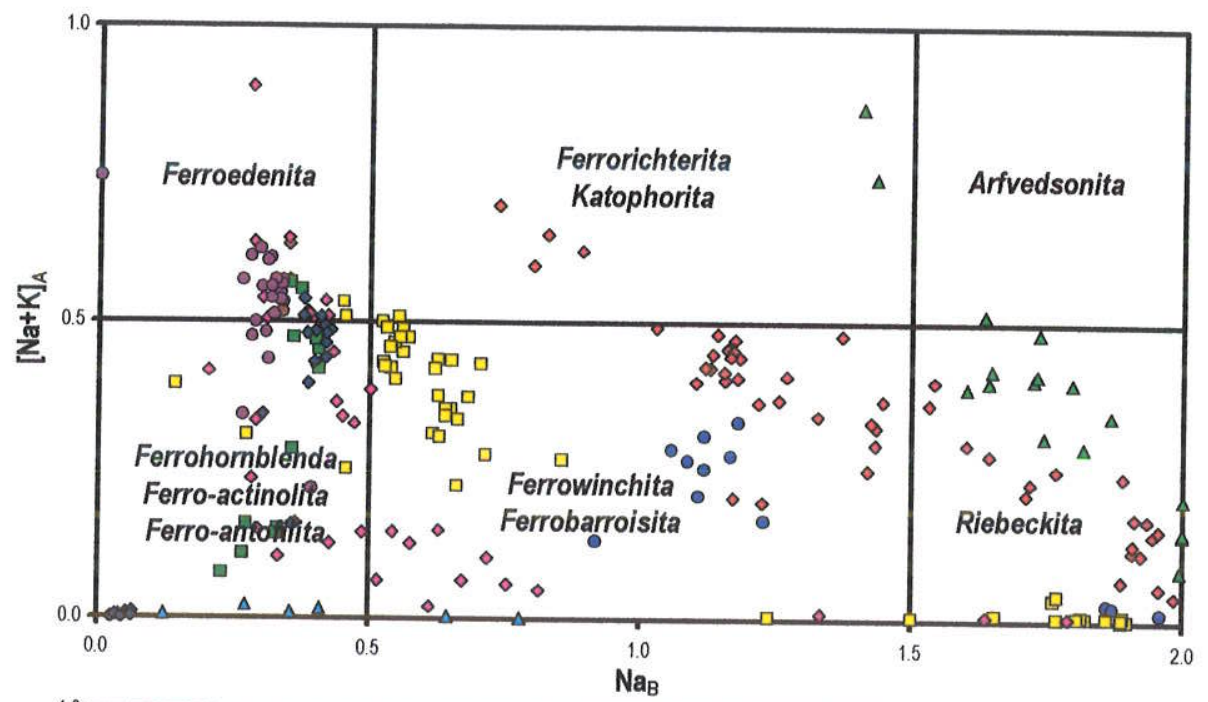

(b)

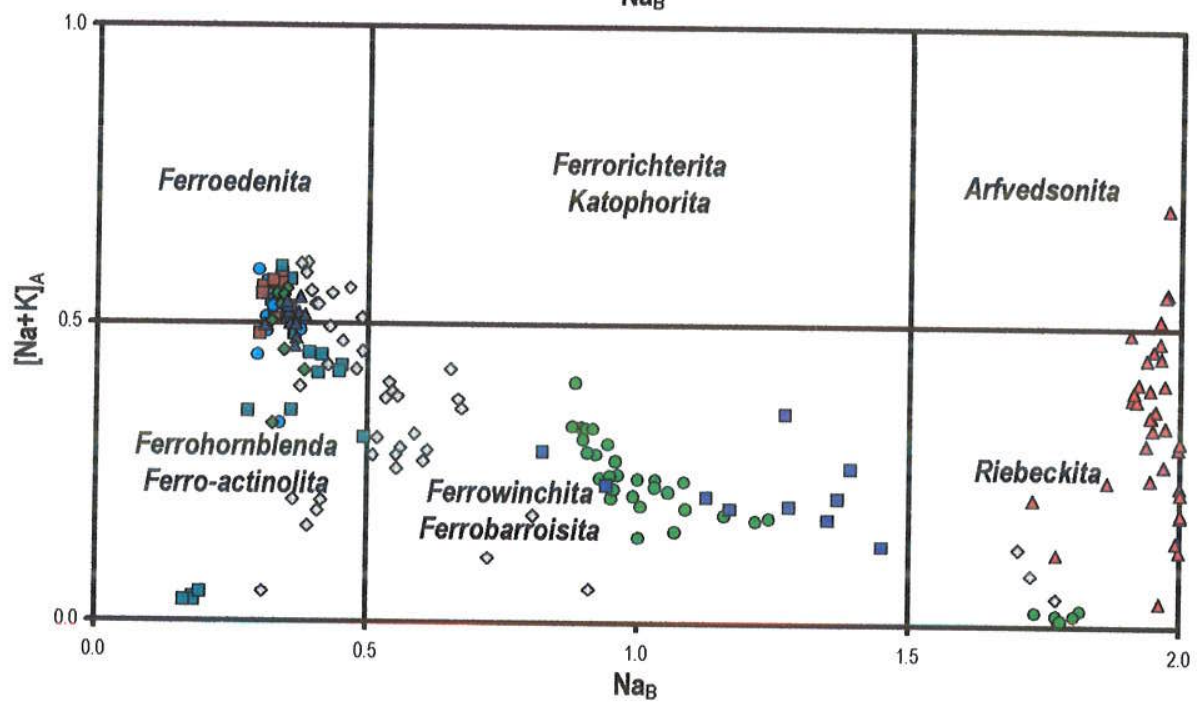

(c)

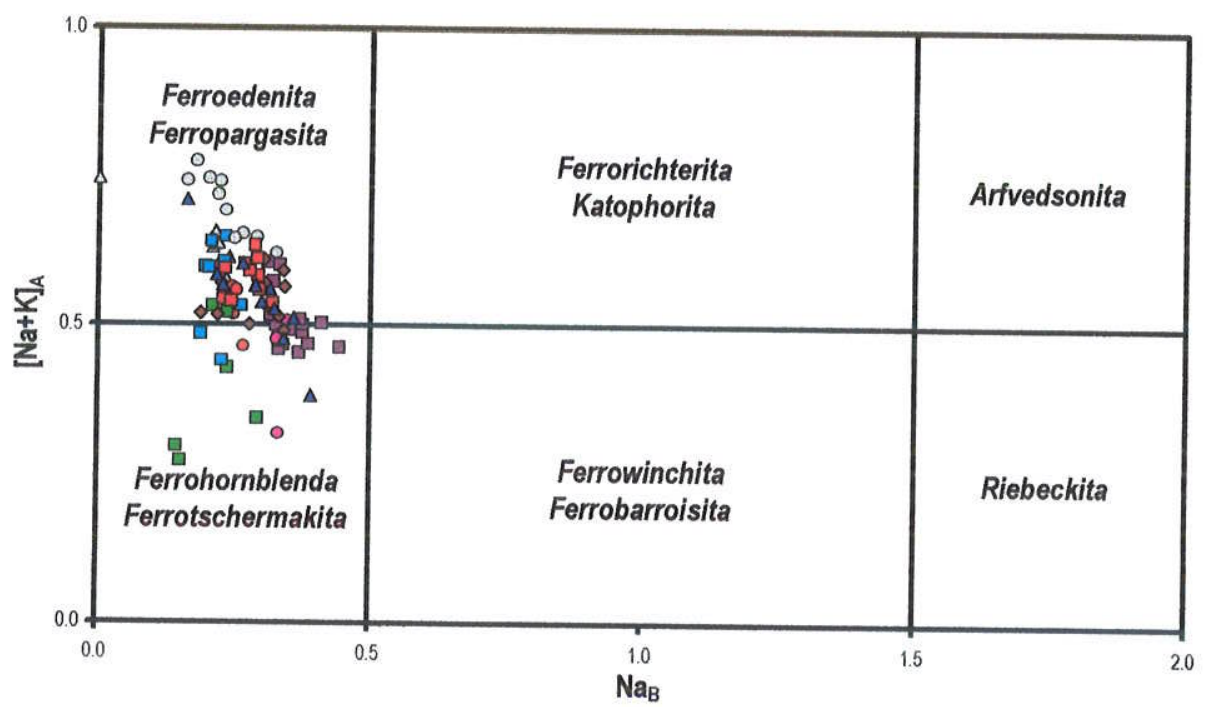

Figura IV.14: (Continua na próxima página) 
(d)

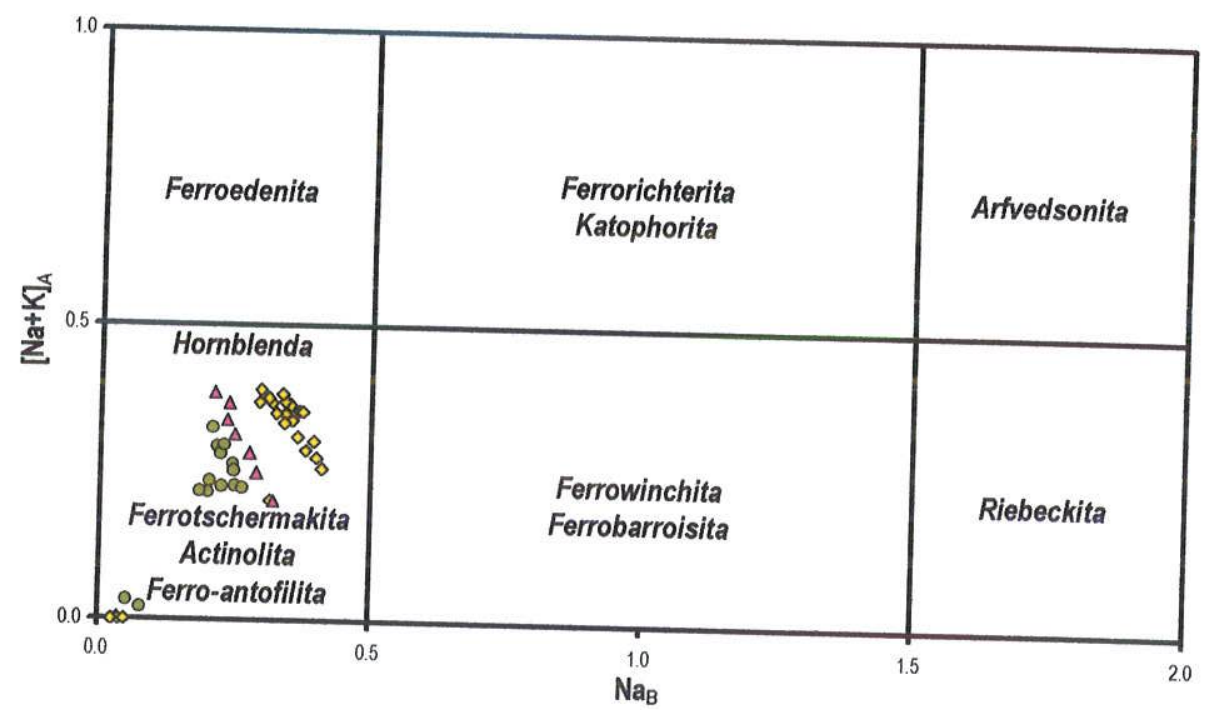

Figura IV.14: Diagramas catiônicos $[\mathrm{Na}]_{B} \times[\mathrm{Na}+\mathrm{K}]_{A}$ de classificação dos anfibólios das associações (a) alcalina I; (b) alcalina II; (c) aluminosa; e (d) das rochas monzodioríticas $e$ associadas dos Granitos da Graciosa (segundo Leake et al., 1997)

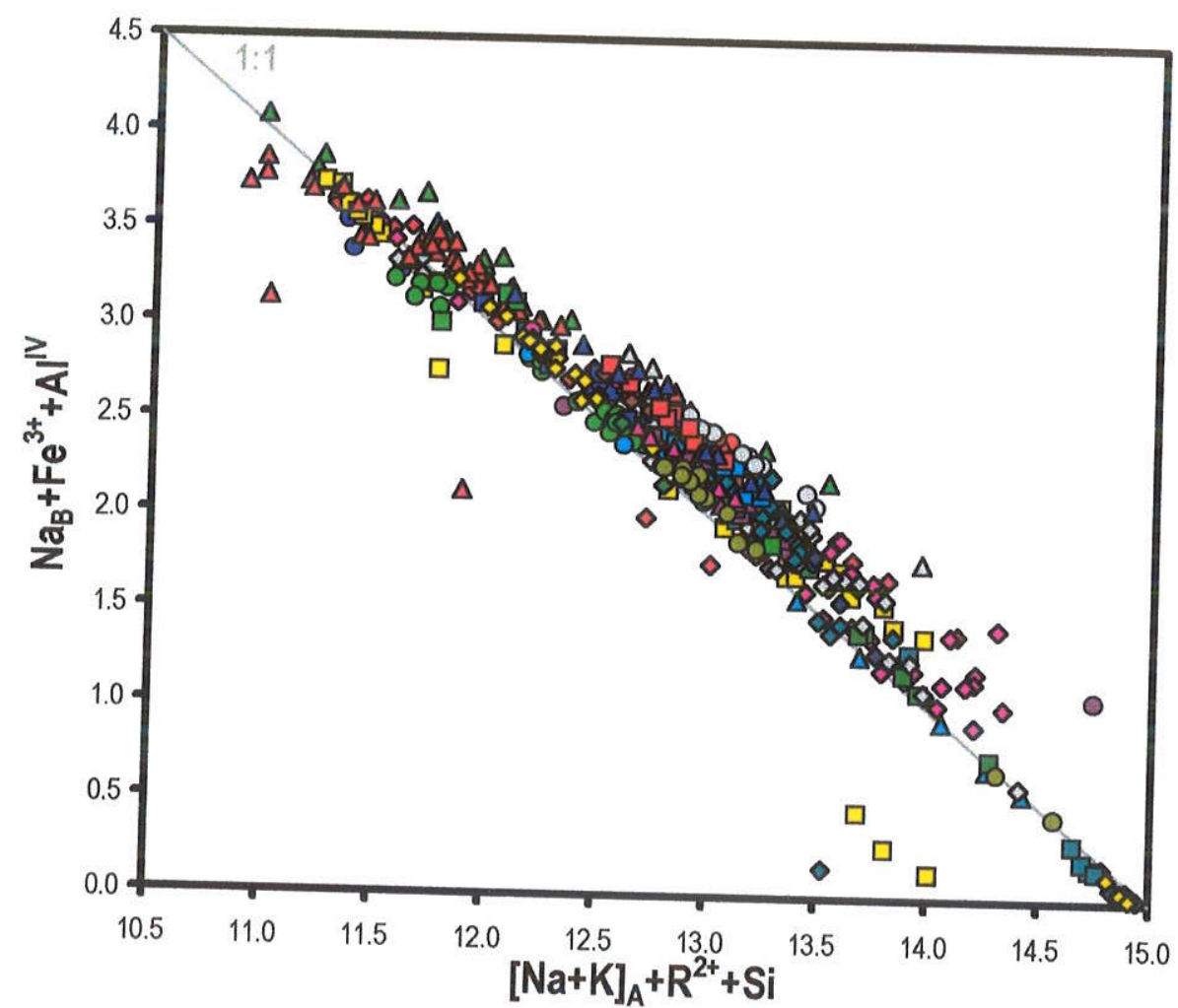

Figura IV.15: Correlação entre as proporções catiônicas de $\left([\mathrm{Na}+K]_{A}+R^{2+}+\mathrm{Si}\right) \quad x$ $\left([\mathrm{Na}]_{B}+\mathrm{Fe}^{3+}+{ }^{\prime N} \mathrm{Al}\right)$ em anfibólios das associações alcalina I, alcalina II, aluminosa $e$ das rochas monzodioríticas e associadas dos Granitos da Graciosa. 
(a)

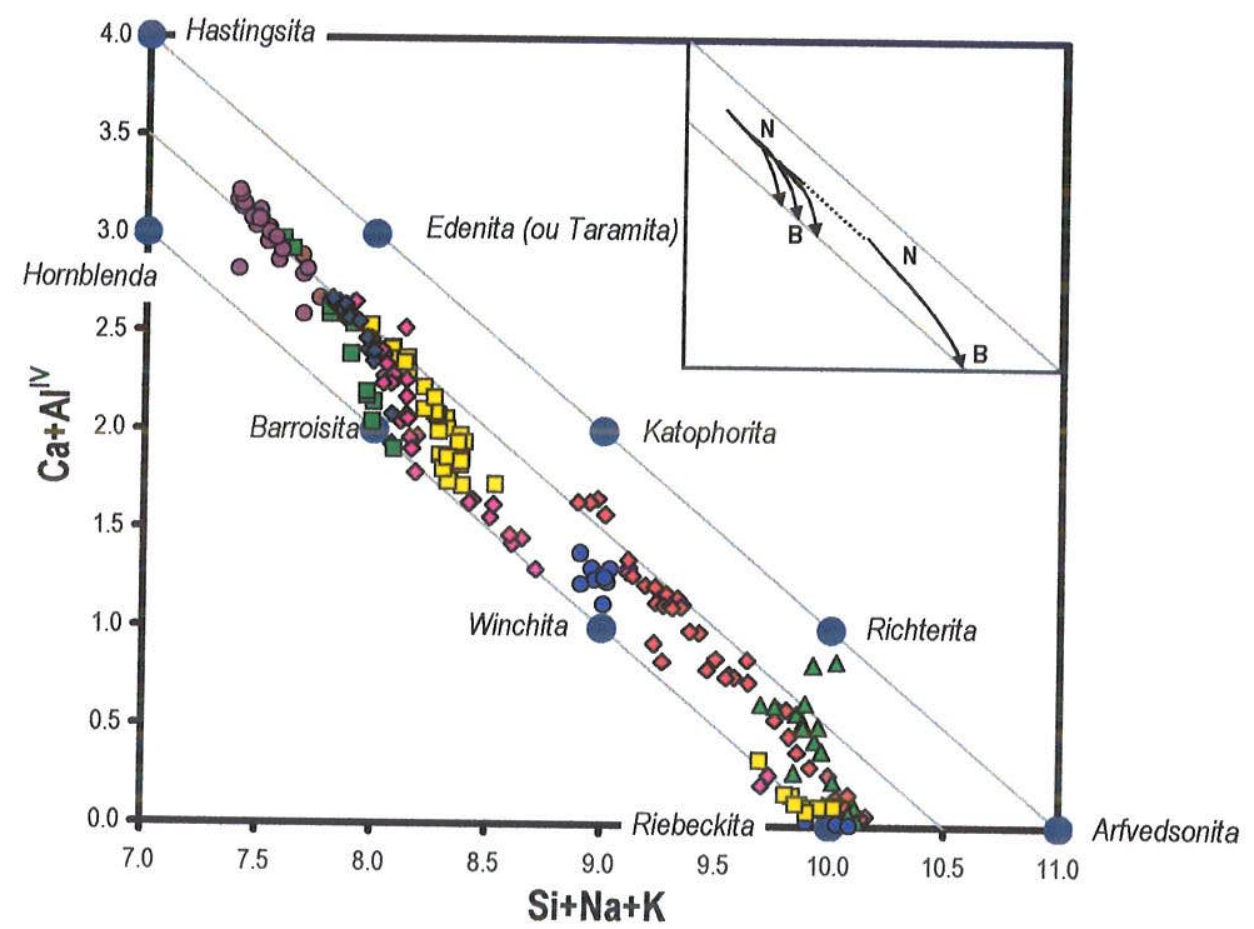

(b)

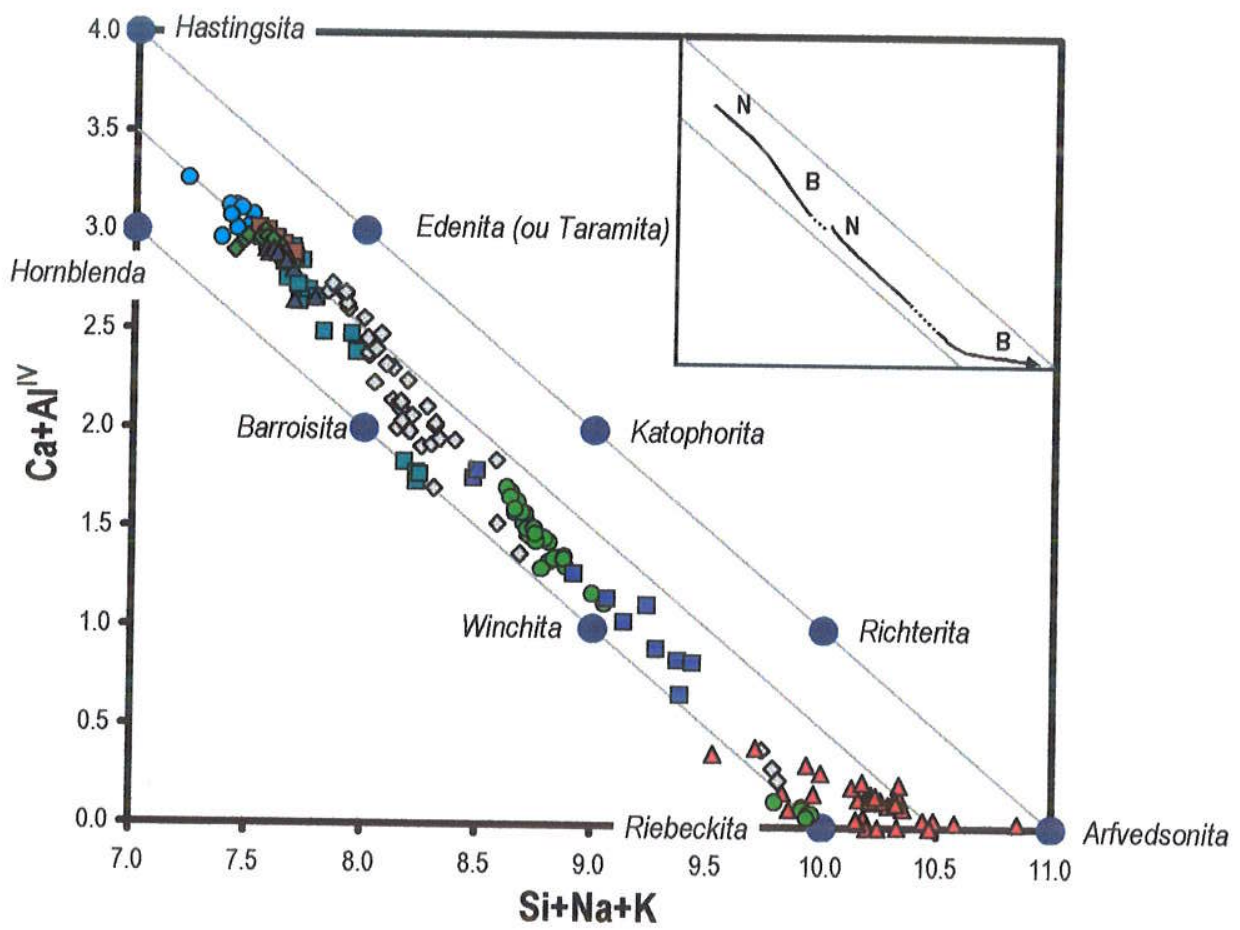

Figura IV.16: (Continua na próxima página) 
(c)

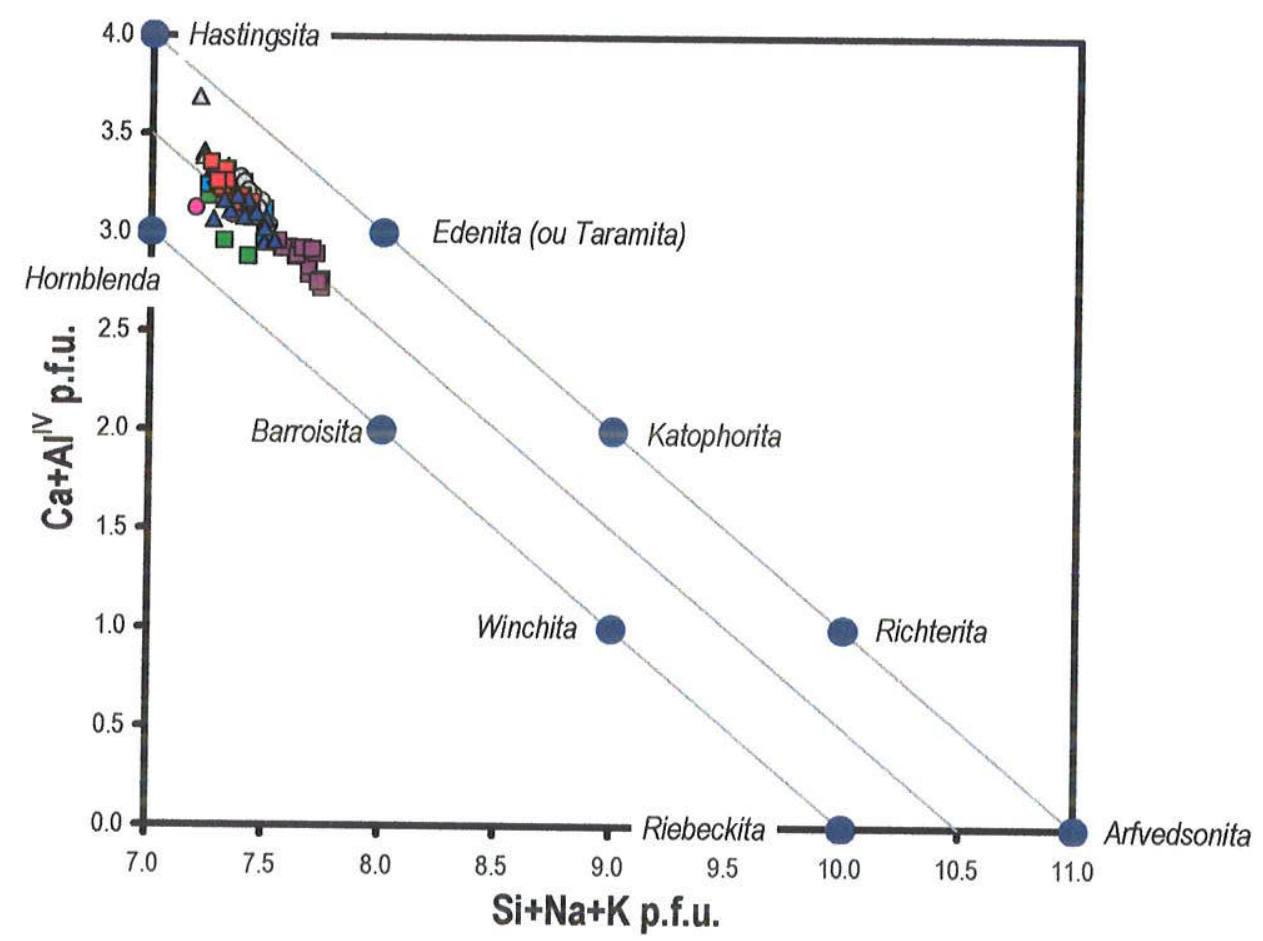

(d)

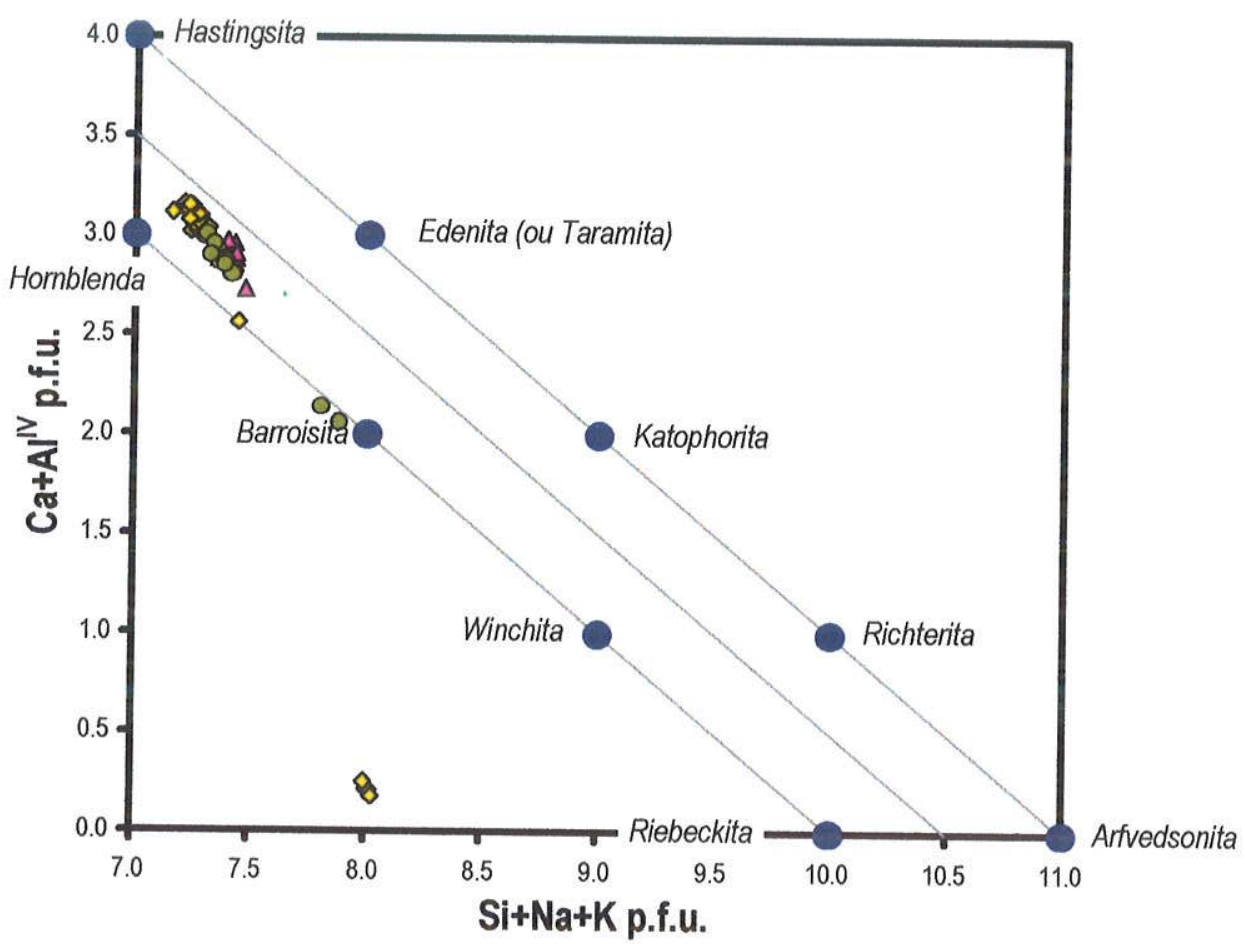

Figura IV.16: Correlação entre as proporções catiônicas [Si+Na+K] $\left[\mathrm{Ca}^{\prime \prime}{ }^{\prime \prime} \mathrm{Al}\right]$ em anfibólios das associações (a) alcalina I; (b) alcalina II; (c) aluminosa; e (d) das rochas monzodioríticas $e$ associadas dos Granitos da Graciosa. Em (a) e (b), inclui esboços mostrando as tendências evolutivas mais importantes ( $N$ - núcleo; $B$ - borda). 
(a)

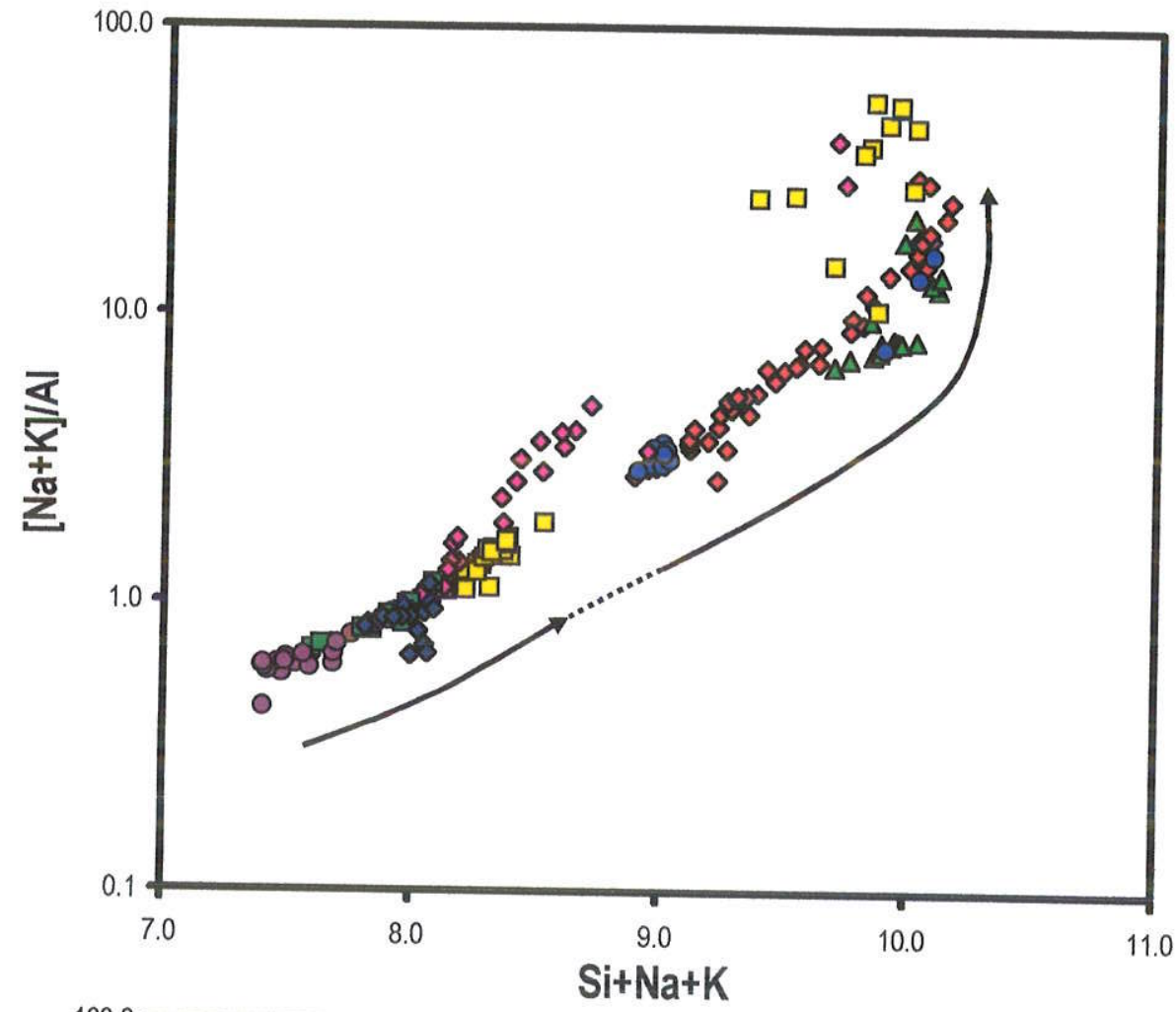

(b)

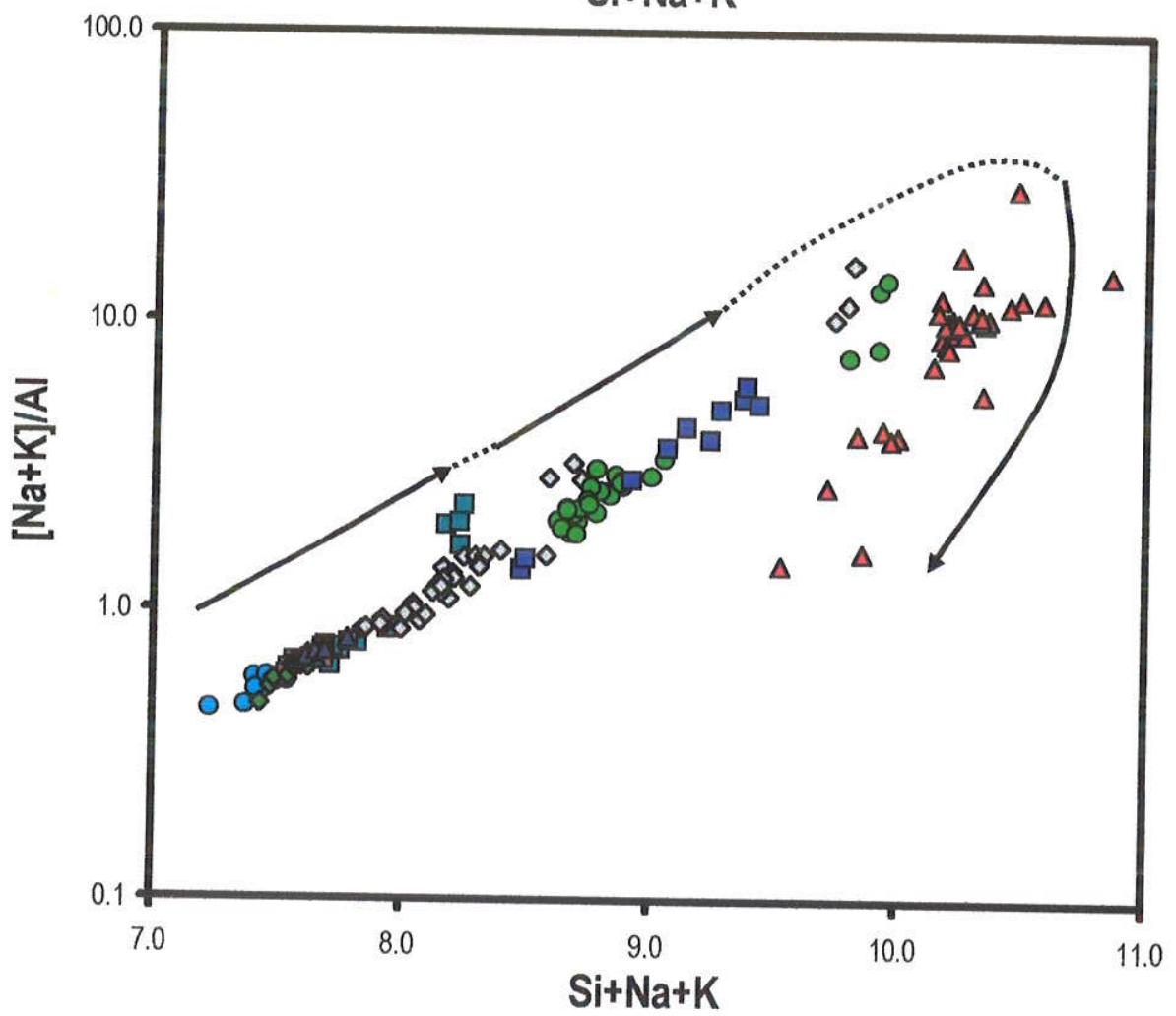

Figura IV.17: Correlação entre as proporções catiônicas [Si+Na $+K] \times[\mathrm{Na}+\mathrm{K}] / \mathrm{A} /$ em anfibólios das associações (a) alcalina I e (b) alcalina II dos Granitos da Graciosa. 
(a)

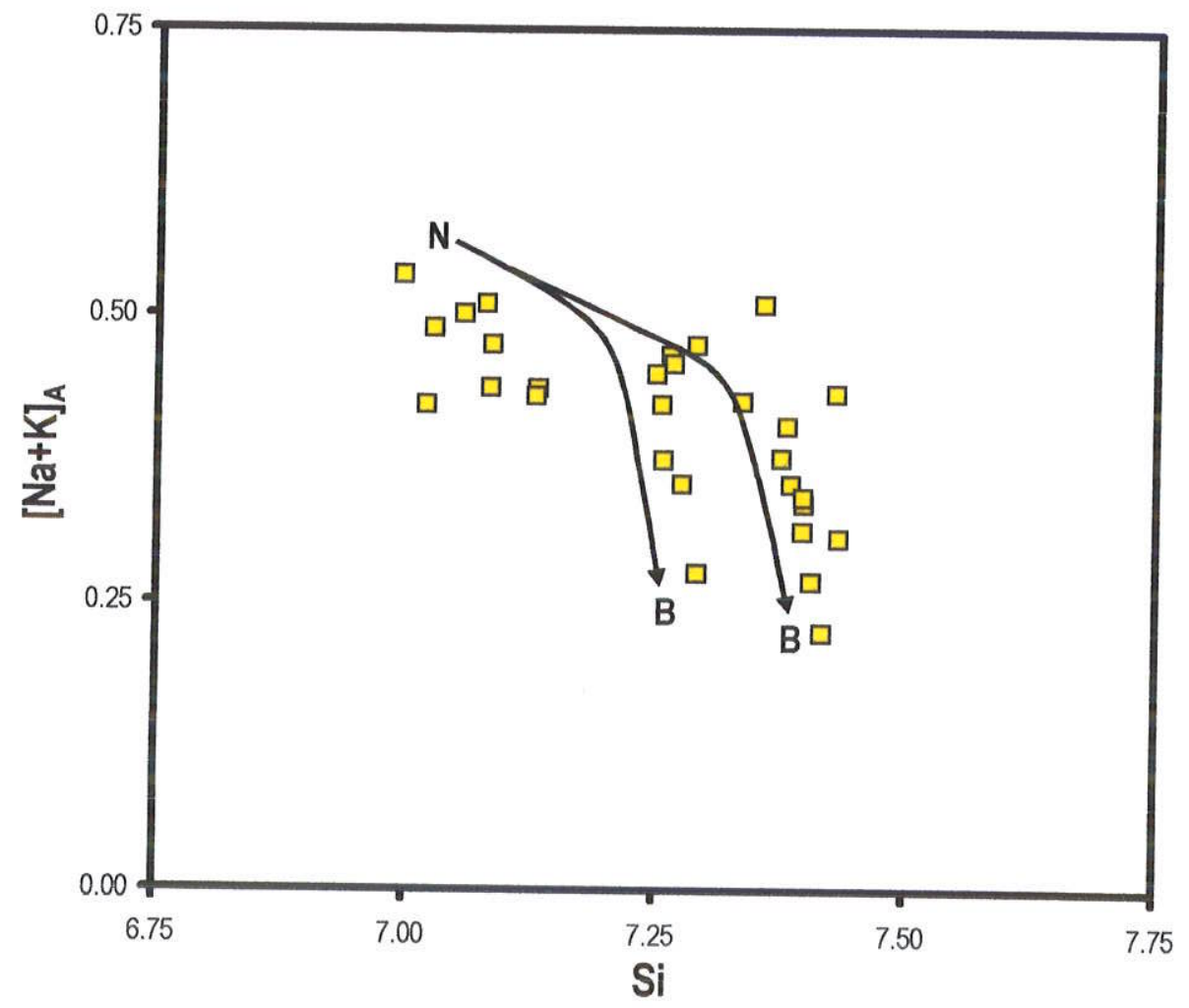

(b)

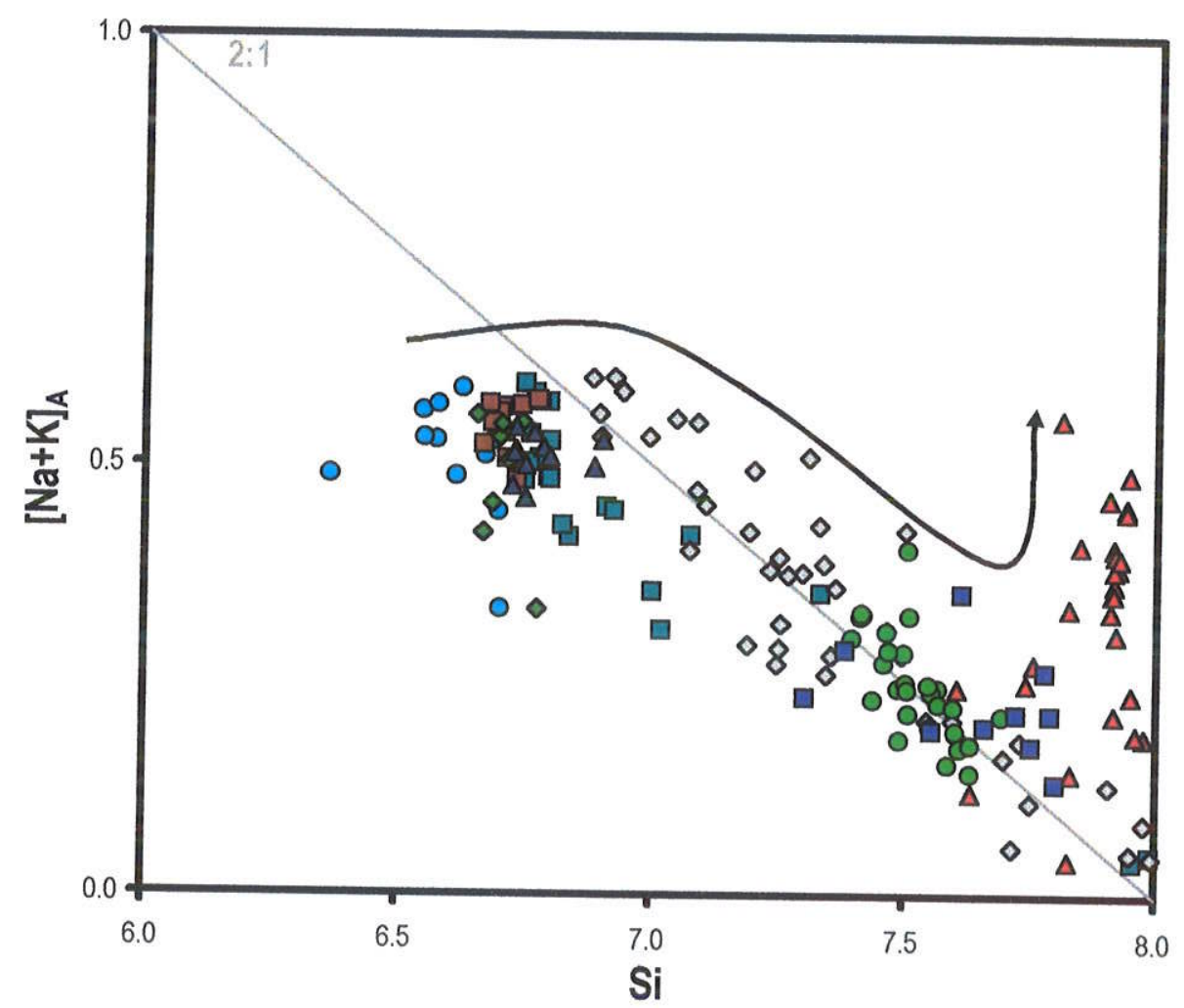

Figura IV.18: Correlação entre as proporções catiônicas Si $x[\mathrm{Na}+\mathrm{K}]_{A}$ em anfibólios das associações (a) alcalina I (apenas Amostra 78A); e (b) alcalina II dos Granitos da Graciosa. Curvas mostram tendências evolutivas mais importantes ( $N$ - núcleo; $B$ - borda). 
(a)

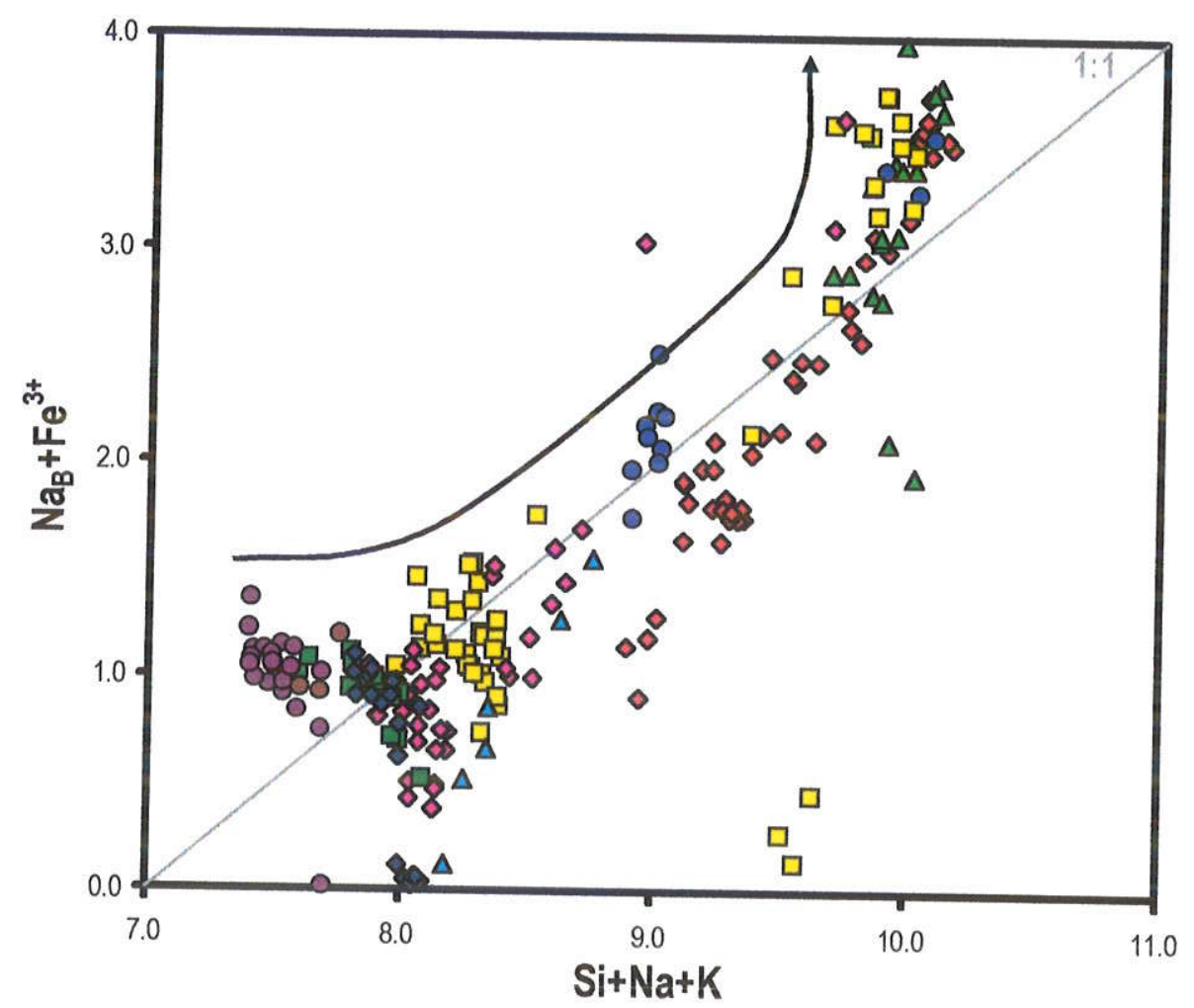

(b)

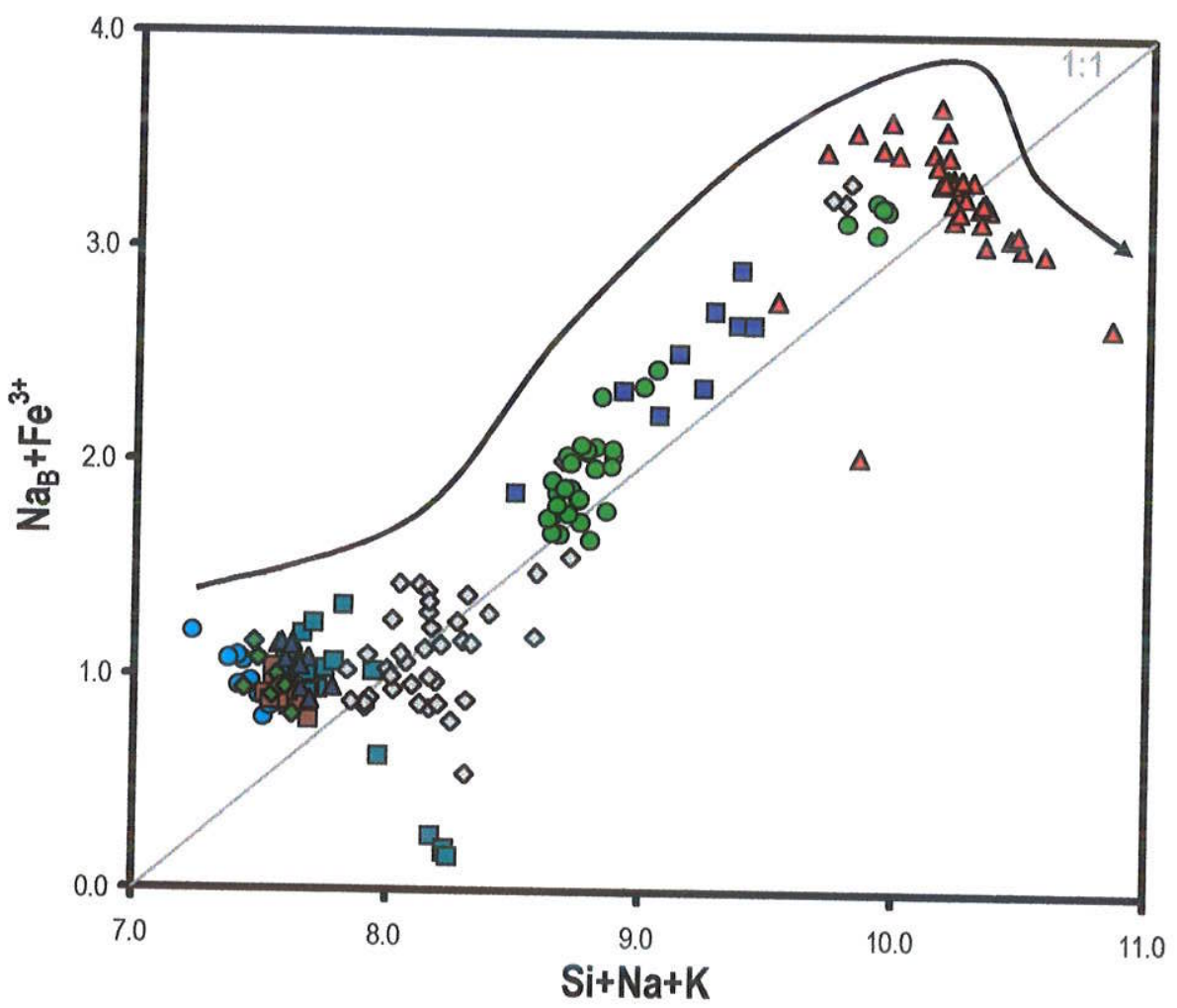

Figura IV.19: Correlação entre as proporções catiônicas $[\mathrm{Si}+\mathrm{Na}+\mathrm{K}] \times\left[\mathrm{Na}_{B}+\mathrm{Fe}^{3+}\right]$ em anfibólios das associações (a) alcalina I; e (b) alcalina II dos Granitos da Graciosa. Curvas mostram tendências evolutivas mais importantes. 
(a)

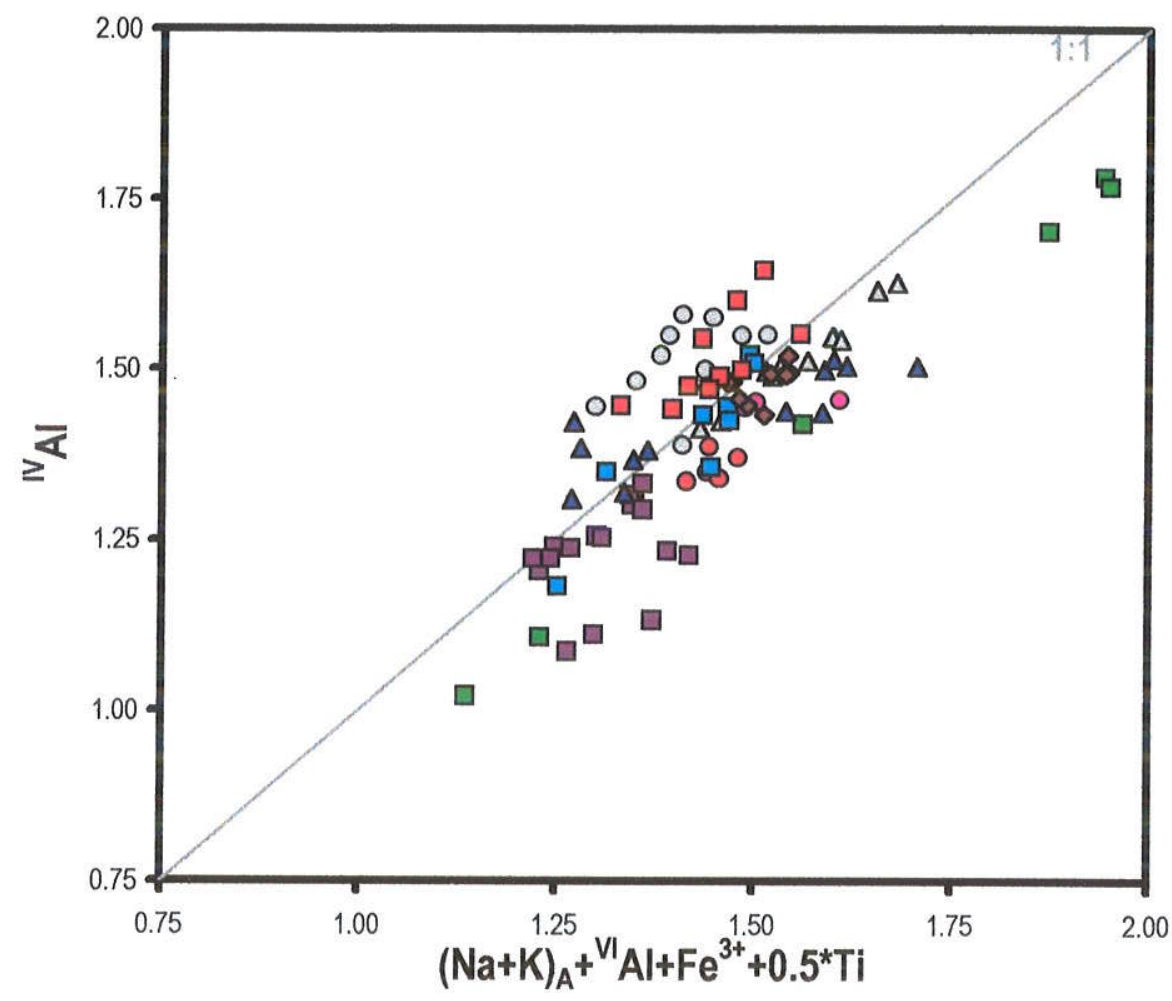

(b)

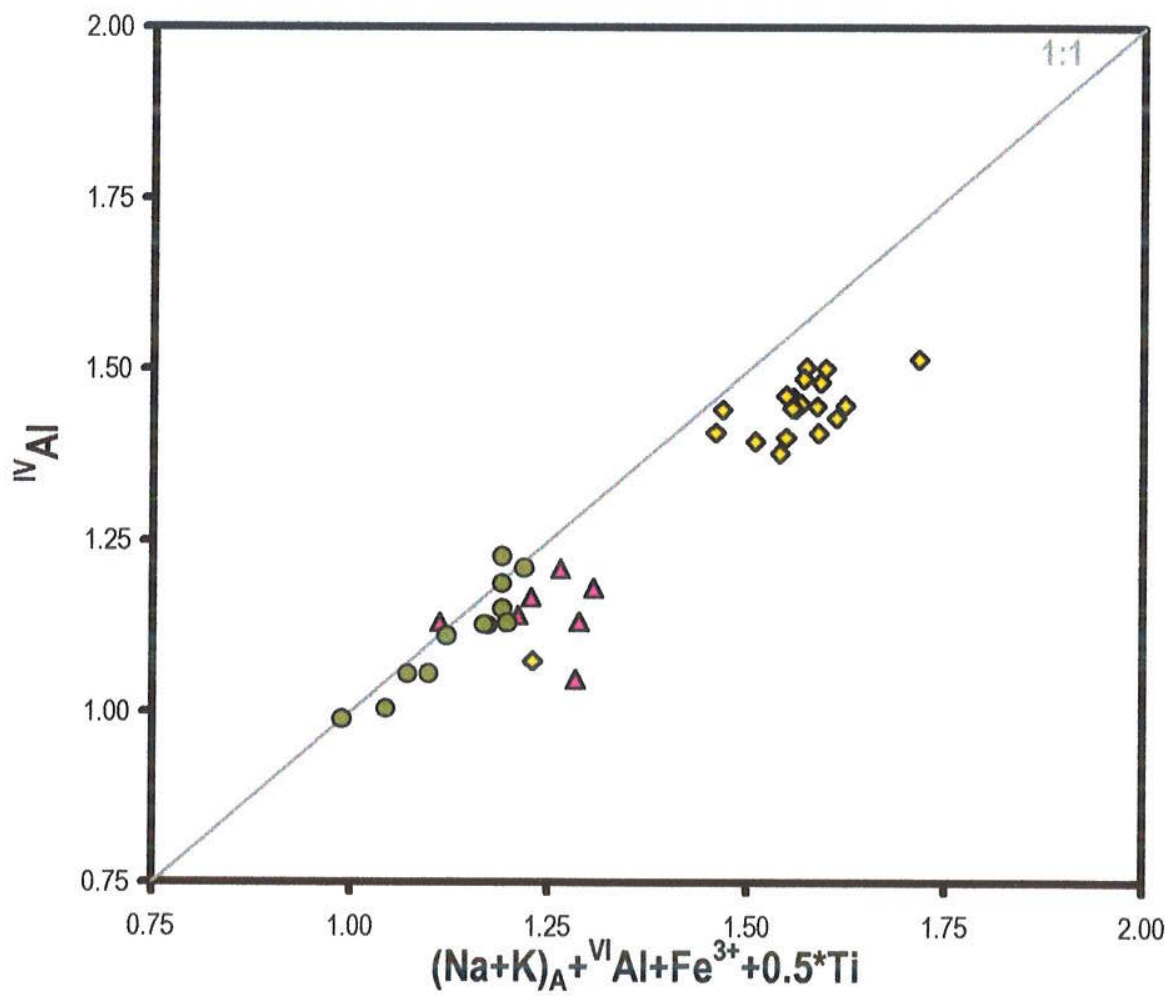

Figura IV.20: Correlação entre as proporções catiônicas $\left[\mathrm{Na}+\mathrm{K}_{A}+{ }^{\mathrm{IV}} \mathrm{Al}+\mathrm{Fe} e^{3+}+1 / 2 \mathrm{Ti} \times{ }^{\mathrm{N}} \mathrm{Al}\right.$ em anfibólios (a) da associação aluminosa; e (b) das rochas monzodioríticas e associadas dos Granitos da Graciosa. 


\section{Biotita}

Biotita é a fase máfica mais importante nas rochas da associaçāo aluminosa. sendo fase máfica única na grande maioria dos álcali-feldspato granitos desta associação. Nas associações a/calinas. biotita aparece apenas como produtos de alteração de anfibólio primário. As características texturais contrastantes entre as biotitas das associaçôes alcalinas e aluminosa justificam a descrição de cada uma delas em separado.

Quimicamente, são todas biotitas ricas na molécula annita, com razōes $\mathrm{Fe} /[\mathrm{Fe}+\mathrm{Nig}]$ relativamente altas e teores de "Al variáveis (Figura IV.21; Tabela IV.7). Assim como ocorre com os anfibólios, as principais variações quimicas podem ser explicadas por uma combinação de mecanismos de substituição:

$$
\begin{aligned}
& {\left[\mathrm{Fe}^{2+}, \mathrm{Mn}, \mathrm{Mg}\right]^{\gamma}+2^{*}[\mathrm{Al}]^{\gamma} \Leftrightarrow[\mathrm{G}]^{\gamma}+2^{*}[\mathrm{Si}]^{\top}} \\
& 3^{*}\left[\mathrm{Fe}^{2+}, \mathrm{Mn}, \mathrm{Mg}\right]^{\gamma} \Leftrightarrow[\square]^{\gamma}+2^{*}[\mathrm{Al}]^{\gamma} \\
& 2^{*}\left[\mathrm{Fe}^{2+}, \mathrm{Mn}, \mathrm{Mg}\right]^{\gamma} \Leftrightarrow[\mathrm{O}]^{\gamma}+[\mathrm{Ti}]^{\gamma}
\end{aligned}
$$

A resultante dessa combinação pode ser escrita com base em uma equação de balanço de cargas entre os sítios Y e T:

$$
\left[\mathrm{Fe}^{2+}, \mathrm{Mn}, \mathrm{Mg}\right]^{\mathrm{y}}+0,5^{*}[\mathrm{All}]^{\mathrm{y}}+[\mathrm{Ti}]^{\mathrm{y}} \Leftrightarrow[\mathrm{Al}]^{\mathrm{i}}
$$

A atuação destes mecanismos parece demonstrada pela boa correlação obtida (Figura IV.22).

\section{Associacões alcalinas}

Nas associaçōes alcalinas, biotita aparece como uma variedade com pleocroísmo em tons de vermelho intenso, seja na forma de cristais isolados intersticiais (Prancha 3j), ou em agregados de cristais aciculares com anfibólio sódico (Prancha 3g-i; cf. acima). Os agregados formam franjas irregulares, compostas por pequenas agulhas dos dois minerais, sobrecrescidas sobre anfibólio primário e, em alguns casos, também sobre clinopiroxênio. Aparecem também preenchendo fraturas.

Como já destacado, tais feiçōes sugerem que a formação dessa variedade de biotita está relacionada à substituição de anfibólio primário. A presença de agregados radiados, franjas, e o preenchimento de fraturas indicam que a formação se deu nos estágios pós-magmáticos de cristalização. A semelhança no padrão pleocróico das agulhas de biotita e dos cristais intersticiais leva à conclusão de que toda a biotita presente nestas amostras tem origem pós-magmática. 
Na associação alcalina //, em algumas das variedades que contém anfibólio mais cálcico, as biotitas apresentam padrāo pleocróico diferenciado, predominando tons de castanho. As caracteristicas texturais, entretanto, são semelhantes às acima descritas; elas aparecem ora como cristais isolados (Prancha 3n). ora substituindo anfibólio (Prancha 30). Apesar das relações texturais serem menos conclusivas quanto ao estágio em que ocorreu sua cristalização. a semelhança textural com as biotitas acima indica a cristalização nos estágios pós-magmáticos.

Como já sugerido pelas variaçoes no pleocroismo, é possivel diferenciar quimicamente as biotitas presentes nos sienitos da associação a/calina / daquelas presentes nos granitos da associação alcalina //. Enquanto as primeiras apresentam razões $\mathrm{Fe} /[\mathrm{Fe}+\mathrm{Mg}]$ sempre muito próximas de 1. as últimas têm razōes em torno de 0,9. Além disso, os teores de $\mathrm{Al}^{N}$ sāo também distintos, mais variáveis na associação a/calina /l.

Nas biotitas da associação alcalina l, os valores de Alv estão no intervalo 1,41-2,17. predominando os valores inferiores a 2. Micas como estas sāo por vezes denominadas "tetrassilícicas" (cf. Robert e Maury. 1979; Czamanske e Dillet, 1988), dados os elevados teores de Si nas posiçōes tetraédricas (Figura IV.23a); o uso deste termo foi. entretanto. desencorajado por Rieder et al. (1998).

Ainda assim. deve ser destacado que referências a micas como estas são bastante escassas na literatura geológica, tendo sido encontradas por nós apenas nos trabalhos de Robert e Maury (1979) e Czamanske e Dillet (1988). Em ambos os casos, as biotitas aparecem associadas a anfibólios sódicos. Nos comenditos manganesíferos estudados por Robert e Maury (1979), os teores de Si tetraédrico atingem valores superiores a 7 . É notável que no caso dos pórfiros peralcalinos descritos por Czamanske e Dillet (1988), as biotitas apareçam como produtos de alteração de anfibólio, de maneira semelhante à aqui observada; os teores de Si por eles encontrados estão no intervalo 6.607,30, significativamente mais altos que os das biotitas da associação a/calina / (i.é. 5,56-6,32; Figura IV.21a).

Os teores mais altos de Alv são observados nas biotitas da associação alcalina // (i.é. 2.21-2.41; Amostra 15. Figura IV.21a). Estas composiçōes são as mais próximas das composicões magmáticas

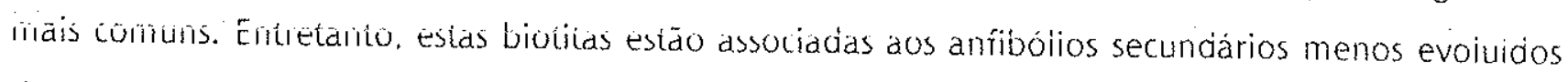
do conjunto. o que sugere que a formação dessas biotitas se deu nos estágios pós-magmáticos de cristalização: porém, tais estágios foram caracterizados por uma menor alcalinidade quando comparados com os das demais amostras. (cf. acima) 
De fato, é nas amostras 25B e 59A que se observam as maiores variaçōes nos teores de Alv (0.51-2.09). Entretanto, essas variações estāo evidentemente relacionadas a uma diminuição da ocupação dos sítios do K (Figura IV.23a), bem como a fechamentos baixos (i.é. 90\%) das análises. o que demonstra que essas variaçōes estāo ligadas à alteração dạ biotita, e não são caracteristicas originais das biotitas.

Além das variaçoes nos teores de $\mathrm{Al}^{*}$. são importantes também variaçôes nos teores de $\mathrm{Ti}$ (Figura IV.24; Equação $(V .14$ ), e Al: como esperado, está ausente na grande maioria das amostras (Tabela IV.7: Equação IV.13). A ausência de All e o relativo enriquecimento em Ti das biotitas da Amostra 15 corrobora a conclusão de que se tratam também de fases pós-magmáticas.

\section{Associacão aluminosa e rochas monzodioríticas}

As biotitas dos granitos da associação aluminosa aparecem predominantemente como cristais isolados ou em agregados de 3-5 grãos. subédricos a anédricos, normalmente intersticiais aos cristais dos minerais félsicos (Pranchas $3 p$ e $3 q$ ). Os padrōes pleocróicos são variáveis, desde verde pálido a amarelo até padrões em que predominam os tons de castanho e vermelho.

Nas amostras onde coexistem com anfibólio. muitas vezes as biotitas o substituem parcialmente (Prancha $3 \mathrm{~m}$ ). Quartzo, magnetita, immenita e fluorita estão normalmente associados nestas áreas. A formaçāo de cristais intersticiais, concordantes com os contornos dos demais, sugere que a substituição se deu em condicõos magmáticas, em contraste com as variedades das associaçōes alcalinas.

Nas rochas monzodioríticas, os cristais de biotita são semelhantes aos da associação aluminosa; entretanto, tendem a ser mais euédricos.

Quimicamente, quando comparadas com as micas das associações a/calinas, as biotitas deste grupo mostram composiçoes que se distribuem por um intervalo mais amplo de razōes $\mathrm{Fe} /[\mathrm{Fe}+\mathrm{Mg}$ ] (i.é. 0,65-0.98 - associação aluminosa: 0,51-0,64 - rochas monzodioriticas). Considerando-se cada amostra individualmente, contudo, observa-se que os limites de variação são mais limitados, da ordem de no máximo 0.1 cátions. De maneira geral, o enriquecimento em Fe se dá dos termos monzograniticos em direço aos alcall-feldspato graniticos, acompanhando a evolução do indice $M$ das rochas em que ocorrem. (cf. Figuras IV.1. IV.2 e IV.21b). 
O intervalo de variação dos teores de $\mathrm{Al}^{\mathrm{N}}$. por sua vez, é relativamente restrito $(2.07-2.56)$, com uma queda perceptivel nos termos mais ferrosos, que leva a composiçoes mais próximas da molécula annita (Figura IV.21 b).

Em contraste com as biotitas das associações alcalinas, os teores de Alv" são apreciáveis. sendo que sua entrada na estrutura dos minerais é descrita pela Equacāo IV.13 (Figura IV.25). Os teores de Ti são semelhantes aos observados nas associaçōes alcalinas, porém as variacōos são menos sistemáticas. 
(a)

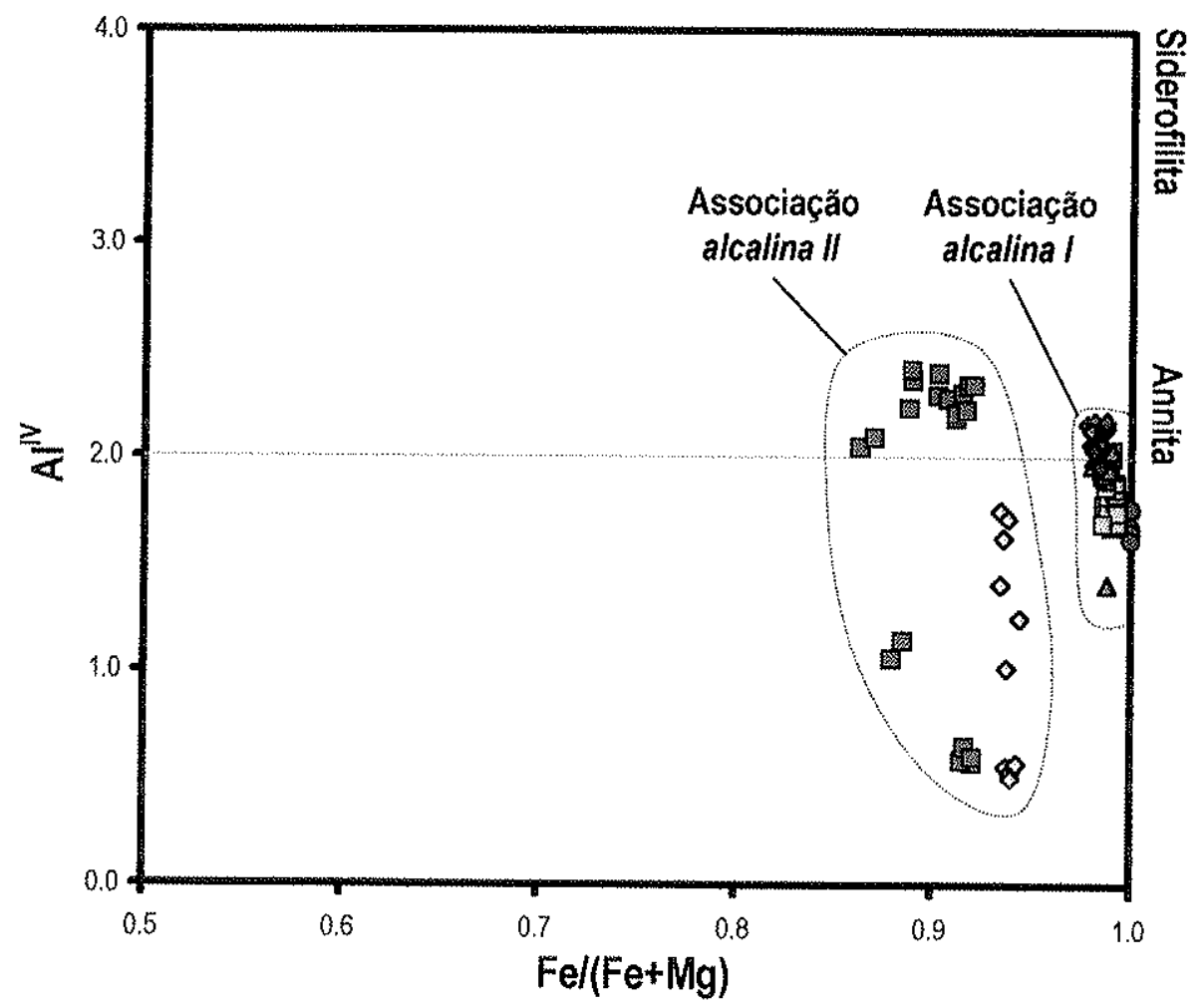

(b)

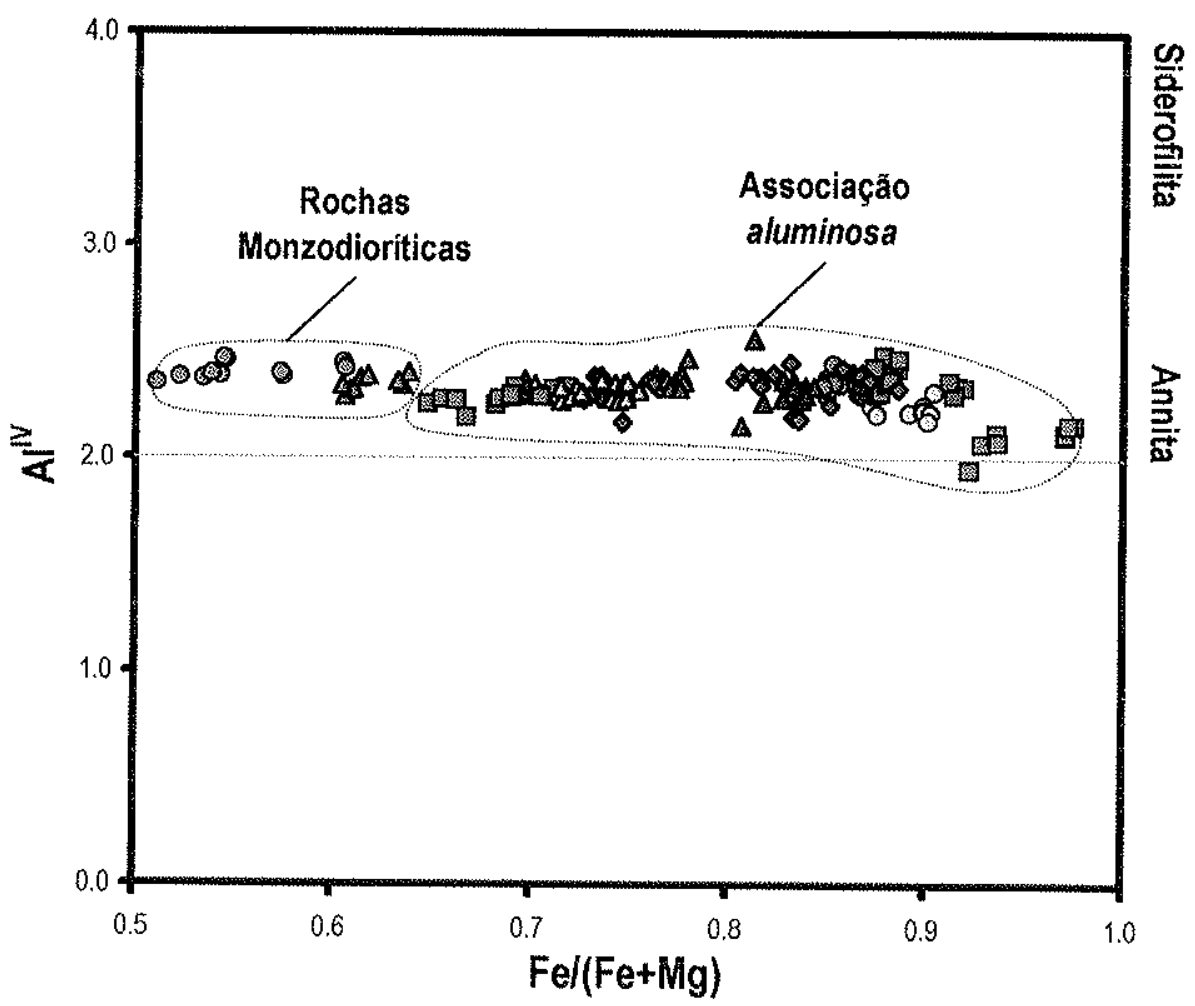

Figura IV.21: Correlaçäo entre as proporçôes cationicas $\mathrm{Fe} /[\mathrm{Fe}+\mathrm{Mg}] \times \mathrm{A}^{\prime V}$ em biotitas das associações (a) alcalinas e (b) da associaçâo aluminosa e das rochas monzodioriticas e associadas dos Granitos da Graciosa. 
(a)

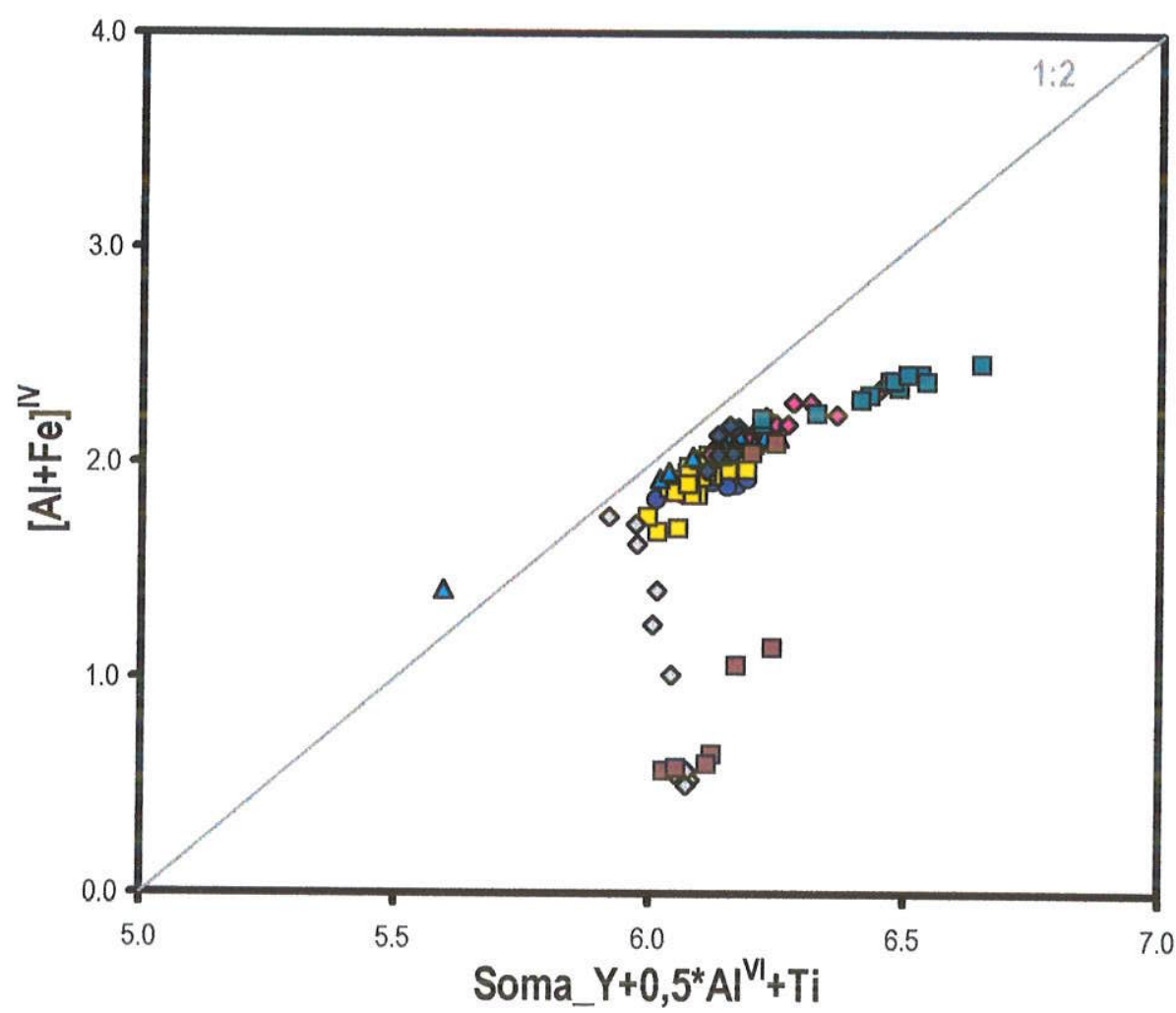

(b)

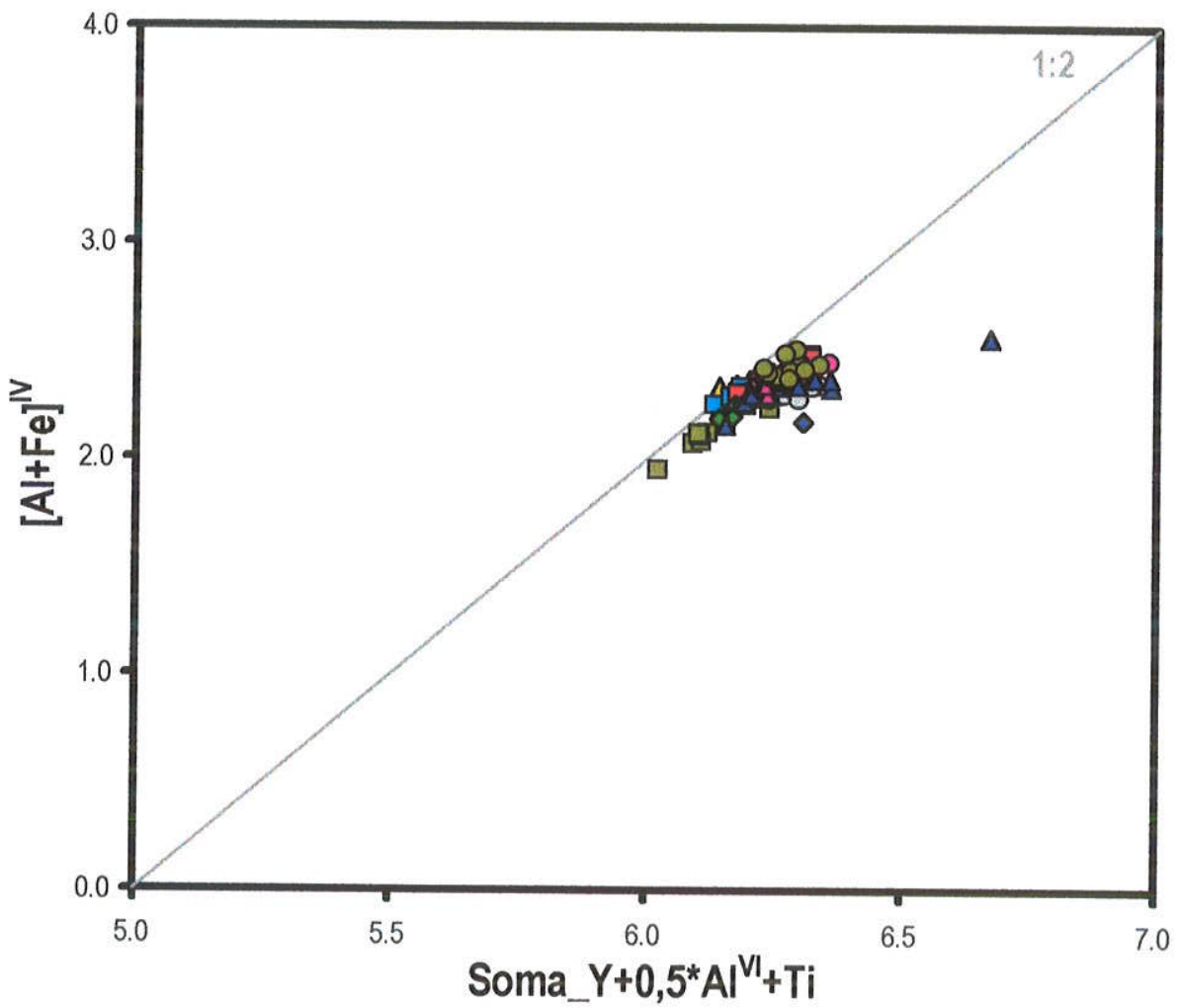

Figura IV.22: Correlação entre as proporções catiônicas [Soma_ $\left.Y+0,5^{*} A{ }^{N \prime}+T i\right] \times A{ }^{N}$ em biotitas das associações (a) alcalinas e (b) da associação aluminosa e das rochas monzodioríticas dos Granitos da Graciosa. 
(a)

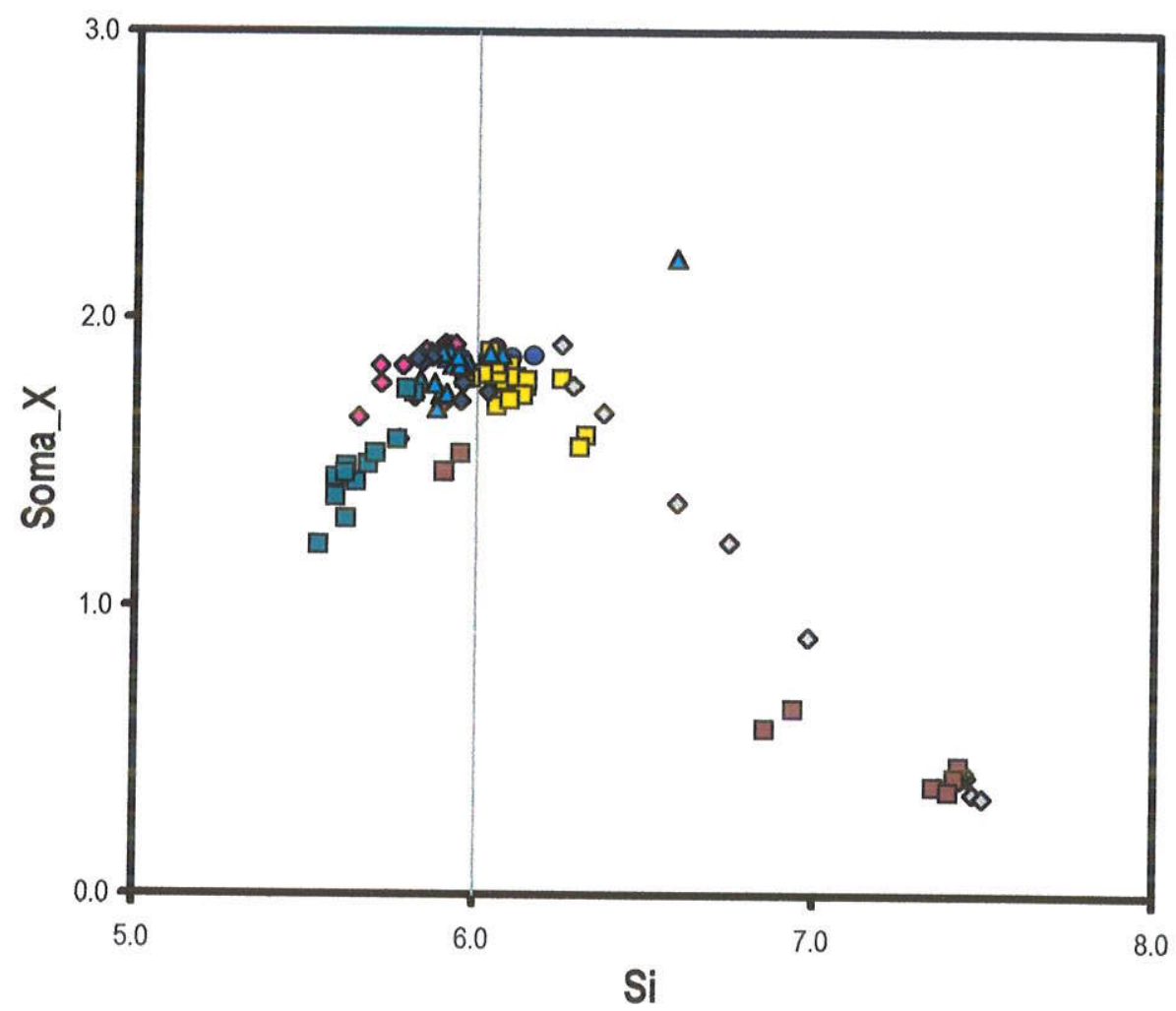

(b)

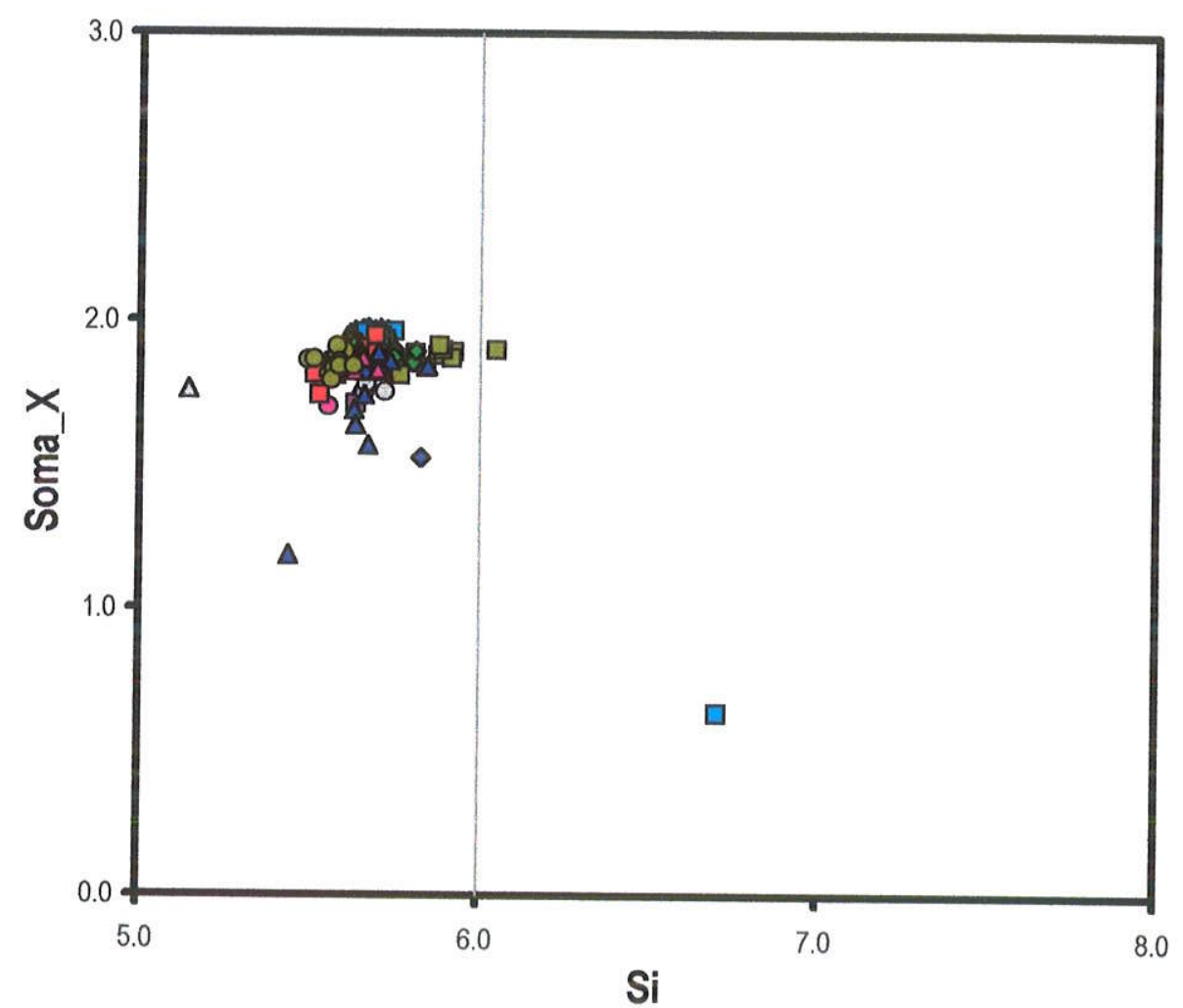

Figura IV.23: Correlação entre as proporçôes cationnicas Si x Soma_X em biotitas das associações (a) alcalinas e (b) da associação aluminosa e das rochas monzodioríticas dos Granitos da Graciosa. 


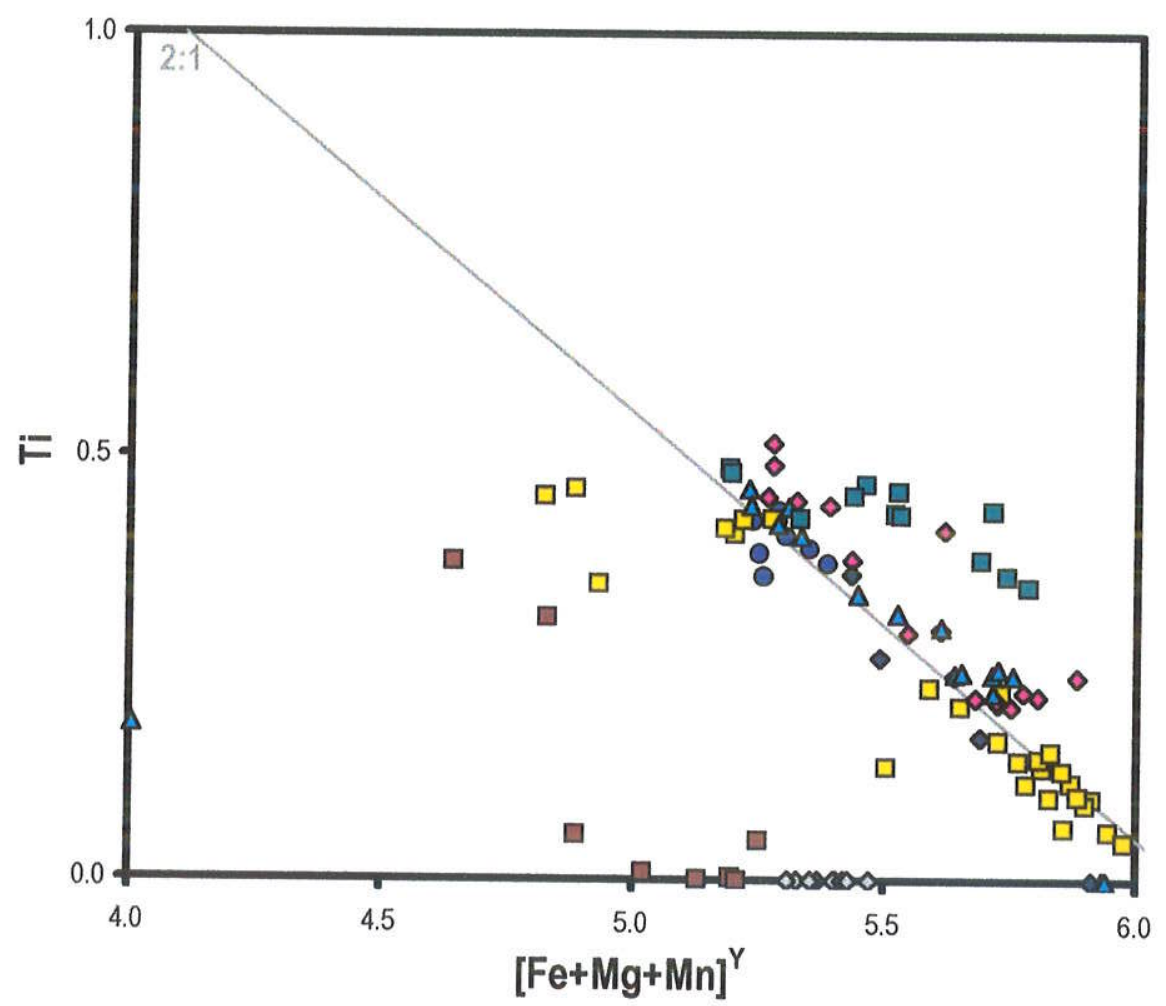

Figura IV.24: Diagramas catiônicos $[\mathrm{Fe}+\mathrm{Mg}+\mathrm{Mn}]^{\gamma} \times \mathrm{Ti}$ mostrando a variabilidade química observada em biotitas das associações alcalinas dos Granitos da Graciosa.

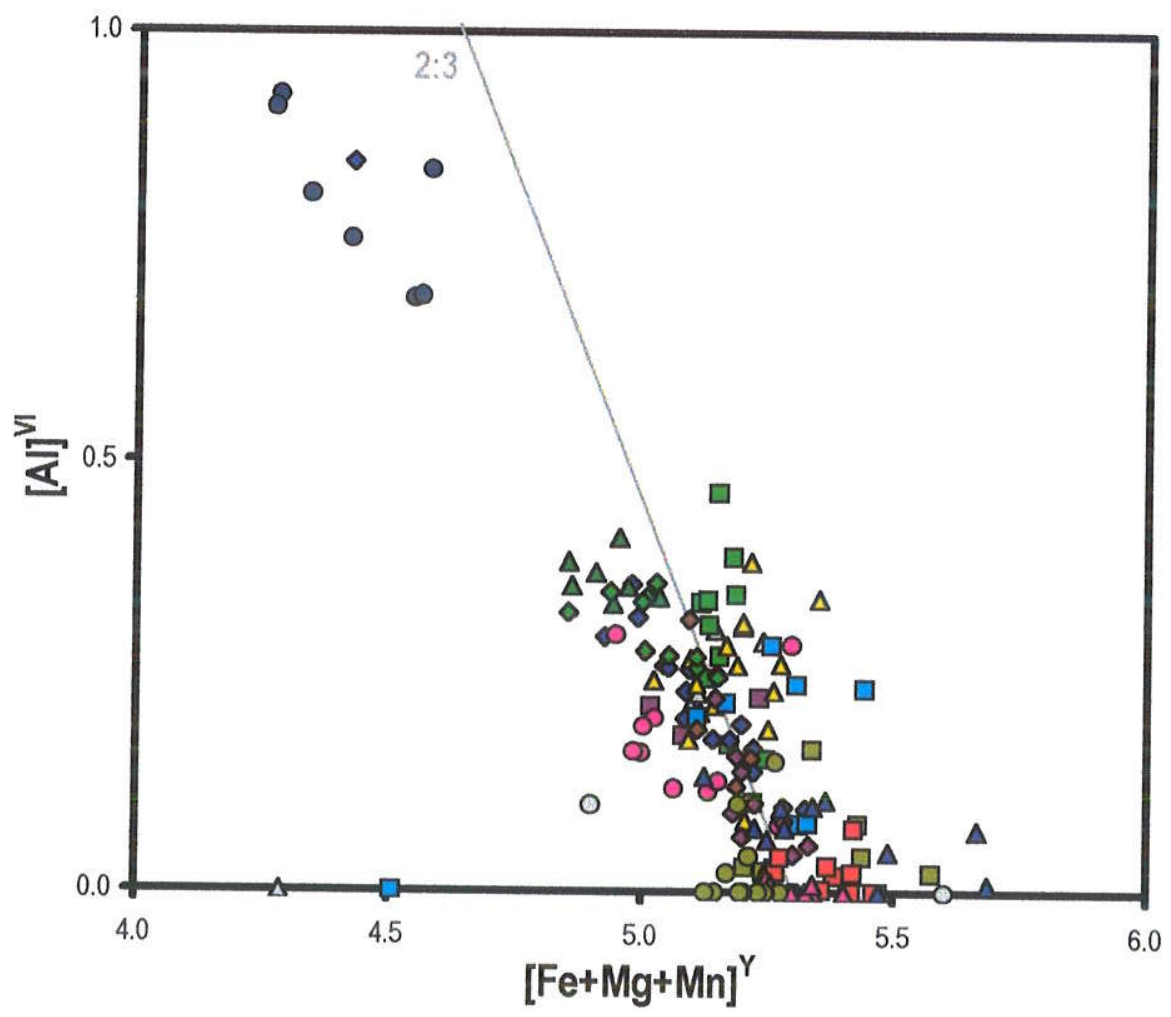

Figura IV.25: Correlação entre as proporções catiônicas $[\mathrm{Fe}+M g+M n]^{\gamma} \times A^{l^{\prime \prime}}$ em biotitas da associação aluminosa e das rochas monzodioríticas dos Granitos da Graciosa. 


\section{V.2. MINERAIS FÉLSICOS}

\section{Plagioclásio}

O plagioclásio é fase importante em todas as fácies de sienogranitos da associação aluminosa e também nos quartzo sienitos do Maciço Farinha Seca. Nas rochas monzodioriticas é, naturalmente, a fase félsica principal.

\section{Texturas}

Nos sieno- e monzogranitos da associação aluminosa, o plagioclásio forma cristais subédricos a euédricos que em geral apresentam bordas albíticas sobrecrescidas quando em contato com o feldspato alcalino que acabam por conferir contornos externos mais anédricos (Prancha 4d). São tipicamente zonados ao microscópio petrográfico (Prancha 1c), mostrando quase sempre zoneamentos primários de caráter oscilatório que se sobrepōem a zoneamentos progressivos normais.

Nos álcali-feldspato granitos com biotita (Amostra 85B), os cristais de plagioclásio aparecem por vezes manteados por feldspato alcalino pertítico. No contato entre os dois, observa-se o desenvolvimento de albita tardia, sempre em continuidade ótica com as lamelas albíticas do feldspato alcalino. (Prancha 4e)

Nas rochas monzodioríticas e associadas, o plagioclásio aparece como cristais mais tipicamente tabulares, subédricos a euédricos, com zoneamentos concêntricos normal e oscilatório bem marcados (Prancha 4a).

Cristais tipicamente anédricos ocorrem nos quartzo sienitos do Maciço Farinha Seca (Amostra 16B3) que também se destacam pelo seu caráter relativamente mais homogêneo. Apresentam abundantes inclusões de quartzo, mais comuns nas borda dos cristais, que lembram intercrescimentos granofíricos, indicativos de cristalização simultânea (Prancha 4b).

\section{Quimismo}

As composições do plagioclásio presente nas variedades da associaçāo aluminosa encontram-se em todos os casos no intervalo do oligoclásio, com teores de An entre 10 e $20 \%$ molecular. A única exceção é a Amostra 32, que contém plagioclásio significativamente mais sódico, com composições albíticas, no intervalo $A n_{5-10}$. (Figura IV.26a). As variações composicionais devem-se essencialmente às moléculas de $\mathrm{An}$, Ab e Or; os teores de $\mathrm{Ba}$, Sr e Fe encontram-se em geral próximos ou abaixo do limite de detecção (cf. Tabela IV.8). 
Na Figura IV.27a é apresentado um perfil analítico típico de plagioclásio dessa associação. Verifica-se diminuição mais ou menos contínua dos teores de An do núcleo para a borda, onde freqüentemente se justapõem os sobrecrescimentos albíticos tipicamente pós-magmáticos. Destaca-se também o leve incremento no conteúdo da molécula de Or dos núcleos para as zonas intermediárias, seguido por diminuição em direção às bordas dos grãos. O padrão mais típico de variações químicas é dado por zonas internas mais homogêneas, seguidas de zoneamento oscilatório nas zonas intermediárias e bordas dos cristais; este último é caracterizado por variaçōes mais bruscas, de menor espaçamento, intercaladas por variaçōes mais suaves, mais espaçadas, bem marcadas pelas moléculas de An e Ab.

Em algumas amostras (e.g., 2E, 7B3 e 32), as tendências de variação núcleo $\rightarrow$ borda não são tão claras como no exemplo acima, sendo parcialmente mascaradas por variaçōes oscilatórias algo mais acentuadas, de forma que os intervalos de variação entre núcleo e borda observados na maioria dos grãos analisados são semelhantes.

As bordas pós-magmáticas são constituídas de albita praticamente pura.

O plagioclásio das rochas monzodioríticas, por sua vez, apresenta zoneamentos químicos com espectro de variaçăo bem mais amplo (Figura IV.26b). Um dos perfís analíticos típicos obtidos para a amostra 59E é destacado na Figura IV.27b. Observa-se uma zona central de composição labradorítica $\left(A n_{50-55}\right)$ que passa em direção á periferia para oligoclásio $\left(A n_{22 \cdot 25}\right)$ de forma contínua e relativamente rápida; ambas com composições pouco variáveis. As variaçōes de caráter oscilatório são melhor marcadas nas zonas mais internas do cristal. Os teores em Or aumentam até um máximo nas zonas intermediárias para após diminuir em direçãos às zonas mais externas. Padrões similares de variação composicional aparecem nos grãos examinados da amostra 16B4, mas embora as composições das zonas de borda sejam similares, nesta os núcleos são bem mais sódicos (andesina: $A n_{40-45}$ ).

O plagioclásio anédrico presente nos quartzo sienitos, mais homogêneo, apresenta composiçōes no intervalo $A n_{19-24}$, semelhante às observadas para as zonas periféricas dos cristais das rochas monzodioríticas para os núcleos dos cristais dos sieno- e monzogranitos da associação aluminosa. (Figura IV.26b).

\section{Feldspato alcalino}

Feldspato alcalino é a fase félsica mais importante nas rochas estudadas, à excessão das rochas monzodioríticas. Normalmente, aparece como cristais subédricos com contorno externo mais 
anédrico intersticial aos demais minerais. É sempre pertítico ou mesopertítico; ao microscópio mostram freqüentemente zoneamentos concêntricos, dados por variações no padrão de extinção. pela morfologia e abundância de lamelas albíticas, ou ainda por anéis albíticos.

\section{Texturas}

Os cristais de feldspato alcalino das variedades menos diferenciadas da associaçāo a/calina / (Amostra 87A) são pertíticos, com finas lamelas de exsolução (Prancha 4f), em contraste com as demais fácies que mostram feldspatos sempre mesopertíticos (Pranchas $4 \mathrm{~g}$ e $4 \mathrm{~h}$ ). Os álcali-feldspato granitos porfiriticos finos desta associação apresentam cristais de feldspato alcalino com uma zona intermediária bastante rica em albita, que por vezes é mais abundante que a fase potássica, sugerindo que parte do componente albítico pode ser de origem tardia (Prancha 4g).

Os feldspatos alcalinos da associaçāo alcalina // são semelhantes aos cristais mesopertíticos da associação alcalina \%. Mais freqüentemente mostram diferenças no padrāo de exsolução do centro para a borda, provavelmente indicativas de zoneamentos concêntricos relativamente bruscos (Prancha 4h).

Os cristais observados nas rochas da associação aluminosa, por sua vez, são mais variados quanto a forma e distribuição das lamelas. Nos sienogranitos porfiríticos, os majores cristais normalmente apresentam-se mais euédricos, sendo também mais pobres em lamelas, que muitas vezes se distribuem marcando contornos euédricos de crescimento (Prancha $4 j$ ). No restante dos sienogranitos, os cristais se assemelham aos observados na associação alcalina //. apesar da menor quantidade de lamelas albíticas (Prancha 4k). Por fim, nos álcali-feldspato granitos com biotita, os cristais de feldspato alcalino ora são mesopertíticos, com lamelas bem definidas (Prancha $4 \mathrm{~m}$ ), ora apresentam-se mais homogêneos, sem lamelas ou com lamelas muito finas e difusas (Prancha 4l). Zoneamentos bruscos são também relativamente comuns (Pranchas 41 e $4 \mathrm{~m}$ ).

As rochas monzodioríticas, em contraste, são relativamente pobres em feldspato alcalino (cf. Figura IV.2; Tabela IV.2), que aparece como cristais intersticiais, homogêneos ou com finas lamelas de exsolução.

\section{Quimismo}

Os resultados obtidos a partir das integraçōes das composições de lamelas e hospedeiros mostram, de maneira geral, diferenças bem marcadas entre as associaçōes petrográficas. Estas variações são dadas essencialmente pelas moléculas Or e Ab; os teores em An são sempre muito 
baixos e as quantidades de $\mathrm{Sr}$. Ba e Fe encontram-se também muito próximas ou abaixo dos limites de detecção (cf. Tabela IV.9).

Na associação alcalina /, apesar das composições obtidas mostrarem uma dispersão ao longo do eixo Ab-Or relativamente grande, a maior parte dos dados integrados se concentra em um intervalo mais restrito $\left(\mathrm{Or}_{35-55}\right)$. Na grande maioria das amostras, verifica-se uma tendência de aumento nos teores de $\mathrm{K}$ do núcleo para a bordas dos cristais. Esta tendência é mais acentuada nas amostras menos evoluídas da associação. em que os intervalos de variação são mais amplos e os teores de Or em geral mais altos. Os teores da molécula anortita, apesar de baixos $\left(A n_{0-4}\right)$, são os maiores entre todas as rochas estudadas. (Figura IV.26c)

É interessante notar que os feldspatos das Amostras $81 \mathrm{D}, 81 \mathrm{~B}$ e $87 \mathrm{~B}$ são anômalos em relação ao restante do conjunto por apresentarem variaçōes químicas mais amplas. É nessas amostras que se desenvolvem as zonas intermediárias ricas em lamelas albíticas descritas acima; o resultado das integrações não só confirma essa observação, mas mostra que o restante dos cristais é relativamente mais rico em Or que os feldspatos mais comuns da associação. Além disso, as variaçōes núcleo $\rightarrow$ borda são menos sistemáticas, com alguns casos de diminuição do $\mathrm{K}$ em direção à borda. Todas essas características indicam que houve uma maior mobilidade do componente albítico dos feldspatos alcalinos.

Em comparação com os feldspatos alcalinos da associação alcalina /, os cristais estudados na associação alcalina // se mostram mais ricos em Or, com composições que se distribuem no intervalo $\mathrm{Or}_{43.63 .}$. Assim como naquela associação, observa-se uma tendência de aumento dos teores de or em direção às bordas dos cristais. Neste contexto, a Amostra 25B figura como uma exceção, já que mostra variaçôes muito mais amplas e bordas mais pobres em Or que os respectivos núcleos. (Figura IV.26d).

Na associação aluminosa (Figura IV.26a) as variações encontradas para as moléculas Ab e Or são significativamente maiores e, pelo menos aparentemente, mais consistentes, ao longo do intervalo Or $_{44-97}$. Os teores mais baixos de or correspondem às variedades de álcali-feldspato granitos, no intervalo Or $_{44.64}$. É notável a sobreposição dessas composiçôes com aquelas dos feldspatos da associação a/calina //. Entretanto, as tendências de variação química são contrárias, verificando-se diminuição do teor em Or em direção à borda dos grãos. Os sieno- e monzogranitos contêm sistematicamente feldspatos alcalinos mais ricos em Or, acima de $65 \%$ molecular, compativel com o caráter subsolvus destes granitos, em que os feldspatos alcalinos coexistem com plagioclásio 
sódico. As variaçōes composicionais destes feldspatos alcalinos, por outro lado, são muito particulares. Se, por um lado, observa-se diminuicão na molécula de or quando se comparam megacristais com cristais da matriz nas rochas porfiríticas, por outro, as variaçoes composicionais observadas para a maioria dos grãos das diversas amostras evidencia aumento progressivo de Or com avançar da cristalização. Este padrão não é compativel com a cristalização simultânea de feldspato alcalino e plagioclásio em ambientes sob pressão litostática e conteúdo constante de voláteis, para os quais os dados experimentais mostram que ambos os feldspatos deveriam tornar-se progressivamente mais albíticos; mas sim, sugere incrementos progressivos, particularmente da atividade de $\mathrm{H}_{2} \mathrm{O}$ no sistema.

Por fim, os feldspatos alcalinos das rochas monzodioríticas e dos quartzo sienitos associados são em média ricos em or ( $84-91 \%$ e $75 \%$, respectivamente), (Figura IV.26b) 
(a)

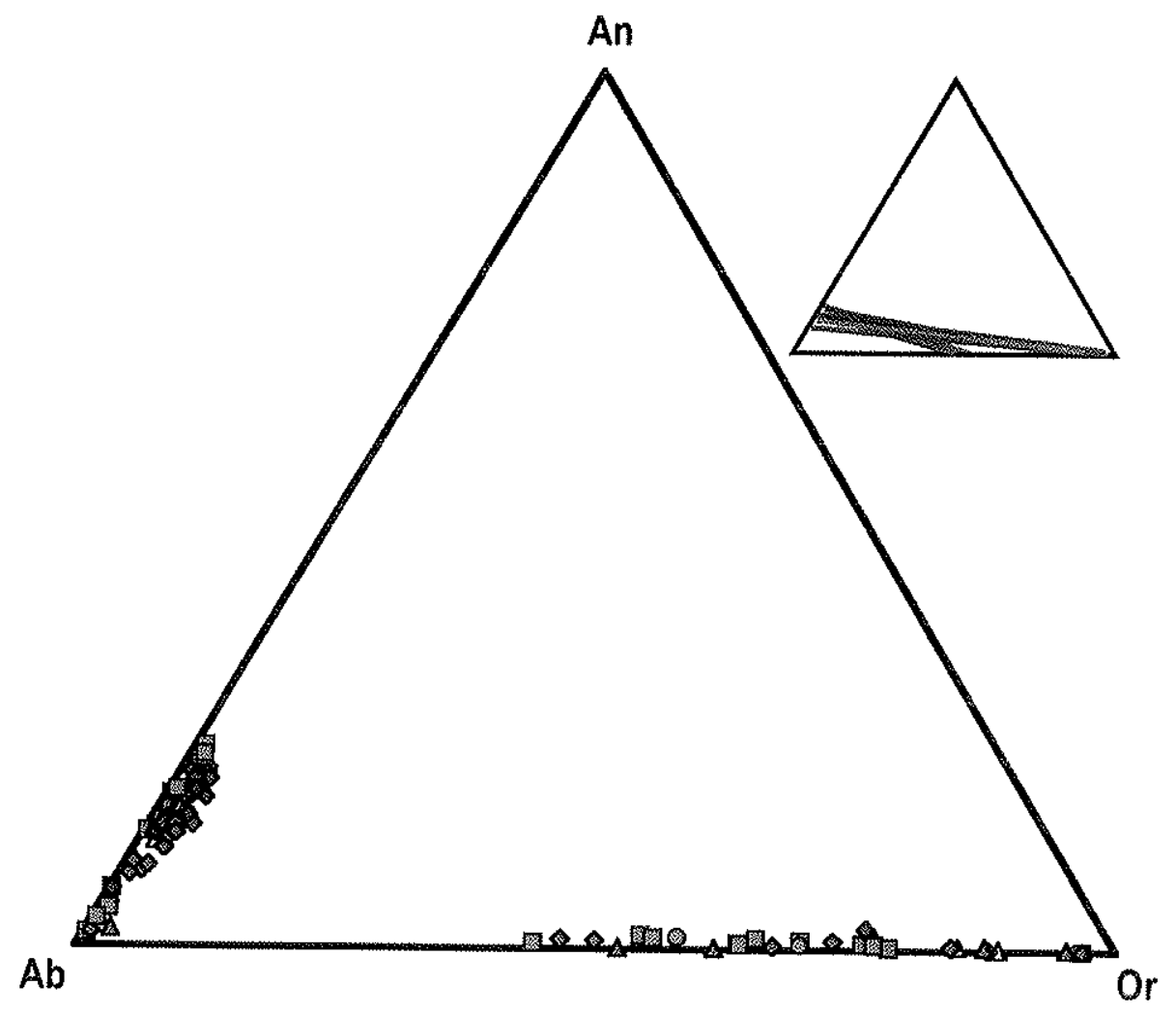

(b)

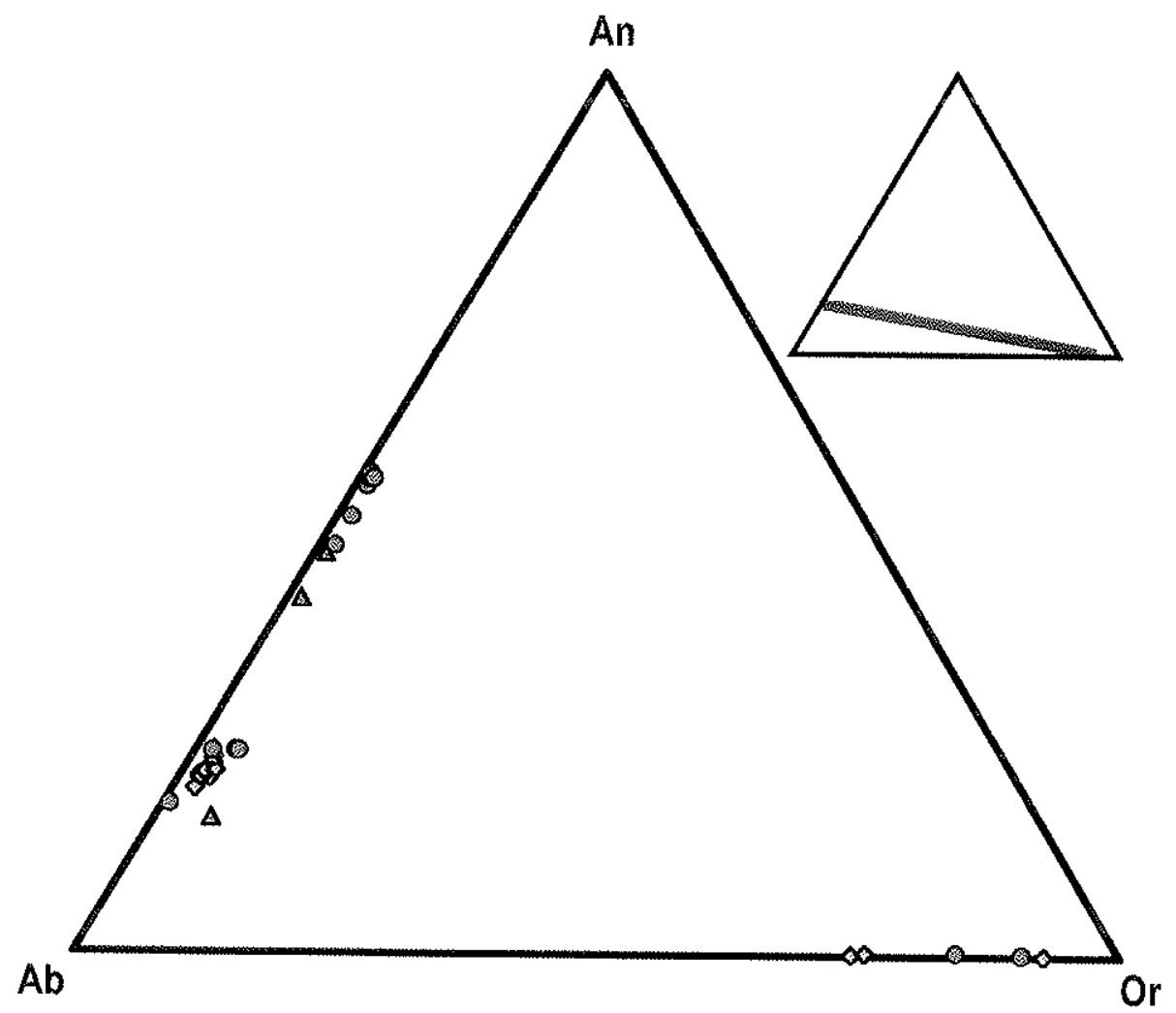

Figura IV.26: (Continua na próxima página) 
(c)

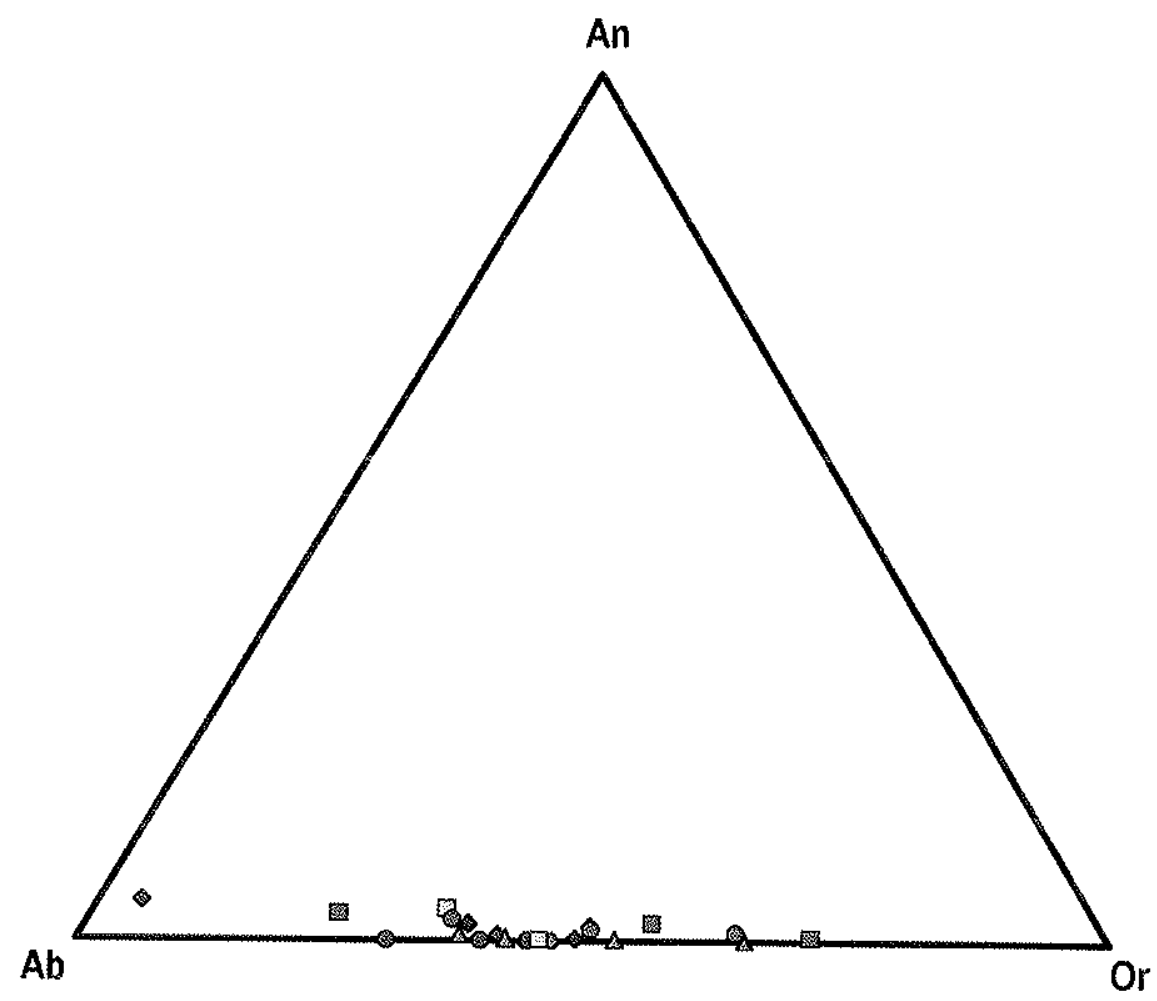

(d)

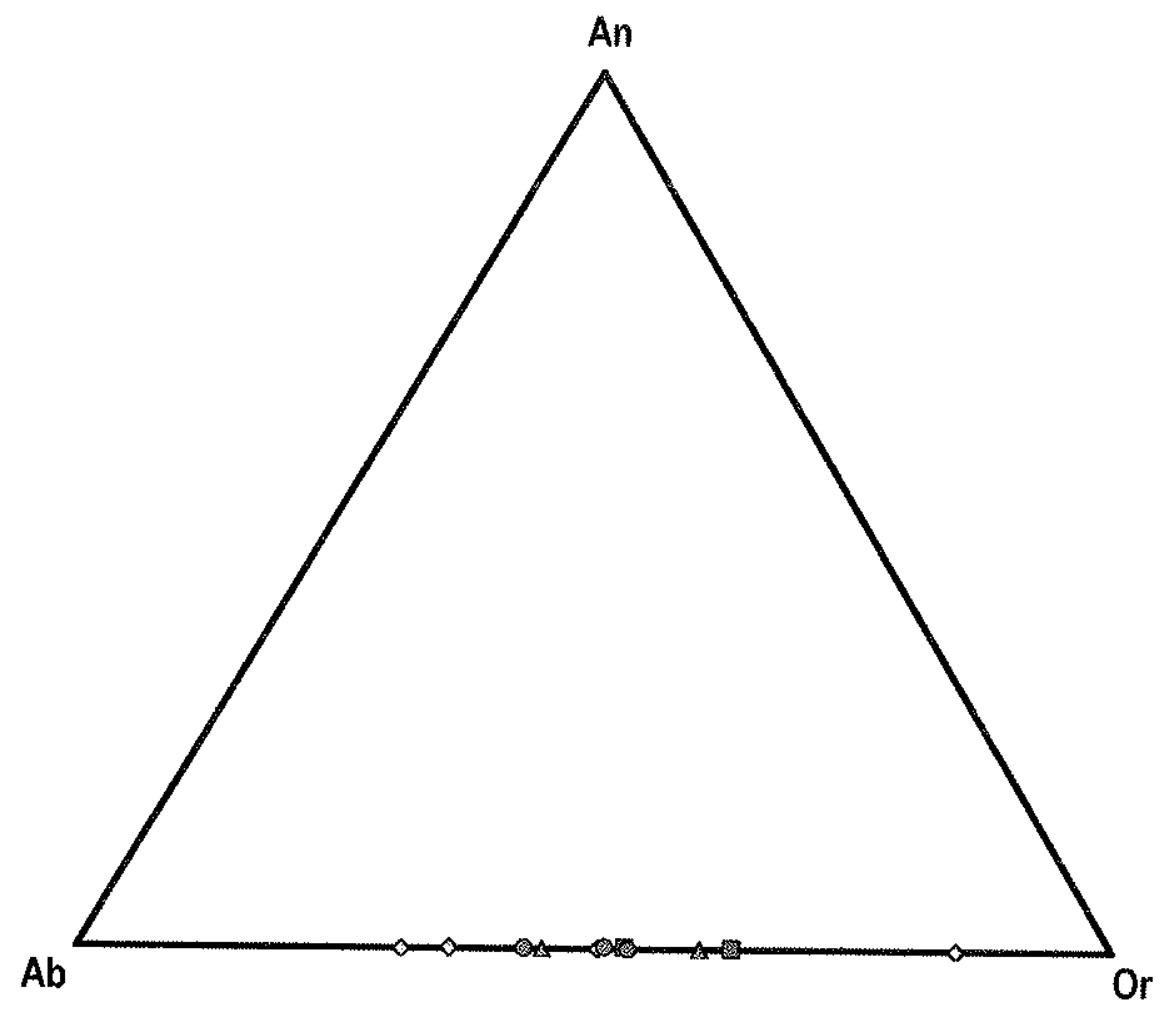

Figura IV.26: Diagrama ternário An-Ab-Or (proporçōes moleculares) com representação das composições de plagioclásio e feldspato alcalino (a) da associação aluminosa; (b) das rochas monzodoriticas e associadas; (c) da associação alcalina l; $e$ (d) da associação alcalina II dos Granitos da Graciosa. As composiçôes dos feldspatos alcalinos representam valores integrados de zonas de núcleo e borda de grãos. Linhas representadas em (a) e (b) unem fases coexistentes. 
(a)
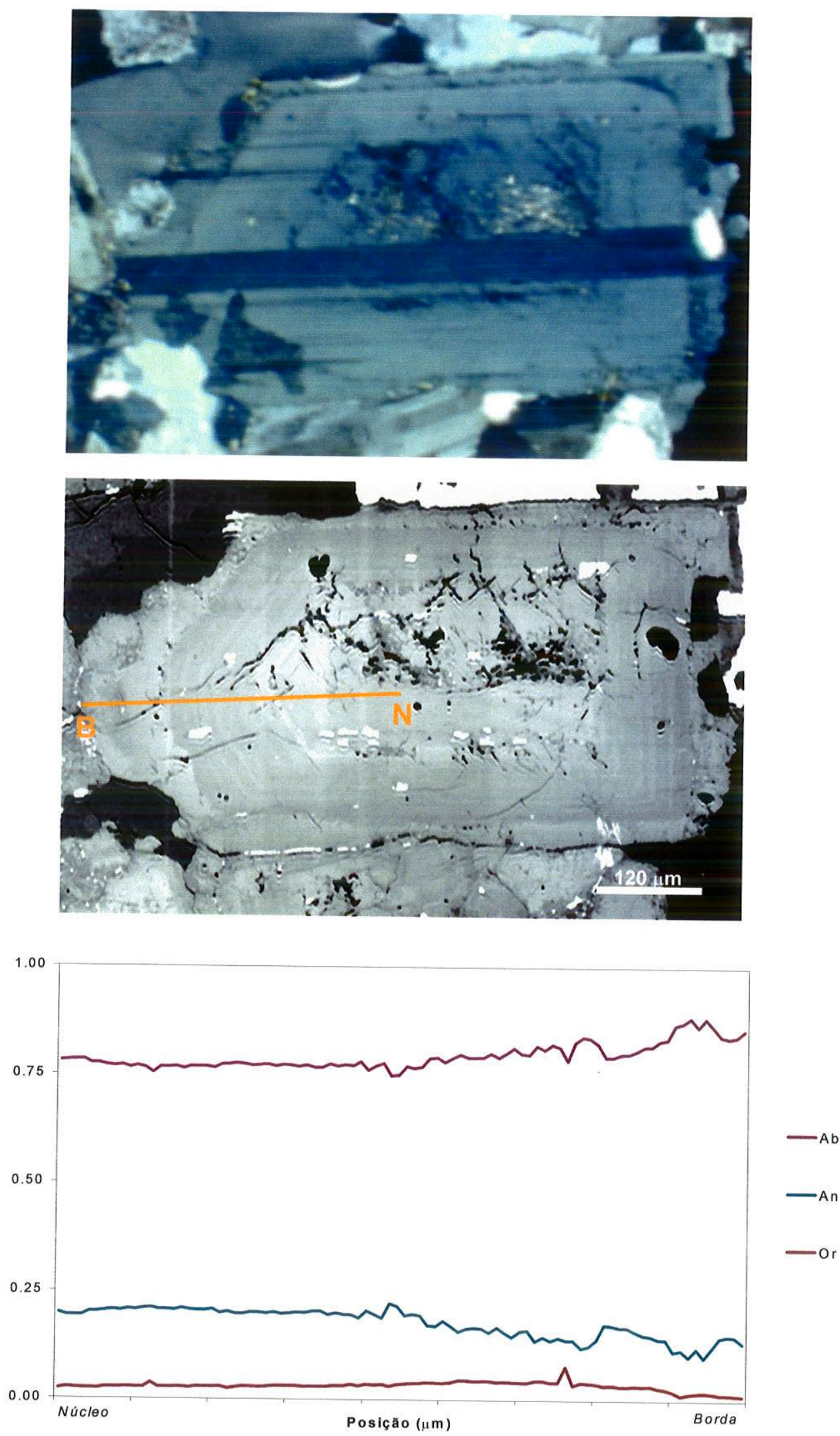

Figura IV.27: (Continua na próxima página) 

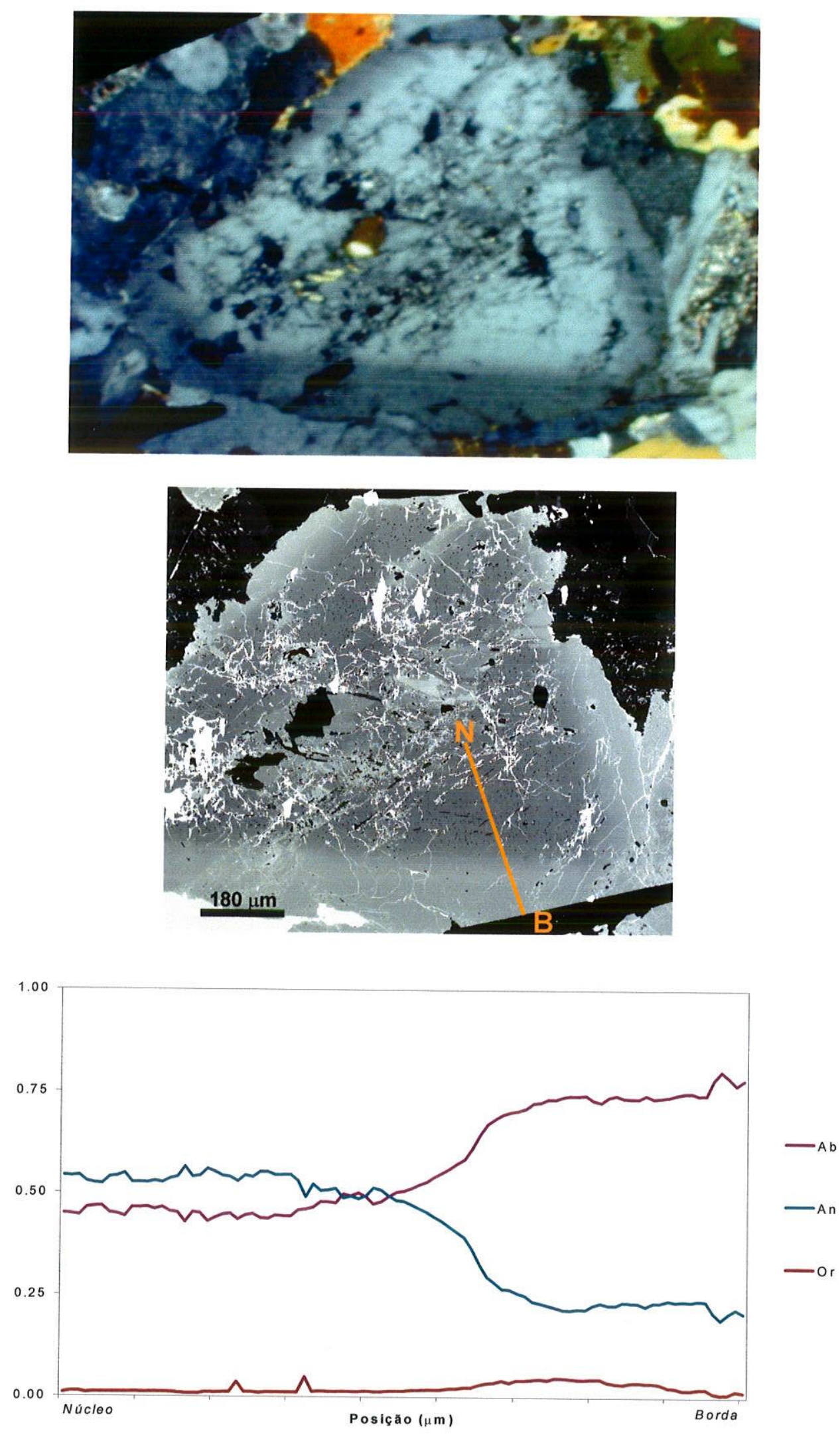

Figura IV.27: Imagens e perfís analíticos quantitativos (WDS) para cristais selecionados de plagioclásio. (a) de sienogranito (Amostra 7B) da associação aluminosa e (b) de monzodiorítico (Amostra 59E). Acima: imagem ótica digital; ao meio, imagem composicional (BEI), abaixo variações composicionais expressas em termos das moléculas de Anortita (An), albita (Ab) e ortoclásio (Or). Espaçamento entre análises sucessivas: (a) $10 \mu \mathrm{m}$; (b) $15 \mu \mathrm{m}$. 


\section{CONDIC̣ÕES DE CRISTALIZAC̣̃̃o}

As informações petrográficas e de quimismo mineral apresentadas permitem tecer consideraçōes genéricas sobre alguns dos parâmetros extensivos e intensivos vigentes ao longo da cristalização das variedades petrográficas identificadas nos Granitos da Graciosa.

Apesar do estudo geoquímico de rochas não se constituir em objetivo deste trabalho, dada a relevância para o tema, são introduzidos brevemente resultados obtidos para temperaturas de saturação de Zr e P nas rochas estudadas.

\section{VI.1. TEMPERATURAS DE LIQUIDUS}

Uma das características tidas como marcantes dos granitos Tipo-A são as temperaturas liquidus relativamente altas quando comparadas com as das demais rochas graníticas leucocráticas a hololeucocráticas. Estas temperaturas podem ser estimadas através das denominadas temperaturas de saturação.

\section{Bases metodológicas}

De interesse para a determinação de temperaturas de saturação são os elementos constituintes estruturais essenciais de fases acessórias específicas, como $\mathrm{Zr}$ (zircão) e P (apatita). A temperatura de saturação do elemento de interesse em um magma de composicão específica é determinada experimentalmente como a temperatura em que ocorre a cristalização do mineral correspondente.

Como as concentrações de elementos traços nos magmas dependem apenas dos coeficientes de distribuição cristal/magma que, por sua vez, são funçōes relativamente simples da temperatura, conhecendo-se a variação da solubilidade destes elementos com a temperatura, as temperaturas em que ocorre a saturação destes elementos em sistemas naturais podem ser estimadas a partir das concentraçōes elementais em rocha total, desde que estas últimas representem as composicōes originais dos magmas progenitores.

As temperaturas de saturação correspondem, na prática, a estimativas mínimas da temperatura liquidus do magma, e, quanto mais precoce for a cristalização da fase em questão - em outras palavras, quanto mais as concentraçōes iniciais de um elemento traço estão próximas do limite de saturação -, mais estas temperaturas corresponderão às reais para o liquidus. 
As variações nas solubilidades do $\mathrm{Zr}$ e do $\mathrm{P}$ em função da temperatura para magmas silicáticos foram estudadas experimentalmente por Watson e Harrison (1983) e Harrison e Watson (1984), respectivamente, que chegaram às seguintes equaçoes:

$$
\begin{array}{lr}
\text { In } D_{\mathrm{zr}}=\{-3,80-[0,85(\mathrm{M}-1)]\}+12900 / \mathrm{T}(\mathrm{K}) & \text { Eq. IV.12 } \\
\text { In } \mathrm{D}_{\mathrm{Ap}}=\left(\left\{8400+\left[\left(\mathrm{SiO}_{2}-0,5\right) * 2,64 * 10^{4}\right]\right\} / \mathrm{T}(\mathrm{K})\right)-\left(3,1+\left\{12,4\left[\mathrm{SiO}_{2}-0,5\right]\right\}\right) & \text { Eq. IV.13 }
\end{array}
$$

onde $D_{Z r}$ e $D_{A p}$ são os coeficientes de participação do $Z r$ e do $P$ entre zircão, apatita e magma respectivamente e $\mathrm{M}=(\mathrm{Na}+\mathrm{K}+2 \mathrm{Ca}) /\left(\mathrm{Si}{ }^{*} \mathrm{Al}\right)_{\text {cat }}$.

Assumindo que as quantidades de $\mathrm{Zr}$ e $\mathrm{P}$ em rocha total correspondem às originalmente presentes nos magmas, $D_{Z r}$ e $D_{A p}$ são obtidos pelas razões de concentrações elementais simples $Z r_{\text {zircăd }} / Z r_{\text {rocha }}$ e $P_{\text {apatital }} / P_{\text {rocha. }}$. Estas equacoóes se aplicam, no caso do $Z$ r, para temperaturas entre 750$1000^{\circ} \mathrm{C}$ e $0.9<\mathrm{M}<1.7$, e no caso da apatita, para teores de $\mathrm{SiO}_{2}$ no intervalo $45-75 \%$ em peso. (cf. Watson e Harrison, 1983: Harrison e Watson, 1984)

\section{Resultados}

Os resultados obtidos para cerca de 40 amostras aparecem resumidos na Figura IV.28 em que se comparam as temperaturas de saturação de zircão $\left(T_{2 r}\right)$ e apatita $\left(T_{A p}\right)$. No conjunto de amostras consideradas, algumas se localizam fora dos limites experimentais permitidos para o cálculo de $T_{2 ;}$ (alguns dos sienitos mais máficos, as rochas monzodioríticas e associadas, por se apresentarem insaturados em $\mathrm{Zr}$, bem como as rochas mais marcadamente peralcalinas, por apresentarem $M>$ $1,7)$, outras além do limite superior de $\mathrm{SiO}_{2}$ para cálculo de $\mathrm{T}_{\mathrm{Ap}}$. Nestes casos, foram fixados valores de $600^{\circ} \mathrm{C}$, sem significado real, para permitir a representação destas duas quantidades em um mesmo diagrama binário simples.

As temperaturas obtidas se distribuem ao longo de um intervalo de aproximadamente $200^{\circ} \mathrm{C}$ (ca. $700-900^{\circ} \mathrm{C}$ ) para a maioria das rochas graniticas. Os valores para $T_{z r}$ concentram-se, preferencialmente, entre 800 e $900^{\circ} \mathrm{C}$. O diagrama demonstra de forma clara que as amostras das associações alcalinas apresentam $T_{z r}$ sistematicamente mais altas $\left(>850^{\circ} \mathrm{C}\right)$, enquanto as maiores $T_{A p}$ estão representadas pelas amostras da associação aluminosa.

As rochas monzodioríticas, tipicamente insaturadas em $\mathrm{Zr}$, apresentam, por sua vez, $\mathrm{T}_{\mathrm{Ap}}$ da ordem de $1000^{\circ} \mathrm{C}$; este valor deve estar muito próximo ao liquidus dos respectivo magma uma vez 
que apatita é acessório relativamente abundante nestas rochas e está entre os primeiros minerais a cristalizar.

Os dados petrográficos aliados a diagramas (não apresentados) que expressam a variação de $\mathrm{Zr}$ e P com parâmetros que medem o grau de diferenciação (e.g., $\mathrm{SiO}_{2}$ ) indicam que, no intervalo de temperaturas aceitáveis, os magmas da associação alcalina l, com exceção apenas daqueles representativos dos sienitos mais máficos, estiveram saturados em $\mathrm{Zr}$. de forma que as $\mathrm{T}_{\mathrm{zr}}$ devem ser aproximações muito adequadas para os respectivos liquidus, já a saturação de $\mathrm{P}$ foi provavelmente alcançada apenas após um certo grau de cristalização. Situação similar pode ser inferida para o caso da associação alcalina //;

No caso da associação aluminosa, a observação mais típica de apatita inclusa em zircão (cf. item IV) é compatível com sua cristalização mais precoce, de forma que as $T_{A p}$ devem ser melhores aproximaçōes para a temperatura liquidus destes magmas.

De maneira geral, admite-se que as temperaturas liquidus dos magmas graniticos de ambas as associações não necessariamente foram muito distintos e devem ter sido próximas a $850 \sim 900^{\circ} \mathrm{C}$, similares aos valores deduzidos para granitos ripo-A de outras localidades (cf. Parte II).

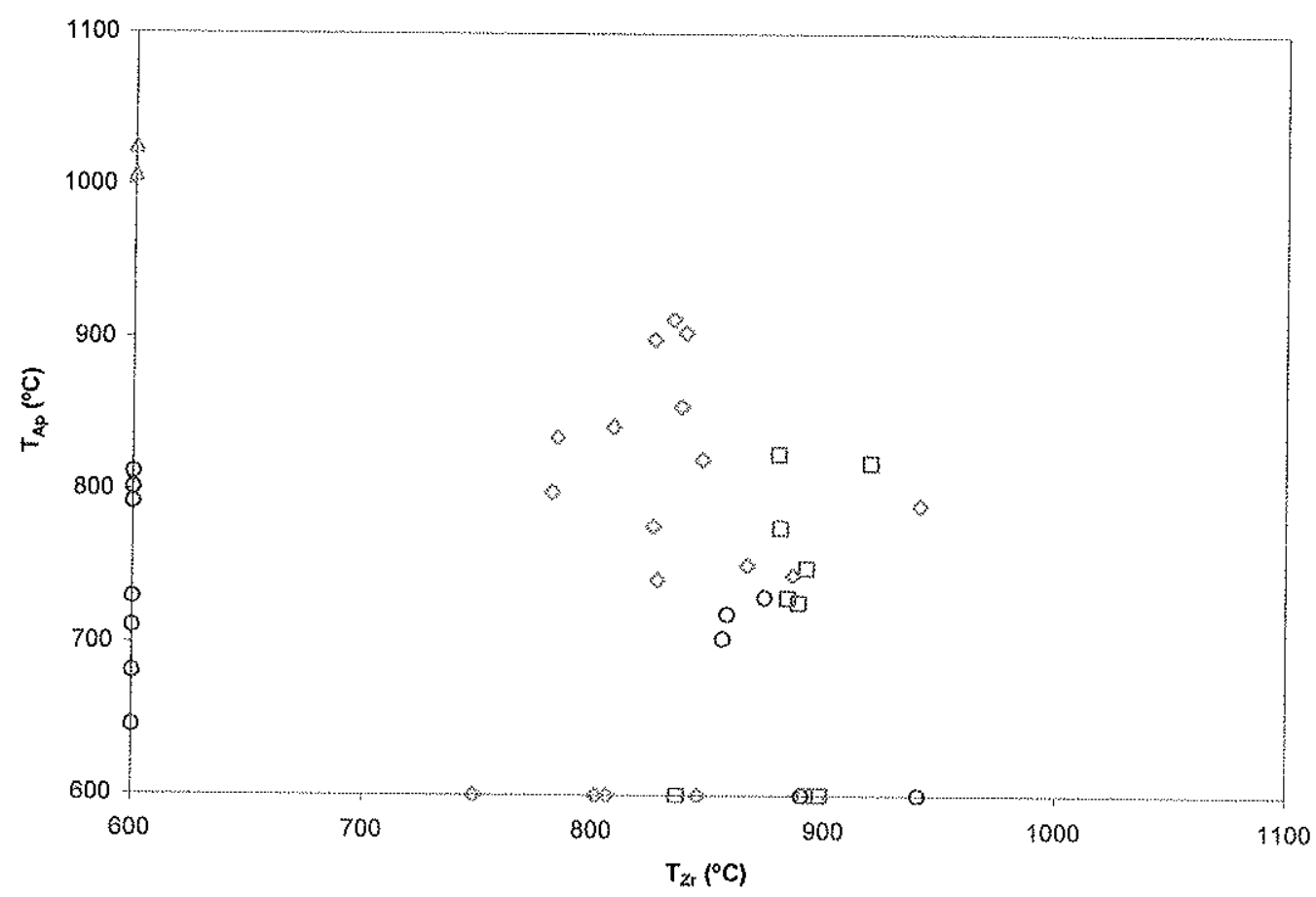

Figura IV.28: Diagrama comparativo para temperaturas de saturação de $\operatorname{Zr}\left(T_{Z i}\right)$ e $P\left(T_{A, p}\right)$ obtidas para amostras dos Granitos da Graciosa. Simbolos como na Figura IV.2. Temperaturas fixas de $600^{\circ} \mathrm{C}$ correspondem a valores obtidos para amostras com caracteristicas químicas fora do limite aceitável para aplicação do método de cálculo correspondente. 


\section{VI.2. TEMPERATURAS SOLIDUS E PRESSÃO DE COLOCACÃO}

\section{Bases metodológicas}

Temperaturas e pressōes confinantes de cristalização de fases minerais são determinadas com base em reações de equilibrio calibradas experimentalmente. No caso de rochas graníticas metaluminosas, os geotermômetros de maior aplicabilidade foram calibrados por Holland e Blundy (1994), com base nas reaçōes:

$$
\begin{array}{lr}
\text { edenita }+4 \text { quartzo } \Leftrightarrow \text { tremolita }+ \text { albita } & \text { Eq. IV.14 } \\
\text { edenita }+ \text { albita } \Leftrightarrow \text { richterita }+ \text { anortita } & \text { Eq. IV.15 }
\end{array}
$$

Assim, com base na composição de plagioclásio e anfibólio cálcico coexistentes, pode-se calcular as temperaturas de sua cristalização. A prática comum, em que se utilizam composiçōes das bordas dos cristais em contanto de modo a garantir equilíbrio entre as fases envolvidas, deve resultar, naturalmente, em temperaturas próximas ao solidus dos magmas (Anderson, 1996). portanto, marcando o final da cristalização magmática. O equilíbrio indicado pela Equacão IV.14 é em geral mais adequada para os sistemas saturados em $\mathrm{SiO}_{2}$, caso das rochas aqui estudadas.

Avaliações para a pressão de cristalização em rochas deste tipo, por sua vez, podem ser obtidas a partir do geobarômetro Al-em-hornblenda (Anderson, 1996). De fato, nas rochas granitóides que apresentam a paragênese biotita +hornblenda +titanita +óxido de Fe-Ti (+quartzo+feldspato alcalino + plagioclásio), a entrada de Al nos anfibólios através da substituição tschermakítica (Equação IV.11) é favorecida pelo aumento da pressāo. Entretanto, como mostram Holland e Blundy (1994) a substituição edenítica - que também leva à incorporação de Al em anfibólio cálcico (Equaçāo IV.9) é favorecida pela temperatura.

Assim, para anfibólios em equilibrio com a paragênese acima referida, uma correção para o efeito da temperatura foi incluída na calibração proposta por Anderson e Smith (1995) para o geobarômetro Al-em-hornblenda, descrita pela equação:

$$
P( \pm 0.6 \mathrm{kbar})=4.76^{*} \mathrm{Al}-3.01-\left\{\left[T\left({ }^{\circ} \mathrm{C}\right)-675\right] / 85\right\}^{*}\left\{0.530^{*} \mathrm{Al}+0.005294 *\left[\mathrm{~T}\left({ }^{\circ} \mathrm{C}\right)-675\right]\right\} \quad \mathrm{Eq} . \mathrm{IV} .12
$$

Desta forma, a utilização acoplada do geotermômetro anfibólio-plagioclásio e do geobarômetro Al-em-hornblenda permite resolver a pressão e a temperatura de cristalização simultaneamente. 
Por outro lado. Anderson e Smith (1995) relatam que os teores de Al em anfibólios cálcicos com baixo mg\# $\left(\left[\mathrm{Mg} /\left(\mathrm{Mg}+\mathrm{Fe}^{2+}\right)\right]_{\text {cal }}\right.$, i.é. $\left.<0,35\right)$, resultam em pressões superestimadas em até duas vezes para condições de cristalização próximas do tampão QFM.

\section{Resu/tados}

A grande maioria das rochas da associação aluminosa e as rochas monzodioríticas apresentam a paragênese adequada para a aplicaçāo destes geotermobarômetros. Entretanto, os anfibólios presentes nas primeiras são em geral muito ricos em $\mathrm{Fe}^{2+}(\mathrm{mg \#}<0,35)$ de forma que apenas as rochas monzodioríticas se mostram, a priori, adequadas para a aplicação do geobarômetro Al-emhornblenda.

As temperaturas de cristalização obtidas para a associação aluminosa são da ordem de 700$750^{\circ} \mathrm{C}$; valores similares foram obtidos para os monzodioritos. Estas temperaturas são compativeis com o final da cristalização magmática em ambos os sistemas.

Apesar das restrições, foram também calculados valores de pressão para sieno- e monzogranitos com a calibração de Anderson e Smith (1995), tendo em vista que estas rochas cristalizaram em condições relativamente mais oxidantes que as indicadas pelos autores. Os resultados obtidos para a grande maioria das amostras variam desde 2 até 4 kbar. As evidências geológicas e petrográficas para a colocação dos maciços na Província Serra do Mar são contudo incompatíveis com pressões de colocação muito superiores a ca. 2,0 kbar (cf. Parte III); também é pouco provável que as rochas estudadas tenham se formado sob condições de pressão muito contrastadas, indicando a limitação deste geobarômetro também para granitos Tipo-A aluminosos cristalizados acima do tampão QFM e a necessidade de correçōes adicionais na calibração proposta para sua aplicaçāo em rochas como as estudadas.

Os resultados obtidos para rochas monzodioríticas são mais consistentes e indicam que a etapa principal de cristalização se deu sob pressões confinantes de aproximadamente $2,0 \pm 0,6 \mathrm{kbar}$ (Amostra 59E: 2,0 e 2,3; Amostra 16B4: 1,8). Aceitas as relações geológicas, embora escassas, indicativas de coexistência de magmas monzodioríticos e graníticos da associação a/calina // e geração de rochas híbridas, parece razoável supor que as pressões litostáticas de colocação destes magmas não foram substancialmente diferentes; assim, fica aqui sugerido que a maioria dos magmas que se colocaram na região tenham cristalizado sob pressões confinantes da ordem de 1,4 - 2,6 kbar. 


\section{VI.3. TEMPERATURAS SUB-SOLIDUS}

Outros equilíbrios minerais podem conferir estimativas de temperaturas de cristalização, com destaque para equilíbrios entre feldspato alcalino e plagioclásio, e entre os óxidos de Fe e Ti. Contudo, como destacado por Anderson (1996), tais equilíbrios são muito suscetíveis a processos pós-magmáticos e esses sistemas freqüentemente indicam condições sub-solidus.

$\mathrm{Na}$ associação aluminosa e nas rochas monzodioríticas, em que plagioclásio coexiste com feldspato alcalino, as condições de equilíbrio podem ser estimadas através da distribuição relativa das moléculas de An, Ab e Or entre estes feldspatos. Para tanto, utilizando-se o programa SOLVCALC2 (Wen e Nekvasil, 1994) foram calculadas as curvas de solvus do sistema feldspático ternário para $2 \mathrm{kbar}$ de pressão e saturação em $\mathrm{H}_{2} \mathrm{O}$ em intervalos de $100^{\circ} \mathrm{C}$, aplicando-se o modelo de Elkins e Grove (1990). As composiçōes de feldspatos alcalinos (integradas) e plagioclásios foram lançadas no mesmo diagrama (Figura IV.29).

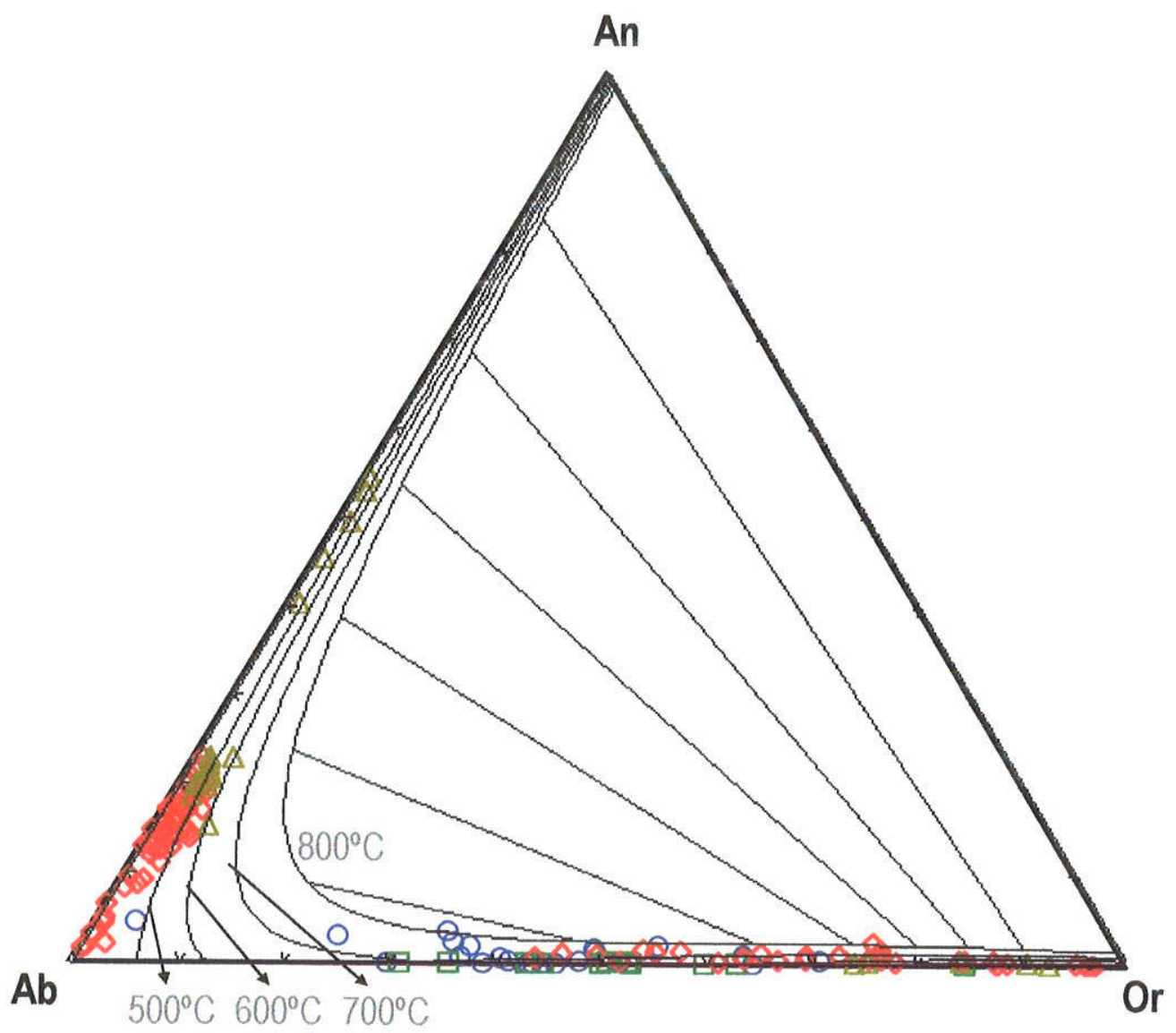

Figura IV.29: Composições dos feldspatos da associação aluminosa e das rochas monzodioríticas no diagrama An x Ab x Or. Em cinza, curvas do solidus para a temperatura indicada e "tie-lines" para $800^{\circ} \mathrm{C}$ (segundo modelo de Elkins e Grove, 1990). Símbolos como na Figura IV.2. 
A análise das curvas de solvus indica que, para estas condiçōes, a presença de feldspatos ternários se dá a temperaturas acima de $700^{\circ} \mathrm{C}$, de forma que esta é uma estimativa para a temperatura mínima do solvus das rochas das associacõos alcalinas.

Por outro lado, para as rochas da associação aluminosa, os pares feldspato alcalino-plagioclásio indicam re-equilíbrio em condiçoes sub-solidus a temperaturas da ordem de $600^{\circ} \mathrm{C}$ ou pouco inferiores (Figura IV.29).

\section{VI.4. CONDICÕES REDOX}

Os dados mineralógicos apresentados não permitem quantificar adequadamente as fugacidades das espécies voláteis $\left(\mathrm{H}_{2} \mathrm{O}, \mathrm{HF}, \mathrm{O}_{2}\right)$ quando da cristalização dos magmas. Merece ser salientado neste aspecto que mesmo dados preliminares para o equilibrio de óxidos de Fe e Ti, cujo estudo foge aos objetivos deste trabalho, no caso da associação aluminosa resultam em valores representativos de condições tipicamente sub-solidus. Apesar disso, algumas evidências de caráter geral permitem contrastar as diferentes associações em termos das condições redox $\left(f \mathrm{O}_{2}\right)$ de cristalização.

As paragêneses contendo quartzo, olivina faialítica e ilmenita como único óxido de Fe-Ti, nas variedades menos evoluídas da associação a/calina / indicam condições de cristalização relativamente redutoras, certamente inferiores às do tampão QFM. Os magmas que cristalizaram estas variedades mais máficas não estavam originalmente saturados em $\mathrm{Zr}$; se admitirmos temperaturas de liquidus da ordem de $850^{\circ} \mathrm{C}$, tal como estimados a partir das temperaturas de saturação, pode-se estimar que a $\log \left(f \mathrm{O}_{2}\right)$ original foi inferior a $-13,5$. Por outro lado, a evolução composicional dos anfibólios nestas rochas mostra, seja em escala de amostra, seja para todo o conjunto amostral, uma tendência de oxidação progressiva, evidenciada pela contribuição cada vez mais importante da substituição representada pela Equação IV.10, culminando com a cristalização de riebeckita nas amostras mais evoluídas.

Neste sentido, a trajetória de cristalização seguida por esta associação é caracteristicamente de tipo oxidante, ou seja desvia-se das trajetórias tamponadas em direção a condições mais oxidantes, mas mesmo assim, nos estágios finais pós-magmáticos, as condições ainda foram significativamente redutoras, uma vez que a desestabilizaçäo dos anfibólios primários gerou biotita annítica (com mg\# muito baixo) em detrimento de feldspato potássico e magnetita, minerais esperados para condições francamente oxidantes (cf. Wones \& Eugster. 1965). 
A presença de titanita e magnetita em algumas das amostras com anfibólio cálcico na associação alcalina //. parecem indicar condições iniciais pouco mais oxidantes, eventualmente bem próximas ao tampão TMQAl (Wones, 1989; Noyes et al., 1983). Por outro lado, as trajetórias composicionais descritas pelos anfibólios presentes nestas rochas são muito contrastadas: não descrevem trajetória oxidante e, pelo contrário, nas amostras mais evoluidas desta associação as trajetórias apontam uma tendência contrária, claramente redutora, caracterizada pela cristalização final de um anfibólio sódico arfvedsonítico. Caracteriza-se, assim, um claro contraste com a associação alcalina /.

A paragênese mineral típica das rochas da associação aluminosa, com titanita, allanita e magnetita ao lado de anfibólio e ilmenita, caracteriza, a priori, o próprio tampão TMQAI e implica, em princípio, condições relativamente oxidantes de cristalização. Situação não muito distinta deve caracterizar as rochas monzodioríticas.

\section{CONCLUSÕES}

As características petrográficas e mineralógicas dos Granitos da Graciosa permitem contrastar diferentes associações petrográficas com padrões evolutivos próprios. Foram reconhecidas duas associacões alcalinas e uma aluminosa de granitos Tipo-A no sentido de Lameyre e Bowden (1982), além de rochas monzodioríticas e híbridas de ocorrência mais discreta.

A primeira entre as associaçōes alcalinas - a associação a/calina / - é composta principalmente por rochas que afloram no Maciço Anhangava, sendo tipicamente consituídas por álcali-feldspato sienitos, que gradam continuamente de variedades contendo anfibólio cálcico, piroxênio e olivina para variedades portando apenas anfibólio cálcico-sódico. Os termos mais diferenciados relacionados a esta associação (álcali-feldspato granitos com anfibólio sódico), afloram numa ocorrência isolada no Maciço Farinha Seca. A associação alcalina // aflora, por sua vez nos Maciços Farinha Seca e Órgãos e é constituída essencialmente por álcali-feldspato granitos com anfibólio de composicão variável desde cálcico a cálcico-sódico e sódico.

A associação aluminosa, predominante na área estudada, inclui principalmente sienogranitos e monzogranitos e subordinadamente álcali-feldspato granitos com biotita acompanhada ou não por anfibólio cálcico. Estas rochas formam a totalidade dos Maciços Capivari e Marumbi, e são dominantes nos Maciços Órgãos e Anhangava. 
Biotita monzodioritos constituem ocorrências isoladas no Maciço Órgãos e aparecem como enclaves em quartzo sienitos com anfibólio cálcico no Maciço Farinha Seca.

Os dados modais mostram que a associação alcalina / segue uma trajetória típica dos termos mais diferenciados (sieníticos e graníticos) das associaçōes alcalinas mais expandidas de outras províncias (e.g., Lameyre e Bowden, 1982), porém não foram encontradas as rochas intermediárias que aparecem nestas últimas: de fato, as rochas monzodioríticas contemporâneas que afloram nesta região parecem representar antes um magmatismo dissociado, de uma linhagem pelo menos em parte contrastada. Neste sentido, a interpretaçăo de que os magmas sieníticos são derivados da cristalizacāo fracionada de magmas básico-intermediários, o conjunto constituindo uma série magmática (s.s.), como sugerem, por exemplo Bonin et al. (1996), não parece tão imediata e cabe questionar se os magmas sieníticos não foram de fato primários.

As trajetórias evolutivas dessas rochas são mais adequadamente acompanhadas pela evolucão composicional dos anfibólios, os quais seguem um caminho em diversos aspectos compativel com uma trajetória agpaítica. A cristalizaçāo procede em ambiente crescentemente oxidante, de alcalinidade crescente, que conduz ao acoplamento do par $\mathrm{Na}^{-\mathrm{Fe}^{3+}}$, características típicas de sistemas agpaíticos. A relativa abundância e complexidade das tranformaçôes pós-magmáticas são também típicas, e ficam melhor evidenciadas pela desestabilização de anfibólios cálcico-sódicos em favor de anfibólio sódico e biotita rica em Si. A presença de acessórios diferenciados, pobres em Al, é o mais confiável diagnóstico da natureza agpaítca de sistemas insaturados; neste sentido, a ocorrência de chevkinita nas rochas desta associação corrobora as conclusões acima.

A associação alcalina //, por outro lado, apresenta-se modalmente muito restrita, no campo dos álcali-feldspato granitos, contendo anfibólio como única fase máfica primária importante. De fato, a afinidade alcalina da associação é bem marcada apenas pela presença de anfibólios cálcico-sódicos. As trajetórias evolutivas dos anfibólios são diferenciadas em relação àquelas observadas na associação alcalina /. Faltam as trajetórias oxidantes típicas da associação anterior, e nos termos mais evoluídos. com anfibólio sódico primário observam-se tendências claramente redutoras.

Em alguns aspectos, sobretudo as composiçoes modais e de feldspatos alcalinos, as rochas da associação alcalina // são semelhantes aos álcali-feldspato granitos com biotita da associação aluminosa. De fato, apesar das afinidades contrastadas, cabe questionar qual a real distância geoquímica entre magmas marginalmente peraluminosos e magmas levemente peralcalinos. Em 
muitos casos, os tipos metaluminosos seriam de difícil distinção caso não ocorressem em áreas geográficas distintas.

Os dados modais para os sieno- e monzogranitos da associação aluminosa, por sua vez, são muito similares aos encontrados para associações aluminosas de outras localidades. Dada a sua homogeneidade, tendências evolutivas expressas seja por variações modais, seja por variações no quimismo de fases minerais, são restritas e de dificil reconhecimento. De forma geral, representam magmas muito próximos ao vale termal granítico.

Acredita-se que as rochas monzodioriticas que afloram na área estudada representam um magmatismo contrastado. Suas características são muito similares as observadas para rochas dioríticas que afloram na Província Itu, associadas temporalmente com granitos Tipo-A aluminosos, e, para as quais, contribuiçōes importantes de crosta continental fértil e/ou manto litosférico relativamente rico em elementos incompativeis foram inferidas por vlach (1993).

Neste contexto, os quartzo sienitos com anfibólio cálcico associados parecem ser chave para a compreensão das relações entre as rochas monzodioríticas e as demaís. Apesar das diferenças texturais, a relativa semelhança da composição modal destas rochas com as da associação a/uminosa, bem como o evidente posicionamento dessas rochas em um alinhamento entre seus enclaves monzodioríticos e as variedades álcali-feldspato graníticas das associacoões alcalina // e aluminosa levam à inferência de que a variabilidade observada nestas associações seja decorrente de processos locais de mistura entre magmas monzodioríticos e álcali-feldspato graníticos.

Finalmente, em termos das fontes envolvidas na geraçāo dos magmas primários que deram origem às rochas da região, não parece haver muitas dúvidas de que a associação alcalina / se formou a partir de magmas mantélicos. Resta saber, de fato, se estes correspondem a magmas primários básicos ou se representam fusões primárias de composiçāo sienítica. Os dados obtidos, aliados aos existentes em literatura, não permitem definir uma ou outra hipótese; de qualquer forma a geração de magmas sieníticos primários encontra dificuldades relativas à coleta e ao transporte de magmas formados por baixos graus de fusão no manto.

Por outro lado, os sienom e monzogranitos da associação aluminosa são rochas com composiçōes relativamente próximas ao vale termal granítico (porém sob temperaturas relativamente elevadas, quando comparadas aos mobilizados crustais mais típicos). portanto facilmente extraídas a partir da crosta inferior. Mais difícil é a compreensão das fontes envolvidas na geração dos magmas 
que formaram os álcali-feldspato granitos. Neste sentido, o posicionamento dos Granitos da Graciosa na interface entre os biotita gnáisses da Microplaca Curitiba e os granulitos do Cráton Luiz Alves, bem como a aparente semelhança entre as variedades álcali-feldspato graníticas aluminosas e alcalinas, conduzem à hipótese de que esse fator pode ter sido importante condicionante na definição do caráter dos magmas que deram origem a essas variedades.

\section{REFERÊNCIAS BIBLIOGRÁFICAS}

Anderson. J.L. (1996) Status of thermobarometry in granitic batholiths. Transactions of the Royal Society of Edinburgh: Earth Sciences, 87: 125-138.

Anderson, J.L.: Smith. D.R. (1995) The effect of temperature and oxygen fugacity on Al-inhornblend barometry. American Mineralogist, 80: 549-559.

Basei, M.A.S.; Siga Jr., O.: Machiavelli, A.; Mancini, F. (1992) Evoluçâo tectônica dos terrenos entre os Cinturões Ribeira e Dom Feliciano (PR-SC). Revista Brasileira de Geociências, 22(2): 216 221.

Chayes, F. (1956) Petrographic modal analysis. John Wiley \& Sons. New York.

Cordani, U.G.; Girardi, V.A.V. (1967) Geologia da Folha de Morretes. Boletim da Universidade Federal do Paraná, Geologia, 26:1-40.

Czamanske, G.K.; Dillet, B. (1988) Alkali amphibole, tetrasilicic mica, and sodic pyroxene in peralkaline siliceous rocks, Questa Caldera, New Mexico. American Journal of Science, 288A: 358-392.

Deer, W.A.; Howie, R.A.; Zussman. M.A. (1978) Rock-forming minerals: Single-Chain Silicates. Vol. 2A Longman. 2nd. Ed. London. $668 \mathrm{p}$.

Deer, W.A.; Howie, R.A.; Zussman, M.A. (1992) An introduction to the rock-forming minerals. Longman. 2nd. Ed. London. 696 p.

Droop, G.T.R. (1987) A general equation for estimating $\mathrm{Fe}^{3+}$ in ferromagnesian silicates and oxides from microprobe analysis, using stoichiometric criteria. Mineralogical Magazine, 51:431-437.

Elkins, L.T.; Grove, T.L. (1990) Ternary feldspar experiments and thermodynamic models. American Mineralogist, 75: 544 559.

Enders, M.: Speer, D.; Maresch, W.V.: McCammon, C.A. (2000) Ferric/ferrous iron ratios in sodic amphiboles: Mössbauer analysis, stoichiometry-based calculations and the high-resolution microanalytical flank method. Contributions to Mineralogy and Petrology, 140: 135-147.

Fuck. R.A. (1966) Geologia da Folha Piraquara. Boletim da Universidade Federal do Paraná. Geologia. Inédito.

Harrison. T.M.; Watson. E.B. (1984) the behavior of apatite during crustal anatexis - equilibrium and kinetic considerations. Geochimica et Cosmochimica Acta, 48: 1467-1477

Holland, Y.; Blundy. J. (1994) Non-ideal interactions in calcic amphiboles and their bearing on amphibole-plagioclase thermometry. Contributions to Mineralogy and Petrology, 116: 433447. 
Kaul, P.F.T. (1984) Significado dos granitos anorogênicos da Suíte Intrusiva Serra do Mar na evoluçấo da crosta do sul-sudeste do Brasil, no âmbito das folhas SG-22, Curitiba e SG-23, Iguape. In: CONGRESSO BRASILEIRO DE GEOLOGIA, 33. Rio de Janeiro. SBG. Anais..., 6:28152825.

Leake. B.E. e 21 membros da IMA (1997) Nomenclature of amphiboles: report of the Subcommittee on Amphiboles of the International Mineralogical Association Commission on New Minerals and Mineral Names. Contributions to Mineralogy and Petrology. 61:295-321.

Maack, R. (1961) Sobre a ocorrência de granitos alcalinos no Estado do Paraná e sua posição dentro das fases orogenéticas algonquianas. Boletim da Universidade Federal do Paraná, Geologia, $4: 1.52$.

Mackenzie, W. S.; Donaldson. C. H.; Guilford. C. (1995) Atlas of igneous rocks and their textures. Longman. Harlow. 148 p.

Martins. L. (2001) Condiçōes de cristalização de granitos sin-e tardi-orogênicos da porção central do Batólito Agudos Grandes, SP, com base em geoquímica de minerais e rochas. Dissertação de Mestrado, IG-USP. Inédita. $132 \mathrm{p}$.

Neilson. M.J.; Brockman, G.F. (1977) The error associated with point counting. American Mineralogist, 62: 1238-1244.

Noyes, H.J.; Wones, D.R.; Frey, F.A. (1983) A tale of two plutons: petrographic and mineralogical constrains on the petrogenesis of the Red Lake and Eagle Plutons. Central Sierra Nevada, California. Journal of Geology, 91 : 353-379.

Robert, J.-L.; Maury, R.C. (1979) Natural occurence of a (Fe, Mn. Mg) tetrasilicic potassium mica. Contributions to Mineralogy and Petrology, 68: 117-123.

Siga Jr., O.; Basei, M.A.S.; Machiavelli, A. (1993) Evolução geotectônica da porção NE de Santa Catarina e SE do Paraná, com base em interpretações geocronológicas. Revista Brasileira de Geociencias, 23(3): 215-223.

Siga Jr., O.; Basei, M.A.S.: Machiavelli, A. (1993) Evolução geotectônica da porção NE de Santa Catarina e SE do Paraná, com base em interpretações geocronológicas. Revista Brasileira de Geociências, 23(3): 215-223.

Streckeisen. A.L. (1967) Classification and nomenclature of ignous rocks. Neues Jahrbush fur Mineralogische, Abtheilung, 107: 144-240.

Vlach. S.R.F. (1985) Geologia, petrografia e geocronologia das regiōes meridional e oriental do Complexo Granítico de Morungaba, SP. Dissertação de Mestrado, IG-USP. Inédita. 253 p.

Vlach, S.R.F. (1999) Ocorrência e variaçôes composicionais de chevkinitamCe e Allanita (-Fe) em quartzo sienitos do Maciço Corupá (SC). Província Serra do Mar. In: V CONGRESSO DE GEOQUIMICA DOS PAISES DE LÍNGUA PORTUGUESA \& VII CONGRESSO BRASILEIRO DE GEOQUIMICA. Anais..., p. 627-630.

Watson; E.B.; Harrison. T.M. (1983) Zircon saturation revisited: temperature and composition effects in a variety of magma types. Earth and Planetary Science Letters, 64: 295-304.

Wen, S. and Nekvasil, H. (1994) SOLVCALC: An interactive graphics package for ternary feldspar calculations and geothermometry. Computers \& Geoscience 20, 1025-1040. 
Wones, D.R. (1989) Significance of the assemblage titanite + magnetite + quartz in granitic rocks. American Mineralogist, 74:744-749.

Wones. D.R.; Eugster, H.P. (1965) Stability of biotite: experiment, theory and application. American Mineralogist, 74: 744-749. 


\section{Prancha 1}
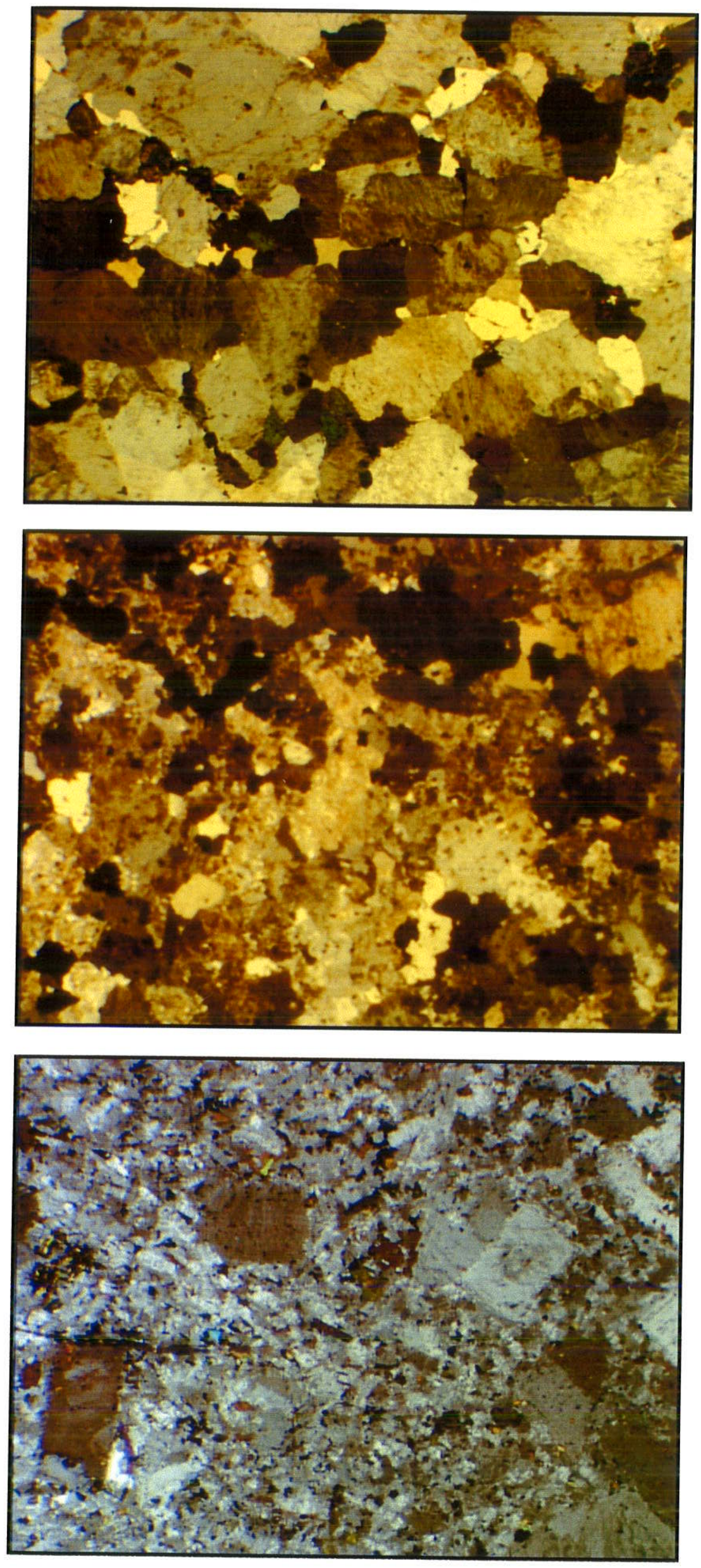

(a) Aspecto textural geral dos álcali-feldspato sienitos equigranulares com piroxênio e olivina.

Luz plano-polarizada; polarização superior parcial; lado maior da fotomicrografia igual a $0,94 \mathrm{~cm}$ em todas as fotomicrografias.

(b) Aspecto textural geral dos álcali-feldspato sienitos equigranulares com anfibólio cálcico.

(c) Aspecto textural geral de uma variedade porfirítica dos álcalifeldspato sienitos equigranulares a porfiríticos finos com anfibólio e piroxênio. 


\section{Prancha 1}
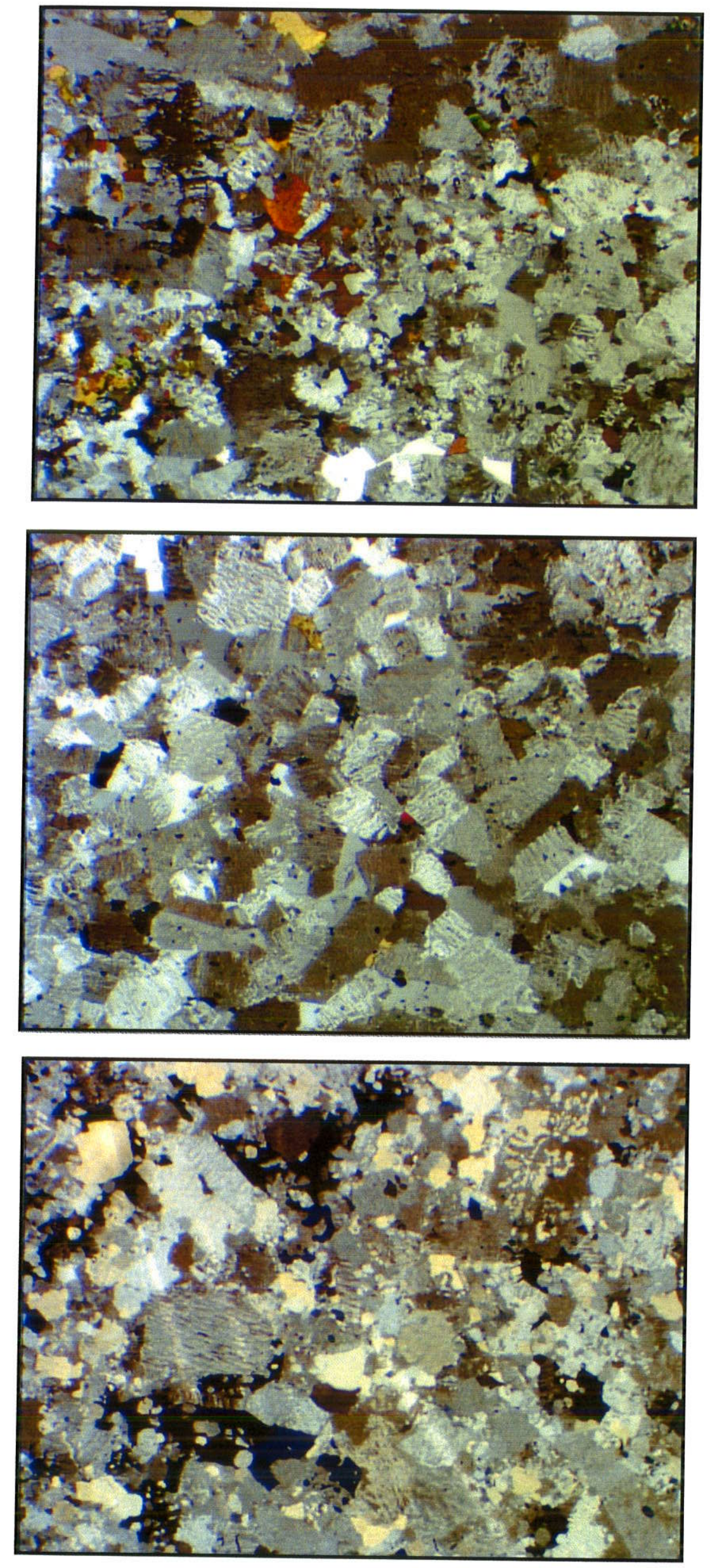

(d) Aspecto textural geral de uma variedade inequigranular dos álcali-feldspato sienitos equigranulares a porfiriticos finos com anfibólio e piroxênio.

(e) Aspecto textural geral de uma variedade equigranular dos álcali-feldspato sienitos equigranulares a porfiríticos finos com anfibólio e piroxênio.

(f) Aspecto textural geral da variedade equigranular dos álcali-feldspato granitos de granulação fina-média com anfibólio sódico. 


\section{Prancha 1}
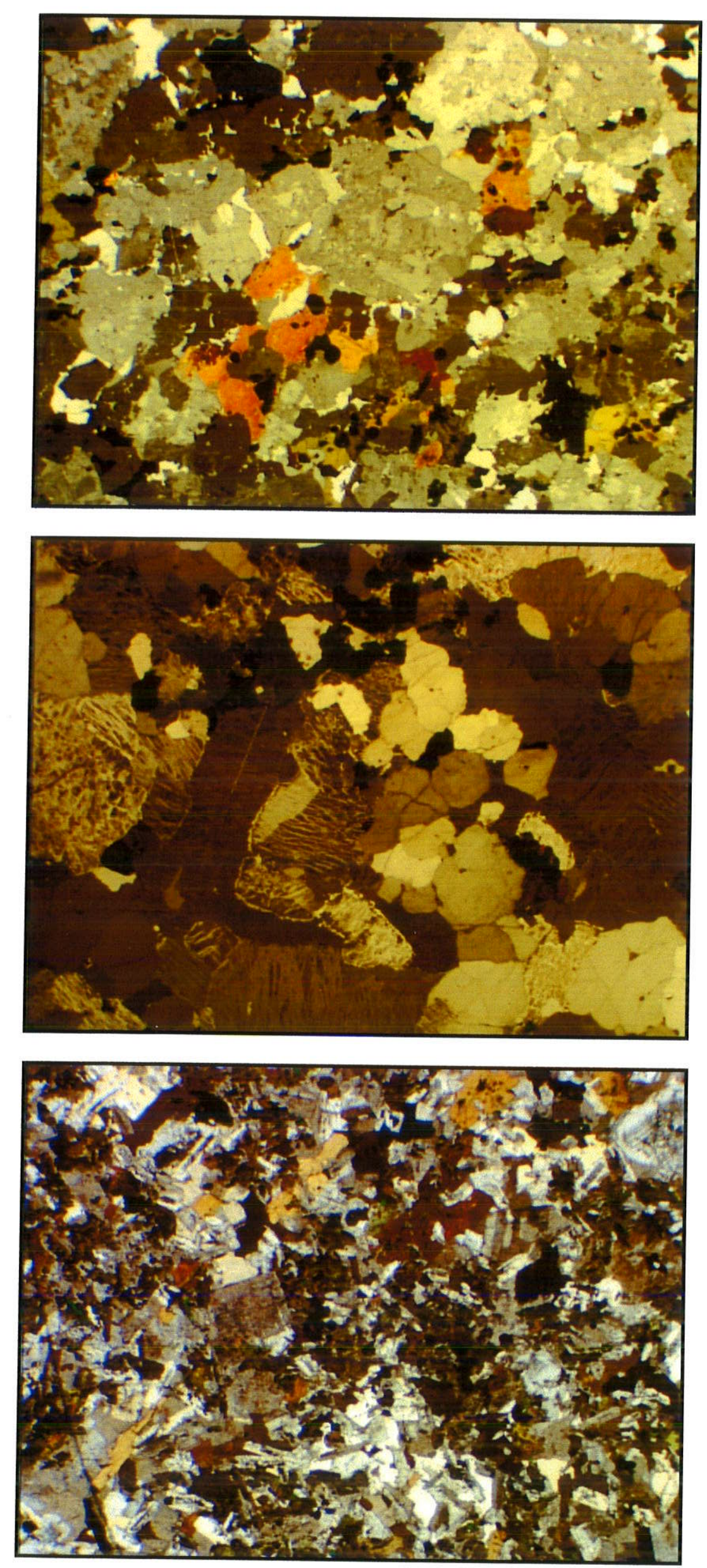

(g) Aspecto textural geral dos quartzo sienitos equigranulares com anfibólio.

(h) Aspecto textural geral dos álcali-feldspato granitos equigranulares com anfibólio.

(i) Aspecto textural geral dos dioritos equigranulares com anfibólio cálcico. 


\section{Prancha 2}
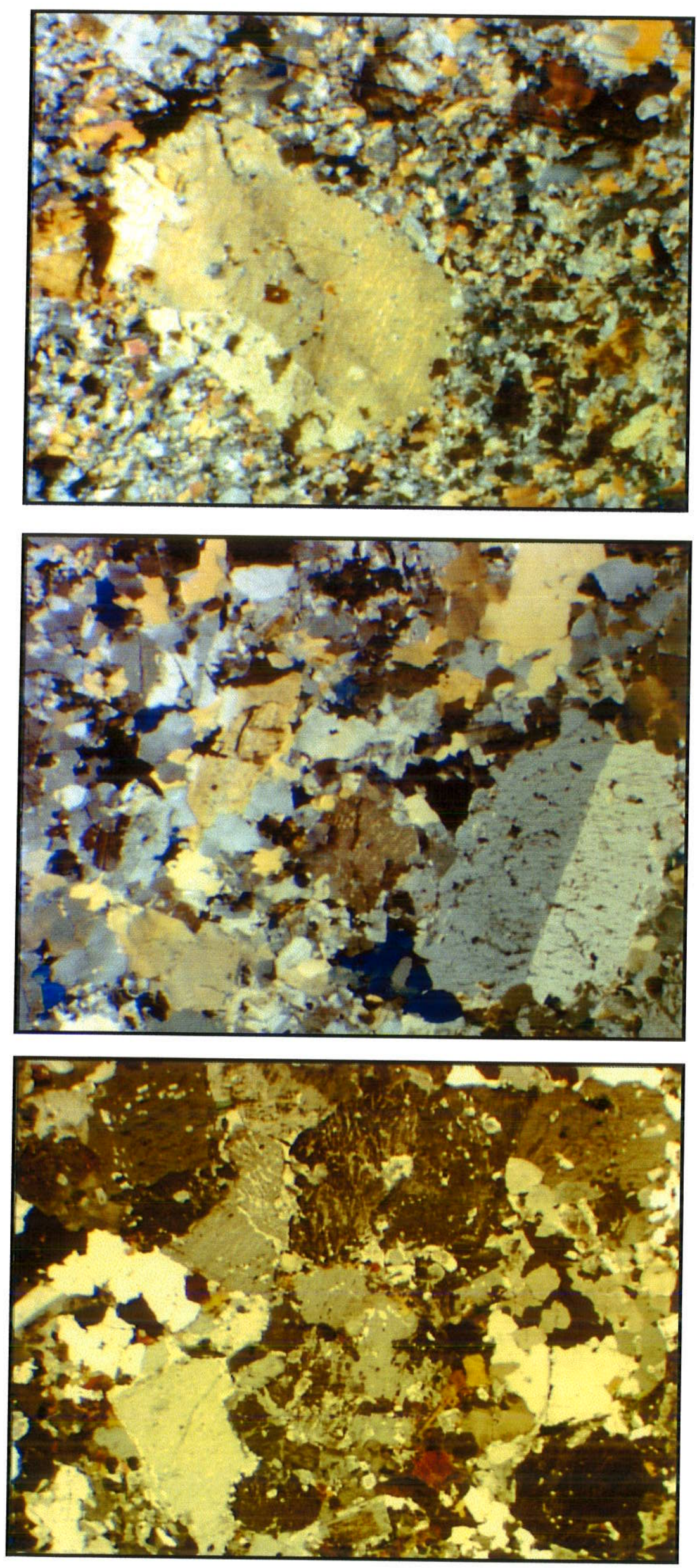

(a) Aspecto textural geral dos sienogranitos porfiríticos com biotita e anfibólio cálcico .

Luz plano-polarizada; polarização superior parcial; lado maior da fotomicrografia igual a $0,94 \mathrm{~cm}$ em todas as fotomicrografias.

(b) Aspecto textural geral dos sienogranitos porfiríticos com biotita e anfibólio cálcico.

(c) Aspecto textural geral dos sienogranitos inequigranulares com biotita e anfibólio cálcico. 


\section{Prancha 3}
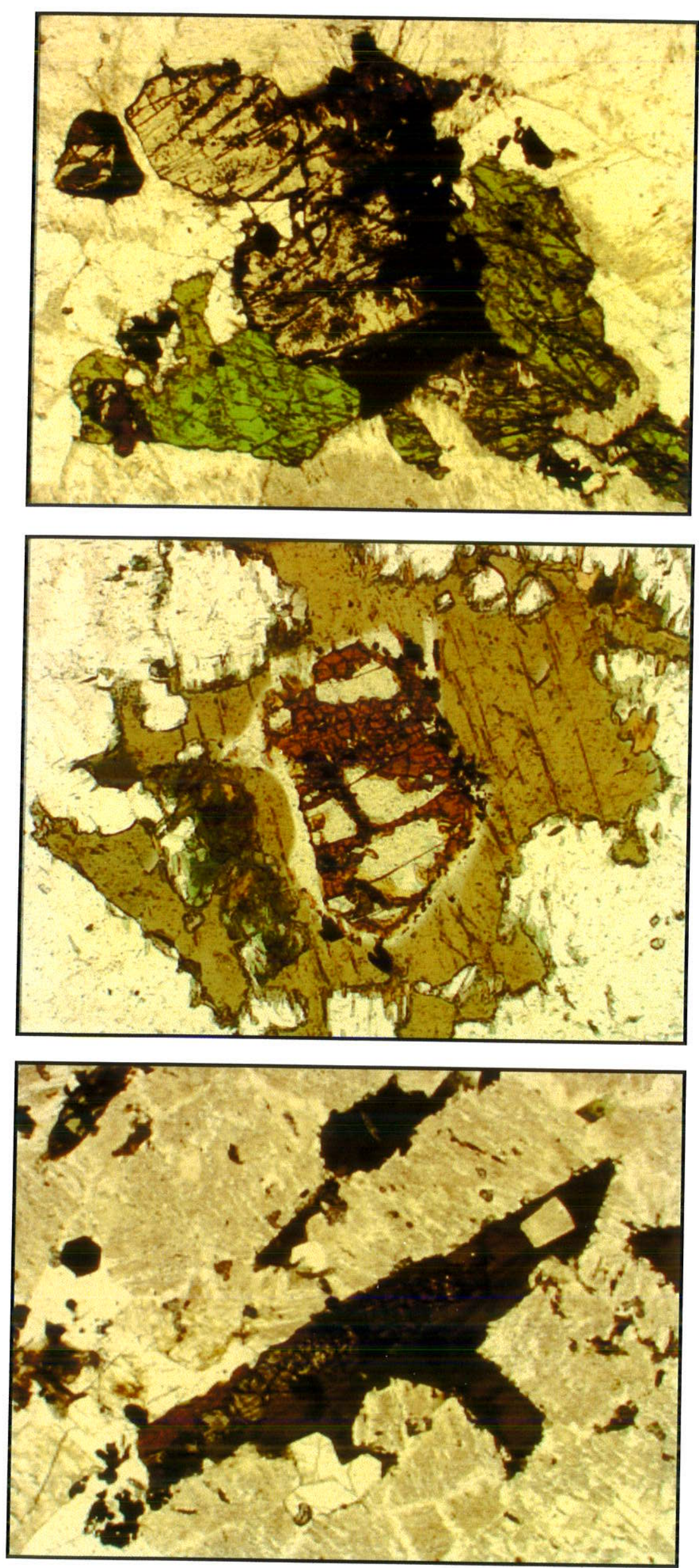

(a) Olivina (amarelo pálido) e clinopiroxênio (verde) dos álcalifeldspato sienitos equigranulares com com piroxênio e olivina.

Lado maior: $0,38 \mathrm{~cm}$

Luz plano-polarizada em todas as fotomicrografias.

(b) Olivina (amarelo pálido) inclusa em anfibólio cálcico (verde) dos álcali-feldspato sienitos equigranulares a porfiríticos finos com anfibólio e piroxênio. Notar no contato entre os dois minerais a formação de anfibólio ferro-magnesiano (amarelo pálido, relevo mais baixo)

Lado maior: $0,12 \mathrm{~cm}$

(c) Clinopiroxênio (verde claro) incluso e parcialmente corroído por anfibólio cálcico (verde escuro) dos álcali-feldspato sienitos equigranulares a porfiríticos finos com anfibólio e piroxênio.

Lado maior: $0,38 \mathrm{~cm}$ 


\section{Prancha 3}
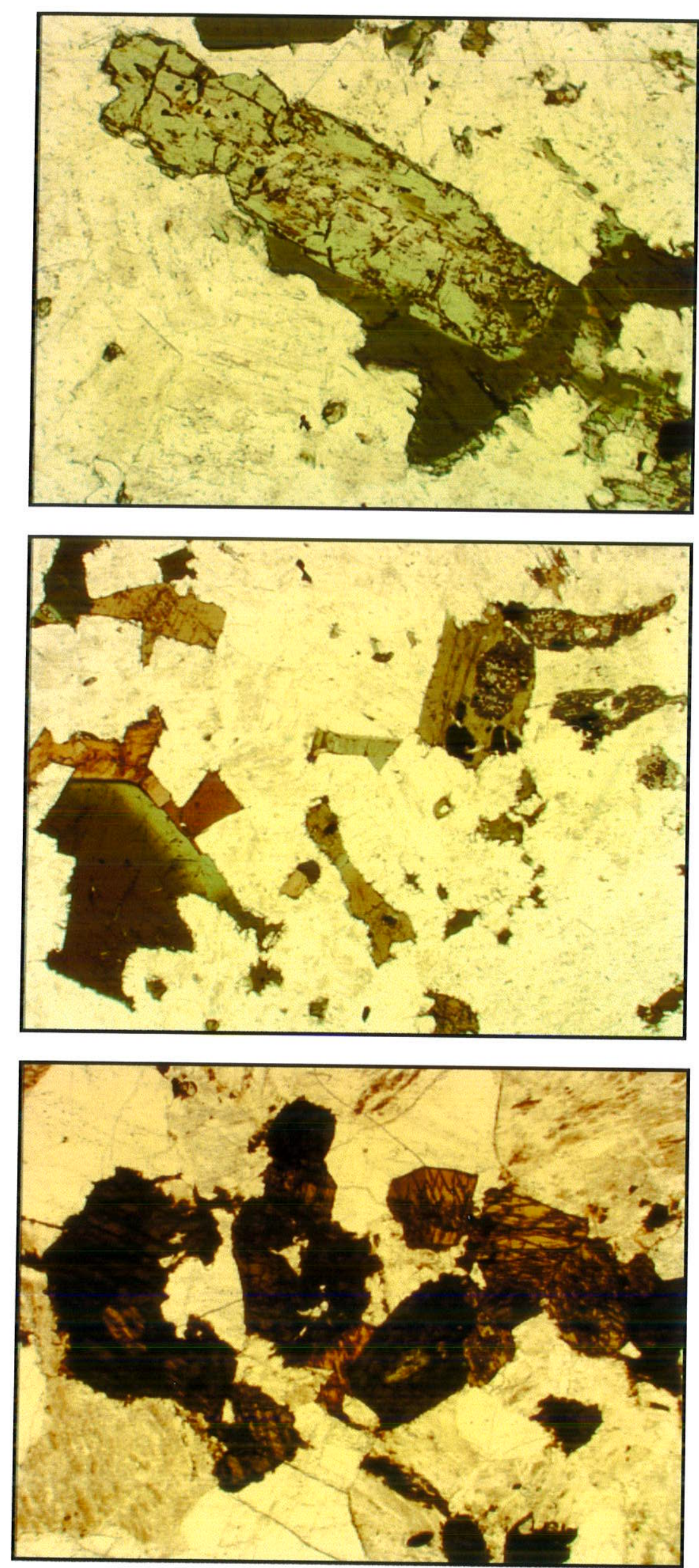

(d) Clinopiroxênio zonado (rosa pálido a verde claro) parcialmente envolto por anfibólio cálcico (verde escuro) dos álcalifeldspato sienitos equigranulares a porfiríticos finos com anfibólio e piroxênio.

Lado maior: $0,12 \mathrm{~cm}$

(e) Cristais intersticiais a subédricos de anfibólio cálcico (verde) nos álcali-feldspato sienitos equigranulares a porfiríticos finos com anfibólio e piroxênio.

Lado maior: $0,38 \mathrm{~cm}$

(f) Agregado de cristais euédricos de anfibólio cálcico (verde escuro e castanho) nos álcali-feldspato granitos equigranulares com anfibólio.

Lado maior: $0,38 \mathrm{~cm}$ 


\section{Prancha 3}
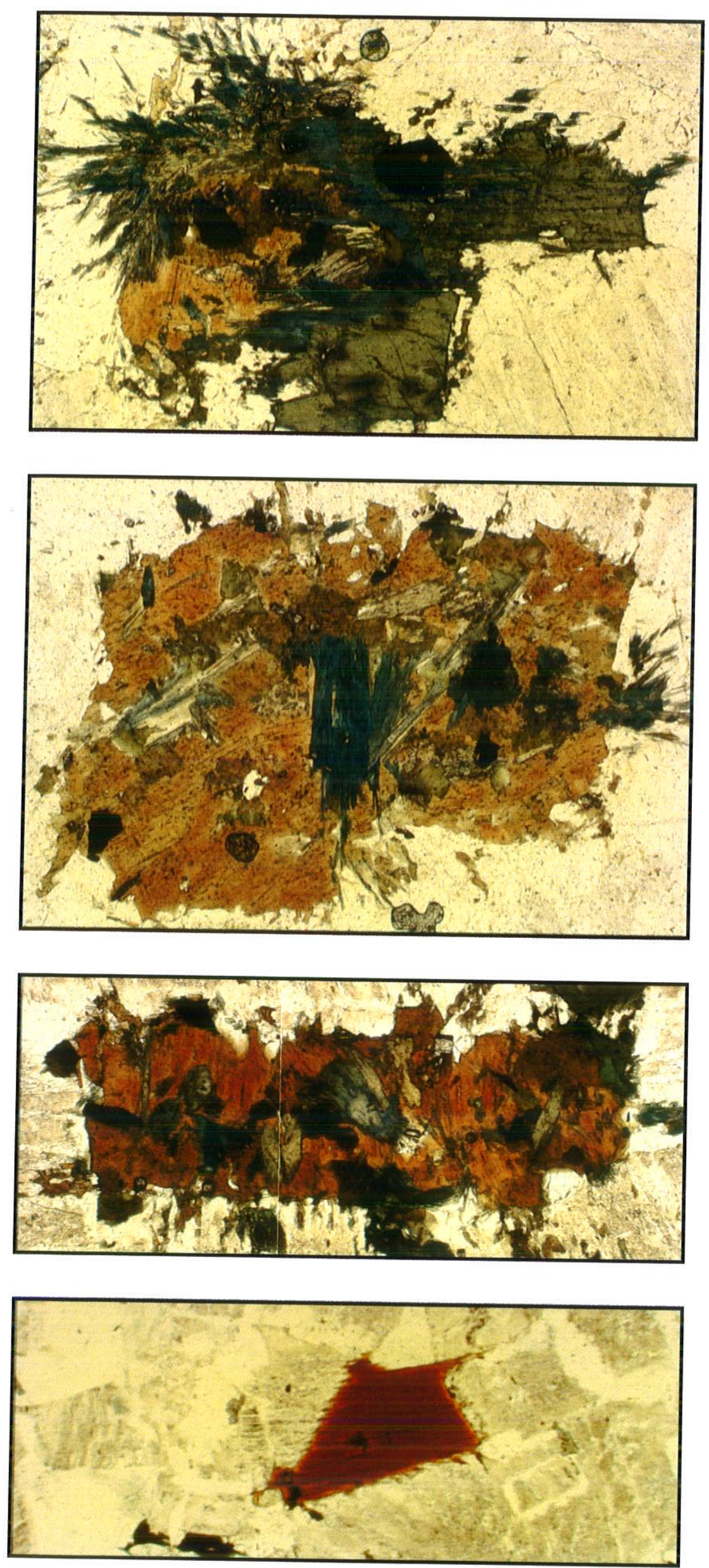

(g) Alteração de anfibólio cálcicosódico (verde) por anfibólio sódico (azul) e biotita (castanho avermelhado) nos álcali-feldspato sienitos equigranulares a porfiríticos finos com anfibólio e piroxênio. Notar a formaçãos de agregados radiados no canto esquerdo superior.

Lado maior: $0,24 \mathrm{~cm}$

(h-i) Agregados de biotita (castanho avermelhado) e anfibólio sódico (azul a amarelo pálido) interpretados como produtos de alteração de anfibólio primário nos álcalifeldspato sienitos equigranulares a porfiríticos finos com anfibólio e piroxênio.

Lado maior: $0,24 \mathrm{~cm}$

(j) Cristal isolado de biotita nos álcali-feldspato sienitos equigranulares a porfiriticos finos com anfibólio e piroxênio.

Lado maior: $0,38 \mathrm{~cm}$ 


\section{Prancha 3}
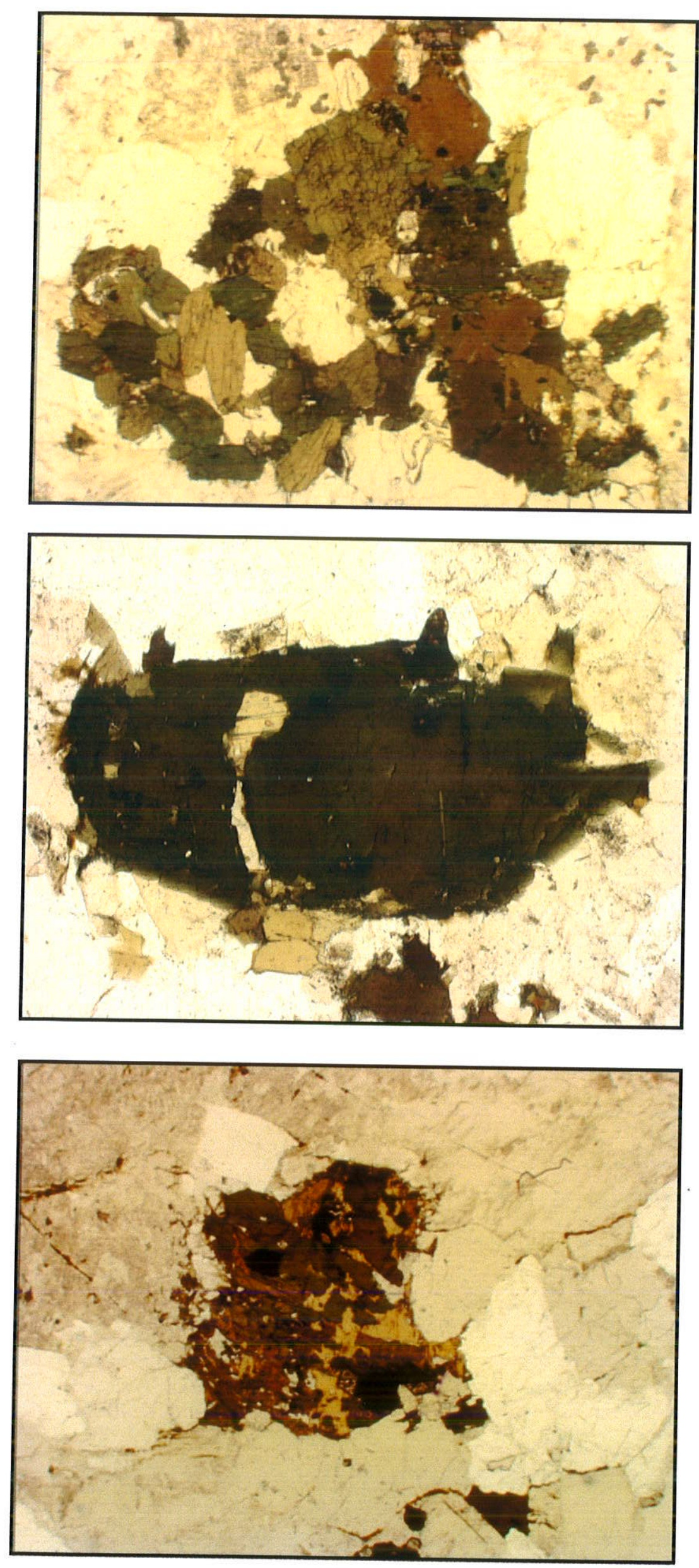

(k) Agregado de cristais subédricos a euédricos de anfibólio cálcico (verde e amarelado) e de biotita (avermelhado) dos sienogranitos equigranulares com biotita $e$ anfibólio cálcico.

Lado maior: $0,38 \mathrm{~cm}$

(I) Cristal subédrico de anfibólio cálcico (verde) nos sienogranitos inequigranulares com biotita e anfibólio cálcico.

Lado maior: $0,12 \mathrm{~cm}$

(m) Cristal de anfibólio (verde) corroído e substituído por biotita (castanho) nos álcali-feldspato granitos equigranulares com biotita.

Lado maior: $0,38 \mathrm{~cm}$ 


\section{Prancha 3}
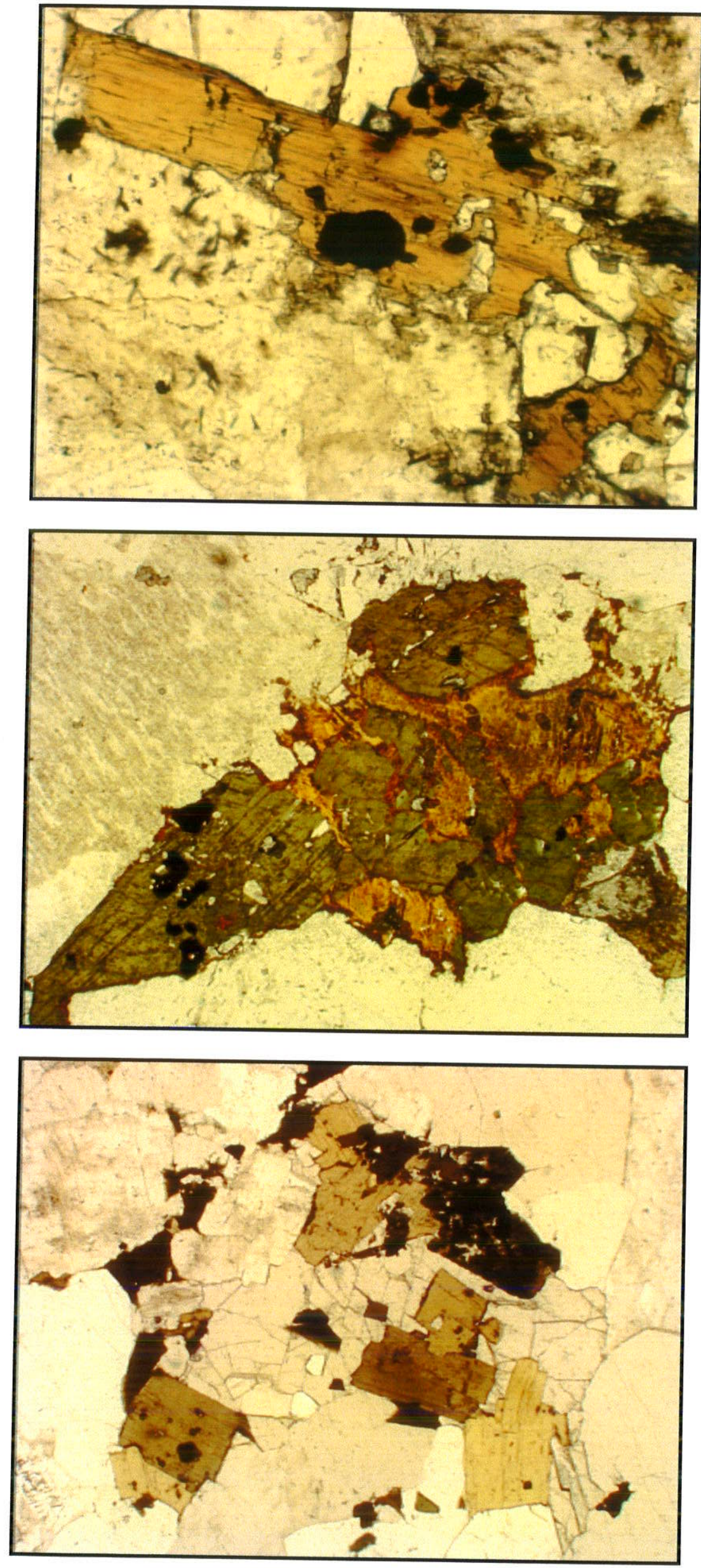

(n) Cristal isolado subédrico de biotita (castanho) dos álcalifeldspato granitos equigranulares com anfibólio.

Lado maior: $0,12 \mathrm{~cm}$

(o) Biotita (castanho) substituindo parcialmente anfibólio (verde) nos álcalifeldspato granitos equigranulares com anfibólio.

Lado maior: $0,38 \mathrm{~cm}$

(p) Agregado de cristais de biotita (verde e castanho) nos sienogranitos equigranulares com biotita e anfibólio cálcico.

Lado maior: $0,38 \mathrm{~cm}$ 


\section{Prancha 3}

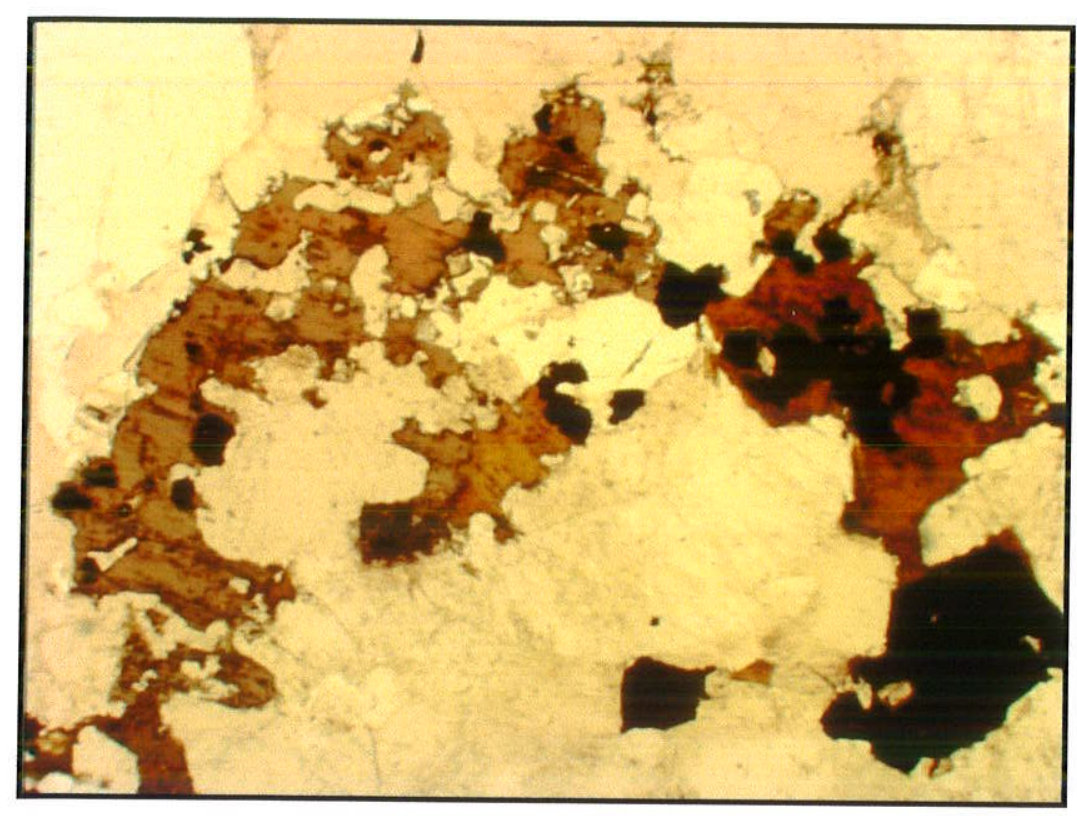

(q) Cristais anédricos de biotita (castanho) dos álcali-feldspato granitos equigranulares com biotita.

Lado maior: $0,38 \mathrm{~cm}$ 


\section{Prancha 4}
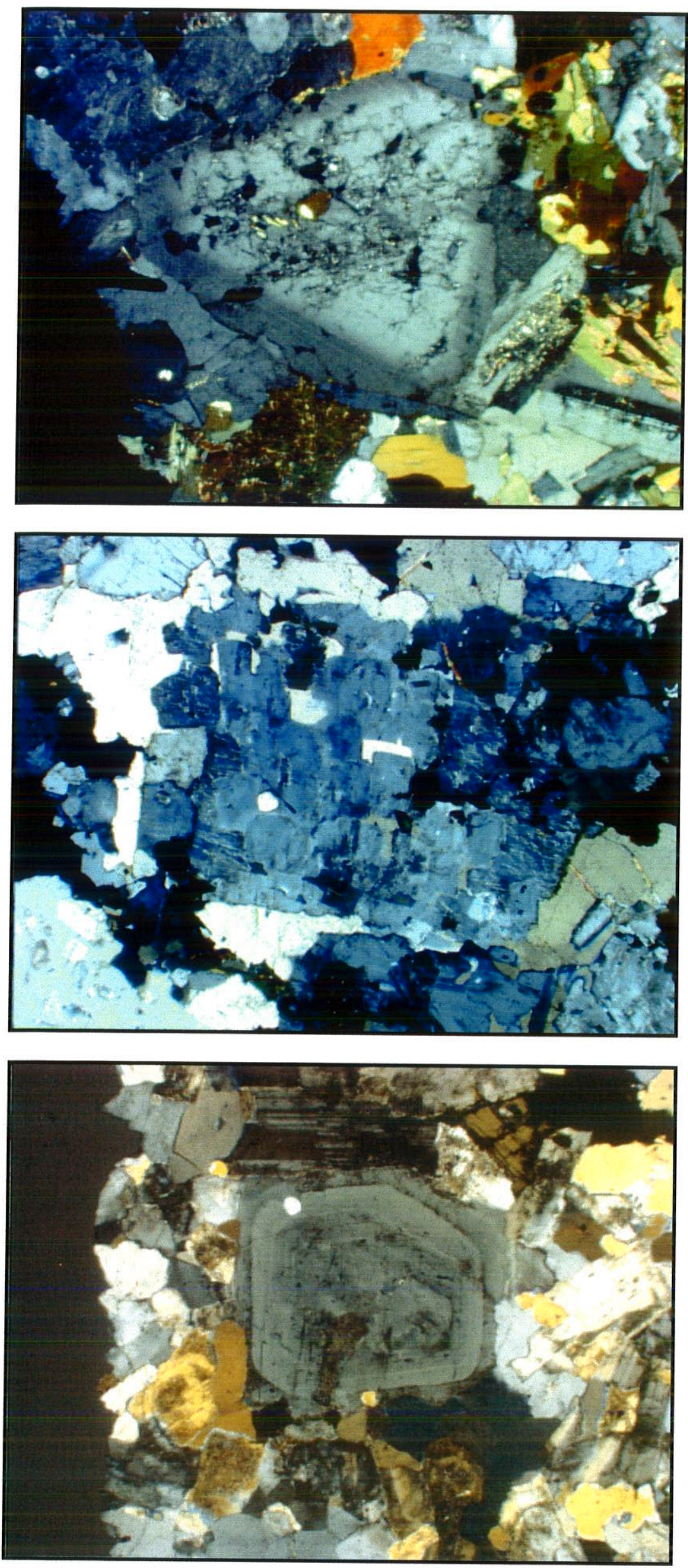

(a) Cristal de plagioclásio dos dioritos equigranulares com anfibólio cálcico.

Lado maior: $0,38 \mathrm{~cm}$

Luz plano-polarizada; polarização superior em todas as fotomicrografias.

(b) Cristal anédrico de plagioclásio nos quartzo sienitos equigranulares com anfibólio cálcico.

Lado maior: $0,38 \mathrm{~cm}$

(c) Cristal de plagioclásio nos sienogranitos porfiríticos com biotita e anfibólio cálcico.

Lado maior: $0,38 \mathrm{~cm}$ 


\section{Prancha 4}
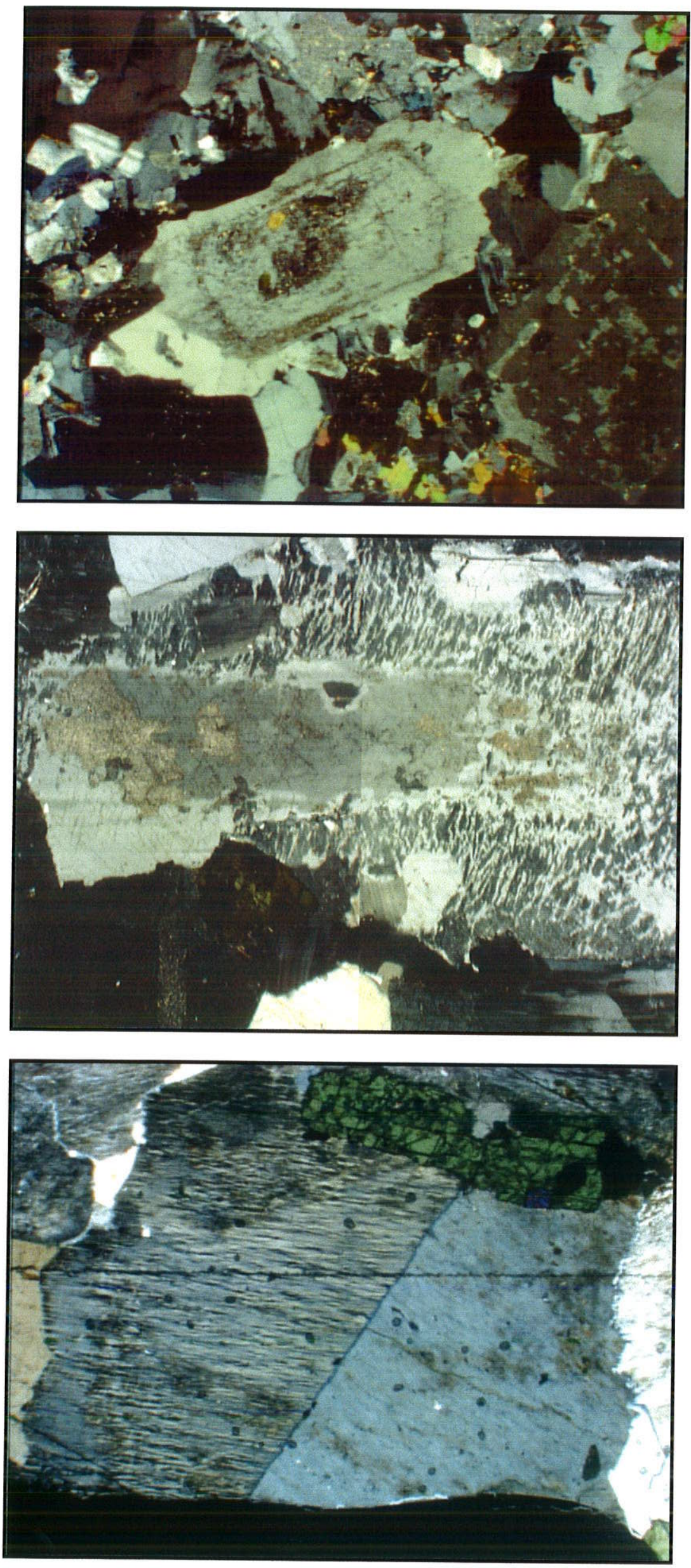

(d) Cristal de plagioclásio nos sienogranitos inequigranulares com biotita e anfibólio cálcico.

Lado maior: $0,38 \mathrm{~cm}$

(e) Cristal de plagioclásio envolto por feldspato alcalino dos álcalifeldspato granitos equigranulares com biotita.

Lado maior: $0,38 \mathrm{~cm}$

(f) Cristal feldspato alcalino pertítico dos álcali-feldspato sienitos equigranulares com piroxênio e olivina.

Lado maior: $0,38 \mathrm{~cm}$ 


\section{Prancha 4}
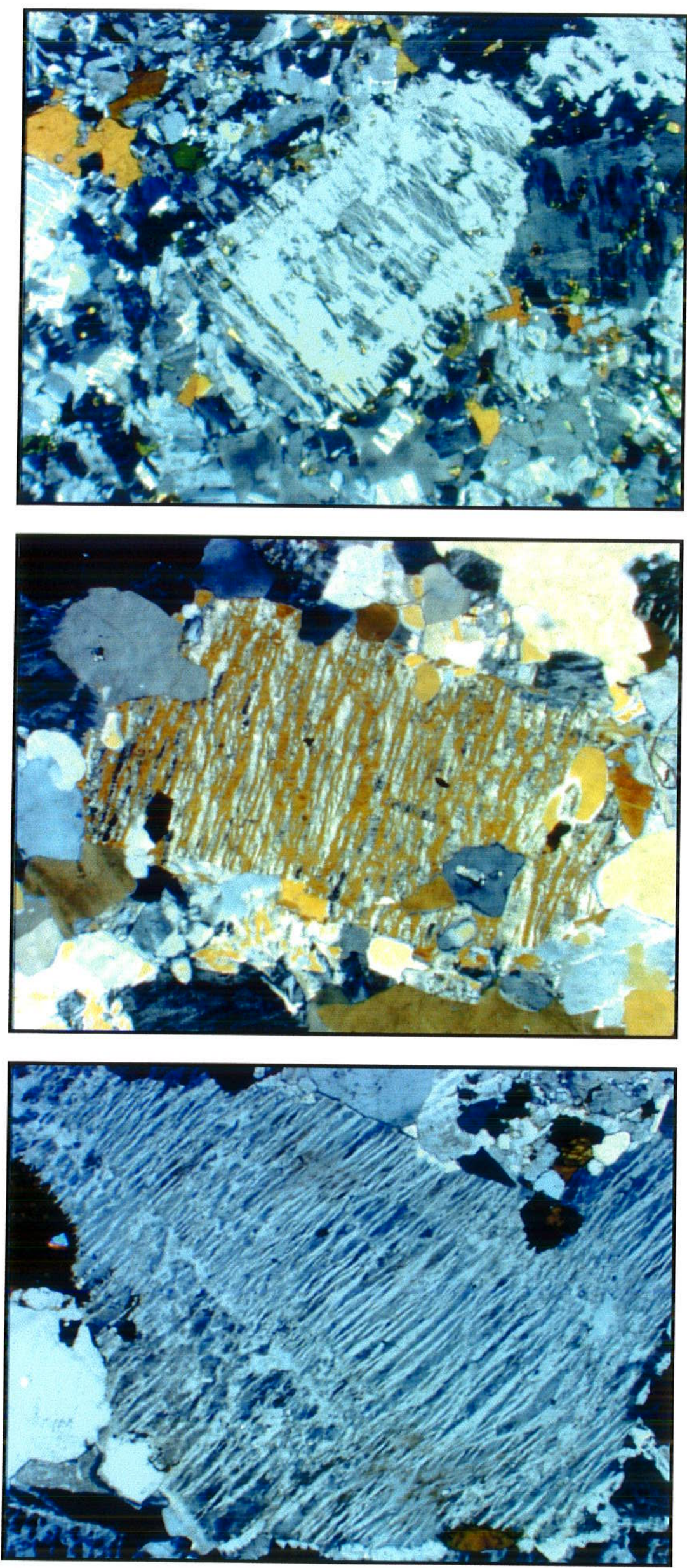

(g) Cristal de feldspato alcalino mesopertítico dos álcali-feldspato sienitos equigranulares a porfiríticos finos com anfibólio e piroxênio.

Lado maior: $0,38 \mathrm{~cm}$

(h) Cristal de feldspato alcalino mesopertítico dos álcali-feldspato granitos equigranulares com anfibólio sódico.

Lado maior: $0,12 \mathrm{~cm}$

(i) Cristal de feldspato alcalino mesopertítico dos álcali-feldspato granitos equigranulares com anfibólio.

Lado maior: $0,38 \mathrm{~cm}$ 


\section{Prancha 4}
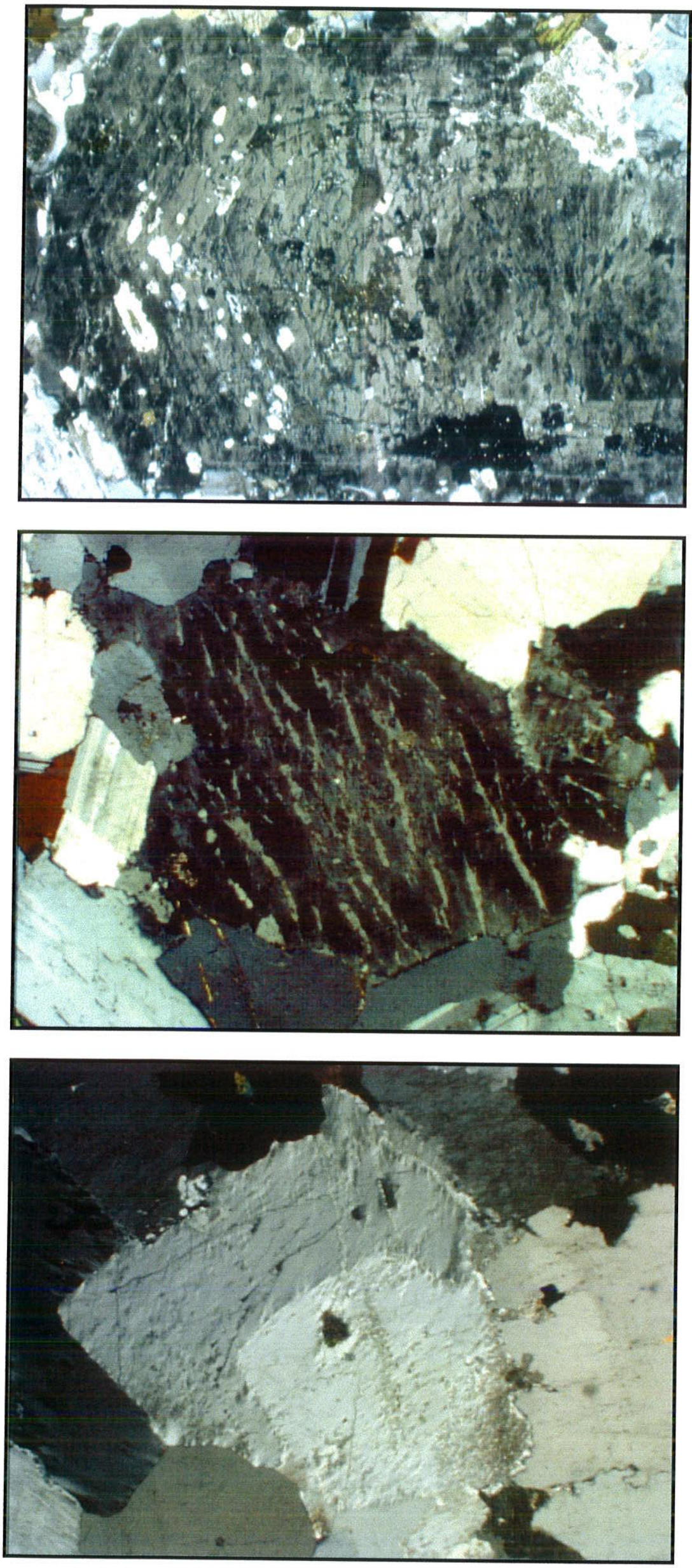

(j) Cristal de feldspato alcalino pertítico dos sienogranitos porfiríticos com biotita e anfibólio cálcico.

Lado maior: $0,38 \mathrm{~cm}$

(k) Cristal de feldspato alcalino pertítico dos sienogranitos equigranulares com biotita e anfibólio cálcico.

Lado maior: $0,38 \mathrm{~cm}$

(I) Cristal de feldspato alcalino mostrando dois estágios de crescimento dos álcali-feldspato granitos equigranulares com biotita.

Lado maior: $0,38 \mathrm{~cm}$ 


\section{Prancha 4}

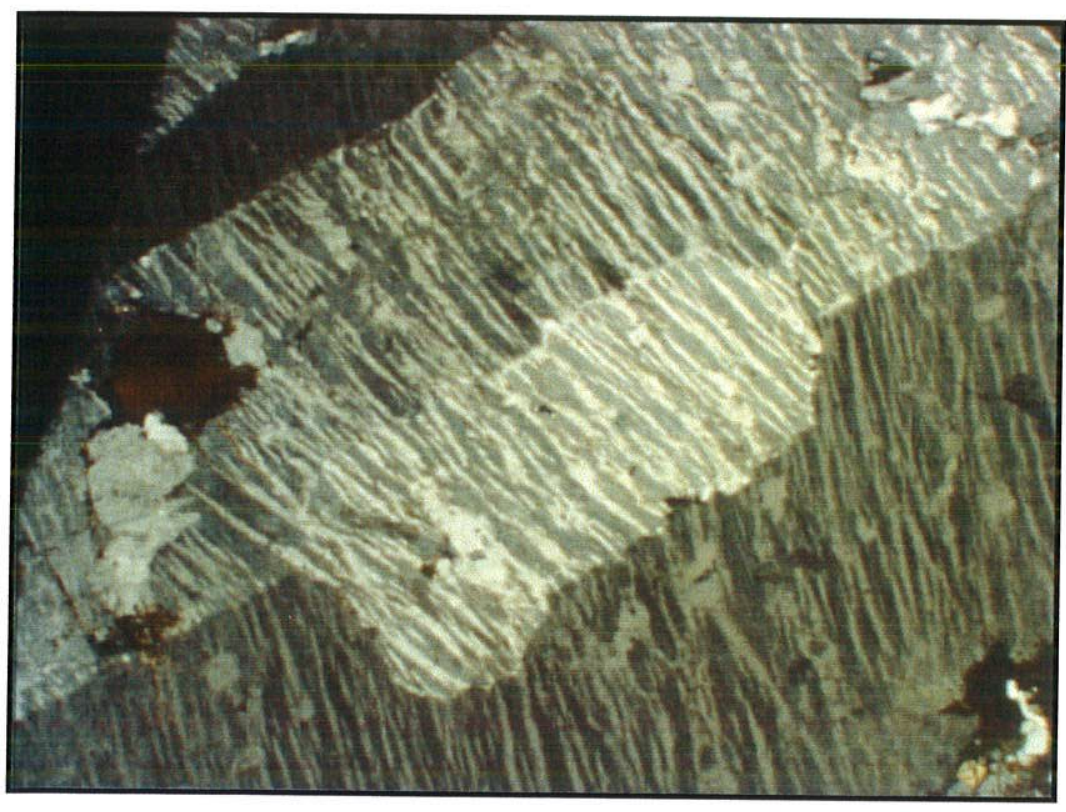

(m) Cristal de feldspato alcalino mostrando dois estágios de crescimento dos álcali-feldspato granitos equigranulares com biotita.

Lado maior: $0,38 \mathrm{~cm}$

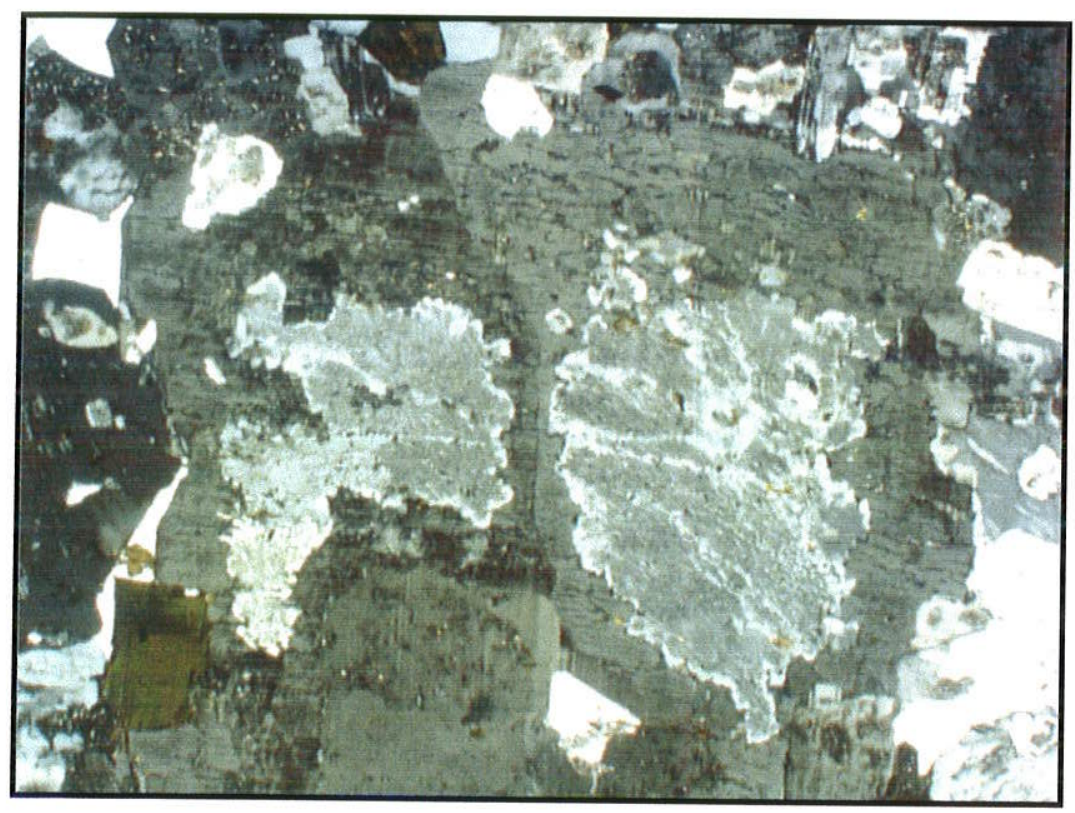

(n) Cristais de feldspato alcalino subédrico com interior alterado para intercrescimento de albita e ortoclásio dos álcali-feldspato granitos porfiríticos com biotita e anfibólio cálcico.

Lado maior: $0,38 \mathrm{~cm}$ 


\section{Tabela IV.2:}

Composiçōes modais e erros estimados ${ }^{\S}$ de amostras representativas das diversas fácies dos Granitos dá Graciosa

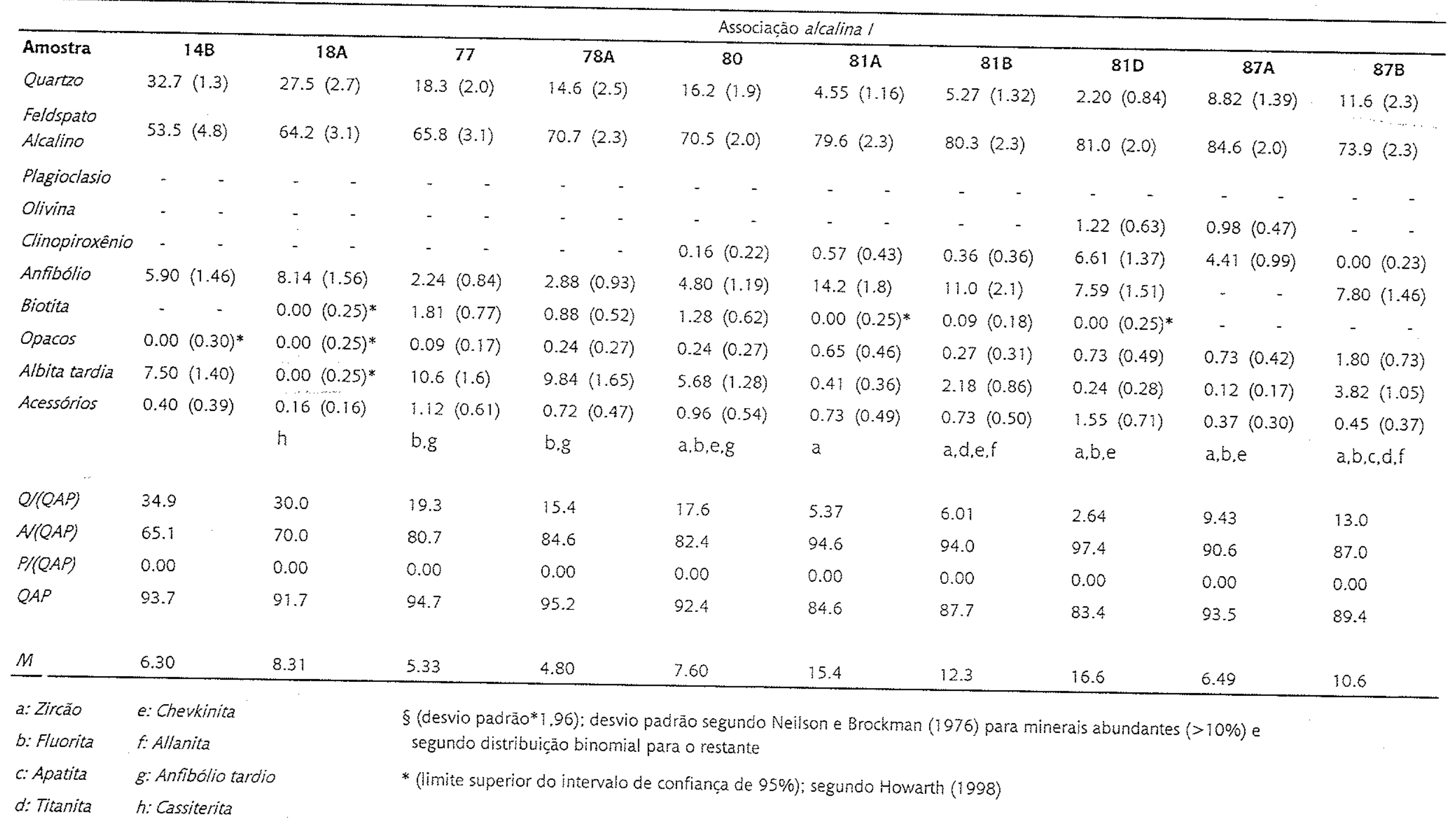


Tabela IV.2:

Composiçôes modais e erros estimados ${ }^{\S}$ de amostras representativas das diversas fácies dos Granitos da Graciosa

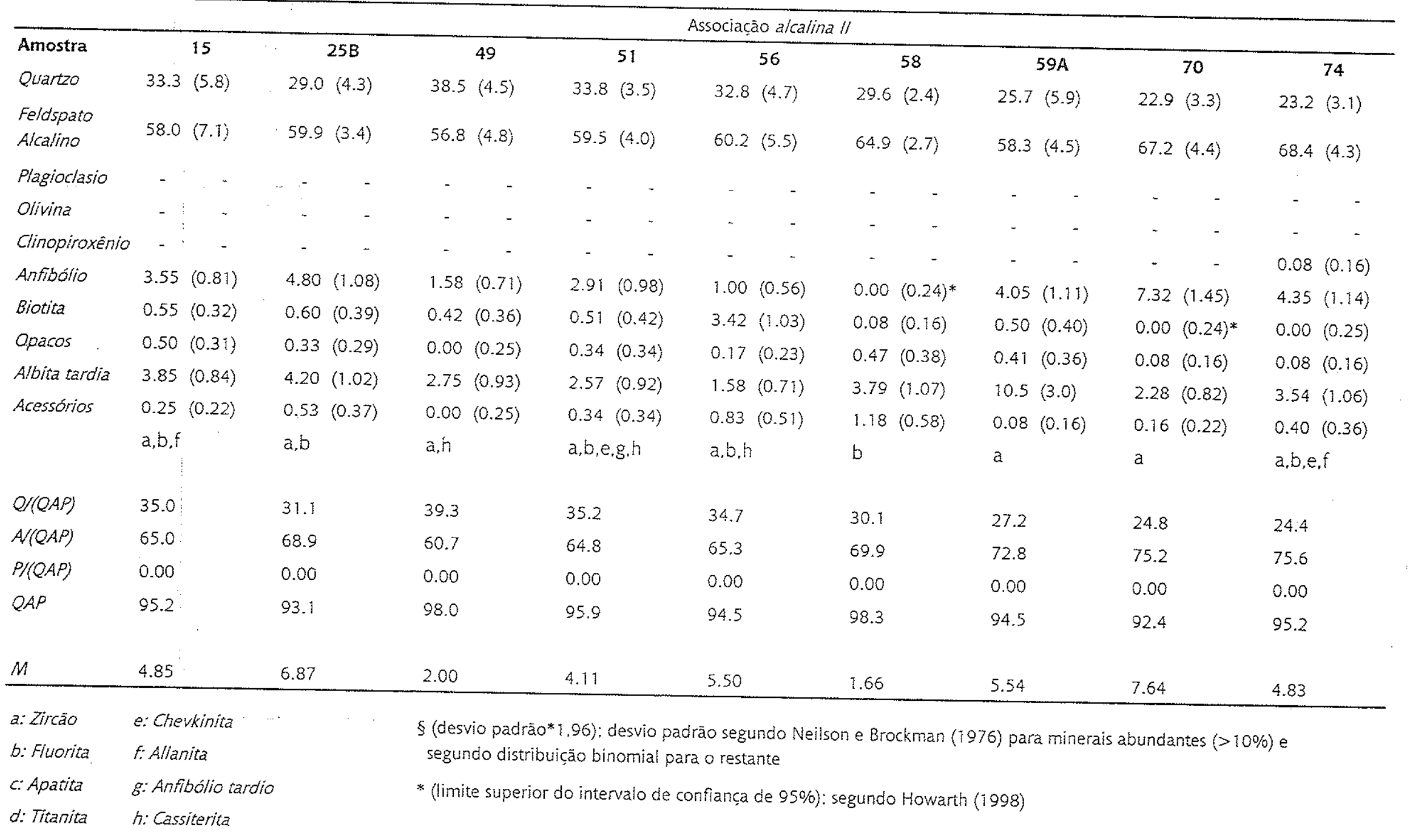




\section{Tabela IV.2:}

Composiçóes modais e erros estimados ${ }^{\mathcal{S}}$ de amostras representativas das diversas fácies dos Granitos da Graciosa

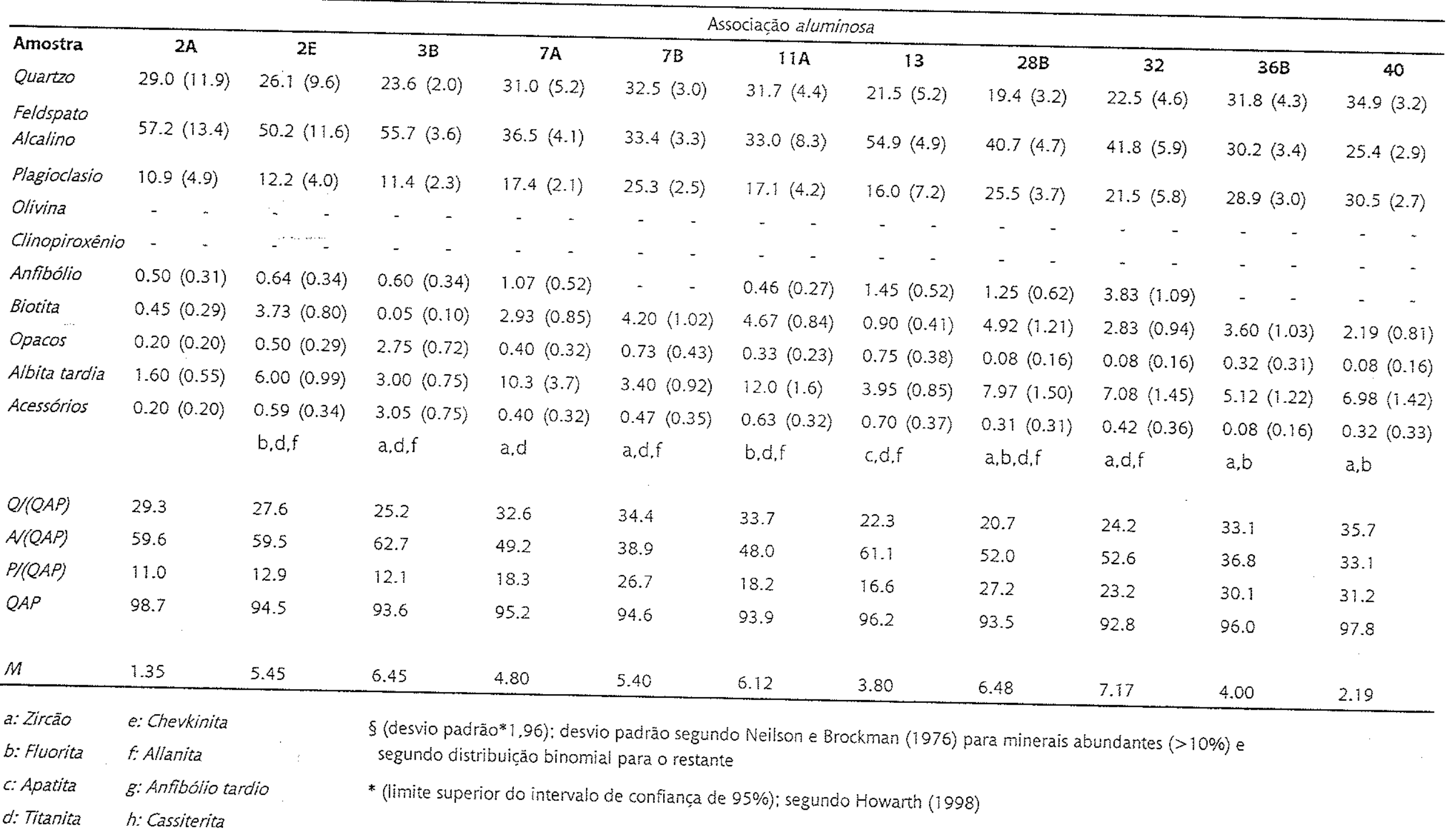


Tabela IV.2:

Composiçóes modais e erros estimados ${ }^{\xi}$ de amostras representativas das diversas fácies dos Cranitos da Graciosa

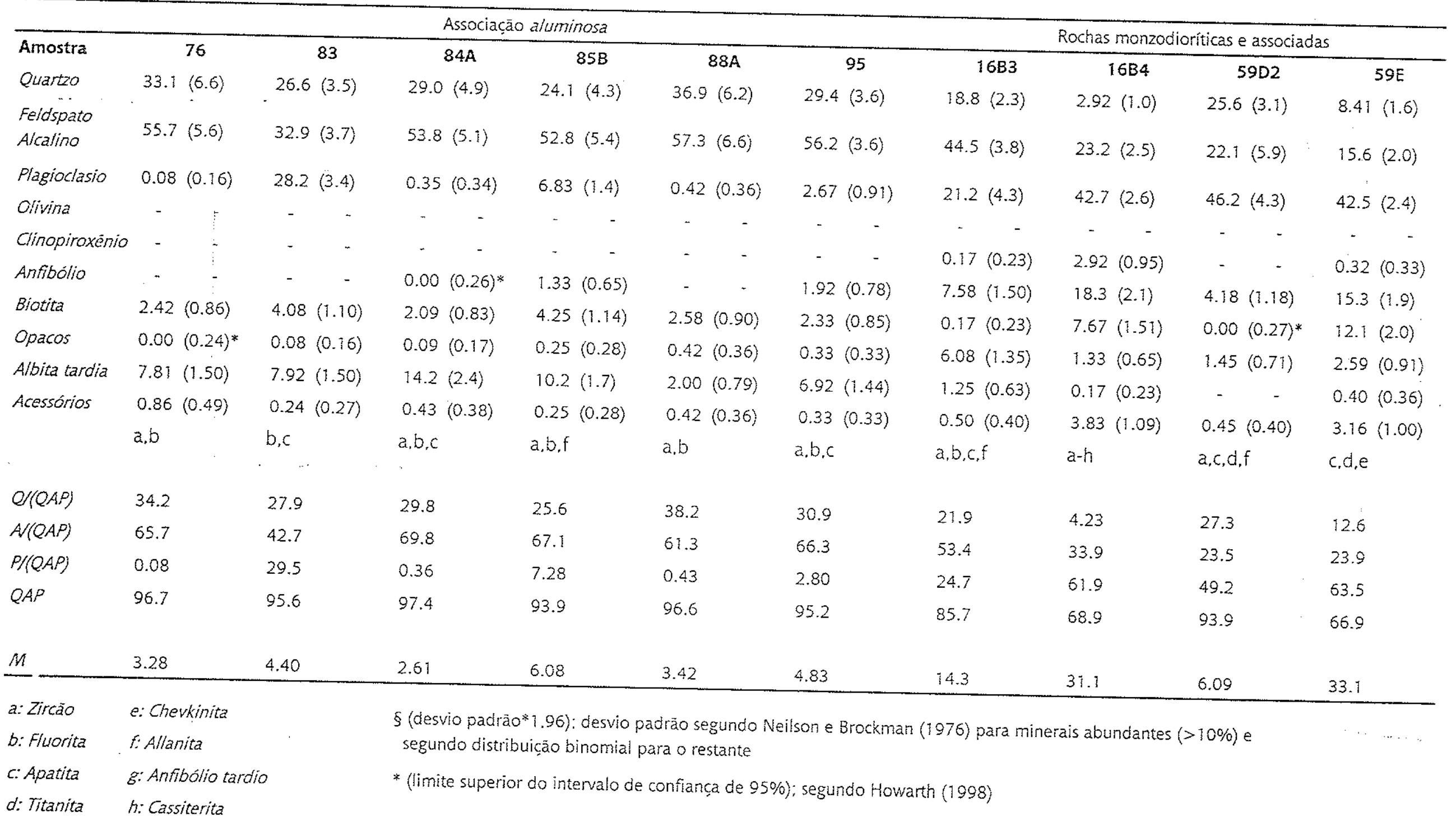


Tabela IV.4:

Análises quimicas completas (WDS) de olivinas dos Granitos da Graciosa

\begin{tabular}{|c|c|c|c|c|c|c|c|c|c|c|}
\hline & & & & & & & & & & \\
\hline Ponto & & & 810 & & & & & $87 \mathrm{~A}$ & & \\
\hline $\mathrm{SiO}_{2}$ & $\begin{array}{c}3 \\
298\end{array}$ & 4 & 7 & 9 & 10 & 7 & 11 & 12 & 14 & 15 \\
\hline $\mathrm{TiO}_{2}$ & $\begin{array}{l}29.8 \\
<10\end{array}$ & 29.8 & 29.5 & 29.6 & 29.8 & 29.8 & 29.7 & 29.7 & 29.7 & 29.6 \\
\hline $\mathrm{ZrO}_{2}$ & $<1 . d$ & $<$ ld & $<$ ld & 0.12 & 0.08 & $<1 . d$ & 0.06 & < I.d. & <ld. & < ld. \\
\hline $\mathrm{FeO}$ & $\begin{array}{l}<\text { l.d. } \\
65.7\end{array}$ & $<$ l.d. & $<$ l.d. & 0.06 & $<$ l.d. & 0.10 & 0.26 & $<$ l.d. & 0.05 & $<$ l.d. \\
\hline $\mathrm{MnO}$ & $\begin{array}{l}65.7 \\
3.16\end{array}$ & 66.0 & 65.7 & 65.7 & 65.0 & 66.9 & 66.7 & 67.3 & 66.7 & 66.6 \\
\hline $\mathrm{MgO}$ & $\begin{array}{l}3.16 \\
0.38\end{array}$ & 3.49 & 3.86 & 4.46 & 4.53 & 2.79 & 2.71 & 2.60 & 2.76 & 3.04 \\
\hline Zno & $\begin{array}{l}0.38 \\
0.07\end{array}$ & 0.31 & 0.26 & 0.13 & 0.14 & 0.09 & 0.12 & 0.09 & 0.07 & 0.11 \\
\hline $\mathrm{CaO}$ & $\begin{array}{l}0.07 \\
0.11\end{array}$ & 0.05 & $<$ l.d. & 0.08 & 0.06 & < l.d. & $<1$. d. & $<$ I.d. & $<$ l.d. & $<$ l.d. \\
\hline $\mathrm{Na}_{2} \mathrm{O}$ & $<1 . d$ & 0.08 & 0.09 & 0.06 & 0.07 & 0.20 & 0.19 & 0.16 & 0.22 & 0.15 \\
\hline Total & $\begin{array}{l}<1.0 . \\
99.2\end{array}$ & $<$ l.d. & $<$ l.d. & $<$ ld & $<$ ld & 0.06 & < ld. & < l.d. & $<$ l.d. & 0.03 \\
\hline & & 99.8 & 99.5 & 100.2 & 99.8 & 100.0 & 99.7 & 100.0 & 99.5 & 99.6 \\
\hline $\mathrm{Si}$ & 1.013 & 1.009 & 1.003 & 1.001 & 1.012 & 1.006 & 1.007 & 1.004 & 1.009 & 1.004 \\
\hline Soma_T & 1.013 & 1.009 & 1.003 & 1.001 & 1.012 & 1.006 & 1.007 & 1.004 & 1.009 & 1.004 \\
\hline$T i$ & 0.000 & 0.000 & 0.000 & 0.003 & 0.002 & 0.000 & 0.002 & 0.001 & 0.000 & 0.000 \\
\hline $\mathrm{Zr}$ & 0.000 & 0.000 & 0.000 & 0.001 & 0.001 & 0.002 & 0.004 & 0.001 & 0.001 & 0.000 \\
\hline$Z n$ & 0.003 & 0.000 & 0.002 & 0.002 & 0.001 & 0.005 & 0.004 & 0.008 & 0.007 & 0.007 \\
\hline $\mathrm{Mg}$ & 0.019 & 0.016 & 0.013 & 0.006 & 0.007 & 0.004 & 0.006 & 0.005 & 0.003 & 0.005 \\
\hline $\mathrm{Fe}$ & 1.870 & 1.871 & 1.867 & 1.857 & 1.844 & 1.891 & 1.891 & 1.902 & 1.891 & 1.889 \\
\hline $\mathrm{Mn}$ & 0.091 & 0.100 & 0.111 & 0.128 & 0.130 & 0.080 & 0.078 & 0.074 & 0.079 & 0.087 \\
\hline $\mathrm{Ca}$ & 0.004 & 0.003 & 0.003 & 0.002 & 0.003 & 0.007 & 0.007 & 0.006 & 0.008 & 0.005 \\
\hline $\mathrm{Na}$ & 0.000 & 0.000 & 0.000 & 0.000 & 0.000 & 0.004 & 0.001 & 0.000 & 0.001 & 0.002 \\
\hline Soma_M2 & 1.984 & 1.990 & 1.995 & 1.994 & 1.984 & 1.986 & 1.982 & 1.986 & 1.983 & 1.989 \\
\hline $\mathrm{Mg} \#$ & 0.010 & 0.008 & 0.007 & 0.003 & 0.004 & 0.002 & 0.003 & 0007 & 0000 & \\
\hline
\end{tabular}


Tabela IV.S:

Análises químicas completas (WDS) de clinopiroxênios dos Granitos da Graciosa

\begin{tabular}{|c|c|c|c|c|c|c|c|c|c|c|c|c|c|c|c|}
\hline Ponto & 1 & 2 & 3 & 8 & \multicolumn{3}{|c|}{ Associação alcalina / } & & & & & & 810 & & \\
\hline $\mathrm{SiO}_{2}$ & 49.0 & 48.2 & 47.8 & 48.2 & $\begin{array}{c}17 \\
47.8\end{array}$ & l & 3 & 5 & 4 & 5 & 3 & 10 & il & 12 & 13 \\
\hline $\mathrm{TiO}_{2}$ & 0.28 & 0.58 & 0.56 & 0.12 & $\begin{array}{l}47.8 \\
0.25\end{array}$ & 48.3 & 48.4 & 48.3 & 49.9 & 49.3 & 49.7 & 49.7 & 48.8 & 48.8 & 48.7 \\
\hline $\mathrm{Al}_{2} \mathrm{O}_{3}$ & 0.53 & 0.85 & 0.85 & 0.21 & $\begin{array}{l}0.25 \\
0.23\end{array}$ & $<$ i.d. & $<$ l.d. & $<$ l.d. & 0.11 & 0.36 & 0.15 & 0.20 & 0.60 & 0.21 & 0.10 \\
\hline $\mathrm{Fe}_{2} \mathrm{O}_{3}^{*}$ & 0.71 & 0.96 & 1.44 & 3.19 & $\begin{array}{l}0.23 \\
1.84\end{array}$ & 0.23 & 0.22 & 0.20 & 0.22 & 0.36 & 0.43 & 0.48 & 0.84 & 0.35 & 0.26 \\
\hline $\mathrm{FeO}^{*}$ & 23.3 & 23.3 & 24.5 & 25.0 & $\begin{array}{l}1.84 \\
27.6\end{array}$ & 4.13. & 3.94 & 4.15 & $<$ l.d. & 0.85 & < l.d. & 0.99 & $<1 d$ & 0.79 & 1.27 \\
\hline Mno & 1.06 & 1.05 & 1.13 & 1.01 & $\begin{array}{l}27.6 \\
1.01\end{array}$ & 25.8 & 25.7 & 25.6 & 21.6 & 22.2 & 23.5 & 22.1 & 24.0 & 27.1 & 27.0 \\
\hline Mgo & 3.69 & 3.42 & 2.72 & 1.08 & $\begin{array}{l}1.01 \\
0.66\end{array}$ & 1.28 & 1.34 & 1.29 & 0.98 & 0.90 & 1.08 & 1.07 & 1.16 & 1.01 & 1.01 \\
\hline Zno & $<$ l.d. & $<$ I.d. & $<$ l.d. & 0.08 & $\begin{array}{l}0.66 \\
<\text { l.d. }\end{array}$ & 0.46 & 0.43 & 0.46 & 4.51 & 4.27 & 3.85 & 4.25 & $3.4 i$ & 1.33 & 1.16 \\
\hline $\mathrm{CaO}$ & 20.4 & 20.1 & 19.8 & 18.1 & $\begin{array}{l}<1 . \mathrm{d} . \\
18.6\end{array}$ & $<1 . d$ & $<$ ld & $<1$. d. & $<$ ld & $<$ l.d. & $<1 . d$ & $<$ ld & $<1 d$ & $<$ l.d. & $<1 d$ \\
\hline $\mathrm{Na}_{2} \mathrm{O}$ & 0.38 & 0.45 & 0.38 & 1.39 & $\begin{array}{l}18.6 \\
0.81\end{array}$ & 18.1 & 18.2 & 18.2 & 21.9 & 20.2 & 20.8 & 20.8 & 20.0 & 19.5 & 19.4 \\
\hline $\mathrm{K}_{2} \mathrm{O}$ & $<$ l.d. & $<$ l.d. & $<$ I.d. & $<$ l.d. & $\begin{array}{l}0.81 \\
<1 . d\end{array}$ & 1.43 & 1.44 & 1.47 & 0.23 & 0.59 & 0.33 & 0.46 & 0.39 & 0.65 & 0.74 \\
\hline Total & 99.4 & 98.8 & 99.2 & 98.0 & $\begin{array}{l}<i . d \\
98.7\end{array}$ & $<1 . d$ & $<$ l.d. & $<1 . d$ & $<1 . d$ & $<$ l.d. & < l.d. & $<l d$ & $<1 . d$ & $<$ l.d. & $<$ ld. \\
\hline & & & & & 98.7 & 99.3 & 99.3 & 99.3 & 99.5 & 99.0 & 99.9 & 100.0 & 99.2 & 99.7 & 99.4 \\
\hline Si & 1.982 & 3.964 & 1.955 & 1.997 & 1.990 & 1.988 & 1.990 & 1.989 & 2.000 & 1.990 & 1.998 & 1.986 & 1.979 & 1.999 & 2.000 \\
\hline Al & 0.018 & 0.036 & 0.041 & 0.003 & 0.010 & 0.011 & 0.010 & 0.009 & 0.000 & 0.010 & 0.002 & 0.014 & 0.021 & 0.001 & 0.000 \\
\hline $\mathrm{Fe}^{3+}$ & 0.000 & 0.000 & 0.004 & 0.000 & 0.000 & 0.001 & 0.000 & 0.001 & 0.000 & 0.000 & 0.000 & 0.000 & 0.000 & 0.000 & 0.000 \\
\hline Soma_T & 2.000 & 2.000 & 2.000 & 2.000 & 2.000 & 2.000 & 2.000 & 2.000 & 2.000 & 2.000 & 2.000 & 2.000 & 2.000 & 2.000 & 2.000 \\
\hline Al & 0.008 & 0.005 & 0.000 & 0.008 & 0.001 & 0.000 & 0.001 & 0.000 & 0.010 & 0.007 & 0.018 & 0.009 & 0.019 & 0.016 & 0.013 \\
\hline $\mathrm{Fe}^{3+}$ & 0.022 & 0.029 & 0.040 & 0.099 & 0.058 & 0.127 & 0.122 & 0.127 & 0.001 & 0.026 & 0.001 & 0.030 & 0.000 & 0.024 & 0.039 \\
\hline$T$ & 0.009 & 0.018 & 0.017 & 0.004 & 0.008 & 0.000 & 0.000 & 0.000 & 0.003 & 0.011 & 0.005 & 0.006 & 0.018 & 0.006 & 0.003 \\
\hline $\mathrm{Zn}$ & 0.001 & 0.000 & 0.001 & 0.003 & 0.000 & 0.000 & 0.000 & 0.000 & 0.000 & 0.001 & 0.000 & 0.000 & 0.001 & 0.001 & 0.000 \\
\hline $\mathrm{Mg}$ & 0.222 & 0.208 & $\ldots 0.166$ & 0.067 & 0.041 & 0.028 & 0.027 & 0.028 & 0.269 & 0.256 & 0.230 & 0.253 & 0.206 & 0.081 & 0.071 \\
\hline $\mathrm{Fe}^{2+}$ & 0.738 & 0.740 & 0.776 & 0.820 & 0.892 & 0.845 & 0.850 & 0.844 & 0.716 & 0.699 & 0.746 & 0.702 & 0.755 & 0.871 & 0.874 \\
\hline $\mathrm{Mn}$ & 0.000 & 0.000 & 0.000 & 0.000 & 0.000 & 0.000 & 0.000 & 0.000 & 0.000 & 0.000 & 0.000 & 0.000 & 0.000 & 0.000 & 0.000 \\
\hline Soma_MI & 1.000 & 1.000 & 1.000 & 1.000 & 1.000 & 1.000 & 1.000 & 1.000 & 1.000 & 1.000 & 1.000 & 1.000 & 1.000 & 1.000 & 1.000 \\
\hline $\mathrm{Mg}$ & 0.000 & 0.000 & 0.000 & 0.000 & 0.000 & 0.000 & 0.000 & 0.000 & 0.000 & 0.000 & 0.000 & 0.000 & 0.000 & 0.000 & 0.000 \\
\hline $\mathrm{Fe}^{2+}$ & 0.049 & 0.052 & 0.063 & 0.046 & 0.069 & 0.042 & 0.034 & 0.036 & 0.009 & 0.049 & 0.043 & 0.037 & 0.059 & 0.057 & 0.053 \\
\hline $\mathrm{Mn}$ & 0.036 & 0.036 & 0.039 & 0.036 & 0.036 & 0.045 & 0.047 & 0.045 & 0.033 & 0.031 & 0.037 & 0.036 & 0.040 & 0.035 & 0.035 \\
\hline $\mathrm{Ca}$ & 0.884 & 0.876 & 0.868 & 0.806 & 0.829 & 0.799 & 0.804 & 0.801 & 0.940 & 0.874 & 0.895 & 0.890 & 0.870 & 0.856 & 0.852 \\
\hline $\mathrm{Na}$ & 0.030 & 0.035 & 0.030 & 0.112 & 0.065 & 0.114 & 0.115 & 0.117 & 0.018 & 0.046 & 0.026 & 0.036 & 0.031 & 0.052 & 0.059 \\
\hline K & 0.000 & 0.000 & 0.000 & 0.001 & 0.001 & 0.000 & 0.000 & 0.000 & 0.000 & 0.000 & 0.000 & 0.000 & 0.000 & 0.000 & 0.000 \\
\hline Soma_M2 & 1.000 & 1.000 & 0.999 & 1.000 & 0.999 & 1.000 & 1.000 & 1.000 & 1.000 & 0.999 & 1.000 & 1.000 & 1.000 & 1.000 & 1.000 \\
\hline $\mathrm{Mg} \#$ & 0.220 & 0.208 & 0.165 & 0.072 & 0.041 & 0.031 & 0.029 & 0.031 & 0.271 & 0.255 & 0.226 & 0.255 & 0.202 & 0.080 & 0.071 \\
\hline
\end{tabular}


Tabela IV.5:

Análises quimicas completas (WDS) de clinopiroxênios dos Granitos da Graciosa

\begin{tabular}{|c|c|c|c|c|c|c|c|c|c|c|c|}
\hline & & \multicolumn{7}{|c|}{ Associaçào alcalina I } & \multicolumn{3}{|c|}{ Associação alcalina $/ /$} \\
\hline \multirow{3}{*}{$\begin{array}{c}\text { Amostra } \\
\text { Ponto } \\
\mathrm{SiO}_{2}\end{array}$} & \multicolumn{4}{|c|}{$87 \mathrm{~A}$} & \multicolumn{4}{|c|}{$87 \mathrm{~B}$} & \multicolumn{3}{|c|}{258} \\
\hline & $\cdots, \cdots$ & 4 & 7 & 17 & 1 & 2 & 3 & 6 & 2 & 3 & 4 \\
\hline & 48.0 & 48.0 & 48.3 & 48.4 & 50.2 & 49.9 & 49.1 & 50.2 & 48.5 & 47.1 & 48.0 \\
\hline $\mathrm{THO}_{2}$ & $<$ l.d. & $<$ ld & $<$ ld & $<\mathrm{l} . \mathrm{d}$ & $<$ l.d. & $<$ l.d. & $<$ l.d. & $<\mathrm{l} . \mathrm{d}$ & $<$ ld & $<$ I.d. & $<$ l.d. \\
\hline $\mathrm{Al}_{2} \mathrm{O}_{3}$ & 0.20 & 0.22 & 0.20 & 0.27 & 0.37 & 0.48 & 1.00 & 0.30 & 3.00 & 3.36 & 3.80 \\
\hline $\mathrm{Fe}_{2} \mathrm{O}_{3}^{*}$ & 2.64 & 2.06 & 2.08 & 2.07 & 0.60 & 0.67 & 1.85 & 0.87 & 2.91 & 5.47 & 4.63 \\
\hline $\mathrm{FeO} *$ & 27.8 & 27.3 & 27.3 & 28.0 & 20.2 & 20.1 & 19.4 & 19.8 & 24.4 & 21.9 & 18.8 \\
\hline Mno & 0.97 & 1.06 & 0.95 & 0.98 & 0.87 & 0.94 & 0.97 & 0.97 & 0.68 & 0.90 & 0.57 \\
\hline $\mathrm{MgO}$ & 0.21 & 0.18 & 0.21 & 0.20 & 5.70 & 5.84 & 5.56 & 5.77 & 6.14 & 4.59 & 7.96 \\
\hline $\mathrm{ZnO}$ & $<$ l.d. & $<$ l.d. & $<1 . d$ & $<$ i.d. & $<$ l.d. & $<$ l.d. & $<1 d$ & $<$ l.d. & $<$ l.d. & $<$ l.d. & $<$ ld \\
\hline $\mathrm{CaO}$ & 18.8 & 19.0 & 18.7 & 18.8 & 21.3 & 20.9 & 20.7 & 21.3 & 9.60 & $\$ 1.4$ & 10.1 \\
\hline $\mathrm{Na}_{2} \mathrm{O}$ & 0.92 & 0.94 & 1.12 & 0.96 & 0.35 & $0.3 i$ & 0.42 & 0.36 & 1.73 & 1.87 & 1.90 \\
\hline $\mathrm{K}_{2} \mathrm{O}$ & $<$ l.d. & $<$ ld. & $<$ I.d. & $<$ l.d. & $<l d$ & < l.d. & $<1 . d$ & $<$ ld & 0.56 & 0.67 & 0.66 \\
\hline Total & 99.3 & 98.5 & 98.7 & 99.4 & 99.5 & 99.2 & 98.9 & 99.5 & 97.3 & 96.7 & 95.9 \\
\hline $\mathrm{Si}$ & 1.990 & 2.000 & & & & & & & & & \\
\hline A! & 0.010 & 0.000 & & 0.000 & $\begin{array}{l}1.996 \\
0.004\end{array}$ & $\begin{array}{l}1.990 \\
0.010\end{array}$ & & $\begin{array}{l}1.994 \\
0.006\end{array}$ & $\begin{array}{l}1.966 \\
0.034\end{array}$ & $\begin{array}{l}1.926 \\
0.074\end{array}$ & $\begin{array}{l}1.931 \\
0.060\end{array}$ \\
\hline $\mathrm{Fe}^{3+}$ & 0.000 & 0.000 & 0.000 & 0.000 & $\begin{array}{l}0.004 \\
0.000\end{array}$ & $\begin{array}{l}0.010 \\
0.000\end{array}$ & $\begin{array}{l}0.036 \\
0.000\end{array}$ & $\begin{array}{l}0.006 \\
0.000\end{array}$ & $\begin{array}{l}0.034 \\
0.000\end{array}$ & $\begin{array}{l}0.074 \\
0.000\end{array}$ & 0.069 \\
\hline Soma_T & 2.000 & 2.000 & 2.007 & 2.001 & 2.000 & $\begin{array}{l}0.000 \\
2.000\end{array}$ & $\begin{array}{l}0.000 \\
2.000\end{array}$ & $\begin{array}{l}0.000 \\
2.000\end{array}$ & 0.000 & 0.000 & 0.000 \\
\hline Al & 0.000 & 0.011 & 0.010 & 0.010 & 0.013 & $\begin{array}{l}2.000 \\
0.013\end{array}$ & $\begin{array}{l}2.000 \\
0.012\end{array}$ & $\begin{array}{l}2.000 \\
0.008\end{array}$ & 2.000 & 2.000 & 2.000 \\
\hline $\mathrm{Fe}^{3+}$ & 0.082 & 0.065 & 0.065 & 0.064 & 0.018 & $\begin{array}{l}0.013 \\
0.020\end{array}$ & 0.012 & $\begin{array}{l}0.008 \\
0.026\end{array}$ & 0.109 & 0.088 & 0.111 \\
\hline $\mathrm{Ti}$ & 0.000 & 0.000 & 0.000 & 0.000 & 0.000 & 0.020 & 0.056 & 0.026 & 0.089 & 0.168 & 0.140 \\
\hline $\mathrm{Zn}$ & 0.000 & 0.000 & 0.000 & 0.000 & 0.000 & 0.000 & 0.000 & 0.000 & 0.000 & 0.000 & 0.000 \\
\hline $\mathrm{Mg}$ & 0.013 & 0.011 & 0.013 & 0.012 & $\begin{array}{l}0.000 \\
0.337\end{array}$ & 0.000 & 0.000 & 0.000 & 0.000 & 0.000 & 0.000 \\
\hline $\mathrm{Fe}^{2+}$ & 0.904 & 0.913 & 0.913 & 0.913 & & 0.347 & 0.331 & 0.342 & 0.371 & 0.280 & 0.478 \\
\hline $\mathrm{Mn}$ & 0.000 & 0.000 & 0.000 & 0.000 & $\begin{array}{l}0.632 \\
0.000\end{array}$ & 0.620 & 0.601 & 0.625 & 0.431 & 0.463 & 0.271 \\
\hline Soma_MI & $1: 000$ & 1.000 & 1.000 & 1.000 & $\begin{array}{l}0.000 \\
1.000\end{array}$ & 0.000 & 0.000 & 0.000 & 0.000 & 0.000 & 0.000 \\
\hline $\mathrm{Mg}$ & 0.000 & 0.000 & 0.000 & 0.000 & $\begin{array}{l}1.000 \\
0.000\end{array}$ & 1.000 & 1.000 & 1.000 & 1.000 & 1.000 & 1.000 \\
\hline $\mathrm{Fe}^{2 \div}$ & 0.059 & 0.037 & 0.037 & 0.056 & 0.000 & 0.000 & 0.000 & 0.000 & 0.000 & 0.000 & 0.000 \\
\hline Min & 0.034 & 0.037 & 0.033 & 0.034 & 0.038 & 0.050 & 0.046 & 0.034 & 0.395 & 0.287 & 0.363 \\
\hline $\mathrm{Ca}$ & 0.833 & 0.849 & 0.831 & 0.832 & 0.029 & 0.032 & 0.033 & 0.033 & 0.023 & 0.031 & 0.019 \\
\hline $\mathrm{Na}$ & 0.074 & 0.076 & 0.090 & $\begin{array}{l}0.832 \\
0.077\end{array}$ & 0.905 & 0.894 & 0.888 & 0.905 & 0.417 & 0.498 & 0.435 \\
\hline$k$ & 0.000 & 0.000 & 0.000 & & 0.027 & 0.024 & 0.033 & 0.028 & 0.136 & 0.148 & 0.148 \\
\hline Soma $M 2$ & 1.000 & 1.000 & 0.992 & $\begin{array}{l}0.000 \\
0.999\end{array}$ & 0.000 & 0.000 & 0.000 & 0.001 & 0.029 & 0.035 & 0.034 \\
\hline & & & & 0.999 & 1.000 & 1.000 & 1.000 & 0.999 & 1.000 & 1.000 & 1.000 \\
\hline $\mathrm{Mg} \#$ & 0.013 & 0.012 & 0.013 & 0.013 & 0.335 & 0.341 & 0.339 & 0.342 & 0.310 & 0.272 & 0.430 \\
\hline
\end{tabular}

<.d.: abaixo do limite de deteção

* calculados pelo método de Droop (i987) com base em 4 cátins totais e 60 
Tabela IV.5:

Análises químicas completas (WDS) de clinopiroxênios dos Granitos da Graciosa

\begin{tabular}{|c|c|c|c|c|c|c|c|c|c|c|c|c|c|}
\hline & & & & & & \multicolumn{8}{|c|}{$\frac{\text { Rochas monzodioniticas e associadas }}{1684}$} \\
\hline Ponto & 1 & 3 & & & & 1684 & & & & & $59 \mathrm{E}^{5}$ & & \\
\hline $\mathrm{SiO}_{2}$ & 49.0 & & 4 & $I$ & 2 & 3 & 5 & $\sigma$ & $i$ & 2 & 3 & 4 & 5 \\
\hline $\mathrm{TiO}_{2}$ & 0.06 & $\begin{array}{l}48.9 \\
0.39\end{array}$ & 49.4 & 51.3 & 51.0 & 50.7 & 51.3 & 51.1 & 52.8 & 52.6 & 53.1 & 52.6 & 51.3 \\
\hline $\mathrm{Al}_{2} \mathrm{O}_{3}$ & 0.50 & $\begin{array}{l}0.39 \\
0.84\end{array}$ & 0.06 & 0.08 & 0.12 & 0.21 & 0.11 & 0.09 & 0.16 & 0.10 & 0.14 & 0.32 & 0.46 \\
\hline $\mathrm{Fe}_{2} \mathrm{O}_{3}{ }^{*}$ & 1.53 & & 0.33 & 0.31 & 0.42 & 0.59 & 0.19 & 0.35 & 0.68 & 0.55 & 0.35 & 1.54 & 2.35 \\
\hline $\mathrm{FeO}^{*}$ & 20.5 & $\begin{array}{l}1.28 \\
20.8\end{array}$ & 0.94 & 0.26 & 0.53 & 0.35 & $<$ ld & < l.d. & 0.45 & 0.49 & 0.31 & < l.d. & 0.71 \\
\hline $\mathrm{MnO}$ & 2.08 & $\begin{array}{l}20.8 \\
1.11\end{array}$ & 21.1 & 16.8 & 17.1 & 17.7 & 16.2 & 17.4 & 10.0 & 11.1 & 9.88 & 12.4 & 12.6 \\
\hline $\mathrm{MgO}$ & 5.81 & $\begin{array}{l}1.17 \\
6.22\end{array}$ & 1.76 & 1.05 & 0.85 & 0.81 & 1.15 & 1.06 & 0.50 & 0.64 & 0.64 & 0.59 & 0.57 \\
\hline Zno & 0.06 & $\begin{array}{l}0.22 \\
<1 . d\end{array}$ & 5.80 & 8.66 & 8.92 & 8.19 & 7.91 & 7.80 & 12.9 & 12.3 & 13.0 & 13.0 & 12.7 \\
\hline $\mathrm{CaO}$ & 18.9 & $\begin{array}{l}<1.0 . \\
18.8\end{array}$ & $<1 . d$ & 0.09 & $<$ l.d. & 0.17 & $<! \dot{\alpha}$ & < l.d. & $<$ ld & 0.06 & $<$ ld. & 0.14 & $<$ ld. \\
\hline $\mathrm{Na}_{2} \mathrm{O}$ & 0.30 & $\begin{array}{l}18.8 \\
0.36\end{array}$ & 19.3 & 21.0 & 20.2 & 20.4 & 22.3 & 21.6 & 21.8 & 21.7 & 22.4 & 18.5 & 17.6 \\
\hline $\mathrm{K}_{2} \mathrm{O}$ & $<$ ld & $\begin{array}{l}0.36 \\
<1 . d .\end{array}$ & 0.26 & 0.24 & 0.29 & 0.30 & 0.21 & 0.22 & 0.38 & 0.31 & 0.26 & 0.46 & $0.6 i$ \\
\hline Total & 98.6 & $\begin{array}{l}<1 . d \\
98.6\end{array}$ & $<$ ld & $<$ ld & 0.02 & 0.02 & $<$ l.d. & 0.02 & $<$ ld & $<$ ld & $<$ ld & 0.13 & 0.19 \\
\hline & & & 98.9 & 99.9 & 99.4 & 99.6 & 99.4 & 99.6 & 99.8 & 99.8 & 100.2 & 99.8 & 99.2 \\
\hline Si & 1.975 & 1.964 & 1.987 & 1.995 & 1.990 & 1.986 & & 2.000 & 1987 & & 1994 & & \\
\hline Al & 0.024 & 0.036 & 0.013 & 0.005 & 0.010 & 0.014 & 0.000 & 0.000 & 0.013 & $\begin{array}{l}1.990 \\
0.010\end{array}$ & 0.006 & $\begin{array}{l}1.984 \\
0.016\end{array}$ & $\begin{array}{l}1.950 \\
0.050\end{array}$ \\
\hline $\mathrm{Fe}^{3 ;}$ & 0.001 & 0.000 & 0.000 & 0.000 & 0.000 & 0.000 & 0.000 & 0.000 & 0.000 & 0.000 & 0.000 & 0.000 & 0.000 \\
\hline Soma $T$ & 2.000 & 2.000 & 2.000 & 2.000 & 2.000 & 2.000 & 2.006 & 2.000 & 2.000 & 2.000 & 2.000 & 2.000 & 2.000 \\
\hline $\mathrm{AI}$ & 0.000 & 0.003 & 0.002 & 0.010 & 0.010 & 0.013 & 0.009 & 0.016 & 0.017 & 0.014 & 0.009 & 0.053 & 0.055 \\
\hline $\mathrm{Fe}^{3+}$ & 0.045 & 0.039 & 0.028 & 0.008 & 0.015 & 0.010 & 0.000 & 0.000 & 0.013 & 0.014 & 0.009 & 0.000 & 0.020 \\
\hline$\pi i$ & 0.002 & 0.012 & 0.002 & 0.002 & 0.003 & 0.006 & 0.003 & 0.003 & 0.004 & 0.003 & 0.004 & 0.009 & 0.013 \\
\hline $\mathrm{Zn}$ & 0.002 & 0.001 & 0.000 & 0.003 & 0.000 & 0.005 & 0.000 & 0.000 & 0.001 & 0.002 & 0.000 & 0.004 & 0.001 \\
\hline $\mathrm{Mg}$ & 0.349 & 0.372 & 0.347 & 0.502 & 0.519 & 0.478 & 0.461 & 0.455 & 0.726 & 0.692 & 0.727 & 0.733 & 0.719 \\
\hline $\mathrm{Fe}^{2+}$ & 0.603 & 0.573 & 0.620 & 0.476 & 0.453 & 0.488 & 0.527 & 0.526 & 0.239 & 0.275 & 0.251 & 0.201 & 0.192 \\
\hline $\mathrm{Mn}$ & 0.000 & 0.000 & 0.000 & 0.000 & 0.000 & 0.000 & 0.000 & 0.000 & 0.000 & 0.000 & 0.000 & 0.000 & 0.000 \\
\hline Soma_MI & 1.000 & 1.000 & 1.000 & 1.000 & 1.000 & 1.000 & 1.000 & 1.000 & 1.000 & 1.000 & 1.000 & 1.000 & 1.000 \\
\hline $\mathrm{Mg}$ & 0.000 & 0.000 & 0.000 & 0.000 & 0.000 & 0.000 & 0.000 & 0.000 & 0.000 & 0.000 & 0.000 & 0.000 & 0.000 \\
\hline $\mathrm{Fe}^{2+}$ & 0.089 & 0.125 & 0.088 & 0.071 & 0.104 & 0.092 & 0.004 & 0.043 & 0.077 & 0.077 & 0.059 & 0.191 & 0.210 \\
\hline $\mathrm{Mn}$ & 0.071 & 0.038 & 0.060 & 0.034 & 0.028 & 0.027 & 0.038 & 0.035 & 0.016 & 0.021 & 0.020 & 0.019 & 0.018 \\
\hline $\mathrm{Ca}$ & 0.817 & 0.808 & 0.831 & 0.876 & 0.845 & 0.856 & 0.935 & 0.905 & 0.878 & 0.879 & 0.902 & 0.748 & 0.717 \\
\hline $\mathrm{Na}$ & 0.023 & 0.028 & 0.021 & 0.018 & 0.022 & 0.023 & 0.016 & 0.016 & 0.028 & 0.023 & 0.019 & 0.033 & 0.045 \\
\hline K & 0.000 & 0.001 & 0.001 & 0.000 & 0.001 & 0.001 & 0.000 & 0.001 & 0.000 & 0.000 & 0.000 & 0.006 & 0.009 \\
\hline Soma_M2 & 1.000 & 1.000 & 1.000 & 1.000 & 1.000 & 0.999 & 0.993 & 1.000 & 0.999 & 1.000 & 1.000 & 0.998 & 0.999 \\
\hline $\mathrm{Mg} \sharp$ & 0.335 & 0.348 & 0.329 & 0.478 & 0.483 & $0.45 i$ & 0.465 & 0.444 & 0.697 & 0.663 & 0.701 & 0.651 & 0.642 \\
\hline
\end{tabular}

< I.d.: abaixo do limite de deteccão

* calculados pelo método de Droop (1987) com base em 4 cátins totais e 60

S-inclui ZrO2: (1) $0.07:(4) 0,10:(5), 0.06$ 
Tabeia 1Y.6:

Análises quinicas completas (WDS) de anfitblios dos Granitos dá Graciosa

\begin{tabular}{|c|c|c|c|c|c|c|c|c|c|c|c|c|c|c|c|c|c|}
\hline \multirow{2}{*}{$\begin{array}{c}\text { Amostra } \\
\text { Ponto }\end{array}$} & \multicolumn{8}{|c|}{148} & \multicolumn{9}{|c|}{ Associaçao a alcalina $\mid$} \\
\hline & 2 & $\varepsilon$ & 11 & 13 & 18 & 2 & 7 & 14 & & & & & & $18 \mathrm{~A}$ & & & \\
\hline $\mathrm{SiO}_{2}$ & 45.9 & 47.6 & si.o & 49.2 & 50.5 & 47.2 & 49.5 & 47.7 & $\begin{array}{c}22 \\
49.0\end{array}$ & 26 & 1 & 2 & 4 & 8 & 9 & $n$ & 20 \\
\hline $\mathrm{TiO}_{2}$ & 1.43 & 1.52 & 0.25 & 0.59 & 0.30 & 1.39 & i. 01 & 1.33 & $\begin{array}{l}49.0 \\
0.70\end{array}$ & 50.8 & 48.4 & 50.3 & 49.0 & 48.7 & 47.5 & 50.7 & 48.4 \\
\hline $\mathrm{ZrO}_{2}$ & $<1 . d$. & 0.07 & $<$ <.d. & $<1, d$ & $<$ i.d. & <i. & <i.t. & 0.10 & & 0.17 & 0.83 & 0.17 & $0.3 i$ & 1.11 & 1.02 & 0.14 & 0.91 \\
\hline $\mathrm{Al}_{2} \mathrm{O}_{3}$ & 2.54 & 1.62 & 0.66 & 1.21 & 0.62 & 2.09 & 1.14 & 1.65 & $\begin{array}{l}<1.4 . \\
1.23\end{array}$ & $<1 . d$ & 0.11 & $<1.6$. & $<$ l.d. & 0.06 & $<$ l.d. & $<i . d$. & 0.15 \\
\hline $\mathrm{Fe}_{2} \mathrm{O}_{3}^{*}$ & 0.69 & 2.57 & 13.8 & 5.44 & 12.0 & 3.28 & 6.15 & 2.69 & $\begin{array}{l}1.23 \\
4.97\end{array}$ & 0.50 & 1.59 & 0.52 & 0.13 & 1.54 & 1.42 & 0.96 & i.4i \\
\hline $\mathrm{FeO}$ & 34.2 & 32.2 & 23.9 & 30.6 & 25.7 & 31.8 & 29.8 & 32.6 & 4.97 & 14.4 & $5.3 ?$ & 11.0 & 7.93 & 5.77 & 8.49 & 13.5 & 6.74 \\
\hline MnO & 0.86 & 0.86 & 0.40 & 0.81 & 0.50 & 0.72 & 0.51 & 0.87 & $\begin{array}{l}30.9 \\
0.73\end{array}$ & 23.5 & 31.5 & 27.2 & 30.8 & 30.7 & 27.0 & 24.8 & 29.4. \\
\hline $\mathrm{MgO}$ & 0.11 & 0.09 & 0.07 & 0.11 & 0.06 & 0.08 & 0.09 & 0.10 & $\begin{array}{l}0.73 \\
0.10\end{array}$ & 0.34 & 0.71 & 0.90 & 0.50 & 0.60 & 0.65 & 0.31 & $0.8 ?$ \\
\hline $2 \pi 0$ & 0.24 & 0.21 & 0.20 & 0.16 & 0.13 & 0.25 & 0.21 & 0.22 & $\begin{array}{l}0.10 \\
0.11\end{array}$ & 0.06 & $<$ i.d. & $<1 . d$ & $<$ i.d. & $<1 . \delta$ & $<$ l.d. & $<$ l.d. & 0.08 \\
\hline $\mathrm{CaO}$ & 6.55 & 4.77 & 0.56 & 3.38 & 0.56 & 4.73 & 2.34 & 4.66 & $\begin{array}{l}0.1 ! \\
3.24\end{array}$ & 0.07 & 0.36 & 0.31 & 0.31 & 0.44 & 0.36 & 0.40 & 0.39 \\
\hline $\mathrm{Na}_{2} \mathrm{O}$ & 3.83 & 4.42 & 6.32 & 4.99 & 6.62 & 4.43 & 5.67 & 4.36 & $\begin{array}{l}3.24 \\
5.18\end{array}$ & 0.46 & 1.87 & $0.8 i$ & 0.37 & 1.91 & 3.26 & $<1 . d$ & $\mathrm{~T} .39$ \\
\hline $\mathrm{K}_{2} \mathrm{O}$ & 1.04 & 1.12 & 0.51 & 1.08 & 0.55 & 1.17 & 0.76 & 1.06 & $\begin{array}{l}5.18 \\
1.05\end{array}$ & 6.34 & 5.77 & 6.37 & 6.32 & 5.98 & 6.23 & 6.97 & 6.28 \\
\hline$a$ & < l.d. & <1. & $<$ id. & < l.d. & $<1.8$ & $<1$. & $<$ ld & $<1 . \dot{d}$ & $\begin{array}{l}1.05 \\
<1.6\end{array}$ & $0.5 i$ & 1.04 & 0.85 & 0.52 & $i .04$ & 1.01 & 0.52 & 0.99 \\
\hline$F$ & 0.32 & $<$ ld. & $<1 . d$ & 0.14 & $<$ id. & <l.d. & $<$ l.d. & 0.11 & $\begin{array}{l}<1 . \dot{ } \\
0.09\end{array}$ & < l.o. & 0.06 & $<$ l.d. & $<i . d$. & 0.06 & 0.05 & $<$ id. & 0.06 \\
\hline Somà & 97.7 & 97. & .97 .6 & 97.8 & 97.6 & 97.1 & 97.3 & 97.5 & 0.09 & $<i . d$ & 0.27 & 0.25 & 0.07 & 0.38 & 0.90 & 0.14 & 0.47 \\
\hline$O_{-} E_{-} C$ & 0.09 & 0.02 & 0.01 & 0.04 & 0.00 & 0.01 & 0.00 & 0.03 & $\begin{array}{l}97.4 \\
0.02\end{array}$ & 97.2 & 97.8 & 98.6 & 97.3 & 98.4 & 98.0 & 98.5 & 97.5 \\
\hline Total & 97.6 & 97.1 & 97.6 & 97.8 & 97.6 & 97.1 & 073 & 075 & 0.02 & 0.01 & 0.09 & 0.06 & 0.02 & 0.11 & 0.23 & 0.03 & 0.12 \\
\hline & & & & & & & (1). & 97.5 & 97.3 & 97.2 & 97.7 & 98.6 & 97.3 & 98.3 & 97.7 & 98.4 & 97.4 \\
\hline Si & 7.523 & 7.745 & 7.995 & 7.887 & 7.973 & 7.671 & 7.926 & 7.713 & 7.807 & 7.995 & 7.812 & & & & & & \\
\hline Al & 0.477 & 0.253 & 0.005 & 0.113 & 0.027 & 0.329 & 0.074 & 0.257 & 0.103 & 0.005 & 0.188 & $\begin{array}{l}7.952 \\
0.048\end{array}$ & 7.854 & 7.808 & 7.683 & 7.938 & 7.825 \\
\hline Soma_T & 8.000 & 8.000 & 8.000 & 8.000 & 8.000 & 8.000 & 8.000 & 8.000 & 8.000 & 8.000 & 8.000 & 0.048 & 0.106 & 0.192 & 0.270 & 0.062 & 0.175 \\
\hline $\mathrm{At}^{-}$ & 0.015 & 0.055 & 0.117 & 0.116 & 0.028 & 0.071 & $0.14 i$ & 0.058 & 0.131 & 0.105 & $\begin{array}{l}8.000 \\
0.116\end{array}$ & 8.000 & 8.000 & 8.000 & 7.953 & 8.000 & 8.000 \\
\hline $\mathrm{Ti}_{\mathrm{i}}$ & 0.176 & 0.186 & 0.030 & 0.084 & 0.035 & 0.170 & 0.122 & 0.163 & & 0.020 & 0.116 & 0.048 & 0.109 & 0.100 & 0.000 & 0.1 is & 0.093 \\
\hline $2 r$ & 0.003 & 0.006 & 0.000 & 0.002 & 0.000 & 0.000 & 0.002 & 0.008 & 0.000 & $\begin{array}{l}0.020 \\
0.000\end{array}$ & 0.101 & 0.021 & 0.037 & 0.134 & 0.124 & 0.016 & 0.111 \\
\hline $\mathrm{Fe}^{3+*}$ & 0.085 & 0.315 & 1.624 & 0.656 & 1.421 & 0.402 & 0.741 & 0.329 & & 0.000 & 0.009 & 0.003 & 0.002 & 0.004 & 0.002 & 0.000 & 0.012 \\
\hline $\mathrm{Mg}$. & 0.027 & 0.022 & 0.016 & 0.026 & 0.015 & 0.020 & 0.021 & 0.023 & 0.024 & 1.702 & 0.646 & 1.303 & $0.95 i$ & 0.596 & 1.033 & 1.585 & 0.819 \\
\hline $\mathrm{Zn}$ & 0.029 & 0.025 & 0.024 & 0.019 & 0.015 & 0.030 & 0.025 & 0.026 & & 0.013 & 0.002 & 0.005 & 0.007 & 0.010 & 0.008 & 0.003 & 0.019 \\
\hline $\mathrm{Fe}^{2+4}$ & 4.665 & $4.37 \gamma$ & 3.131 & 4.097 & 3.400 & 4.305 & 3.948 & 4.393 & $\begin{array}{l}0.014 \\
4.144\end{array}$ & 0.009 & 0.043 & 0.036 & 0.037 & 0.052 & 0.043 & 0.046 & 0.047 \\
\hline Mn & 0.000 & 0.014 & 0.054 & 0.000 & 0.025 & 0.000 & 0.000 & 0.000 & 4.144 & 3.089 & 4.084 & 3.585 & 3.846 & 4.004 & 3.646 & 3.234 & 3.900 \\
\hline Soma_ $C$ & 5.000 & 5.000 & 4.996 & 5.000 & 5.000 & 5.000 & 5.000 & 5.000 & $\begin{array}{l}0.000 \\
5.000\end{array}$ & 0.046 & 0.000 & 0.000 & 0.000 & 0.000 & 0.089 & 0.000 & 0.000 \\
\hline $\mathrm{Mg}^{-}$ & 0.000 & 0.000 & 0.000 & 0.000 & 0.000 & 0.000 & 0.000 & 0.000 & 5.000 & 4.984 & 5.000 & 5.000 & 5.000 & 5.000 & 4.943 & 5.000 & 5.000 \\
\hline $\mathrm{Fe}^{2+}$ & 0.020 & 0.000 & 0.000 & 0.008 & 0.000 & 0.015 & 0.043 & 0.038 & 0.000 & 0.000 & 0.000 & 0.000 & 0.000 & 0.000 & 0.000 & 0.000 & 0.000 \\
\hline Mn & 0.119 & 0.105 & 0.000 & 0.110 & 0.042 & 0.099 & 0.069 & 0.120 & 0.024 & 0.000 & 0.172 & 0.006 & 0.306 & 0.116 & 0.000 & 0.015 & 0.072 \\
\hline$c$ & 1.152 & 0.832 & 0.093 & 0.580 & 0.111 & 0.825 & 0.402 & $0.8 \mathrm{i} i$ & 0.100 & 0.000 & 0.097 & 0.120 & 0.068 & 0.081 & 0.000 & $0.04 i$ & 0.111 \\
\hline $\mathrm{Na}$ & 0.709 & 1.063 & 1.907 & 1.302 & 1.846 & 1.062 & 1.485 & $\begin{array}{l}.811 \\
1.031\end{array}$ & 0.559 & 0.077 & 0.323 & 0.137 & 0.064 & 0.327 & 0.564 & 0.000 & 0.241 \\
\hline Soma_ $B$ & $2.000^{\circ}$ & $2.000^{\circ}$ & 2.000 & 2.000 & 2.000 & 2.000 & 2.000 & 2.000 & 1.317 & 1.923 & $i .408$ & 1.737 & 1.563 & 1.475 & 1.436 & 1.944 & 1.576 \\
\hline $\mathrm{Na}{ }^{-}$ & 0.509 & 0.332 & 0.017 & $0.25 i$ & 0.182 & 0.334 & 0.274 & 0.342 & 2.000 & 2.000 & 2.000 & 2.000 & 2.000 & 2.000 & 2.000 & 2.000 & 2.000 \\
\hline$x$ & 0.219 & 0.233 & 0.102 & 0.221 & 0.111 & 0.243 & 0.156 & $\begin{array}{l}0.342 \\
0.219\end{array}$ & 0.301 & 0.010 & 0.400 & 0.215 & 0.412 & 0.383 & $0.5: 5$ & 0.170 & 0.390 \\
\hline Soma $A$ & 0.728 & 0.565 & 0.119 & 0.472 & 0.293 & 0.577 & 0.430 & $\begin{array}{l}0.219 \\
0.561\end{array}$ & 0.215 & 0.102 & 0.214 & 0.171 & 0.107 & 0.212 & 0.208 & 0.103 & 0.205 \\
\hline & 15.728 & 75.565 & 15.114 & 15.472 & 15.293 & 15.577 & 15.430 & $\begin{array}{l}0.561 \\
15.561\end{array}$ & 0.516 & 0.112 & 0.675 & 0.386 & 0.519 & 0.595 & 0.724 & 0.273 & 0.505 \\
\hline a & 0.013 & 0.008 & 0.002 & 0.002 & 0.000 & 0.005 & 0.000 & $\begin{array}{l}15.567 \\
0.007\end{array}$ & 35.516 & 15.096 & 15.615 & 15.386 & 15.579 & 15.595 & 15.620 & 15.273 & 15.505 \\
\hline $\mathrm{F}$ & 0.165 & 0.022 & 0.010 & 0.073 & 0.001 & 0.007 & 0.009 & $\begin{array}{l}0.007 \\
0.054\end{array}$ & $\begin{array}{l}0.002 \\
0.046\end{array}$ & 0.000 & 0.016 & 0.003 & 0.005 & 0.016 & 0.014 & 0.000 & 0.016 \\
\hline MgH & & & & & & & & & 0.046 & 0.024 & 0.140 & 0.125 & 0.035 & 0.195 & 0.461 & 0.068 & 0.208 \\
\hline $\mathrm{Na} /\langle\mathrm{Na}+\mathrm{Ca}\rangle$ & $\begin{array}{l}0.006 \\
0.514\end{array}$ & $\begin{array}{l}0.005 \\
0.526\end{array}$ & $\begin{array}{l}0.005 \\
0.954\end{array}$ & $\begin{array}{l}0.006 \\
0.728\end{array}$ & $\begin{array}{l}0.004 \\
0.048\end{array}$ & 0.005 & 0.005 & 0.005 & 0.006 & 0.004 & 0.000 & $0.00 i$ & 0.002 & 0.002 & & & \\
\hline & & & & & & 0.629 & $0.8: 4$ & 0.629 & 0.743 & 0.962 & 0.848 & 0.934 & 0.069 & 0.550 & $\begin{array}{l}0.002 \\
0.776\end{array}$ & $\begin{array}{l}0.003 \\
1.000\end{array}$ & $\begin{array}{l}0.005 \\
0.891\end{array}$ \\
\hline
\end{tabular}

- calculados comn base nas estinativas máximas do método de Schumacher (Leake et al. 1997) 
Tabela IV.6:

Análises quimicas completas (WDS) de anfibblios dos Cranitos da Graciosa

\begin{tabular}{|c|c|c|c|c|c|c|c|c|c|c|c|c|c|c|c|c|c|c|}
\hline & & & & & & & & & & & & & & & \multirow{2}{*}{\multicolumn{4}{|c|}{80}} \\
\hline Ponto & 1 & 2 & 7 & 10 & 2 & $y$ & $\begin{array}{c}78 \mathrm{~A} \\
B\end{array}$ & 13 & & & & 79 & & & & & & \\
\hline $\mathrm{SiO}_{2}$ & 47.6 & 46.9 & 47.6 & 51.5 & 43.1 & 43.7 & 44.7 & 44.7 & $\begin{array}{r}16 \\
452\end{array}$ & 5 & 7 & 12 & 27 & 42 & I & 3 & 4 & $s$ \\
\hline $\mathrm{TOO}_{2}$ & 0.65 & 0.89 & 0.84 & 0.12 & 1.48 & 1.45 & 1.30 & 0.13 & $\begin{array}{l}45.2 \\
1.37\end{array}$ & 44.6 & 43.7 & 41.9 & 45.9 & 48.5 & 48.0 & $48 . i$ & 47.6 & 48.8 \\
\hline $\mathrm{ZrO}_{2}$ & $<$ l.d. & $<1 . \delta$ & $<$ l.d. & $<$ l.d. & <i.d. & $<$ f.d. & $<1 . d$ & $<$ <.d. & $\begin{array}{l}1.37 \\
<10\end{array}$ & 1.05 & 1.24 & 1.32 & 0.32 & 0.09 & $<$ l.d. & 0.05 & 0.09 & $<i .6$. \\
\hline $\mathrm{Al}_{2} \mathrm{O}_{3}$ & 2.06 & 2.49 & 2.13 & 0.75 & 5.10 & 4.96 & 3.92 & 3.89 & $\begin{array}{l}<1.4 \\
3.22\end{array}$ & $<$ l.d. & $<i d$. & $<1 . \delta$. & $<$ l.d. & 0.06 & $<$ l.d. & <i.d. & $<$ i.d. & $<$ i.d. \\
\hline $\mathrm{Fe}_{2} \mathrm{O}_{3}$ * & 5.27 & 4.35 & 5.09 & 15.6 & 3.27 & $3.3 i$ & 2.21 & 2.36 & 3.22 & $3.9:$ & 4.65 & 5.54 & 2.29 & 0.99 & 0.50 & 0.36 & 0.33 & 0.24 \\
\hline $\mathrm{FeO}$ & 29.5 & 30.2 & 28.3 & 21.2 & 30.1 & 30.1 & 32.0 & 32.2 & $\begin{array}{l}1.72 \\
33.6\end{array}$ & 2.43 & 2.60 & 5.38 & 1.65 & 3.54 & $i .81$ & 1.89 & 1.42 & 4.53 \\
\hline MnO & 1.01 & 0.98 & 0.95 & 0.3 & 0.69 & 0.77 & 0.79 & 0.86 & $\begin{array}{l}33.6 \\
0.87\end{array}$ & 30.8 & 31.2 & 27.5 & 34.1 & 31.1 & 39.4 & 39.9 & 40.0 & 36.5 \\
\hline $\mathrm{MgO}$ & 0.94 & 0.95 & 1.15 & 0.46 & 0.80 & 0.70 & 0.70 & 0.67 & $\begin{array}{l}0.87 \\
0.78\end{array}$ & 0.87 & 0.80 & $0.7 i$ & 1.76 & 1.54 & 4.38 & 4.27 & 3.96 & $4.2 \mathrm{i}$ \\
\hline Zno & 0.24 & 0.09 & 0.17 & 0.15 & 0.12 & 0.15 & 0.26 & 0.20 & $\begin{array}{l}0.78 \\
0.19\end{array}$ & 1.10 & 1.09 & 1.31 & 0.18 & 0.32 & 0.23 & 0.18 & 0.32 & 0.19 \\
\hline $\mathrm{CaO}$ & 4.27 & 4.85 & 5.13 & 0.10 & 8.23 & 8.22 & 7.80 & 7.84 & $\begin{array}{l}0.19 \\
6.58\end{array}$ & 0.15 & 0.14 & 0.17 & $<1 . d$ & $<i d \dot{\theta}$. & $<$ ld. & 0.14 & 0.06 & 0.06 \\
\hline $\mathrm{Na}_{2} \mathrm{O}$ & 4.02 & 4.06 & 3.92 & 6.10 & 2.66 & 2.65 & 2.66 & $2.5 i$ & $\begin{array}{l}6.58 \\
2.39\end{array}$ & 8.77 & 8.66 & 8.89 & 8.44 & 7.65 & 1.31 & 0.92 & 1.55 & 0.72 \\
\hline $\mathrm{K}_{2} \mathrm{O}$ & 0.73 & 0.80 & 0.74 & 0.13 & 0.99 & 1.03 & 0.84 & 0.83 & $\begin{array}{l}2.39 \\
0.94\end{array}$ & 1.93 & 2.22 & 2.39 & 1.31 & 2.16 & 1.28 & 1.10 & 0.84 & 2.03 \\
\hline$a$ & <i.d. & $<$ t.d. & <l.d. & $<1 . d$ & 0.07 & 0.07 & $<1 . d$ & $<1.0$ & $\begin{array}{l}0.94 \\
<1 . d .\end{array}$ & 0.87 & 0.97 & 1.03 & $0.4 \mathcal{E}$ & 0.28 & 0.08 & $<1, d$ & 0.11 & $<$ L.e. \\
\hline$F$ & 0.26 & 0.61 & 0.54 & 0.07 & 0.56 & 0.50 & 0.47 & 0.57 & $\begin{array}{l}<1.6 . \\
0.35\end{array}$ & $<$ <.d. & 0.07 & 0.10 & <i.c. & $<1 . d$ & $<$ id. & $<$ l.d. & $<1.0$ & $<$ <.d. \\
\hline Soma & 96.6 & 97.2 & 96.7 & 96.4 & 97.1 & 97.6 & 977 & & 0.35 & 0.11 & 0.54 & 0.87 & < l.d. & 0.10 & $<1.8$ & $<$ l.d. & 0.19 & <i.d. \\
\hline O.F_a & 0.06 & 0.14 & 0.13 & 0.02 & 0.16 & 0.14 & 0.11 & $\begin{array}{l}97.8 \\
0.14\end{array}$ & 97.3 & 96.6 & 97.8 & 97.2 & 96.5 & 96.3 & 97.3 & 96.9 & 96.6 & 97.4 \\
\hline Total & 96.5 & 97.1 & 96.5 & 96,4 & 97.0 & 97.5 & 075 & & 0.09 & 0.04 & 0.15 & 0.24 & 0.02 & 0.03 & 0.00 & 0.00 & 0.04 & 0.00 \\
\hline & & & & & & & & 97.7 & 97.2 & 96.6 & 97.7 & 97.0 & 96.5 & 96.3 & 97.1 & 96.9 & 96.5 & 97.4 \\
\hline Si & 7.720 & 7.618 & 7.705 & 8.058 & $\overline{7} .068$ & 7.119 & 7.293 & 7.302 & 7.415 & 7.297 & 7.129 & & & & & & & \\
\hline A. & 0.280 & 0.382 & 0.295 & 0.000 & 0.932 & 0.881 & 0.707 & 0.698 & 0.585 & 0.703 & $0.87 i$ & $\begin{array}{l}6.892 \\
1073\end{array}$ & 7.589 & 7.900 & 7.959 & 7.987 & 7.967 & 7.991 \\
\hline Soma_r & 8.000 & 8.000 & 8.000 & 8.058 & 8.000 & 8.000 & 8.000 & 8.000 & 8.000 & & 8.000 & 1.073 & 0.411 & 0.100 & $0.04 i$ & 0.013 & 0.033 & 0.009 \\
\hline Al & 0.115 & 0.094 & 0.111 & 0.138 & 0.055 & 0.072 & 0.048 & 0.051 & 0.037 & 0.053 & & 7.964 & 8.000 & 8.000 & 8.000 & 8.000 & 8.000 & 8.000 \\
\hline$\pi i$ & 0.081 & 0.109 & 0.102 & 0.015 & 0.183 & 0.178 & 0.160 & 0.139 & 0.168 & & & 0.000 & 0.036 & 0.089 & 0.057 & 0.053 & 0.031 & 0.037 \\
\hline$\ddot{z r}$ & 0.002 & 0.001 & 0.003 & 0.000 & 0.000 & 0.001 & 0.000 & 0.000 & 0.001 & & 0.152 & 0.163 & 0.040 & $0.0: 0$ & 0.002 & 0.007 & 0.011 & 0.003 \\
\hline $\mathrm{Fe}^{3+}$ & 0.643 & $0.53 i$ & 0.520 & 1.834 & 0.404 & 0.406 & 0.272 & 0.292 & 0.212 & & & 0.001 & 0.000 & 0.005 & 0.000 & 0.001 & 0.003 & 0.002 \\
\hline $\mathrm{Mg}_{\mathrm{g}}$ & 0.226 & 0.231 & 0.276 & 0.107 & 0.197 & 0.171 & 0.170 & 0.162 & 0.191 & 0.299 & 0.320 & 0.556 & 0.206 & 0.435 & 0.226 & 0.237 & 0.179 & 0.570 \\
\hline $2 n$ & 0.028 & $0.0 \div 1$ & 0.020 & 0.018 & 0.015 & 0.018 & 0.031 & 0.024 & 0.023 & 0.270 & 0.264 & 0.321 & 0.044 & 0.078 & 0.056 & 0.045 & 0.080 & 0.047 \\
\hline $\mathrm{Fe}^{2+}$ & 3.905 & 4.023 & 3.835 & 2.775 & 4.129 & 4.110 & 4.320 & 4.331 & 4.360 & 0.019 & 0.016 & 0.020 & 0.006 & 0.000 & 0.005 & 0.017 & 0.008 & 0.008 \\
\hline $\mathrm{Mn}$ & 0.000 & 0.000 & 0.033 & $0.04 i$ & 0.018 & 0.044 & 0.000 & 0.000 & 0.000 & 4.217 & 4.222 & 3.786 & 4.669 & 4.237 & 4.653 & 4.635 & 4.688 & 4.333 \\
\hline Soma_c & 5.000 & 5.000 & 5.000 & 4.927 & 5.000 & 5.000 & 5.000 & 5.000 & 5.000 & 0.012 & 0.000 & 0.042 & 0.000 & 0.146 & 0.000 & 0.000 & 0.000 & 0.000 \\
\hline $\mathrm{Mg}^{-}$ & 0.000 & 0.000 & 0.000 & 0.000 & 0.000 & 0.000 & 0.000 & 0.000 & 0.000 & $\begin{array}{l}5.000 \\
0.000\end{array}$ & 5.000 & 5.000 & 5.000 & 5.000 & 5.000 & 5.000 & 5.000 & 5.000 \\
\hline $\mathrm{Fe}^{2+}$ & $0.09 i$ & 0.069 & 0.000 & 0.000 & 0.000 & 0.000 & 0.053 & 0.063 & 0.244 & 0.000 & 0.000 & 0.000 & 0.000 & 0.000 & 0.000 & 0.000 & 0.000 & 0.000 \\
\hline Mn & 0.138 & 0.135 & 0.096 & 0.000 & 0.078 & 0.052 & 0.109 & 0.119 & 0.121 & $\begin{array}{l}0.000 \\
0.108\end{array}$ & 0.033 & 0.000 & 0.042 & 0.000 & 0.815 & 0.903 & 0.912 & 0.662 \\
\hline $\mathrm{Ca}$ & 0.741 & 0.843 & 0.889 & 0.017 & 1.449 & 1.436 & 1.363 & 1.372 & & $\begin{array}{l}0.108 \\
: 538\end{array}$ & 0.110 & 0.056 & 0.246 & 0.067 & 0.615 & 0.601 & 0.551 & 0.583 \\
\hline $\mathrm{Na}$ & 1.029 & 0.953 & 1.014 & 1.853 & 0.474 & 0.502 & 0.474 & 0.445 & & $\begin{array}{r}1.538 \\
0353\end{array}$ & 1.515 & $i .566$ & 1.496 & $i .336$ & 0.233 & 0.164 & 0.277 & 0.125 \\
\hline Soma_B $B$ & 2.000 & 2.000 & 2.000 & 1.870 & 2.000 & 2.000 & 2.000 & 2.000 & & $\begin{array}{l}0.353 \\
2.000\end{array}$ & 0.342 & 0.378 & 0.215 & 0.597 & 0.338 & 0.332 & 0.250 & 0.629 \\
\hline $\mathrm{Na}$ & 0.234 & 0.325 & 0.215 & 0.000 & 0.374 & 0.335 & 0.367 & 0.349 & 0.279 & $\begin{array}{l}2.000 \\
0.260\end{array}$ & 2.000 & 2.000 & 2.000 & 2.000 & 2.000 & 2.000 & 2.000 & 2.000 \\
\hline $\mathrm{x}$ & 0.152 & 0.166 & 0.153 & 0.025 & 0.207 & 0.214 & 0.174 & 0.173 & 0.197 & $\begin{array}{l}0.260 \\
0.182\end{array}$ & 0.359 & 0.383 & 0.204 & 0.085 & 0.073 & 0.024 & 0.023 & 0.016 \\
\hline Soma_ $A$ & 0.386 & 0.491 & 0.369 & 0.025 & 0.581 & 0.548 & 0.542 & 0.522 & 0.476 & $\begin{array}{l}0.182 \\
0.442\end{array}$ & 0.203 & 0.215 & 0.101 & 0.058 & 0.017 & 0.010 & 0.023 & 0.004 \\
\hline Cátrons & 75.386 & 75.497 & 15.369 & 14.880 & 15.581 & 75.548 & 15.542 & 15.522 & $\begin{array}{l}0.470 \\
15.476\end{array}$ & 0.442 & 0.562 & 0.598 & 0.305 & 0.143 & 0.091 & 0.034 & 0.045 & 0.020 \\
\hline a & 0,000 & 0.003 & 0.002 & 0.000 & 0.019 & 0.018 & 0.005 & 0.0 & $\begin{array}{l}15.476 \\
0.008\end{array}$ & 15.442 & 15.562 & 15.563 & 15.305 & 15.143 & 15.097 & 15.034 & 15.045 & 15.020 \\
\hline F & 0.135 & 0.314 & 0.278 & 0.037 & $0.29 i$ & 0.256 & 0.245 & 0.292 & $\begin{array}{l}0.008 \\
0.83\end{array}$ & 0.012 & 0.019 & $0.02 \varepsilon$ & 0.010 & 0.006 & 0.001 & $0.00 i$ & 0.000 & 0.000 \\
\hline & & & & & & & & & 0.83 & 0.055 & 0.281 & 0.453 & 0.015 & 0.053 & 0.000 & 0.000 & 0.099 & 0.000 \\
\hline $\begin{array}{c}\mathrm{Mg} \# \\
\mathrm{Na} /(\mathrm{Na}+\mathrm{Ca}\rangle\end{array}$ & $\begin{array}{l}0.054 \\
0.630\end{array}$ & $\begin{array}{l}0.053 \\
0.603\end{array}$ & $\begin{array}{l}0.067 \\
0.580\end{array}$ & $\begin{array}{l}0.037 \\
0.991\end{array}$ & 0.045 & 0.040 & 0.037 & 0.036 & 0.040 & 0.060 & 0.059 & 0.078 & 0.009 & & & & & \\
\hline & & & & & 0.359 & 0.368 & 0.382 & 0.367 & 0.396 & 0.285 & 0.317 & 0.327 & 0.219 & 0.338 & $\begin{array}{l}0.010 \\
0.638\end{array}$ & $\begin{array}{l}0.008 \\
0.684\end{array}$ & $\begin{array}{l}0.014 \\
0.496\end{array}$ & $\begin{array}{l}0.009 \\
0.837\end{array}$ \\
\hline
\end{tabular}

* caiculados com base nas estimativas máximas do método de Schumacher (teake et af., i99i) 
Tabeia IV.6:

Anafises quimicas completas (WDS) de anfibólios dos Granitos da Graciosa

\begin{tabular}{|c|c|c|c|c|c|c|c|c|c|c|c|c|c|c|c|c|c|c|}
\hline & & & & & & & & & Asssociaçăg & kalina ! & & & & & & & & \\
\hline Ponto & $t$ & 2 & 3 & 4 & 6 & 8 & $1 i$ & 15 & 1 & & 810 & & & & & 878 & & \\
\hline $\mathrm{SiO}_{2}$ & 43.4 & 43.9 & $42 . i$ & $4 i .3$ & 43.3 & 45.0 & 46.6 & 43.1 & $\stackrel{1}{45.5}$ & 4 & 7 & 71 & 19 & 7 & 4 & 9 & 71 & 19 \\
\hline $\mathrm{mO}_{2}$ & 0.99 & 1.74 & 1.55 & 1.72 & $i .46$ & 0.73 & 0.49 & 1.40 & $\begin{array}{l}45.5 \\
0.94\end{array}$ & 43.9 & 47.6 & 42.9 & 48.0 & 40.9 & 41.8 & 43.8 & 40.3 & 39.9 \\
\hline $\mathrm{ZrO}_{2}$ & <l.d. & $<1 . d$. & < l.d. & $<1 . d_{0}$ & $<$ l.d. & $<i d$. & $<$ l.d. & < l.d. & & 1.00 & < I.d. & 1.54 & $<$ <.j. & 1.54 & 0.84 & 0.38 & 1.58 & 1.78 \\
\hline $\mathrm{Al}_{2} \mathrm{O}_{3}$ & 5.73 & 6.84 & 6.73 & 7.05 & 5.15 & 3.94 & 2.67 & 5.71 & $\begin{array}{l}<1.6 . \\
3.73\end{array}$ & $<1 d$ & $<$ l.d. & $<$ l.d. & $<$ i.d. & <i.d. & $<$ l.d. & $<$ i.d. & $<$ i.d. & $<i . \delta$ \\
\hline $\mathrm{Fe}_{2} \mathrm{O}_{3} *$ & 4.72 & $3.5 \hat{a}$ & 4.55 & 3.95 & 2.35 & 2.83 & 2.38 & 3.75 & $\begin{array}{l}3.73 \\
2.40\end{array}$ & 4.88 & 0.28 & 5.78 & 0.24 & 7.26 & 6.22 & 4.85 & 7.58 & 7.93 \\
\hline $\mathrm{FeO}^{*}$ & 27.8 & 28.9 & 27.2 & 27.6 & 30.2 & 30.4 & 31.2 & 28.2 & $\begin{array}{l}2.40 \\
30.3\end{array}$ & 3.45 & 0.17 & 3.08 & 1.02 & 5.39 & 8.51 & 5.43 & 7.73 & 6.79 \\
\hline Mno & 0.92 & 1.08 & 1.04 & 0.76 & 1.14 & 1.20 & $: .27$ & 0.93 & $\begin{array}{l}30.5 \\
0.89\end{array}$ & 29.2 & 44.3 & 29.4 & 42.5 & 25.8 & 25.2 & 27.7 & 25.0 & 26.1 \\
\hline $\mathrm{MgO}$ & 1.95 & 1.07 & 1.58 & 1.86 & 1.33 & 1.19 & 1.36 & T.SO & $\begin{array}{l}0.89 \\
1.21\end{array}$ & 1.01 & 3.08 & 0.85 & 4.04 & 1.01 & 1.30 & 1.27 & 1.05 & 1.05 \\
\hline Zno & $<1 . d$ & 0.11 & 0.10 & 0.07 & $<$ id. & 0.07 & 0.07 & 0.11 & 0.11 & 1.07 & 0.46 & 1.27 & 0.29 & 1.42 & 0.79 & 1.26 & 1.12 & 1.05 \\
\hline $\mathrm{CaO}^{\circ}$ & 9.34 & 9.64 & 9.63 & 9.51 & 8.96 & 9.47 & 9.70 & 9.25 & 9.82 & $\begin{array}{l}0.09 \\
9.21\end{array}$ & 0.05 & 0.09 & 0.08 & 0.06 & 0.15 & 0.16 & 0.08 & 0.16 \\
\hline $\mathrm{Na}_{2} \mathrm{O}$ & 2.03 & 1.98 & 2.14 & 2.15 & 2.19 & 1.55 & 5.14 & 2.15 & 1.53 & $\begin{array}{l}9.21 \\
2.04\end{array}$ & 0.71 & 9.16 & 0.70 & 9.72 & 9.56 & 9.53 & 9.65 & 9.76 \\
\hline $\mathrm{K}_{2} \mathrm{O}$ & 0.98 & 8.15 & 1.18 & 1.19 & 0.97 & 0.76 & 0.56 & 0.95 & 0.81 & $\begin{array}{l}2.04 \\
0.90\end{array}$ & 0.12 & 2.22 & 0.14 & 1.95 & 1.69 & $i .41$ & 2.13 & $2: 12$ \\
\hline$a$ & 0.06 & 0.12 & 0.12 & 0.14 & 0.05 & $<$ l.d. & $<$ l.d. & 0.09 & $<$ f.d. & 0.90 & $<$ l.d. & 1.04 & $<$ <. & 1.16 & 1.03 & $0.8 i$ & 1.21 & 1.21 \\
\hline$F$ & 0.45 & 0.23 & 0.41 & 0.30 & 0.43 & 0.31 & 0.08 & 0.39 & 0.13 & $<1.8$ & $<i d$ & 0.09 & $<$ !.d. & 0.17 & 0.40 & 0.28 & 0.20 & 0.25 \\
\hline Soma & 98.4 & 98.4 & 98.5 & 97.6 & 97.6 & 97.6 & 97.4 & 97.6 & 976 & 0.17 & $<1 . d$. & 0.20 & 0.10 & 0.37 & 0.59 & 0.41 & 0.70 & 0.54 \\
\hline$O_{-} F_{-} a$ & 0.13 & 0.10 & 0.14 & 0.13 & 0.12 & 0.08 & 0.04 & 0.12 & 0.04 & $\begin{array}{l}97.0 \\
0.05\end{array}$ & 96.8 & 97.7 & 97.1 & 97.2 & 98.2 & 98.4 & 98.4 & 98.7 \\
\hline Total & 98.3 & 98.3 & 98.4 & 97.5 & 97.5 & 97.5 & 97.3 & 97.4 & 076 & & & 0.08 & 0.03 & 0.16 & 0.30 & 0.21 & 0.24 & 0.23 \\
\hline $\mathrm{Si}$ & & & & & & & & & & 96.9 & 96.7 & 97.6 & 97.0 & $97 .:$ & 97.9 & 98.2 & 98.2 & 98.4 \\
\hline Ait & 6.962 & 6.769 & 6.775 & 6.705 & 7.059 & 7.299 & 7.542 & 6.988 & 7.351 & 7,148 & 7.982 & 6.962 & 8.006 & 6.659 & 6.793 & & & \\
\hline Solna $T$. & $\begin{array}{l}1.038 \\
8.000\end{array}$ & 1.231 & 1.225 & 1.295 & $0.94 i$ & $0.70:$ & 0.458 & $1.0: 2$ & 0.649 & 0.852 & 0.018 & 1.038 & 0.000 & $1.34\}$ & 1.191 & $\begin{array}{l}7.073 \\
0.022\end{array}$ & 6.537 & 6.471 \\
\hline $\mathrm{Al}$ & $\begin{array}{l}8.000 \\
0.046\end{array}$ & -8.000 & 8.000 & 8.000 & 8.000 & 8.000 & 8.000 & 8.000 & 8.000 & 8.000 & 8.000 & 8.000 & 8.006 & 8.000 & 7.984 & 0.922 & $1.44 i$ & 1.515 \\
\hline ii & & 0.071 & 0.049 & 0.053 & 0.047 & 0.051 & 0.051 & 0.079 & $0.06 i$ & 0.085 & 0.036 & 0.057 & 0.046 & 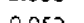 & & 7.994 & 7.984 & 7.987 \\
\hline $\mathrm{Zr}$ & $\begin{array}{l}0.120 \\
0.004\end{array}$ & 0.212 & 0.127 & 0.209 & 0.378 & 0.089 & 0.059 & 0.170 & 0.115 & 0.122 & 0.000 & 0.188 & 0.000 & 0.052 & 0.000 & 0.000 & 0.000 & 0.000 \\
\hline $\mathrm{Fe}^{2+}$ & $\begin{array}{l}0.004 \\
0.570\end{array}$ & 0.004 & 0.003 & 0.001 & 0.001 & 0.002 & 0.002 & 0.000 & 0.002 & 0.002 & 0.000 & 0.000 & 0.000 & 0.189 & 0.103 & 0.046 & 0.193 & 0.218 \\
\hline $\mathrm{Mg}$ & $\begin{array}{l}0.570 \\
0.467\end{array}$ & 0.435 & 0.551 & 0.482 & 0.288 & 0.346 & 0.290 & 0.457 & 0.292 & 0.423 & 0.021 & 0.376 & 0.128 & 0.000 & 0.000 & 0.001 & 0.000 & 0.000 \\
\hline $2 n$ & $\begin{array}{l}0.467 \\
0.005\end{array}$ & 0.257 & 0.402 & 0.449 & 0.324 & 0.287 & 0.279 & 0.362 & 0.292 & 0.260 & 0.115 & 0.308 & 0.071 & 0.722 & 1.040 & 0.781 & 0.943 & 0.828 \\
\hline $\mathrm{Fe}^{2+}$ & $\begin{array}{l}0.005 \\
3.729\end{array}$ & 0.013 & 0.012 & 0.009 & 0.005 & 0.008 & 0.008 & 0.014 & 0.014 & $0.01 ;$ & 0.006 & 0.011 & 0.010 & 0.344 & 0.192 & 0.302 & 0.271 & 0.253 \\
\hline Mn & 3.729 & 3.910 & 3.663 & 3.746 & 4.111 & 4.132 & 4.215 & 3.819 & 4.113 & 3.983 & $4.82 i$ & 3.994 & & 0.007 & 0.019 & $0.0: 9$ & 0.009 & 0.019 \\
\hline somen & 0.061 & 0.098 & 0.133 & $0.05 i$ & 0.045 & 0.083 & 0.096 & 0.099 & $0.1: 2$ & $0.1: 4$ & 0.000 & 0.057 & 4.745 & 3.510 & 3.420 & 3.743 & 3.394 & 3.537 \\
\hline Soma_c & 5.000 & 5.000 & 5.000 & 5.000 & 5.000 & 5.000 & 5.000 & 5.000 & 5.000 & 5.000 & 5.000 & 5.000 & 0.000 & 0.140 & 0.179 & 0.107 & 0.144 & 0.144 \\
\hline $\mathrm{Mg}$ & 0.000 & 0.000 & 0.000 & 0.000 & 0.000 & 0.000 & 0.000 & 0.000 & 0.000 & 0.000 & 0.000 & & 5.000 & 4.970 & 4.952 & 5.000 & 4.954 & 4.999 \\
\hline $\mathrm{Fe}^{2+}$ & 0.000 & 0.000 & 0.000 & 0.000 & 0.000 & 0.000 & 0.000 & 0.000 & 0.000 & 0.000 & & 0.000 & 0.000 & 0.000 & 0.000 & 0.000 & 0.000 & 0.000 \\
\hline $\mathrm{Mn}$ & 0.064 & 0.049 & 0.009 & 0.054 & 0.112 & 0.090 & 0.079 & 0.028 & 0.009 & 0.025 & & 0.000 & 1.183 & 0.000 & 0.000 & 0.000 & 0.000 & 0.000 \\
\hline $\mathrm{Ca}$ & 1.607 & 1.669 & $\mathrm{I} .659$ & 1.655 & 1.565 & 1.647 & 1.682 & $i .604$ & 1.699 & 1.607 & 0.438 & 0.060 & 0.571 & 0.000 & 0.000 & 0.056 & 0.000 & 0.000 \\
\hline $\mathrm{Na}$ & 0.329 & 0.282 & 0.332 & 0.291 & 0.323 & 0.263 & 0.239 & 0.368 & 0.292 & 100 & 0.127 & 1.593 & 0.125 & 1.696 & 1.680 & 1.665 & 1.676 & 1.695 \\
\hline Sorna $B$ & 2.000 & 2.000 & 2.000 & 2.000 & 2.000 & 2.000 & 2.000 & 2.000 & 2.000 & 0.367 & 0.038 & 0.347 & 0.044 & 0.304 & 0.320 & 0.269 & 0.324 & 0.305 \\
\hline $\mathrm{Na}^{-}$ & 0.303 & 0.338 & 0.336 & 0.384 & 0.369 & 0.226 & $0.1: 9$ & 0.307 & $\begin{array}{l}2.000 \\
0.168\end{array}$ & 2.000 & 1.997 & 2.000 & 1.923 & 2.000 & 2.000 & 2.000 & 2.000 & 2.000 \\
\hline $\mathrm{k}$ & 0.201 & 0.238 & 0.241 & 0.247 & 0.201 & 0.158 & 0.115 & 0.197 & $\begin{array}{l}0.188 \\
0.168\end{array}$ & 0.276 & 0.000 & 0.353 & 0.000 & 0.213 & 0.212 & 0.172 & 0.346 & 0.361 \\
\hline Sorma_A & 0.505 & 0.576 & 0.577 & 0.631 & 0.570 & 0.384 & 0.234 & 0.503 & $\begin{array}{l}0.168 \\
0.356\end{array}$ & 0.87 & 0.005 & 0.215 & 0.000 & 0.240 & 0.233 & 0.166 & 0.250 & 0.251 \\
\hline Cátions & 15.505 & 15.576 & 15.577 & 15.631 & 15.570 & 15.384 & 15.234 & 15.503 & $\begin{array}{l}0.356 \\
15.356\end{array}$ & 0.463 & 0.005 & 0.566 & 0.000 & 0.553 & 0.425 & 0.338 & 0.597 & 0.612 \\
\hline o & 0.017 & 0.033 & 0.033 & 0.039 & 0.014 & 0.007 & 0.011 & 0.024 & 15.356 & 15.463 & 15.002 & 15.566 & 14.929 & 75.523 & 15.361 & 15.332 & 15.535 & 15.598 \\
\hline F & 0.227 & 0.119 & 0.208 & 0.154 & 0.221 & 0.151 & 0.042 & 0.199 & $\begin{array}{l}0.009 \\
0.065\end{array}$ & 0.007 & 0.002 & 0.025 & 0.005 & 0.048 & 0.110 & 0.077 & 0.054 & 0.068 \\
\hline & & & & & & & & & 0.065 & 0.090 & 0.007 & 0.101 & 0.055 & 0.189 & 0.304 & 0.208 & 0.361 & 0.277 \\
\hline $\begin{array}{c}\mathrm{Mg} \# \\
\mathrm{Na} /(\mathrm{Na}+\mathrm{Ca})\end{array}$ & 0.111 & $\begin{array}{l}0.062 \\
0.271\end{array}$ & 0.099 & 0.107 & 0.073 & 0.065 & 0.062 & 0.087 & 0.066 & 0.061 & 0.018 & 0.072 & 0.012 & 0.089 & & 0.075 & & 0.067 \\
\hline & & $0.27 i$ & 0.287 & 0.290 & 0.307 & 0.229 & 0.175 & 0.295 & 0.220 & 0.286 & 0.232 & 0.305 & 0.250 & 0.265 & $\begin{array}{l}0.053 \\
0.240\end{array}$ & $\begin{array}{l}0.035 \\
0.200\end{array}$ & $\begin{array}{l}0.074 \\
0.285\end{array}$ & $\begin{array}{l}0.21 \\
0.282\end{array}$ \\
\hline
\end{tabular}

<i.d.: abaixo do linite de detecç̧o 
Tabela IV.6:

Análises químicas completas (WDS; de anfibólios dos Granitos da Graciosa

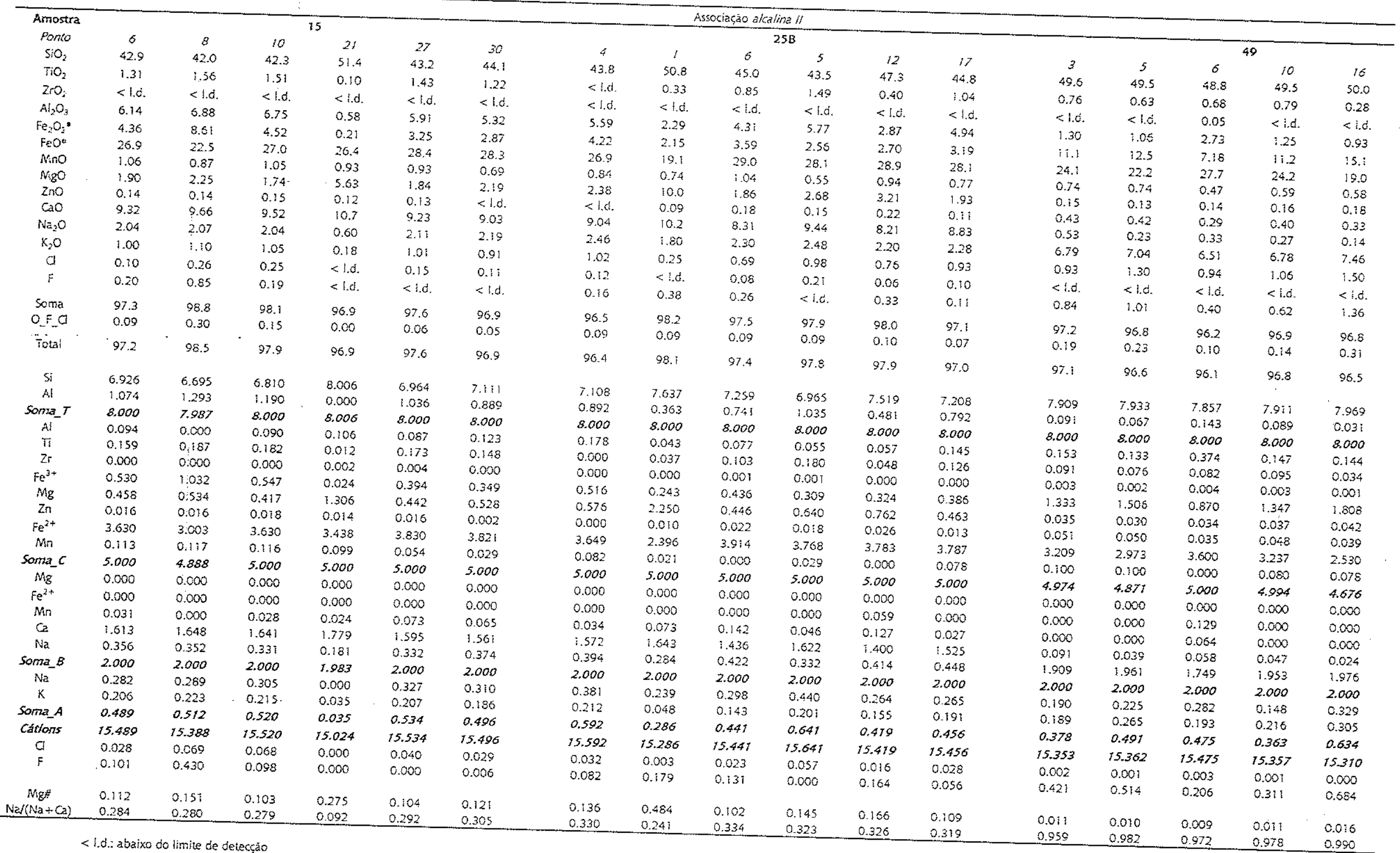

- calculados com base nas estimativas máximas do método de Schumacher (Leake ecal. ig97) 
Tabela IV.6:

Análises quifmicas completas (WOS) de anfibolios dos Cranitos da Graciosa

\begin{tabular}{|c|c|c|c|c|c|c|c|c|c|c|c|c|c|c|c|c|}
\hline \multirow{3}{*}{$\begin{array}{l}\text { Amosira } \\
\text { Ponto } \\
\mathrm{SiO}_{2}\end{array}$} & & & & 51 & & \multicolumn{11}{|c|}{$\frac{\text { Associaçao akalina II }}{56}$} \\
\hline & 17 & 13 & 17 & 19 & 25 & 32 & 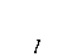 & & & & & & & & & \\
\hline & 48.7 & 46.7 & 46.2 & $46 . i$ & 47.2 & 46.2 & 47.6 & $\begin{array}{c}2 \\
47.7\end{array}$ & $\begin{array}{c}3 \\
47.2\end{array}$ & $\begin{array}{c}8 \\
48.3\end{array}$ & $\begin{array}{c}1 \\
41: ;\end{array}$ & 2 & $s$ & $\sigma$ & 10 & 11 \\
\hline $\mathrm{TH}_{2}$ & 0.29 & 0.73 & 1.00 & 0.86 & 0.72 & 1.04 & $0.8 i$ & 0.74 & 0.90 & $\begin{array}{r}48.3 \\
<i . d .\end{array}$ & $41 . ;$ & 40.9 & 42.0 & 41.5 & 39.9 & 41.7 \\
\hline $2 \mathrm{rO}_{2}$ & 0.16 & <..d. & <i.d. & 0.06 & $<1 . d$ & $<! d$. & $<1 . d$ & $<$ <..ं. & < I.d. & <id. & 1.73 & 1.84 & 1.78 & $i .60$ & 1.78 & 1.85 \\
\hline $\mathrm{Al}_{2} \mathrm{O}_{3}$ & 2.33 & 3.06 & 3.40 & 2.58 & 2.37 & 2.79 & 2.18 & 1.79 & 2.53 & <i.d. & $<i, d$. & $<1 . \delta$ & $<i, d$ & <l.d. & <I.J. & $<i . \delta$. \\
\hline $\mathrm{Fe}_{2} \mathrm{O}_{3}$ & 13.7 & 6.14 & 4.67 & 7.11 & 4.42 & 3.65 & 6.02 & 5.04 & 5.26 & 1.66 & 7.91 & 8.46 & 7.60 & 7.94 & 10.1 & 7.95 \\
\hline $\mathrm{FeO}^{\circ}$ & 21.4 & 26.4 & 27.0 & 20.5 & $27 . \varepsilon$ & 28.7 & 26.9 & 28.0 & 5.26 & 7.82 & 7.73 & 5.68 & 4.99 & 6.02 & 8.87 & 3.49 \\
\hline Mino & 0.65 & 1.09 & 0.96 & 1.09 & $0.9 \varepsilon$ & 0.98 & 0.98 & 1.13 & 27.6 & 26.2 & 23.0 & $24 . i$ & 25.8 & 24.4 & 21.2 & 26.9 \\
\hline $\mathrm{NigO}$ & 0.13 & 1.49 & 2.01 & 1.60 & 2.14 & 1.70 & 1.63 & 1.59 & 0.74 & 1.18 & 0.65 & 0.65 & 0.74 & 0.81 & 0.69 & 0.76 \\
\hline $2 \pi 0$ & 0.49 & 0.23 & 0.24 & 0.29 & 0.20 & 0.25 & 0.32 & $\begin{array}{l}1.59 \\
0.32\end{array}$ & 1.58 & 1.10 & 2.63 & 2.65 & 2.13 & 2.02 & 2.23 & 2.10 \\
\hline $\mathrm{CaO}$ & 0.17 & 5.62 & 6.15 & 5.48 & 5.77 & 6.17 & 4.26 & $\begin{array}{l}0.32 \\
4.03\end{array}$ & 0.23 & $<i d$. & 0.06 & 0.14 & $<1.0$ & $<1.8$ & 0.07 & 0.05 \\
\hline $\mathrm{Na}_{2} \mathrm{O}$ & 7.15 & 3.54 & 3.48 & 3.59 & 3.34 & 3.28 & 4.60 & $\begin{array}{l}4.03 \\
4.20\end{array}$ & 4.83 & 3.52 & 9.77 & 9.77 & 9.72 & 9.72 & $9.5 i$ & 9.79 \\
\hline $\mathrm{K}_{2} \mathrm{O}$ & 1.50 & $0.83^{\circ}$ & 0.80 & 0.74 & 0.81 & 0.80 & 0.96 & & 3.78 & 4.73 & 2.06 & 2.17 & $1.5 i$ & 2.11 & 2.11 & 1.85 \\
\hline C & $<$ l.d. & $<$ l.d. & 0.05 & 0.07 & 0.05 & 0.06 & $<i$. & $\begin{array}{l}0.82 \\
<1.0 .\end{array}$ & 0.92 & 0.85 & 1.06 & 1.06 & 0.99 & 0.94 & 1.04 & 1.08 \\
\hline $\mathrm{F}$ & 1.03 & 0.28 & 0.40 & 1.28 & 0.30 & 0.42 & 0.69 & $\begin{array}{l}<1.0 \\
0.27\end{array}$ & $<1 . \delta$ & $<1$. & 0.21 & 0.19 & 0.15 & 0.15 & 0.20 & 0.18 \\
\hline Soma & 97.7 & $96 . i$ & 96.5 & 97.3 & 96.1 & 96.1 & & 0.27 & 0.05 & 0.67 & 0.53 & 0.23 & 0.15 & 0.34 & 0.39 & $<$ i.t. \\
\hline $0_{-} C$ & 0.23 & 0.08 & 0.11 & 0.32 & 0.09 & 0.12 & 0.17 & $\begin{array}{l}95.6 \\
0.05\end{array}$ & 95.7 & 96.0 & 98.5 & 97.8 & 97.5 & 97.6 & 96.0 & 97.1 \\
\hline Tota: & 97.5 & 96.1 & 96.4 & 97.0 & 36.0 & 96.0 & 968 & & 0.02 & 0.16 & 0.21 & 0.13 & 0.10 & 0.14 & 0.17 & 0.08 \\
\hline & & & & & & & & 95.6 & 95.7 & 95.9 & 98.3 & 97.7 & 97.4 & 97.4 & 97.9 & 97.0 \\
\hline Si & 7.744 & 7.551 & 7.458 & 7.486 & 7.643 & 7.543 & 7.672 & 7.760 & 7.643 & 7.831 & & & & & & \\
\hline A! & 0.256 & 0.449 & 0.542 & 0.494 & 0.357 & 0.457 & 0.328 & & 0.357 & 0.169 & 6.548 & 6.539 & 6.722 & 6.656 & 6.331 & 6.544 \\
\hline Soma_ $T$ & 8.000 & 8.000 & 8.000 & 7.950 & 8.000 & 8.000 & 8.000 & & 8.000 & 8000 & 3.452 & 1.461 & 1.278 & 1.344 & 1.669 & 1.356 \\
\hline $\mathrm{Al} \mathbf{I}^{-}$ & 0.181 & 0.134 & 0.106 & 0.000 & 0.096 & 0.080 & 0.086 & 8.000 & & & 8.000 & 8.000 & 8.000 & 8.000 & 8.000 & 8.000 \\
\hline$\pi$ & 0.034 & 0.088 & 0.121 & 0.105 & 0.088 & 0.128 & 0.098 & 0.110 & & & 0.032 & 0.132 & 0.157 & 0.156 & 0.222 & 0.160 \\
\hline $\mathrm{Zr}$ & 0.012 & 0.002 & 0.000 & 0.005 & 0.002 & 0.001 & 0.001 & 0.091 & & 0.000 & 0.207 & 0.221 & 0.215 & 0.193 & 0.213 & 0.225 \\
\hline $\mathrm{Fe}^{3+}$ & 1.639 & 0.748 & 0.592 & 0.868 & 0.539 & 0.449 & 0.731 & 0.002 & 0.002 & 0.001 & 0.000 & 0.000 & 0.001 & 0.000 & 0.001 & 0.001 \\
\hline $\mathrm{Mg}$ & $0.03 i$ & 0.359 & 0.484 & 0.387 & 0.518 & 0.415 & 0.392 & 0.618 & $0.64 i$ & 0.955 & 0.926 & 0.683 & 0.501 & 0.726 & 1.060 & 0.425 \\
\hline$Z_{i i}$ & 0.057 & 0.028 & 0.029 & 0.035 & 0.024 & 0.030 & 0.038 & 0.385 & 0.406 & 0.266 & 0.624 & 0.630 & 0.509 & 0.482 & 0.527 & 0.505 \\
\hline $\mathrm{Fe}^{\hat{i+}}$ & 2,849 & 3.570 & 3.647 & 3.598 & 3.733 & 3.899 & 3.623 & $\begin{array}{l}0.039 \\
3754\end{array}$ & 0.028 & 0.000 & 0.007 & 0.016 & 0.004 & 0.002 & 0.009 & 0.007 \\
\hline $\mathrm{Mn}$ & 0.087 & 0.070 & 0.022 & 0.003 & 0.000 & 0.000 & 0.031 & 3.754 & 3.685 & 3.555 & 3.063 & 3.215 & 3.453 & 3.274 & 2.810 & 3.634 \\
\hline Soma $c$ & 4.890 & 5.000 & 5.000 & 5.000 & 5.000 & 5.000 & 5.000 & $\begin{array}{l}0.000 \\
5.000\end{array}$ & 0.050 & 0.075 & 0.088 & 0.088 & 0.050 & 0.110 & 0.093 & 0.043 \\
\hline $\mathrm{Mg}$ & 0.000 & 0.000 & 0.000 & 0.000 & 0.000 & 0.000 & 0.000 & $\begin{array}{l}5.000 \\
0.000\end{array}$ & 5.000 & 5.000 & 4.947 & 4.985 & 5.000 & 4.944 & 4.934 & 5.000 \\
\hline $\mathrm{Fe}^{2+}$ & 0.000 & 0.000 & 0.000 & 0.000 & 0.027 & 0.020 & 0.000 & 0.000 & 0.000 & 0.000 & 0.000 & 0.000 & 0.000 & 0.000 & 0.000 & 0.000 \\
\hline $\min$ & 0.000 & 0.079 & 0.109 & 0.847 & 0.135 & 0.135 & 0.103 & 0.052 & $0.05 i$ & 0.000 & 0.000 & 0.000 & 0.000 & 0.000 & 0.000 & 0.000 \\
\hline $\mathrm{co}$ & 0.029 & 0.974 & $i .064$ & 0.954 & 1.000 & 1.078 & 0.736 & $\begin{array}{l}0.155 \\
0.704\end{array}$ & 0.102 & 0.087 & 0.000 & 0.000 & 0.040 & 0.000 & 0.000 & 0.062 \\
\hline $\mathrm{Na}$ & 1.971 & 0.948 & 0.827 & 0.899 & 0.837 & 0.767 & 1.161 & 0.704 & 0.839 & 0.613 & 1.558 & 1.673 & 1.668 & 1.669 & 1.617 & 1.596 \\
\hline Soma $B$ & 2.000 & 2.000 & 2.000 & 2.000 & 2.000 & 2.000 & 2.000 & $\begin{array}{l}1.089 \\
2.000\end{array}$ & 1.008 & 1.300 & 0.332 & 0.327 & 0.292 & 0.331 & 0.383 & 0.242 \\
\hline $\mathrm{Na}$ & $0.23 i$ & 0.162 & 0.264 & 0.231 & 0.211 & $0.27 i$ & 0.276 & 2.000 & 2.000 & 2.000 & 2.000 & 2.000 & 2.000 & 2.000 & 2.000 & 2.000 \\
\hline k & 0.303 & 0.171 & 0.165 & 0.154 & 0.168 & 0.167 & 0.197 & $\begin{array}{l}0.237 \\
0.170\end{array}$ & 0.8 & 0.189 & 0.304 & 0.345 & 0.178 & 0.324 & 0.265 & 0.336 \\
\hline Soma_A & 0.534 & 0.333 & 0.429 & 0.385 & 0.379 & 0.438 & 0.474 & $\begin{array}{l}0.170 \\
0.407\end{array}$ & 0.191 & 0.175 & 0.215 & 0.216 & 0.202 & 0.193 & 0.211 & 0.223 \\
\hline Cations & 15.424 & 15.3 .33 & 15.429 & 15.365 & 15.379 & 15.438 & 15.474 & $\begin{array}{l}0.407 \\
15.407\end{array}$ & 0.372 & 0.364 & 0.519 & 0.561 & 0.380 & 0.577 & 0.476 & 0.567 \\
\hline c & 0.000 & 0.011 & 0.015 & 0.018 & 0.014 & 0.017 & 0.007 & $\begin{array}{l}75.407 \\
0.02\end{array}$ & 15.372 & 15.364 & 15.466 & 75.546 & 15.380 & 15.462 & 15.410 & 15.561 \\
\hline $\mathrm{F}$ & $0.5: 7$ & 0.143 & 0.203 & 0.657 & 0.152 & 0.215 & 0.350 & $\begin{array}{l}0.003 \\
0.137\end{array}$ & 0.007 & 0.003 & 0.058 & 0.052 & 0.039 & 0.040 & 0.053 & 0.049 \\
\hline & & & & & & & & 0.137 & 0.027 & 0.346 & 0.259 & 0.117 & 0.077 & 0.171 & 0.193 & 0.012 \\
\hline $\begin{array}{c}\mathrm{Mg}_{\mathrm{H}} \\
\mathrm{Na} /(\mathrm{Na} \div \mathrm{Ca}\end{array}$ & 0.011 & $0.091^{\prime}$ & 0.117 & 0.097 & 0.121 & 0.096 & 0.098 & 0.092 & 0.098 & 0.070 & & & & & & \\
\hline & & 0.533 & 0.506 & 0.542 & $0.5: 2$ & 0.490 & 0.562 & 0.653 & 0.566 & 0.709 & $\begin{array}{r}0.169 \\
0.276 \\
\end{array}$ & $\begin{array}{l}0.164 \\
0.287\end{array}$ & $\begin{array}{l}0.129 \\
0.220\end{array}$ & $\begin{array}{l}0.128 \\
0.282\end{array}$ & $\begin{array}{l}0.158 \\
0.286\end{array}$ & $\begin{array}{l}0.122 \\
0.255\end{array}$ \\
\hline
\end{tabular}


Tabela IV.6:

Análises quinticas conplecas (WDS) de anfibolios dos Cranitos da Graciosa

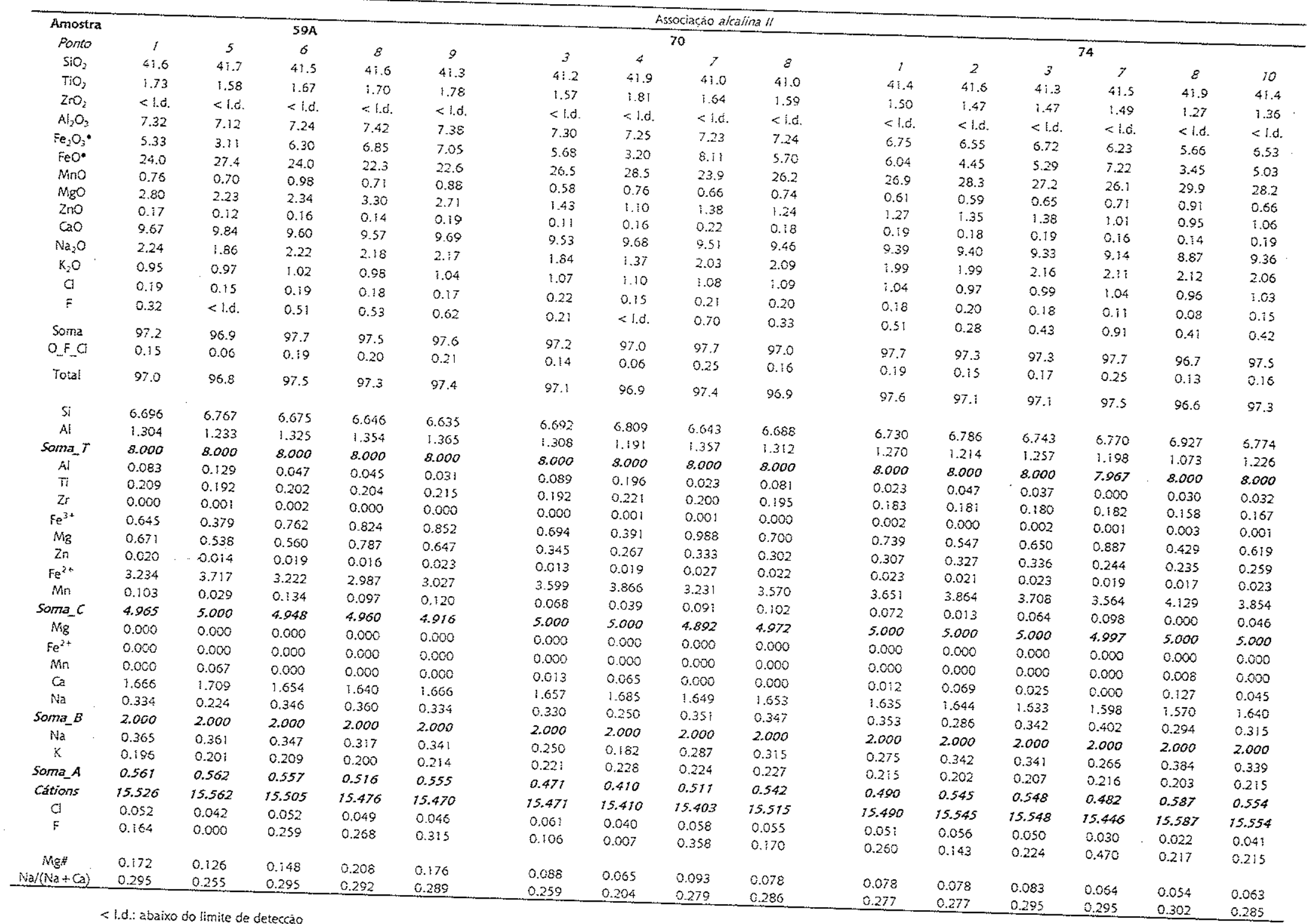

- calculados com base nas estintativas máximas do mètodo de Schumacher (Leake et al. ; 1997) 
Tabela IV.6:

Análises quimicas completas (WOS) de antibólios clos Granitos da Graciosa

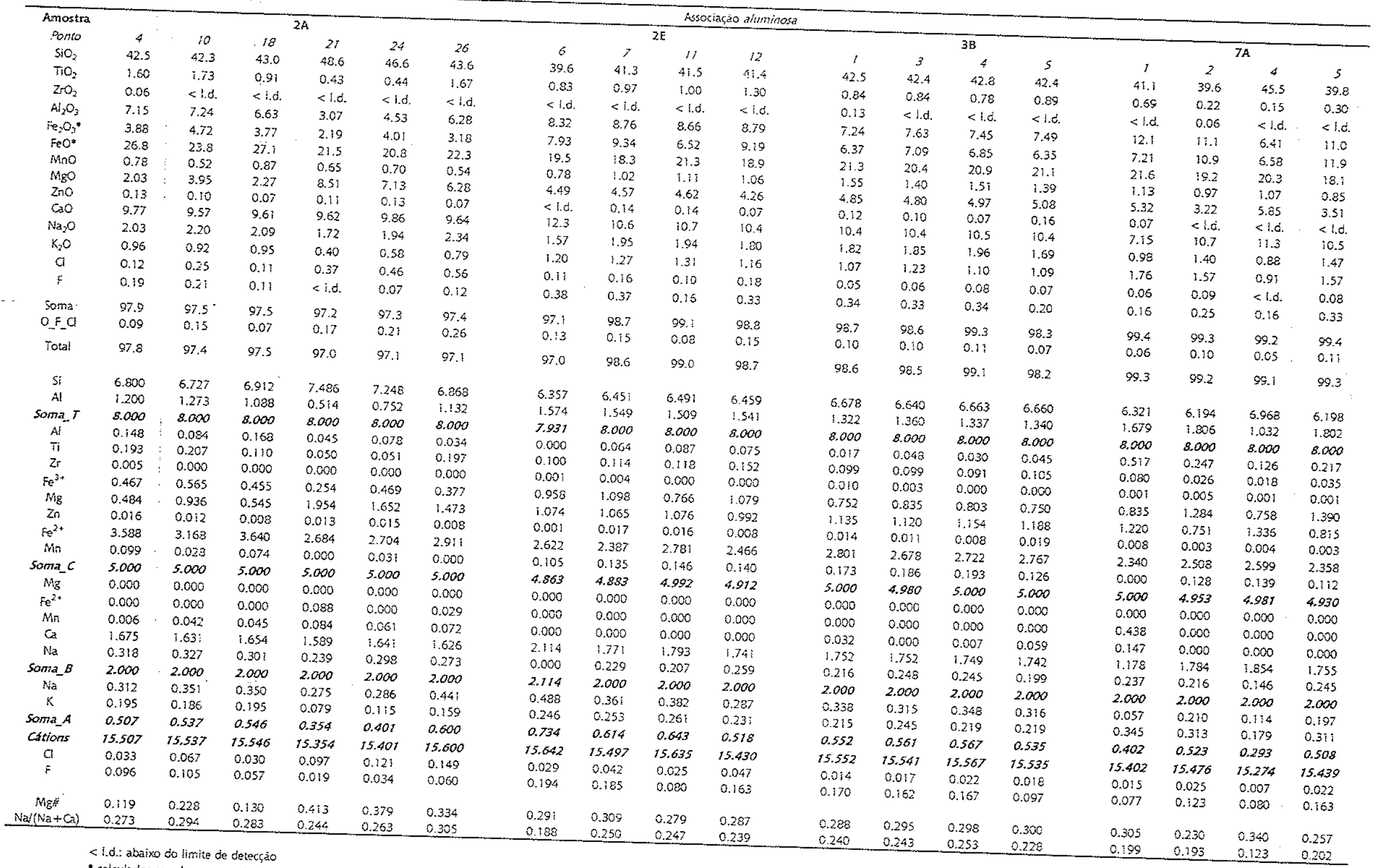

Pág. 7 de 9 
Tabela IV.6:

Antalises quimicas completias (WDS) de anfióbitios cios Gramilos da Graciosa

\begin{tabular}{|c|c|c|c|c|c|c|c|c|c|c|c|c|c|c|c|c|c|c|c|c|}
\hline \multirow{3}{*}{$\begin{array}{l}\text { Amostra } \\
\text { fonto } \\
\text { sio. }\end{array}$} & \multicolumn{4}{|c|}{$; 13$} & \multirow{2}{*}{\multicolumn{4}{|c|}{$28 B$}} & \multicolumn{4}{|c|}{ Associaça siluminosa } & \multirow{2}{*}{\multicolumn{4}{|c|}{$34 B$}} & \multirow{2}{*}{\multicolumn{4}{|c|}{$85 B$}} \\
\hline & $i$ & 2 & 3 & 4 & 4 & 5 & $s$ & & $z^{2}$ & & & & & & & & & & & \\
\hline & 40.7 & 40.9 & 40.8 & 40.3 & 41.7 & 41.6 & 42.5 & 41.2 & 41.0 & $\begin{array}{r}5 \\
41.0\end{array}$ & 10 & "I & '́ & 3 & 5 & $\mathcal{B}$ & 6 & 8 & 9 & 10 \\
\hline $\mathrm{TO}_{2}$ & 1.66 & 0.98 & 1.53 & 1.53 & 1.49 & 0.81 & 1.47 & 1,10 & $i .89$ & $\begin{array}{l}41.0 \\
1.86\end{array}$ & 41.2 & 40.7 & 41.3 & 41.0 & 40.8 & 40.5 & 40.4 & 40.5 & 40.6 & 40.2 \\
\hline $2 \mathrm{rO}^{2}$ & $=1 . d$. & $<$ f.d. & $<1 . d$ & $<$ !.d. & 0.06 & <i.d. & $<$ i.d. & $<$ l.d. & <1.d. & $\begin{array}{l}1.86 \\
<i . \delta .\end{array}$ & 1.59 & 1.12 & 2.02 & 1.86 & $: .23$ & 1.36 & 8.44 & 1.04 & 1.90 & 1.36 \\
\hline $\mathrm{Al}_{2} \mathrm{O}_{3}$ & 7.78 & 7.99 & 7.68 & 7.68 & 8.78 & 8.50 & 7.30 & 3.38 & 8.12 & & $<i .0$ & $<$ i.d. & <.d. & $<f . d$ & $<$ i.c. & 0.09 & $<d$ & $<1.0$ & $<$ <.. & 0.07 \\
\hline $\mathrm{Fe}_{2} \mathrm{O}_{2}$ & 4.45 & 7.92 & 4.84 & 4.84 & 11.2 & 5.94 & 8.78 & 9.33 & 5.09 & $\begin{array}{l}3.29 \\
10.4\end{array}$ & 8.12 & 8.56 & 8.54 & 8.35 & 7.27 & 7.95 & 7.85 & 7.77 & 7.61 & 8.03 \\
\hline Feo" & 25.1 & 22.8 & 25.9 & 25.9 & 13.5 & 21.5 & 15.7 & 18.4 & 22.8 & $\begin{array}{l}10.4 \\
17.5\end{array}$ & $8.3 !$ & 7.97 & 10.5 & 8.86 & 7.74 & 8.70 & 6.17 & 5.11 & 6.60 & 6.59 \\
\hline Mno & 1.01 & 0.94 & $: .07$ & 1.07 & 0.64 & 0.86 & 0.35 & 0.90 & 0.87 & $\begin{array}{l}17.5 \\
0.82\end{array}$ & 19.9 & 20.8 & 17.0 & 20.7 & 25.9 & 23.5 & 25.4 & 24.9 & 24.9 & 25.4 \\
\hline Mgo & 2.95 & 2.88 & 2.67 & 2.67 & 6.55 & 4.60 & 6.54 & 4.29 & 4.05 & & 0.92 & 0.83 & 0.77 & 0.89 & 1.05 & 0.73 & 1.05 & 0.90 & 1.02 & $: .07$ \\
\hline zno & <i.d. & 0.07 & $<$ l.d. & $<l . d$ & $<1, d$. & < l.d. & 0.08 & 0.11 & 0.12 & $\begin{array}{l}4.26 \\
0.05\end{array}$ & & 3.97 & 4.95 & 3.76 & $: .4 i$ & 2.04 & 2.08 & 2.34 & 2.17 & 1.54 \\
\hline $\mathrm{CaO}$ & 9.58 & 9.74 & 9.51 & 9.51 & 10.6 & 10.7 & 10.6 & 0.5 & 9.80 & 9.96 & $\begin{array}{l}<i .6 . \\
9.94\end{array}$ & <..d. & 0.18 & 0.18 & 0.12 & $<1 . d$ & 0.10 & 0.10 & $0 . \mathrm{i} 8$ & 0.14 \\
\hline $\mathrm{Na}_{z} \mathrm{O}$ & 2.02 & 1.37 & 1.39 & 1.89 & 2.15 & 1.36 & 2.07 & 1.75 & 2.02 & 2.23 & $\begin{array}{l}9.94 \\
2.07\end{array}$ & 10.4 & $i 0.00$ & 10.2 & 9.51 & 9.85 & 10.3 & 9.87 & 9.85 & 0.1 \\
\hline $\mathrm{K}_{2} \mathrm{O}$ & 1.09 & i.it & 1.05 & $: .05$ & 1.14 & 1.27 & 1.05 & 1.26 & 1.09 & i. ii & $\begin{array}{l}2.07 \\
0.99\end{array}$ & 1.77 & 2.36 & 2.24 & 2.07 & 2.22 & 1.63 & 1.97 & $i .81$ & 1.66 \\
\hline a & < t.d. & 0.13 & 0.07 & 0.07 & 0.18 & $<i . d$ & 0.15 & 0.09 & 0.17 & 0,16 & $\begin{array}{l}0.99 \\
0.13\end{array}$ & 1.23 & 1.17 & 1.16 & $3 .: 8$ & $i .2 !$ & 1.28 & 1.22 & 3.26 & 8.27 \\
\hline$F$ & 0.15 & 0.11 & 0.16 & 0.16 & 0.85 & 0.12 & 0.71 & 0.46 & 0.17 & 1.01 & 0.13 & 0.12 & 0.27 & 0.27 & 0.27 & 0.49 & 0.25 & 0.24 & 0.21 & $0.2 \varepsilon$ \\
\hline Soma & 96.5 & 97.0 & 97.2 & 97.2 & 98.8 & 97.3 & 98.2 & 97.7 & 97.2 & & 0.57 & 0.25 & 1.09 & 0.82 & 0.66 & 0.79 & 0.22 & 0.45 & 0.58 & 0.17 \\
\hline OFO & 0.05 & 0.08 & 0.07 & 0.07 & 0.27 & 0.04 & 0.22 & 0.14 & $0 . i 1$ & $\begin{array}{l}08.6 \\
0.29\end{array}$ & $\begin{array}{l}97.9 \\
0.18\end{array}$ & $\begin{array}{l}97.8 \\
0.10\end{array}$ & $\begin{array}{l}100.2 \\
0.36\end{array}$ & $\begin{array}{l}100.3 \\
0.30\end{array}$ & $\begin{array}{l}99.2 \\
0.27\end{array}$ & 100.2 & 98.2 & 98.3 & 92.7 & 98.1 \\
\hline Total & 96.5 & 96.9 & 97.1 & 97.1 & 98.5 & 97.3 & 98.0 & 97.6 & 97.1 & 98.3 & 97.7 & $\begin{array}{l}0.10 \\
977\end{array}$ & & & 0.27 & 0.38 & 0.15 & 0.20 & 0.22 & 0.16 \\
\hline $\mathrm{Si}$ & & 6.577 & & & & & & & & & & 97.7 & 99.9 & 100.0 & 99.0 & 99.8 & 98.0 & $98 . i$ & $\S \varepsilon .5$ & 97.9 \\
\hline Al & $\begin{array}{l}0.059 \\
1.401\end{array}$ & 1.423 & $\begin{array}{l}6.597 \\
1.403\end{array}$ & 5.597 & 6.412 & 6.585 & 6.573 & 6.498 & 6.546 & 6.441 & 6.514 & 5.461 & 6.381 & 6.404 & 6.575 & 6.449 & $5.52 \mathrm{i}$ & 6.520 & & 5.505 \\
\hline Somra_ $T$ & 8.000 & 8.000 & 8.000 & $\begin{array}{l}1.403 \\
8.000\end{array}$ & 1.588 & 1.415 & 1.422 & 1.502 & 1.454 & 1.534 & 1.486 & 1.539 & 1.555 & 1.539 & $i .38 i$ & 1.468 & 1.479 & i. 475 & $\begin{array}{l}6.527 \\
i .440\end{array}$ & 0.495 \\
\hline Ai & 0.086 & 0.091 & 0.061 & $\begin{array}{l}8.000 \\
0.061\end{array}$ & $\begin{array}{l}8.000 \\
0.004\end{array}$ & $\begin{array}{l}8.000 \\
0.170\end{array}$ & $\begin{array}{l}3.000 \\
0.003\end{array}$ & 8.000 & 8.000 & 7.975 & 8.000 & 8.000 & 7.936 & 7.943 & 7.956 & 7.936 & 8.000 & 7.996 & 7.967 & 8.000 \\
\hline Ti & 0.202 & 0.118 & 0.185 & 0.186 & 0.172 & $\begin{array}{l}0.170 \\
0.096\end{array}$ & $\begin{array}{l}0.003 \\
0.172\end{array}$ & $\begin{array}{l}0.056 \\
0.130\end{array}$ & 0.075 & 0.000 & 0.028 & 0.061 & 0.000 & 0.000 & 0.000 & 0.000 & 0.013 & 0.000 & 0.020 & 0.036 \\
\hline $\mathrm{Zr}$ & 0.001 & 0.000 & 0.000 & 0.000 & 0.004 & $\begin{array}{l}0.096 \\
0.000\end{array}$ & $\begin{array}{l}0.172 \\
0.003\end{array}$ & $\begin{array}{l}0.130 \\
0.001\end{array}$ & $\begin{array}{l}0.227 \\
0.002\end{array}$ & 0.219 & 0.189 & 0.134 & 0.235 & 0.218 & 0.150 & 0.222 & 0.175 & 0.223 & 0.230 & 0.155 \\
\hline $\mathrm{Fe}^{3+}$ & 0.545 & 0.958 & 0.589 & 0.589 & 1.297 & 0.707 & 1.023 & 1.09 & $\begin{array}{l}0.002 \\
0.512\end{array}$ & 0.001 & 0.000 & 0.000 & 0.002 & 0.000 & 0.001 & 0.007 & 0.050 & $0.00 i$ & 0.000 & 0.005 \\
\hline $\mathrm{Mg}$ & 0.712 & 0.689 & 0.645 & 0.645 & 1.500 & 1.085 & 1.509 & 1.009 & $\begin{array}{l}0.612 \\
0.964\end{array}$ & $1.22 \varepsilon$ & 0.939 & 0.952 & 1.234 & 1.042 & 0.938 & 1.039 & 0.749 & 0.741 & 0.808 & 0.802 \\
\hline$Z n$ & 0.005 & 0.008 & 0.000 & 0.000 & 0.001 & 0.005 & 0.009 & 0.012 & $\begin{array}{l}0.964 \\
0.015\end{array}$ & 0.997 & 0.970 & 0.938 & 1.140 & 0.875 & 0.338 & 0.483 & 0.500 & 0.552 & 0.505 & 0.395 \\
\hline $\mathrm{Fe}^{2 \cdot}$ & 3.398 & 3.072 & 3.509 & 3.509 & 1.732 & 2.241 & 2.029 & 2.426 & $\begin{array}{l}0.015 \\
3.041\end{array}$ & 0.006 & 0.005 & 0.005 & 0.021 & 0.021 & 0.014 & 0.006 & 0.012 & 0.012 & 0.022 & 0.017 \\
\hline Min & $0.05 i$ & 0.063 & 0.010 & 0.010 & 0.083 & 0.095 & 0.112 & 0.120 & $\begin{array}{l}3.04 ! \\
0.064\end{array}$ & 2.296 & 2.639 & 2.760 & 2.195 & 2.709 & 3.490 & 3.226 & 3.430 & 3.356 & 3.343 & 3.441 \\
\hline Soma_c & 5.000 & 5.000 & 5.000 & 5.000 & 4.794 & 5.000 & 4.859 & 4.863 & $\begin{array}{l}0.064 \\
5.000\end{array}$ & 0.109 & 0.124 & $0.11:$ & 0.100 & 0.118 & 0.069 & 0.098 & 0.120 & 0.106 & 0.094 & 0.39 \\
\hline $\mathrm{Mg}_{\mathrm{g}}$ & 0.000 & 0.000 & 0.000 & 0.000 & 0.000 & 0.000 & 0.000 & 0.000 & $\begin{array}{l}5.000 \\
0.000\end{array}$ & 4.857 & 4.994 & 4.962 & 4.927 & 4.983 & 5.000 & 4.982 & 5.000 & 5.000 & 5.000 & 5.000 \\
\hline $\mathrm{Fe}^{2+}$ & 0.000 & 0.000 & 0.600 & 0.000 & 0.000 & 0.000 & 0.000 & 0.000 & $\begin{array}{l}0.000 \\
0.000\end{array}$ & 0.000 & 0.000 & 0.000 & 0.060 & 0.000 & 0.000 & 0.000 & 0.000 & 0.000 & 0.000 & 0.000 \\
\hline Mn & 0.087 & 0.065 & 0.137 & 0.137 & 0.000 & 0.020 & 0.000 & 0.000 & $\begin{array}{l}0.000 \\
0.054\end{array}$ & 0.000 & 0.000 & 0.000 & 0.000 & 0.000 & 0.000 & 0.000 & 0.000 & 0.000 & 0.000 & 0.000 \\
\hline $\mathrm{Ca}$ & 1.665 & $i .678$ & 1.648 & 1.648 & 1.740 & 1.816 & 1.750 & 1.779 & $\begin{array}{l}0.054 \\
1.677\end{array}$ & 0.000 & 0.000 & 0.000 & 0.000 & 0.000 & 0.074 & 0.000 & 0.024 & 0.017 & 0.045 & 0.008 \\
\hline $\mathrm{Na}$ & 0.248 & 0.258 & $0.2 i 5$ & 0.215 & 0.260 & 0.163 & 0.250 & 0.221 & $\begin{array}{l}1.677 \\
0.270\end{array}$ & 1.675 & 1.634 & 3.770 & 1.655 & 1.705 & $i .64 i$ & 1.576 & 0.772 & 1.703 & 1.695 & 1.758 \\
\hline Soma $B$ & 2.000 & 2.000 & 2.000 & 2.000 & 2.000 & 2.000 & 2.000 & 2.000 & $\begin{array}{l}0.270 \\
2.000\end{array}$ & 0.325 & 0.316 & 0.230 & 0.344 & 0.295 & 0.286 & 0.324 & 0.204 & 0.280 & 0.259 & 0.233 \\
\hline $\mathrm{Na}$ & 0.387 & 0.168 & 0.378 & 0.370 & 0.382 & 0.253 & 0.372 & $0.3: 5$ & $\begin{array}{l}2.000 \\
0.357\end{array}$ & 2.000 & 2.000 & 2.000 & 2.000 & 2.000 & 2.000 & 2.000 & 2.000 & 2.000 & 2.000 & 2.000 \\
\hline k & 0.225 & 0.227 & 0.217 & 0.217 & 0.224 & 0.257 & 0.207 & 0.254 & $\begin{array}{l}0.357 \\
0.222\end{array}$ & 0.355 & 0.320 & $0.3: 5$ & 0.364 & 0.385 & 0.362 & 0.359 & 0.305 & 0.336 & 0.305 & 0.286 \\
\hline Soma_ $A$ & 0.612 & 0.395 & 0.595 & 0.595 & 0.606 & 0.510 & 0.578 & 0.569 & $\begin{array}{l}0.222 \\
0.578\end{array}$ & 0.222 & 0.200 & 0.248 & 0.230 & 0.232 & 0.242 & 0.246 & 0.264 & 0.250 & 0.258 & 0.252 \\
\hline Cations & 15.612 & 15.395 & 15.595 & 15.595 & 15.400 & 15.510 & 15.437 & 15.432 & 15.578 & 0.577 & 0.520 & 0.563 & 0.594 & 0.617 & 0.604 & 0.605 & 0.570 & 0.586 & 0.563 & 0.550 \\
\hline a & 0.011 & 0.036 & 0.021 & 0.021 & 0.047 & 0.007 & 0.038 & 0.025 & $\begin{array}{l}13.318 \\
0.045\end{array}$ & 15.408 & 15.464 & 15.526 & 15.456 & 15.543 & 15.560 & 75.523 & 15.570 & 15.581 & 15.531 & 15.550 \\
\hline$F$ & 0.079 & 0.055 & $0.0 \varepsilon 2$ & 0.082 & 0.412 & 0.058 & 0.343 & 0.229 & 0.087 & $\begin{array}{l}0.042 \\
0.500\end{array}$ & 0.035 & 0.032 & 0.07 & 0.07 & 0.075 & 0.130 & 0.067 & 0.056 & 0.056 & 0.077 \\
\hline Mg\# & 0.173 & & & & & & & & & 0.500 & 0.286 & 0.123 & 0.532 & 0.405 & 0.339 & 0.397 & 0.112 & 0.227 & 0.297 & 0.089 \\
\hline $\mathrm{Na} /(\mathrm{Na}+\mathrm{Ca})$ & 0.276 & 0.202 & $\begin{array}{l}0.155 \\
0.265\end{array}$ & $\begin{array}{l}0.155 \\
0.265\end{array}$ & $\begin{array}{r}0.464 \\
0.269\end{array}$ & 0.276 & 0.427 & 0.294 & 0.241 & 0.303 & 0.269 & 0.256 & 0.342 & 0.244 & & & & & & \\
\hline & & & & 0.603 & & 0.186 & 0.252 & 0.232 & 0.272 & 0.289 & 0.274 & 0.236 & 0.299 & 0.285 & 0.283 & $\begin{array}{l}0.134 \\
0.290 \\
\end{array}$ & $\begin{array}{l}0.127 \\
0.223\end{array}$ & $\begin{array}{l}0.143 \\
0.266\end{array}$ & $\begin{array}{l}0.13 ! \\
0.249\end{array}$ & $\begin{array}{l}0.103 \\
0.229\end{array}$ \\
\hline
\end{tabular}


Tabela IV.6:

Análises quimicas completas (WDS) de anfibólios dos Granitos da Graciosa

\begin{tabular}{|c|c|c|c|c|c|c|c|c|c|c|c|c|c|c|c|c|c|}
\hline \multirow{3}{*}{$\begin{array}{c}\text { Anrostra } \\
\text { fonto } \\
\mathrm{SiO}_{2}\end{array}$} & \multicolumn{4}{|c|}{ Associaçáa aluminosa } & \multicolumn{13}{|c|}{ Rochas monzodioriticas e associadas } \\
\hline & 2 & 4 & 5 & 7 & $g$ & & $16 \mathrm{~B} 3$ & & & & 1684 & & & & $59 E$ & & \\
\hline & 42.2 & 40.8 & 41.3 & 41.3 & $\begin{array}{c}8 \\
4 i .8\end{array}$ & 12 & 20 & 22 & 24 & 3 & 5 & $s$ & 2 & 3 & 7 & g & 14 \\
\hline $\mathrm{TiO}_{2}$ & 1.85 & 0.04 & 1.05 & 1.09 & $\mathrm{i} .2 \mathrm{~T}$ & $\begin{array}{l}42.1 \\
1.44\end{array}$ & $4: .9$ & 42.2 & $4: 2$ & 44.8 & 45.2 & 45.4 & 46.3 & 45.8 & 45.4 & 52.4 & 46.9 \\
\hline $\mathrm{ZrO}_{2}$ & $<i . \dot{\sigma}$ & $<$ l.d. & $<1 . d$. & $<i . d$ & $<i, d$ & $\begin{array}{r}1.44 \\
<10\end{array}$ & $i .12$ & 1.01 & $1.4 i$ & 0.84 & 0.93 & 0.95 & 1.09 & $: .40$ & 0.91 & 0.15 & 1.11 \\
\hline $\mathrm{At}_{2} \mathrm{O}_{3}$ & 7.75 & $7.98^{\circ}$ & $3 . i$ & 7.63 & 8.14 & $\begin{array}{l}<1.0 \\
8.09\end{array}$ & $<$ I.d. & $<1 . d$ & $<$ I.d. & $<$ <.d. & $<$ i.d. & $<$ l.d. & $<$ l.d. & 0.06 & $<$ l.d. & $<i, j$ & $<i . d$. \\
\hline $\mathrm{Fe}_{2} \mathrm{O}_{3}{ }^{\circ}$ & 6.00 & 10.5 & 7.12 & 9.80 & 7.94 & $\begin{array}{l}8.09 \\
9.45\end{array}$ & 8.48 & 8.39 & 8.20 & 6.85 & 6.65 & 6.60 & 6.35 & 7.04 & 6.28 & 1.22 & 6.50 \\
\hline $\mathrm{FeO}^{\circ}$ & 23.6 & 21.9 & 25.6 & 22.7 & 19.5 & $\begin{array}{l}9.45 \\
17.2\end{array}$ & 10.3 & 3.66 & 8.59 & 8.71 & 7.95 & 0.65 & 5.36 & 6.08 & 5.83 & 2.94 & 5.74 \\
\hline Mno & 1.03 & 1.14 & 1.03 & 1.23 & 1.37 & $\begin{array}{l}17.2 \\
1.47\end{array}$ & 16.9 & 18.8 & 18.3 & 14.5 & 15.6 & 14.1 & 12.0 & $: 2.4$ & 12.1 & 14.2 & 12.3 \\
\hline MgO & 3.32 & 2.48 & 2.42 & 2.35 & 4.52 & 5.08 & & 1.38 & 1.60 & 0.58 & 0.59 & 0.68 & 0.43 & 0.45 & 0.42 & 0.60 & 0.47 \\
\hline Zno & 0.07 & 0.09 & 0.06 & 0.09 & 0.05 & $<$ I.d. & $\begin{array}{l}4.90 \\
0.07\end{array}$ & $4.5 !$ & 4.77 & 8.44 & 8.69 & $\varepsilon .83$ & 11.7 & 11.7 & 11.3 & 13.2 & $i 2.2$ \\
\hline Cao & 10.0 & 9.88 & 9.27 & 9.64 & 9.57 & $10 . i$ & $\begin{array}{l}0.07 \\
9.91\end{array}$ & $<i d$ & $<1 . d$ & $<i, d$ & $<$ ld. & 0.08 & $<$ i.d. & $<$ <.o. & $<$ l.d. & $<1.0$. & $<$ id. \\
\hline $\mathrm{Na}_{i} \mathrm{O}$ & 2.17 & 2.03 & 1.76 & 1.97 & 1.73 & 1.50 & 1.64 & $\begin{array}{l}10.2 \\
1.53\end{array}$ & 9.84 & $1: 0$ & 10.5 & $: 0.9$ & 11.2 & 11.2 & $\$ 1.2$ & 11.7 & 11.3 \\
\hline$k_{2} \mathrm{O}$ & 1.08 & 1.19 & i.i8 & 1.14 & 0.87 & $i .0 \mathrm{i}$ & 1.07 & $\begin{array}{l}1.53 \\
0.93\end{array}$ & 1.67 & i. 48 & 1.36 & 1.43 & 1.30 & $: .37$ & 1.02 & 0.27 & 1.17 \\
\hline a & 0.23 & 0.39 & 0.32 & 0.37 & 0.17 & 0.21 & 0.24 & $\begin{array}{l}0.98 \\
0.15\end{array}$ & 1.03 & 0.82 & 0.74 & 0.80 & 0.69 & 0.74 & 0.52 & $0.7 i$ & 0.64 \\
\hline F & 0.41 & 0.75 & 0.07 & 0.70 & 0.17 & 0.46 & 0.37 & $\begin{array}{l}0.15 \\
0.25\end{array}$ & $0.2 i$ & $<i . d$. & $<i \delta$. & < l.c. & 0.05 & 0.05 & $<$ l.d. & $<$ l.d. & <1.C. \\
\hline Soma & 99.7 & 100.2 & 99.3 & 100.1 & 97.6 & 98.2 & 98.3 & & 0.37 & 0.53 & 0.44 & 0.60 & 0.14 & 0.26 & 0.18 & 0.12 & 0.08 \\
\hline$O_{-} F_{-} \mathrm{a}$ & $0.1 \varepsilon$ & 0.33 & 0.15 & 0.32 & 0.11 & 0.19 & 0.18 & $\begin{array}{l}98.0 \\
0.12\end{array}$ & $\begin{array}{l}97.4 \\
0.17\end{array}$ & $\begin{array}{l}98.6 \\
0.14\end{array}$ & 98.8 & 90.1 & 98.2 & $98 . \overline{7}$ & 96.4 & 97.7 & 92.5 \\
\hline Total & 99.5 & 99.8 & 99.2 & 99.3 & 97.5 & 98.0 & 98.1 & 97.9 & , & 0.14 & 0.12 & 0.15 & 0.05 & 0.08 & 0.05 & 0.03 & 0.04 \\
\hline & & & & & & & & & & 98.5 & 98.7 & 98.9 & $98 . \hat{\imath}$ & 98.6 & 96.3 & 97.6 & 58.5 \\
\hline $\begin{array}{l}5 i \\
\text { Al }\end{array}$ & 6.610 & 6.454 & 6.556 & 6.529 & 6.588 & 6.563 & 6.527 & 6.591 & 6.517 & 6.793 & 5.334 & 5.830 & 6.864 & 5.790 & & & \\
\hline $\begin{array}{c}\text { Al } \\
\text { Sorma } T\end{array}$ & 1.390 & 1.488 & 1.444 & 1.430 & 1.412 & 1.437 & 1.473 & :.409 & 1.483 & 1.207 & 1.160 & 1.170 & 1.336 & $1.2 \div 0$ & $\begin{array}{l}5.995 \\
1.004\end{array}$ & 7.698 & 6.908 \\
\hline $\begin{array}{l}\text { Sorna } T \\
\mathrm{Al}^{-}\end{array}$ & 8.000 & 7.942 & 8.000 & 7.959 & 8.000 & 8.000 & 8.000 & 8.000 & 8.000 & 8.000 & 8.000 & 8.000 & 8.000 & 8.000 & 1.004 & 0.302 & 1.092 \\
\hline Al & 0.042 & 0.000 & 0.074 & 0.000 & 0.099 & 0.049 & 0.083 & 0.137 & 0.043 & 0.017 & 0.012 & 0.001 & 0.06 & & 8.000 & 8.000 & 8.000 \\
\hline $\begin{array}{l}\pi i \\
\mathrm{zr}\end{array}$ & 0.218 & $0.1 \mathrm{i2}$ & 0.125 & 0.130 & 0.143 & 0.169 & 0.131 & $0.1: 9$ & 0.160 & 0.096 & 0.05 & 0.102 & & 0.019 & 0.131 & 0.014 & 0.055 \\
\hline Zr & 0.001 & 0.002 & 0.000 & 0.000 & 0.004 & 0.002 & 0.001 & 0.000 & 0.000 & 0.002 & 0.003 & 0.000 & $0.12 i$ & 0.156 & 0.103 & 0.018 & 0.123 \\
\hline $\mathrm{Fe}^{3+}$ & 0.708 & 1.255 & 0.850 & 1.166 & 0.941 & 1.109 & 1.213 & 1.019 & 1.033 & 0.993 & 0.904 & & 0.000 & 0.005 & 0.002 & 0.000 & 0.000 \\
\hline $\mathrm{Mg}$ & 0.775 & 0.585 & 0.573 & 0.553 & $1.06:$ & 1.179 & 1.136 & 1.052 & 1.124 & $i .905$ & .056 & & 0.709 & 0.678 & 0.662 & 0.325 & 0.637 \\
\hline $2 n$ & 0.009 & 0.010 & 0.008 & 0.010 & 0.006 & 0.005 & 0.008 & 0.006 & 0.003 & 0.004 & $\begin{array}{l}1.930 \\
0.000\end{array}$ & 1.930 & 2.586 & 2.589 & 2.542 & 2.892 & 2.670 \\
\hline $\mathrm{Fe}^{2+}$ & 3.092 & 2.895 & 3.370 & 3.003 & 2.571 & 2.236 & 2.203 & 2.458 & 745 & & & 0.008 & 0.004 & 0.000 & 0.002 & 0.004 & 0.004 \\
\hline $\mathrm{Min}$ & 0.137 & 0.140 & 0.000 & 0.137 & 0.176 & 0.194 & 0.173 & 0.133 & $\begin{array}{l}2.413 \\
0.16\end{array}$ & $\begin{array}{l}1.833 \\
0.074\end{array}$ & 1.975 & 1.779 & 1.494 & $1.54 i$ & 1.525 & 1.745 & 1.512 \\
\hline Soma_c & 4.981 & 5.000 & 5.000 & 5.000 & 5.000 & 4.944 & 4.949 & $\begin{array}{l}0.133 \\
4.974\end{array}$ & $\begin{array}{l}0.216 \\
5.000\end{array}$ & $\begin{array}{l}0.074 \\
4.925\end{array}$ & 0.039 & 0.087 & 0.026 & 0.012 & 0.052 & 0.003 & 0.000 \\
\hline $\mathrm{mg}^{-}$ & 0.000 & 0.000 & 0.000 & 0.000 & 0.000 & 0.000 & 0.000 & $\begin{array}{l}4.974 \\
0.000\end{array}$ & 5.000 & 4.925 & 5.000 & 4.943 & 5.000 & 5.000 & 5.000 & 5.000 & 5.000 \\
\hline $\mathrm{Fe}^{2+}$ & 0.000 & 0.000 & 0.030 & 0.000 & $0.00 \%$ & 0.000 & 0.000 & $\begin{array}{l}0.000 \\
0.000\end{array}$ & 0.000 & 0.000 & 0.000 & 0.000 & 0.000 & 0.000 & 0.000 & 0.000 & 0.000 \\
\hline $\mathrm{Mn}$ & 0.000 & 0.013 & 0.138 & 0.034 & 0.074 & 0.000 & 0.000 & $\begin{array}{l}0.000 \\
0.000\end{array}$ & 0.000 & 0.000 & 0.000 & 0.000 & 0.000 & 0.000 & 0.000 & 0.000 & 0.007 \\
\hline $\mathrm{ca}$ & .683 & 1.675 & 1.577 & 1.633 & 1.615 & 1.683 & .654 & 0.000 & 0.009 & 0.000 & 0.037 & 0.000 & 0.028 & 0.044 & 0.001 & 0.072 & 0.059 \\
\hline $\mathrm{Na}$ & 0.317 & 0.312 & 0.255 & 0.333 & 0.311 & 0.317 & 0.346 & $\begin{array}{l}1.703 \\
0.297\end{array}$ & 1.666 & 1.780 & 1.708 & .759 & $1.78:$ & 1.785 & $i .30 i$ & 1.842 & 1.784 \\
\hline Soma $_{B} B$ & 2.000 & 2.000 & 2.000 & 2.000 & 2.000 & 2.000 & 2.000 & $\begin{array}{l}0.297 \\
2.000\end{array}$ & 0.324 & 0.220 & 0.255 & 0.241 & 0.391 & 0.171 & 0.198 & 0.073 & 0.150 \\
\hline $\mathrm{Na}$ & 0.342 & 0.309 & 0.285 & 0.272 & 0.216 & 0.166 & 0.148 & & 2.000 & 2.000 & 2.000 & 2.000 & 2.000 & 2.000 & 2.000 & 1.992 & 2.000 \\
\hline K & 0.215 & 0.240 & 0.239 & 0.229 & 0.174 & 0.20 & 0.213 & $\begin{array}{l}0.168 \\
0.996\end{array}$ & 0.187 & $0.2 i 4$ & 0.142 & 0.176 & 0.183 & 0.222 & 0.099 & 0.000 & 0.184 \\
\hline Soma $A$ & 0.557 & 0.548 & 0.524 & 0.501 & 0.391 & 0.367 & 0.367 & $\begin{array}{l}0.196 \\
0.365\end{array}$ & 0.208 & 0.155 & 0.142 & 0.153 & 0.131 & 0.141 & 0.119 & 0.02 & 0.120 \\
\hline Cations & 15.538 & 15.491 & 15.524 & 15.460 & 15.391 & 15.310 & 15.310 & $\begin{array}{l}0.365 \\
15.338\end{array}$ & 0.395 & 0.371 & 0.284 & 0.329 & 0.314 & 0.363 & 0.219 & 0.021 & 0.304 \\
\hline a & 0.055 & 0.106 & 0.086 & 0.100 & 0.045 & 0.055 & 0.064 & $\begin{array}{c}15.338 \\
0.041\end{array}$ & 15.395 & 15.296 & 15.284 & 15.272 & 15.314 & 15.363 & 15.219 & 15.013 & 15.304 \\
\hline$F$ & 0.203 & 0.375 & 0.033 & $0.35 !$ & 0.086 & 0.227 & 0.182 & $\begin{array}{l}0.041 \\
0.025\end{array}$ & 0.057 & 0.012 & 0.010 & $0.01 ?$ & 0.013 & 0.013 & 0.007 & 0.003 & 0.012 \\
\hline & & & & & & & & 0.325 & 0.187 & 0.252 & 0.212 & 0.286 & 0.066 & 0.121 & 0.085 & 0.057 & 0.036 \\
\hline $\begin{array}{c}\mathrm{Nig}^{H} \\
\mathrm{Na} / \mathrm{Ni}^{2}+\mathrm{Ca}\end{array}$ & 0.200 & 0.168 & 0.144 & 0.156 & 0.292 & 0.345 & 0.340 & 0.300 & 0.318 & 0.510 & & & & & & & \\
\hline & & 0.271 & 0.255 & 0.270 & 0.246 & 0.223 & 0.230 & 0.214 & 0.235 & 0.196 & $\begin{array}{l}0.498 \\
0.189\end{array}$ & $\begin{array}{l}0.527 \\
0.191\end{array}$ & $\begin{array}{l}0.174 \\
0.174\end{array}$ & $\begin{array}{l}0.627 \\
0.180\end{array}$ & $\begin{array}{l}0.625 \\
0.142\end{array}$ & 0.624 & 0.637 \\
\hline
\end{tabular}


Tabela IV.7:

Análises quimicas completas (WOS) de biotitas dos Granitos da Graciosa

\begin{tabular}{|c|c|c|c|c|c|c|c|c|c|c|c|c|c|c|c|c|c|}
\hline Ponto & 1 & 2 & 4 & 6 & & & & & & & & & & & & & \\
\hline $\mathrm{SiO}_{2}$ & 34.6 & 35.3 & 34.9 & 35.3 & $\begin{array}{c}10 \\
34.8\end{array}$ & $\begin{array}{c}16 \\
35.4\end{array}$ & 21 & 23 & I & 2 & 4 & 16 & 4 & 12 & 14 & is & 2 \\
\hline $\mathrm{TiO}_{2}$ & 2.84 & 3.27 & 3.34 & 3.27 & 0.99 & $\begin{array}{l}35.4 \\
0.88\end{array}$ & 35.0 & 35.2 & 34.2 & 34.2 & 34.0 & 33.5 & 35.1 & 34.7 & 34.9 & 35.2 & 34.7 \\
\hline $\mathrm{ZrO}_{2}$ & $<1.0$ & $<$ i.d. & < l.d. & $<$ l.d. & < lớ. & $\begin{array}{l}0.88 \\
<i . d .\end{array}$ & 3.35 & 3.26 & $: .61$ & 1.58 & 2.28 & 3.44 & 1.91 & 3.63 & 3.18 & 3.48 & 2.85 \\
\hline $\mathrm{Al}_{2} \mathrm{O}_{3}$ & 8.06 & 8.03 & 8.08 & 8.65 & 8.76 & $\begin{array}{l}\text { <i.d. } \\
9.33\end{array}$ & $<$ <. & $\because$ id & $<$ I.d. & $<$. d. & $<1 . d$. & $<$ i.d. & $<$ t.d. & $<1 . d$ & $<i . d$ & $<$ i.d. & $<$ l.t. \\
\hline $\mathrm{FeO}$ & 38.2 & 37.9 & 37.7 & 36.9 & 39.9 & $\begin{array}{l}9.33 \\
38.8\end{array}$ & 10.0 & 10.5 & 9.65 & 9.37 & 9.83 & 10.8 & 9.78 & 10.2 & 9.74 & 9.82 & 10.8 \\
\hline Mno & 0.47 & 0.50 & $0.51^{\circ}$ & 0.44 & 1.00 & $\begin{array}{l}38.8 \\
0.88\end{array}$ & 37.0 & 35.8 & 39.1 & 39.5 & 38.7 & 37.4 & 38.7 & 36.6 & 37.5 & 36.7 & 37.7 \\
\hline $\mathrm{MgO}$ & $<\downarrow d$. & $<$ l.d. & < l.d. & $<$ l.d. & 0.15 & $\begin{array}{l}0.88 \\
0.19\end{array}$ & 0.43 & 0.45 & 0.79 & 0.85 & 0.79 & 0.47 & 1.00 & 0.67 & 0.62 & 0.59 & 0.57 \\
\hline Zno & 0.19 & 0.25 & 0.22 & 0.27 & 0.06 & $\begin{array}{l}0.19 \\
<1 . d .\end{array}$ & 0.20 & 0.20 & 0.32 & 0.33 & 0.32 & 0.40 & 0.29 & 0.20 & 0.20 & 0.23 & 0.27 \\
\hline $\mathrm{CaO}$ & $<l d$ & $<$ l.d. & $<1 . d$ & < l.d. & $<1$. & $\begin{array}{l}<1 . d . \\
<1 . d .\end{array}$ & 0.14 & 0.13 & $<$. & $<$ l.d. & $<$ l.d. & $<$ I.d. & 0.09 & 0.15 & 0.14 & 0.16 & 0.07 \\
\hline $\mathrm{BaO}$ & $<$ l.d. & $<$ <.d. & <!d. & < 1.c. & 0.08 & $\begin{array}{l}<\text { l.d. } \\
<\text { l.d. }\end{array}$ & $<$ l.d. & $<i d$. & $<1,6$ & $<$ l.d. & $<$ <. & $<$ l.d. & $<$ l.d. & $<$ l.d. & < I.c. & $<1 . \dot{c}$ & $<$ l.d. \\
\hline $\mathrm{Na}, \mathrm{O}^{\circ}$ & $<$ i.d. & $<$ <.d. & $<i . d$ & < l.t. & < I.c. & 0.03 & $\begin{array}{l}<\text { l.d. } \\
<i . d .\end{array}$ & 0.15 & $<! .0$ & $<$ l.d. & < I.d. & <i, d. & $<$ l.d. & 0.07 & $<1.6$ & 0.15 & $<$ i.d. \\
\hline $\mathrm{K}_{2} \mathrm{O}$ & 8.50 & 8.27 & 8.20 & 8.26 & 8.24 & 8.09 & $\begin{array}{l}<\text { i.d. } \\
8.57\end{array}$ & 0.03 & $<\mid . d$ & 0.03 & < l.e. & 0.03 & <.d. & $<$ i.d. & < I.C. & 0.02 & $<i . d$. \\
\hline $\mathrm{c}$ & 0.05 & $<$ id. & 0.07 & 0.06 & 0.10 & 0.14 & $\begin{array}{l}8.57 \\
0.12\end{array}$ & $8.2 !$ & 8.65 & 8.60 & 8.57 & 8.41 & 8.45 & 8.70 & 8.68 & 8.59 & 8.59 \\
\hline$F$ & $<$ t.d. & $<$ id & $<1$ d. & $<$ l.c. & 0.20 & $<$ l.d. & $\begin{array}{l}0.12 \\
0.27\end{array}$ & 0.08 & 0.15 & 0.16 & 0.14 & 0.10 & $<$ i.d. & $<! d$ & 0.07 & 0.06 & 0.05 \\
\hline Soma & 92.9 & 93.6 & 93.1 & 93.3 & 94.3 & 93.9 & $\begin{array}{l}0.27 \\
95.2\end{array}$ & 0.24 & <!.d. & 0.07 & < l.ర. & 0.17 & 0.13 & 0.09 & 0.13 & $<1.0$ & $<$ <. \\
\hline$O_{-} \mathrm{Cl}$ & 0.02 & 0.02 & 0.03 & 0.02 & 0.09 & 0.06 & $\begin{array}{l}95.2 \\
0.11\end{array}$ & 94.3 & 94.6 & 0.47 & 94.7 & 94.8 & 95.5 & 95.0 & 95.2 & 95.0 & 95.7 \\
\hline Total & 92.9 & 93.6 & 93.1 & 93.2 & 94.2 & 93.8 & 95.1 & 0.09 & 0.07 & 0.08 & 0.07 & 0.08 & 0.05 & 0.04 & 0.06 & 0.03 & 0.02 \\
\hline $\mathrm{Si}$ & & & & & & & 93.1 & 94.2 & 94.5 & 94.7 & 94.7 & 94.7 & 95.5 & 95.0 & $95 .:$ & 95.0 & 95.5 \\
\hline Al & 6.058 & 6.101 & 6.072 & 6.090 & 6.050 & 5.116 & 5.918 & 5.964 & 5.908 & 5.922 & 5.850 & & & & & & \\
\hline $\mathrm{Fe}$ & 1.663 & 1.636 & 1.655 & 1.758 & 1.797 & 1.884 & 2.002 & 2.036 & 1.965 & 1.911 & 1.993 & 5.717 & 5.960 & 5.865 & 5.920 & 5.943 & 5.840 \\
\hline Soma_T & 0.279 & 0.264 & 0.272 & 0.152 & 0.143 & 0.000 & 0.080 & 0.000 & 0.127 & 0.167 & 0.157 & 2.172 & 1.959 & 2.039 & 1.948 & 1.955 & 2.146 \\
\hline $\mathrm{Al}^{-2}$ & 8.000 & 8.000 & 8.000 & 8.000 & 8.000 & $\mathcal{S} .000$ & 8.000 & 8.000 & 8.000 & 8.000 & 8.000 & $\begin{array}{l}0.111 \\
8.000\end{array}$ & 0.081 & 0.095 & 0.132 & 0.102 & 0.014 \\
\hline $\mathrm{Ti}$ & 0.000 & 0.000 & 0.000 & 0.000 & 0.000 & 0.014 & 0.000 & 0.056 & 0.000 & 0.000 & 0.000 & 8.000 & 8.000 & 8.000 & 8.000 & 8.000 & 8.000 \\
\hline $\mathrm{Zr}$ & $\begin{array}{l}0.3 / 4 \\
0.003\end{array}$ & 0.424 & 0.436 & 0.424 & 0.130 & $0.1: 4$ & 0.426 & 0.415 & 0.209 & 0.205 & 0.295 & 0.000 & 0.000 & 0.000 & 0.000 & 0.000 & 0.000 \\
\hline $\mathrm{Fe}$ & $\begin{array}{l}0.003 \\
5.316\end{array}$ & 0.002 & 0.000 & 0.000 & 0.000 & 0.004 & 0.003 & 0.000 & 0.000 & 0.001 & 0.003 & 0.442 & 0.243 & 0.452 & 0.406 & 0.442 & $0.36 ?$ \\
\hline $\mathrm{Min}$ & & 5.213 & 5.212 & 5.172 & 5.665 & 5.604 & 5.160 & 5.067 & 5.528 & 5.542 & 5.413 & 0.000 & 0.001 & 0.000 & 0.000 & 0.001 & 0.000 \\
\hline $\mathrm{Nig}$ & $\begin{array}{l}0.069 \\
0.000\end{array}$ & 0.073 & 0.075 & 0.064 & 0.148 & 0.129 & 0.052 & 0.065 & 0.116 & 0.124 & 0.116 & 5.220 & 5.422 & 5.082 & 5.194 & 5.080 & 5.283 \\
\hline $\mathrm{Zn}$ & $\begin{array}{l}0.000 \\
0.024\end{array}$ & 0.000 & 0.000 & 0.001 & 0.040 & 0.049 & $0.05 i$ & 0.049 & 0.082 & 0.086 & 0.082 & 0.068 & 0.144 & 0.096 & 0.089 & 0.084 & $0.08 i$ \\
\hline Soma_M $M$ & $\begin{array}{l}0.024 \\
5.786\end{array}$ & 0.031 & 0.028 & 0.035 & 0.008 & 0.002 & 0.017 & 0.016 & 0.006 & 0.005 & 0.000 & 0.101 & 0.074 & 0.050 & 0.050 & 0.059 & 0.069 \\
\hline $\mathrm{Ca}$ & $\begin{array}{l}3.786 \\
0.000\end{array}$ & 5.744 & 5.752 & 5.696 & 5.997 & 5.915 & 5.721 & 5.668 & 5.947 & 5.963 & 5.909 & $\begin{array}{l}0.006 \\
5.836\end{array}$ & $0.01:$ & 0.019 & 0.017 & 0.020 & 0.008 \\
\hline $\mathrm{Ba}$ & $\begin{array}{l}0.000 \\
0.000\end{array}$ & 0.000 & 0.000 & 0.001 & 0.000 & 0.003 & 0.001 & 0.005 & 0.000 & 0.000 & 0.002 & 5.836 & 5.896 & 5.709 & 5.756 & 5.695 & 5.802 \\
\hline $\mathrm{Na}$ & 0.000 & 0.000 & 0.003 & 0.002 & 0.005 & 0.003 & 0.002 & 0.010 & 0.003 & 0.000 & 0.001 & 0.000 & 0.003 & 0.000 & 0.003 & 0.002 & 0.000 \\
\hline K & 1.897 & 0.000 & 0.000 & 0.000 & 0.003 & 0.010 & 0.007 & 0.010 & 0.003 & 0.009 & 0.005 & 0.000 & 0.000 & 0.004 & 0.000 & 0.010 & 0.000 \\
\hline Soma_f & 1.897 & 1.823 & 1.819 & 1.816 & 1.830 & 1.782 & 1.849 & 1.773 & $: .908$ & 1.898 & 1.882 & $\begin{array}{l}0.009 \\
1.870\end{array}$ & 0.002 & 0.000 & 0.002 & 0.008 & 0.005 \\
\hline Cátions & 15.683 & 1.823 & 1.821 & 1.818 & 1.837 & 1.795 & 1.857 & 1.793 & 1.914 & 1.907 & 1.888 & $\begin{array}{l}1.829 \\
1.838\end{array}$ & 1.832 & 1.878 & 1.880 & 1.851 & 1.843 \\
\hline $\mathrm{Cl}$ & 0.016 & 15.567 & 15.573 & 15.514 & 15.828 & 15.710 & 15.578 & 15.461 & 15.855 & 15.870 & 15.797 & $\begin{array}{l}1.838 \\
15.670\end{array}$ & 1.834 & 1.882 & 1.882 & 1.869 & 1.847 \\
\hline$F$ & 0.000 & $0.01 i$ & 0.020 & 0.017 & 0.028 & 0.041 & 0.033 & 0.024 & 0.044 & 0.046 & 0.042 & 15.674 & 15.730 & 15.591 & 15.637 & 15.564 & 15.649 \\
\hline $\mathrm{MgH}$ & 0.000 & 0.000 & 0.000 & 0.000 & 0.109 & 0.000 & 0.145 & 0.129 & 0.020 & 0.038 & 0.019 & 0.028 & 0.013 & 0.014 & 0.020 & 0.018 & 0.015 \\
\hline & & 0.000 & 0.000 & 0.000 & 0.007 & 0.009 & 0.010 & 0.010 & 0.014 & 0.015 & $\begin{array}{r}0.019 \\
0.015 \\
\end{array}$ & 0.090 & 0.058 & 0.046 & 0.059 & 0.000 & 0.000 \\
\hline
\end{tabular}


Tabela N.7:

Análises quinicas completas (WDS) de biotitas dos Granitos da Graciosa

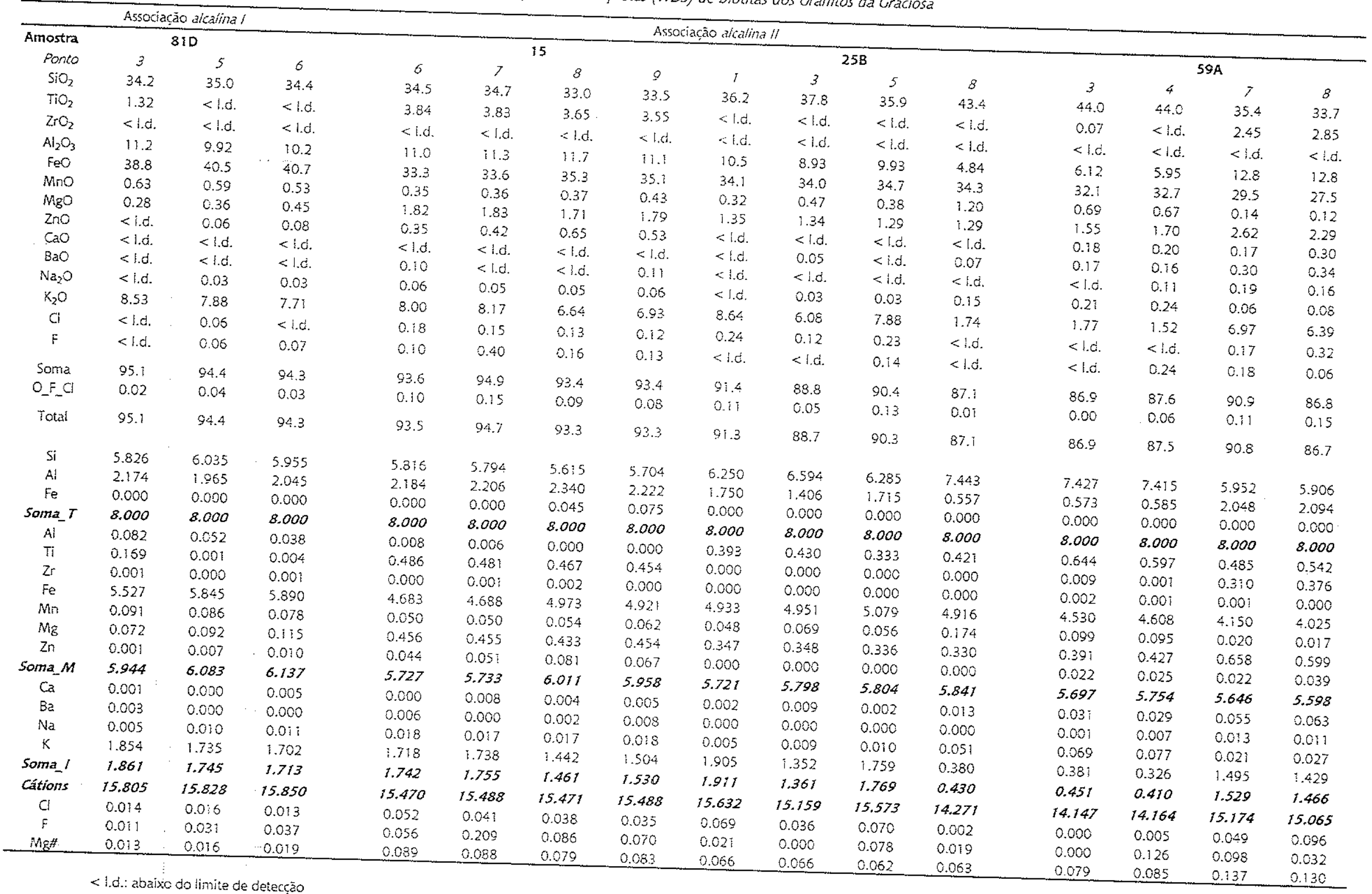


Tabela IV.7:

Análises químicas completas (WOS) de biouttas dos Granitos da Graciosa

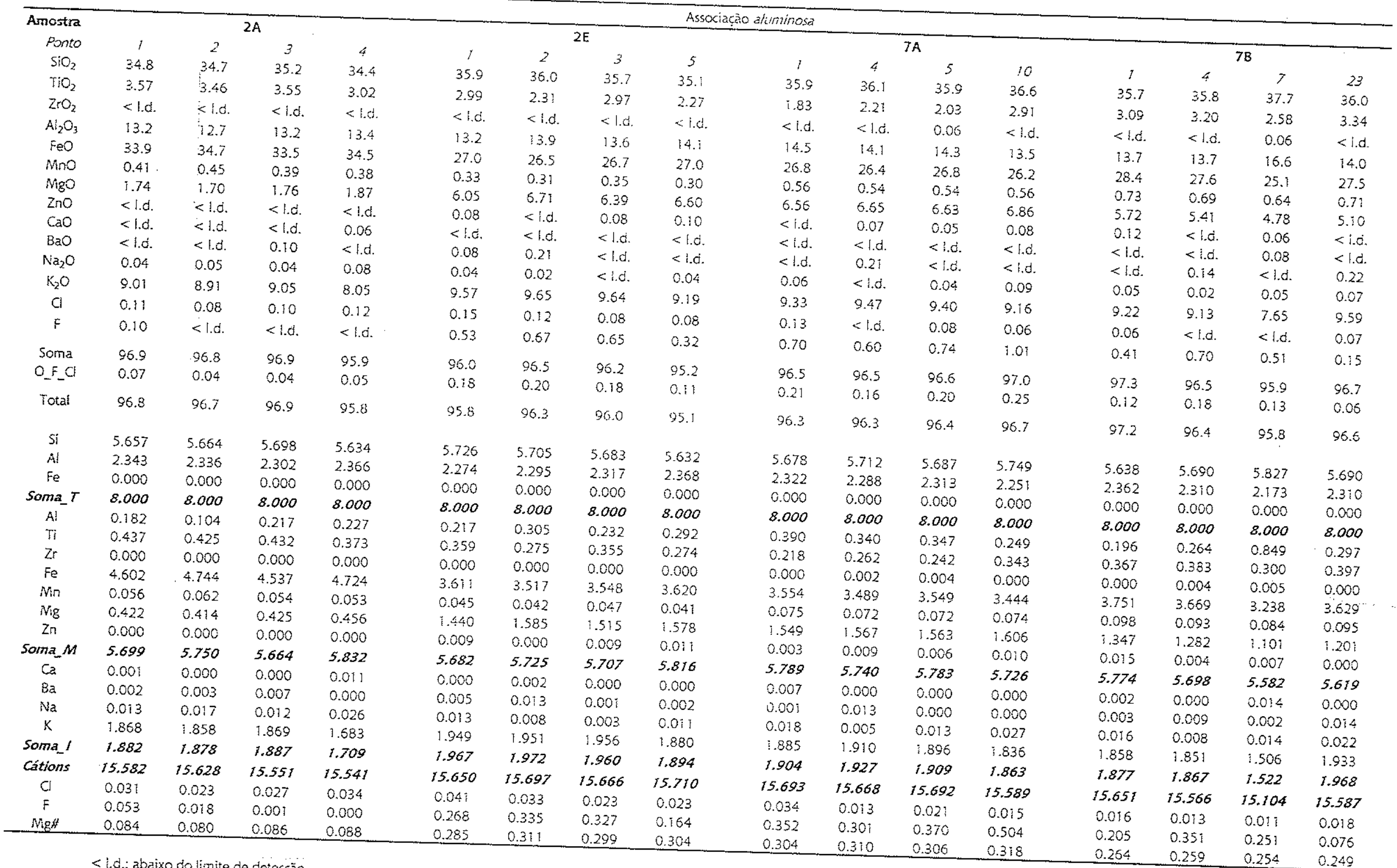


Tabela IV.7:

Análises quimicas completas (WDS) de biotitas dos Granitos da Graciosa

\begin{tabular}{|c|c|c|c|c|c|c|c|c|c|c|c|c|c|c|c|c|}
\hline \multirow{2}{*}{$\begin{array}{c}\text { Amostra } \\
\mathrm{POnto} \\
\mathrm{SiO}_{2}\end{array}$} & 1 & 2 & 8 & 10 & \multicolumn{4}{|c|}{ Associação aluminosã } & & 28 & & & \multicolumn{4}{|c|}{32} \\
\hline & 35.4 & 35.4 & 36.1 & 36.2 & 8 & 10 & 11 & 13 & $i$ & 2 & 4 & 9 & 1 & 2 & 3 & 5 \\
\hline $\mathrm{TiO}_{2}$ & 3.23 & 3.06 & $2.19 \ldots$ & 2.37 & 35.4 & 34.0 & 35.2 & 35.3 & 36.1 & 36.0 & 36.2 & 36.1 & 34.6 & 34.6 & 34.9 & 35.4 \\
\hline $\mathrm{ZrO}_{2}$ & $<$ <. & $<1 . d$ & $<$ l.d. & $<$ i.d. & 3.51 & 2.56 & 3.57 & 3.86 & 1.89 & 1.49 & 2.05 & 2.82 & 3.13 & 3.32 & 3.36 & 2.77 \\
\hline $\mathrm{Al}_{2} \mathrm{O}_{3}$ & 13.8 & 13.8 & 14.1 & 13.7 & $\begin{array}{l}<\text { id. } \\
1>8\end{array}$ & $<$ i.d. & $<$ i.d. & $<$ l.d. & $<$ l.d. & $<$ i.d. & $<$ l.d. & $<$ ld & <t.é. & $<$ l.d. & $<1, d$ & $<$ i.d. \\
\hline $\mathrm{FeO}$ & 27.8 & 28.0 & 28.1 & 28.5 & $\begin{array}{l}12.8 \\
32.2\end{array}$ & 14.2 & 13.4 & 13.4 & 13.3 & 13.4 & 13.7 & 13.5 & 13.2 & 13.2 & 12.7 & 14.2 \\
\hline MnO & 0.64 & 0.62 & 0.59 & 0.64 & $\begin{array}{l}32.2 \\
0.44\end{array}$ & 32.7 & 31.2 & 31.2 & 25.5 & 26.5 & 26.1 & 26.6 & 28.8 & 28.3 & 29.4 & 28.7 \\
\hline $\mathrm{MgO}$ & 5.62 & 5.45 & 5.98 & 5.51 & $\begin{array}{l}0.44 \\
3.19\end{array}$ & 0.45 & 0.40 & 0.47 & 0.48 & 0.45 & 0.38 & 0.44 & 0.45 & 0.48 & 0.50 & 0.47 \\
\hline $\mathrm{ZnO}$ & $<$ I.d. & $<$ l.d. & $<$ l.d. & $<$ l.d. & $\begin{array}{l}3.19 \\
\text { <i.d. }\end{array}$ & 3.17 & 3.17 & 3.15 & 7.79 & 7.84 & 7.47 & 6.73 & 5.11 & 4.82 & 5.10 & 5.03 \\
\hline $\mathrm{CaO}$ & $<$ l.d. & $<$ ld & $<$ l.d. & $<1 . d$ & $\begin{array}{l}<i . d . \\
<\text { l.d. }\end{array}$ & <i.d. & $<1 . d$ & $<$ l.d. & 0.10 & 0.10 & $<$ l.d. & 0.08 & 0.07 & 0.06 & 0.12 & 0.16 \\
\hline $\mathrm{BaO}$ & $<1 . \dot{0}$ & 0.11 & 0.13 & 0.12 & 0.12 & 0.07 & $<$ I.d. & $<$ l.d. & $<$ l.d. & $<$ l.d. & $<$ <.d. & $<$ l.d. & < l.d. & $<$ l.d. & $<1 . d$ & $<1 . \dot{c}$ \\
\hline $\mathrm{Na}_{2} \mathrm{O}$ & 0.14 & 0.09 & 0.05 & 0.09 & 0.05 & 0.10 & 0.07 & $<$ l.d. & 0.27 & 0.08 & 0.23 & $<$ ld. & 0.30 & $<$ l.d. & 0.14 & 0.09 \\
\hline $\mathrm{K}_{2} \mathrm{O}$ & 9.49 & 9.34 & 9.42 & 9.40 & 9.13 & 0.05 & 0.02 & 0.03 & 0.04 & 0.02 & $<$ l.c. & 0.03 & < l.c. & 0.02 & 0.02 & $<$ l.d. \\
\hline $\mathrm{Cl}$ & 0.07 & 0.07 & 0.07 & $<$ l.d. & 0.07 & 8.07 & 9.40 & 9.24 & 9.52 & 9.40 & 9.34 & 9.56 & 0.06 & 9.19 & 8.92 & 9.00 \\
\hline$F$ & 0.44 & 0.27 & 0.25 & 0.37 & 0.24 & < l.d. & <l.d. & 0.05 & $<1 . \mathrm{d}$ & 0.06 & 0.06 & 0.05 & < l.d. & $<$ ld. & 0.06 & 0.05 \\
\hline Soma & 96.7 & & & & 97.2 & $<$ i.d. & 0.08 & 0.19 & 0.79 & 1.22 & 0.97 & 0.65 & $0.6:$ & 0.55 & 0.55 & 0.29 \\
\hline$O_{-} F_{-} C l$ & 0.13 & 0.09 & 0.09 & $\begin{array}{l}97.0 \\
0.10\end{array}$ & $\begin{array}{l}97.2 \\
0.09\end{array}$ & 95.5 & 96.5 & 96.9 & 95.9 & 96.6 & 96.6 & 96.6 & 95.5 & 94.6 & 95.8 & 96.2 \\
\hline Total & 96.5 & 96.2 & 060 & 069 & & 0.01 & 0.04 & 0.07 & 0.19 & 0.30 & 0.24 & 0.17 & 0.16 & 0.14 & 0.15 & 0.09 \\
\hline & & & 90.9 & 90.9 & 97.1 & 95.5 & 96.4 & 96.9 & 95.7 & 96.3 & 96.3 & 96.4 & 95.3 & 94.5 & 95.6 & $96 . i$ \\
\hline $\mathrm{Si}$ & 5.631 & 5.648 & 5.690 & 5.731 & 5.697 & 5.553 & 5.565 & & & & & & & & & \\
\hline A! & 2.369 & 2.352 & 2.310 & 2.269 & 2.303 & 2.447 & 2.335 & & 205 & 5.724 & 5.728 & 5.704 & 5.628 & 5.643 & 5.654 & 5.643 \\
\hline $\mathrm{Fe}$ & 0.000 & 0.000 & 0.000 & 0.000 & 0.000 & 0.000 & 0.000 & $\begin{array}{l}2.343 \\
0.000\end{array}$ & 2.254 & 2.276 & 2.272 & 2.296 & 2.372 & 2.357 & 2.346 & 2.357 \\
\hline Soma_T & 8.000 & 8.000 & 8.000 & 8.000 & 8.000 & 8.000 & 8.000 & $\begin{array}{l}0.000 \\
8.000\end{array}$ & 0.000 & 0.000 & 0.000 & 0.000 & 0.000 & 0.000 & 0.000 & 0.000 \\
\hline $\mathrm{Al}^{-}$ & 0.210 & 0.243 & 0.313 & 0.288 & 0.129 & 0.288 & 0.203 & $\begin{array}{l}8.000 \\
0.193\end{array}$ & 8.000 & 8.000 & 8.000 & 8.000 & 8.000 & 8.000 & 8.000 & 8.000 \\
\hline ii & 0.386 & 0.366 & 0.260 & 0.282 & 0.424 & 0.314 & 0.432 & 0.193 & 0.242 & 0.238 & 0.287 & 0.220 & 0.157 & 0.190 & 0.082 & 0.318 \\
\hline $\mathrm{Zr}$ & 0.000 & 0.000 & 0.000 & 0.000 & 0.000 & 0.000 & 0.000 & 0.465 & 0.226 & 0.178 & 0.243 & 0.336 & 0.382 & 0.408 & 0.410 & 0.332 \\
\hline $\mathrm{Fe}$ & 3.699 & 3.729 & 3.713 & 3.780 & 4.326 & $4.464 i$ & 4.208 & 0.000 & 0.000 & $0.00 !$ & 0.002 & 0.000 & 0.001 & 0.001 & 0.000 & 0.000 \\
\hline $\mathrm{Mn}$ & 0.086 & 0.084 & 0.079 & 0.086 & $0.06 ?$ & 0.062 & 0.055 & 4.186 & 3.396 & 3.524 & 3.444 & 3.523 & 3.917 & 3.869 & 3.982 & 3.833 \\
\hline $\mathrm{Mg}$ & 1.331 & 1.295 & 1.406 & 1.301 & 0.755 & 0.770 & 0.761 & 0.064 & 0.064 & 0.061 & $0.05 i$ & 0.059 & 0.062 & 0.066 & 0.069 & 0.063 \\
\hline $\mathrm{Zn}$ & 0.000 & 0.000 & 0.000 & 0.000 & 0.000 & 0.000 & $\begin{array}{l}0.761 \\
0.000\end{array}$ & 0.752 & 1.846 & 1.857 & 1.761 & $i .585$ & 1.237 & 1.174 & 1.231 & 1.196 \\
\hline Soma_M & 5.711 & 5.716 & 5.772 & 5.736 & 5.705 & 5.899 & $\begin{array}{l}0.000 \\
5.660\end{array}$ & 0.000 & 0.012 & 0.012 & 0.000 & 0.009 & 0.008 & 0.007 & $0.0 i 4$ & 0.019 \\
\hline $\mathrm{Ca}$ & 0.000 & 0.000 & 0.002 & 0.000 & 0.006 & 0.013 & 5.660 & 5.660 & 5.785 & 5.870 & 5.789 & 5.732 & 5.763 & 5.714 & 5.788 & 5.761 \\
\hline $\mathrm{Ba}$ & 0.000 & 0.007 & 0.008 & 0.008 & 0.008 & 0.006 & 0.000 & 0.000 & 0.005 & 0.008 & 0.000 & 0.000 & 0.002 & 0.000 & 0.000 & 0.003 \\
\hline $\mathrm{Na}$ & 0.042 & 0.029 & 0.018 & 0.029 & $0.0: 5$ & 0.016 & 0.004 & 0.000 & 0.017 & 0.005 & 0.014 & 0.001 & 0.019 & 0.000 & 0.009 & 0.005 \\
\hline K & 1.923 & 1.900 & 1.896 & 1.900 & 1.873 & 1.670 & $\begin{array}{l}0.007 \\
1.932\end{array}$ & 0.009 & 0.013 & 0.007 & 0.005 & 0.010 & 0.003 & 0.007 & 0.007 & 0.004 \\
\hline Soma_' & 1.965 & 1.936 & 1.921 & 1.937 & 1.896 & 1.707 & $\begin{array}{l}1.932 \\
1.943\end{array}$ & 1.890 & 1.932 & 1.907 & 1.882 & 1.929 & 1.878 & 1.914 & 1.844 & 1.832 \\
\hline Cations & 15.676 & 15.653 & 15.693 & 15.673 & 15.601 & 15.600 & $\begin{array}{c}1.943 \\
15.603\end{array}$ & 1.899 & 1.962 & 1.919 & 1.902 & 1.939 & 7.900 & 1.921 & 1.860 & 1.842 \\
\hline a & 0.018 & 0.018 & 0.018 & 0.013 & 0.020 & 0.010 & $\begin{array}{c}15.603 \\
0.014\end{array}$ & 15.559 & 75.747 & 15.789 & 15.690 & 15.671 & 15.663 & 15.635 & 15.648 & 15.603 \\
\hline $\mathrm{F}$ & 0.221 & 0.135 & 0.127 & 0.187 & 0.122 & 0.000 & $\begin{array}{l}0.014 \\
0.043\end{array}$ & 0.014 & 0.007 & 0.015 & 0.015 & 0.014 & 0.012 & 0.012 & 0.017 & 0.014 \\
\hline $\mathrm{Mg} / \mathrm{f}$ & 0.265 & 0.258 & 0.275 & 0.256 & 0.150 & 0.147 & $\begin{array}{l}0.041 \\
0.153\end{array}$ & 0.098 & 0.398 & 0.613 & 0.486 & 0.326 & 0.315 & 0.283 & 0.283 & 0.148 \\
\hline
\end{tabular}


Tabela IV.7

Análises quimicas conpletas (WDS) de biotitas dos Granitos da Graciosa

\begin{tabular}{|c|c|c|c|c|c|c|c|c|c|c|c|c|c|c|c|c|}
\hline & & & & & \multirow{2}{*}{\multicolumn{8}{|c|}{ Associaçăo aluminosa }} & \multirow{2}{*}{\multicolumn{4}{|c|}{83}} \\
\hline \multirow{2}{*}{$\begin{array}{c}\text { Amostra } \\
\text { Ponto } \\
\mathrm{SiO}_{2}\end{array}$} & 4 & 5 & 6 & 7 & & & & & & 76 & & & & & & \\
\hline & 35.8 & 34.8 & 36.2 & 35.5 & $\begin{array}{c}7 \\
36.2\end{array}$ & 2 & s & 6 & $t$ & 4 & 5 & 7 & 1 & 3 & 5 & 7 \\
\hline $\mathrm{TH}_{2}$ & 2.91 & 3.56 & 3.28 & 3.15 & $\begin{array}{l}36.2 \\
2.18\end{array}$ & 35.8 & 35.3 & 35.1 & 35.5 & 36.2 & 35.1 & 35.3 & 34.5 & 34.5 & 34.6 & 34.1 \\
\hline $\mathrm{ZrO}_{2}$ & < l.d. & $<$ l.d. & <l.d. & $<$ l.d. & & 2.68 & 2.59 & 2.60 & 2.20 & 1.50 & 3.02 & 3.13 & 3.87 & 3.38 & 3.57 & 3.19 \\
\hline $\mathrm{Al}_{2} \mathrm{O}_{3}$ & 14.6 & 5.0 & 14.7 & 14.6 & $\begin{array}{l}<1 . d \\
17.5\end{array}$ & $<$ l.d. & $<1 . d$ & $<$ l.d. & $<$ d.d. & $<$ l.d. & $<1 . d$ & $<$ l. & $<$ l.d. & 0.06 & $<1.0$ & $<i d$ \\
\hline $\mathrm{FeO}$ & 28.8 & 28.5 & 28.0 & 28.3 & $\begin{array}{l}17.5 \\
27.2\end{array}$ & 16.8 & 16.1 & 16.3 & 10.8 & 10.8 & 10.8 & 10.9 & 12.8 & 12.6 & $i 3.1$ & 14.0 \\
\hline MnO & 0.71 & .0 .65 & 0.54 & 0.59 & $\begin{array}{l}27.2 \\
1.06\end{array}$ & 27.6 & 28.4 & 28.7 & 35.7 & 34.8 & 35.9 & 36.0 & 30.6 & 30.6 & 30.7 & 30.9 \\
\hline $\mathrm{MgO}$ & 4.88 & 4.52 & 4.69 & 4.55 & $\begin{array}{l}1.06 \\
2.36\end{array}$ & 1.11 & 1.10 & 1.17 & 0.53 & 0.49 & 0.53 & 0.58 & 0.73 & 0.73 & 0.79 & 0.69 \\
\hline Zno & $<$ i.d. & $<$ t.d. & 0.11 & 0.11 & $\begin{array}{l}2.36 \\
0.12\end{array}$ & 2.27 & 2.44 & 2.31 & 1.55 & 1.65 & $0.6 i$ & 0.61 & 3.85 & 4.21 & 3.98 & 3.52 \\
\hline $\mathrm{CaO}$ & $<1 . d$ & 0.05 & 0.06 & $<$ l.d. & $\begin{array}{l}0.12 \\
<\text { l.d. }\end{array}$ & 0.14 & 0.12 & 0.13 & 0.31 & 0.48 & 0.29 & 0.32 & 0.07 & 0.13 & $<$ i.d. & 0.13 \\
\hline $\mathrm{BaO}$ & 0.06 & 0.12 & 0.16 & $<$ l.d. & 0.40 & $<$ l.d. & $<$ <.d. & $<$ l.d. & $<i, d$ & < l.d. & <i.d. & <i.d. & 0.06 & $<$ l.d. & $<1 . d$ & 0.07 \\
\hline $\mathrm{Na}_{2} \mathrm{O}$ & $<$ I.d. & 0.04 & 0.03 & $<! . \mathrm{G}$ & 0.02 & $\begin{array}{l}<i . d . \\
0.04\end{array}$ & 0.07 & <i.d. & $<! d$ & 0.07 & < l.d. & 0.07 & 0.11 & 0.13 & $<$ l.d. & 0.14 \\
\hline $\mathrm{K}_{2} \mathrm{O}$ & 9.30 & 9.01 & 9.24 & 9.33 & 9.32 & $\begin{array}{l}0.04 \\
9.37\end{array}$ & 0.04 & 0.05 & 0.07 & 0.08 & 0.09 & 0.16 & 0.04 & 0.04 & 0.02 & 0.09 \\
\hline a & 0.06 & 0.06 & 0.10 & 0.08 & 0.05 & 9.32 & 9.18 & 9.22 & 8.77 & 8.77 & 8.74 & 8.73 & 8.83 & 9.09 & 8.99 & 8.76 \\
\hline $\mathrm{F}$ & 0.33 & 0.43 & 0.59 & 0.64 & 0.79 & 0.06 & $<1.6$ & 0.07 & 0.06 & 0.10 & 0.10 & 0.09 & 0.13 & 0.13 & 0.12 & 0.12 \\
\hline Soma & 97.5 & 96.8 & 97.8 & & 97.2 & 0.65 & 0.75 & 0.92 & 2.41 & 3.01 & 2.55 & 1.96 & 0.52 & 0.61 & 0.87 & 0.66 \\
\hline O.F_Cl & 0.10 & 0.12 & 0.18 & $\begin{array}{l}97.0 \\
0.18\end{array}$ & $\begin{array}{l}97.2 \\
0.20\end{array}$ & 96.5 & 96.2 & 96.6 & 97.9 & 97.9 & 97.7 & 97.8 & 96.0 & 96.2 & 96.8 & 96.3 \\
\hline Total & 97.4 & 96.6 & 97.6 & 95.8 & 97.0 & 0.17 & 0.19 & 0.24 & 0.57 & 0.72 & 0.62 & 0.48 & 0.17 & 0.19 & 0.25 & 0.20 \\
\hline & & & & 90.0 & צ्र.0 & 96.3 & 96.0 & 96.4 & 97.4 & 97.2 & 97.1 & 97.4 & 95.8 & 96.0 & 96.6 & 95.1 \\
\hline Si & 5.630 & 5.528 & 5.667 & 5.636 & 5.688 & 5.579 & 5.653 & 5.618 & 5.924 & & & & & & & \\
\hline Al & 2.370 & 2.472 & 2.333 & 2.364 & 2.312 & 2.321 & 2.347 & 2.382 & & 6.049 & 5.891 & 5.881 & 5.614 & $5.63 i$ & 5.609 & 5.545 \\
\hline $\mathrm{Fe}$ & 0.000 & 0.000 & 0.000 & 0.000 & 0.000 & 0.000 & 0.000 & & 2.076 & 1.951 & 2.109 & 2.119 & 2.386 & 2.369 & 2.391 & 2.455 \\
\hline Soma_ $T$ & 8.000 & 8.000 & 8.000 & 8.000 & 8.000 & 8.000 & 8.000 & $\begin{array}{l}0.000 \\
8.000\end{array}$ & 0.000 & 0.000 & 0.000 & 0.000 & 0.000 & 0.000 & 0.000 & 0.000 \\
\hline Al & 0.343 & 0.335 & 0.384 & 0.371 & 0.927 & 0.811 & 0.591 & $\begin{array}{l}8.000 \\
0.603\end{array}$ & 8.000 & 8.000 & 8.000 & 8.000 & 8.000 & 8.000 & 8.000 & 8.000 \\
\hline Ii & 0.344 & 0.425 & 0.386 & 0.376 & 0.257 & 0.319 & 0.313 & $\begin{array}{l}0.593 \\
0.313\end{array}$ & 0.041 & 0.166 & 0.028 & 0.024 & 0.065 & 0.044 & 0.103 & 0.226 \\
\hline$Z r$ & 0.002 & 0.001 & 0.001 & 0.000 & 0.000 & 0.000 & 0.000 & $\begin{array}{l}0.313 \\
0.000\end{array}$ & 0.276 & 0.188 & $0.38 i$ & 0.392 & 0.474 & 0.415 & 0.435 & 0.390 \\
\hline Fe & 3.793 & 3.782 & 3.672 & 3.752 & 3.579 & 3.653 & 3.812 & $\begin{array}{l}0.000 \\
3.85 i\end{array}$ & 0.001 & 0.000 & 0.000 & 0.000 & 0.000 & 0.005 & 0.002 & 0.002 \\
\hline $\mathrm{Min}$ & 0.095 & 0.088 & 0.085 & 0.080 & 0.141 & 0.149 & 0.149 & $\begin{array}{l}3.85 i \\
0.158\end{array}$ & 4.977 & 4.858 & 5.035 & 5.010 & 4.154 & 4.177 & 4.155 & 4.197 \\
\hline $\mathrm{Mg}$ & 1.144 & 1.071 & 1.097 & 1.075 & 0.554 & 0.537 & 0.584 & $\begin{array}{l}0.158 \\
0.550\end{array}$ & 0.075 & 0.069 & 0.075 & $0.08 i$ & 0.100 & 0.100 & 0.108 & 0.095 \\
\hline $\mathrm{Zn}$ & 0.005 & 0.004 & 0.013 & 0.013 & 0.013 & 0.016 & 0.014 & 0.550 & 0.385 & 0.410 & 0.153 & 0.150 & 0.935 & 1.024 & 0.950 & 0.853 \\
\hline Soma_M & 5.727 & 5.706 & 5.638 & 5.666 & 5.472 & 5.485 & 5.563 & 0.015 & 0.039 & 0.060 & 0.036 & 0.039 & 0.009 & 0.016 & 0.003 & 0.016 \\
\hline $\mathrm{Ca}$ & 0.000 & 0.009 & 0.011 & 0.005 & 0.001 & 0.001 & 0.005 & 5.581 & 5.794 & 5.751 & 5.709 & 5.697 & 5.746 & 5.781 & 5.766 & 5.778 \\
\hline $\mathrm{Ba}$ & 0.004 & 0.008 & 0.010 & 0.003 & 0.025 & 0.002 & $\begin{array}{l}0.005 \\
0.004\end{array}$ & 0.000 & 0.000 & 0.001 & 0.001 & 0.000 & $0.01 i$ & 0.002 & 0.008 & 0.012 \\
\hline $\mathrm{Na}$ & 0.006 & 0.014 & 0.009 & 0.005 & 0.006 & 0.012 & $\begin{array}{l}0.004 \\
0.011\end{array}$ & 0.002 & 0.003 & 0.005 & 0.000 & 0.005 & 0.007 & 0.008 & 0.002 & 0.009 \\
\hline$k$ & 1.868 & 1.825 & $i .848$ & 1.887 & $i .869$ & 1.884 & $\begin{array}{l}0.011 \\
1.877\end{array}$ & 0.015 & 0.023 & 0.026 & 0.030 & 0.052 & 0.011 & 0.012 & 0.006 & 0.029 \\
\hline Soma I & 1.878 & 1.846 & 1.868 & 1.895 & 1.900 & 1.397 & 1.892 & 1.883 & $i .865$ & 1.868 & 1.870 & 1.856 & 1.835 & 1.892 & 1.857 & 1.818 \\
\hline Cátions & 15.605 & 15.552 & 15.506 & 15.561 & 15.372 & 15.382 & $\begin{array}{c}1.892 \\
15.455\end{array}$ & 1.900 & 1.891 & 1.900 & 1.900 & 1.912 & 1.853 & 1.912 & 1.865 & 1.856 \\
\hline o & 0.016 & 0.015 & 0.028 & 0.022 & 0.014 & 0.016 & $\begin{array}{c}15.455 \\
0.013\end{array}$ & 15.480 & 15.685 & 15.651 & 15.609 & 15.609 & 15.599 & 15.693 & 15.631 & 75.634 \\
\hline$F$ & 0.165 & 0.216 & 0.291 & 0.319 & 0.391 & 0.327 & $\begin{array}{l}0.013 \\
0.381\end{array}$ & 0.018 & 0.016 & 0.029 & 0.027 & 0.024 & 0.036 & 0.037 & 0.034 & 0.033 \\
\hline $\mathrm{MgH}$ & 0.232 & 0.221 & 0.230 & 0.223 & 0.134 & 0.128 & $\begin{array}{l}0.381 \\
0.133\end{array}$ & 0.467 & 1.273 & 1.593 & 1.355 & 1.034 & 0.266 & 0.315 & 0.445 & 0.339 \\
\hline & & & & & & & & 0.125 & 0.072 & 0.078 & 0.029 & 0.029 & 0.183 & 0.197 & 0.188 & 0.169 \\
\hline
\end{tabular}


Tabela IV.7:

Análises quínicas completas (WDS) de biotitas dos Granitos da Graciosa

\begin{tabular}{|c|c|c|c|c|c|c|c|c|c|c|c|c|c|c|c|c|}
\hline \multirow{2}{*}{$\begin{array}{l}\text { Amostra } \\
\text { Ponto }\end{array}$} & & 84 & & & & & & & & 88 & & & & 9 & & \\
\hline & $i$ & 2 & 3 & 7 & 2 & 5 & $\sigma$ & 7 & 1 & 5 & 7 & 9 & 3 & 4 & $\sigma$ & 10 \\
\hline $\mathrm{SiO}_{2}$ & 34.4 & 34.8 & 34.5 & 34.0 & 34.1 & 33.3 & 33.4 & 34.0 & 34.3 & 34.1 & 35.4 & 35.4 & 35.3 & 36.1 & 34.5 & 35.2 \\
\hline $\mathrm{THO}_{2}$ & 3.62 & 3.79 & 3.80 & 3.35 & 3.21 & 3.59 & 3.26 & 3.45 & 3.33 & 2.75 & 2.88 & 2.52 & 3.04 & 3.05 & 3.18 & 2.84 \\
\hline $\mathrm{ZrO}_{2}$ & $<$ l.d. & $<$ l.d. & $<1 . d$ & < l.d. & < l.di. & <i.d. & $<$ l.d. & <l.d. & < l.d. & <i.d. & 0.06 & $<1.0$ & 0.05 & < t.. & $<1 . d$ & $<$ l.d. \\
\hline $\mathrm{Al}_{2} \mathrm{O}_{3}$ & 11.6 & 11.4 & 11.4 & 11.3 & 11.8 & 12.8 & 12.2 & 12.2 & 14.0 & 14.0 & i 3.6 & 13.1 & 12.3 & 11.7 & 12.6 & 12.5 \\
\hline FeO & 34.4 & 34.0 & 34.2 & 35.1 & 33.7 & 33.7 & 34.5 & 33.7 & 30.9 & 30.9 & 30.4 & 29.8 & 31.5 & 31.1 & 33.2 & 32.3 \\
\hline MnO & 0.62 & 0.43 & 0.53 & 0.54 & 0.58 & 0.50 & 0.38 & 0.45 & 0.91 & 0.88 & 0.70 & 0.76 & 0.36 & 0.39 & 0.39 & 0.40 \\
\hline $\mathrm{MgO}$ & 2.82 & 2.72 & 2.33 & 2.20 & 2.65 & $2.6 i$ & 2.55 & 2.53 & 2.75 & 2.55 & 2.97 & 3.29 & 3.94 & 4.19 & 3.74 & 3.78 \\
\hline Zno & 0.18 & 0.18 & 0.19 & 0.17 & 0.05 & 0.10 & 0.09 & 0.13 & 0.17 & 0.19 & 0.14 & 0.10 & 0.18 & 0.11 & 0.12 & 0.06 \\
\hline $\mathrm{CaO}$ & < I.d. & $<$ l.d. & $<$ l.d. & 0.06 & $<$ i.d. & 0.06 & 0.14 & 0.05 & $<$ d.d. & <!.d. & $<$ l.d. & <i.d. & $<$ l.d. & $<$ l.d. & $<$ l.d. & $<$ ld. \\
\hline $\mathrm{BaO}$ & $<$ ld & < l.d. & $<1 . d$ & $<$ l.d. & <i.d. & 0.13 & $<$ l.d. & 0.08 & 0.11 & <id. & < i.d. & 0.09 & 0.11 & 0.07 & $<$ ld & 0.11 \\
\hline $\mathrm{Na}_{2} \mathrm{O}$ & 0.06 & 0.03 & 0.04 & 0.09 & 0.07 & 0.05 & 0.05 & 0.06 & 0.16 & 0.10 & 0.12 & 0.18 & $<$ l.d. & 0.03 & 0.03 & 0.03 \\
\hline $\mathrm{K}_{2} \mathrm{O}$ & 8.22 & 8.75 & 8.62 & 8.36 & 8.78 & 8.47 & 8.53 & 8.73 & 8.70 & 8.94 & 8.86 & 8.75 & 8.93 & 8.84 & 7.82 & 8.72 \\
\hline$a$ & 0.22 & 0.23 & 0.23 & 0.25 & 0.18 & 0.15 & 0.16 & 0.17 & 0.58 & 1.03 & 0.66 & 0.65 & 0.33 & 0.36 & 0.30 & 0.34 \\
\hline$F$ & 0.53 & 0.65 & 0.86 & 0.97 & 0.43 & 0.43 & 0.25 & 0.27 & 2.62 & 2.09 & 2.43 & 3.09 & 0.37 & 0.57 & 0.43 & 0.28 \\
\hline Soma & 96.6 & 97.1 & 96.7 & 96.4 & 95.7 & 95.9 & 95.4 & 95.8 & 98.6 & 97.6 & 98.2 & 97.8 & 96.5 & 96.6 & 96.4 & 96.5 \\
\hline $\mathrm{O}_{-} \mathrm{F}_{-} \mathrm{C}$ & 0.21 & 0.24 & 0.29 & 0.32 & 0.17 & 0.16 & 0.13 & 0.12 & 0.84 & 0.81 & 0.83 & 0.97 & 0.22 & 0.30 & 0.22 & 0.21 \\
\hline Total & 96.4 & 96.8 & 96.4 & 96.0 & 95.5 & 95.8 & 95.3 & 95.7 & 97.7 & 96.7 & 97.4 & 96.8 & 96.2 & 96.3 & 96.1 & 96.3 \\
\hline $\mathrm{si}$ & 5.658 & 5.708 & 5.701 & 5.678 & 5.674 & 5.513 & 5.571 & 5.626 & 5.592 & 5.626 & 5.745 & 5.811 & 5.735 & 5.845 & 5.634 & 5.715 \\
\hline Al & 2.250 & 2.211 & 2.218 & 2.227 & 2.315 & 2.487 & 2.396 & 2.374 & 2.408 & 2.374 & 2.255 & 2.189 & 2.265 & 2.155 & 2.366 & 2.285 \\
\hline $\mathrm{Fe}$ & 0.092 & 0.081 & 0.081 & 0.096 & 0.012 & 0.000 & 0.033 & 0.000 & 0.000 & 0.000 & 0.000 & 0.000 & 0.000 & 0.000 & 0.000 & 0.000 \\
\hline Soma_t & 8.000 & 8.000 & 8.000 & 8.000 & 8.000 & 8.000 & 8.000 & 8.000 & 8.000 & 8.000 & 8.000 & 8.000 & 8.000 & 8.000 & 8.000 & 8.000 \\
\hline Al & 0.000 & 0.000 & 0.000 & 0.000 & 0.000 & 0.019 & 0.000 & 0.003 & 0.281 & 0.343 & 0.349 & 0.337 & 0.098 & 0.075 & 0.047 & 0.107 \\
\hline$T i$ & 0.448 & 0.467 & 0.473 & 0.420 & 0.401 & 0.447 & 0.409 & 0.43 & 0.409 & 0.340 & 0.352 & 0.311 & 0.372 & 0.372 & 0.391 & 0.347 \\
\hline $\mathrm{Zr}$ & 0.000 & 0.000 & 0.000 & 0.000 & 0.000 & 0.002 & 0.000 & 0.000 & 0.002 & 0.000 & 0.005 & 0.003 & 0.004 & 0.000 & 0.002 & 0.000 \\
\hline $\mathrm{Fe}$ & 4.546 & 4.582 & 4.650 & 4.807 & 4.678 & 4.666 & 4.774 & 4.670 & 4.210 & 4.257 & $4.12 i$ & 4.090 & 4.272 & 4.219 & 4.527 & 4.394 \\
\hline $\mathrm{Min}$ & 0.086 & 0.059 & 0.075 & 0.076 & $0.08 i$ & 0.071 & 0.054 & 0.063 & 0.125 & 0.123 & 0.096 & 0.105 & 0.049 & 0.054 & 0.054 & 0.055 \\
\hline $\mathrm{Mg}$ & 0.691 & 0.564 & 0.575 & 0.548 & 0.656 & 0.645 & 0.633 & 0.624 & 0.669 & 0.627 & 0.718 & 0.805 & 0.955 & 1.012 & 0.908 & 0.915 \\
\hline $2 n$ & 0.022 & 0.022 & 0.024 & $0.02 i$ & 0.006 & 0.012 & 0.012 & 0.016 & 0.021 & 0.023 & 0.017 & 0.012 & 0.021 & 0.013 & 0.015 & 0.007 \\
\hline Soma_M $M$ & 5.893 & 5.795 & 5.796 & 5.872 & 5.823 & 5.863 & 5.882 & 5.808 & 5.717 & 5.715 & 5.659 & 5.662 & 5.771 & 5.744 & 5.944 & 5.826 \\
\hline $\mathrm{Ca}^{-}$ & 0.002 & 0.005 & 0.004 & 0.012 & 0.002 & 0.011 & 0.025 & 0.009 & 0.000 & 0.003 & 0.000 & 0.000 & 0.003 & 0.000 & 0.003 & 0.000 \\
\hline $8 \mathrm{a}$ & 0.000 & 0.000 & 0.000 & 0.000 & 0.003 & 0.009 & 0.001 & 0.005 & 0.007 & 0.001 & 0.000 & 0.006 & 0.007 & 0.005 & 0.000 & 0.007 \\
\hline $\mathrm{Na}$ & 0.021 & 0.010 & 0.013 & 0.030 & 0.021 & 0.016 & 0.015 & 0.021 & 0.049 & 0.032 & 0.037 & 0.057 & 0.004 & 0.010 & 0.011 & 0.009 \\
\hline$K$ & 1.728 & 1.830 & 1.819 & 1.78 & 1.861 & 1.780 & 1.815 & i.844 & 1.809 & 1.880 & 1.835 & 1.831 & 1.850 & 1.828 & ก.628 & 1.808 \\
\hline Soma_I & 1.748 & 1.847 & 1.831 & 1.817 & 1.885 & 1.813 & 1.832 & 1.870 & 1.866 & 1.913 & 1.873 & 1.894 & 1.861 & 1.843 & 1.638 & 1.823 \\
\hline Cátions & 15.641 & 15.635 & 15.628 & 15.683 & 15.708 & 15.676 & 15.713 & 15.677 & 15.582 & 15.627 & 15.532 & 15.556 & 15.632 & 15.587 & 15.583 & 15.650 \\
\hline $\mathrm{a}$ & 0.060 & 0.064 & 0.053 & 0.071 & $0.05 i$ & 0.042 & 0.046 & 0.049 & 0.160 & 0.289 & 0.182 & 0.180 & 0.091 & 0.098 & 0.082 & 0.095 \\
\hline$F$ & 0.278 & 0.339 & 0.448 & 0.511 & 0.228 & 0.223 & 0.133 & $0.14 i$ & 1.352 & 1.089 & 1.247 & $1.60 \mathrm{i}$ & 0.189 & 0.341 & 0.224 & 0.142 \\
\hline $\mathrm{Mg} \#$ & 0.127 & 0.125 & 0.108 & 0.701 & 0.123 & 0.121 & 0.116 & 0.118 & 0.137 & 0.128 & 0.148 & 0.164 & 0.183 & 0.193 & 0.167 & 0.173 \\
\hline
\end{tabular}


Tabela IV.7:

Análises quinicas conipletas (NDS) de biotitas dos Granitos da Graciosa

\begin{tabular}{|c|c|c|c|c|c|c|c|c|}
\hline \multirow[b]{2}{*}{ Amostra } & \multicolumn{8}{|c|}{ Rochas monzodioriticas e associadas } \\
\hline & & $16 B 4$ & & & & & & \\
\hline Ponto & 1 & 3 & y & 9 & $l$ & 3 & 8 & $i$ \\
\hline $\mathrm{SiO}_{2}$ & 35.8 & 36.1 & 35.9 & 35.9 & 36.3 & 35.8 & 35.4 & 36.4 \\
\hline $\mathrm{TiO}_{2}$ & 3.86 & 3.90 & 3.88 & 4.17 & 4.50 & 3.42 & 4.84 & 4.77 \\
\hline $2 \mathrm{rO}_{2}$ & < l.d. & $<$ l. & $<$ i.d. & $<$ i.d. & <id. & $<$ l.d. & $<$ id. & $<$ L.d. \\
\hline $\mathrm{AH}_{2} \mathrm{O}_{3}$ & 12.5 & 12.6 & 12.9 & 13.0 & 13.2 & 14.2 & 13.4 & 13.0 \\
\hline $\mathrm{FeO}$ & 24.6 & 24.7 & 24.8 & 24.7 & 22.8 & 24.4 & 21.4 & 20.9 \\
\hline Mno & 0.26 & 0.24 & 0.25 & 0.26 & $0.2 i$ & 0.22 & 0.21 & 0.23 \\
\hline $\mathrm{MgO}$ & 8.89 & 8.85 & 8.78 & 8.58 & 9.49 & 8.94 & 10.0 & 11.2 \\
\hline Zno & 0.07 & 0.05 & 0.08 & $<$ l.d. & <i.d. & 0.07 & 0.09 & $<$ id. \\
\hline $\mathrm{CaO}$ & < I.d. & $<i, d$ & $<$ l.d. & $<$ i.d. & $<$ i.d. & $<$ l.d. & $<$ id. & <i.d. \\
\hline 820 & 0.20 & 0.45 & 0.36 & 0.10 & 0.18 & 0.41 & 1.68 & 0.22 \\
\hline $\mathrm{Na}_{2} \mathrm{O}$ & 0.07 & 0.06 & 0.10 & 0.03 & 0.06 & 0.04 & 0.18 & 0.19 \\
\hline $\mathrm{K}, \mathrm{O}$ & 9.27 & 9.24 & 9.03 & 9.30 & 0.25 & 8.98 & 8.60 & 9.05 \\
\hline $\mathrm{Cl}$ & 0.07 & 0.06 & <i.d. & 0.05 & 0.06 & 0.05 & 0.08 & 0.09 \\
\hline$F$ & 0.99 & 0.94 & 0.75 & 0.95 & 0.31 & 0.27 & 0.37 & 0.37 \\
\hline Soma & 96.6 & 97.3 & 97.0 & 97.8 & 96.4 & 96.8 & 96.3 & 96.6 \\
\hline $\mathrm{O}_{-} \mathrm{F}_{-} \mathrm{Cl}$ & 0.25 & 0.24 & 0.19 & 0.24 & 0.09 & 0.08 & 0.12 & 0.12 \\
\hline Total & 96.3 & 97.0 & 96.8 & 96.8 & 96.4 & 96.8 & 96.2 & 96.4 \\
\hline$S$ & 5.639 & 5.649 & 5.620 & 5.613 & 5.618 & 5.554 & 5.512 & 5.584 \\
\hline At & 2.318 & 2.326 & 2.375 & 2.387 & 2.382 & 2.446 & 2.457 & 2.352 \\
\hline $\mathrm{Fe}$ & 0.044 & 0.025 & 0.005 & 0.000 & 0.000 & 0.000 & 0.021 & 0.064 \\
\hline Soma $\gamma$ & 8.000 & 8.000 & 8.000 & 8.000 & 8.000 & 8.000 & 8.000 & 8.000 \\
\hline $\mathrm{Al}$ & 0.000 & 0.000 & 0.000 & 0.010 & 0.023 & 0.152 & 0.000 & 0.000 \\
\hline $\mathrm{Ti}$ & 0.458 & 0.458 & 0.456 & 0.490 & 0.524 & 0.400 & 0.567 & 0.549 \\
\hline $\mathrm{Zr}$ & 0.000 & 0.002 & 0.002 & 0.000 & 0.002 & 0.001 & 0.000 & 0.002 \\
\hline $\mathrm{Fe}$ & 3.201 & 3.204 & 3.246 & 3.223 & 2.953 & 3.168 & 2.767 & 2.611 \\
\hline $\mathrm{Mr}$ & 0.034 & 0.032 & 0.034 & 0.035 & 0.028 & 0.030 & 0.028 & 0.029 \\
\hline $\mathrm{Mg}$ & 2.089 & 2.063 & 2.048 & 1.998 & 2.188 & 2.067 & 2.331 & 2.564 \\
\hline Zn & 0.008 & 0.006 & 0.010 & 0.000 & 0.004 & 0.008 & 0.010 & 0.005 \\
\hline Soma_M & 5.797 & 5.766 & 5.796 & 5.756 & 5.721 & 5.824 & 5.704 & 5.760 \\
\hline $\mathrm{Ca}$ & 0.000 & 0.002 & 0.000 & 0.005 & 0.000 & 0.003 & 0.001 & 0.002 \\
\hline$B a$ & 0.012 & 0.027 & 0.022 & 0.006 & 0.011 & 0.025 & 0.103 & 0.013 \\
\hline $\mathrm{Nà}$ & 0.021 & 0.019 & 0.029 & 0.009 & 0.017 & 0.012 & 0.053 & 0.057 \\
\hline k & 1.863 & 1.843 & $i .803$ & 1.854 & i. .828 & 1.777 & 1.709 & 1.769 \\
\hline Soma_ & 1.896 & 1.889 & 1.854 & 1.869 & 1.856 & 1.814 & 1.864 & 1.840 \\
\hline Cátions & 15.686 & 15.656 & 15.650 & 15.626 & 15.576 & 35.638 & 15.568 & 15.600 \\
\hline ci & 0.018 & 0.015 & 0.012 & 0.013 & 0.016 & 0.015 & 0.021 & 0.024 \\
\hline $\bar{F}$ & 0.494 & 0.465 & 0.370 & 0.470 & 0.149 & 0.130 & 0.182 & 0.180 \\
\hline $\mathrm{Mg} \#$ & 0.392 & 0.390 & 0.386 & 0.383 & 0.426 & 0.395 & 0.455 & 0.490 \\
\hline
\end{tabular}

$<$ l.d.: àbaixo do limite de deteccāo 
Tabela IV.8:

Análises químicas completas (WDS) de plagioclásios dos Granitos da Graciosa

\begin{tabular}{|c|c|c|c|c|c|c|c|c|c|c|c|c|c|c|}
\hline \multirow{3}{*}{ Amostra } & \multicolumn{14}{|c|}{ Associaçāo aluminosa } \\
\hline & & & $2 \mathrm{E}$ & & & & & $7 A$ & & & & $7 \mathrm{~B}$ & & \\
\hline & 1 & 2 & 3 & 4 & 5 & 1 & 2 & 3 & 4 & 5 & 1 & 2 & 3 & 4 \\
\hline $\mathrm{SiO} 2$ & 66.3 & 65.7 & 66.0 & 66.1 & 65.5 & 65.9 & 66.8 & 66.0 & 66.8 & 68.9 & 63.7 & 64.6 & 64.3 & 64.4 \\
\hline $\mathrm{Al} 2 \mathrm{O} 3$ & 21.4 & 21.7 & 21.7 & 21.8 & 21.6 & 21.8 & 22.1 & 21.7 & 21.9 & 20.5 & 22.8 & 23.0 & 22.6 & 22.5 \\
\hline $\mathrm{TiO} 2$ & 0.06 & $<$ I.d. & $<$ I.d. & $<$ I.d. & $<$ l.d. & $<$ l.d. & $<$ l.d. & $<$ l.d. & $<$ l.d. & $<$ l.d. & < I.d. & < l.d. & $<$ l.d. & $<$ l.d. \\
\hline $\mathrm{FeO}$ & 0.17 & 0.17 & 0.15 & 0.12 & 0.19 & 0.11 & 0.17 & 0.09 & 0.13 & 0.06 & 0.09 & 0.16 & 0.10 & 0.15 \\
\hline $\mathrm{MgO}$ & $<$ ld & $<$ l.d. & $<$ l.d. & $<$ l.d. & $<$ l.d. & $<1 . d$ & $<$ l.d. & $<$ I.d. & $<$ l.d. & $<$ l.d. & $<1 . d$ & $\because 1 . d$ & $<$ l.d. & < I.d. \\
\hline $\mathrm{CaO}$ & 2.56 & 3.20 & 3.09 & 3.09 & 3.04 & 2.97 & 3.29 & 2.59 & 2.74 & 1.38 & 4.11 & 4.32 & 4.13 & 4.01 \\
\hline $\mathrm{BaO}$ & $<$ l.d. & 0.09 & $<$ I.d. & $<$ l.d. & $<$ I.d. & < I.d. & 0.08 & 0.05 & $<$ l.d. & $<$ ld & $<$ I.d. & < I.d. & $<$ l.d. & $<$ i.d. \\
\hline 510 & $<\mathrm{l} . \mathrm{d}$ & $<$ Idd & $<$ l.d. & $<$ l.d. & 0.06 & $<$ I.d. & $<1 . d$ & 0.08 & $<$ l.d. & $<$ l.d. & < l.d. & 0.07 & $<\mathrm{ld}$ & 0.06 \\
\hline $\mathrm{Na} 2 \mathrm{O}$ & 10.1 & 9.74 & 9.84 & 9.46 & 9.70 & 9.49 & 9.63 & 9.65 & 10.0 & 10.8 & 9.18 & 9.04 & 8.96 & 9.01 \\
\hline $\mathrm{K} 2 \mathrm{O}$ & 0.28 & 0.30 & 0.26 & 0.69 & 0.29 & 0.49 & 0.21 & 0.37 & 0.07 & 0.05 & 0.43 & 0.45 & 0.49 & 0.58 \\
\hline Total & 100.8 & 100.9 & 101.2 & 101.3 & 100.5 & 100.8 & 102.3 & 100.6 & 101.7 & 101.7 & 100.3 & 101.7 & 100.6 & 100.8 \\
\hline $5 i$ & 2.894 & 2.872 & 2.875 & 2.878 & 2.875 & 2.876 & 2.876 & 2.888 & 2.887 & 2.962 & 2.809 & 2.812 & 2.824 & 2.829 \\
\hline Al & 1.099 & 1.118 & 1.116 & 1.118 & 1.118 & 1.124 & 1.121 & 1.116 & 1.115 & 1.040 & 1.186 & 1.181 & 1.171 & 1.162 \\
\hline Soma_ $T$ & 3.993 & 3.990 & 3.991 & 3.995 & 3.993 & 4.000 & 3.996 & 4.004 & 4.002 & 4.002 & 3.995 & 3.992 & 3.995 & 3.991 \\
\hline$T i$ & 0.002 & 0.000 & 0.001 & 0.000 & 0.000 & 0.001 & 0.000 & 0.001 & 0.000 & 0.000 & 0.000 & 0.001 & 0.001 & 0.001 \\
\hline $\mathrm{Fe}$ & 0.006 & 0.006 & 0.006 & 0.004 & 0.007 & 0.004 & 0.006 & 0.003 & 0.005 & 0.002 & 0.003 & 0.006 & 0.004 & 0.006 \\
\hline $\mathrm{Mg}$ & 0.000 & 0.000 & 0.000 & 0.000 & 0.000 & 0.001 & 0.001 & 0.000 & 0.000 & 0.000 & 0.000 & 0.000 & 0.000 & 0.001 \\
\hline $\mathrm{Ca}$ & 0.120 & 0.150 & 0.144 & 0.144 & 0.143 & 0.139 & 0.152 & 0.121 & 0.127 & 0.064 & 0.194 & 0.201 & 0.194 & 0.189 \\
\hline $\mathrm{Ba}$ & 0.000 & 0.002 & 0.000 & 0.000 & 0.001 & 0.000 & 0.001 & 0.001 & 0.000 & 0.000 & 0.000 & 0.000 & 0.000 & 0.001 \\
\hline$S r$ & 0.000 & 0.001 & 0.001 & 0.001 & 0.001 & 0.000 & 0.001 & 0.002 & 0.000 & 0.000 & 0.000 & 0.002 & 0.001 & 0.002 \\
\hline $\mathrm{Na}$ & 0.853 & 0.826 & 0.831 & 0.799 & $0.825^{\prime}$ & 0.804 & 0.803 & 0.818 & 0.841 & 0.898 & 0.785 & 0.763 & 0.763 & 0.767 \\
\hline$k$ & 0.016 & 0.016 & 0.014 & 0.038 & 0.016 & 0.027 & 0.012 & 0.020 & 0.004 & 0.003 & 0.024 & 0.025 & 0.027 & 0.032 \\
\hline Sorna 1 & 0.997 & 1.000 & 0.997 & 0.987 & 0.993 & 0.976 & 0.976 & 0.968 & 0.976 & 0.967 & 1.006 & 0.999 & 0.990 & 0.997 \\
\hline
\end{tabular}

$<$ I.d.: abaixo do limite de deteccão 
Tabela IV.8:

Análises químicas completas (WDS) de plagioclásios dos Granitos da Graciosa

\begin{tabular}{|c|c|c|c|c|c|c|c|c|c|c|c|c|c|c|}
\hline \multirow{3}{*}{ Amostra } & \multicolumn{14}{|c|}{ Associaçāo aluminosa } \\
\hline & & & & & $7 B$ & & & & & & & $28 B$ & & \\
\hline & 5 & 6 & 7 & 8 & 1 & 2 & 3 & 4 & 5 & 1 & 2 & 3 & 4 & 5 \\
\hline $\mathrm{SiO} 2$ & 65.3 & 65.9 & 65.5 & 66.3 & 66.0 & 65.0 & 65.4 & 65.7 & 68.8 & 64.4 & 64.7 & 63.4 & 65.5 & 69.1 \\
\hline $\mathrm{Al} 2 \mathrm{O} 3$ & 22.2 & 21.5 & 21.8 & 21.5 & 23.0 & 22.8 & 22.3 & 21.5 & 21.0 & 22.3 & 22.2 & 22.3 & 21.6 & 19.4 \\
\hline $\mathrm{TIO} 2$ & $<$ l.d. & $<$ l.d. & $<$ l.d. & $<$ l.d. & $<$ l.d. & < l.d. & $<$ l.d. & < I.d. & $<$ ld & $<$ l.d. & $<$ I.d. & $<$ I.d. & < l.d. & 0.05 \\
\hline $\mathrm{FeO}$ & 0.11 & 0.13 & 0.12 & 0.11 & 0.11 & 0.13 & 0.13 & 0.13 & $<$ l.d. & 0.15 & 0.14 & 0.18 & 0.12 & < l.d. \\
\hline $\mathrm{MgO}$ & < l.d. & $<$ l.d. & < l.d. & $<1 . d$ & < l.d. & $<$ i.d. & $<$ l.d. & $<$ l.d. & $<$ l.d. & $<$ I.d. & $<$ l.d. & $<$ l.d. & $<$ l.d. & $<$ l.d. \\
\hline $\mathrm{CaO}$ & 3.63 & 2.96 & 3.17 & 2.79 & 3.68 & 4.08 & 3.56 & 2.98 & 1.40 & 3.67 & 3.59 & 3.60 & 2.92 & 0.33 \\
\hline $\mathrm{BaO}$ & $<$ l.d. & < I.d. & $<$ I.d. & < I.d. & $<$ l.d. & $<$ l.d. & $<$ l.d. & $<$ l.d. & $<$ l.d. & 0.06 & $<$ l.d. & $<$ l.d. & < I.d. & $<\mathrm{l} . \mathrm{d}$ \\
\hline sro & $<$ l.d & $<$ l.d. & < l.d. & $<1 . \phi$ & $<1 . d$ & < I.d. & $<$ l.d. & < l.d. & $<$ l.d. & 0.05 & $<1 . d$ & 0.06 & $<$ l.d. & $<$ I.d. \\
\hline $\mathrm{Na} 2 \mathrm{O}$ & 9.27 & 9.57 & 9.52 & 10.1 & 8.05 & 9.26 & 9.20 & 9.70 & 10.9 & 9.63 & 9.59 & 9.05 & 10.2 & 11.7 \\
\hline $\mathrm{K} 20$ & 0.70 & 0.77 & 0.59 & 0.22 & 0.17 & 0.34 & 0.44 & 0.44 & 0.05 & 0.11 & 0.15 & 0.25 & 0.17 & 0.07 \\
\hline Total & 101.2 & 100.8 & 100.8 & 101.2 & 101.1 & 101.7 & 101.1 & 100.4 & 102.2 & 100.4 & 100.4 & 98.9 & 100.6 & 100.7 \\
\hline $\mathrm{Si}$ & 2.849 & 2.884 & 2.868 & 2.886 & 2.859 & 2.825 & 2.852 & 2.880 & 2.944 & 2.835 & 2.843 & 2.830 & 2.873 & 2.998 \\
\hline $\mathrm{Al}$ & 1.142 & 1.106 & 1.126 & 1.105 & 1.172 & 1.170 & 1.148 & 1.112 & 1.061 & 1.156 & 1.151 & 1.173 & $1.116^{\circ}$ & 0.993 \\
\hline Soma_t & 3.991 & 3.990 & 3.994 & 3.991 & 4.032 & 3.994 & 4.000 & 3.992 & 4.006 & 3.991 & 3.994 & 4.003 & 3.989 & 3.991 \\
\hline $\mathrm{Ti}^{-}$ & 0.001 & 0.000 & 0.001 & 0.001 & 0.001 & 0.000 & 0.001 & 0.000 & 0.000 & 0.001 & 0.000 & 0.000 & 0.000 & 0.002 \\
\hline $\mathrm{Fe}$ & 0.004 & 0.005 & 0.004 & 0.004 & 0.004 & 0.005 & 0.005 & 0.005 & 0.000 & 0.006 & 0.005 & 0.007 & 0.004 & 0.001 \\
\hline $\mathrm{Mg}$ & 0.000 & 0.000 & 0.000 & 0.000 & 0.002 & 0.000 & 0.000 & 0.000 & 0.000 & 0.000 & 0.000 & 0.000 & 0.001 & 0.000 \\
\hline $\mathrm{Ca}$ & 0.170 & 0.139 & 0.149 & 0.130 & 0.171 & 0.190 & 0.166 & 0.140 & 0.064 & 0.173 & 0.169 & 0.172 & 0.137 & 0.015 \\
\hline $\mathrm{Ba}$ & 0.000 & 0.000 & 0.000 & 0.000 & 0.001 & 0.001 & 0.000 & 0.000 & 0.000 & 0.001 & 0.000 & 0.000 & 0.000 & 0.000 \\
\hline $\mathrm{Sr}$ & 0.001 & 0.000 & 0.000 & 0.000 & 0.001 & 0.001 & 0.000 & 0.000 & 0.000 & 0.001 & 0.001 & 0.002 & 0.000 & 0.001 \\
\hline $\mathrm{Na}$ & 0.784 & 0.812 & 0.808 & 0.855 & 0.676 & 0.781 & 0.778 & 0.825 & 0.907 & 0.822 & 0.818 & 0.783 & 0.865 & 0.983 \\
\hline K & 0.039 & 0.043 & 0.033 & 0.012 & 0.009 & 0.019 & 0.024 & 0.025 & 0.003 & 0.006 & 0.008 & 0.014 & 0.010 & 0.004 \\
\hline Soma_I & 0.999 & 1.000 & 0.995 & 1.003 & 0.865 & 0.996 & 0.975 & 0.996 & 0.975 & 1.010 & 1.001 & 0.979 & 1.018 & 1.006 \\
\hline
\end{tabular}

$<$ I.d.: abaixo do limite de deteccão

Pág. 2 de 5 
Tabela IV.8:

Análises químicas completas (WDS) de plagioclásios dos Granitos da Graciosa

\begin{tabular}{|c|c|c|c|c|c|c|c|c|c|c|c|c|c|c|c|}
\hline \multirow{3}{*}{ Amostra } & \multicolumn{15}{|c|}{ Associaçào aluminosa } \\
\hline & \multicolumn{5}{|c|}{32} & \multicolumn{5}{|c|}{$36 B$} & \multicolumn{5}{|c|}{83} \\
\hline & 1 & 2 & 3 & 4 & 5 & 1 & 2 & 3 & 4 & 5 & $t$ & 2 & 3 & 4 & 5 \\
\hline $\mathrm{SiO} 2$ & 67.2 & 66.6 & 66.6 & 65.6 & 67.8 & 65.4 & 65.8 & 65.7 & 66.3 & 70.0 & 65.1 & 65.9 & 65.2 . & 65.2 & 69.6 \\
\hline $\mathrm{Al} 2 \mathrm{O} 3$ & 20.5 & 20.5 & 20.5 & 21.3 & 20.0 & 21.9 & 21.9 & 22.2 & 21.8 & 19.9 & 22.1 & 21.6 & 21.8 & 21.9 & 19.5 \\
\hline TiO2 & $<$ l.d. & $<$ l.d. & < l.d. & $<$ l.d. & $<$ l.d. & $<$ I.d. & $<$ l.d. & $<$ I.d. & $<i d$ & $<1 . d$ & < ld. & $<$ l.d. & $<$ l.d. & $<$ l.d. & $<$ l.d. \\
\hline $\mathrm{FeO}$ & 0.12 & 0.14 & 0.11 & 0.13 & 0.05 & 0.13 & 0.12 & 0.12 & 0.10 & $<$ l.d. & 0.15 & 0.21 & 0.17 & 0.26 & $<$ l.d. \\
\hline $\mathrm{MgO}$ & $<$ l.d. & $<$ ld. & $<$ l.d. & $<$ l.d. & $<$ l.d. & $<$ l.d. & $<$ l.d. & $<$ l.d. & $<$ l.d. & $<$ l.d. & $<$ l.d. & < I.d. & $<$ l.d. & 0.06 & $<$ l.d. \\
\hline $\mathrm{CaO}$ & 1.80 & 1.78 & 2.05 & 1.92 & 1.08 & 3.12 & 3.33 & 3.43 & 2.83 & 0.44 & 3.62 & 2.95 & 2.74 & 2.26 & 0.37 \\
\hline $\mathrm{BaO}$ & $<$ I.d. & $<1 . d$ & < l.d. & $<$ l.d. & < I.d. & 0.06 & $<$ l.d & < l.d. & $<$ ld & < l.d. & $<$ l.d. & $<$ I.d. & < ld & $<$ l.d. & $<$ I.d. \\
\hline sto & $<$ l.d. & $<$ l.d. & $<$ l.d. & $<\mathrm{l} . \mathrm{d}$ & $<$ l.d. & $<1 . d$ & $<1 . d$ & $<$ l.d. & < l.d. & $<$ l.d. & 0.06 & $<$ l.d. & $<$ l.d. & $<$ l.d. & $<$ l.d. \\
\hline $\mathrm{Na} 2 \mathrm{O}$ & 10.1 & 10.7 & 10.5 & 10.1 & 11.1 & 9.77 & 9.47 & 9.63 & 10.1 & 11.2 & 9.46 & 9.70 & 9.81 & 9.55 & 11.7 \\
\hline $\mathrm{k} 20$ & 0.35 & 0.19 & 0.15 & 0.41 & 0.15 & 0.06 & 0.37 & 0.34 & 0.16 & 0.43 & 0.35 & 0.46 & 0.56 & 0.49 & 0.14 \\
\hline Total & 100.2 & $1(10.0$ & 100.0 & 99.4 & 100.1 & 100.5 & 101.0 & 101.5 & 101.3 & 101.9 & 100.9 & 100.9 & 100.3 & 99.7 & 101.4 \\
\hline $\mathrm{Si}$ & 2.942 & 2.925 & 2.926 & 2.898 & 2.965 & 2.867 & 2.868 & 2.856 & 2.880 & 2.998 & 2.850 & 2.881 & 2.867 & 2.875 & 3.000 \\
\hline Al & 1.056 & 1.263 & 1.063 & 1.108 & 1.029 & 1.131 & 1.126 & 1.139 & 1.116 & 1.003 & 1.139 & 1.112 & 1.130 & 1.138 & 0.993 \\
\hline Soma_T & 3.998 & 3.988 & 3.989 & 4.006 & 3.994 & 3.998 & 3.995 & 3.994 & 3.996 & 4.001 & 3.989 & 3.993 & 3.997 & 4.013 & 3.992 \\
\hline $\mathrm{Ti}$ & 0.001 & 0.701 & 0.001 & 0.001 & 0.000 & 0.001 & 0.001 & 0.000 & 0.000 & 0.001 & 0.001 & 0.000 & 0.000 & 0.000 & 0.000 \\
\hline $\mathrm{Fe}$ & 0.005 & 0.005 & 0.004 & 0.005 & 0.002 & 0.005 & 0.004 & 0.004 & 0.003 & 0.000 & 0.006 & 0.008 & 0.006 & 0.009 & 0.002 \\
\hline $\mathrm{Mg}$ & 0.000 & 0.201 & 0.000 & 0.000 & 0.000 & 0.000 & 0.000 & 0.000 & 0.000 & 0.000 & 0.000 & 0.000 & 0.001 & 0.004 & 0.000 \\
\hline $\mathrm{Ca}$ & 0.084 & 0.084 & 0.097 & 0.091 & 0.051 & 0.146 & 0.156 & 0.160 & 0.132 & 0.020 & 0.170 & 0.1 .38 & 0.129 & 0.107 & 0.017 \\
\hline $\mathrm{Ba}$ & 0.000 & 0.000 & 0.000 & 0.000 & 0.000 & 0.001 & 0.000 & 0.001 & 0.000 & 0.000 & 0.001 & 0.001 & 0.001 & 0.000 & 0.000 \\
\hline $\mathrm{Sr}$ & 0.000 & 0.000 & 0.000 & 0.000 & 0.000 & 0.000 & 0.001 & 0.000 & 0.000 & 0.000 & 0.002 & 0.000 & 0.000 & 0.001 & 0.000 \\
\hline $\mathrm{Na}$ & 0.860 & 0.913 & 0.894 & 0.862 & 0.938 & 0.830 & 0.801 & 0.812 & 0.851 & 0.929 & 0.803 & 0.822 & 0.837 & 0.816 & 0.977 \\
\hline$K$ & 0.020 & 0.911 & 0.008 & 0.023 & 0.009 & 0.003 & 0.021 & 0.019 & 0.009 & 0.023 & 0.019 & 0.026 & 0.031 & 0.028 & 0.008 \\
\hline Soma 1 & 0.971 & 1.015 & 1.003 & 0.983 & 0.999 & 0.986 & 0.983 & 0.996 & 0.996 & 0.974 & 1.002 & 0.994 & 1.005 & 0.965 & 1.004 \\
\hline
\end{tabular}

< l.d.: abaixo do limite de detecção 
Tabela IV.8:

Análises químicas completas (WDS) de plagioclásios dos Cranitos da Graciosa

\begin{tabular}{|c|c|c|c|c|c|c|c|c|c|c|c|c|c|c|c|}
\hline \multirow{3}{*}{ Amostra } & \multicolumn{7}{|c|}{ Associação aluminosa } & \multicolumn{8}{|c|}{ Rochas monzodioriticas e associadas } \\
\hline & \multirow[b]{2}{*}{$t$} & \multirow[b]{2}{*}{2} & \multicolumn{3}{|c|}{85} & \multirow[b]{2}{*}{6} & \multirow[b]{2}{*}{7} & \multicolumn{8}{|c|}{$16 \mathrm{B3}$} \\
\hline & & & 3 & 4 & 5 & & & I & 2 & 3 & 4 & 5 & 6 & 7 & 8 \\
\hline $\mathrm{SiO} 2$ & 63.7 & 52.8 & 63.6 & 64.8 & 68.6 & 68.6 & 67.8 & 64.0 & 64.1 & 63.8 & 63.9 & 63.8 & 63.8 & 64.6 & 63.6 \\
\hline $\mathrm{A} 1203$ & 23.0 & 23.1 & 23.1 & 22.3 & 19.9 & 20.0 & 19.5 & 22.6 & 22.2 & 22.7 & 22.3 & 22.4 & 22.5 & 22.3 & 22.4 \\
\hline $\mathrm{TiO} 2$ & $<$ l.d. & $\therefore$ I.d. & $<$ l.d. & $<$ l.d. & $<$ l.d. & $<$ l.d. & $<$ l.d. & $<1, d$ & $<$ l.d. & $<$ l.d. & $<$ l.d. & $<$ I.d. & $<$ l.d. & $<$ l.d. & < l.d. \\
\hline $\mathrm{FeO}$ & 0.15 & 3.08 & 0.13 & 0.23 & 0.09 & 0.10 & 0.19 & 0.10 & 0.13 & 0.12 & 0.21 & 0.19 & 0.12 & 0.13 & 0.17 \\
\hline $\mathrm{MgO}$ & < l.d. & $\therefore 1 . d$ & $<$ l.d. & $<$ I.d. & $<$ l.d. & $<$ l.d. & < l.d. & < l.d. & $<$ l.d. & $<1 . d$ & < I.d. & $<$ l.d. & $<$ l.d. & $<1.0$ & $<$ l.d. \\
\hline $\mathrm{CaO}$ & 4.57 & 1.78 & 4.57 & 3.78 & 0.98 & 0.93 & 0.69 & 4.35 & 4.21 & 4.56 & 4.25 & 4.17 & 4.32 & 3.93 & 4.29 \\
\hline $\mathrm{BaO}$ & 0.11 & 3.09 & 0.08 & < ld. & $<$ l.d. & 0.05 & < l.d. & $<$ l.d. & $<$ l.d. & $<$ l.d. & $<$ l.d. & $<$ I.d. & < I.d. & 0.06 & $<$ l.d. \\
\hline Sro & 0.09 & 1.06 & $<$ l.d. & $<$ l.d. & $<$ I.d. & $<$ l.d. & $<$ l.d. & < l.d. & $<$ f.d. & $<$ l.d. & $<$ l.d. & $<$ l.d. & $<$ l.d. & < l.d. & 0.06 \\
\hline $\mathrm{Na} 2 \mathrm{O}$ & 9.08 & 3.76 & 8.82 & 9.48 & 11.1 & 11.2 & 11.5 & 8.90 & 9.10 & 8.95 & 9.09 & 9.09 & 8.99 & 9.21 & 8.71 \\
\hline $\mathrm{K} 2 \mathrm{O}$ & 0.22 & 1). 18 & 0.24 & 0.14 & 0.18 & 0.19 & 0.10 & 0.48 & 0.52 & 0.45 & 0.31 & 0.37 & 0.38 & 0.38 & 0.54 \\
\hline Total & 101.0 & 99.9 & 100.6 & 100.8 & 100.8 & 101.1 & 99.8 & 100.5 & 100.3 & 100.6 & 100.1 & 100.0 & 100.1 & 100.7 & 99.8 \\
\hline $\mathrm{Si}$ & 2.798 & 2.787 & 2.800 & 2.838 & 2.976 & 2.973 & 2.977 & 2.817 & 2.827 & 2.809 & 2.823 & 2.820 & 2.818 & 2.836 & 2.820 \\
\hline Al & 1.191 & 1.206 & 1.195 & 1.153 & 1.019 & 1.020 & 1.011 & 1.175 & 1.157 & 1.179 & 1.163 & 1.169 & 1.172 & 1.155 & 1.172 \\
\hline Soma_ $T$ & 3.989 & 3.993 & 3.995 & 3.991 & 3.995 & 3.993 & 3.987 & 3.992 & 3.985 & 3.988 & 3.986 & 3.989 & 3.991 & 3.992 & 3.993 \\
\hline$\pi$ & 0.000 & 0.001 & 0.001 & 0.001 & 0.000 & 0.001 & 0.000 & 0.001 & 0.001 & 0.000 & 0.001 & 0.001 & 0.000 & 0.000 & 0.000 \\
\hline $\mathrm{Fe}$ & 0.005 & 0.003 & 0.005 & 0.009 & 0.003 & 0.004 & 0.007 & 0.004 & 0.005 & 0.004 & 0.008 & 0.007 & 0.004 & 0.005 & 0.006 \\
\hline $\mathrm{Mg}$ & 0.000 & 0.000 & 0.000 & 0.000 & 0.000 & 0.000 & 0.000 & 0.000 & 0.000 & 0.000 & 0.000 & 0.000 & 0.000 & 0.000 & 0.000 \\
\hline $\mathrm{Ca}$ & 0.215 & 0.227 & 0.215 & 0.177 & 0.046 & 0.043 & 0.033 & 0.205 & 0.199 & 0.215 & 0.201 & 0.197 & 0.204 & .0 .185 & 0.204 \\
\hline $\mathrm{Ba}$ & 0.002 & 0.002 & 0.001 & 0.001 & 0.000 & 0.001 & 0.000 & 0.000 & 0.000 & 0.000 & 0.000 & 0.000 & 0.000 & 0.001 & 0.000 \\
\hline $\mathrm{Sr}$ & 0.002 & 0.002 & 0.001 & 0.000 & 0.000 & 0.000 & 0.000 & 0.000 & 0.000 & 0.000 & 0.000 & 0.000 & 0.000 & 0.001 & 0.001 \\
\hline $\mathrm{Na}$ & 0.773 & 0.754 & 0.752 & 0.805 & 0.931 & 0.938 & 0.976 & 0.759 & 0.778 & 0.764 & 0.779 & 0.779 & 0.771 & 0.784 & 0.749 \\
\hline $\mathrm{K}$ & 0.012 & 0.010 & 0.013 & 0.008 & 0.010 & 0.011 & 0.006 & 0.027 & 0.029 & 0.025 & 0.018 & 0.021 & 0.021 & 0.021 & 0.030 \\
\hline Soma I & 1.010 & 0.998 & 0.989 & 1.001 & 0.990 & 0.997 & 1.021 & 0.996 & 1.013 & 1.009 & 1.007 & 1.006 & 1.001 & 0.997 & 0.991 \\
\hline
\end{tabular}

< I.d.: abaixo do limite de detecção 
Tabeia IV.8:

Análises químicas completas (WDS) de plagioclásios dos Granitos da Graciosa

\begin{tabular}{|c|c|c|c|c|c|c|c|c|c|c|}
\hline \multirow{3}{*}{ Amostra } & \multicolumn{10}{|c|}{ Rochas monzodioriticas e associadas } \\
\hline & & & $16 \mathrm{~B} 4$ & & & & & $59 E$ & & \\
\hline & 1 & 2 & 3 & 4 & 5 & 1 & 2 & 3 & 4 & 5 \\
\hline $\mathrm{SiO} 2$ & 57.2 & 57.8 & 63.3 & 63.5 & 64.4 & 54.5 & 54.4 & 55.1 & 62.3 & 62.6 \\
\hline A 1203 & 27.2 & 26.3 & 23.5 & 23.0 & 21.7 & 28.6 & 28.3 & 27.7 & 23.0 & 23.5 \\
\hline TiO2 & $<$ l.d. & 0.10 & $<$ l.d. & $<$ l.d. & 0.24 & $<$ I.d. & 0.09 & 0.07 & $<1 . d$ & $<$ l.d. \\
\hline $\mathrm{FeO}$ & 0.09 & 0.09 & 0.10 & 0.14 & 2.65 & 0.10 & 0.13 & 0.19 & 0.16 & 0.15 \\
\hline $\mathrm{MgO}$ & $<$ l.d. & < l.d. & $<$ l.d. & $<$ l.d. & 1.01 & $<$ l.d. & $<$ l.d. & $<i . d$ & $<$ l.d. & $<$ l.d. \\
\hline $\mathrm{CaO}$ & 9.61 & 8.36 & 4.83 & 4.61 & 3.00 & 11.4 & 10.8 & 10.1 & 4.76 & 4.73 \\
\hline $\mathrm{BaO}$ & $<$ l.d. & $<$ l.d. & 0.05 & 0.07 & $<$ l.d. & 0.09 & 0.09 & 0.17 & 0.08 & < l.d. \\
\hline sro & 0.09 & 0.11 & 0.11 & $<$ l.d. & 0.05 & 0.15 & 0.19 & 0.14 & 0.17 & 0.15 \\
\hline $\mathrm{Na} 2 \mathrm{O}$ & 6.25 & 6.69 & 8.74 & 8.70 & 8.56 & 5.16 & 5.16 & 5.51 & 8.38 & 8.61 \\
\hline$k 20$ & 0.19 & 0.22 & 0.30 & 0.36 & 0.88 & 0.12 & 0.20 & 0.24 & 0.67 & 0.29 \\
\hline Total & 100.7 & 99.8 & 100.9 & 100.4 & 102.5 & 100.0 & 99.4 & 99.2 & 99.6 & 100.0 \\
\hline $\mathrm{Si}$ & 2.554 & 2.597 & 2.779 & 2.799 & 2.810 & 2.463 & 2.472 & 2.507 & 2.781 & 2.774 \\
\hline Al & 1.433 & 1.394 & 1.218 & 1.196 & 1.116 & 1.522 & 1.519 & 1.485 & 1.210 & 1.226 \\
\hline Soma_ $T$ & $3.987^{\circ}$ & 3.991 & 3.996 & 3.995 & 3.926 & 3.986 & 3.991 & 3.992 & 3.991 & 4.000 \\
\hline$T i$ & 0.000 & 0.003 & 0.000 & 0.000 & 0.008 & 0.000 & 0.003 & 0.002 & 0.001 & 0.000 \\
\hline $\mathrm{Fe}$ & 0.003 & 0.003 & 0.004 & 0.005 & 0.097 & 0.004 & 0.005 & 0.007 & 0.006 & 0.005 \\
\hline $\mathrm{Mg}$ & 0.000 & 0.000 & 0.001 & 0.000 & 0.065 & 0.000 & 0.000 & 0.000 & 0.000 & 0.001 \\
\hline $\mathrm{Ca}$ & 0.460 & 0.403 & 0.227 & 0.218 & 0.140 & 0.550 & 0.526 & 0.490 & 0.228 & 0.225 \\
\hline $\mathrm{Ba}$ & 0.000 & 0.001 & 0.001 & 0.001 & 0.000 & 0.002 & 0.002 & 0.003 & 0.001 & 0.001 \\
\hline Sr & 0.002 & 0.003 & 0.003 & 0.001 & 0.001 & 0.004 & 0.005 & 0.004 & 0.004 & 0.004 \\
\hline $\mathrm{Na}$ & 0.542 & 0.583 & 0.744 & 0.744 & 0.724 & 0.452 & 0.455 & 0.486 & 0.724 & 0.740 \\
\hline K & 0.011 & 0.013 & 0.017 & 0.020 & 0.049 & 0.007 & 0.012 & 0.014 & 0.038 & 0.016 \\
\hline Soma I & 1.018 & 1.009 & 0.997 & 0.989 & 1.085 & 1.019 & 1.008 & 1.007 & 1.003 & 0.992 \\
\hline
\end{tabular}

$<$ I.d.: abaixo do limite de deteccão 
Tabela IV.9:

Estimativas da composição química primária de feldspatos alcalinos dos Granitos da Graciosa

\begin{tabular}{|c|c|c|c|c|c|c|c|c|c|c|c|}
\hline \multirow{3}{*}{ Amostra } & \multicolumn{11}{|c|}{ Associaçào alcalina / } \\
\hline & \multicolumn{2}{|c|}{$14 \mathrm{~B}$} & \multirow{2}{*}{$\begin{array}{c}18 \mathrm{~A} \\
\text { Total }\end{array}$} & \multicolumn{3}{|c|}{77} & \multicolumn{2}{|c|}{$78 \mathrm{~A}$} & \multicolumn{3}{|c|}{$81 B$} \\
\hline & Núcleo & Borda & & Núcleo & Borda 1 & Borda 2 & Núcleo & Borda & Núcleo & Interm. & Borda \\
\hline $\mathrm{SiO}_{2}$ & 67.7 & 67.7 & 67.2 & 68.2 & 67.1 & 67.2 & 67.3 & 67.4 & 66.3 & 67.5 & 65.6 \\
\hline $\mathrm{Al}_{2} \mathrm{O}_{3}$ & 18.5 & 18.4 & 18.1 & 18.6 & 18.3 & 18.7 & 18.3 & 18.6 & 18.8 & 19.4 & 18.3 \\
\hline $\mathrm{TiO}_{2}$ & $<$ l.d. & $<$ l.d. & $<$ l.d. & $<1 . d$ & $<$ l.d. & $<1, d$ & $<$ l.d. & $<1 . d$ & $\therefore$ l.d. & $<1 . d$ & $<\mathrm{l}$ d \\
\hline $\mathrm{FeO}$ & 0.15 & 0.36 & 0.38 & 0.21 & 0.19 & 0.20 & 0.24 & 0.20 & 0.06 & 0.06 & 0.16 \\
\hline $\mathrm{MgO}$ & $<$ l.d. & $<1 . d$ & < I.d. & $<$ l.d. & $<$ l.d. & $<$ l.d. & $<$ l.d. & $<$ l.d. & $<1 . d$ & $<$ l.d. & $<$ I.d. \\
\hline $\mathrm{CaO}$ & $<$ l.d. & $<$ I.d. & $<$ l.d. & $<$ l.d. & $<$ l.d. & $<$ l.d. & 0.78 & $<$ l.d. & 0.42 & 0.65 & 0.09 \\
\hline $\mathrm{BaO}$ & $<$ l.d. & $<$ l.d. & $<$ l.d. & $<$ l.d. & $<$ l.d. & $<$ l.d. & $<$ l.d. & $<$ l.d. & 0.07 & $<$ l.d. & < I.d. \\
\hline SrO & $<$ l.d. & $<$ l.d. & $<$ l.d. & $<$ l.d. & $<$ l.d. & $<$ l.d. & $<$ I.d. & $<$ l.d. & $<$ l.d. & $<$ l.d. & $<$ l.d. \\
\hline $\mathrm{Na}_{2} \mathrm{O}$ & 6.47 & 6.19 & 3.96 & 8.06 & 6.45 & 6.95 & 7.40 & 6.33 & 4.92 & 8.46 & 3.22 \\
\hline $\mathrm{K}_{2} \mathrm{O}$ & 7.55 & 8.03 & 11.0 & 5.26 & 7.64 & 6.79 & 6.14 & 7.82 & 9.46 & 4.21 & 12.0 \\
\hline Total & 100.3 & 100.7 & 100.6 & 100.4 & 99.7 & 99.9 & 100.2 & 100.4 & 100.0 & 100.3 & 99.5 \\
\hline $\mathrm{Si}$ & 3.020 & 3.020 & 3.027 & 3.020 & 3.018 & 3.008 & 3.005 & 3.012 & 2.994 & 2.982 & 3.006 \\
\hline $\mathrm{Al}$ & 0.971 & 0.966 & 0.960 & 0.970 & 0.971 & 0.987 & 0.964 & 0.979 & 0.999 & 1.012 & 0.988 \\
\hline Soma_t & 3.991 & 3.986 & 3.987 & 3.990 & 3.988 & 3.994 & 3.969 & 3.991 & 3.994 & 3.994 & 3.994 \\
\hline $\mathrm{Ti}$ & 0.001 & 0.001 & 0.000 & 0.001 & 0.000 & 0.000 & 0.001 & 0.001 & 0.000 & 0.001 & 0.001 \\
\hline $\mathrm{Fe}$ & 0.006 & 0.014 & 0.014 & 0.008 & 0.007 & 0.007 & 0.009 & 0.007 & 0.002 & 0.002 & 0.006 \\
\hline $\mathrm{Mg}$ & 0.000 & 0.000 & 0.000 & 0.000 & 0.000 & 0.000 & 0.000 & 0.000 & 0.000 & 0.000 & 0.000 \\
\hline $\mathrm{Ca}$ & 0.000 & 0.000 & 0.000 & 0.001 & 0.001 & 0.001 & 0.037 & 0.001 & 0.021 & 0.031 & 0.004 \\
\hline $\mathrm{Ba}$ & 0.000 & 0.000 & 0.000 & 0.001 & 0.000 & 0.000 & 0.000 & 0.000 & 0.001 & 0.000 & 0.000 \\
\hline $\mathrm{Sr}$ & 0.000 & 0.000 & 0.000 & 0.000 & 0.000 & 0.000 & 0.000 & 0.000 & 0.000 & 0.000 & 0.000 \\
\hline $\mathrm{Na}$ & 0.560 & 0.535 & 0.346 & 0.692 & 0.562 & 0.603 & 0.641 & 0.548 & 0.431 & 0.725 & 0.286 \\
\hline K & 0.430 & 0.457 & 0.634 & 0.297 & 0.438 & 0.388 & 0.350 & 0.446 & 0.545 & 0.237 & 0.704 \\
\hline Soma_l & 0.997 & 1.007 & 0.995 & 1.000 & 1.008 & 0.999 & 1.038 & 1.003 & 1.000 & 0.997 & 1.001 \\
\hline
\end{tabular}

< I.d.: abaixo do limite de detecção 
Tabela IV.9:

Estimativas da composição quimica primária de feldspatos alcalinos dos Granitos da Graciosa

\begin{tabular}{|c|c|c|c|c|c|c|c|c|c|c|c|}
\hline \multirow{3}{*}{ Amostra } & \multicolumn{11}{|c|}{ Associaçào alcalina l } \\
\hline & & & 810 & & & & $87 \mathrm{~A}$ & & & $87 \mathrm{~B}$ & \\
\hline & Núcleo & Interm. & Borda & Núcleo & Borda & Nücleo & Interm. & Borda & Nücleo & Interm. & Borda \\
\hline $\mathrm{SiO}_{2}$ & 67.4 & 68.8 & 67.6 & 67.8 & 67.9 & 68.0 & 68.1 & 67.5 & 67.0 & 67.3 & 67.4 \\
\hline $\mathrm{Al}_{2} \mathrm{O}_{3}$ & 19.0 & 20.0 & 18.4 & 19.2 & 18.5 & 18.7 & 18.7 & 18.1 & 18.4 & 18.7 & 19.2 \\
\hline $\mathrm{TiO}_{2}$ & $<$ i.d. & 0.05 & < l.d. & $<$ l.d. & < I.d. & $<$ I.d. & $<$ l.d. & < l.d. & $<$ l.d. & $<$ I.d. & $<$ l.d. \\
\hline FeO & 0.16 & 0.16 & 0.59 & 0.08 & 0.17 & 0.17 & 0.17 & 0.22 & 0.13 & 0.14 & 0.14 \\
\hline $\mathrm{MgO}$ & $<$ l.d. & $<$ I.d. & $<$ l.d. & $<$ l.d. & $<$ I.d. & $<$ I.d. & $<$ l.d. & < l.d. & $<$ l.d. & $<$ l.d. & $<$ l.d. \\
\hline $\mathrm{CaO}$ & 0.35 & 0.97 & 0.13 & 0.42 & 0.06 & 0.07 & 0.16 & < l.d. & 0.20 & 0.28 & 0.52 \\
\hline $\mathrm{BaO}$ & $<$ I.d. & < l.d. & $<$ l.d. & $<$ l.d. & $<$ I.d. & $<$ l.d. & $<$ I.d. & $<$ I.d. & 0.05 & 0.05 & $<1 . d$ \\
\hline $\mathrm{SrO}$ & $<$ l.d. & $<$ l.d. & $<$ l.d. & $<$ l.d. & $<$ l.d. & $<$ l.d. & $<$ l.d. & $<$ l.d. & < l.d. & < I.d. & $<$ l.d. \\
\hline $\mathrm{Na}_{2} \mathrm{O}$ & 5.69 & 10.8 & 6.70 & 7.17 & 5.92 & 6.70 & 7.31 & 5.53 & 4.13 & 5.69 & 7.35 \\
\hline $\mathrm{K}_{2} \mathrm{O}$ & 8.55 & 0.73 & 7.00 & 6.59 & 8.40 & 7.23 & 6.51 & 9.15 & 11.1 & 8.58 & 6.31 \\
\hline Tota! & 101.2 & 101.5 & 100.5 & 101.3 & 101.0 & 100.8 & 101.0 & 100.7 & 101.1 & 100.8 & 101.0 \\
\hline Si & 2.995 & 2.974 & 3.012 & 2.993 & 3.020 & 3.016 & 3.012 & 3.024 & 3.012 & 3.004 & 2.987 \\
\hline Al & 0.998 & 1.016 & 0.969 & 0.997 & 0.970 & 0.976 & 0.975 & 0.958 & 0.974 & 0.986 & 1.000 \\
\hline Soma_T & 3.993 & 3.991 & 3.982 & 3.990 & 3.990 & 3.992 & 3.987 & 3.982 & 3.986 & 3.990 & 3.987 \\
\hline Ti & 0.001 & 0.002 & 0.001 & 0.001 & 0.001 & 0.000 & 0.001 & 0.001 & 0.000 & 0.001 & 0.000 \\
\hline $\mathrm{Fe}$ & 0.006 & 0.006 & 0.022 & 0.003 & 0.006 & 0.006 & 0.006 & 0.008 & 0.005 & 0.005 & 0.005 \\
\hline $\mathrm{Mg}$ & 0.000 & 0.000 & 0.001 & 0.000 & 0.000 & 0.000 & 0.000 & 0.000 & 0.000 & 0.000 & 0.000 \\
\hline $\mathrm{Ca}$ & 0.017 & 0.045 & 0.006 & 0.020 & 0.003 & 0.003 & 0.008 & 0.002 & 0.010 & 0.014 & 0.025 \\
\hline $\mathrm{Ba}$ & 0.000 & 0.001 & 0.000 & 0.000 & 0.000 & 0.000 & 0.000 & 0.000 & 0.001 & 0.001 & 0.001 \\
\hline $\mathrm{Sr}$ & 0.000 & 0.000 & 0.000 & 0.000 & 0.000 & 0.000 & 0.000 & 0.000 & 0.000 & 0.001 & 0.001 \\
\hline $\mathrm{Na}$ & 0.490 & 0.903 & 0.579 & 0.614 & 0.511 & 0.576 & 0.627 & 0.480 & 0.359 & 0.492 & 0.632 \\
\hline$k$ & 0.485 & 0.040 & 0.398 & 0.371 & 0.477 & 0.409 & 0.367 & 0.523 & 0.638 & 0.489 & 0.356 \\
\hline Soma 1 & 0.999 & 0.996 & 1.008 & 1.009 & 0.998 & 0.996 & 1.009 & 1.016 & 1.013 & 1.003 & 1.020 \\
\hline
\end{tabular}

:1.d.: abaixo do limite de detecção 
Tabela IV.9:

Estimativas da composição quimica primária de feldspatos alcalinos dos Granitos da Graciosa

\begin{tabular}{|c|c|c|c|c|c|c|c|c|c|c|c|}
\hline \multirow{3}{*}{ Amostra } & \multicolumn{11}{|c|}{ Associação alcalina // } \\
\hline & \multicolumn{2}{|c|}{15} & \multicolumn{4}{|c|}{258} & \multicolumn{2}{|c|}{49} & \multicolumn{3}{|c|}{51} \\
\hline & Núclieo & Borda & Núcleo & Borda & Núcleo & Borda & Núcleo & Borda & Nücleo & Interm. & Borda \\
\hline $\mathrm{SiO}_{2}$ & 67.5 & 66.9 & 68.1 & 68.8 & 66.0 & 57.9 & 67.4 & 66.5 & 67.1 & 66.0 & 66.7 \\
\hline $\mathrm{Al}_{2} \mathrm{O}_{3}$ & 18.4 & 18.3 & 18.6 & 18.8 & 18.0 & 17.3 & 18.0 & 17.9 & 18.1 & 18.3 & 18.0 \\
\hline $\mathrm{TiO}_{2}$ & $<$ I.d. & $<$ l.d. & < l.d. & $<$ l.d. & $<$ l.d. & $<$ l.d. & $<$ l.d. & $<1 . d$ & $<$ I.d. & $<$ i.d. & $<$ l.d. \\
\hline $\mathrm{FeO}$ & 0.13 & 0.12 & 0.15 & 0.06 & 0.17 & 0.23 & 0.43 & 0.46 & 0.21 & 0.17 & 0.15 \\
\hline $\mathrm{MgO}$ & $<$ l.d. & < l.d. & $<$ l.d. & $<$ l.d. & $<$ l.d. & $<$ l.d. & $<$ l.d. & $<$ I.d. & $<$ |cd. & $<$ l.d. & < l.d. \\
\hline $\mathrm{CaO}$ & < l.d. & $<$ l.d. & < ld. & $<$ l.d. & $<$ l.d. & $<$ l.d. & $<$ I.d. & $<$ l.d. & $<$ l.d. & $<$ l.d. & $<$ l.d. \\
\hline $\mathrm{BaO}$ & 0.05 & 0.06 & $<$ l.d. & < l.d. & 0.10 & $<$ l.d. & $<$ l.d. & $<$ l.d. & < l.d. & $<$ I.d. & $<$ ld \\
\hline SrO & $<$ l. & $<1 . d$ & $<$ l.d. & < l.d. & $<$ l.d. & $<$ l.d. & $<$ l.d. & $<$ l.d. & $<\mathrm{l}$ d & $<$ l.d. & < l.d. \\
\hline $\mathrm{Na}_{2} \mathrm{O}$ & 5.25 & 4.11 & 5.61 & 7.34 & 1.64 & 7.68 & 6.04 & 4.38 & 6.35 & 5.40 & 5.11 \\
\hline $\mathrm{K}_{2} \mathrm{O}$ & 8.95 & 10.7 & 8.63 & 6.25 & 13.9 & 5.31 & 7.48 & 10.0 & 7.34 & 8.52 & 8.82 \\
\hline Total & 100.3 & 100.3 & 101.1 & 101.3 & 99.8 & 88.4 & 99.4 & 99.4 & 99.2 & 98.5 & 98.9 \\
\hline $\mathrm{Si}$ & 3.025 & 3.020 & 3.023 & 3.024 & 3.025 & 2.944 & 3.035 & 3.028 & 3.027 & 3.013 & 3.031 \\
\hline Al & 0.970 & 0.976 & 0.973 & 0.972 & 0.974 & 1.033 & 0.956 & 0.961 & 0.965 & 0.983 & 0.966 \\
\hline Soma_T & 3.955 & 3.996 & 3.997 & 3.996 & 3.999 & 3.978 & 3.991 & 3.989 & 3.992 & 3.996 & 3.997 \\
\hline $\mathrm{Ti}$ & 0.001 & 0.000 & 0.000 & 0.001 & 0.000 & 0.000 & 0.000 & 0.001 & 0.000 & 0.001 & 0.001 \\
\hline $\mathrm{Fe}$ & 0.007 & 0.005 & 0.006 & 0.002 & 0.006 & 0.010 & 0.016 & 0.018 & 0.008 & 0.007 & 0.006 \\
\hline $\mathrm{Mg}$ & 0.000 & 0.000 & 0.000 & 0.000 & 0.000 & 0.001 & 0.000 & 0.000 & 0.000 & 0.000 & 0.000 \\
\hline $\mathrm{Ca}$ & 0.002 & 0.001 & 0.000 & 0.001 & 0.000 & 0.000 & 0.000 & 0.000 & 0.00 & 0.002 & 0.000 \\
\hline $\mathrm{Ba}$ & 0.001 & 0.001 & 0.000 & 0.001 & 0.002 & 0.000 & 0.000 & 0.000 & 0.000 & 0.001 & 0.000 \\
\hline$S r$ & 0.000 & 0.000 & 0.000 & 0.000 & 0.000 & 0.000 & 0.000 & 0.000 & 0.000 & 0.000 & 0.000 \\
\hline $\mathrm{Na}$ & 0.457 & 0.360 & 0.483 & 0.626 & 0.146 & 0.757 & 0.528 & 0.386 & 0.556 & 0.478 & 0.450 \\
\hline $\mathrm{K}$ & 0.512 & 0.618 & 0.489 & 0.350 & 0.814 & 0.344 & 0.429 & 0.582 & 0.423 & 0.496 & 0.511 \\
\hline Soma! & 0.980 & 0.985 & 0.979 & 0.980 & 0.968 & 1.112 & 0.974 & 0.986 & 0.988 & 0.985 & 0.969 \\
\hline
\end{tabular}

$<$ i.d.: abaixo do limite de deteccāo 
Tabela IV.9:

Estimativas da composição química primária de feldspatos alcalinos dos Granitos da Graciosa

\begin{tabular}{|c|c|c|c|c|c|c|c|c|c|c|c|c|c|}
\hline \multirow{3}{*}{$\begin{array}{c}\text { Amostra } \\
\mathrm{SiO}_{2}\end{array}$} & & $2 E$ & & & & & & & & & & & \\
\hline & Nücleo & & & & $7 A$ & & & $7 \mathrm{~B}$ & & & & & \\
\hline & 64.3 & interm. & Borda & Núcleo & Interm. & Borda & Nücleo & Interm. & Borda & Nücleo & Borda & Nücleo & Borda \\
\hline $\mathrm{Al}_{2} \mathrm{O}_{3}$ & 18.7 & & 65.5 & 66.9 & 66.4 & 66.3 & 66.7 & 66.1 & 66.4 & 66.1 & 65.0 & 66.1 & 64.7 \\
\hline $\mathrm{TiO}_{2}$ & $<$ l.d. & $\begin{array}{r}18.6 \\
<1 d\end{array}$ & 18.2 & 19.0 & 18.5 & 18.1 & 18.4 & 18.9 & 18.2 & 38.6 & 17.9 & 18.5 & 18.0 \\
\hline $\mathrm{FeO}$ & 0.08 & $\begin{array}{l}<1 . d . \\
0.06\end{array}$ & < l.d. & $<$ l.d. & $<$ l.d. & < l.d. & $<$ l.d. & $<$ l.d. & $<$ l.d. & $<$ l.d. & $<$ I.d. & $<$ l.d. & < I.d. \\
\hline $\mathrm{MgO}$ & $<$ l.d. & $\begin{array}{l}0.06 \\
<\text { l.d. }\end{array}$ & 0.07 & 0.09 & 0.06 & < l.d. & 0.09 & 0.07 & 0.06 & 0.10 & 0.10 & 0.09 & 0.11 \\
\hline $\mathrm{CaO}$ & 0.10 & $\begin{array}{l}<1 . d . \\
0.34\end{array}$ & $<$ l.d. & < l.d. & $<$ l.d. & $<$ l.d. & $<$ l.d. & $<$ l.d. & $<$ l.d. & $<$ I.d. & < l.d. & $<$ l.d. & $<$ l.d. \\
\hline $\mathrm{BaO}$ & 1.71 & $\begin{array}{l}0.34 \\
0.39\end{array}$ & $<$ l.d. & 0.22 & 0.07 & < l.d. & 0.19 & 0.51 & $<1 . d$ & 0.12 & $<$ l.d. & 0.29 & $<$ l.d. \\
\hline SrO & 0.05 & $\begin{array}{l}0.39 \\
<1 . d\end{array}$ & 0.28 & 0.27 & 0.25 & 0.05 & $<$ l.d. & 0.19 & 0.08 & 0.08 & $<$ I.d. & < l.d. & 0.08 \\
\hline $\mathrm{Na}_{2} \mathrm{O}$ & 1.61 & $\begin{array}{l}<1 . d \\
2.50\end{array}$ & < l.d. & $<$ l.d. & $<$ l.d. & < l.d. & $<$ l.d. & $<$ l.d. & < l.d. & $<$ l.d. & $<$ l.d. & $<$ l.d. & $<1 . d$ \\
\hline $\mathrm{K}_{2} \mathrm{O}$ & 13.9 & & 1.27 & 3.34 & 2.43 & 0.36 & 2.59 & 2.59 & 1.39 & 3.33 & 0.40 & 4.64 & 0.33 \\
\hline Total & 100.4 & & 15.3 & 11.8 & 13.4 & 16.7 & 13.2 & 13.0 & 15.2 & 11.7 & 16.0 & 9.73 & 16.2 \\
\hline & & 100.0 & 100.7 & 101.8 & 101.1 & 101.5 & 101.1 & 101.4 & 101.4 & 100.0 & 99.5 & 99.4 & 99.4 \\
\hline $\mathrm{Si}$ & 2.974 & 2.985 & 3.004 & 2.996 & 3.008 & 3.018 & 3.013 & 2.985 & 3.015 & 3.005 & 3.018 & 3.004 & 3.010 \\
\hline $\mathrm{Al}$ & 1.019 & 1.007 & 0.985 & 1.005 & 0.986 & 0.973 & 0.978 & 1.007 & 0.975 & 0.995 & 0.980 & 0.990 & 0.985 \\
\hline Soma_ $T$ & 3.993 & 3.992 & 3.989 & 4.000 & 3.994 & 3.991 & 3.991 & 3.992 & 3.990 & 3.999 & 3.997 & 3.994 & 3.996 \\
\hline $\mathrm{Ti}$ & 0.001 & 0.001 & 0.001 & 0.000 & 0.001 & 0.001 & 0.000 & 0.001 & 0.000 & 0.000 & 0.000 & 0.001 & 0.000 \\
\hline $\mathrm{Fe}$ & 0.003 & 0.002 & 0.003 & 0.003 & 0.002 & 0.001 & 0.004 & 0.003 & 0.002 & 0.004 & 0.004 & 0.004 & 0.004 \\
\hline $\mathrm{Mg}$ & 0.000 & 0.000 & 0.000 & 0.000 & 0.000 & 0.000 & 0.001 & 0.000 & 0.000 & 0.001 & 0.000 & 0.000 & 0.000 \\
\hline $\mathrm{Ca}$ & 0.005 & 0.017 & 0.002 & 0.010 & 0.003 & 0.000 & 0.009 & 0.025 & 0.001 & 0.006 & 0.000 & 0.014 & 0.000 \\
\hline $\mathrm{Ba}$ & 0.031 & 0.007 & 0.005 & 0.005 & 0.004 & 0.001 & 0.000 & 0.003 & 0.001 & 0.001 & 0.000 & 0.000 & 0.001 \\
\hline $\mathrm{Sr}$ & 0.001 & 0.000 & 0.000 & 0.000 & 0.000 & 0.000 & 0.000 & 0.000 & 0.000 & 0.000 & 0.000 & 0.000 & 0.000 \\
\hline $\mathrm{Na}$ & 0.145 & 0.223 & 0.113 & 0.290 & 0.214 & 0.032 & 0.227 & 0.227 & 0.122 & 0.293 & 0.036 & 0.409 & 0.030 \\
\hline$k$ & 0.818 & 0.757 & 0.893 & 0.675 & 0.772 & 0.968 & 0.758 & 0.748 & 0.883 & 0.679 & 0.945 & 0.564 & 0.959 \\
\hline Soma & 1.004 & 1.007 & 1.017 & 0.984 & 0.997 & 1.004 & 0.999 & 1.006 & 1.010 & 0.985 & 0.986 & 0.992 & 0.995 \\
\hline
\end{tabular}

< I.d.: abaixo to limite de detecção 
Tabela IV.9:

Estimativas da composição química primária de feldspatos alcalinos dos Granitos da Graciosa

\begin{tabular}{|c|c|c|c|c|c|c|c|c|c|c|c|}
\hline & & \multicolumn{10}{|c|}{ Associaçāo aluminosa } \\
\hline \multirow{2}{*}{ Amostra } & \multicolumn{3}{|c|}{$28 \mathrm{~B}$} & \multicolumn{2}{|c|}{32} & \multicolumn{2}{|c|}{$36 B$} & \multicolumn{2}{|c|}{83} & \multicolumn{2}{|c|}{$84 A$} \\
\hline & Núcleo & Interm. & Borda & Núcleo & Borda & Núcleo & Borda & Nücleo & Borda & Nücleo & Borda \\
\hline $\mathrm{SiO}_{2}$ & 55.0 & 65.6 & 65.9 & 65.6 & 65.2 & 65.1 & 65.4 & 66.7 & 65.9 & 67.6 & 67.1 \\
\hline $\mathrm{Al}_{2} \mathrm{O}_{3}$ & 18.6 & 18.4 & 18.2 & 18.3 & 17.8 & 18.2 & 18.2 & 18.8 & 18.0 & 18.5 & 18.6 \\
\hline $\mathrm{TiO}_{2}$ & $<$ l.d. & $<$ l.d. & $<$ l.d. & $<$ l.d. & $<1 . d$ & $<$ l.d. & $<$ l.d. & < l.d. & $<$ l.d. & $<1.0$ & $<$ I.d. \\
\hline $\mathrm{FeO}$ & 0.05 & 0.08 & 0.10 & 0.07 & 0.09 & 0.10 & 0.07 & 0.08 & 0.06 & 0.19 & 0.15 \\
\hline $\mathrm{MgO}$ & $<$ l.d. & $<1 . d$ & $<$ l.d. & $<$ I.d. & $<$ l.d. & $<$ i.d. & $<1 . d$ & $<$ l.d. & $<$ l.d. & $<$ I.d. & $<$ l.d. \\
\hline $\mathrm{CaO}$ & 0.26 & 0.14 & 0.13 & 0.22 & $<$ l.d. & 0.09 & $<$ l.d. & 0.11 & 0.10 & 0.05 & 0.05 \\
\hline $\mathrm{BaO}$ & 0.21 & 0.38 & 0.28 & 0.10 & $<$ l.d. & 0.24 & 0.31 & 0.16 & $<$ l.d. & $<$ l.d. & $<$ id. \\
\hline SrO & $<$ l.d. & $<$ l.d. & $<$ l.d. & $<$ I.d. & $<$ I.d. & $<$ I.d. & $<$ l.d. & $<$ l.d. & $<$ l.d. & < i.d. & $<1 . \mathrm{d}$ \\
\hline $\mathrm{Na}_{2} \mathrm{O}$ & 3.77 & 2.60 & 2.47 & 3.01 & 0.36 & 1.39 & 0.52 & 3.72 & 1.74 & 5.56 & 4.43 \\
\hline $\mathrm{K}_{2} \mathrm{O}$ & 10.9 & 12.5 & 12.6 & 12.5 & 16.3 & 15.0 & 16.3 & 11.6 & 14.3 & 9.19 & 10.7 \\
\hline Total & 99.9 & 99.7 & 99.7 & 99.8 & 99.8 & 100.1 & 100.8 & 101.2 & 100.1 & 101.2 & 101.1 \\
\hline Si & 3.001 & 3.004 & 3.018 & 3.004 & 3.019 & 3.001 & 3.005 & 3.001 & 3.019 & 3.014 & 3.009 \\
\hline $\mathrm{Al}$ & 0.997 & 0.995 & 0.980 & 0.986 & 0.974 & 0.989 & 0.985 & 0.994 & 0.974 & 0.973 & 0.981 \\
\hline Soma_ $T$ & 3.998 & 3.999 & 3.998 & 3.990 & 3.992 & 3.989 & 3.990 & 3.995 & 3.992 & 3.987 & 3.990 \\
\hline $\mathrm{Ti}$ & 0.001 & 0.001 & 0.000 & 0.000 & 0.000 & 0.000 & 0.000 & 0.000 & 0.000 & 0.001 & 0.001 \\
\hline $\mathrm{Fe}$ & 0.002 & 0.003 & 0.004 & 0.003 & 0.003 & 0.004 & 0.003 & 0.003 & 0.002 & 0.007 & 0.006 \\
\hline $\mathrm{Mg}$ & 0.000 & 0.000 & 0.000 & 0.000 & 0.000 & 0.000 & 0.000 & 0.000 & 0.000 & 0.000 & 0.001 \\
\hline $\mathrm{Ca}$ & 0.013 & 0.007 & 0.006 & 0.011 & 0.000 & 0.005 & 0.002 & 0.005 & 0.005 & 0.002 & 0.002 \\
\hline $\mathrm{Ba}$ & 0.004 & 0.007 & 0.005 & 0.002 & 0.000 & 0.004 & 0.006 & 0.003 & 0.000 & 0.000 & 0.001 \\
\hline $\mathrm{Sr}$ & 0.000 & 0.000 & 0.001 & 0.000 & 0.000 & 0.001 & 0.000 & 0.000 & 0.000 & 0.000 & 0.000 \\
\hline $\mathrm{Na}$ & 0.332 & 0.231 & 0.219 & 0.267 & 0.032 & 0.124 & 0.046 & 0.324 & 0.154 & 0.480 & 0.385 \\
\hline k & 0.634 & 0.728 & 0.735 & 0.728 & 0.963 & 0.879 & 0.955 & 0.664 & 0.833 & 0.523 & 0.613 \\
\hline Soma I & 0.985 & 0.978 & 0.971 & 1.011 & 1.000 & 1.017 & 1.012 & 1.000 & 0.996 & 1.013 & 1.008 \\
\hline
\end{tabular}

< l.d.: abaixo do limite de detecção 
Tabela IV.9:

Estimativas da composição química primária de feldspatos alcalinos dos Granitos da Graciosa

\begin{tabular}{|c|c|c|c|c|c|c|c|c|c|c|c|c|}
\hline \multirow{3}{*}{ Amostra } & \multicolumn{7}{|c|}{ Associação aluminosa } & \multicolumn{5}{|c|}{ Rochas monzodioríticas e associadas } \\
\hline & & & $85 B$ & & & & & & & $16 B 3(2)$ & & \\
\hline & Borda 7 & interm. 1 & Núcleo & Interm. 2 & Borda 2 & Núcleo & Borda & Nücleo & Borda & Total & Nücleo & Borda \\
\hline $\mathrm{SiO}_{2}$ & 67.7 & 66.5 & 66.7 & 66.9 & 66.5 & 67.8 & 67.6 & 66.1 & 65.7 & 64.9 & 65.0 & 64.6 \\
\hline $\mathrm{Al}_{2} \mathrm{O}_{3}$ & 18.4 & 18.4 & 18.3 & 18.6 & 18.6 & 18.7 & 18.6 & 18.2 & 18.1 & 17.9 & 18.3 & 18.4 \\
\hline $\mathrm{TiO}_{2}$ & $<$ l.d. & $<$ l.d. & $<$ l.d. & $<$ l.d. & $<$ l.d. & $<$ l.d. & $<$ l.d. & $<$ l.d. & $<$ I.d. & < I.d. & $<$ l.d. & $<$ l.d. \\
\hline $\mathrm{FeO}$ & 0.15 & 0.11 & 0.11 & 0.16 & 0.11 & 0.12 & 0.11 & 0.11 & 0.15 & 0.17 & 0.09 & 0.08 \\
\hline $\mathrm{MgO}$ & $<$ l.d. & $<$ i.d. & $<1 . d$ & $<$ l.d & $<$ l.d. & $<$ l.d. & < l.d. & $<$ I.d. & $<$ l.d. & $<$ l.d. & < l.d. & < I.d. \\
\hline $\mathrm{CaO}$ & 0.14 & 0.15 & 0.14 & 0.34 & 0.28 & 0.24 & 0.23 & $<$ I.d. & 0.08 & $<$ l.d. & 0.09 & < l.d. \\
\hline $\mathrm{BaO}$ & $<$ l.d. & $<$ l.d. & $<$ I.d. & $<$ l.d. & $<$ I.d. & $<$ l.d. & $<$ ld & 0.12 & 0.10 & 0.11 & 0.97 & 1.09 \\
\hline Sro & $<$ I.d. & < l.d. & $<$ l.d. & $<$ l.d. & $<$ l.d. & $<$ l.d. & $<\mathrm{l} . \mathrm{d}$ & $<$ l.d. & < l.d. & $<1 . d$ & 0.07 & 0.08 \\
\hline $\mathrm{Na}_{2} \mathrm{O}$ & 6.33 & 4.07 & 4.08 & 5.14 & 5.04 & 6.04 & 5.67 & 2.89 & 2.71 & 0.80 & 1.63 & 0.99 \\
\hline $\mathrm{K}_{2} \mathrm{O}$ & 7.55 & 10.9 & 11.0 & 9.32 & 9.58 & 8.00 & 8.60 & 12.7 & 12.8 & 15.5 & 13.6 & 14.7 \\
\hline Total & 100.3 & 100.2 & 100.4 & 100.5 & 100.1 & 100.9 & 100.9 & 100.2 & 99.7 & 99.5 & 99.8 & 99.9 \\
\hline $\mathrm{Si}$ & 3.023 & 3.009 & 3.015 & 3.004 & 2.999 & 3.013 & 3.014 & 3.012 & 3.012 & 3.013 & 3.001 & 2.995 \\
\hline Al & 0.967 & 0.983 & 0.974 & 0.986 & 0.991 & 0.979 & 0.977 & 0.978 & 0.979 & 0.979 & 0.997 & 1.003 \\
\hline Soma_T & 3.990 & 3.993 & 3.989 & 3.990 & 3.990 & 3.992 & 3.991 & 3.990 & 3.991 & 3.992 & 3.998 & 3.998 \\
\hline $\mathrm{Ti}$ & 0.001 & 0.000 & 0.001 & 0.000 & 0.000 & 0.001 & $0.00 i$ & 0.001 & 0.001 & 0.000 & 0.001 & 0.000 \\
\hline $\mathrm{Fe}$ & 0.006 & 0.004 & 0.004 & 0.006 & 0.004 & 0.004 & 0.004 & 0.004 & 0.006 & 0.006 & 0.003 & 0.003 \\
\hline $\mathrm{Mg}$ & 0.000 & 0.000 & 0.000 & 0.000 & 0.000 & 0.000 & 0.000 & 0.000 & 0.000 & 0.000 & 0.000 & 0.000 \\
\hline $\mathrm{Ca}$ & 0.007 & 0.007 & 0.007 & 0.016 & 0.014 & 0.012 & 0.011 & 0.002 & 0.004 & 0.001 & 0.004 & 0.002 \\
\hline $\mathrm{Ba}$ & 0.000 & 0.000 & 0.000 & 0.000 & 0.000 & 0.000 & 0.000 & 0.002 & 0.002 & 0.002 & 0.018 & 0.020 \\
\hline $\mathrm{Sr}$ & 0.000 & 0.000 & 0.000 & 0.000 & 0.000 & 0.000 & 0.000 & 0.000 & 0.000 & 0.001 & 0.002 & 0.002 \\
\hline $\mathrm{Na}$ & 0.548 & 0.357 & 0.357 & 0.448 & 0.441 & 0.521 & 0.490 & 0.256 & 0.240 & 0.072 & 0.146 & 0.089 \\
\hline K & 0.430 & 0.631 & 0.635 & 0.534 & 0.552 & 0.454 & 0.489 & 0.741 & 0.750 & 0.916 & 0.798 & 0.867 \\
\hline Soma I & 0.991 & 1.000 & 1.005 & 1.004 & 1.011 & 0.992 & 0.995 & 1.007 & 1.003 & 0.998 & 0.974 & 0.984 \\
\hline
\end{tabular}

<.d.: abaixo do limite de deteccão 
Parte V:

CONSIDERAÇÕES FINAIS 


\section{Os Granitos da Graciosa}

O estudo geológico de campo, integrado com a caracterização petrográfica de fácies e o tratamento de imagens de satélite e de dados aerogamaespetrométricos permitiu estabelecer uma nova divisão para as rochas graníticas presentes na região da Serra da Graciosa. Neste sentido, propõe-se a compartimentação do denominado "Maciço Graciosa" em três unidades independentes: Maciço Capivari, Maciço Órgãos e Maciço Farinha Seca que, juntamente com os Maciços Marumbi e Anhangava são aqui reunidos sob a denominação de Granitos da Graciosa.

Os contatos externos inferidos para os cinco maciços sāo apresentados em mapa e mostram formas elípticas de orientação NE-SW, cada uma com áreas entre 34 e $100 \mathrm{~km}^{2}$. A independência estrutural das cinco unidades fica em geral ressaltada nas imagens de satélite, em modelo digital de terreno, bem como em mapas aerogamaespectrométricos.

O Maciço Capivari é constituido de sieno- e monzogranitos com biotita e anfibólio cálcico. Nas porções central e E do Maciço Órgãos afloram fácies petrográficas semelhantes, enquanto na porção W. predominam álcali-feldspato granitos com anfibólio cálcico, com ocorrência subordinada de quartzo monzodioritos. O Maciço Farinha Seca, por sua vez, é composto por álcali-feldspato granitos com anfibólio de composição variável desde cálcica até sódica, com uma ocorrência isolada de quartzo sienitos com enclaves de rochas monzodioríticas. Nas porções $\mathrm{N}$ e $\mathrm{S}$ do Maciço Anhangava, afloram álcali-feldspato sienitos com anfibólio; já na porção central, predominam sieno- e monzogranitos com biotita e anfibólio semelhantes aos observados nos Macicos Capivari e Órgāos, além de álcali-feldspato granitos com biotita similares aos do Maciço Anhangava.

A distribuição espacial e as relações estruturais entre as fácies petrográficas mapeadas nestes maciços não são bem conhecidas devido às dificuldades de acesso e à precariedade dos afloramentos.

\section{Associações petrográficas}

Com base em critérios petrográficos, as rochas presentes nos cinco maciços estudados foram agrupadas em quatro associações distintas.

A associação alcalina / é caracterizada por álcali-feldspato sienitos do Maciço Anhangava e ocorrências isoladas de álcali-feldspato granitos do Maciço Farinha Seca. São rochas tipicamente hipersolvus, que mostram um aumento contínuo dos teores de quartzo e uma diminuiçăo na 
quantidade de máficos em direção aos termos mais evoluídos. As variedades mais máficas são marcadas pela presença de anfibólio cálcico + clinopiroxênio \pm olivina +allanita + titanita (+ilmenita, +zircão, +apatita), enquanto nas variedades intermediárias o anfibólio é cálcico-sódico, clinopiroxênio é raro, olivina está ausente e chevkinita-perrierita é acessório típico; nas variedades mais félsicas, anfibólio sódico é a única fase máfica importante. Biotita, quando presente, está claramente associada às transformações pós-magmáticas, juntamente com anfibólio sódico tardio. A evolução modal é semelhante à das típicas séries alcalinas (e.g. Lameyre e Bowden, 1982; Bonin et al. 1998), porém faltam os termos básico-intermediários portadores de plagioclásio.

Os álcali-feldspato granitos com anfibólio dos Maciços Farinha Seca e Órgãos compõem a associação alcalina //. Esta associação contrasta com a anterior por apresentar intervalos restritos de variação modal e pela presença de anfibólio como máfico essencial. Destaca-se que, apesar da homogeneidade modal, as variações composicionais dos anfibólios cobrem todo o espectro observado nos anfibólios da associação anterior. Dentre os acessórios, o maior contraste é a presença de magnetita nas variedades com anfibólio cálcico.

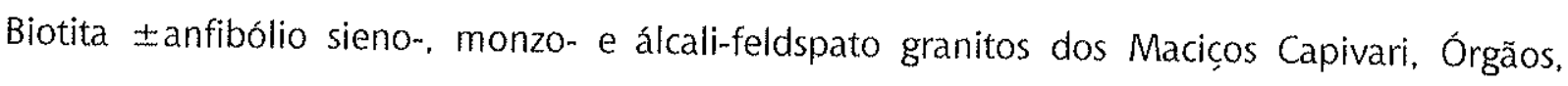
Anhangava e Marumbi, tipicamente subsolvus, caracterizam a associação aluminosa. As tendências modais mostram variações menores nos teores de quartzo e máficos, e, de maneira geral, as variedades mais ricas em feldspato alcalino (e pobres em plagioclásio), também são as mais pobres em quartzo. Os minerais acessórios típicos são titanita, allanita, magnetita e ilmenita.

As rochas monzodioríticas, de afinidade potássica, são caracterizadas pela paragênese biotita +anfibólio cálcico + clinopiroxênio augítico + magnetita +ilmenita (+apatita, allanita, zircão) e aparecem como ocorrências discretas isoladas. Evidências geológicas e modais sugerem interação local entre magmas dioríticos e graníticos da associação alcalina //, que propiciou a geração de rochas híbridas (granodioritos e quartzo sienitos) caracterizados pela presença de enclaves microgranulares ricos em minerais máficos.

\section{Quimismo mineral}

De maneira geral, os minerais máficos presentes em todas as associações são ricos em Fe e pobres em $\mathrm{Mg}$ e Al. Nas associações alcalinas, os anfibólios são os mais importantes indicadores da evolução química dos respectivos magmas, principalmente através do aumento progressivo nos teores de $\mathrm{Na}$ e $\mathrm{Fe}^{3+}$. 
Na associação alcalina /, os anfibólios seguem um caminho em diversos aspectos compativel com uma trajetória agpaitica. A cristalização se dá em ambiente progressivamente mais oxidante e alcalino. A relativa abundância e complexidade das transformaçōes pós-magmáticas são típicas de sistemas agpaíticos, e ficam melhor evidenciadas, nas rochas estudadas, principalmente pela substituição de anfibólios cálcico-sódicos por anfibólio sódico e biotita rica em Si. Na associação alcalina //, as trajetórias evolutivas dos anfibólios são algo diferenciadas: faltam as trajetórias oxidantes típicas, e nas variedades com anfibólio sódico primário observam-se tendências contrárias, claramente redutoras. Os anfibólios da associação aluminosa, por outro lado, se destacam pela sua homogeneidade, com composiçōes tipicamente cálcicas. Os anfibólios das rochas monzodioríticas contrastam com os presentes nas rochas sieníticas e graníticas pelas suas composições mais magnesianas; situação similar é observada para os clinopiroxênios.

Plagioclásio está presente apenas na associação aluminosa e nas rochas monzodioríticas e associadas. Na associação aluminosa, as composiçōes variam de oligoclásio no núcleo, em direção a albita cálcica nas bordas $\left(\mathrm{An}_{10-20}\right)$. Bordas albíticas pós-magmáticas são comuns. As rochas monzodioríticas apresentam plagioclásios com núcleos labradoríticos $\left(\mathrm{An}_{40-55}\right)$ e bordas de oligoclásio $\left(A n_{20-25}\right)$. As composições observadas nos quartzo sienitos são semelhantes às dessas bordas.

As diferenças mais marcantes nos teores de Or estão associadas, como esperado, à coexistência ou não com plagioclásio. Assim, os feldspatos alcalinos presentes nos sieno- e monzogranitos têm valores de ortoclásio bem superiores $\left(\mathrm{Or}_{65-97}\right)$ quando comparados aos álcali-feldspato sienitos e granitos das associações alcalinas (Or ${ }_{35-55}$ - alcalina l; $\mathrm{Or}_{43-63}$ - alcalina I/) e aos álcali-feldspato granitos da associação aluminosa $\left(\mathrm{Or}_{44-64}\right)$. Analogamente, os feldspatos alcalinos das rochas monzodioríticas são ricos na molécula ortoclásio $\left(\mathrm{Or}_{84-91}\right)$.

\section{Condicỗes de cristalização}

Pressões de cristalização foram estimadas com base no teor de Al em anfibólios das rochas da associação aluminosa e monzodioríticas. As primeiras resultaram em valores entre 2 e 4 kbar. provavelmente superestimados devido aos teores elevados de Fe nos anfibólios. Os melhores resultados ( $2 \pm 0.6 \mathrm{kbar}$ ), mais compativeis com dados geológicos e petrográficos, foram obtidos para os monzodioritos.

As temperaturas de saturação calculadas para Zr e P, aliados aos dados petrográficos, apontam temperaturas de liquidus no intervalo entre 800 e $900^{\circ} \mathrm{C}$ tanto para as associacõos a/calinas $\left(\mathrm{T}_{Z_{i}}\right)$ 
como para a aluminosa $\left(T_{A p}\right)$. Já as temperaturas de solidus foram estimadas em $700-750^{\circ} \mathrm{C}$, com base no equilíbrio anfibólio cálcico - plagioclásio (variedades aluminosas) e no caráter hipersolvus $\left(P_{\mathrm{H} 2 \mathrm{O}}=2 \mathrm{kbar}\right)$ dos álcali-feldspato granitos. Vale a pena destacar que a evolução química dos feldspatos nas rochas subsolvus indica cristalização sob condiçōes de aumento progressivo na atividade de água. No caso das rochas monzodioríticas, as temperaturas de liquidus devem ter sido próximas a $1000^{\circ} \mathrm{C}\left(\mathrm{T}_{\mathrm{Ap}}\right)$ e as de solidus pouco mais altas, em torno de $750^{\circ} \mathrm{C}$

As associações petrográficas estudadas mostram também condições redox diferenciadas. Na associação alcalina /. os termos mais máficos cristalizaram em condiçōes algo inferiores ao tampão QFM; condiçōes relativamente redutoras, em que biotita rica em Fe permaneceu estável, prevaleceram até os estágios pós-magmáticos. Esta evoluçăo se dá tipicamente segundo uma trajetoria oxidante, como indicado pela evolução química dos anfibólios. Já na associação a/calina //. as variedades menos evoluídas sugerem pelo menos em parte condições mais oxidantes (presença de titanita e magnetita) e o quimismo dos anfibólios indica trajetórias relativamente redutoras nas rochas mais evoluídas. A associação aluminosa, assim como as rochas monzodioríticas, cristalizou em condições comparativamente oxidantes, próximas ao tampão TMQAI.

\section{Perspectivas}

O magmatismo Tipo-A da região da Graciosa guarda similaridades com o observado em diversas províncias pós-colisionais em que afloram associaçōes petrográficas de afinidades alcalinas e aluminosas contemporâneas, para as quais sāo inferidas contribuiçōes importantes do manto e da crosta continental (Poitrasson et al., 1995). Na área estudada, entretanto, a ausência de rochas intermediárias com plagioclásio claramente vinculadas com as rochas sieníticas e graníticas permite questionar se as rochas das associaçōes alcalinas de fato representam produtos de diferenciação de magmas básicos, provenientes do manto. As únicas ocorrências contemporâneas de rochas intermediárias, os monzodioritos, parecem representar, ao nível atual de erosão, atividades discretas e dissociadas. Assim, ficam abertas algumas possibilidades para estudos futuros. 
Apêndice l:

\section{ANÁLISE MODAL REVISTA:}

Precisão e exatidão associadas à contagem de pontos 
I. INTRODUÇÃO 2

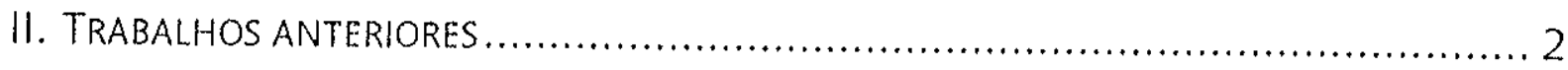

11.1. De Delesse a Huribut (1850-1940) .......................................................... 2

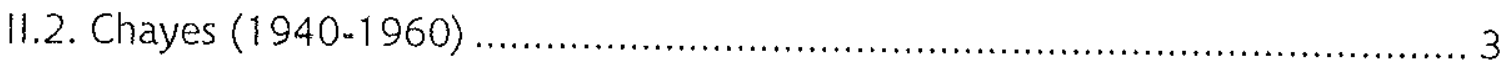

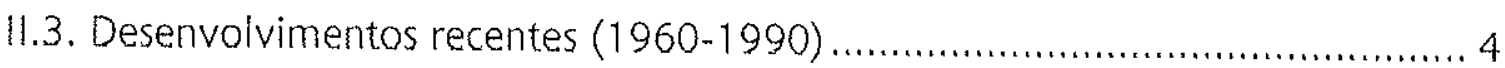

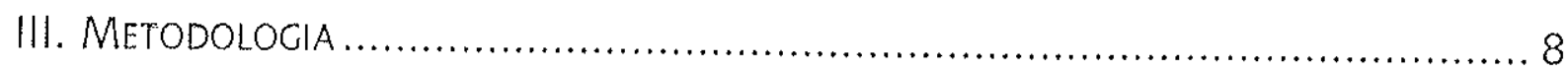

III.1. Abordagem metodológica .................................................................. 8

1II.2. Aquisição de imagens...................................................................... 9

III.3. Simulações .................................................................................. 10

111.4. Método de Neilson e Brockman (1977) ............................................ 11

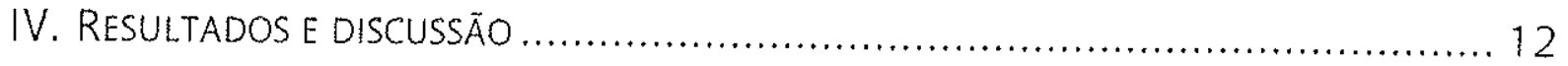

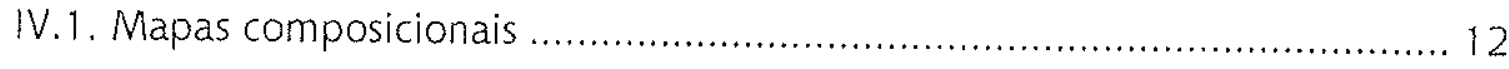

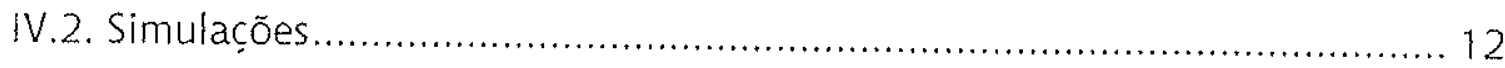

IV.3. Método de Neilson e Brockman (1977) ............................................ 18

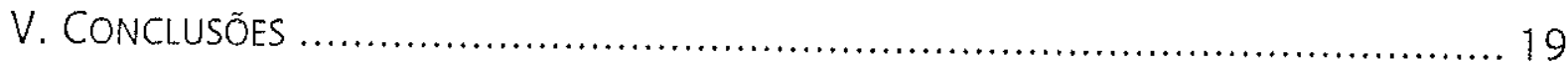

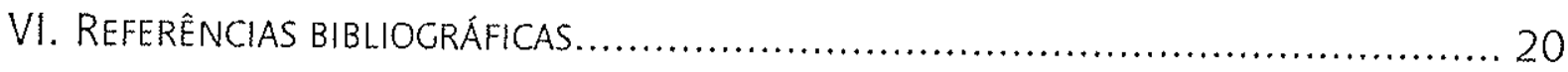




\section{INTRODUÇÃO}

A abundância relativa entre os minerais presentes em uma rocha é uma informações essencial na maioria dos estudos em petrologia ígnea. Desde a classificação das rochas, até a compreensão de trajetórias evolutivas de séries magmáticas, uma boa estimativa das composições modais se faz sempre necessária. Particularmente em trabalhos envolvendo modelamentos geoquímicos, em que é fundamental conhecer estimativas dos volumes de fases acessórias, não só as composiçōes modais dessas fases são relevantes, mas também os erros associados a essas medidas.

Apesar da importância singular destas estimativas, chama a atenção a escassez de trabalhos avaliando a qualidade das técnicas utilizadas. Formas de obter estimativas de erro, foram delineadas apenas teoricamente, não se tendo chegado a um consenso. Talvez por esta razão, erros nunca sejam apresentados em estudos petrológicos convencionais.

Fica evidente, portanto, a necessidade de se avaliar a qualidade das diferentes técnicas de estimativa da composição modal de rochas ígneas, bem como de se escolher um método de avaliação dos erros envolvidos como base para a correta utilizaçāo destes dados.

Esta contribuição busca fazer esta avaliaçăo tendo como base a realização de simulaçōes em computador, a partir de imagens ideais - obtidas a partir de amostras reais - de composiçăo conhecida, utilizando a técnica de contagem de pontos, a mais amplamente utilizada até hoje.

\section{TRABALHOS ANTERIORES}

\subsection{DE DELESSE A HURLBUT (1850-1940)}

As primeiras tentativas de obtenção análises modais remontam ao meio do século XIX e se devem a Delesse (1848, apud Chayes, 1956). A técnica por ele utilizada consistia em desenhar uma seção de rocha em papel e a seguir transferi-la para uma folha metálica. Os diferentes pedaços, depois de cortados, eram pesados, de forma a se atingir uma estimativa de suas quantidades. Apesar de utilizar uma técnica trabalhosa e demorada. Delesse abriu as portas para a avaliação das composiçōes modais. Mesmo com os avanços propostos por outros autores ainda no século XIX, a técnica esteve sempre muito distante de ser suficientemente rápida para ser utilizada sistematicamente.

Rosiwal, no final do mesmo século (1898), propôs um novo procedimento, que serviu como base para os estudos realizados na primeira metade do século XX. A técnica consistia emn utilizar 
como base linhas de referência que atravessavam a amostra; a abundância relativa dos minerais era obtida a partir da proporção entre a distância ocupada por um dado mineral e o comprimento total analisado. O estabelecimento da técnica como padrão na época se deve a Shand (1916, apud Chayes, 1956), que introduziu a utilização de micrômetros para a medida das proporções relativas entre os segmentos. A utilização de diversos micrômetros simultaneamente (Wentworth. 1923; Hunt, 1924), posteriormente movidos por um motor (Hurlbut, 1939), foram avanços naturais da técnica.

\subsection{CHAYES (1940-1960)}

Os trabalhos desenvolvidos por Chayes nas décadas de 40 e 50 representam um verdadeiro marco na história do desenvolvimento das técnicas de análise modal e os avanços encontram-se resumidos em Chayes (1956).

Em primeiro lugar. Chayes definitivamente demonstrou a propriedade que permite a estimativa das proporções volumétricas entre as fases minerais a partir das proporções em área - a relação de Delesse - ou das proporções lineares, o que ainda não havia sido feito apropriadamente até então.

Além disso, Chayes propôs um novo método de estimativa - a contagem de pontos (Chayes, 1949) -, até hoje o método mais utilizado pelos petrólogos. Chayes (1956) conclui que a nova técnica, além de diminuir pela metade o tempo de análise, deve, pelo menos teoricamente, levar a resultados mais consistentes.

Chayes (1956) permanece até hoje como o único a avaliar a reprodutibilidade dos procedimentos, demonstrando que esta depende da área analisada; os resultados de seu estudo estāo apresentados em diagramas para avaliar a área mínima necessária com base na precisão desejada (ct. Figuras 11 a 13 de Chayes, 1956).

No mesmo trabalho, Chayes foi pioneiro em identificar que os erros podem ser satisfatoriamente estimados assumindo-se uma distribuição binomial, permitindo pela primeira vez a sua avaliação.

Finalmente, Chayes (1956) demonstra que seu método, desde que aplicado com critério, pode ser adaptado à pior situação possivel. em rochas perfeitamente bandadas, o que até então figurava como um problema sem solução. 
É por estas razões que os trabalhos de Chayes revolucionaram a compreensão e as técnicas de análise modal.

\subsection{DESENVOLVIMENTOS RECENTES (1960-1990)}

A partir dos trabalhos de Chayes, pouco foi feito no sentido de refinar as técnicas e as avaliaçōes de erro propostas por ele.

As principais contribuiçoes buscaram definir métodos de se estimar os erros envolvidos na análise modal, havendo pelo menos duas linhas concorrentes.

\section{Van der Plas e Tobi (1965) e Howarth (1998)}

Após um intervalo de quase uma década, van der Plas e Tobi (1965) apresentam um diagrama que permite obter o erro associado a uma medida com base no número de pontos contados e na abundância relativa de um dado mineral. Como destacado por Howarth (1998), o diagrama é construido tomando-se por base uma distribuição binomial de probabilidades; entretanto, van der Plas e Tobi (1965) não demonstram a adequação deste pressuposto, valendo-se apenas de argumentos teóricos bastante simplificados e da dedução de Chayes (1956).

Apesar de Chayes nāo encontrar uma relação direta entre tamanho de grão e distância entre os pontos, a afirmação de van der Plas e Tobi (1965) - "... because obviously in analyzing a pegmatite with a grain size of several centimeters it would be a waste of time to count with a point distance of say 0.2 mm." - figura como uma evidente supersimplificação das ponderaçōes feitas por Chayes (1956) acerca do número de pontos a ser contado e da área a ser analisada em função da granulação da amostra. Ainda assim, van der Plas e Tobi (1965) argumentam que a correta avaliação dos erros, assumindo uma distribuição binomial, pressupōe que observaçoes sucessivas sejam independentes; ou seja. o espaçamento entre os pontos analisados tem de ser maior que o maior grão presente na área analisada, de forma que nenhum grão seja contado mais de uma vez.

Howarth (1998), por sua vez, argumenta que apesar do avanco representado pelo diagrama de van der Plas e Tobi, a distribuição binomial foi aproximada a uma distribuiçăo normal com base na aplicaçăo do Teorema do Limite Central para a sua construção. Esta aproximação conduz a uma imprecisão relativamente grande, o que leva Howarth (1998) a apresentar novas aproximaçōes. muito mais exatas, para o cálculo de uma distribuição binomial:

$$
\tilde{p}=100 * \pi / N
$$




$$
\begin{aligned}
& p(n)^{4}=100 *[\operatorname{Betalnv}(1-\alpha / 2, n+1, N-n)] \\
& p(n)^{\prime}=100 *[1-\operatorname{Betalnv}(1-\alpha / 2, N-n+1, n)]
\end{aligned}
$$

Eq. API.IC

onde $p(n)^{\prime \prime}$ e $p(n)^{\prime}$ sāo, respectivamente, os limites superior e inferior do intervalo de confiança da estimativa de $\mathrm{p}(\tilde{\mathrm{p}})$; n é o número de contagens de um dado mineral e $\mathrm{N}$ o número total de contagens; $\alpha$ é o limite de confiança; Betalnv retorna o inverso da distribuiçăo Beta cumulativa. O autor, com base nestas aproximaçoes, produz novos diagramas em substituição ao de van der Plas e Tobi.

Ao contrário do diagrama de van der Plas e Tobi, os diagramas e cálculos propostos por Howarth (1998) podem levar a intervalos assimétricos em tomo da média. Além disso, uma vantagem deste segundo método é que ele permite avaliar a concentração máxima apresentada por um mineral identificado petrograficamente, mas com zero contagens durante a análise modal:

$$
\begin{array}{ll}
\tilde{p}=0 & \text { Eq. API.2a } \\
p(0)^{u}=100^{*}\left(1-\alpha^{1 / N}\right) & \text { Eq. API.2b } \\
p(0)^{\prime}=0 & \text { Eq. API.2c }
\end{array}
$$

Com os diagramas de Howarth (1998), assim como o de van der Plas e Tobi, é possivel estimar o número de contagens necessárias de um dado mineral para se chegar a uma dada precisão com base na sua proporçāo. Segundo Howarth, mais do que isso, é possivel estimar o número total de contagens necessárias para que, em um conjunto com pelo menos 3 constituintes, tenha-se $100^{*}(1-$ ү) porcento de certeza de que todos eles estão dentro de um intervalo de confiança de comprimento $100 * 2 \Delta$ porcento em relação ao valor real:

$$
N=C_{\gamma} / \Delta^{2}
$$

onde $c_{\gamma}$ é definido como um fator de cobertura (Tabela API.1; cf. Howarth, 1998).

Tabela API.1:

Valores de cy em função de $\gamma^{*}$

\begin{tabular}{cc}
\hline$\gamma$ & $c_{\gamma}$ \\
\hline 0.01 & 1.96989 \\
0.05 & 1.27359 \\
0.10 & 1.00635 \\
0.20 & 0.74739 \\
\hline
\end{tabular}


A combinação do número total de pontos a serem contados, com o espaçamento da malha a ser utilizada - que deve ser maior que o maior dos grãos analisados, como discutido acima - leva automaticamente à área mínima a ser contada.

\section{Neilson e Brockman (1977)}

Todo o arcabouço teórico desenvolvido por van der Plas e Tobi (1965) e Howarth (1998) para se obter estimativas de erros para as análises modais tem como pressuposto que a distribuição dos grãos de um dado mineral em uma amostra segue uma distribuição binomial. Neilson e Brockman (1977) discutem a propriedade deste pressuposto para o caso da contagem de pontos.

A distribuiçāo binomial pressupõe, no caso da contagem de pontos, que a proporção relativa dos diversos minerais seja constante na amostra analisada. No caso de amostras heterogêneas. portanto, os erros estimados com base em uma distribuição binomial serão claramente subestimados.

Por outro lacio, é necessário que observaçöes sucessivas sejam independentes.

A utilização de uma malha de pontos com espaçamento maior que o maior dos grãos analisados, alocada aleatoriamente na amostra, garante que, de um ponto para outro da malha. sempre ocorra a passagem de um grão para outro da amostra. Não havendo correlação entre a distribuição de grãos adjacentes, os cálculos apresentados por Howarth (1998) podem ser aplicados. Entretanto, segundo Neilson e Brockman (1977), há evidências de que a independência entre grāos não é seguida pelas rochas mais comuns.

No caso de uma malha com espaçamento menor, mas ainda com grãos adjacentes independentes, parte das transiçöes de um ponto para outro na malha é caracterizada pela passagem de um ponto em um grão para outro no mesmo grão, causando correlação entre observações sucessivas. Neilson e Brockman (1977) demonstram, através de simulações de Monte Carlo, que neste caso, os erros observados são sempre maiores que os previstos pela distribuição binomial. sendo tanto maiores quanto maior a correlação entre pontos sucessivos (i.é. tanto maiores quanto menor a maltha).

No caso de grãos adjacentes dependentes, os pressupostos da distribuição binomial não sāo atendidos, independentemente do tamanho da malha utilizada.

Portanto, havendo ou nāo dependência entre grāos adjacentes, uma malha maior que o maior dos grãos tende a minimizar a correlaçăo entre observaçōes sucessivas. Ainda assim, como são 
analisadas seções, mesmo que as rochas sejam estritamente equigranulares, a área ocupada por cada grão na seção é variável, permitindo que pontos sucessivos na malha levem à análise de grăos não adjacentes, o que complica a modelaçāo do processo de amostragem.

Para testar a aplicabilidade da distribuição binomial, Neilson e Brockman (1977) realizam um experimento em que as contagens são feitas em $k$ conjuntos cada un com uma malha quadrada com um total de $\mathrm{N}$ pontos. Seguem-se os cálculos:

$$
\begin{array}{ll}
\text { se } \Sigma(a)=\sum_{j=1}^{k} a_{j}: & \\
\tilde{p}=100 /(k N) * \Sigma(x) & \text { Eq. API.4a } \\
s^{2}(\tilde{p})=\frac{10000 /\left[(k-1) N^{2} k\right]^{*}\left[\Sigma\left(x^{2}\right)-(\Sigma(x))^{2} / k\right]}{} & \text { Eq. APl.4b }
\end{array}
$$

onde $x_{j}(j=1, \ldots, k)$ é o número de ocorrências de um dado mineral no j-ésimo conjunto.

Aplicando um teste $F$, os referidos autores rejeitam - com uma confiabilidade de $99 \%$ - a hipótese de que a variância observada é igual à variância calculada assumindo-se uma distribuição binomial.

Além disso, a distribuição de freqüências do número de ocorrências de um dado mineral nos $k$ conjuntos é mal aproximada por uma distribuição de freqüências binomial. Por outro lado, essa mesma distribuição de freqüências se aproxima bastante de uma "distribuição normal de contagens" (cf. Neilson e Brockman, 1977).

Sendo assim, Neilson e Brockman (1977) conciuem: "This discussion leads to the inevitable conclusion that analytical errors in point-counting cannot be estimated realistically from established formulae..." e "It should be further emphasized that collection of data as one large set [...] precludes any realistic estimate of analytical error whatsoever.".

Os referidos autores propōe, então, que sejam distribuídas pela amostra, aleatoriamente e sem sobreposiçāo, $k$ malhas quadradas, cada uma com $N$ pontos equidistantes, e que os cálculos sejam feitos com base nas Equaçōes $4 a$ e 4b. Para um total de aproximadamente 1000 pontos, os autores sugerem $k=30$ e $N=36$. 


\section{Metodologia}

\subsection{ABORDAGEM METODOLÓGICA}

A discussão precedente mostra que todos os estudos até hoje estiveram fundamentados em discussōes teóricas, mas normalmente com poucos exemplos práticos. Tal ausência se deve em grande parte ao alto dispêndio de tempo necessário para se obter análises modais, o que inviabiliza a realização de um grande número de análises em uma mesma amostra. Além disso, como já destacado por Chayes (1956), há dificuldades práticas em se alocar aleatoriamente um grande número de malhas em uma única seção.

Sendo assim, não existem padrōes com composição conhecida que possam servir como base para aferil a exatidāo e a precisão dos métodos propostos, nem mesmo para se avaliar os diferentes métodos propostos para estimar os erros associados a estas medidas.

Com a utilização da microssonda eletrônica, entretanto, é possivel fazer um mapeamento detalinado da composição das amostras. São gerados simultaneamente diversos mapas, um para cada porção do espectro característico de emissão de raios-X, revelando os contrastes nos teores de elementos químicos previamente selecionados.

Vários mapas são necessários para que cada mineral presente na amostra apresente uma assinatura espectral especifica, e possa, dessa forma, ser identificado inequivocamente. Para visualização dos dados, no entanto, a informação contida nas diversas bandas deve ser resumida em imagens contendo cada uma no máximo três bandas (i.é. de forma a possibilitar a geração de uma composição RGB). No tratamento de imagens de satélite multiespectrais, isto é freqüentemente feito através de análises de principais componentes. Launeau et al. (1994) utilizam-se de técnicas como esta e observam que mais de $80 \%$ da variabilidade original está contida nos três primeiros principais componentes. Combinando estas três bandas, por comparação com observações em microscópio, torna-se possivel delimitar classes de diferentes cores na imagem e associá-las aos seus respectivos minerais. A seguir, a imagem é classificada, e as proporçôes em área são facilmente obtidas.

Um dos problemas encontrados por Launeau et al. (1994) reside no fato de que parte significativa da imagem (e.g. > 5\%) acaba não sendo classificada, por não se encaixar em nenhuma das classes preestabelecidas. Tal fato se deve em grande parte à presença de ruído nas imagens originais, mas também devido ao diâmetro relativamente grande do feixe eletrônico utilizado (e.g. $50 \mu \mathrm{m})$, que faz com que pixels localizados nos contatos intergranulares contenham informações 
mistas, e portanto, nāo se enquadrem em nenhuma das classes. Tal problema pode ser minimizado utilizando-se o menor feixe possivel, o que leva a uma diminuição na possibilidade de serem obtidas informações mistas, sem prejuizo para a resolução espacial das imagens.

A diminuição do ruído, por sua vez, pode ser obtida utilizando-se um feixe eletrônico com voltagem e/ou corrente mais altas, o que leva a um aumento das razöes de intensidade pico/radiação de fundo. Outra forma de diminuir o ruído nas imagens originais é aumentar os tempos de integração de contagens por ponto. Entretanto, tal procedimento acentua ainda mais o maior problema da técnica, que é o tempo excessivo necessário para a obtenção de imagens com grande resolução espacial de áreas significativas da amostra. Por exemplo, a aquisição de uma imagem de uma área de $1000 \mathrm{~mm}^{2}$ com espaçamento entre os pontos de análise de $250 \mu \mathrm{m}$, utilizando-se tempo de contagem igual a $0,1 \mathrm{~s}$, leva no mínimo 18 horas. Deste ponto de vista, torna-se evidente que uma técnica como esta nunca se tornará corriqueira nos estudos petrológicos convencionais. Com o aumento do espaçamento entre as análises, como realizado por Minnis (1984), o problema de amostragem torna-se o mesmo observado no caso da contagem em microscópio.

Ainda assim, imagens como estas, mesmo que em última análise não retratem fielmente a amostra, podem servir como padrões para que sejam testados os procedimentos de amostragem e estimativa de erros; ou seja, a partir de imagens deste tipo, é possivel simular diversas vezes os diferentes procedimentos propostos de maneira relativamente rápida, com a vantagem adicional de que a composição "real" da imagem é conhecida. Este é o objetivo do presente trabalho.

\section{III.2. AQUISICÃO DE IMAGENS}

Imagens de rochas graníticas pertencentes aos Granitos da Graciosa (Sul do Brasil; cf. Parte Iil) foram obtidas em microssonda eletrônica JEOL. JXA-86005, com sistema de automação Voyager 3.6.1 da NORAN, instalada no Laboratório de Microssonda Eletrônica do Instituto de Geociências Universidade de São Paulo.

Foram utilizadas seçōes delgadas polidas com dimensōes de $75 \times 49 \mathrm{~mm}$, que foram cobertas com um filme de C ( $25 \mathrm{~nm})$ com o evaporador AUTO 206 da EDWARDS.

As condições de voltagem e corrente do feixe eletrônico foram ajustadas para $20 \mathrm{kV}$ e $50 \mathrm{nA}$. respectivamente: foi utilizado feixe com diâmetro mínimo $(1 \mu \mathrm{m})$. Foram obtidos mapas em modo EDS para $\mathrm{Na}, \mathrm{Al}, \mathrm{Fe}, \mathrm{Ca}, \mathrm{K}, \mathrm{Si}, \mathrm{Ti}, \mathrm{Zr}$ e o conjunto formado pelos elementos terras raras leves (ETRL). O espaçamento entre as análises foi de $250 \mu \mathrm{m}$ e o tempo efetivo de contagem por ponto igual a 0.1 
5. As áreas ámostradas foram de aproximadamente $35 \times 55 \mathrm{~mm}$ (cf. Tabela API.2). O tempo total para obtençāo de cada imagem foi de cerca de 30 horas:

Tabela API.2:

Caracteristicas das imagens obtidas

\begin{tabular}{cccc}
\hline Amostra & $\begin{array}{c}\text { Dimensões } \\
(\mathbf{m m})\end{array}$ & $\begin{array}{c}\text { Área aprox. } \\
\left(\mathbf{m m}^{2}\right)\end{array}$ & Pontos \\
\hline Gra-11A & $53.75 \times 37,00$ & 1.990 & 32.184 \\
Gra-3A & $56.75 \times 30,00$ & 1.700 & 27.588 \\
Gra-9 & $52,75 \times 36,75$ & 1.940 & 31.376 \\
\hline
\end{tabular}

As imagens foram tratadas com o auxilio do programa ER-MAPER ${ }^{(\otimes)}$ no Laboratório de Geoprocessamento do Instituto de Geociências - Universidade de São Paulo. Foram geradas composiçōes RGB falsa cor com diferentes combinaçōes de elementos e com os três principais componentes (PC1, PC2, PC3), a fim de visualizar os resultados do mapeamento. As imagens foram classificadas de maneira supervisionada utilizando-se o método da máxima verossimilhança.

\section{III.3. SIMULACÕES}

Obtidas as imagens, foram escritas rotinas no programa Microsoft EXCEL, utilizando-se as facilidades do Microsoft VISUAL BASIC FOR APPLICATIONS para realização das simulaçōes dos métodos de amostragem em computador.

Foram feitas simulações utilizando-se o método da contagem de pontos variando-se tanto o támanho da área contada como o número de pontos (Tabela API.3). Para cada combinação de área e número de pontos, foram realizadas 50 simulações, com as áreas posicionadas aleatoriamente na área disponível para cada amostra.

Tabela API.3:

Codigos e caracteristicas das simulaçóes realizadas para cada amostra (P, M, G como indicado)

\begin{tabular}{|c|c|c|c|}
\hline \multirow{2}{*}{ Pontos } & \multicolumn{3}{|c|}{ Tamanhos } \\
\hline & P: $25 \times 20 \mathrm{~mm}$ & $\mathrm{M}: 25 \times 30 \mathrm{~mm}$ & G. $25 \times 40 \mathrm{~mm}$ \\
\hline 500 & P_500 & $M \leq 500$ & G_500 \\
\hline 1000 & P_1000 & $M \quad 1000$ & G_1000 \\
\hline 2000 & P_2000 & M_2000 & G_2000 \\
\hline 4000 & P...4000 & M 4000 & G 4000 \\
\hline
\end{tabular}


Os 36 conjuntos (12 para cada amostra) de 50 simulações foram comparados entre si e com grupos de controle através de técnicas de análise de variância (ANOVA) e de comparações múltiplas. seguindo-se as recomendaçōes de Zar (1999).

Os grupos de controle foram criados com o intuito de comparar os resultados obtidos nas simulaçōes com os esperados, assumindo-se que as distribuiçóes esperadas sejam binomiais. Para tanto, foi utilizado o gerador de números aleatórios do programa Microsoft EXCEL. Para a criação de cada grupo controle, foi necessário definir a proporçăo esperada (obtida, para cada mineral de cada amostra. com base na análise das imagens) e o número de tentativas (igual ao número de pontos na malha: 500, 1000, 2000 ou 4000). Sendo assim, foram criados 84 conjuntos (minerais -7 * diferentes números de pontos na malha $-4 *$ amostras - 3), cada um com 150 números aleatórios. Cada um desses grupos serviu de controle para as três simulações com tamanho da área analisada diferentes (i.é. P, $M, G$ ).

Como os conjuntos têm distribuição esperada binomial, foram utilizados testes estatísticos nãoparamétricos. Para a comparação das médias obtidas com as esperadas, foi utilizado o método de Kruskal-Wallis, seguido de comparaçöes com um grupo controle por um teste análogo ao teste paramétrico de Dunnet (Dunn, 1964 apud Zar, 1999). Para a comparação das variâncias foi utilizado o teste de Barlett, seguido de comparaçoes com um grupo controle também por um teste tipo Dunnet (Levy, 1975 apud Zar, 1999).

\subsection{MÉTODO DE NEILSON E BROCKMAN (1977)}

Foram obtidas ainda 31 análises modais para amostras graníticas dos Granitos da Graciosa (cf. Parte (1i). Dada a dificuldade de realização das análises pelo método de Neiison e Brockman (1977). as contagens foram realizadas segundo a metodologia de Chayes (1956), porém foram armazenados os resultados a cada 50 pontos, num total de $20-25$ conjuntos. Os espacamentos utilizados variaram entre 0,8 e 1,2 mm, normalmente próximo de metade ou de um terço do tamanho dos maiores grãos, dependendo da granulometria da amostra. As áreas amostradas foram de 1 ou 2 seções petrográficas convencionais.

A partir destes dados foram calculadas variâncias através das Equações APl.4a e API.4b, que foram comparadas com aquelas esperadas pela distribuiçăo binomial através do teste de Razão de Variâncias baseado no parâmetro $F\left(F=s_{1}{ }^{2} / s_{2}{ }^{2}\right.$ ) (cf. Zar, 1999). Além disso, foi aplicado o teste 
estatístico apresentado por Neilson e Brockman (1977) que combina os parâmetros $f$ de todos os minerais de cada amostra.

\section{RESULTADOS E DISCUSSÃO}

\section{IV.1. MAPAS COMPOSICIONAIS}

Foram obtidos mapas composicionais para três amostras de sienogranitos contendo biotita e/ou anfibólio como máficos principais. A textura das amostras é variável, desde equigranular de granulação média (Amostra 3A), a inequigranular, também de granulação média (Amostra 11A), e finalmente porfirítica, de granulação fina-média (Amostra 9).

Os minerais podem ser facilmente identificados nas composicões $P C 1(R)-P C 2(G)-P C 3(B)$ (Figura API.1). As imagens foram classificadas e permitiram identificar seis (Amostra 3A) ou sete (Amostras 11A e 9) fases minerais (Tabela API.4).

Tabela API.4:

Composiç̃es modais "ideais"

\begin{tabular}{|c|c|c|c|}
\hline \multirow{2}{*}{ Mineral } & \multicolumn{3}{|c|}{ Quantidade (\%) } \\
\hline & Amostra $11 \mathrm{~A}$ & Amostra $3 A$ & Amostra 9 \\
\hline Feldspato aicalino (1) & $33.1 \%$ & $41,0 \%$ & $38,5 \%$ \\
\hline Quartzo (2) & $31,3 \%$ & $28.4 \%$ & $29.0 \%$ \\
\hline Plagioclásio (3) & $30,7 \%$ & $28,6 \%$ & $27,3 \%$ \\
\hline Anfibólio (4) & $4,28 \%$ & $1.82 \%$ & $0,73 \%$ \\
\hline Biotita (5) & $0,19 \%$ & - & $3.99 \%$ \\
\hline IImenita (6) & $0.43 \%$ & $0,12 \%$ & $0,42 \%$ \\
\hline Zircão (7) & $0,03 \%$ & $0.01 \%$ & $0,03 \%$ \\
\hline
\end{tabular}

\section{IV.2. SIMULACÕES}

\section{Médias}

Os resultados da comparação estatística entre as médias obtidas com aquelas esperadas a partir da análise das imagens são resumidos na Figura API.2. As barras do histograma representam a freqüência (relativa) com que os valores obtidos podem ser considerados iguais aos valores esperados com um nível de confiabilidade de $95 \%$. 

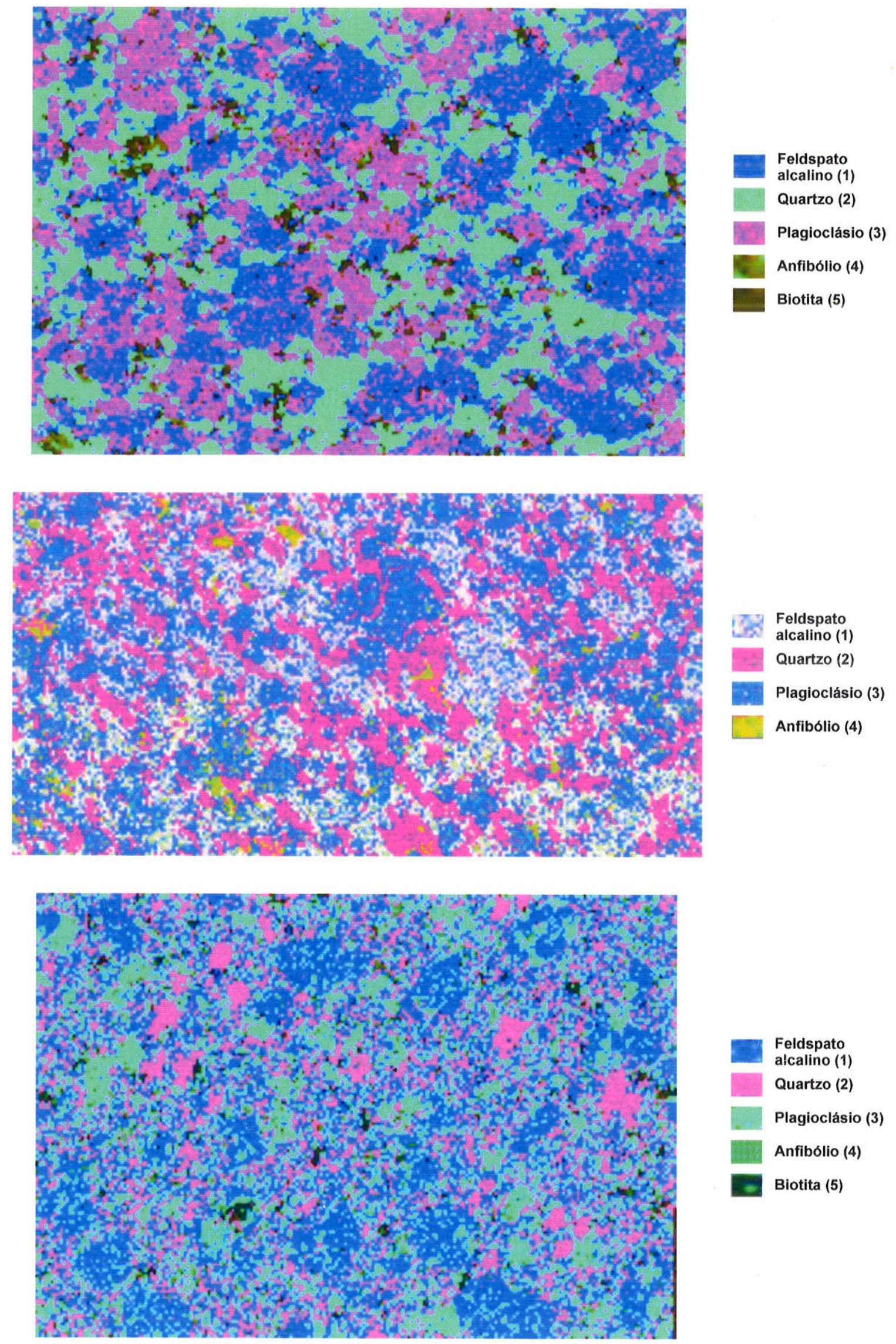

Figura API.1: Composições $P C 1(R)-P C 2(G)$ - $P C 3(B)$. Amostras (a) 11A; (b) 3A; (c) 9 . 


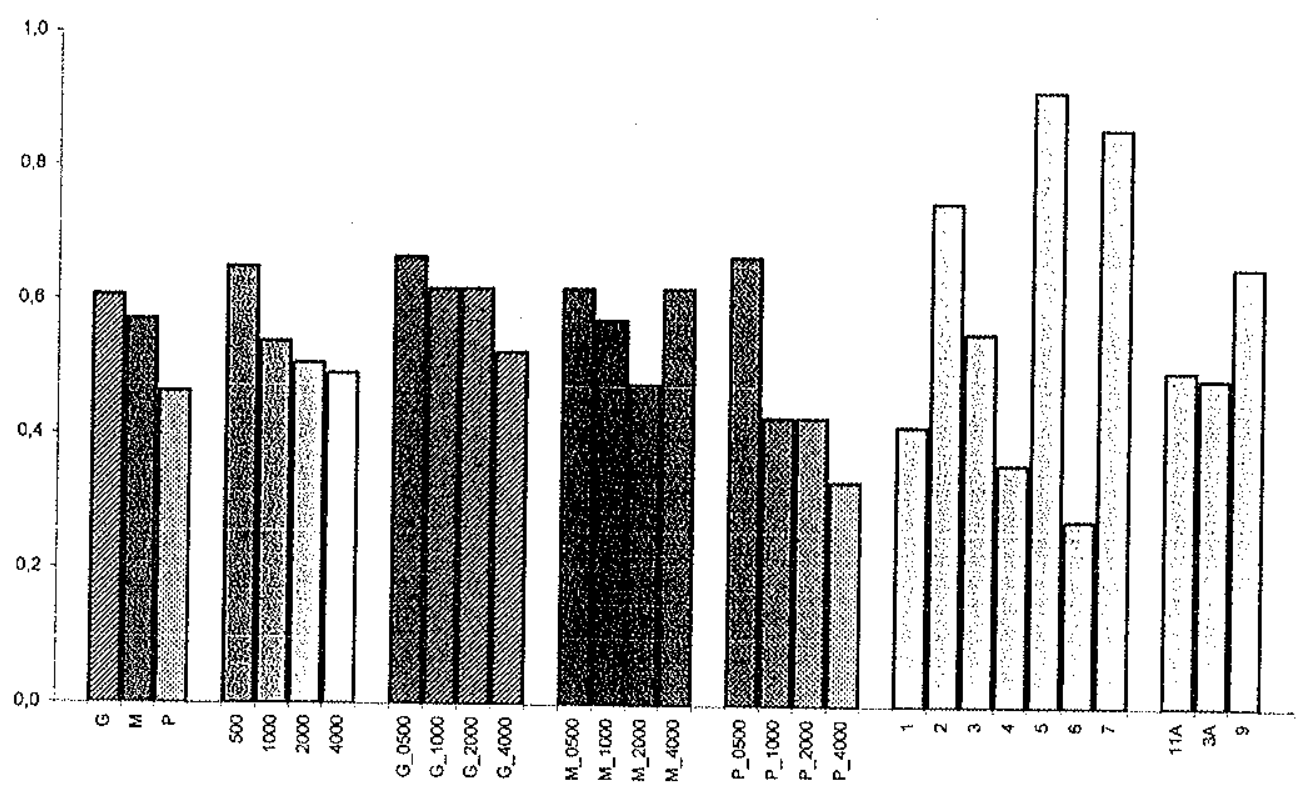

Figura API.2: Histograma mostrando a freqüência relativa de simulaçóes que levaram a médias iguais aos valores esperados com nivel de confiabilidade de $95 \%$.

Observause que, de maneira geral, o número de simulações em que as médias observadas são iguais às esperadas diminui com a diminuição da área (e.g. maior nas simulações $G$, intermediário nas $M$ e menor nas $P$ ) e com o aumento do número de pontos (e.g. diminui de 500 até 4000). Tanto um como o outro têm como efeito a diminuição do tamanho do espaçamento da malha, demonstrando que o pressuposto de independência de observaçöes consecutivas é violado, e que essa violação impõe um viés nos resultados. (Figura API.2)

É interessante notar que a Amostra 9, aquela com granulação mais fina (ct. Figura API.1). apresenta maior número de valores iguais aos esperados (Figura API.2), o que corrobora a dedução acima, já que a violação do referido pressuposto deve ser menos acentuada nesse caso.

Já os resultados para cada uma das fases minerais (1-7. Figura API.2) são pouco claros. Com base na discussão acima, pode-se deduzir que as fases 1,2 e 3 (feldspato alcalino, quartzo e plagioclásio, respectivamente) deveriam apresentar menos valores iguais aos esperados que as demais fases (biotita e acessórios), porém este comportamento só observado entre as fases 1 e 3 , e 5 e 7. Tal resultado pode refletir heterogeneidades na distribuiçắo das fases 2.4 e 6 na amostra.

Na Figura API.3 são apresentados os módulos dos desvios relativos à média esperada ([valor. observado-valor esperado]/valor esperado) para cada uma das simulações executadas. Observa-se que com a diminuição da área amostrada (e.g. de G, para $M$ e para P), há uma tendência geral de aumento desses desvios relativos, reforçando as conclusōes obtidas com base na Figura API.2. 

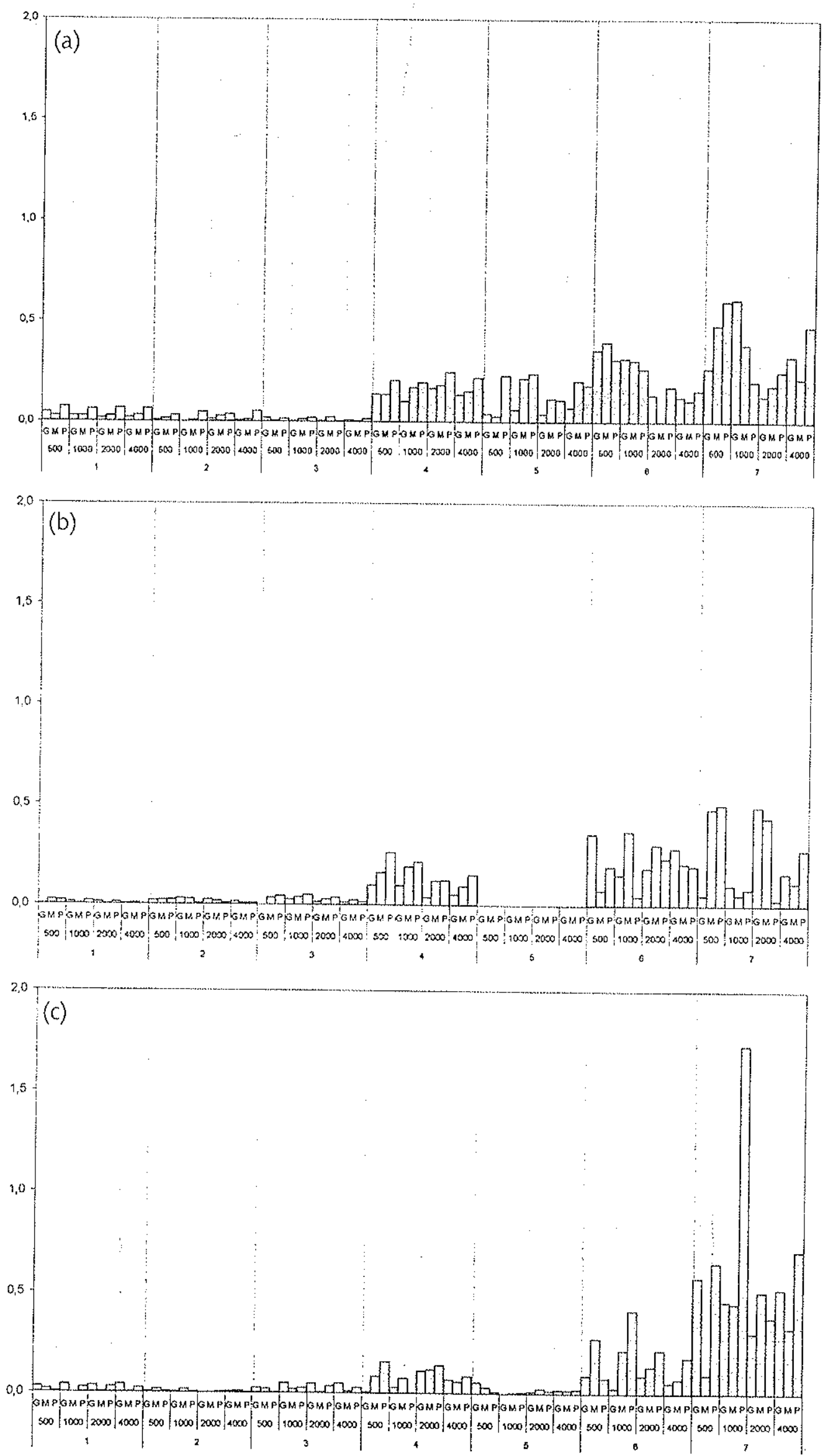

Figura API.3: Histogramas mostrando os módulos dos desvios relativos das médias em relação ao valor esperado ([observado - esperado]/valor esperado). Amostras (a) $11 A$, (b) $3 A$. (c) 9 . 
Em contrapartida, a tendência de aumento desses desvios com a variação do número de pontos é menos clara. Ainda assim, em muitos casos parece haver uma diminuição do desvio em relação ao esperado com o aumento do número de pontos (Figura API.3). Este aparente ganho de exatidão parece ser o resultado de dois fatores com efeitos contrários. Por um lado. o aumento no número de pontos tende a melhorar as estatísticas de contagem, levando a desvios menores. Entretanto, o que a análise de variâncias (Figura API.2) mostra é que a diminuição do espaçamento da malha, resultante do aumento do número de pontos, tende a inserir um viés no resultado, de forma que o ganho de exatidão é apenas aparente.

\section{Desvios padrão}

Uma das mais importantes questões colocadas na literatura internacional quanto ao método de contagem de pontos é decidir qual a melhor forma de se avaliar os erros resultantes ( $c$. acima).

Uma análise semelhante à precedente pode ser feita para o caso dos desvios padrão observados e esperados com base em uma distribuição binomial. Neste sentido, as Figuras API.4 e API.5 são análogas às Figuras API.2 e API.3, à exceção de que na Figura API.5 são apresentados os desvios relativos e não seus módulos. As relações para os desvios padrão são em geral mais claras que para as médias.

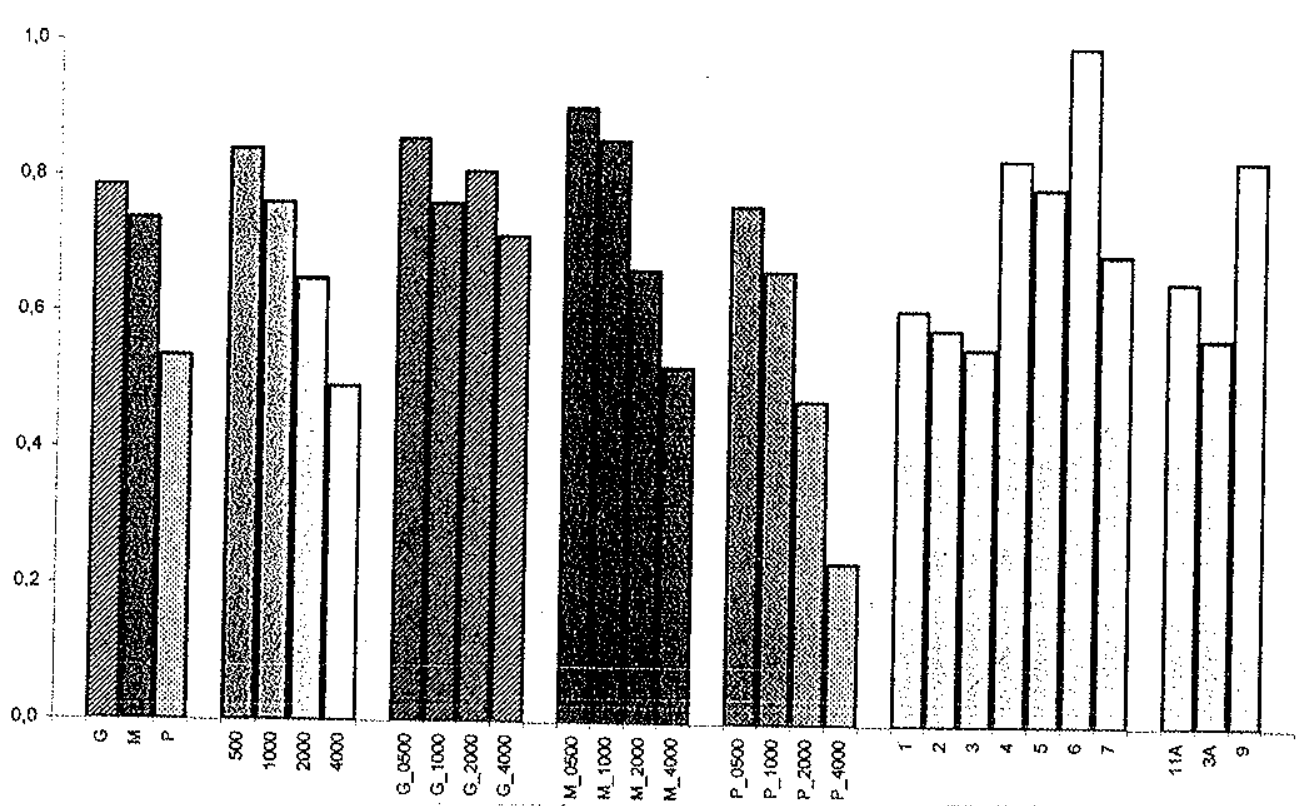

Figura API.4: Histograma mostrando a freqüência relativa de simulaçốes que levaram a desvios padrão observados iguais aos esperados com nivel de confiabilidade de $95 \%$. 

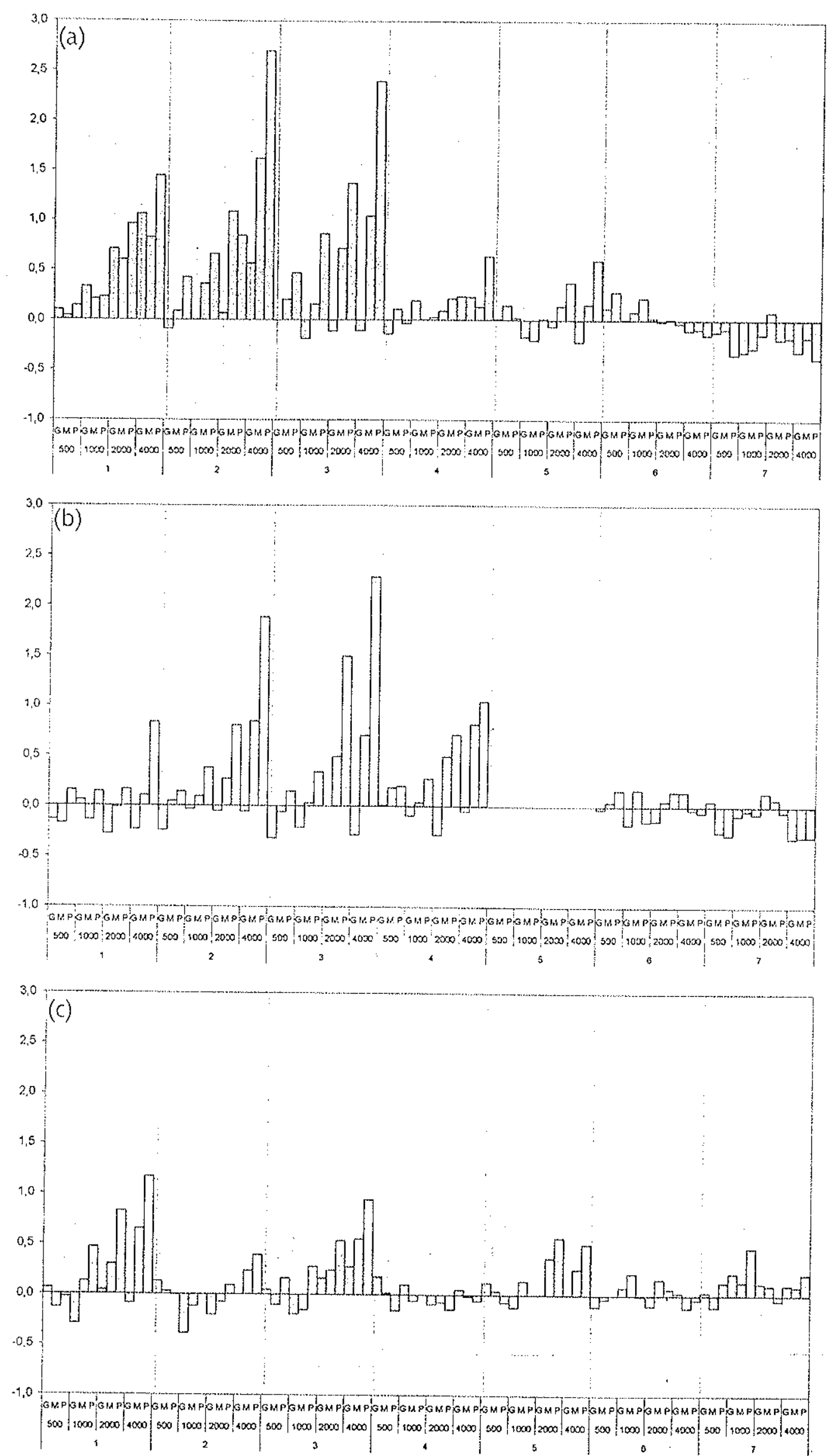

Figura API.5: Histogramas mostrando os modulos dos desvios relativos dos desvios padrão em relação aos esperados ([valor - esperado]/ esperado). Amostras (a) 11A, (b) 3A, (c) 9 . 
A Figura API. 4 mostra que em cerca de $70 \%$ dos casos, os desvios padrão observados podem ser considerados iguais aos desvios padrão esperados a partir de uma distribuição binomial. A tendência de distanciamento em relaçăo à binomial com a diminuição do espaçamento da malha seja por aumento do número de pontos ou por diminuição da área - é. entretanto, ainda mais acentuada.

Percebe-se ainda que para os minerais 1,2 e 3 , o número de simulações que levaram a desvios iguais aos binomiais é menor que para os demais minerais (cf. Figura API.1). Da mesma forma que para as médias, a Amostra 9, de granulaçāo mais fina, mostra um número maior de valores iguais aos binomiais. Fica evidente a partir destes dados que a violação do pressuposto de independência de observaçōes sucessivas leva a um desvio em relação à distribuição binomial.

Os desvios dos valores observados em relação aos esperados ([observado - esperado]/esperado) são apresentados na Figura API.5. São bem marcadas as tendências de aumento dos desvios em relação à binomial tanto com a diminuição do tamanho da área amostrada, como com o aumento do número de pontos, em concordância com as conclusões a partir da Figura API.4. O ponto a ser aqui destacado é que a maioria das simulações com a maior das áreas (G) mostra desvios padrōes próximos, e em muitos casos menores, que os desvios esperados. Conclui-se, portanto, que estas áreas são satisfatórias para a realização de contagens modais em rochas de granulacãa média.

\section{IV.3. MÉTODO DE NEILSON E BROCKMAN (1977)}

Os desvios padrão calculados com base nas 31 análises modais realizadas foram comparados com aqueles esperados por uma distibuição binomial (Figura API.6 v. também Tabela IV.2).

Cerca de 70\% dos desvios padrão calculados podem ser considerados iguais aos esperados. Entretanto, em apenas 30\% das amostras os desvios padrão dos vários minerais presentes são simultaneamente iguais aos esperados, o que é avaliado pelo teste de Neilson e Brockman (1977) (cf. Figura API.6).

A diferença nestes valores pode ser explicada com base na análise do comportamento de cada mineral individualmente. Dë maneira semelhante ao observado nas simulações, para os minerais mais aburidantès e com grãos maiores (eig. feldspato alcalino, quartzo), os desvios padrão são distintos daqueles esperados um maior número de vezes, enquanto para minerais menores e menos abundantes (e.g. opacos) a concordância com os valores esperados é muito maior. (cf. Figura API.6) 


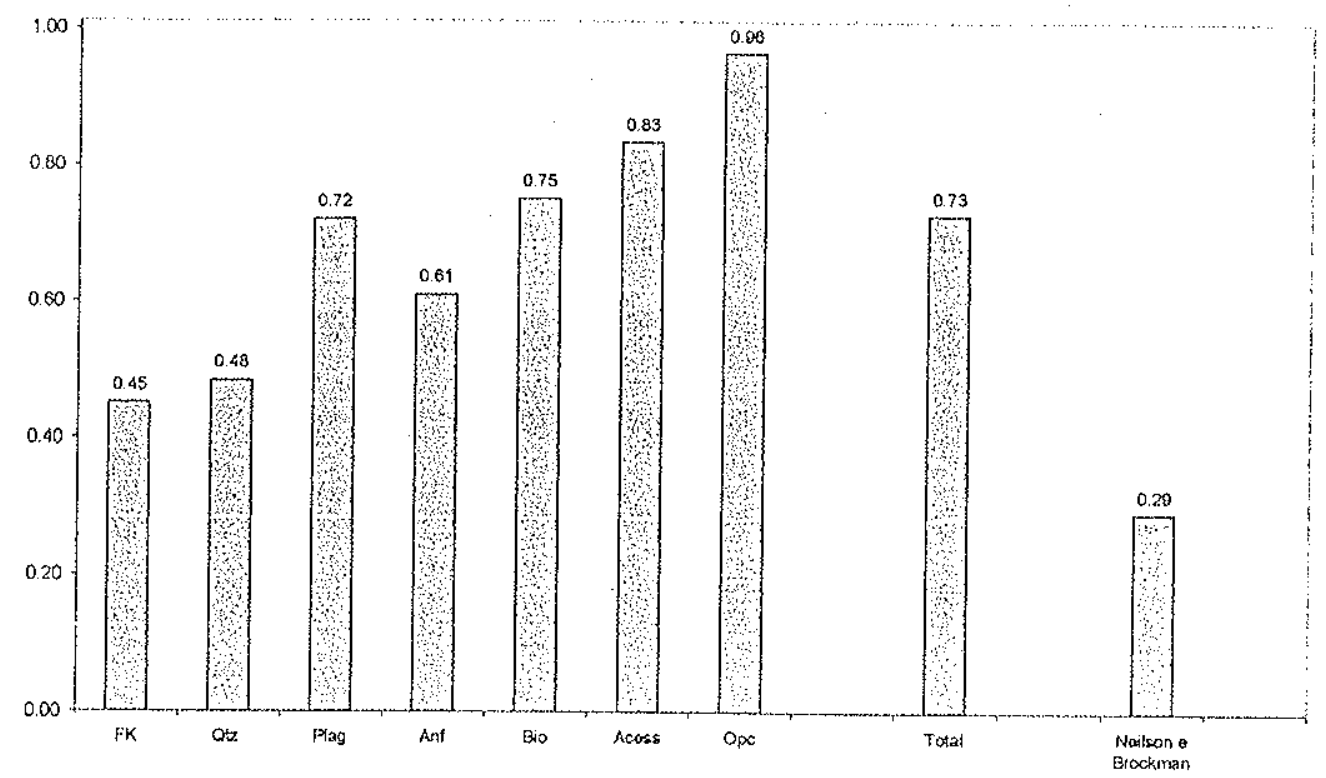

Figura AP1.6: Histograma mostrando a freqüência relativa de simulaçóes que levaram a desvios padrão observados iguais aos esperados por uma distribuição binomial, com nivel de confiabilidade de 95\%. De FK a Plag, integração dos resultados de testes de Razão de Variâncias: Neilson e Brockman corresponde a um método que considera todos os minerais de cada amostra.

É interessante notar que as amostras em que os desvios padrão de todos os minerais foram considerados iguais aos binomiais săo aquelas de granulação mais fina, o que está de acordo com os resultados acima. Para as amostras de granulação mais grossa, por outro lado, a utilização de duas seções petrográficas e espaçamentos maiores $(1,0$ a $1.2 \mathrm{~mm}$ ) não foi suficiente para anular o efeito da dependência de observações consecutivas.

Portanto, as conclusōes alcançadas com base na análise de um número significativo de amostras reais são muito similares àquelas obtidas através das simulaçōes.

\section{CONCLUSÕES}

O presente trabalho mostra que a integração de técnicas de microanálise e de análise de imagens multiespectrais permite produzir mapas da composição mineralogica de rochas de maneira relativamente simples, porém demorada.

A partir de três mapas deste tipo foram produzidas simulações do processo de contagem de pontos. A violação do pressuposto de independência de observações consecutivas em grau crescente tem como efeito um progressivo enviesamento dos resultados, com simultâneo aumento dos desvios padrāo observados em relação aos esperados segundo uma distribuição binomial. Essa tendência permite inferir que os desvios padrão binomiais podem ser utilizados como boa aproximação aos 
erros reais desde que se utilize espaçamento superior à dimensão do maior gräo, o que não foi possivel nas simulaçöes devido às dimensões relativamente limitadas dos mapas obtidos. Demonstrase ainda que o ganho de precisão esperado com o aumento do número de pontos é parcialmente anulado pela dependência de observacōes consecutivas.

As contagens modais realizadas segundo o método de Neilson e Brockman (1977) mostraram resultados semelhantes aos das simulações, evidenciando ainda mais o efeito da dependência de observaçoes consecutivas. Os resultados mostra ainda que a prática comum de contagem de cerca de 1000 pontos em uma ou duas seções petrográficas convencionais (Chayes, 1956; Neilson e Brockman, 1977) é razoável apenas para rochas de granulação fina a fina-média.

Considerando que o método de Neilson e Brockman (1977), mesmo na variante aqui utilizada, leva a um aumento considerável do tempo dispendido nas contagens, sugere-se que seja feito um esforço para a utilização de malhas com espaçamento maior que o tamanho dos maiores grãos. Em muitos casos isto pode ser inviável na prática, e nesse caso, a utilização do método de Neilson e Brockman (1977) é necessária pelo menos para algumas amostras de referência, para se avaliar a qualidade da aproximação por uma distribuição binomial.

Ao contrário do que ocorre hoje, deve se tomar prática corriqueira a apresentação de estimativas de erros associados às estimativas das composiçōes modais.

Um prolongamento importante do presente trabalho seria o estudo da representatividade das amostras utilizadas para finalidades petrográficas e geoquímicas bem como da sua homogeneidade. temas em parte correlacionados.

\section{REFERÊNCIAS BIBLIOGRÁFICAS}

Chayes, F. (1949) A simple point counter for thin-section analysis. American Mineralogist, 34: 1-11. Chayes, F. (1956) Petrographic modal analysis. John Wiley \& Sons. New York.

Howarth. R.\}. (1998) Improved estimators of uncertainty in proportions, point-counting, and passfail test results. American Journal of Science, 298: 594-607.

Hunt, W.F. (1924) An improved Wentworth recording micrometer. American Mineralogist, 9: 190193.

Hurlbut, C. (1939) An electric counter for thin-section analysis. American Journal of Science, 237: 253-261.

Járai. A.; Kozák, M.: Rózsa, P. (1997) Comparison of the methods of rock-microscopic grain-size determination and quantitative analysis. Mathematical Geology, 29(8): 977-991. 
Launeau, P.; Cruden, A.R.; Bouchez, J.-L. (1994) Mineral recognition in digital images of rocks: a new approach using multichannel classification. Canadian Mineralogist. 32: 919-933.

Minnis, M.M. (1984) An automatic point-counting method for mineralogical assessment. AAPG Bulletin, 68: 744^752.

Neilson, M.J.; Brockman, G.F. (1977) The error associated with point counting. American Mineralogist, 62: 1238-1244.

Van der Plas, L..; Tobi, A.C. (1965) A chart for judging the reliability of point counting results. American Journal of Science, 263: 87-90

Zar, J.H. (1999) Biostatiscal analysis, $4^{\text {th }}$ Ed. Prentice-Hall. New Jersey. 929 p.

Wentworth. C.J. (1923) An improved recording micrometer for rock analysis, Journal of Geology. 31: $228-232$. 
Apêndice //:

\section{UMA AVALIACÃO CRITICA DO}

MÉTODO DE SCHUMACHER DE AVALIACÃO DAS

RAZÕES FE ${ }^{2+} / F E^{3+}$ EM ANFIBÓLIOS 


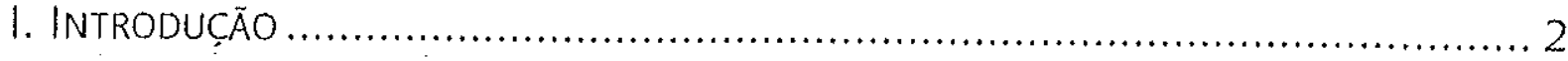

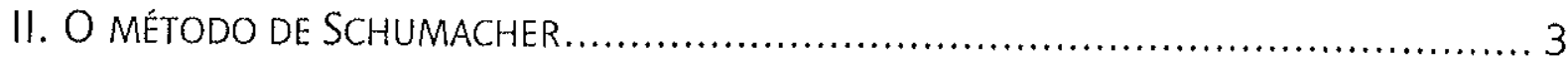

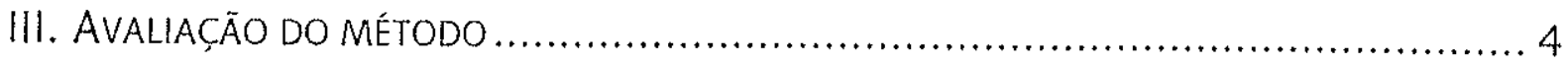

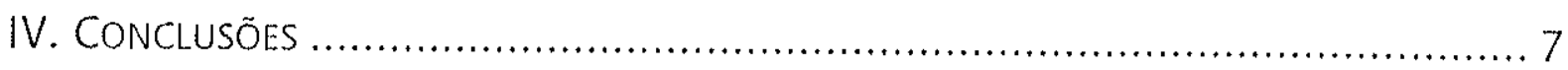

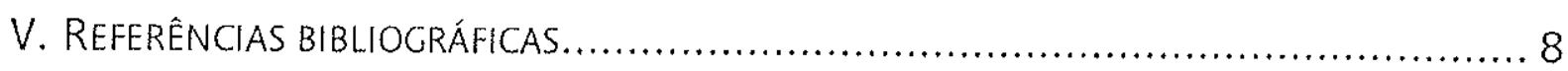




\section{INTRODUCÃO}

Com a disseminação das microssondas eletrônicas e a sua incapacidade de discriminar, pelo menos em trabalhos de rotina, diferentes valências de um mesmo elemento químico, com destaque para $\mathrm{Fe}^{2+}$ e $\mathrm{Fe}^{3+}$, e considerando ainda a relevância mineralógica e petrológica dessas determinaçōes, o desenvolvimento de metodologias que permitam estimar ou fazer diretamente essas medidas se tornou um problema de maior importância para mineralogistas e petrólogos.

Apesar de uma série de técnicas analíticas virem sendo desenvolvidas nos últimos anos, elas ainda não estão disponíveis para a grande maioria dos usuários, seja pela escassez de equipamentos especializados (e.g. sondas Synchrotron - Delaney et al., 1998; microscópios eletrônicos de transmissão - Buseck e Self, 1992; entre outros - cf. Enders et al., 2000), seja pelas dificuldades analíticas envolvidas (e.g. métodos do flanco, da deriva de picos, etc. - ct. Enders et al., 2000 e referências lá citadas).

Determinações diretas en concentrados, por sua vez, esbarram na dificuldade de preparação dos mesmos (e.g. separação de inclusōes), bem como nas complexidades derivadas da presenca de zoneamentos composicionais na grande maioria das situaçöes geológicas.

Sendo assim, apesar das incertezas involvidas, a melhor alternativa continua sendo a utilização de cálculos estequiométricos. Para uma grande quantidade de minerais, de estrutura relativamente simples e pouco variável e nos quais apenas um elemento apresenta diferentes valências, tais métodos sāo relativamente confiáveis e têm como maior problema a necessidade de análises bastante precisas, a fim de se evitar resultados finais com erros excessivos (ct. Droop, 1987; Enders et al., 2000).

Para o caso especial dos anfibólios, em que a necessidade de determinação dos teores de $\mathrm{Fe}^{2+}$ e $\mathrm{Fe}^{3+}$, bem como as dificuldades de estabelecimento de critérios cristaloquímicos adequados para o cálculo são críticas, uma literatura relativamente longa se desenvolveu sobre o problema, com destaque para as contribuiçōes de Robinson et al. (1982) e Schumacher (1991; 1997. in Leake et al., 1997).

O método de Schumacher passou a ter destaque na literatura internacional depois da publicaçăo da nova classificação dos anfibólios (Leake et al., 1997), que sugere a utilização do mesmo. Entretanto, o método tem gerado certa controvérsia, já que trabalhos recentes têm 
demonstrado que sua aplicação resulta em valores inadequados em diversas situações (e.g. Enders et al., 2000; Martins, 2001).

O grande número de análises químicas de anfibólios obtidas no escopo deste trabalho (c.a. 600: (f. Parte IV) e a diversidade de tipos analisados - que se distribuem continuamente no espectro desde anfibólios tipicamente cálcicos até tipicamente sódicos, e incluem ainda tipos ferromagnesianos - permitem que uma análise crítica do método de Schumacher possa ser feita (Figura APII.1). Uma característica interessante do conjunto de dados é que eles foram obtidos em condiçoes de rotina - na verdade, como parte de um estudo petrológico mais amplo - e não com o objetivo específico de se avaliar o método.

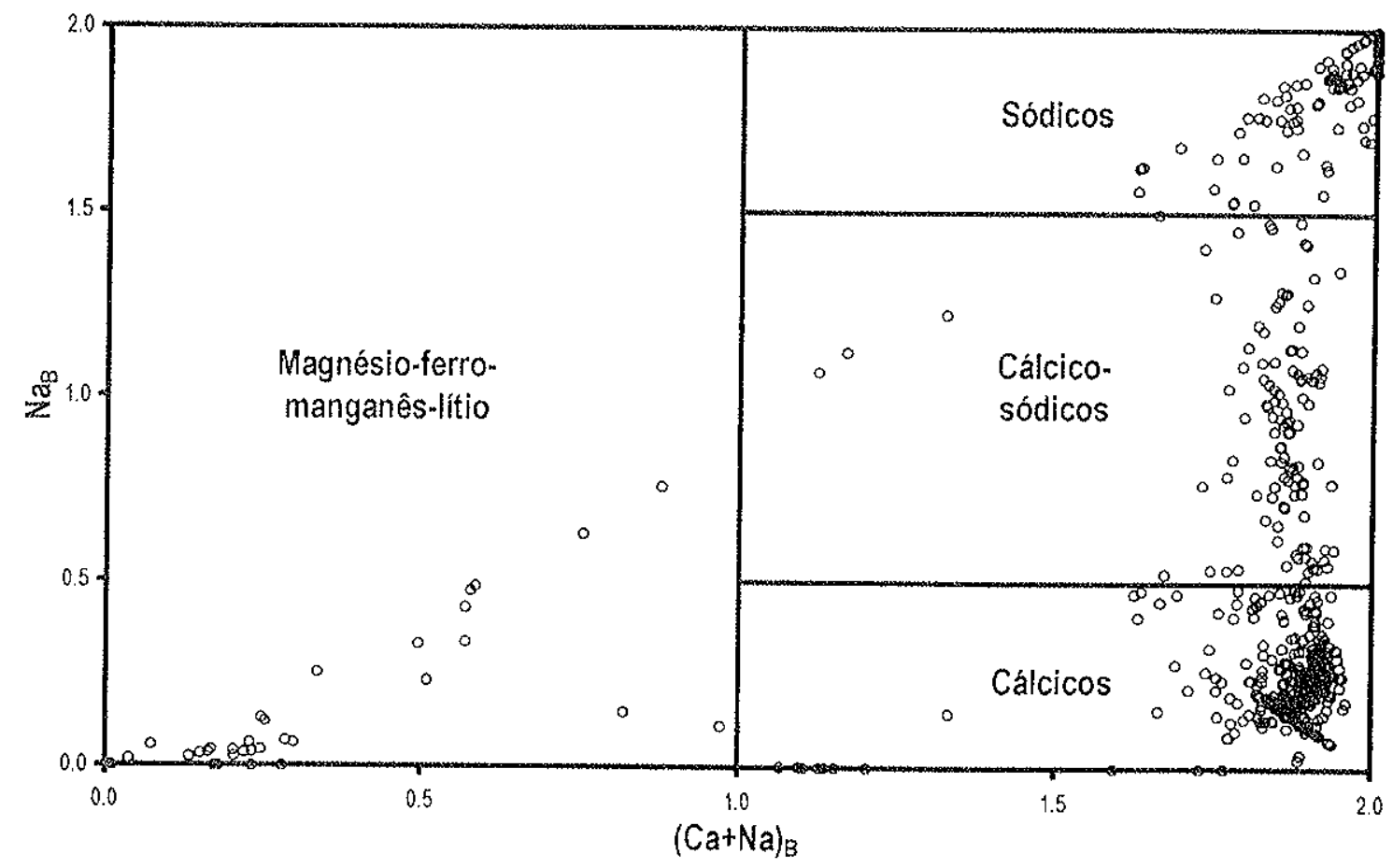

Figura APII.1: Diagrama $\mathrm{Na}_{B} \times[\mathrm{Ca}+\mathrm{Na}]_{B}$ para classificação dos anfibolios (Leake et al., 1997) mostrando a diversidade composicional do conjunto analisado. Cátions calculados com base no método de Schumacher (n Leake et al., 1997)

\section{O MÉTOdO DE SCHUMACHER}

Segundo Schumacher (in Leake et al., 1997). a grande dificuldade na utilização de métodos estequiométricos para o caso dos anfibólios reside na escolha do grupo de cátions a ser mantido fixo. já que a maioria das escolhas leva a resultados com estequiometria viável. o método por ele proposto tem como base o cálculo de um total de nove fatores de correção, com suposiçōes variáveis, a partir de análises recalculadas para 230 . considerando todo ferro como bivalente. 
Este procedimento fornece quatro opções que resultam em estimativas mínimas de $\mathrm{Fe}^{3+}$ :

(a) 8 cátions Si (8Si);

(b) 16 cátions totais (16Cat);

(c) 15 cátions totais excluindo-se Na e K (15eNK):

(d) todo ferro como $\mathrm{Fe}^{2+}$ (a// Fe2);

e cinco outras se caracterizam como estimativas máximas de $\mathrm{Fe}^{3++}$ :

(e) 8 cátions Si + Al (8SiAl);

(f) 15 cátions totais excluindo-se $\mathrm{K}(15 \mathrm{eK})$;

(g) 13 cátions totais excluindonse Ca. Na e K (1.3eCNK);

(h) todo ferro como Fe3+ (a//Fe3);

(i) todos os íons tri- e tetravalentes presentes nos 2 sítios M2-36/[46-Si-Ti-Al-Cr] (10SFe3).

Para se obter o teor final de $\mathrm{Fe}^{3+}$ devem ser consideradas a menor entre as estimativas mínimas e a maior entre as máximas, a partir das quảs se obtém, por média simples, um fator de correção final, a ser aplicado a todos os íons presentes. O teor de ferro trivalente será igual a $2 \times(23-0)$, onde $O$ corresponde ao número de íons O obtido após esta última correção.

O autor ressalta que o intervalo de variação dos resultados finais possiveis pode ser grande em função da complexidade composicional, fato que acarreta significativa influência na classificação final dos minerais do grupo dos anfibólios, e recomenda que sempre seja explicitado claramente o procedimento adotado para o cálculo, qualquer que seja ele. (cf. Leake et al., 1997)

\section{Avaliação do mÉTOdo}

Para que se avalie o método de Schumacher, é necessário que se conheça quais critérios cristaloquímicos foram efetivamente utilizados pelo método (i.é. qual foi a estimativa máxima utilizada e qual foi a mínima), o que é possivel com a utilização das planilhas MINCAL (Gualda e Vlach, em preparação).

A sintese dos resultados aparece nas Figuras APll.2 e APII.3. Na Figura APII.2, é mostrada a freqüência com que cada critério cristaloquímico foi selecionado para o cálculo do resultado final para os anfibólios por nós analisados. Já na figura APII:3, são ilustradas as freqüências com que cada combinação de critérios foi utilizada; considerando-se cada grupo de anfibólios independentemente. 


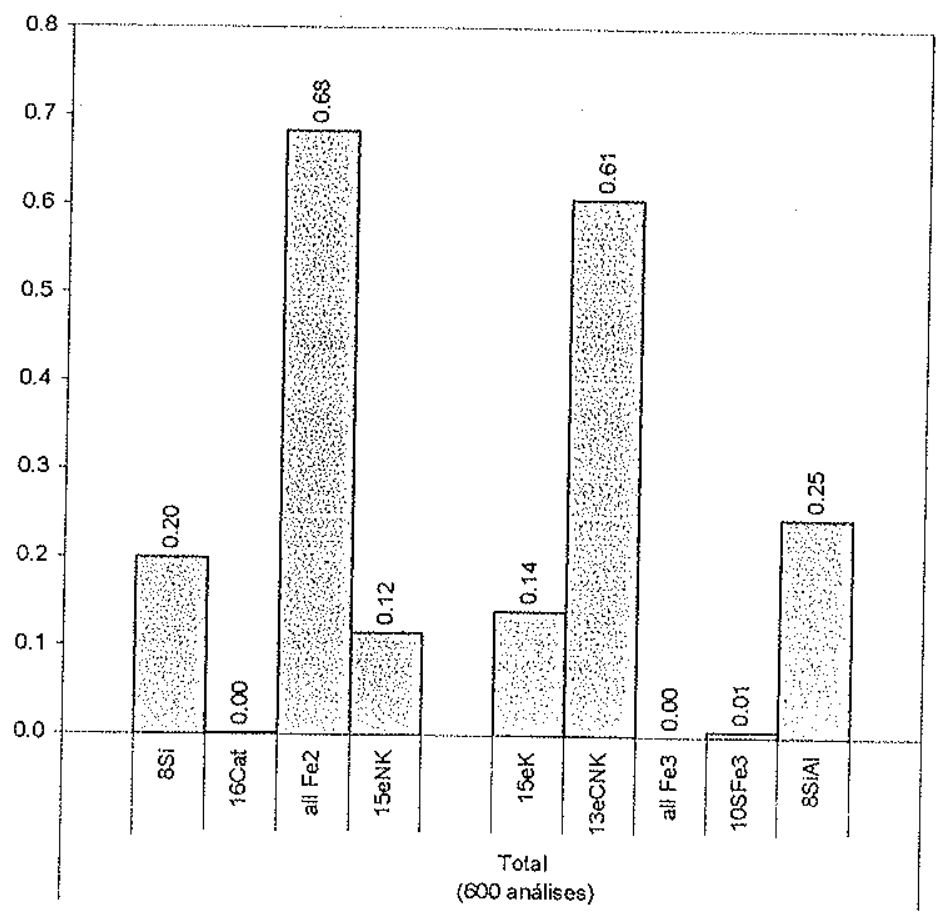

Figura APIl.2: Histograma mostrando a freqüencia relativa com que cada criterio cristaloquímico foi utilizado pelo método de Schumacher (in Leake et al. 1997) para o conjunto total de dados.

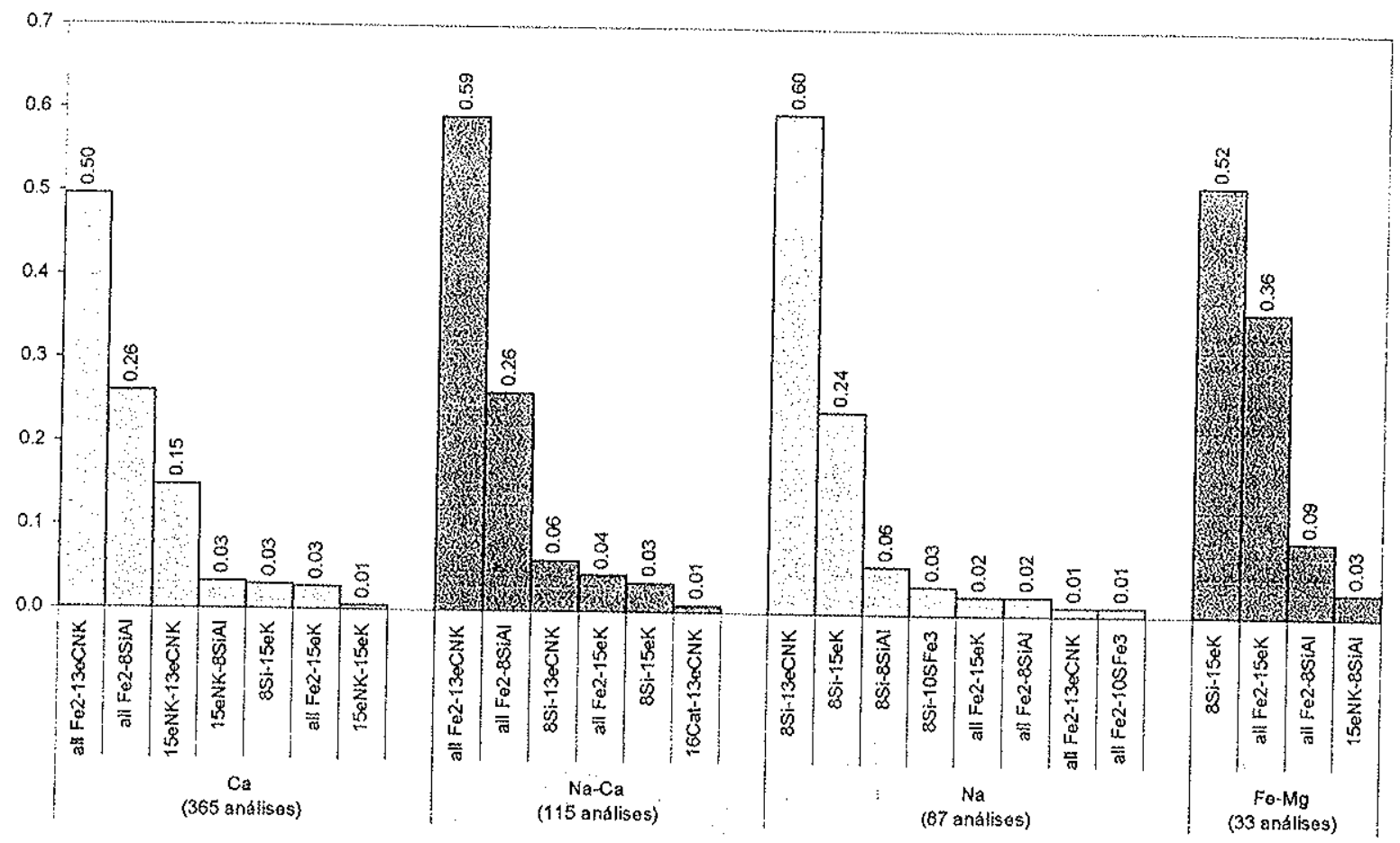

Figura APII.3: Histograma mostrando a freqüência relativa com que determinadas combinaçōes de criterios cristaloquímicos foram utilizadas pelo metodo de Schümacher (in Leake et al., 1997) para cada um dos grupos principais de anfibolios (classificação segundo leake et al., 1997). Combinaçōes com freqüencia relativa menor que 0,01 foram omitidas. 
Os critérios 16Cat, all Fe3 e $10 \mathrm{FFe} 3$ näo foram selecionados ou foram selecionados apenas marginalmente. Desta forma, não há necessidade de discussão a seu respeito.

Dentre as estimativas mínimas, al/ Fe2, 8Si e 15eNK foram Litilizadas, nesta ordem de freqüência (Figura APII.2).

Estimativas utilizando-se a// Fe2 são muito pouco realistas para a grande maioria dos casos - à exceção de anfibólios ferro-magnesianos, que compõem apenas 5\% das análises do conjunto -, já que existem inúmeras evidências de que ferro aparece em mais de uma valência em todos os tipos de anfibólio (cf. Deer et al., 1997).

Analogamente, a presença de Al em coordenação tetraédrica é certa também para a grande maioria dos casos, o que evidencia a falta de propriedade no uso das estimativas 8Si. Robinson et al. (1982) argumentam que para alguns anfibólios sódicos pobres em Al, tais estimativas poderiam ser razoáveis; entretanto, Enders et al. (2000) demonstram que este não é o caso, e que as estimativas baseadas em 8 Si estão entre as menos adequadas.

Como discutido por Robinson et al. (1982), as estimativas com base em $15 \mathrm{eNK}$ podem ser as mais recomendadas para anfibólios ferro-magnesianos e para aqueles da série tremolita-actinolitaferro-actinolita; infelizmente, o conjunto de dados aqui analisado inclui apenas uma pequena proporção de anfibólios ferro-magnesianos e não possui representantes desta última série. Ainda assim, a análise da Figura APII.3 mostra que o método 15 eNK é importante apenas para os anfibólios cálcicos, que em todos os casos incluem Na nas posições B (Figura APIl.1: cf. também Deer et al, 1997).

Já dentre as estimativas máximas, $13 \mathrm{eCNK}$, 8SiAl e $15 \mathrm{eK}$ foram utilizadas, nesta ordem de freqüência (Figura APII.2).

As estimativas $13 \mathrm{eCNK}$ são as mais recomendadas para a maioria dos anfibólios (Robinson et al. 1982), à excessão dos anfibólios ferro-magnesianos, em que não têm fundamento cristaloquímico. Em algumas situaçoes, entretanto, as estimativas $13 \mathrm{eCNK}$ conduzem a resultados em que a posiçăo tetraédrica fica apenas parcialmente preenchida, o que não deve ocorrer na realidade. Nestes casos, as melhores aproximaçōes serāo dadas péläs estimativas 8SiAl. Entretanto, somente nestes casos elas são recomendadas, já que não permitem a presença do Al em coordenação octaédrica. 
Finalmente, estimativas $15 \mathrm{eK}$ podem ser razoáveis para anfibólios que apresentam a posição A vacante, situação mais típica em anfibólios sódicos da série glaucofânio-riebeckita e cálcico-sódicos da série winchita -barroisita. Entretanto, a situação mais comum deve ser de ocupação parcial do sítio A.

Da análise acima depreende-se que os métodos que levam a resultados mais apropriados são 15 eNK, $13 \mathrm{eCNK}$ e $15 \mathrm{eK}$ (8SiAl em casos especiais). Neste sentido, a utilizaçăo de médias entre essas estimativas pode ser defendida. Cabe destacar que estas estimativas são aquelas mais utilizadas na literatura anterior ao método de Schumacher sendo que alguns pesquisadores de fato já utilizavam a média entre $13 \mathrm{e} C \mathrm{NK}$ e $15 \mathrm{eNK}$.

Ainda assim, em menos de 10\% das análises aqui apresentadas essas foram as combinaçōes escolhidas pelo método de Schumacher (Figura APII.3), sendo que a combinação 1 SeNK-15ek responde por menos de $1 \%$ dos casos. Portanto, a seleção de combinaçōes de critérios cristaloquímicos realizada pelo método de Schumacher se mostra problemática, e parece ser a fonte dos problemas observados.

\section{CONCLUSÕES}

A escoiha da estimativa a ser utifizada entre 15eNK, 13eCNK e $15 \mathrm{eK}$ (e eventualmente 8SiAl) depende do grupo de anfibólios a ser estudado, como já destacado por Robinson et al. (1982). Vale destacar, neste contexto, que as estimativas 15 eK deveriam conferir melhores resultados para anfibólios da série glaucofânio-riebeckita. Porém. Enders et al. (2000) apresentam evidência contundente de que essas estimativas não são melhores que as estimativas $13 \mathrm{eCNK}$ nem mesmo para essa série.

Com efeito, conclui-se aqui que as estimativas de $\mathrm{Fe}^{2+}$ e $\mathrm{Fe}^{3+}$ potencialmente mais adequadas são as 15 eNk e 13 eCNK, ou ainda a média entre elas. Do ponto de vista cristaloquímico, as estimativas 13 eCNK parecem ser as mais adequadas para todo o conjunto de anfibólios cálcicos. cálcico-sódicos e sódicos, o que é confirmado por comparacōes com resultados em concentrados minerais (cf. Enders et al., 2000; Martins, 2001). As estimativas 15eNK, por sua vez, são recomendadas para ạnfibólios ferro-magnesianos. Reafirmam-se, desta forma, as recomendações de Robinson et al. (1982).

A utilização de médias entre 13 eCNK e 15 eNk deve ser feita com cautela. Ela só se justifica para minerais da série tremolita-ferro-actinolita. Neste caso, as estimativas 15 eNK permitem a 
entrada de Fe e Mg e excluem Na do sítio B, enquanto as 13 eCNK fazem o oposto. Provavelmente. as composições naturais se encontram entre esses dois extremos, porém cabe avaliar mais adequadamente se a utlização das médias leva a resultados com significado cristaloquímico. Se Deer et al. (1993) estão certos ao afirmar que provavelmente existe maior solução sólida em direção à richterita (Equação APII.1) que ao glaucofânio (Equação APII.2), as composições naturais devem se aproximar mais das estimativas 13 eCNK.

$$
\begin{array}{lr}
[\mathrm{C}]]^{A}+[\mathrm{Ca}]^{B} \Leftrightarrow[\mathrm{Na}]^{A}+[\mathrm{Na}]^{B} & \text { Eq. APII.1 } \\
{[\mathrm{Ca}]^{B}+[\mathrm{Fe}, \mathrm{Mg}]^{C} \Leftrightarrow[\mathrm{Na}]^{B}+[\mathrm{Al}]^{\mathrm{C}}} & \text { Eq. APII.1 }
\end{array}
$$

De fato, a utilização de médias é a principal fragilidade do método de Schumacher. Para anfibólios cálcicos a sódicos como os aqui estudados, percebe-se que o método de Schumacher avalia corretamente quais as melhores estimativas máximas, ou seja, ele é capaz de decidir corretamente entre $13 \mathrm{eCNK}, 15 \mathrm{eK}$ e $8 \mathrm{SiAl}$. Tal acerto é também encontrado no caso da aplicação para os dados de Enders et al. (2000). Por outro lado, as estimativas mínimas, mesmo que selecionadas corretamente, são muito inferiores a essas estimativas máximas, o que pode ser visualizado pelo fato da maioria (i.é. 68\%) das estimativas minimas obtidas serem as all Fe2. Resulta que o método conduz a intervalos muito grandes entre as melhores estimativas mínimas e máximas.

Das discussöes acima deduz-se que, para anfibólios cáicicos a sódicos, os valores reais devem estar muito mais próximos das estimativas máximas que das mínimas, e portanto, os valores das médias entre elas acaba sendo excessivamente reduzido em relação ao valor real (cf. Martins, 2001). Desta forma, sugere-se que para anfibólios destes grupos sejam utilizadas as estimativas máximas obtidas com o método de Schumacher.

Por outro lado, é possivel inferir que as melhores estimativas no caso dos anfibólios ferromagnesianos são as estimativas mínimas. Porém, a verificação desta hipótese está além das possibilidades dos dados aqui disponíveis.

\section{REFERÊNCIAS BIBLIOGRÁFICAS}

Delaney, J.S.; Dyar M.D.: Sutton S.R.; Bajt S. (1998) Redox ratios with relevant resolution: Solving an old problem by using the synchrotron microXANES probe. Geology, 26: 139-142.

Buseck P.R.; Self. P. (1992) Electron energy-loss spectroscopy (EELS) and electron channeling (ALCHEMI). Reviews in Mineralogy 27: 141-180.

Deer. W.A.: Howie, R.A.: Zussman. M.A. (1992) An introduction to the rock-forming minerals. Longman. 2nd. Ed. London. 696 p. 
Droop, G.T.R. (1987) A general equation for estimating $\mathrm{Fe}^{3+}$ in ferromagnesian silicates and oxides from microprobe analysis, using stoichiometric criteria. Mineralogical Magazine, 51:431-437.

Enders, M.; Speer, D.; Maresch, W.V.; McCammon, C.A. (2000) Ferric/ferrous iron ratios in sodic amphiboles: Mössbauer analysis, stoichiometry-based calculations and the high-resolution microanalytical flank method. Contributions to Mineralogy and Petrology, 140: 135-147.

Leake, B.E. e 21 membros da IMA (1997) Nomenclature of amphiboles: report of the Subcommittee on Amphiboles of the International Mineralogical Association Commission on New Minerals and Mineral Names. Contributions to Mineralogy and Petrology. 61:295-321.

Martins. L. (2001) Condições de cristalização de granitos sin-e tardi-orogênicos da porção central do Batólito Agudos Grandes, SP. com base em geoquímica de minerais e rochas. Dissertação de Mestrado, IGuUSP. Inédita. $132 \mathrm{p}$.

Robinson, P.; Spear, F.; Schumacher, J.C.; Laird. J.; Klein. C.; Evans. B.W.: Dooland. B.L. (1982) Phase relations of metamorphic amphiboles: natural occurrences and theory. Reviews in Mineralogy, 9B: 69-76. 